\title{
"El concepto de la fiscalización parlamentaria en el ordenamiento constitucional chileno"
}

\author{
Leslie Valeska Sánchez Lobos
}

Tesis para optar al grado académico de Doctora en Derecho Director Pontificia Universidad Católica de Chile: Dr. Sebastián Zárate Rojas

Tesis para optar al grado de Doctora en

Estado de derecho y gobernanza global

Directora Universidad de Salamanca: Dra. Mercedes Iglesias Bárez.

SANTIAGO, CHILE

2016 


\section{AGRADECIMIENTOS}

Son muchas las personas a quienes quiero agradecer en este momento que logro cumplir con un importante objetivo académico de mi vida. Especialmente a mi familia por su permanente apoyo. A mi madre por haber estado junto a mí y entregarme incondicionalmente su cariño el que me ha servido para superar los obstáculos y enfrentar los desafíos que la vida nos va colocando. A mis abuelos por aconsejarme con sabiduría en los momentos complejos y de desaliento.

Agradezco con el mismo afecto a mis directores de tesis, Mercedes Iglesias Bárez y Sebastián Zárate Rojas, por su dedicación en las correciones, la generosidad al entregarme sus conocimientos y su apoyo constante, pero, principalmente, por haberme concedido su amistad y palabras de aliento.

Adicionalmente, quisiera agradecer a la profesora Dra. Silvia Bagni de la Universidad de Bolonia, por su constante apoyo en una de las pasantías de investigación más significativas, tanto en lo académico como en lo humano.

Por último, a mis amigos, amigas y compañeros del programa doctoral de la Universidad Católica de Chile, y muy especialmente a mi amiga Andrea Aguilera que siempre fue un soporte en todo este largo proceso que culmina con esta tesis doctoral. 


\section{ÍNDICE}




\section{$\underline{\text { ÍNDICE }}$}

\section{Introducción}

"La fiscalización de los actos de gobierno" p.2.

\section{Introduzione}

p.12

\section{Capítulo Primero}

"Poder, libertad y Estado constitucional" p.21.

I. Consideraciones generales.

p.23.

II. El poder y la libertad: elementos claves en el desarrollo del constitucionalismo moderno p.27.

a) La naturaleza del poder.

p.28.

b) El pacto social, el constitucionalismo de las revoluciones y el cambio en el paradigma del poder

c) El constitucionalismo del siglo XIX y el poder estatal. .p.45.

III. La limitación del poder: una institución del constitucionalismo moderno. p.55.

a) Limitaciones jurídicas al poder. p.56.

b) Limitaciones políticas al poder. p.69.

c) Teoría de la división de poderes, como mecanismo jurídico-político de control. p.80.

IV. Los regímenes de gobierno y el control parlamentario. p.85.

a) El régimen parlamentario p.88.

b) El régimen presidencial p.98.

c) El control parlamentario, análisis comparativo entre regímenes

d) Chile una democracia presidencial reforzada y la necesidad de control.......p.131. 


\section{Capítulo Segundo}

"El Parlamento y la función de control parlamentario" p.141.

I. El Parlamento. .p.143.

a) Elementos históricos y políticos relativos al origen del Parlamento. p.143.

b) El Parlamento y sus funciones: legislar, representar y controlar. ..p.155.

b.1.La función de representación como fundamento del control .p.157.

b.1.1. Antecedentes históricos. p.157.

b.1.2. La representación como fundamento del control parlamentario...p.166.

b.1.3. La crisis de la representatividad y su vínculo con el control parlamentario. p.173.

b.1.4. La representatividad en el contexto chileno.......................................186.

b.2. La función legislativa como expresión de control parlamentario...........p.190.

b.2.1. Evolución de la Ley como control jurídico del poder.

b.2.2. El control parlamentario en la ley de presupuesto nacional.........p.203.

b. 2.3. El rol de las mayorías y minorías en el procedimiento legislativo.

b.2.4. La función legislativa en Chile y sus manifestaciones como control parlamentario. p.213.

II. La función de control parlamentario...... ..p.220.

a) Dificultades en torno al concepto de control parlamentario. p.223.

a.1. Relevancia en la determinación de un concepto de control parlamentario. p. 226

a.2. Clasificación metodológica de los conceptos de control parlamentario.

a.2.1. Discusión semántica del concepto de control parlamentario...........p.229.

a.2.2. El concepto amplio del control parlamentario

- La doctrina española y el concepto amplio control

p.233.

- La doctrina italiana y el concepto amplio del control. p.237.

- La doctrina francesa y el concepto amplio del control .p.242. 
a.2.3. El control parlamentario interpretado como mecanismos de información p.249.

b) La estructura del control parlamentario p. 258 .

b.1. Naturaleza y efectos del control parlamentario p.259.

b.1.1. Control parlamentario naturaleza: jurídica o política. p. 260.

b.1.2. Control parlamentario función de naturaleza iuspolítica p.266.

b.2. Agentes del control parlamentario p.269.

b.2.1. Sujeto pasivo y objeto del control. p.269.

b.2.2. Sujeto activo o agente controlador p. 272 .

b.3. Parámetro del control parlamentario. p. 281.

III. El rol de la responsabilidad política en la configuración del control parlamentario. p.291.

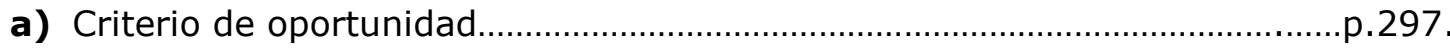

b) La sanción en la responsabilidad política p. 303.

c) La responsabilidad penal como elemento distorsionador de la responsabilidad política p.310.

IV. Consideraciones finales...... p.317.

* Capítulo Tercero

"El control parlamentario en el derecho constitucional chileno" p.319.

I. La limitación al poder en el derecho patrio y sus primitivas manifestaciones. p.325.

a) El juicio de residencia como expresión del control político en el Chile colonial. p. 329.

b) Reglamentos, ensayos constitucionales y el control político del poder. p.332.

b.1. La Patria vieja y los Reglamentos constitucionales................................333.

b.2. La Patria nueva y la Independencia de Chile....................................p.346. 
II. El control parlamentario en el constitucionalismo de la República.................p.366.

a) Consideraciones generales en torno a la Constitución Política de 1833.

b) Examen de la fiscalización parlamentaria y la acusación constitucional en la Constitución Política de 1833. ..p.371.

c) Otros mecanismos de fiscalización parlamentaria en la Constitución Política de 1833. .p.387.

d) La Revolución de 1891: etapa parlamentaria y sus mecanismos de control parlamentario en el ordenamiento constitucional chileno. ..p.389.

e) Consideraciones generales en torno a la Constitución Política de 1925. p.402.

f) Análisis general de la fiscalización parlamentaria, en la Constitución Política de 1925.

g) La acusación constitucional en la Carta Fundamental de 1925. p.421.

h) El artículo 39 y la delimitación de un concepto de fiscalización parlamentaria. p.435.

III. Apogeo y declive de una revolución política e intelectual nacional..................444.

IV. Crisis política, Golpe de Estado y la fiscalización parlamentaria.

V. Regulación de la fiscalización parlamentaria en el ordenamiento constitucional original de 1980. p.471.

a) Artículo $48 \mathrm{~N}^{\circ} 1$ "Fiscalizar los actos de Gobierno" ..p.472.

b) Artículo $48 \mathrm{~N}^{\circ} 2$ "Acusación constitucional"..... .p. 481 .

VI. Reformas constitucionales y la fiscalización parlamentaria...........................p.491.

a) La reforma constitucional de 1989 y el pacto de transición p.492.

b) La reforma constitucional del 2005 y la profundización de la democracia. p.495.

VII. Elementos de la fiscalización parlamentaria en el ordenamiento constitucional y legal nacional vigente. p.508.

a) Los sujetos de la fiscalización parlamentaria. ..p.508.

b) Objeto de la fiscalización parlamentaria. p.512.

c) Parámetro y finalidad de la fiscalización parlamentaria p.519. 
VIII. Conceptualización de la fiscalización parlamentaria: propuestas en torno a un nuevo concepto....................................................................................................... 532.

a) El sistema electoral nacional como factor determinante en la fiscalización

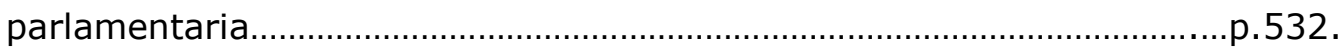

b) La confusión interpretativa entre la información y la fiscalización

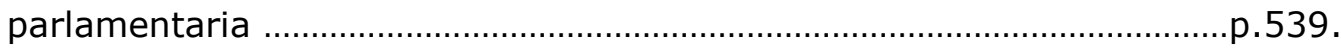

c) Propuestas para un nuevo concepto de fiscalización.................................p.541.

IX. Consideraciones finales...................................................................................

Conclusiones.............................................................

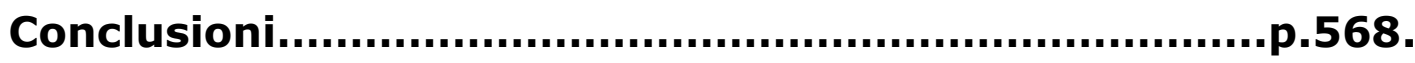

Bibliografía................................................................p.582. 


\section{INTRODUCCIÓN}




\section{"La fiscalización de los actos de gobierno"}

La presente investigación tiene por finalidad esencial determinar cuál es el concepto que se ha utilizado en el Derecho Constitucional chileno para referirse al control parlamentario. En el cumplimiento de tal cometido, pretendemos realizar dos tareas. Por un lado, deseamos detectar aquellas particularidades teóricas y prácticas que, en definitiva, construyen la noción de control parlamentario en el régimen presidencial chileno. Por otro lado, esperamos poder dilucidar las fortalezas y debilidades del ordenamiento constitucional nacional. Para ello, hemos realizado un arduo trabajo el cual nos ha llevado a recorrer un largo camino investigativo que esperamos se vea reflejado en la presente tesis doctoral. El objetivo central de esta investigación, no sólo implicaba determinar un concepto de control parlamentario, sino que, y en conjunto con ello, comprendía otorgar una definición propia de la institución y proponer -modestamente- algunas sugerencias que pueden perfeccionar y fortalecer el sistema constitucional y parlamentario en esta materia.

La siguiente investigación se basa en un estudio exploratorio de carácter descriptivo en el que se combinarán varios métodos de análisis. Por una parte, se realizará un análisis de las tendencias doctrinales española, francesa, italiana y chilena más significativas en materia de derecho parlamentario, a fin de esclarecer si existe o no un concepto unívoco de control parlamentario. Por otra parte, mediante el método dogmático se revisará el cuerpo normativo nacional que regula la facultad fiscalizadora, lo cual nos permitirá extraer de él los indicadores jurídicos pertinentes para detectar los elementos que dan cuerpo a un posible concepto de fiscalización parlamentaria y así obtener los argumentos necesarios para elaborar nuestro concepto. Finalmente, utilizaremos el mecanismo de análisis de casos nacionales, el cual estará ceñido principalmente al Juicio Político con el fin de indagar cómo se ha desarrollado la fiscalización parlamentaria desde su ejercicio concreto. Esto nos permitirá dos cosas: por un lado, observar su extensión y alcance en el régimen presidencial nacional y las consecuencias que de ella derivan; y, por otro lado, verificar si existe la responsabilidad política y el modo en que ésta es exigida. El presente método (análisis de casos) favorece la investigación de hechos políticos y jurídicos de forma ajustada y pertinente. 
Ahora bien, para lograr los objetivos planteados al comienzo hemos de utilizar una combinación de metodologías a fin de elaborar cada Capítulo de la tesis. Con todo, nuestra investigación se desarrollará en tres capítulos, cuyo contenido se explica brevemente a continuación.

Desde las formas más antiguas de organización humana y de expresión del poder, siempre ha sido necesario diseñar mecanismos para controlar los impulsos humanos $y$, en consecuencia, limitar el ejercicio del poder. El poder es un elemento inherente a la naturaleza humana. Por ende, siempre estará presente en todo tipo de estructura organizativa. Empero, la forma en que él se ejerza será determinante en el desarrollo de aquel grupo humano organizado e incluso de ello dependerá la continuidad del mismo. En este contexto, la relación que se establezca entre el control y el poder será el factor concluyente para el progreso de las sociedades modernas porque, en definitiva, un poder limitado configura a su vez un poder controlado que respeta las garantías mínimas encarnadas en los derechos humanos. Es por ello, que Manuel Aragón dirá que "el control es el vehículo a través del cual se hacen efectivas las limitaciones del poder"1. Así, comenzar una investigación sobre la fiscalización parlamentaria implicará necesariamente tratar la teoría del poder y sus implicancias, puesto que el poder, sus limitaciones y la protección de la libertad, constituyen el fundamento inicial en la teoría del control y en la protección de derechos fundamentales. Así, tal temática será el eje central desde el cual se dé comienzo a nuestro trabajo, y a partir de dicha base teórica se planteará nuestro Primer Capítulo.

Conforme a lo señalado precedentemente, el Primer Capítulo tendrá por objetivo esbozar aquel íntimo y estrecho vínculo que nace entre el control y la Constitución, toda vez que la limitación del poder se establece como uno de los pilares fundamentales del constitucionalismo moderno, puesto que el control en sí mismo fue comprendido como una limitación a través de la cual se garantizaban los derechos de la persona -entendida desde su individualidad-. Tal como describe Maurice Hauriou, el proceso de constitucionalización moderno comenzó en el siglo XVIII y se ha ido desarrollando en olas sucesivas y consecutivas de movimientos revolucionarios o de guerras mundiales. Según este autor, dichas olas pueden clasificarse en cuatro etapas: el período de la Independencia americana y la Revolución francesa; el período que sigue a la Revolución de Francia, entre 1830 y

${ }^{1}$ ARAgón (1982) p. 87. 
1848; el período posterior a la Primera Guerra Mundial; y, por último, el período posterior a la Segunda Guerra Mundial, ligado con la descolonización del Tercer Mundo. En este orden de ideas, dirá el autor que el derecho constitucional será en consecuencia: "la técnica de la conciliación de la autoridad y la libertad en el marco del Estado"'2.

La construcción del Estado constitucional moderno contemplaba un delicado equilibrio de poderes. Para cumplir su misión, era necesario establecer múltiples controles y de diversos tipos, a través de los cuales se articularían las limitaciones institucionales concretas. Éstas, además, debían favorecer un desarrollo interrelacionado de dichos controles. Es por ello, que Carl Friedrich dirá que el constitucionalismo, al dividir el poder, ofrece un sistema de limitaciones efectivas a la acción gubernamental. En términos concretos, el constitucionalismo supone un conjunto de reglas que aseguran el "juego limpio", haciendo al Gobierno responsable de sus actos ${ }^{3}$. En este mismo sentido, y en razón de aquel proceso de concepción de secularización y limitación del poder, se alcanza una verdadera revelación de las necesidades sociales. Este cambio remeció a los ciudadanos y generó una metamorfosis en los estándares de vinculación en la relación gobernantesgobernados, los cuales fueron promovidos por la misma sociedad. Tal como describe Karl Lowenstein, las "instituciones para controlar el poder no nacen ni operan por sí solas, sino que deberían ser creadas ordenadamente e incorporadas conscientemente en el proceso del poder"it.

Dada la profunda transformación producida durante la construcción del constitucionalismo moderno, en razón del cual el control del poder se torna un elemento fundante, estimamos ineludible no abarcar en el estudio el tránsito entre el constitucionalismo clásico y el moderno. Este tránsito será presentado claramente desde la óptica de las limitaciones al poder. Lo anterior, se realizará con el fin de establecer un hilo conductor que permita comprender el origen, evolución y estado actual de nuestra institución en estudio y, desde allí, continuar con nuestra labor.

Es por todo lo anterior, que en el Primer Capítulo de esta tesis se expondrá parte de aquellos múltiples acontecimientos jurídicos y políticos que durante los siglos XVIII y XIX generaron modificaciones a la estructura del sistema político y

\footnotetext{
${ }^{2}$ HAURIOU (1971) Pp.42 y 98.

3 FRIEDRICH (1975) p. 68 y 69.

${ }^{4}$ LOWENSTEIN p.149.
} 
representativo. Estos hechos dieron forma a un proceso evolutivo que aspiraba a configurar una sociedad más justa e igualitaria que otorgara y garantizara derechos a los ciudadanos, la cual necesariamente debía contar con la existencia de límites impuestos al poder y a sus detentadores. Algunos de estos límites debían tener una naturaleza jurídica, mientras que otros debían poseer una naturaleza política, todo con el fin de legitimarse a sí mismos y construir el Estado de derecho. Finalmente, como explica Johann Allesch, supervisar el actuar de la administración permitía otorgarle legitimidad democrática y proteger los derechos de los individuos de posibles abusos, razón por la cual este autor recalca la necesaria modernización del Congreso como ente encargado de aquella labor $^{5}$.

En este sentido, es menester hacer presente que ante tan complejo desafío emergieron no sólo variados medios a través de los cuales fuese posible cumplir con este fin, sino que también nacieron diversos objetos sobre los que éste podía recaer, en conjunto con una diversidad de instrumentos mediante los cuales ejercerlo. Por esta razón, germinaron una serie de controles políticos, jurídicos y sociales, los cuales serán presentados en nuestro Segundo Capítulo. En este segundo apartado, pretendemos explicar el control parlamentario a través de los sustentos doctrinales más importantes en el ámbito del Derecho Parlamentario.

El Segundo Capítulo de nuestra investigación tiene por propósito acotar nuestra línea de trabajo e ir delimitando nuestra temática investigativa, la que se refiere específicamente al estudio del control parlamentario. Para ello, debemos primeramente analizar el control político, puesto que el control parlamentario no es más que una subespecie del control político. En un Estado democrático de Derecho deben existir dos tipos de controles: los jurídicos, que surgen mediante el ejercicio de la jurisdicción constitucional, asegurando que el legislador someta la producción normativa a la Constitución; y los controles políticos, que pretenden vigilar la actuación del gobernante sometiendo a control los actos de la administración para que ésta se adecue y respete una voluntad más alta: la voluntad nacional. De acuerdo a lo anterior, y debido a que el texto constitucional goza de esta doble naturaleza jurídico-política, han de emanar desde la Carta Fundamental ambos tipos de control. Así, el control jurídico es objetivo y el control político subjetivo porque puede regular competencias y procedimientos, pero no puede limitar o determinar la necesaria libertad de acción con la que debe contar un gobernante al llevar a cabo

${ }^{5}$ AlLesCh (2003) p. 54. 
sus ideas o programas. Por esta razón, el control jurídico no es suficiente. Debe haber un control político que vele por la existencia de una adecuada armonía entre lo jurídico y los principios y valores nacionales ${ }^{6}$. Aquel control es el control parlamentario.

Una de las primeras aproximaciones estará orientada a determinar si existe o no un concepto unívoco del control o si, como describe Manuel Aragón, para la teoría de la Constitución el fenómeno del control "escapa al corsé de una única definición conceptual", situación que no significa que posea una pluralidad de sentidos sino muy por el contrario, apunta a que existe un sentido constitucionalmente unívoco. Esto querría decir que el control reviste una idea común: hacer efectivo el principio de la limitación del poder ${ }^{7}$. No obstante, a pesar de que exista un núcleo común entre los diversos tipos de poder, del examen de cada uno de ellos emergen matices que dificultan su determinación conceptual.

La tarea de examinar en profundidad el control parlamentario, implica el análisis de varias aristas. Por una parte, se debe explicar la pluralidad de sentidos y las diversas formas en las que ha sido definido este control. Ejemplo de ello son las voces fiscalizar, criticar, supervisar, freno, inspección, vigilancia, revisión, rendición de cuentas u orientación. De este modo, se realizará un detallado análisis del concepto de control parlamentario, naturaleza, objeto y sujetos del mismo. Por otra parte, y para clarificar con mayor precisión el sentido y alcance del control parlamentario, en el segundo apartado de la tesis se realizará una exposición extensa de los rasgos más trascendentales en cuanto al parámetro del mencionado control, y un análisis sobre el juicio o valoración del objeto y, de esta manera, dilucidar su arquitectura. Para ello, se expondrán las expresiones teóricas más significativas y se plantearán las nociones más elementales de la doctrina española, italiana y francesa, con el propósito de manifestar las tendencias clásicas respecto al control parlamentario y así cotejar dicha elaboración teórica con las realidades actuales.

Por otra parte, se examinarán los regímenes de gobierno y se detallará la forma en la cual se presenta el control parlamentario tanto en un régimen presidencial como en uno parlamentario, analizando los factores más relevantes que inciden en su comportamiento. En concordancia con lo anterior, en este Segundo

${ }^{6}$ RUBIO (1993) p. 245.

7 ARAGÓn (1986) p. 88. 
Capítulo examinaremos dos factores que influyen directamente en el comportamiento del control parlamentario: las formas de gobierno y el sistema electoral. Tal y como describe Phlip Norton, dos serán los factores que afecten derechamente el ejercicio del control parlamentario: por un lado, el régimen político y, por otro lado, el sistema electoral.

En cuanto a los regímenes de gobierno, nos haremos cargo de aquellas diferencias que atañen a cada cual: en un régimen presidencial, a pesar de la obviedad del análisis, es dable recordar que cada uno de los poderes -es decir, el Ejecutivo y el Legislativo- poseen su propia legitimidad popular. Por ende, la justificación del control es particular e incluso cuestionada. En el régimen parlamentario, en cambio, la legitimidad de aquellos poderes se fusiona y por tal motivo la razón de ser del control encuentra un fundamento enérgico. De este modo, la naturaleza del régimen influirá fundamentalmente en la capacidad del Parlamento de controlar al Gobierno. Inicialmente, podría señalarse que en un presidencialismo el Parlamento es claramente independiente del Ejecutivo, por lo que podría ejercer un fuerte control y desafiar al gobierno. No obstante, dicha capacidad podrá estar coartada o limitada por variables políticas. Por otra parte, en un régimen parlamentario, a primera vista, el Parlamento se configura como un órgano poderoso que podría dirigir los destinos del Ejecutivo. Sin embargo, en la práctica y en virtud del crecimiento de los partidos políticos y la disciplina partidaria, el socio dominante de la relación es el Ejecutivo ${ }^{8}$. De este modo, profundizaremos en aquellas mutaciones políticas y nos haremos cargo de la desnaturalización de los regímenes, así como de la forma en que ello influye en el desarrollo del control parlamentario.

En dicho contexto, otro elemento anexo de suma relevancia que se analizará en el Segundo Capítulo es la responsabilidad política como consecuencia o efecto que teóricamente debe emanar del ejercicio del control. En esa dirección, advertimos que las atribuciones parlamentarias $y$, en especial, la función de control -fruto de las vastas modificaciones políticas generadas por las trasformaciones lógicas de las nuevas realidades sociales- han promovido que tanto el control como sus mecanismos presenten otros perfiles y fines diversos a los clásicamente contemplados. Además, advertimos que la función de control debe contemplar una variada gama de situaciones que se encuentran estrechamente vinculadas al fin perseguido. Es por ello, que han nacido voces como la de Rafael Bustos sosteniendo

\footnotetext{
${ }^{8}$ NORTON (2010) Pp. 12, 13 y 14.
} 
que el proceso de rendición de cuentas constituye la esencia de la responsabilidad política. Según este autor, el proceso de rendición de cuentas es el principio que regula la relación Ejecutivo-Legislativo, cuya aspiración no es necesariamente la dimisión de los gobiernos sino, más bien, la regulación de las relaciones entre ambos. Bustos reconoce que la rendición de cuentas se manifestará de forma habitual en los instrumentos de control político, principalmente, en las funciones de fiscalización y de información. No obstante, el autor también destaca que el control podrá estar presente en otras actividades parlamentarias. De esta forma, el control parlamentario se distanciaría de las posturas más clásicas, puesto que se postula una distinción entre control y responsabilidad, por operar en niveles diversos ${ }^{9}$.

Considerando dicha perspectiva, explicaremos en este estudio la noción de responsabilidad difusa, elaborada por Ugo Rescigno. Esta noción implica una interpretación de la responsabilidad que está vinculada a las realidades democráticas modernas, en las que la decisión de realizar un juicio negativo o positivo de la gestión del gobierno es delegada, en cierta medida, en los ciudadanos y, en especial, en la opinión pública. Esta posición teórica señala que la opinión de la sociedad ha de traducirse en determinados comportamientos electorales. Por ende, las sanciones políticas se verán reflejadas con mayor preponderancia en medios diversos al derrocamiento de gobiernos o destitución de Ministros.

Finalmente, el Tercer Capítulo de esta investigación tendrá por objetivo realizar un estudio acabado del Derecho Constitucional nacional. Principalmente, realizaremos un análisis evolutivo de la fiscalización parlamentaria en los textos constitucionales de los años 1833, 1925 y 1980, junto a sus respectivas modificaciones constitucionales. De esta manera, podremos describir las razones y la manera en virtud de la cual fue introducida la fiscalización como institución en el constitucionalismo chileno, además de identificar sus primeras manifestaciones. En el cumplimiento de esta labor, realizaremos una breve contextualización histórica y política relativa al nacimiento de las Cartas Fundamentales, a fin de exponer todos los elementos necesarios que nos permitan comprender de forma acabada el origen de la fiscalización e, idealmente, dilucidar el motivo por el cual fue contemplada en los códigos políticos de cada época.

\footnotetext{
${ }^{9}$ Bustos (2001) Pp. 11-20.
} 
Considerando lo anterior, debemos precisar dos aspectos que fueron nuestro punto de partida en esta investigación. Primeramente, es menester señalar que nuestro ordenamiento jurídico utiliza la voz fiscalizar. El uso de esta voz fue un elemento importante a tener en consideración en el inicio de la investigación y es un factor que, como se verá en el transcurso del Tercer Capítulo, tiene una justificación teórica consistente. En segundo lugar, cabe destacar que en el desarrollo de nuestra historia institucional y republicana existen varios hitos de suma importancia que configuran indicadores a considerar respecto de la fiscalización parlamentaria. Estos hitos incluyen a la Revolución de 1891, al régimen parlamentario instaurado de facto, al particular Gobierno del presidente Alessandri, a la fuerte influencia ideológica de los años sesenta y, finalmente, al Golpe de Estado del año 1973. Todos estos factores incidieron directamente en el tipo de control político que se diseñó y dan lugar a elementos relevantes en la evolución de la institución en nuestro país.

Adicionalmente, el Tercer Capítulo utilizará como referente práctico al Juicio Político, el cual será utilizado como el parámetro empírico en razón del cual se analizarán las expresiones parlamentarias. Por tanto, se tomarán las acusaciones constitucionales como el elemento mediante el cual se indague el comportamiento e interpretación de la fiscalización parlamentaria en nuestro país. Se seleccionó el Juicio Político básicamente porque es uno de los mecanismos de control más antiguos de nuestro ordenamiento, el cual encuentra normativa prácticamente en los tres textos constitucionales estudiados. Así, éste es el mecanismo de mayor continuidad, por lo que su estudio nos permitirá percibir los avances, mejoras y problemáticas a lo largo de los años respecto de la institución que investigamos, ya que es la herramienta que nos entrega la perspectiva más extensa desde una óptica evolutiva.

Es preciso recordar que, durante las últimas décadas, los chilenos hemos sido testigos presenciales en el desarrollo institucional de una frecuente utilización de la acusación constitucional y, en algunos casos, del juzgamiento político a través del Juicio Político respecto de actores relevantes del acontecer nacional. En consecuencia, desde una perspectiva investigadora, cabe examinar las lógicas de responsabilidad jurídico-política de los congresistas y dirigentes de los partidos políticos y verificar si estamos frente a un sano ejercicio democrático o si, 
simplemente, nos encontramos frente a un "obstruccionismo parlamentario"10, a riesgo de abusar de los instrumentos de control.

De tal modo, el Tercer y último Capítulo tendrá como objetivo esencial realizar una descripción de la regulación de la fiscalización en el texto constitucional vigente. La primera etapa, tendrá por propósito exponer rasgos relevantes de la discusión constituyente respecto de la institución en su concepción original, para evidenciar la orientación de la misma. La segunda etapa, analizará las dos reformas constitucionales de mayor envergadura (1989 y 2005), a fin de detectar las modificaciones que pudieren emanar de ellas. Adicionalmente, por razones metodológicas, se efectuará la formulación conceptual respecto de cada uno de los elementos que construyen la fiscalización parlamentaria (naturaleza, objeto, sujetos, parámetro), los cuales serán cotejados con las normas y la realidad política nacional, con la clara intención de ilustrar los rasgos que configuran la fiscalización en nuestro país.

Una vez realizadas todas las etapas antes descritas, se procederá a entregar un concepto de fiscalización parlamentaria que, idealmente, abarcará la realidad jurídica y política de Chile y, fruto del examen de aquellos dos pilares, se habrá de realizar el cuerpo de esta tesis doctoral.

${ }^{10}$ SeRRA (2009) P. 106 
INTRODUZIONE 


\section{"La Fiscalizzazione degli atti del governo"}

Questa ricerca ha come obiettivo essenziale determinare il concetto che è stato utilizzato nel Diritto Costituzionale cileno per riferirsi alla fiscalizzazione parlamentare.

In ottemperanza di questa missione, ci proponiamo di realizzare due compiti. Da un lato, vogliamo rilevare quelle peculiarità teoriche e pratiche che, infine, costruiscono la nozione di fiscalizzazione parlamentare nel regime presidenziale cileno. D'altra parte, speriamo di chiarire i punti di forza e di debolezza del ordine costituzionale nazionale. Per far ciò, abbiamo fatto un lavoro molto arduo che ci ha portato a fare un lungo percorso di ricerca, che speriamo si riflette in questa tesi di dottorato. L'obiettivo principale di questa ricerca, non solo si tratta di determinare un concetto di fiscalizzazione parlamentare, ma anche di conferire una propria definizione dell'istituzione e di proporre -modestamente- alcuni suggerimenti che possono migliorare e rafforzare il sistema costituzionale e parlamentare in questo settore.

La seguente ricerca si basa su uno studio esplorativo descrittivo in cui sono combinati diversi metodi analitici. Da un lato, sarà effettuato un'analisi delle tendenze dottrinali spagnole, francese, italiane e cilene più significativi in termini di diritto parlamentare, al fine di chiarire se c'è o non c'è un concetto univoco di fiscalizzazione parlamentare.

Inoltre, con il metodo dogmatico sarà rivisto l'organismo di regolamentazione nazionale che regola l'autorità di vigilanza, che ci permetterà di estrarre gli indicatori giuridici rilevanti per rilevare gli elementi che danno corpo ad un possibile concetto di fiscalizzazione parlamentare e quindi ottenere gli argomenti necessari per sviluppare il nostro concetto.

Infine, useremo il meccanismo di analisi dei casi nazionali, che sarà aderito principalmente al Giudizio Politico al fine di indagare lo sviluppo di fiscalizzazione parlamentare da un determinato esercizio.

Questo ci consentirà di due cose: in primo luogo, osservare la ampiezza e la portata nel regime presidenziale nazionale e le conseguenze che ne derivano; e 
dall'altro, vedere se c'è responsabilità politica e come è richiesta. Il presente metodo (analisi di casi) favorisce la ricerca di fatti politici e giuridici in maniera trasparente e pertinente.

Tuttavia, per raggiungere gli obiettivi fissati all'inizio dobbiamo usare una combinazione di metodi per sviluppare ogni capitolo della tesi. Di conseguenza, la nostra ricerca sarà sviluppata in tre capitoli i cui contenuti sono brevemente spiegato di seguito.

Dalle più antiche forme di organizzazione umana ed di espressione del potere, è sempre stato necessario progettare meccanismi per controllare gli impulsi umani e quindi limitare l'esercizio del potere. Il potere è un elemento intrinseco della natura umana. Pertanto, sempre presente in tutti i tipi di struttura organizzativa. Tuttavia, il modo in cui viene esercitato sarà decisivo nello sviluppo del gruppo umano organizzato e anche da questo dipenderà la continuità. In questo contesto, il rapporto che si instaura tra la fiscalizzazionee il potere sarà determinante per il progresso delle società moderne perché, in definitiva, un potere limitato configura un potere controllato che rispetta le garanzie minime incorporati nel campo dei diritti umani. Per questo, Manuel Aragón dice che: "La fiscalizzazione è il veicolo attraverso il quale $i$ limiti di potere diventano effettivi" ${ }^{11}$. Quindi, iniziare una ricerca sulla fiscalizzazione parlamentare necessariamente includerà trattare la teoria del potere e le sue implicazioni, perché il potere, i limiti e la protezione della libertà costituiscono la base iniziale nella teoria della fiscalizzazione e nella protezione di diritti fondamentali. Quindi, questo tema sarà il punto centrale da cui il nostro lavoro inizia, e da quel base teorica si prenderà in considerazione il nostro Primo Capitolo.

In base a quanto precede, il Primo Capitolo avrà lo scopo di delineare quel rapporto intimo e stretto che si sviluppa tra la fiscalizzazione e la Costituzione, purché sia accertata la limitazione di potere come uno dei pilastri fondamentali del costituzionalismo moderno, dato che la fiscalizzazione è stata intesa come una limitazione attraverso la quale i diritti della persona sono garantiti -dal loro individualità-.

Come dice Maurice Hauriou, il processo di costituzionalizzazione moderno ha avuto inizio nel XVIII secolo ed è stato sviluppato in ondate successive e consecutivi di movimenti rivoluzionari o di guerre mondiali. Secondo lui, queste ondate possono

${ }^{11}$ ARAgón (1982) p. 87. 
essere classificati in quattro fasi: il periodo della Indipendenza Americana e della Rivoluzione Francese; il periodo successivo alla Rivoluzione di Francia, tra il 1830 e il 1848; il periodo dopo la Prima Guerra Mondiale; e, infine, il periodo dopo la Seconda Guerra Mondiale, legato alla decolonizzazione del Terzo Mondo.In tale ottica, dice l'autore che il diritto costituzionale sarà: "la tecnica della riconciliazione tra autorità e libertà nell'ambito dello Stato"12.

La costruzione del stato costituzionale moderno contemplava un delicato equilibrio di poteri. Per compiere la sua missione, è stato necessario stabilire più controlli e di vari tipi, attraverso i quali i vincoli istituzionali specifici sarebbero articolati. Inoltre, dovrebbero promuovere uno sviluppo interrelato di tali controlli. E 'per questo motivo che Carl Friedrich dice che il costituzionalismo, dividendo il potere, fornisce un sistema di limitazioni effettive rispetto all'azione di governo. In termini concreti, il costituzionalismo implica un insieme di regole che assicurano un "fair play", spingendo il governo di far fronte alle sue azioni ${ }^{13}$. In questo senso, e grazie a questo processo di concezione della secolarizzazione e limitazione del potere, si raggiunge una vera rivelazione di esigenze sociali. Questo cambiamento ha scosso i cittadini e ha generato una metamorfosi tra gli standard di collegamento all'interno della relazione governanti-governati, cui sono stati promossi dalla stessa società. Come dice Karl Lowenstein "Le istituzioni per controllare il potere non sono create né azionati da soli, ma dovrebbero essere create ordinatamente e incorporati coscientemente nel processo di potere ${ }^{114}$.

A causa della profonda trasformazione prodotta durante la costruzione del costituzionalismo moderno, per cui la fiscalizzazione del potere diventa un elemento importante, stimiamo inevitabili nello studio non coprire la transizione tra il costituzionalismo classico e moderno. Questa transizione sarà chiaramente presentata dal punto di vista delle limitazioni al potere. Tutto questo sarà effettuato al fine di stabilire un filo conduttore per comprendere l'origine, l'evoluzione e lo stato attuale di nostra istituzione in studio, e da lì, continuare il nostro lavoro.

E 'per questo che nel Primo Capitolo di questa tesi saranno mostrati alcune di quelle molteplici sviluppi legali e politici che nel corso dei secoli XVIII e XIX hanno generato modifiche alla struttura del sistema politico e rappresentativo.

\footnotetext{
12 HAURIOU (1971) Pp.42 y 98.

${ }^{13}$ FRIEDRICH (1975) p. 68 y 69.

14 LOWENSTEIN p.149.
} 
Questi fatti hanno dato forma ad un processo evolutivo che mira a creare una società più giusta ed egualitaria che garantisca diritti ai cittadini, che necessariamente deve avere l'esistenza di limiti al potere e ai suoi titolari. Alcuni di questi limiti dovrebbeno avere una natura giuridica, mentre altri dovrebbeno avere un carattere politico, tutto ciò al fine di legittimare se stessi e costruire lo Stato di Diritto. Infine, come dice Johann Allesch, monitorare le azioni dell'amministrazione ha permesso di dare legittimità democratica e proteggere i diritti degli individui dagli abusi, ragione per cui questo autore sottolinea la necessaria modernizzazione del Congresso come soggetto incaricato di tale lavoro. ${ }^{15}$

Quindi, è importante ricordare che di fronte a questa complessa sfida sono emersi diversi ostacoli che saranno presentati nel nostro Secondo Capitolo. In questa seconda sezione, spieghiamo la fiscalizzazione parlamentare attraverso le più importanti basi dottrinali nel campo del Diritto Parlamentare.

Il Secondo Capitolo della nostra ricerca ha lo scopo di inquadrare la nostra linea di lavoro e definire il nostro tema di ricerca, che si riferisce specificamente allo studio della fiscalizzazione parlamentare. Per fare questo, dobbiamo prima analizzare il controllo politico, perché la fiscalizzazione parlamentare è solo una sottospecie di controllo politico. In uno Stato democratico di Diritto ci dovrebbero essere due tipi di controlli: gli giuridici, derivante attraverso l'esercizio della giurisdizione costituzionale, assicurando che il legislatore sottoponga la produzione normativa alla Costituzione; e i controlli politici, che pretendono monitorare la performance del governo assoggettando alla fiscalizzazione gli atti dell'amministrazione in modo che si adegui e rispetti una volontà maggiore: la volontà nazionale. Su tale base, e perché il testo costituzionale ha questa natura duale giuridico-politica, si devono derivare entrambi i tipi di controllo dalla Carta Fondamentale Così, la fiscalizzazione giuridica è oggettiva e la fiscalizzazione politica soggettiva, perché può regolare le competenze e le procedure, ma non è possibile limitare o determinare la necessaria libertà di azione che dovrebbe avere un governo per svolgere le iniziative. Per questo motivo, la fiscalizzazione giuridica non è sufficiente. $\mathrm{Ci}$ deve essere una fiscalizzazione politica per garantire l'esistenza di una armonia adeguata tra il sistema giuridico e principi e valori nazionali ${ }^{16}$. Questa fiscalizzazione è il parlamentare.

\footnotetext{
${ }^{15}$ AlLesCh (2003) p. 54.
}

${ }^{16}$ Rubio (1993) p. 245. 
Uno dei primi approcci saranno volti a determinare se c'è o non un concetto univoco di fiscalizzazione o se, come dice Manuel Aragon, per la teoria della Costituzione il fenomeno della fiscalizzazione "non può essere definito in una singola definizione", situazione che non significa che ha una pluralità di sensi ma, al contrario, suggerisce che c'è un senso costituzionalmente univoco. Ciò significa che la fiscalizzazione è di un'idea comune: rendere effettivo il principio della limitazione del potere ${ }^{17}$. Tuttavia, anche se c'è un nucleo comune tra i vari tipi di potere, dal esame di essi emergono sfumature che ostacolano la sua determinazione concettuale.

Il compito di esaminare in modo approfondito la fiscalizzazione parlamentare, comprende I'analisi di diversi bordi. Da un lato, si spiega la pluralità di sensi ed i vari modi in cui è stata definita questa fiscalizzazione. Alcuni esempi sono le voci controllare, criticare, monitorare, freno, ispezione, vigilanza, revisione, orientamento o responsabilità. Così, sarà realizzata una dettagliata analisi del concetto di fiscalizzazione parlamentare, origine, oggetto e soggetto. Inoltre, e per chiarire con maggiore precisione il significato e la portata della fiscalizzazione parlamentare, nella seconda sezione della tesi sarà effettuata una vasta esposizione delle caratteristiche più significative per quanto riguarda il parametro della fiscalizzazione, e una analisi sul processo o valutazione del oggetto e, quindi, stabilire la sua architettura. A tal fine, saranno presentate le più significative espressioni teoriche e saranno discusse le nozioni più elementari della dottrina spagnola, italiana e francesa, con lo scopo di manifestare le tendenze classiche rispetto alla fiscalizzazione parlamentare e, quindi, confrontare questo sviluppo teorico con la realtà attuale.

D'altro canto, i sistemi di governo saranno riesaminati e si spiegherà il modo in cui è presentato la fiscalizzazione parlamentare (sia di un presidente o di un sistema parlamentare), analizzando i fattori più importanti che influenzano il comportamento. A tale proposito, in questo Secondo Capitolo esamineremo due fattori che influenzano direttamente il comportamento della fiscalizzazione parlamentare: le forme di governo e del sistema elettorale. Come dice Phlip Norton, due saranno i fattori che influenzano direttamente l'esercizio della fiscalizzazione parlamentare, da un lato, il regime politico, e d'altra parte, il sistema elettorale.

${ }^{17}$ ARAgón (1986) p. 88. 
Per quanto riguarda i regimi di governo, noi comprendiamo queste differenze: in un regime presidenziale, nonostante l'evidenza dell'analisi, è possibile ricordare che ciascuno dei poteri (vale a dire, il potere Esecutivo e Legislativo) hanno una propria legittimità popolare. Pertanto, la giustificazione della fiscalizzazione è particolare e anche in discussione. Nel sistema parlamentare, invece, si fonde la legittimità di tali poteri e quindi la finalità essenziale della fiscalizzazione è una base solida. Così, la natura del regime influenzerà fondamentalmente la capacità del Parlamento di controllare al Governo. Inizialmente, si potrebbe notare che in un presidenzialismo il Parlamento è chiaramente indipendente dall'esecutivo, e pertanto potrebbe esercitare un forte controllo e sfidare il governo. Nonostante, tale capacità può essere limitata da variabili politiche. Inoltre, in un sistema parlamentare, a prima vista, il Parlamento si configura come un organo potente che potrebbe dirigere i destini del Esecutivo.

Tuttavia, nella pratica e sotto la crescita dei partiti politici e la disciplina di partito, il partner dominante nel rapporto è l'Esecutivo ${ }^{18}$. Di conseguenza, approfondiremo le mutazioni politiche e noi vigileremo il snaturamento dei regimi e anche il modo in cui influenza lo sviluppo della fiscalizzazione parlamentare.

In questo contesto, un elemento annesso importante che sarà analizzato nel Secondo Capitolo è la responsabilità politica come un risultato o effetto che teoricamente dovrebbe sorgere dal esercizio della fiscalizzazione. In questa direzione, richiamiamo l'attenzione sul fatto che i poteri parlamentari e, in particolare, la funzione di fiscalizzazione (risultato di vasti cambiamenti politici generati dalle trasformazioni logiche delle nuove realtà sociali) hanno promosso che la fiscalizzazione e i meccanismi presentano altri profili e scopi diversi da quelli convenzionalmente usati. Inoltre, si segnala che la funzione di fiscalizzazione dovrebbe includere una vasta gamma di situazioni che sono strettamente legate allo scopo perseguito. Ecco perché hanno nati voci come la voce di Rafael Bustos sostenendo che il processo di responsabilità è l'essenza della responsabilità politica. Secondo lui, il processo di responsabilità è il principio che regola i rapporti EsecutivoLegislativo, cui aspirazione non è necessariamente la rinuncia dei governi, ma la regolazione dei rapporti tra di loro. Bustos riconosce che la responsabilità si manifesterà regolarmente negli strumenti di fiscalizzazione politica, soprattutto nelle funzioni di controllo e di informazione. Tuttavia, l'autore sottolinea anche che la

\footnotetext{
${ }^{18}$ NORTON (2010) Pp. 12, 13 y 14.
} 
fiscalizzazione può essere presente in altre attività parlamentari. Così, la fiscalizzazione parlamentare prenderebbe distanza delle posizioni classiche, poiché è postulata una distinzione tra il controllo e la responsabilità per funzionare a diversi livelli ${ }^{19}$.

Considerando questo punto di vista, questo studio spiega il concetto di responsabilità diffusa, redatta da Ugo Rescigno. Questa nozione implica un'interpretazione della responsabilità che è collegata alle moderne realtà democratiche in cui la decisione di rendere una visione negativa o positiva della gestione del governo è delegata in una certa misura, sui cittadini e, in particolare, nell'opinione pubblica. Questa posizione teorica indica che il giudizio della società deve essere tradotto in alcuni comportamento elettorale. Pertanto, le sanzioni politiche si rifletteranno in gran parte in mezzi diversi al rovesciamento di governi o destituzione dei Ministri.

Infine, il Terzo Capitolo di questa ricerca avrà lo scopo di fare uno studio del Diritto Costituzionale nazionale. Principalmente, faremo un'analisi evoluzionistica della fiscalizzazione parlamentare nelle costituzioni degli anni 1833, 1925 e 1980, insieme ai rispettivi emendamenti costituzionali. In questo modo, siamo in grado di descrivere le ragioni e il modo in base al quale la fiscalizzazione è stata introdotta come istituzione nel costituzionalismo cileno, e anche potremo identificare le prime manifestazioni. In questo compito, faremo una breve contestualizzazione storica e politica sulla creazione delle Carte Fondamentali, per esporre tutti gli elementi che ci permettono di capire l'origine della fiscalizzazione e, idealmente, chiarire il motivo per cui è stato indicato nei codici politici di ogni epoca.

In considerazione di quanto precede, si deve precisare due aspetti che sono stati il nostro punto di partenza in questa inchiesta. In primo luogo, dobbiamo indicare che il nostro sistema giuridico utilizza la voce controllare.

L'utilizzo di questa voce era una cosa importante da considerare all'inizio della ricerca ed è un fattore che, come si vedrà nel Terzo Capitolo, ha una giustificazione teorica coerente. In secondo luogo, si osserva che nello sviluppo della nostra storia istituzionale e repubblicana ci sono diversi momenti importanti che modellano indicatori da considerare per quanto riguarda la fiscalizzazione parlamentare. Questi momenti includono la rivoluzione del 1891 , il regime parlamentare stabilito de facto,

19 Bustos (2001) Pp. 11-20. 
il particolare governo del presidente Alessandri, la forte influenza ideologica degli anni sessanta e, infine, il Colpo di Stato del 1973. Tutti questi fattori hanno portato direttamente al tipo di fiscalizzazione politica che è stata progettata e danno origine ad elementi rilevanti nell'evoluzione dell'istituzione nel nostro paese.

Inoltre, il Terzo Capitolo userà un Giudizio Politico come referente pratico, che sarà utilizzato come parametro empirico per cui le espressioni parlamentari saranno analizzati. Pertanto, le dichiarazioni costituzionali saranno l'elemento con cui si osserva la condotta e l'interpretazione di fiscalizzazione parlamentare nel nostro paese.

Un Giudizio Politico è stato selezionato principalmente perché è uno dei più antichi meccanismi di fiscalizzazione del nostro sistema, che praticamente governa i tre testi costituzionali studiati. Quindi, questo è il meccanismo di maggiore continuità, per cui il suo studio ci permetterà di percepire i progressi, i miglioramenti e problemi nel corso degli anni per quanto riguarda l'istituzione indagata, perché è lo strumento che ci dà la prospettiva più ampia dal punto di vista evolutivo.

È opportuno ricordare che, che nel corso degli ultimi decenni, i cileni siamo stati testimoni nello sviluppo istituzionale del frequente uso della dichiarazione interistituzionale, e, in alcuni casi, del processo politico attraverso un Giudizio Politico per quanto riguarda eventi nazionali. Di conseguenza, dal punto di vista della ricerca, vale la pena di esaminare la logica giuridica e politica dei membri del Congresso e dirigenti dei partiti politici e vedere se siamo di fronte ad un sano esercizio democratico 0 se siamo semplicemente di fronte ad un "ostruzionismo parlamentare ${ }^{\prime 20}$, a rischio di abusare di strumenti di fiscalizzazione.

Così, il terzo e ultimo capitolo farà una descrizione oggettiva essenziale del regolamento della fiscalizzazione nel testo costituzionale corrente. La prima fase, avrà lo scopo di esporre le caratteristiche rilevanti della discussione costituente riguardante l'istituzione nella sua concezione originale, per mostrare l'orientamento. La seconda fase, analizza le due riforme costituzionali più grande (1989 e 2005) al fine di rilevare i cambiamenti che possono derivare da queste riforme. Inoltre, per ragioni metodologiche, sarà effettuata la formulazione concettuale rispetto a ciascuno degli elementi che costruiscono la fiscalizzazione parlamentare (origine, oggetto, soggetto, parametro), cui saranno raccolti con le norme e la realtà politica

${ }^{20}$ SeRRA (2009) P. 106 
nazionale, con la chiara intenzione di illustrare le caratteristiche che compongono la fiscalizzazione nel nostro paese.

Dopo l'esecuzione di tutte le fasi, si procede a fornire un concetto di fiscalizzazione parlamentare che, idealmente, riguarderà la realtà giuridica e politica del Cile e, come risultato dell'esame di tali due pilastri, sarà possibile l'oggetto di questa tesi di dottorato. 


\section{CAPÍTULO PRIMERO}

"Poder, libertad y Estado constitucional" 


\section{"Poder, libertad y Estado constitucional"}

Comenzar una investigación jurídica sobre el control parlamentario impone la obligación de realizar un examen indispensable respecto de los elementos esenciales que lo componen. Dichos elementos son: el poder y la libertad. Estos componentes fueron a su vez los factores basales del surgimiento del Estado democrático y constitucional moderno y del sistema de controles jurídicos y políticos. Por tanto, realizar un análisis de tal binomio implica reconstruir las claves histórico-políticas y los planteamientos más célebres respecto de la teoría del control del poder. En consecuencia, en este Primer Capítulo nuestro objetivo comprende describir la construcción intelectual, los aspectos históricos, políticos y sociales de mayúscula importancia que sientan las bases de la organización jurídica constitucional de las sociedades modernas, la cual que se centró principalmente en la transformación del sustento ideológico y normativo que hasta la fecha había sobrellevado el feudalismo y, posteriormente, el Estado absoluto.

El propósito de analizar ambos elementos (poder y libertad), indefectiblemente nos llevará a reiterar algunos hechos y teorías ya conocidas, tales como el Contractualismo y el Liberalismo, entre otros. Sin embargo, creemos pertinente contextualizar nuestro trabajo exponiendo algunos antecedentes históricos, sociales, jurídicos y políticos de gran importancia a través de los cuales se comprenderá de mejor manera las ideas expuestas en los capítulos siguientes y, en particular, nos permite ilustrar en profundidad los orígenes y evolución de nuestro tema central de investigación: el control parlamentario.

Con todo, nuestra finalidad en el presente Capítulo es dotar de cierta armonía y coherencia nuestro trabajo respecto a la evolución de las instituciones jurídicopolíticas propias del control. Asimismo, intentaremos otorgar una acotada descripción respecto de cómo se arriba a la convicción que establecer controles jurídicos y políticos constituirá el gran mecanismo limitador del poder y protector de la libertad de las personas y sus derechos fundamentales. El temor siempre presente ante la posible existencia de un gobierno arbitrario que abuse de los ciudadanos, es y ha sido el núcleo central del desarrollo del Derecho Político y Constitucional. Evitar el abuso de poder y las arbitrariedades son la médula de tal ciencia del Derecho. Lograr armonizar los términos poder, libertad e igualdad ha sido el hilo conductor del 
desarrollo histórico-jurídico del constitucionalismo moderno. Es por ello que en este apartado intentaremos exhibir sus aristas más significativas, motivo por el cual expondremos cómo la relación entre ellos produjo un movimiento parsimonioso, difuso y complejo que dio nacimiento a un nuevo orden social, político y jurídico, sustentado en el control del poder, el respeto de los derechos humanos y en el equilibrio de poderes.

\section{Consideraciones generales:}

En primer lugar, cabe hacer presente que los órdenes políticos y jurídicos que se inician fundamentalmente a través de un proceso de re-significación del concepto de poder y libertad, estimulan el nacimiento de movimientos políticos-filosóficos tales como la Ilustración, el Renacimiento y el Liberalismo, los que generaron múltiples cambios en cuanto a la organización de las sociedades. Particular importancia tuvo la Reforma Protestante del siglo XVI. Mediante ella no sólo se llevaron a cabo transformaciones ligadas a la libertad religiosa de los pueblos, sino también hubo cambios en cuanto a su emancipación en términos políticos. Debido a esto, se produjo -en definitiva- una reforma política a través de una crisis religiosa la cual afectó en profundidad la estructura social y cultural de los pueblos de aquellos tiempos.

En un principio, la fuerte influencia de la Iglesia de Roma había instalado la noción de origen divino del poder. En dicho orden de ideas, Dios era el creador del universo, por tanto, era el creador del poder el que a su vez era conferido al Papa como vicario de Dios para actuar conforme a sus designios. Con posterioridad, el poder fue delegado a un monarca dando nacimiento con ello a las monarquías teocráticas. Sin embargo, el rey gobernaba de igual manera que la divinidad, con plena autoridad y poderes porque su posición de poder era conferida por gracia de Dios $^{21}$. Empero, será precisamente la influencia de Lutero y Calvino en virtud de la cual surgirá el derecho natural cristiano protestante y la teoría económica del Liberalismo. Estos nuevos paradigmas propendieron el nacimiento y desarrollo de nuevas organizaciones sociales sustentadas en la secularización del poder. Debido a este cambio de concepción del origen y expresión del poder, se producirá la separación entre el poder secular y el poder papal o espiritual.

${ }^{21}$ Loughlin (2010) Pp.19, 20 y 25. 
Así, gracias al protestantismo se liberó al Estado de la subordinación religiosa y se separó a la iglesia de la política. Esto conllevó a la reformulación de los conceptos de autoridad, obediencia y orden, y como consecuencia el consentimiento de los súbditos pasó a ocupar un lugar relevante en la construcción del poder. La raíz protestante emerge de las guerras de religión de Francia y del conflicto constitucional inglés, introduciendo un nuevo elemento: el pacto originario, a través del cual se atribuye el poder al Rey. Según Fioravanti, con dichas transformaciones y el ideal del pacto, entre otras que analizaremos a continuación, se configura un particular constitucionalismo, mediante el cual el poder siempre puede ser recuperado cuando las cláusulas de aquel pacto sean violadas por el rey, y para el caso que éste intente imponer formas de gobiernos no moderadas. Se dará nacimiento a aquel ideal que expone que el pueblo es anterior al rey y que, por ello, puede vivir sin él ${ }^{22}$. La Reforma altera y acentúa las divisiones ideológicas y políticas de manera decisiva, la renovación de la religión, la relación entre lo espiritual y lo temporal y una cierta primacía de lo religioso sobre lo político imprimirán un sello en los hombres del siglo XVI. Las doctrinas de los reformadores produjeron gran agitación y reacciones políticas $^{23}$, las que a continuación examinaremos.

Como consecuencia de este fenómeno, surgirán dos corrientes de pensamiento: el luteranismo y el calvinismo. Por un lado, en el luteranismo político su autor expresa el pensamiento político que posee sobre la autoridad. Sin ostentar una mirada sistémica sobre el Estado ni el poder político, el fraile se preocupa por la autoridad encargada de ejercer el poder y postula la separación del poder temporal del espiritual, sometiendo el primero al segundo pero recalcando que ambos eran necesarios ${ }^{24}$. Es por ello que Lutero pone en jaque la hegemonía del supuesto representante de Dios en la tierra y logra separar el lenguaje religioso de las categorías políticas. En este sentido, exhibió que los límites del poder secular están contenidos en la ley, la cual solamente ha de regular situaciones externas, ya que el ámbito interno de las personas debe ser regulado por la religión, por tratarse de temas espirituales y temporales. Según Lutero, este último punto habría sido el error más profundo en el que habría incurrido la Iglesia de Roma, es decir, intervenir en

22 FIORAVANTI (2014) p. 26.

23 TOUCHARD (1981) p. 214.

24 GARCíA (2013) Pp. 47,48 y 49. 
ámbitos que no le eran propios. Así, el pensamiento luterano tiene por consecuencia el nacimiento del individualismo ${ }^{25}$.

Por otro lado, la segunda corriente es la configurada por el pensamiento político calvinista. Del mismo modo que Lutero, el francés diferencia el reino espiritual del gobierno civil. Su argumento se basa en la naturaleza de las esferas, en el que dictamina que el primer reino mencionado posee competencias en el ámbito espiritual y, el segundo, en el orden temporal. Sin embargo, este pensador va más allá y aborda temas como la teoría de la democracia participativa, el contrato social, la teoría de la resistencia y los derechos fundamentales. Por consiguiente, en Calvino es posible detectar un espíritu democrático inclinado a la forma republicana de gobierno y el régimen representativo. Calvino señaló, con respecto a los límites de la autoridad, que un poder descontrolado sería un poder injustificado.

La Reforma Protestante habrá de buscar en un texto jurídico el puntal necesario para sostener sus novedosos postulados. Con este propósito, se otorgó al Derecho la tarea de materializar el poder secular, además de conferirle el especial atributo de limitarlo. Mediante el iusnaturalismo racionalista, fundado en la razón humana, se llevará a cabo la secularización del poder como paradigma relativo a la ley natural, lo cual la desvinculará de la ley eterna y la dejará en manos de la razón humana. Tal como describe Loughlin, con la Reforma resurge un especial interés por la Biblia. Con ello, se produce una nueva conceptualización de la naturaleza de las obligaciones y el poder. Sin embargo, dicha relación entre la secularización del poder y la nueva interpretación del texto bíblico fue la que provocó resultados tan fructíferos y promovió actos tan revolucionarios como la Revolución americana y la Revolución francesa. Es por ello que según Loughlin, el surgimiento del constitucionalismo moderno está estrechamente vinculado con el derecho subjetivo y la doctrina teológica individualista, motivo por el cual ha de reconocerse que en gran parte el nacimiento del constitucionalismo moderno emerge sustentado en fuertes bases teológicas ${ }^{26}$.

Las transformaciones en torno al iusnaturalismo, seguido por las Revoluciones americana y francesa, trajo como resultado un constitucionalismo moderno que además de sustentarse en el control y división de poderes, se compone de otro fenómeno de trascendencia: el reconocimiento de la atribución de los

${ }^{25}$ Simiele (2010) Pp. 79, 84, 87 y 88.

26 Loughin (2010) P.47. 
derechos a las personas -consideradas ellas individualmente-, los que se activan por simple hecho de nacer, derechos que sólo se volverán concretos y materializables gracias a su consagración en la ley, o sea, a la igualdad de los individuos ante la ley. La soberanía de la norma generó la destrucción de los privilegios estamentales y el colapso de las vastas autoridades que poblaban el antiguo régimen. Es por ello que Fioravanti expresa "no hay revolución sin igualdad. Pero tampoco hay igualdad sin ${ }^{\prime e y} y^{\prime 27}$. Este suceso forjó el espacio necesario para el nacimiento del principio de igualdad, el cual constituye el motor central del surgimiento moderno del constitucionalismo. Por consiguiente, el Derecho se instituye como el instrumento jurídico de estabilidad y seguridad del Estado, y es por ello que mediante la Ley se limitará el ejercicio del poder, garantizándose así los derechos de las personas. En consecuencia, de aquella conjugación de elementos emanará a su vez el Estado de derecho.

Siguiendo este orden de ideas, diremos que la Reforma Protestante constituye la causa inicial en el surgimiento de las teorías de la soberanía, secularización del poder, la abstracción y generalidad en la creación del derecho -único y soberano-, la protección y seguridad de las personas mediante la declaración de derechos esenciales e inalterables y la representación política. Todos estos elementos configuraron los pilares fundamentales del Estado moderno y el constitucionalismo.

En conclusión, nuestra misión en este Primer Capítulo es contextualizar al control parlamentario en sus aspectos históricos relevantes y analizar de manera breve la configuración de los sistemas de gobierno, como consecuencia de la división funcional del poder. Con estos objetivos fijados, intentaremos describir la forma en la que el control nace, se desarrolla y evoluciona en cada etapa del constitucionalismo hasta alcanzar el protagonismo que posee en nuestros días, con el fin de otorgar las herramientas necesarias para poder analizar, posteriormente, el control parlamentario en el contexto presidencial chileno. Por ende, definiremos en este Capítulo inicial todos los componentes que han hecho del control parlamentario una institución de gran relevancia para el Estado de derecho y el sistema democrático en todos los tiempos.

${ }^{27}$ Fioravanti (2014) p. 115. 


\section{El poder y la libertad: elementos claves en el desarrollo del constitucionalismo moderno}

Tanto el poder como la libertad y la igualdad, entre otros factores relevantes, constituyen el centro neurálgico del desarrollo del Derecho Político y Constitucional moderno. Es por ello que de forma preliminar daremos inicio al presente Capítulo con un examen de aquellos elementos, entendidos como forjadores del constitucionalismo moderno y la noción de control del poder.

En efecto, la gran barrera que dividirá el antiguo constitucionalismo con el moderno es, precisamente, el surgimiento del principio de igualdad. Durante el desarrollo del constitucionalismo primigenio no se concebían los conceptos de soberanía, derechos personales, libertad e igualdad como principios rectores. La norma constitucional se encontraba estrechamente ligada a un espacio político y territorial en el cual actuaban diversas fuerzas. Ergo, las leyes consuetudinarias o escritas que regulaban al conjunto de fuerzas estamentales existentes se establecían como un conjunto de reglas que adquirían la calidad de Constitución, cuya finalidad esencial era mantener la paz y el equilibrio entre dichas fuerzas mediante el respeto y la garantía de privilegios otorgados a ciertos estamentos. Es por ello que dichas leyes se mantenían vigentes mientras cumplieran tal labor. En este sentido, se expresaron los ideales de Maquiavelo con la noción de gobierno moderado y constitución mixta. Pese a esto, en el siglo XVIII se modificaron los rasgos del constitucionalismo en virtud del surgimiento del principio de igualdad impulsado inicialmente por las revoluciones, cuyo antecedente filosófico-político fue el pensamiento reformista protestante. Los modelos constitucionales ingleses y franceses comenzaron a delinear una nueva identidad constitucional, principalmente mediante el reconocimiento de derechos a las personas consideradas de forma individual. Este fenómeno genera, en consecuencia, una renovación del concepto de Constitución, cuyo objetivo era derribar el absolutismo monárquico.

En dicho contexto, por una parte se unifica el poder en una sola autoridad y, por tanto, surge la noción de soberanía. Por otra parte, el sometimiento al poder debía ser consensuado, lo que dio origen a la noción de pacto social, mediante el cual el pueblo reclama participación en la configuración de los términos de dicho pacto. A este respecto, las decisiones debían ser representativas, dando origen a la noción de voluntad general como elemento legitimador de la autoridad. Dicha voluntad se debía materializar en la Ley, la cual se aplica de manera igualitaria a todos los 
miembros del pacto. Por consiguiente, con el constitucionalismo moderno no se apelará a la Constitución mixta, sino que se apelará a un poder fuerte al cual se le atribuirá sin miramientos los poderes de la soberanía 28.

De esta manera, a partir del siglo XVIII se comienza a deslindar un constitucionalismo renovado. A través de las revoluciones, se profundizaron otras aristas: la tutela de derechos, formas de gobierno moderada y equilibrada, la limitación del poder y las relaciones equilibradas del mismo. En este escenario, se configuró un constitucionalismo propio de las revoluciones -caracterizado por las declaraciones de derechos-, para luego avanzar a aquellas tendencias constitucionales liberales que buscaron mayor certeza, seguridad y estabilidad política-jurídica en la Ley Fundamental, lo cual desencadenó finalmente en aquellas doctrinas de cuño más democrático. Es por ello que en el presente apartado realizaremos un breve recorrido por la evolución de la conceptualización del poder, la libertad e igualdad, puesto que constituyen el corazón del constitucionalismo moderno. De la interpretación del poder emerge, precisamente, la necesidad de proteger la libertad e igualdad de aquellos intentos abusivos del poder autoritario. Sin embargo, tal como se evidenciará más tarde, al constitucionalismo no le bastará con la sola limitación, sino que además habrá de consagrar derechos. A diferencia de lo que ocurría en el constitucionalismo antiguo que sencillamente buscaba un gobierno moderado que no resultaba ser suficiente, y en virtud de las reformas políticas e intelectuales, surge la necesidad de poner al ciudadano como eje central en la configuración del sistema político y jurídico. En consecuencia, la interacción de todas aquellas aristas fue el motor del sistema de controles y equilibrios políticosjurídicos que serán los antecedentes naturales del control parlamentario.

\section{a) La naturaleza del poder}

Una particularidad del ser humano -y tendencia inevitable por lo demás- es su natural inclinación hacia el ejercicio del poder. Así lo describió Hobbes cuando declaró que la primera inclinación natural de toda la humanidad es un "perpetuo e incansable deseo de conseguir poder tras poder, el cual sólo cesa con la muerte"29.

\footnotetext{
${ }^{28}$ Fioravanti (2014) Pp. 20, 27 y 33.

29 HobBes (1989) p.87. Resulta interesante analizar como el autor describe que este deseo no tiene termino sino solamente con la muerte, pues el poder no es perpetuo y debe ir renovándose independientemente de la íntima motivación que mueva al deseo.
} 
Lo anterior, se debe a que el ser humano es un ente de carácter social que inevitablemente se agrupa y realiza su vida en colectividad. Así también lo señaló Aristóteles, cuando planteó que el hombre tiende a comportarse socialmente, aun cuando no tenga la necesidad de auxilio mutuo, y tiende a convivir en sociedad por razones de utilidad y bienestar, pero también simplemente por vivir en comunidad política, por la bondad, felicidad e incluso dulzura que aquello le provoca. Por estas razones, el autor lo denominó como "animal político". Junto con ello, Aristóteles formuló importantes tesis sobre las diversas desigualdades existentes entre los mismos hombres. El filósofo griego señala, a modo de premisa, que regir y ser regidos no sólo son hechos necesarios, sino convenientes. Desde el momento del nacimiento hay personas destinadas a regir y otros a ser regidos ${ }^{30}$. De acuerdo a este análisis, esta situación se encontraría presente en la humanidad desde tiempos remotos ${ }^{31}$.

Si bien la explicación de Aristóteles contiene un elemento social que considera al poder como resultado de las relaciones sociales, hay quienes han planteado una visión diferente. Así, se puede observar en Bertrand de Jouvenel una negación de la posibilidad de que el poder sea una consecuencia de las relaciones sociales. Para el francés el poder no es más que el instinto de dominación que habita en todo ser humano ${ }^{32}$. Otra interpretación en torno al poder que no es social ni intuitiva, es la planteada por Schmitt, en la cual el poder respondería más bien a una necesidad de sobrevivencia. Para el autor, el hombre es un ser viviente débil y es esta condición de debilidad la que instaura la necesidad de dominar y dirigir otras especies e, incluso, el orden natural en el que vive. Esta condición lleva al hombre a romper las barreras naturales que se le imponen, lo cual es la causante de la necesidad de vivir en comunidad: el temor a lo incontrolable y a aquello que no estaba en sus manos modificar y que sólo en sociedad puede desarrollar. Debido a lo anterior, Schmitt dirá que el hombre que no tiene poder se sentirá como un cordero hasta que alcance su propio poderío y desempeña el papel de lobo ${ }^{33}$, lo cual nos recuerda así al viejo adagio de Hobbes "el hombre es un lobo para el hombre".

\footnotetext{
30 ARIStóteles (1970) Pp.7 y 78.

${ }^{31}$ Respecto a las primeras manifestaciones del poder vemos en el trabajo de: García RuIz (2010) p. 31. Argumentos que señalan que el poder como tal se habría manifestado ya en la Prehistoria, encontrando vestigios en períodos como el paleolítico, neolítico y mesolítico.

32 De JuOVEnel (1974) p. 129

33 SCHMITT (1962) Pp. 65 y 67.
} 
Por nuestra parte, adherimos a esta mirada del poder porque comprendemos que lo que en definitiva hace surgir al mismo es el temor del ser humano al estado de indefensión al que se ve expuesto. Por ende, el instinto de sociabilidad del que nos habla Aristóteles se puede interpretar más bien como una necesidad de sobrevivencia que despierta en él la idea de que reunidos pueden realizar acciones mayores y con mejor resultado. Esto, a su vez, está siempre vinculado a una búsqueda de protección y seguridad como objetivo central de dicha organización. Precisamente, este fenómeno fue analizado y detectado por los pensadores constractualistas y será materializado en sus postulados, los cuales analizaremos.

Ahora bien, debemos continuar este trabajo puntualizando brevemente qué debemos entender por poder y libertad; qué desencadenó su protagonismo en el desarrollo de las relaciones políticas; y, cómo la vinculación entre ambos produjo el surgimiento del Estado Moderno de Derecho y todas sus aristas.

A continuación, realizaremos una descripción sucinta del poder y sus elementos característicos, no sin antes advertir la amplitud y complejidad del concepto del cual Loewenstein expresaría lo siguiente: "se podrá conocer como éste opera pero nunca captar lo que es realmente, todo intento humano toda preparación lógica es insuficiente para penetrar su esencia, los estudios deben quedar reducidos a sus manifestaciones, efectos y resultados" ${ }^{\prime 34}$. De este modo, damos pie a la dificultosa labor de interpretar los vínculos entre poder y libertad para esclarecer el origen del sistema de controles y equilibrios.

Un patrón relativamente común en la literatura cuando se busca una conceptualización del poder, es la opinión que determina al mismo como neutral o abstracto, es decir, no puede ser calificado moral o éticamente. El poder en sí mismo no es ni bueno ni malo. Siguen dicha interpretación expuesta por Sartori, Loewenstein y Bertrand de Jouvenel, para quien el poder posee un estado puro y "existe por sí y para si"135, lo cual contradece la posición que considera el poder como un efecto social.

Por su parte, en los estudios de Schmitt, el poder es sencillamente neutral y dependerá de su utilización. Debido a esto, si quien ejerce el poder es un hombre bueno, éste será bueno y si lo utiliza un hombre malo, éste será malo. A pesar de

\footnotetext{
34 LOEWENSTEIN (1976) p. 23

35 De Jouvenel (1974) Pp. 126 y 127.
} 
esta premisa, el mismo Schmitt detecta la dificultad de tal concepción y señalará a continuación que la complejidad se presenta en quién define lo bueno y lo malo. Para el alemán, el peligro del poder está en los mismos hombres quienes al traspasar ciertos límites naturales habrían dejado escapar el poder de sus manos. No obstante, y afortunadamente, esta realidad autónoma del poder lo hace más fuerte que cualquier voluntad de poder, más fuerte que la bondad humana, pero también más fuerte que la maldad humana ${ }^{36}$.

Existen diversos argumentos que han pretendido explicar al poder político y los elementos asociados a éste. De acuerdo a la comprensión del poder como fuerza, la idea de poder es una noción difícil de determinar y si se tuviera que establecer dentro de algún margen, dicho margen sería simplemente un concepto político y no ético, ya que el poder es "la fuerza y la capacidad de controlar a otros"137. De acuerdo a la comprensión del poder como decisión, el cual es entendido como un concepto funcional y libre de toda valoración, el poder no transforma una situación o conjunto de hechos desde una perspectiva ética en buena o mala. De esta manera, el poder político involucra "la posibilidad o función de tomar o determinar una decisión, así como la capacidad de obligar a sus destinatarios a obedecerla"138. De acuerdo a la comprensión del poder como temor, concepción elaborada por el utilitarismo, el poder es "un medio para un fin", en el que el fin será cualquier aspecto que el ser humano defina como placer y evite el dolor. Alcanzar determinado placer involucra la utilización de medios para la obtención de dicho placer, los cuales serán las acciones de otros hombres que se obtendrán a través de la utilización del placer o el dolor ${ }^{39}$. En definitiva, para el utilitarismo será el miedo ${ }^{40}$ el mejor instrumento de conformidad de las acciones. El poder se nos presentará también como un hecho que, descrito por Duguit a través de su doctrina realista y positiva como él mismo la define, no posee en sí mismo carácter alguno, ni legítimo ni ilegítimo, siendo simplemente el producto de la evolución social. Consecuentemente, en todos los

${ }^{36}$ SCHMITT (1962) Pp. 83, 89, 90 y 92.

37 SARTORI (1988) Pp.51 y 52. Cuando Sartori habla del poder como sinónimo de fuerza, se refiere a utilizar esa fuerza aun cuando ello signifique disponer de la vida respecto de quienes se ejerce, como lo dijimos anteriormente para el autor el poder es simplemente exercitium: el ejercicio del poder.

38 LOEWENSTEIN (1976) p.27

${ }^{39}$ Para el autor utilizar el placer implica que cuando una persona es quien posee los objetos de deseo y placer al otorgárselos a las demás personas y provocarles bienestar tendrá asegurada la conformidad, e incluso a mayor cantidad de objetos de deseo que entregue mayor conformidad tendrá. Escenario contrario es el del dolor, toda vez que puede ser que algunas personas desprecien en placer y no sigan órdenes, pero es muy improbable que alguien quiera someterse al dolor por sola rebeldía. Por ende, este último es el más efectivo instrumento de obediencia, pues el riesgo de ser objeto de la aplicación de dolor de forma ilimitada provoca la sumisión automática.

40 MiLl (1997) Pp. 28,29, 30 y 31. 
grupos sociales siempre existe el hecho transversal de que los "fuertes imponen su voluntad a los más débiles". En consecuencia, "siempre hay individuos más fuertes que otros que cuando quieren y pueden impondrán su voluntad sobre otros"41.

Sin perjuicio de lo anterior, creemos que cuando hablamos de poder no estamos frente a un ente abstracto que exista por sí mismo, así como tampoco estamos frente a una fuerza pura (ya sea en la forma de decisiones o temor), sino que estamos frente a una construcción social que puede tomar tantos caminos como intenciones humanas existan y que, sólo en virtud de la necesidad de protección y la inseguridad del ser humano, nace como ente organizativo. De allí que podamos diferenciar necesaria e inmediatamente entre el poder $y$ el simple poderío. Este último se identifica por la utilización de algún mecanismo de opresión ya sea físico, económico, religioso, entre otros, ejercido contra un sujeto determinado a fin de que realice una acción determinada sin ninguna validez que la justifique, por una mera intención particular, sin ninguna finalidad de carácter común. Por otro lado, el poder propiamente tal es resultado de un actuar racional que debe estar enmarcado dentro de ciertos límites de respeto irrestricto de la persona humana, precisamente de su libertad e igualdad, encaminado lógicamente a un fin justificado de protección, seguridad y bienestar.

Si comprendemos que el poder no está formado por un solo elemento que implique imponerse por fuerza o temor, reconocemos en la explicación de Alberto Montoro una acertada comunión respecto a los elementos que componen el poder. Para el autor, el poder nace fruto de un proceso que concluye en una síntesis ${ }^{\mathbf{4 2}}$ de dos factores, uno espiritual y otro material. El primero es la autoridad, la cual es el factor que induce a la obediencia, legitima el poder e incluye comprender el derecho a mandar y emitir órdenes. El segundo corresponde a la fuerza que se aplicará en el caso de no ser cumplidas dichas órdenes voluntariamente. Conforme a lo anterior, el poder se presentará a lo largo de la historia en diversas manifestaciones que se caracterizarán por su grado de intensidad, naturaleza expansiva y el grado de institucionalización del mismo. Por tanto, su fortalecimiento, crisis o disolución serán determinantes en el desarrollo organizativo de los pueblos.

${ }^{41}$ Duguit (1926) p.25

42 Montoro (2004) Pp. 125 y 129. 
Es por lo antes descrito, que sólo cuando se incorporan al proceso de mando o de imposición del poder elementos tales como el consentimiento $y$, en consecuencia, la obediencia a un poder determinado, será cuando estemos frente al verdadero poder político. Este último será aquel que articula y entrega organización al orden político de un pueblo, y será el instrumento que mediante el Derecho dotará de cohesión y firmeza a un orden social, el cual establecerá sus propios fines, garantizará e impulsará su cumplimiento ${ }^{43}$. El poder político surge como un gen ordenador y estabilizador de las sociedades y comunidades que, ciertamente, se presentará inicialmente por la fuerza, pero que nunca podrá subsistir como tal sin el consentimiento o el elemento espiritual, es decir, sin contar con la legitimidad. Es por ello que coincidimos con Montoro cuando se refiere al poder como un proceso de síntesis entre dos factores. Tal como recalca Constant, no existen más que dos poderes: uno ilegítimo -la fuerza- y otro legítimo -la voluntad general-, puesto que aun cuando el poder se concentre en unos pocos, si éste es sancionado por el asentimiento de todos, ese poder se transforma en voluntad general ${ }^{44}$.

Para Pérez Royo, el poder político sólo empieza a serlo desde el momento en que precisamente divide a la sociedad en clases estamentales y antagónicas, compuestas por los que mandan y los que obedecen. Dicha división social implica que sólo un grupo ejercerá realmente el poder. La forma en que lo ejerza será la raíz de nuestro problema de investigación. En toda ocasión en que se sitúe a ambos grupos en posiciones opuestas, será necesario contar con un elemento de control que establezca un orden entre ambas y, a su vez, haga surgir la necesidad de establecer una forma de organizar dicho poder político. Esta organización dependerá de las relaciones que finalmente se establezcan entre dichos grupos antagónicos, los que finalmente darán origen al estado de clases ${ }^{45}$.

Tal como hemos planteado, el poder no sólo puede imponerse por quienes se encuentren en una posición de supuesta superioridad física, sino que también requiere idealmente de una superioridad moral y de una contramanifestación humana basada en la creencia, credibilidad, legitimidad y confianza para poder consolidarse y actuar de forma válida. No es suficiente la fuerza, pues ella en algún momento decaerá ante otra forma de fuerza mayor que aspire a ejercer el poder. En el caso de ocurrir lo antes descrito, se configuraría una lucha constante y violenta

\footnotetext{
43 Montoro (2004) p. 126.

${ }^{44}$ CONSTANT (1989) p. 8.

45 Perez Royo (1980) p. 107.
} 
por el poder que sólo generaría inestabilidad en el desarrollo de los pueblos y, con ello, una serie de complicaciones en la esfera social e individual. Con esto queremos demostrar que, si bien el poder es algo natural y necesario, estará siempre ligado a la fuerza $y$, por ende, a la superioridad de algunos que imponen su voluntad. No obstante, obviar por completo a los sometidos, a los súbditos o a los gobernados es pretender ver una sola cara de la moneda. Debido a que los seres humanos comprenden las razones y fines que originan la necesidad de ser dirigidos $y$ gobernados, es posible comprender con ello lo justo y útil de la existencia de esta estructura de mandantes y mandados que se justificará mediante pactos o contratos sociales, cuyo producto será la obediencia como factor esencial del poder político.

Para proseguir con nuestro planteamiento, traeremos a un autor que también explica y fundamenta lo antes expuesto. Maurice Duverguer estima que el poder político está compuesto de dos elementos ${ }^{46}$ : a.- elemento coacción y b.- el elemento legitimidad, de acuerdo a los cuales debe actuar necesariamente el segundo antes que el primero. La legitimidad consistiría en contar con la íntima creencia de que es válido ser coaccionado por alguien para realizar determinadas acciones, o sea, tener la convicción de que es bueno, justo y legítimo dicho poder ejercido. Por su parte, el primer elemento, la coacción, implicaría solamente una eventual posibilidad de aplicar sanciones a quienes actúan en sentido contrario. Como podemos evidenciar, Duverguer plasma del mismo modo un elemento interno del poder, casi de orden espiritual, sin el cual éste no logra establecerse como tal. Debido a esto, el poder político como proceso será comprendido como un "poder consensual" cuya finalidad será conducir y guiar a la comunidad. Un poder consensual poseerá un fin justo y deberá presentarse bajo condiciones tales como la influencia. Esto significa que las personas deben creer que quien manda tiene derecho a hacerlo, lo cual configura con ello la legitimidad, sin olvidar sus derechos y garantías. Además, quien detente el poder debe contar con un proyecto que responda a los intereses de los gobernados ${ }^{47}$ y establezca comunicaciones dotadas de una elaboración razonada en directa armonía con las creencias de la mayoría de la población ${ }^{48}$.

\footnotetext{
46 Duverguer (1970) Pp. 26, 27 y 28.

${ }^{47}$ González se refiere al proyecto como un "chantaje" toda vez que el mismo puede solamente ser una simple sumatoria de promesas.

48 GONZÁLEZ (1980) Pp. 21, 22 y 24.
} 
Comprendido el poder político como una síntesis de dos factores que confluirán en un mecanismo consensual en búsqueda del orden y la paz social, será de suma importancia la legitimidad y la obediencia para garantizar su estabilidad. Con respecto a la obediencia, Aristóteles señalaba que una persona debe ser capaz tanto de mandar como de obedecer, y que un gobernante no puede mandar de forma correcta si no ha obedecido antes ${ }^{49}$. Es innegable que la obediencia es un elemento esencial del poder, pues, tal como manifiesta Sánchez Agesta "no manda quien quiere sino quien puede, quien encuentra obediencia"50. No obstante, es también necesario establecer por qué se obedece. En este orden de ideas, Schmitt otorga someramente algunas razones por las que la obediencia puede ser entendida como una forma de confianza, miedo, esperanza o desesperanza. Sin embargo, el autor agrega que siempre habrá una necesidad aún mayor: la necesidad de protección ${ }^{51}$. Será de esa relación protección-obediencia de la cual nace el consenso social. En consecuencia, develar los motivos o razones que logren generar obediencia en las personas es el elemento central para comprender el poder. Así lo expresó Bertrand de Jouvenel cuando señala que "conocer las causas de la obediencia es conocer la naturaleza del poder ${ }^{\prime \prime 52}$. El mismo autor planteará que, desde esta perspectiva, lo que hace soportar el mando es solamente un hábito ${ }^{53}$, el que se manifiesta a través de la costumbre y solamente se cree en éste porque se tiene la convicción de que puede alcanzar finalidades positivas para el conjunto. El francés denomina esta finalidad como la "capacidad bienhechora del poder", la posibilidad de generarles el bien común ${ }^{54}$.

En este contexto, y para comprender de mejor manera la obediencia, es menester recurrir a Max Weber, para quien las personas obedecen o siguen a una autoridad debido a la existencia de razones como la presencia de una voluntad de obedecer y por confianza en que el cuadro administrativo ${ }^{55}$ del gobernante realizará

\footnotetext{
49 ARISTÓteles (1970) P .75.

50 SANCHEZ (1945): P. 143.

${ }^{51}$ SCHMITT (1962) P.68.

52 De Jouvenel (1974) Pp. 22, 23,24 y 25

53 Para Jouvenel las personas son gobernadas o "mandadas" principalmente como resultado de las constantes guerras y la invasión lo cual implica la llegada de otros sujetos que ordenan, coordinan y establecen las normas de forma que estimen conveniente, por su parte las personas de las localidades invadidas no desean íntimamente ser lideradas por ellos o por otros, sino que simplemente no tienen más caminos que seguir que obedecer a quien ejerce la fuerza, motivo que finalmente provoca su aceptación a las nuevas condiciones y finalmente se transforman en su realidad de vida por ende en su costumbre. Bajo estos argumentos expone también el francés la expansión del poder, pues su crecimiento depende de la guerra y junto con ello del desarrollo de su ejército y de la posibilidad de aplicar y definir impuestos.

54 De Jouvenel (1974) Pp. 27 y 28.

55 Weber (1964) Pp. 39 y 43. Al referirse al cuadro administrativo simboliza con ello al grupo de hombres que junto al dirigente tienen el poder de representación y serán quienes ejercen los poderes y funciones
} 
las acciones que los que obedecen esperan de él. Sin embargo, los motivos que provocan la voluntad de obedecer pueden ser de la más diversa naturaleza, puesto que todos pueden ser válidos o aceptables, pero será sólo la creencia o elemento interno la que da origen a la legitimidad. Una vez que se goza de su presencia puede existir un orden válido ${ }^{56}$. No obstante, tal como lo hemos planteado, el fin último de la obediencia, pese a su ambigüedad, es un factor clave para la estabilidad del poder.

Por otra parte, este factor fue interpretado por David Hume como un nuevo deber que se le impone al hombre, deber que ha de inventarse para dar apoyo a la justicia y a los vínculos de equidad que se intentan construir entre las personas a fin de mantener un orden social, dado que la obediencia -o sometimiento en los términos de Hume- no se produce simplemente por consentimiento, ya que de ser así los seres humanos en el momento de haber comprendido el valor de la paz y el orden, siempre habrían vivido en armonía. En contradicción con esto, y tal como señala Hume, el hombre sólo presta su obediencia por miedo o por necesidad y no por respeto a una idea o fidelidad a una obligación moral ${ }^{57}$.

En consecuencia, el poder en sí mismo siempre reunirá fuerza y voluntad, pero sólo una vez que se ha tomado conciencia de los perniciosos efectos que produce el desorden, las virtudes del orden y de la paz harán posible justificar y legitimar el poder mediante las diversas teorías del origen del poder. De este modo, son las teorías contractualistas las que establecerán las bases más significativas en la búsqueda del anhelado límite del poder a través de la defensa de la libertad, materializada en las declaraciones de derechos esenciales. Sin perjuicio de lo anterior, en todo gobierno u organización social siempre existirá, tal como recalca Hume, una lucha intestina y perpetúa entre la autoridad y la libertad ${ }^{58}$. En esta disputa, y de modo permanente, una de ellas intentará vencer a la otra. El poder -como ya ha sido señalado- es un elemento connatural a la persona humana, por

de gobierno. Similar designación es la que realiza Bertrand de Jouvenel en su obra "El Poder" respecto de este mismo grupo de funcionarios y personas de confianza que rodean a quien ejerce el poder, a quienes denomina como "Cámara de Maquinas". Respecto de selecto grupo de personas consideramos interesante traer a colación lo descrito por Schmitt en sus "Diálogos sobre el poder" donde describe que las relaciones con poder pueden ser directas e indirectas, con ello el autor explica el complejo juego que se produce entre aquellas personas que desean fuertemente influir en las decisiones del poder, por ende, intentan acercarse de los más diversos modos al gobernante $y$, como este a su vez deposita sus verdaderas confianzas en aquellos que menos lo requerían, (ejemplifica lo anterior en las figuras del chofer o amante).

56 WeBER (1964) p. 170.

57 HUME (1965) Pp. 43 y 55.

58 HUME (1965) p. 45. 
tanto siempre existirá una predisposición instintiva hacia obtener la sumisión de los gobernados y en la que, a su vez, los hombres de una comunidad no aceptarán fácilmente ser sometidos, ya que se negarán en definitiva a perder su libertad.

Aquí se origina el conflicto político inicial respecto a la organización normativa de la política. La pregunta asociada al cómo lograr un justo equilibrio entre el derecho a mandar y el respeto a las libertades esenciales de las personas ha sido central en el debate, puesto que la libertad es exponencialmente más frágil conforme a la mayor extensión e intensidad del poder. Es así como arrebatar o despojar la libertad de las personas fue un hecho frecuente en el pasado, y lo sigue siendo hasta hoy. Nos recuerda Panebianco que el poder político es potencialmente peligroso para la libertad, puede si quiere amenazarla y, en casos extremos, devorarla. Alcanza llegar a ser más peligroso que otros poderes, tales como el económico o religioso, pues éste cuenta con la posibilidad de utilizar los instrumentos de coacción física ${ }^{59}$.

Así, la alteración de la libertad como derecho y condición humana se produce generalmente por el uso abusivo de poder. Evidencia de esto, fue el periodo absolutista y todas las arbitrariedades que motivaron la necesidad de diseñar y de recurrir a distintas herramientas políticas y jurídicas que pudieran evitar tal fenómeno de agravio hacia la humanidad. La evidente susceptibilidad de la libertad en cuanto a la facilidad con la que puede ser privada, y todos los efectos negativos que ello habría generado durante los Estados absolutistas, fueron las imperiosas razones que impulsaron el nacimiento de las teorías liberales. Dicho pensamiento comprendió que la libertad era un fenómeno frágil. En palabras de Laski, era totalmente necesario dificultar la facilidad con la que ésta se podía suprimir mediante el establecimiento de derechos que fueran reflejo del peso de una tradición ${ }^{60}$. Las nociones liberales se extendieron y fueron profundizadas al hacer hincapié en la necesidad de proteger la libertad de los extensos brazos del poder. Por esta razón, se diseñaron pactos, contratos y la teoría de la soberanía nacional como medios de protección de las libertades individuales, la legitimación del poder y la garantía de ciertos derechos esenciales.

\footnotetext{
59 PANEBIANCO (2009) Pp.27 y 28.

${ }^{60}$ LASKI (1932) p.16.
} 


\section{b) El pacto social, el constitucionalismo de las revoluciones $y$ el cambio en el paradigma del poder}

Como bien es sabido, durante los siglos XVI al XVIII Europa se encontraba regida por estados absolutistas, bajo una fuerte influencia filosófica ${ }^{61}$ que postulaba fundamentalmente la supremacía del Rey como expresión del poder unificado -sin límites temporales- consecuencia de una divinización del origen del poder. Esta concepción naturalista y cristiana establecía que dicha potestad de gobernar tenía su origen en Dios, quien como creador de la naturaleza creaba también sus fines $y$, conforme a esto, los medios para alcanzarlos ${ }^{62}$. El origen divino del poder justificó la existencia de reyes y de monarquías en su variante sobrenatural ${ }^{63}$, en la cual Dios crea al poder público. Junto con ello, designa a la persona que debe ejercer dicho poder y, posteriormente, serán los hombres quienes se encuentran investidos de él y quienes lo delegarán o lo depositarán en un monarca. Como podemos observar, el primer postulado sobrenatural no hace más que confirmar que la división de clases entre gobernantes y gobernados, es decir, la estructura del poder es producto simplemente de un hecho inevitable, sobre el cual el pueblo no tiene más participación que aceptarlo pues su consentimiento no juega ningún rol frente a la voluntad de Dios. En la segunda variante de carácter providencial, se produce una revelación según la cual se establece que el verdadero detentador del poder es la comunidad, la que a través de un acto simbólico lo delega en un monarca. Tal interpretación no excluye el origen divino del poder, sino que solamente modifica el motivo por el cual llega tal poder al monarca. Por ende, será a través de la voluntad de los hombres que por delegación o transferencia lo pondrán en manos del Rey ${ }^{64}$.

Dicha corriente de delegación del poder intenta hacer partícipe a los gobernados del proceso de organización del poder, aunque de manera muy débil, dado que dichos argumentos no hacían más que insistir en justificar el poder a través de argumentos teológicos. De este modo, con la idea de "pacto" se busca reforzar el vínculo entre rey y pueblo, pero sin ninguna garantía ya que en el momento en que

\footnotetext{
${ }^{61}$ Postulada fundamentalmente por Santo Tomás de Aquino, Nicolás Maquiavelo, Bodin, Thomas Hobbes y Suarez (estos últimos con la variante del pacto político),

62 AlberTi (1980) Pp. 163, 164 y 165.

63 Duguit (1926) Pp. 17 y 18.

${ }^{64}$ Alberti (1980) Pp. 218 a 223.
} 
esto ocurría no había ni libertad, ni democracia, ni mucho menos esbozos de constitucionalismo ${ }^{65}$.

Conforme a dicho ordenamiento político-jurídico, se establece un Estado absoluto monárquico que no es más que una autoridad impositiva $\mathrm{y}$, por tanto, no proteccionista. Este Estado se presenta como entidad ordenadora y unificadora, dentro de la cual fueros y privilegios estamentales, institucionales, locales o personales evidencian los tratos desiguales de la Corona para con el pueblo. Dentro de las máximas atribuciones del monarca, quien como ya hemos señalado posee un poder absoluto, se le concedía la facultad de crear la ley, además de estar por sobre ella. Reflejo de tal tipo de poderío es graficado en los postulados de Bodin, defensor de la centralización del poder absoluto en la figura del monarca, quien señala: "después de Dios nada hay sobre la tierra que los príncipes soberanos, instituidos por El como sus lugartenientes para mandar a los demás hombres"66. Tal poder de carácter absoluto y perpetuo se presenta totalmente desvinculado de control 0 límites institucionales. Así también lo establece el mismo autor cuando describe que el poder soberano de un monarca es una soberanía que debe ser recibida sin condiciones de ningún tipo, ya que no acepta divisiones ni limitaciones ${ }^{67}$.

Durante el siglo XVI, las monarquías no eran objeto de control o límites jurídicos o políticos. Autores como Grassaille, Seyssel, Vitoria, Erasmo y el mismo Bodin coinciden en tal concepción del poder absoluto ${ }^{68}$. Sin embargo, éstos mismos recalcan que en el caso de existir limitaciones, ellas no son más que la ley natural, el cristianismo o la misma razón del rey. Consecuentemente, el único control al que se somete al rey es su propia conciencia. Esta situación se agudiza aún más para el pueblo, ya que las leyes tampoco fueron un instrumento de protección ciudadana, dado que era el mismo rey quien las dictaba. En tal escenario, el Derecho Constitucional era más bien de carácter consuetudinario, sin facultades de garantizar ni derechos, ni seguridad, ni orden, ni protección a los ciudadanos. Debido a esta situación, sólo existe una subordinación de derechos individuales y colectivos al Estado absoluto.

65 Crossman (1958) p. 47

66 BODIN (1985) p. 72.

67 BODIN (1985) Pp. 49, 50 y 51.

68 TOUCHARD (1981) Pp. 197-200 y 205-206. 
La nula participación y consideración de la población en torno a la estructuración de las relaciones de poder y el inexistente respeto de sus derechos y libertades, fue paulatinamente objeto de diversos cuestionamientos. Estos cuestionamientos cimentaron, a su vez, los pilares para la modificación de la organización política y jurídica. El quiebre intelectual y científico se produce con la llegada del Renacimiento, la Reforma, la Ilustración y el Liberalismo, los cuales remecieron todos y cada uno de los pilares que resistían el origen divino del poder y la construcción social en general. En este contexto, hombres y mujeres desarrollan y experimentan una de las más importantes trasformaciones del pensamiento político, a través del proceso por el que se reconocen a sí mismos como portadores del poder soberano, libre de dominaciones divinas, capaces de organizarse, dignos de respeto y protección. La metamorfosis política y jurídica presenta dos factores esenciales: uno religioso y otro económico. Por una parte, la Iglesia que estaba presente en todas y cada una de las esferas de desarrollo social, exhibe una conducta carente de toda moralidad. Por otra parte, el crecimiento económico basado en la propiedad y el mercantilismo cimentaron el surgimiento de una nueva clase social que protagonizará las posteriores revoluciones: la burguesía. En definitiva, se produce lo que Crossman califica como la "época de colapso moral"69.

El ingreso a la arena política del "pacto político", sustentado fundamentalmente por Suárez, Marina, Hobbes y luego por Locke, impulsa la idea de que el consentimiento popular, entendido como forjador del poder del Estado civil, implica concebir al hombre total y esencialmente libre. Debido a esto, en el caso de ser sujeto a un poder, deberá serlo bajo su consentimiento.

En efecto, Hobbes inicia su exposición en el Leviatán realizando un importante reconocimiento respecto a los hombres al considerarlos iguales en cuerpo y alma. Asimismo, añadirá que éste se encuentra en un estado de naturaleza en el cual se encuentra en permanente guerra ${ }^{70}$. Estas razones justifican, a juicio de Hobbes, el establecimiento de un poder consensual pero absoluto que aleje al hombre de aquel estado y que, en un nuevo estado civil, se garantice lo que él describe como la primera ley natural, la que dictamina: "la paz y la conservación de los individuos", en la que se crea así el gran Leviatán. Desde esta nueva perspectiva de la configuración del poder, el autor cambia el paradigma medieval de la relación pueblo-soberano y

${ }^{69}$ CROSSMAN (1958) p. 40.

70 HobBes (1989) Pp.105 y 107. 
declara la existencia de un contrato que se consuma entre soberanos ${ }^{71}$. Sin embargo, la existencia de este contrato solamente permite justificar el establecimiento del poder con tintes de inclusividad, más no altera esencialmente las amplias facultades reunidas en el monarca. La indivisibilidad de la soberanía es garantía de paz, seguridad y protección en el pensamiento hobbesiano y el poder seguirá sin limitaciones más que la ley natural y la ley divina ${ }^{72}$.

Por su parte, el pensamiento revolucionario ilustrado posee un exponente insigne. Los postulados de Jean Jacques Rousseau constituyen elementos de vital importancia para sustentar las nuevas formas organizativas del Estado moderno. Para el filósofo, un convenio será vano y contradictorio si, por un lado, sólo hay una autoridad absoluta, y, por otro, obediencia sin límites ${ }^{73}$. Es por ello que al establecer la noción de "contrato social" cada uno se une a todos sin obedecer a nadie más que sí mismo. En esta condición, los sujetos quedan tan libres como antes de la celebración del contrato social. Es por esta razón, que se da nacimiento a un cuerpo moral y colectivo que se expresa a través de la voluntad general, la cual obliga a favorecer a todos sus integrantes, situación que en el ideario de Rousseau no admite posibilidad alguna de perjudicar a sus integrantes, toda vez que nadie puede perjudicarse a sí mismo ${ }^{74}$.

Por consiguiente, el pensamiento de Rousseau da origen a la supremacía del pueblo como gestor de las directrices del Estado, el cual además se encuentra fortalecido al atribuírsele la potestad legisladora, la que se manifiesta a través de la voluntad general. Esta nueva y trasgresora postura lleva implícita la idea no sólo de reconocer el origen del poder en el pueblo, sino que además comienza a dar luces de la limitaciones que el mismo poder deberá sufrir a consecuencia de la existencia de esta voluntad general expresada en forma de ley. De este modo lo explica el autor cuando señala que "no hay que preguntar ya a quién pertenece hacer las leyes, puesto que son actos de la voluntad general y ni el príncipe está por encima de las leyes, puesto que él es un miembro del Estado" ${ }^{\prime 75}$.

\footnotetext{
${ }^{71}$ HOBBES (1985) p. 145.

72 HOBBes (1985) p. 267.

73 ROUSSEAU (1980) p. 32.

74 Rousseau (1980) Pp. 38, 41 y 56.

75 Rousseau (1980) p.62.
} 
Bajo esta rupturista interpretación de las relaciones de poder, Rousseau declara que el gobierno no es más que un cuerpo intermedio que recibirá órdenes del pueblo en su calidad de súbditos y soberanos, cuya finalidad no es otra que la libertad e igualdad de los ciudadanos. El autor sitúa finalmente el origen, fin y objetivo del poder en manos del pueblo, por ende, el Ejecutivo queda subordinado a él ${ }^{76}$. De acuerdo a sus postulados, el límite del poder es, precisamente, el pueblo y a través de aquella interpretación establece la más fuerte barrera y limitación al poder del rey, puesto que despoja a éste de la posibilidad de legislar y lo subordina a la voluntad general. Sin embargo, no establece límites a la voluntad del pueblo más que la razón de sus integrantes.

Hasta este estado del arte, las modificaciones filosóficas se posicionan en dos direcciones: por un lado, la conceptualización del pacto deposita el poder en manos del pueblo, interpretación que en palabras de Hobbes implicaba la entrega del poder a un soberano en su totalidad y, por otra parte -a juicio de Rousseau-, la delegación era solamente parcial, puesto que tal poder siempre lo mantiene el pueblo porque él es el soberano. Conjuntamente, con estos matices en torno a la concepción de la delegación del poder, se cuestiona el rol que ha de jugar la voluntad general. Según Fioravanti, tanto Hobbes como Rousseau consideraban que la protección de derechos no podía depender del equilibrio de poderes, sino que debía estar tutelado por la fuerza de una ley general y abstracta. No obstante, Rousseau planteó un argumento particular puesto que instala la noción de desconfianza respecto de los gobernantes $y$, en este sentido, expuso que la aplicación e interpretación de la norma podía ser vulnerable ante la conquista corrosiva de gobernantes e intereses particulares. Debido a tal motivo, Rousseau consideraba indispensable que el poder del pueblo continuara vigente en sus manos y que éste pudiera revisar el contrato y sus términos cuando fuese necesario, incluso la facultad de hacer la norma. Es por ello que el pueblo delega su poder parcialmente sin cederlo por completo. En definitiva, no podía vulnerarse de ninguna manera la voluntad general del pueblo soberano, lo cual tiene por consecuencia la construcción del mandato imperativo ${ }^{77}$. Empero, dichos argumentos generan inseguridad jurídica, toda vez que se pone en entredicho la estabilidad del pacto constitucional que encontrará una réplica en el constitucionalismo liberal que analizaremos posteriormente.

\footnotetext{
76 ROUSSEAU (1980) Pp.76, 82 y 83

77 FIORAVANTI (2014) p.33.
} 
Por su parte, John Locke construirá la teoría del pacto social fruto del consenso de los hombres, quienes libremente desean dejar de lado el estado de naturaleza en el cual el peligro y la desprotección crean sólo inseguridad. En este sentido, las personas deciden fundar una sociedad civil, cuando cierto número de personas se unen en torno a renunciar a la facultad de ejecutar la ley natural. Solamente en ese momento estamos frente a la sociedad política o civil $^{78}$. Siguiendo el camino trazado por este pensador inglés, se otorga especial énfasis a la protección y conservación de los derechos, ya que para Locke la autoridad política se origina para perfeccionar un orden anterior. Debido a esto, no bastará con la creación de una ley y su fuerza, sino que deberá ser interpretada de forma imparcial por la judicatura y aplicada correctamente por un Ejecutivo vigoroso. Como consecuencia de esto, surge la división de poderes como instrumento que perfecciona la protección de los derechos. En dicha dirección, el Poder Legislativo es el más relevante puesto que mediante éste se realiza tal perfeccionamiento en la tutela de derechos. Sin embargo, aquel Poder Legislativo no puede disponer de modo arbitrario de los derechos, ya que para Locke aquellos derechos son preexisten al poder, por lo que éste sólo debe velar por su cautela ${ }^{79}$.

Los postulados de los pensadores antes descritos, comienzan a dar paso a los nuevos tipos de organización estatal, arquetipos políticos que alterarán los cánones tradicionales. En este orden de ideas, la necesidad de posicionar el poder fuera del contexto religioso da inicio al proceso de secularización del mismo. Los criterios de legitimación del poder son cuestionados y con ello toda la simbología política y jurídica se ve alterada. Una sociedad cansada de las guerras religiosas y el sometimiento del cual era víctima, da lugar a un período de replanteamiento de su propia realidad. Fundado esencialmente en la libertad, igualdad y en los derechos esenciales, se introduce el pensamiento de que sólo el consenso social del pueblo puede originar el poder y a su vez delegarlo. De este modo, se produce un cambio de domicilio político del poder y con ello de sus actores protagónicos: el pueblo deja de ser un mero espectador de una realidad en la cual no tenían posibilidad alguna de interferir y se posiciona, de modo paulatino, como el constructor político y jurídico de su propia sociedad. De allí la importancia de la labor desarrollada por las teorías pactistas, dado que al explicar el surgimiento de la relación mandante-mandatario mediante argumentos diversos a las reinantes y simplistas ideas, casi mitológicas y

\footnotetext{
78 LOCKE (1969) Pp. 65, 66 y 67.

${ }^{79}$ FioRAVANTI (2014) p. 35.
} 
teológicas, relativas al origen del poder, no contribuían en nada al desarrollo de la consagración del respeto y la libertad individual.

Aspecto culminante en tal proceso de liberación popular fue el razonamiento de Emmanuel Sieyés, en la elaboración de la noción de soberanía nacional. De acuerdo al autor, esta soberanía contribuye a mermar aquella diferenciación de roles y clases, y con ello las profundas desigualdades generadas entre los detentadores del poder y, en particular, sus círculos cercanos de mando ${ }^{80}$ y el resto de la población o Estado llano. El autor estableció las causas por las cuales ve necesario instituir una única jerarquía que debe existir y nacer a través de la soberanía. Sólo a través de ésta se deben graduar los poderes, y sólo en ella se podrán establecer graduaciones de superior a inferior. Fuera de este espacio de organización, todos los ciudadanos son iguales ante la ley ${ }^{81}$. Este fenómeno acarrea la creación de la primera gran barrera a los poderes absolutos de la Corona. Para Sieyés sólo hay un soberano: la Nación.

A través de este autor se perfila una reivindicación de derechos y dignidades del pueblo, planteando la desigualdad y los atropellos de los cuales el pueblo había sido víctima y respecto al cual sus derechos políticos y civiles eran nulos. A nuestro juicio, es el teórico francés quien construye los fundamentos de mayor trascendencia para el desarrollo constitucional y político moderno, toda vez que bajo un elemento cardinal, la "unidad", construye dos aristas de necesaria concurrencia para la conformación y organización política del Estado. Como primera arista, expone que era preciso unificar a todas las clases sociales dentro de los límites del contrato social. Esta unidad abstracta es denominada la nación, la cual define como "un cuerpo de asociados que viven bajo una ley común y están representados por la misma legislatura" ${ }^{\prime \prime 2}$. En un segundo aspecto, Sieyés señala que una vez constituida esta corporación de ciudadanos iguales en derechos, es imperioso unificar la voluntad común de la nación y su ejercicio.

Bajo tales premisas, finalmente el autor concluye que es necesaria la existencia de un gobierno representativo del pueblo de carácter limitado por la voluntad común nacional y que actúe por delegación de funciones. Este gobierno deberá velar por los cuidados públicos de la comunidad. Junto con lo anterior, la nación deberá autodefinirse y organizarse tanto en las formas como en las leyes, para lo cual será

${ }^{80}$ Cabe destacar la dureza con la cual Sieyés se refiere a los grupos cercanos al poder como cuerpos intermedios, masas extrañas e inútiles y perjudiciales para la relación gobernantes-gobernados.

81 SIEYÉS (1988) p.19.

82 SiEYÉS (1988) P.40 y 82. 
necesario dotarse de una Constitución ${ }^{83}$. Según el autor, este texto constitucional reúne ciertas particularidades, puesto que debe ser obra del pueblo en su rol constituyente y diferente del rol legislativo, además de atribuirle un papel esencial de legalidad, pues las reglas de la constitución son esenciales y sin ellas un poder sería ilegal. Con todo, tal como recalca el autor: "el Gobierno no ejerce un poder real más que en tanto es constitucional, sólo es legal cuando es fiel a las leyes que le han sido impuestas" ${ }^{\prime 84}$.

A modo de conclusión, diremos que como consecuencia del cambio de mentalidad imperante -fruto de los movimientos filosóficos e intelectuales-, las sociedades europeas y americanas responderán con manifestaciones revolucionarias y declaraciones de derechos. A través de este proceso, buscarán establecer criterios proclives a imponer limitaciones reales y efectivas al monarca en el ejercicio de su cargo. Tal proceso implicará sacar del ámbito de las facultades del monarca algunas funciones que tuvieran directa vinculación con el pueblo, y colocarlas en manos del mismo pueblo. Por medio de este proceso, el monarca aceptará compartir el poder con órganos compuestos por representantes del pueblo en asambleas pseudo representativas y, luego, en los parlamentos. Este último fenómeno establecerá el surgimiento del régimen representativo, el que además favorecerá el ascenso de una burguesía cada vez más poderosa en términos políticos y económicos. De este modo, se estableció la pauta de lo que será el constitucionalismo, de las revoluciones mediante poderes soberanos legitimados que podrán y deberán imponer la autoridad de la ley. Sin lugar a dudas, la formación del Estado civil fue objeto de diversos estudios e interpretaciones. No obstante, lo relevante es situar en el centro de la construcción teórica de modo irrefutable la libertad y la protección de los derechos.

\section{c) El constitucionalismo del siglo XIX $y$ el poder estatal}

El desarrollo político descrito en el apartado anterior, será reforzado intelectualmente en el marco del pensamiento político decimonónico. Provenientes del positivismo jurídico se promueve el protagonismo del principio de legalidad, la fuerza constitucional y el Estado de derecho. Orientada por la filosofía política y jurídica alemana, la denominada "batalla del estado" volvía a remecer la

83 SIEYÉS (1988) Pp. 103-105 y 106.

84 SIEYÉS (1988) p.107. 
configuración del poder y sus relaciones. Nuevamente el domicilio del poder y la soberanía se ve alterado, en esta oportunidad será el Derecho y el Estado los nuevos fundamentos últimos que contribuyan en aportar elementos en la construcción del Estado civil. En este contexto, los argumentos que justificaban el tránsito de un estado de naturaleza a un estado civil por parte del ser humano vuelven a ser cuestionados. En este escenario, no bastará con un simple "pacto o contrato" para justificar la conformación de una voluntad común o general, sino que será menester la presencia de otros elementos como el derecho contenido en el ordenamiento jurídico. Tales manifestaciones respecto de la mutación en la organización, son exhibidas por el pensamiento filosófico alemán.

Para el filósofo alemán Carl Friedrich, el nacimiento del Estado civil no fue la simple sumatoria de voluntades, sino que fue producto de un proceso evolutivo que dará forma a algo superior. En este orden de ideas, las voluntades estaban supeditadas a algo general o universal cuya finalidad era garantizar y alcanzar los mayores niveles de libertad. De ahí que el autor se refiera al Estado de la siguiente manera: "esta unidad sustancial, como fin absoluto y móvil de sí misma, es donde la libertad alcanza la plenitud de sus derechos" 85 . A lo anterior añade que el "Estado es la realidad de la libertad concreta" ${ }^{86}$. Debido a esto, Hegel gráfica que sólo en el Estado pueden las personas, de forma individual, lograr un pleno desenvolvimiento y reconocimiento de derechos ${ }^{87}$. Dicho Estado para Hegel se ordenará, actuará y expresará a través de la ley y tendrá por límite de sus actos lo universal. Este Estado además configurará un sistema de protección a las arbitrariedades del mismo y del gobierno basado en un sistema jerárquico y responsable ${ }^{88}$. Según Larenz el "espíritu de pueblo" es para Hegel el sujeto concreto de la historia universal y, para la escuela histórica, la sustancia metafísica del derecho y tal espíritu de pueblo es el creador del derecho y del Estado ${ }^{89}$.

\footnotetext{
85 HEGEL (1937) p. 208.

${ }^{86}$ HEGEL (1937) p.211.

${ }^{87} \mathrm{La}$ estructura del pensamiento hegeliano se configura básicamente a través de entes mediadores, así las cosas entre la libertad concreta y el interés universal hay un primer ente mediador, la razón humana que hará que las personas "quieran en y para lo universal" y tengan actividades consientes de ese fin, el Estado se presenta a su vez como un segundo ente mediador conciliador entre lo subjetivo y lo objetivo logrando finalmente la organización racional de la libertad formando lo absoluto.

88 La dialéctica hegeliana permitió reconceptualizar la organización social civil a través de un proceso evolutivo del espíritu histórico que logra constituirse como Estado, es una concepción histórico-política, la que en definitiva devela un contenido metafísico-religioso que está por sobre los interese particulares. Tales argumentos han permitido que Jellineck ubique la dialéctica hegeliana dentro de aquellas teorías que justifican al Estado ética y sicológicamente, restándole total valor pues al igual que Kant no explican la construcción comunitaria de la sociedad civil sino solamente el imperium.

89 LARENZ (1942) Pp. 34 y 38.
} 
Por otra parte, la filosofía moral de Immanuel Kant expone que dejar el estado de naturaleza es dejar la incertidumbre y las ambigüedades proteccionistas. Para poder llegar al estado civil es menester materializar la seguridad mediante un único mecanismo: las leyes, cuyo poder coercitivo será el mejor garante de la libertad y la seguridad tan anhelada. En Kant la razón humana es la que crea el Estado y no solamente un simple pacto o contrato. Éste se constituirá como un progreso homogéneo de la humanidad hacia la libertad y la moralidad, lo que permitirá vivir en la paz perpetua, o sea, en una organización social racional y estable.

De la excesiva racionalización del autor se pueden desprenden dos elementos. En primer lugar, es preciso señalar que el contenido de dichas normas jurídicas parece no ser elemento de análisis relevante porque para Kant basta con formalizar la norma para que ésta sea válida. En segundo lugar, el autor establece que el gran mecanismo de control del poder ya no es el derecho natural o divino, ni una elite ni el pueblo, sino que será el ordenamiento jurídico quien limite al soberano. Por ende, eliminar los antagonismos sólo es posible bajo principios de libertad y dependencia a una única legislación común y de igualdad ${ }^{90}$. De los planteamientos de Kant se puede colegir que se da paso a la soberanía del ordenamiento jurídico y al Estado de derecho en su plenitud.

El Estado de derecho, como institución política limitadora del poder, implica dejar de someter al poder a una persona o asamblea de personas y comenzar a someterlo al imperio de la ley. En este sentido, Hermann Heller explicará que en oposición al hombre medieval, el hombre moderno prefirió someterse a un poder que fuera ininfluenciable e impersonal ${ }^{91}$ como el de la ley. El Estado de derecho que permitió objetivizar la voluntad general, nace con la doctrina de la soberanía del pueblo y configura una legalidad formal que constituía una muralla protectora para los ciudadanos. Con la evolución del Estado de derecho se produce la victoria del orden jurídico y la exclusión del poder de cualquier autoridad originaria.

Ahora bien, si la abstracción jurídica ya había generado alteraciones en la comprensión de la construcción de la sociedad civil y la limitación del poder, los argumentos formulados por Hans Kelsen vendrán a crear mayores discrepancias al suprimir por completo la entidad del Estado y dar total supremacía al ordenamiento jurídico como génesis de la formación social.

\footnotetext{
90 KANT (1985) Pp.14 y 15.

${ }^{91}$ HeLLeR (1995) p.85.
} 
Para Kelsen, sólo un ordenamiento jurídico válido puede dar origen al Estado en el cual los individuos -que representan a una comunidad- actuarán como órgano de la misma, ejerciendo ciertas funciones que se encuentran previamente determinadas por un ordenamiento social que constituye a la comunidad. En el caso del Estado, dicho ordenamiento es de carácter puramente jurídico, el cual es validado conforme al cumplimiento de sus normas para hacerlo eficaz ${ }^{92}$. El positivismo jurídico de Kelsen omite el porqué de la configuración de la sociedad bajo un Estado, puesto que se centra solamente en establecer cómo debe de ser tal organización. Por ende, el Estado es solamente una construcción lógico-normativa.

La "teoría pura del Derecho" pretendió justificar que ni el Estado ni la sociedad crearán las leyes, sino que sólo se identifican con ellas, pues el derecho es un sistema de juicios que la ciencia jurídica creará. El positivismo, en general, y los axiomas de Kelsen, en particular, fueron objeto de fuertes críticas. Una de ellas es la formulada por Larenz al señalar que la "teoría pura del Derecho" no es más que nominalismo jurídico que niega la sustancia ético-espiritual del derecho y que el Estado, al destruir los lazos más profundos que unen al individuo con los valores supra personales, disuelve la comunidad $y$, por tanto, constituye un nihilismo político $^{93}$.

Posterior a la racionalización de la filosofía liberal, el posicionamiento de la Constitución como ley fundamental y carta de navegación de las naciones en términos de principios y valores políticos es eliminado por el positivismo. Debido a esto, se prescinde de todo elemento axiológico y político y se centra sólo en las normas. Esto tiene como consecuencia la reducción de la Constitución, tal como recalca García Pelayo, a pura legalidad ${ }^{94}$. Según este autor, se cambió la concepción respecto de los límites otorgados al Estado que consagraba la Constitución. Ya no serán límites los valores y principios políticos contenidos en ella, sino que solamente lo serán las normas que emanan de él ${ }^{95}$.

Debido a lo anterior, se produce una total desvinculación entre los elementos históricos y sociales primarios de la norma fundamental e incluso de las razones por las cuales ella emerge. El racionalismo jurídico elimina el componente social de la estructura jurídica y excluye el reconocimiento de valores históricos respecto a los

92 KeLSEN (1988) Pp. 215 y 216

93 LARENZ (1942) p.70.

94 García-Pelayo (1984) p.55.

95 García-Pelayo (1984) p.57. 
cuales lo británicos habían fundado su Lly fundamental. Lo anterior, por ejemplo, para Heller no era un atributo positivo, muy por el contrario, con la soberanía del orden jurídico se da comienzo a un proceso de degeneración y descomposición del concepto mismo de soberanía. Esto tiene como resultado la despersonalización y vaciamiento del Estado ${ }^{96}$.

Con la corriente filosófica alemana decimonónica se produce una pérdida de fuerza del derecho natural, tomando impulso un derecho político racional, evolutivo y legalista, con una clara tendencia hacia el establecimiento de un Derecho Constitucional universal. Debido a la insatisfacción de los fundamentos presentados por el derecho natural providencial y racional -toda vez que dichas corrientes no permiten dar una explicación lógica al origen y justificación del Estado y del Derecho, se provoca una conversión del derecho natural al derecho positivo, lo cual da origen a una nueva concepción de la sociedad civil y su organización. El Estado será, desde este momento, un Estado de derecho de tinte proteccionista y verdadero garante de la libertad y la igualdad de las personas. Siguiendo esta misma línea, las leyes tendrán como fundamento los derechos individuales y naturales de todo hombre, anteriores a la sociedad e incluso anteriores al Estado mismo. En conclusión, durante este proceso de desarrollo intelectual, se fortalecen ciertos pilares del constitucionalismo moderno, como la incorporación de la ley como el ente limitador de quienes detentan el poder y los derechos del hombre como el limitador de la ley. Sin embargo, principalmente en esta etapa se sentarán las bases fundamentales del principio de legalidad. Con todo, podemos señalar que en este período de desarrollo constitucional "el poder ha de expresarse en derecho"97, los mandatos jurídicos harán carne al poder y constituirán sus brazos y piernas al volverlo presente, tangible y estable. Por tanto, desde la elaboración de esta concepción, poder y derecho marcharán juntos ${ }^{98}$.

Ahora bien, las doctrinas descritas a lo largo de estos párrafos fueron objeto de fuertes críticas y cuestionamientos. Toda creación innovadora que altera los órdenes establecidos se verá sujeta a los cuestionamientos de quienes a su vez pretenden proponer sus propios postulados. En lo sucesivo, presentaremos algunas de aquellas voces que discreparon con las argumentaciones antes señaladas.

\footnotetext{
${ }^{96}$ HELLER (1995) p.89.

97 SÁNCHEZ AGESTA (1966) p.153.

98 DUVERGUeR (1970) p.41.
} 
En concordancia con lo anterior, es necesario traer a colación los juicios de un pensador crítico que pondrá una nota distintiva en cuanto a su análisis respecto de las teorías descritas, nos referimos a Georg Jellinek y sus rotundos comentarios en este aspecto. El autor señaló que las teorías contractualistas sólo han contribuido a destruir al Estado así como también aquellas que justifican que el derecho antecede al Estado y, más nefasto aún, aquellas que pretenden fijar en el ordenamiento jurídico la razón de ser y origen de la sociedad civil.

Así las cosas, para Jellinek tanto erecho como Estado son consecuencia de la organización de la comunidad humana y son producto de un hecho social, de una construcción comunitaria. Es por esta razón, que este autor señalará que "toda comunidad terrena organizada, que no tenga asociación alguna sobre sí, es Estado" $^{99}$, lo cual demostraba a su vez las condiciones rudimentarias de su nacimiento. Para el autor, todo Estado actual tuvo una forma embrionaria de expresión. En esa instancia fue necesario que el derecho, como única fuente, estableciera una organización y que luego se mantuviera a través del ordenamiento jurídico. En este contexto, lo más relevante del análisis del autor será declarar que Derecho y Estado se encuentran enlazados por una misma finalidad, otorgar seguridad social y jurídica a la comunidad. De este modo, el Derecho como fenómeno social no sólo transforma en normativo lo real, sino que además establece garantías de su cumplimiento a los sometidos al mismo. Estas garantías se materializarán en la sujeción del funcionamiento de los órganos del Estado al derecho a través de los que solamente puede actuar el Estado, dado que están obligados a actuar conforme a la Ley y a la Constitución.

En esta exposición de críticas elaboradas respecto de construcciones doctrinales descritas anteriormente, es menester traer a colación a León Duguit, opositor a las teorías democráticas del ejercicio del poder $y$, por ende, a las teorías que depositan a la soberanía en el pueblo. Este autor advierte los riesgos que ellas generaban, puesto que el poder como hecho social también puede desbordarse en manos de la unidad colectiva. Según el autor, la posibilidad de que se configuren despotismos democráticos o asamblearios es un riesgo existente y latente, razón por la que rechaza la idea de gobiernos populares de Rousseau y Sieyés. Estas propuestas son consideradas para el autor como una "hipótesis gratuita y postulado inútil"100.

99 JELLINEK (1914) p.462.

100 Duguit (1926) Pp. 20 y 21. 
Para Duguit, la relación entre gobernantes y gobernados es un simple hecho social y, por tanto, radicada en el reconocimiento del hecho que siempre existirá un grupo de personas que posea más fuerza y pueda imponerse sobre el más débil. De esta forma, será la fuerza la que determina las relaciones de poder. Sin embargo, la simple fuerza no basta para obtener legitimidad y obediencia, puesto que ésta debe de fundarse en otro elemento. Este elemento es, a criterio del autor, el derecho. El poder sólo será legítimo si es conforme a derecho, razón por la cual el autor recalca que el poder no es más que la "fuerza puesta al servicio del derecho"101.

La relevancia de estos argumentos permite detectar que, si bien los autores clásicos elaboraban sus interpretaciones en base a fundamentos teóricos disímiles, existió un elemento común compuesto por aquel análisis que sitúa al Derecho como el factor esencial limitador y legitimador del poder. En conclusión, el hilo conductor de estas doctrinas tendió a sostener la necesidad de vigilancia del poder y aquello fue precisamente la piedra angular en el desarrollo del Estado moderno y el constitucionalismo. Por consiguiente, a través de la secularización del poder y la teoría de la soberanía, se arriba a una de las más importantes afirmaciones filosóficas: allí donde el poder no está restringido ni limitado, éste se excede.

Debido a esto, los hombres del siglo XVIII elaboraron la noción de frenos y equilibrios del poder como mecanismo principal para garantizar la libertad económica y política. Esto tiene por efecto la liberación de las naciones soberanas de la tiranía. Tal como es manifestado por Whright Mill, la noción de frenos y equilibrios representó en dicha época una fórmula alternativa al refrán "dividir y gobernar". La teoría del equilibrio se funda, a juicio del autor, sobre la idea moral de una armonía natural de intereses, en relación con los cuales la codicia y la crueldad se concilian con la justicia y el progreso ${ }^{102}$.

En definitiva, el constitucionalismo y su división de poderes, aportó un sistema de limitaciones efectivas contra la acción gubernamental. En palabras de Carl Friedrich "el constitucionalismo constituyó un conjunto de reglas que aseguran el "juego limpio", haciendo al gobierno responsable de sus actos"103.

\footnotetext{
${ }^{101}$ DUGUIT (1926) p. 25.

102 WRIGHT (1963) Pp. 229-234.

103 FRIEDRICH (1975) p. 68.
} 
Ahora bien, a modo conclusivo diremos que la gran cantidad de dificultades que había provocado la relación poder-libertad se produce en virtud de aquella doble faz que caracteriza al poder. En ese escenario, este último posee por un lado, la facultad de convertirse en un ente ordenador, protector y unificador de la fuerza y los poderes locales; empero, por otro lado, también puede ser una lamentable herramienta de opresión y vulneración de derechos para una comunidad, impulsando obstáculos y restricciones para los ciudadanos. Precisamente, Jouvenal ha aludido a esta doble naturaleza del poder al señalar que el poder es tanto un ordenador social que genera múltiples beneficios a la comunidad, como un componente de egoísmo que puede incitar las más complejas intenciones en quien lo detente sin ninguna limitación ni prudencia. Es debido a este último componente que el autor hace hincapié en la necesidad de que éste se encuentre vigilado por un cuerpo idealmente representativo ${ }^{104}$.

El poder que ha sido conocido y experimentado durante los reinados autoritarios y absolutistas, provocó el desamparo y temor en la sociedad debido a que llevaba implícito en él un potencial negativo, ya que el amor al dominio es fuerte en el corazón de los hombres ${ }^{105}$ y sus resultados fueron nefastos. Las razones de la extensión o descontrol del poder fueron y serán variadas, puesto que el poder lleva en sí mismo un estigma. En el momento en que éste no es controlado se transforma -debido a su propia naturaleza- en algo malo. El poder contiene una semilla de degeneración y para evitar este peligro deberá surgir en cada época la necesidad de limitar al poder político, lo que implica restringir a sus detentadores y lograr el justo equilibrio con la libertad de los destinatarios. Este procedimiento constituye, a juicio de Loewenstein, el núcleo de la historia antigua y junto con ello el núcleo del constitucionalismo ${ }^{106}$.

Finalmente, el eje central del Estado y del constitucionalismo moderno fue legitimar el poder fundado en una organización equilibrada entre el gobierno y el control de su ejercicio. De esta forma, es posible entender al control como la herramienta indispensable para lograr un justo equilibrio entre poder y libertad. Por ende, una vez transitado aquel camino de pugna entre estos dos factores, sólo el

\footnotetext{
${ }^{104}$ De Jouvenel (1974) Pp. 46, 47 y 144, 145. Cabe destacar que cuando el autor se refiere al cuerpo representativo formula una distinción respecto de quien detenta el poder, si es de origen divino será la iglesia quien realizará la función de control y en el caso que tenga un origen democrático será el parlamento quien cumpla dicha función.

${ }_{105}$ HUME (1965) p.44.

106 LOEWENSTEIN (1976) PP. 28 Y 29.
} 
control del poder se configura como el instrumento imprescindible para mediar entre dichos elementos $\mathrm{y}$, además, para generar un equilibrio en el cual la libertad y la dignidad del ser humano se transformen en realidad. Por otra parte, la relevancia del control del poder como pilar fundamental en el nacimiento del constitucionalismo moderno, esbozó múltiples mecanismos mediante los cuales se concretizaba. De esta manera, el control se expresó mediante factores y construcciones teóricas fundamentales tales como: el derecho la representación política, la rendición de cuentas y la responsabilidad política.

Debido a la diversidad en la creación de instrumentos de control, nosotros con una finalidad metodológica clasificaremos solamente en dos aristas dichas fórmulas diseñadas para limitar al poder, a pesar de que ellas fueron construidas desde múltiples perspectivas y en momentos disímiles. En nuestra interpretación, las limitaciones se reúnen básicamente en dos grandes grupos: por una parte, están las limitaciones jurídicas, y por otra parte, las limitaciones políticas, las que vinculadas entre sí generaron un sistema de equilibrios que pasaremos a examinar. Nuestro planteamiento pretende establecer una diferenciación entre ellos, sustentada en las razones de origen del nacimiento de los controles específicos y -en razón de su naturaleza- con el objetivo de comprenderlos mediante una metodología didáctica que distinga unos de otros.

En primer lugar, las limitaciones jurídicas en nuestra opinión nacerán como aquella herramienta de objetivación del derecho, que promueve la creación abstracta de la voluntad general y la ordenación colectiva cuya máxima expresión es una ley fundamental que lo despersonaliza. Es por ello que toda ley debe emanar de un proceso racionalizado, a fin de garantizar su generalidad y abstracción. Por consiguiente, la norma en sí misma era un elemento de control puesto que hasta el Estado Absoluto en su creación era esencialmente discrecional de la voluntad real. Pero además, no sólo las normas de rango ordinario debían estipular límites al poder, sino que, con mayor preponderancia, las constituciones posteriores a la conceptualización del Estado Moderno ya no serían concebidas como legítimas salvo que contemplasen en el mismo texto constitucional mecanismos de control.

A mayor abundamiento, diremos que el establecimiento del derecho como un mecanismo de control se presenta inicialmente a través de una serie de importantes declaraciones que paulatinamente van edificando al control en sí mismo. En este sentido, examinaremos textos como el Agreements of the people, el Bill of Right, la 
Declaración de los Derechos del Hombre, la Constitución de Estados Unidos y la Constitución Francesa, entre otros, junto con la elaboración jurídica de la noción de control y equilibrios de poderes que posteriormente se plasmará en las restantes normas fundamentales de los estados modernos -lo que ha sido consecuencia del significado que los mencionados textos han representado- .

Por tanto, el derecho en todas sus expresiones y -en especial a través de la Carta Magna- contenía y reforzaba los controles jurídicos y políticos. Tal escenario se ha mantenido hasta la actualidad y ha llevado a autores como Manuel Aragón Reyes a señalar que cuando no hay control no sólo se puede observar el debilitamiento de la Constitución, o la anulación de sus garantías, sino que el hecho de mayor gravedad es que simplemente no hay Constitución ${ }^{107}$. De este modo, los tratadistas de la época de las luces y las revoluciones comprendieron que sólo a través de una Constitución se produce la ordenación concreta de la existencia y actividad política de un pueblo ${ }^{108}$. Debido a esto es que la Constitución se convierte en la columna vertebral de los Estados ${ }^{109}$.

En segundo lugar, la doble naturaleza política y jurídica que posee la misma Ley Fundamental faculta a que en su misma redacción se puedan establecer limitaciones jurídicas y políticas. Por su parte, las limitaciones políticas se expresaron a través de la supresión de las facultades o poderes de la Corona y su depósito en órganos de representación nacional o popular, así como en la división del mismo poder en funciones específicas entregadas a órganos competentes para cada materia. Las limitaciones políticas implicaron despojar de determinadas atribuciones a los gobernantes y ponerlas en manos del soberano, mediante la creación de la representación política y la creación de cuerpos populares, como el Parlamento. Las restricciones políticas configuraron un proceso social y cultural diverso del empoderamiento social, y por tal razón lo analizaremos separadamente. No obstante, su consagración y efectividad depende de su regulación constitucional, por ende, reiteramos que hemos separado el análisis de los controles solamente por una finalidad clarificadora al tratar ambos controles, sin embargo, ellos se encuentran estrechamente ligados y regulados en una matriz común: la Constitución.

\footnotetext{
107 ARAGÓn (1995) p.19 y 65.

108 GARCía-PELAYO (1984) p.26.

109 VALDÉS (2009) p. 24.
} 
También es preciso señalar, que ambas limitaciones políticas y jurídicas se fueron desarrollando de manera simultánea y continuada en el tiempo, a través de un proceso de larga data que solamente trataremos de forma separada para lograr una mayor comprensión de los mismos. Sin perjuicio de aquello, vale recordar que son hechos y fenómenos que se van produciendo de manera sincronizada.

\section{La limitación del poder: una institución del constitucionalismo moderno}

En los párrafos precedentes examinamos y expusimos las razones por las que es necesario limitar el poder. En esta instancia, nos corresponde indagar los mecanismos y técnicas diseñadas para lograr dicho objetivo. Tal como es posible apreciar en lo expuesto hasta el momento, podemos señalar mediante los postulados de Friedrich que la idea de limitación tuvo dos puntos de partida importantes. En primer lugar, la doctrina del derecho natural que se manifiesta en el constitucionalismo medieval y su impulso en versiones secularizadas del derecho natural y el poder. En segundo lugar, el liberalismo filosófico y, en cierta medida, la doctrina cristiana de la personalidad, dado que ambos -debido a sus establecimientos en torno a las nociones de igualdad, libertad y dignidad-forjan otros medios de limitación del poder a través del constitucionalismo moderno ${ }^{110}$.

Por consiguiente, las fuerzas transformadoras del constitucionalismo trajeron consigo un cambio en el tipo y forma de limitaciones al poder. En particular, el constitucionalismo moderno, mediante su evolución, fortalece la idea del gobierno mixto de Aristóteles y la noción de equilibrio de poderes. Asimismo, éste formula una minuciosa teoría de la separación de los poderes del Estado y, a su vez, constituye nuevos procesos en la creación de las leyes a través de la regulación de su aplicación, ejecución e interpretación. Este suceso dio pie al principio de legalidad para, finalmente, depositar en órganos representativos la voluntad del pueblo. Estas fueron algunas de las nuevas formas de limitación del poder que a continuación examinaremos en detalle, respecto de las cuales hemos realizado una diferenciación

${ }^{110}$ FRIEDRICH (1975) Pp. 69-70. 
analítica, a fin de lograr su mayor comprensión. Es debido a esto que las trataremos como limitaciones jurídicas y políticas.

\section{a) Limitaciones jurídicas al poder}

La estrecha vinculación existente entre poder y derecho involucra dos caras de una misma moneda. El derecho es quien organiza al poder, lo institucionaliza, lo limita y lo legitima, pero es el poder el que crea al derecho, lo estatuye y garantiza su eficacia. En consecuencia, es precisamente la dinámica del poder la que articula la evolución del Estado y del derecho ${ }^{111}$.

Tal como ha sido expuesto con anterioridad, durante el período en que el poder descansó en manos de un monarca con poderes absolutos, el derecho era consuetudinario y arbitrario, ya que la ley era producto de las libres concepciones del rey. Es decir, un producto exclusivo de su voluntad y capaz de ser modificado a su libre antojo. Mediante las transformaciones filosóficas relativas a la secularización del poder, el contractualismo y la voluntad general como ente creador de la ley, el derecho se despersonaliza y se vuelve objetivo, dado que se aplica en términos generales sin restricciones de clases o circunstancias sociales. A partir de este momento, el derecho es abstracto. En consecuencia, tal vinculación entre derecho y poder dio lugar a un nuevo sistema de organización del Estado dentro del cual se originará el Estado de derecho. Producto de esta instancia, comenzarán a gestarse las primeras manifestaciones del constitucionalismo moderno.

En efecto, el Estado de derecho surgió como respuesta al Estado Absoluto para luego dar lugar al nacimiento del Estado Constitucional. Este proceso se sustenta en la legitimidad del poder, sus decisiones y la limitación material funcional y temporal del mismo mediante normas jurídicas y procedimientos políticos ${ }^{112}$. De este mismo modo lo expone Adolfo Posada, al señalar que la esencia del constitucionalismo es la aplicación del derecho al Estado en búsqueda de la sumisión del Estado, con su sistema de poderes y funciones, a un régimen de normas que emerge del mismo Estado-pueblo. En definitiva, es un régimen que busca someter a reglas jurídicas al Estado y al Gobierno en virtud de una autodeterminación que aspira lograr con ello la

\footnotetext{
${ }^{111}$ MONTORO (2004) p.130 y 131. Acertadamente expone el autor que la evolución del Estado y sus cambios de absoluto, liberal, de derecho y constitucional impacta directamente a las fuentes del derecho.

112 ARAGón (1995) p. 24 y 25.
} 
protección de sus mismos creadores. En este sentido, la Constitución se expresará como un valor esencialmente histórico que sintetiza la lucha por la liberación humana y la consagración de los derechos del ciudadano113.

La influencia del derecho, en su calidad de limitador del poder, es fruto de un proceso de carácter parsimonioso que presentó diversas etapas y distintas finalidades según su época, razón o fundamento. En este orden de ideas, señalaremos que en el antiguo constitucionalismo, propio de la época medieval, ya se comenzaban a vislumbrar los primeros eslabones de lo que iba a ser el camino hacia la limitación del poder, libertad e igualdad como sus pilares esenciales. No obstante, si bien el antiguo constitucionalismo perseguía solamente la limitación del poder, su finalidad última lo constituía el gobierno moderado y la Constitución mixta, la que solamente procuraba la concreción de algunos específicos derechos (privilegios) sustentados en el principio de igualdad y seguridad jurídica. Bajo un disperso sistema feudal, asentado en un poderío territorial agrícola de autosubsistencia y conformado bajo una división social estamental sustentada en un rigurosa jerarquía de clases social ${ }^{114}$-basada en derechos y obligaciones de la propiedad que desarrollaban los "gobiernos territoriales"115 ${ }^{1}$, surgirán las primeras formas de Estado.

Dicho gobierno de carácter territorial, se caracterizó por la existencia de un señor que ejercía los poderes del imperium ${ }^{116}$ y la existencia de asambleas representativas que cumplían dos funciones: la primera, poner límites al señor al defender los privilegios y ordenamientos de los estamentos; y, la segunda, colaborar en la determinación de tributos y la defensa de las fronteras. Como bien es sabido, en el sistema feudal el derecho se expresaba en reglas de origen consuetudinario que comenzaron a redactarse por escrito, mediante las cuales se forjarán los verdaderos contratos entre señor y las fuerzas presentes en el territorio, los que serán conocidos como "contratos de sujeción"117. El conjunto de dichas normas fue lo que, en definitiva, dio origen a la Constitución del antiguo constitucionalismo. Sin embargo,

\footnotetext{
113 Posada (1930) Pp.7,8 y 106

${ }^{114}$ En la que cada grado debía obediencia al inmediatamente superior, estructura denominada pirámide. Pirámide social que también ha sido denominada pirámide trilateral por estar conformada por tres estamentos, la caballería, per hastam, y per preces.

115 CROSSMAN (1958) p.22

116 Con la denominación imperium se han comprendido en términos generales las facultades de hacer justicia, exigir tributos y llevar las armas.

117 FiORAVANTI (2004) p.14.
} 
dichas leyes solamente aspiraban a mantener privilegios, estamentos y la paz entre una pluralidad de fuerzas que convivían en un mismo territorio.

La variada gama de poderes existentes en dicha época no permitía unificar criterios en torno a la centralización del poder, como tampoco en cuanto a las normas y prerrogativas que regulaban el funcionamiento de las sociedades feudales. De este modo, los límites que se imponían a los gobernantes no eran más que el producto de una tensa negociación relativa a privilegios e impuestos. En este escenario, tampoco el derecho poseía fuerza y orden, ya que era eminentemente consuetudinario. La ley se reducía a costumbre y tradición, dado que las leyes que se reconocían eran concebidas como una "verdad eterna" $y$, por ende, era un derecho que se revelaba y que debía ser descubierto por príncipes, barones y siervos, pues Dios los había dotado de tal don de interpretación. En aquel proceso de descubrimiento de las leyes, se pueden detectar las primigenias manifestaciones del germen del constitucionalismo o, tal como es referido por Crossman, el "espíritu de constitucionalismo"118.

La diversificación de normas y poderes del sistema feudal provocará la necesidad de canalizar la fuerza y el poder en una sola estructura, que permita gozar de seguridad y protección a la sociedad medieval exhausta de guerras y desprotección. En dicho contexto, surge como fórmula de solución la monarquía absoluta, basada en la centralización del poder, el cual no tiene temporalidad superior y está por sobre la comunidad que rige. Junto con ello, la fuerte influencia ejercida por el Vaticano y la imposibilidad de diferenciar el poder civil del espiritual, provocó la reacción de pensadores como Maquiavelo, quien postuló la necesidad de colocar al Estado por sobre cualquier poder espiritual, mediante la centralización de los poderes en el mismo. Mediante este proceso de secularización del poder, se configura una segunda fórmula resolutiva para la eliminación del feudalismo y el nacimiento del Estado absoluto.

Es preciso recordar que, a través del advenimiento de las monarquías absolutas, surgieron múltiples dificultades y obstáculos para el pueblo, pues sería esta misma la que violentase sus atribuciones al presionar a los súbditos, restringiendo sus libertades e imponiendo fuertes tributos. La teoría divina de los reyes no admitía cuestionamientos, pues requería una obediencia pasiva y sumisa con la clara

${ }^{118}$ Crossman (1958) Pp. 24 y 26. 
finalidad de crear fieles creyentes y no ciudadanos que opusieran resistencia a monarquías, las que, además, no admitían límite alguno: "los nuevos gobernantes no se encontraban limitados ni por cielo, ni por los súbditos"119. En tal régimen, la ley era prerrogativa exclusiva del rey, razón por la cual comprendía la sola voluntad del monarca en el sentido que él quisiera manifestarla. Así, su modificación se llevaba a cabo de la misma manera conforme a su exclusiva voluntad, lo que a su vez fue causa de las tremendas arbitrariedades del sistema monárquico.

Debieron pasar años de dominación para que el pueblo comenzara una lenta pero importante reivindicación de sus libertades y derechos a través de la exigencia de seguridad y protección. Mediante este proceso, el Estado, la ley y el pueblo se conjugarán en la construcción de un nuevo orden político-social. Los movimientos renacentistas, reformistas, revolucionarios y liberales, tal como lo hemos expuesto con anterioridad ${ }^{120}$, fueron el sustento popular y dogmático de los nuevos postulados políticos. Por otra parte, surge una sociedad mercantilista la cual forjará propietarios y comerciantes que darán origen a una nueva clase social, la burguesía, la cual -de la mano de lo que García Pelayo denomina "doctrina pactista"121-, comenzará a exigir participación en las relaciones de poder $y$, con ello, el establecimiento y reconocimiento de las denominadas "leyes fundamentales", las que tendrán por finalidad limitar el poder monárquico mediante la garantía de ciertos derechos.

Con todo, en el Estado moderno el constitucionalismo se consolida a través de la idea de pacto social, la concentración del poder, su secularización, el nacimiento de la soberanía, la limitación del poder a través de la ley para garantizar derechos y la participación social mediante la representación política. Todos estos elementos conducen hacia el nacimiento de un moderno constitucionalismo, cuyos pilares fundamentales son los principios de igualdad y libertad -en búsqueda de la seguridad jurídica- y la protección política necesaria para garantizar el pleno ejercicio de los derechos de sujetos considerados iguales entre sí. La Constitución que este nuevo modelo contempla es una Norma Fundamental que presupone un cuerpo articulado y complejo, formado por diversos cuerpos con equilibrios y proporcionalidad entre ellos que deberán coexistir ${ }^{122}$.

\footnotetext{
119 CROSSMAN (1958) p.34.

120 Supra p.5, cita $\mathrm{N}^{\circ} 7$.

${ }^{121}$ GARCía-PELAYo (1984) p.25

122 FioRAVANTI (2014) Pp. 17 y 18.
} 
Fruto de este cambio de paradigma, en el constitucionalismo se produjeron diversos fenómenos jurídicos en tiempos disímiles de suma trascendencia, que dan nacimientos a los límites jurídicos que comenzaremos a estudiar. Primeramente, nos referiremos a las revoluciones o movimientos que configuran un proceso fundacional que carece de homogeneidad, pero que se verá plasmado en diversos textos jurídicos muy significativos para la limitación jurídica del poder y la consagración de la igualdad y la seguridad en la protección de los derechos de las personas. Tales texto son: Carta Magna, Agreements of the people, Bill of Rights, Declaración de Derechos del Hombre y del Ciudadano, la Constitución de Estados Unidos y la Constitución de Francia de 1791. Dichos documentos emergen en momentos históricos y contextos políticos diversos. No obstante, todos confluían en torno a la idea de protección de derechos individuales. Los principios primordiales contemplados fueron los derechos humanos, la separación de poderes, el gobierno representativo, la limitación del poder gubernamental y, por ende, la responsabilidad política. Por ende, advirtiendo que aquellos textos emergen fruto de razones diversas y circunstancias particulares, sólo por fines metodológicos los trataremos en un mismo apartado.

Dentro de aquel periodo de revoluciones, el desarrollo del constitucionalismo inglés da los primeros pasos hacia la limitación del poder mediante el derecho. Es así como la Carta Magna del 15 de junio del año 1215 será prueba fiel de aquel proceso constitucional. En este texto constitucional el pueblo inglés enumeró una serie de principios y reglas que se suponían existentes, relativas a las libertades individuales y la limitación del poder a las que se otorgó un rango jurídico relevante. En palabras de Walter Bagehot, la Carta Magna fue una especie de "pacto destinado a fijar lo que, en las costumbres, era dudoso, y se tenía el cuidado de proclamarlo de tiempo en tiempo"123. Según este autor, este documento tiene como objetivo solamente confirmar antiguos derechos y no innovar o hacer leyes en sentido ordinario. De esta manera, dicho texto tenía por finalidad última zanjar o dar por terminado los debates entre el rey y la nación. El aspecto relevante del análisis de Bagehot es la forma en la que percibe y presenta el constitucionalismo de Gran Bretaña como aquella pausada evolución de libertades existentes, cuya consagración en un texto legalconstitucional no es más que una actualización de los mismos derechos.

${ }^{123}$ BAGEHOT (1826-1877) p.316 
Sin embargo, para otros autores la importancia de la Carta Magna fue mayor, ya que fue considerada como el medio a través del cual Inglaterra limitaba fuertemente a la monarquía y daba paso hacia un gobierno constitucional. En este sentido, tal como expresa Harold Zink, mediante la Carta Magna Inglaterra decidía si era gobernada conforme a derecho o capricho real ${ }^{124}$. Si bien a través de este documento no se establecían cortapisas constitucionales tal como las conocemos hoy, tal acuerdo solemne limitaba las funciones del Rey de Inglaterra y señalaba una serie de atribuciones que éste podía o no ejecutar. Junto con lo anterior, establecía una especie de guardia noble a quien le correspondía vigilar el cumplimiento de los compromisos contemplados en dicho texto. Del mismo modo, Jiménez de Parga señaló que la Carta Magna otorgaba soluciones precisas y principios generales que orientaron la organización de la política al condensar todo el espíritu liberal que emanaba del edificio constitucional de la época ${ }^{125}$.

El proceso constitucional inglés continuaría consagrándose mediante el Bill of Right del año 1689. A través de él se sintetiza el proceso revolucionario, en el que se enumeran y se prohíben ciertas prácticas consideradas irregulares de la Corona, además de declararse claros y concretos límites al monarca mediante la supremacía del derecho por sobre la voluntad real y la preponderancia legal del Parlamento. De este modo, se comienza a delinear la soberanía parlamentaria.

La Carta de Derechos contenía, según K.C. Wheare, la limitación de poderes del Rey y la garantía de ciertos derechos de los súbditos. No obstante, esta Carta no limitaba los poderes del Parlamento, ya que una de las consecuencias de la Revolución Gloriosa de 1688 fue precisamente desarrollar la supremacía o soberanía del Parlamento, como sujeto legal del sistema de gobierno inglés. Este punto, a juicio del autor, dimanará una importante consecuencia puesto que al momento de atribuirle al Parlamento la calidad de soberano, posteriormente, no se pudo proyectar ninguna Constitución que limitara sus poderes. El conjunto de estos antecedentes conformaron una doctrina predominante: la soberanía parlamentaria $^{126}$.

\footnotetext{
124 ZINK (1965) p. 28

125 JiMÉNEZ DE PARGA (1983) Pp.290-291.

126 WHEARE (1971) P. $16 y 17$.
} 
Luchas del siglo XVII entre la Corona y el Parlamento eliminaron, además, la última reminiscencia de la doctrina relativa a una Ley Fundamental obligatoria para ambos. En Gran Bretaña, dicha noción fue reemplazada por la noción de soberanía ilimitada e indefectible del Parlamento. En virtud de esta doctrina, la posición del Parlamento fue trascendental, situación que Young describe correctamente al decir: "nuestro Parlamento puede cambiar la sucesión a la Corona, puede modificar los poderes y la composición de una o ambas Cámaras, y puede ensanchar o restringir el sufragio. Pero lo único que no le está permitido es imponer obligaciones al Parlamento que lo suceda"127.

La doctrina de la soberanía parlamentaria otorgaba poderes ilimitados al Parlamento, pero también imponía cargas ilimitadas cuya máxima expresión la constituía la facultad legislativa considerada como absoluta e irrestringible. Para Bagehot, particularmente es en el segundo período constitucional de Inglaterra donde se produce un desenvolvimiento progresivo que acaba por otorgar la supremacía al Parlamento. El origen de dicho fenómeno, según los postulados del autor, se encuentra contenido esencialmente en la siguiente frase: "el instinto natural del pueblo inglés es resistir a la autoridad"128. Respecto a dicha premisa y al análisis restante del autor, es posible comprender un componente neutral propio del pensamiento inglés -el que se relaciona con una concepción de la nacióncomprendiéndola como un ente generador de la condición de libertad. Debido a esto, no se debe temer por la usurpación del poder por parte del Ejecutivo, ya que el pueblo libre se gobierna a sí mismo. En este contexto, el Ejecutivo sólo es un cuerpo político que el pueblo utiliza para gobernarse. De este modo, el pueblo se encuentra representado por un Parlamento que le otorga su máxima autoridad, el que esbozará los rasgos arquetípicos del futuro régimen parlamentario.

Los mencionados instrumentos legales-constitucionales antes examinados, se han entendido como una expresión del movimiento liberal, puesto que consiguen expresar en términos jurídicos precisos todo el planteamiento de un movimiento filosófico. Estos documentos, posteriormente, diseñan un estándar jurídico que se convierte en una regla social y jurídica inalterable. Es por ello que el denominado legado político de Inglaterra se puede reunir en dos características: a.- la virtud de otorgar soluciones concretas y actuales a los conflictos políticos mediante soportes

127 YOUNG (1882) p.26.

128 BAGEHOT (1826-1877) p.323. 
tradicionales, lo cual resulta en un afortunado acoplamiento entre ambos aspectos y, b. - el establecimiento de la Rule of Law, principio a través del cual se consagraba el imperio del derecho, la igualdad ante la ley y la formalización judicial de los derechos públicos como centro de la vida política y jurídica. La Rule of Law, en definitiva, encausa toda la actividad política y da nacimiento a una verdadera actitud generalizada y adoptada por parte de gobernados y gobernantes, vinculada a un estricto respeto por las normas jurídicas. Mediante este principio se consagra el respeto por el derecho, lo que tiene, a su vez, como consecuencia la preeminencia de la soberanía del Parlamento ${ }^{129}$.

Por su parte, Estados Unidos de cierto modo abandona el ideal político instituido por la Revolución Gloriosa en Inglaterra, el que establecía la monarquía limitada como una doctrina constitucional. La Revolución americana, en su esfuerzo por asegurar la libertad individual, transforma aquella doctrina en el principio constitucional de un Gobierno limitado. Tal como describe Dippel por primera vez, la idea tradicional de limitar el poder había derivado en la concesión de derechos positivizados a los individuos, los cuales podían ser amparados a través de su reclamo ante la Corte. Debido a que la legitimidad de la Constitución de Estados Unidos la otorgaba únicamente el pueblo.

De la mano del proceso revolucionario norteamericano, avanzó el fundamento conceptual del constitucionalismo moderno, puesto que emergen principios de carácter universales, tales como el Gobierno representativo -limitado y responsable-, la división de poderes, la independencia del Poder Judicial, la Constitución como ley suprema escrita. Conjuntamente con ello, se establecen procedimientos de reforma de la Constitución los que contemplaban la participación del pueblo o sus representantes. Es por esto que, según Dippel, a partir de la Declaración de Virginia, el proceso constitucional de Estados Unidos declaró los principios fundacionales del constitucionalismo moderno, tales como la responsabilidad y la obligación de rendir cuentas por sus actos, como también la armonía entre principios y elementos estructurales bajo el Estado de derecho ${ }^{130}$.

Por su parte, la Declaración de Derechos del Hombre y del Ciudadano de 1789 es el cuerpo jurídico más importante en la modificación de los paradigmas del absolutismo. Mediante una clara inclinación a convertirse en el amparo requerido por

129 JiMÉNEZ DE PARGA (1983) Pp.296-297.

130 DiPPEL (2005) Pp. 183, 184 y 187. 
el pueblo, viene a reconocer y garantizar tanto derechos naturales como civiles, lo cual se refleja a partir de la primaria y esencial declaración de igualdad entre los hombres ${ }^{131}$. Conjuntamente con lo anterior, la Declaración en el artículo 16 establece las bases del Estado Constitucional en el que se dictamina que una sociedad que no estuviera instituida en garantía de derechos y en la división de poderes carecía de Constitución. Tal fue la importancia de aquellos principios -tanto el respeto de los derechos esenciales e inalienables, como el respeto al gobierno equilibrado conformado por la división de funciones- para los hombres de 1789, que le atribuyen un carácter similar al Estado constitucional, porque sin la presencia de estos pilares fundamentales no podía existir un gobierno limitado. Con tal declaración, los derechos serán el eje central de los gobiernos, pues ya no dependerán de situaciones sociales jerarquizadas o de privilegios reales.

De este modo, los derechos del hombre dejarán de ser verdades que deben ser reveladas. Con el iusnaturalismo los derechos no se "crean", se "declaran", puesto que éstos existen desde siempre como acervo esencial de la naturaleza humana. Según Costa, la labor de la constituyente francesa fue una labor de reconocimiento que logra sacar dichos derechos de su humillación y olvido ${ }^{132}$ y colocarlos en primera línea. A través de su establecimiento como derecho positivo, se encuentran protegidos y son inviolables por quienes detentan el poder $y$, dado que están por sobre los poderes estatales, son establecidos por la nación soberana. Esta última es expresada mediante la voluntad general materializada en la ley, a través de la cual los derechos toman existencia y conformarán los pilares del nuevo orden de la Nación ${ }^{133}$.

Por su parte, el proceso constituyente de 1789 en Francia finaliza con el texto constitucional de 1791, el cual marca un hito político-jurídico en cuanto a la modificación del sistema de organización del Estado. Como es posible observar de sus preceptos constitucionales, desde el Título primero se comienza a ratificar y consagrar las directrices de la que fue una larga batalla para estipular las garantías

\footnotetext{
${ }^{131} \mathrm{~A}$ modo ilustrativo citaremos algunos de los artículos más relevantes de la Declaración: "Los hombres nacen y permanecen libres e iguales en derechos"; el artículo 3 relativo a la soberanía delimitará al poder y su origen pues "la soberanía reside esencialmente en la Nación" y nadie podrá ejercerla sin su previa delegación; artículo cuarto contiene el reconocimiento de la libertad "la libertad consiste en poder hacer todo lo que no perjudique a los demás", estableciéndose como límite de la libertad los derechos de los demás miembros de la sociedad; artículo sexto relativo al reconocimiento y validación de la voluntad general dirá que "la Ley es la expresión de la voluntad general" la cual debe ser manifestada por todos los ciudadanos y obligar en condiciones de igualdad a todos sus miembros.

${ }^{132}$ COSTA (2004) p.52

133 Costa et al. (2004) p.53
} 
de los ciudadanos y la protección de la libertad. El Título tercero constata en su artículo primero que la soberanía "pertenece en la Nación", principio que será ratificado en otros preceptos como los contenidos en el capítulo segundo. En el artículo tercero se estipula que "No hay en Francia autoridad alguna superior a la Ley. El Rey no reina si no es por ella, y sólo en nombre de la Ley puede exigir obediencia", con lo cual se establece el principio de legalidad.

Con la consagración de tal articulado, la asamblea constituyente establece constitucionalmente que el poder reside en el pueblo y determina límites jurídicos del mismo en la voluntad general. La asamblea constituyente logró establecer además la organización del Estado mediante la separación del Estado de la persona del rey. En virtud de la teoría de la soberanía nacional, se declaró a la nación como el verdadero origen del Estado civil y, de esta manera, como el único propietario de la soberanía y como único sujeto facultado para modificarla, alterarla o enmendarla. Esto produce -a modo de consecuencia- las declaraciones manifestadas por Carré de Malberg, quien señala que la idea esencial de los hombres de 1789 fue declarar al Estado como la personificación misma de la nación. Según el autor, desde este momento: "Estado y Nación no son más que un todo... son dos caras de un mismo ente de derecho; en cuanto persona, la nación se Ilama Estado"134.

La trascendencia de la Declaración de Derechos de Francia y la Constitución de 1791 son tan significativas, que Dippel declara que ambos documentos constituyen la quintaesencia del logro constitucional de la fase inicial de la Revolución y que, a pesar de no hacer referencia a la independencia judicial, la responsabilidad gubernamental, el gobierno limitado, la independencia judicial, ni a la Constitución como ley suprema -como sí lo hacía la Constitución de Estados Unidos-por primera vez fue establecido en el artículo 16 de la Declaración la obligación de fijar ciertos elementos esenciales sin los cuales no era posible hablar de "Constitución". De esta manera, se había fijado un precedente entre lo que se hacía llamar Constitución en los tiempos pasados y lo que se había comenzado a levantar como un lenguaje político diferente sobre una nueva teoría constitucional.

\footnotetext{
134 CarRe de Malberg (1948) P.105

Para el autor es inconcebible permitir que existan en el Estado dos sujetos diferentes, el Estado y la Nación tal dualismo es inaceptable, se puede comprender que el autor consideró al Estado como persona si y sólo sí personifica a la colectividad nacional, el dualismo propio de la revolución nación-persona es negado por el francés.
} 
Por consiguiente y debido a estos sucesos, emerge en definitiva el fundamento teórico de moderno constitucionalismo ${ }^{135}$.

Ciertamente, las motivaciones u objetivos perseguidos por cada revolución eran diversos. Los americanos pretendían limitar un poder existente y los franceses necesitaban consolidar un nuevo poder. Debido a que el modelo europeo continental requería fijar el poder de dirección política en un único poder de carácter representativo, ya sea mediante el Gobierno o Parlamento, precisaba que dos poderes debían interactuar y entre los cuales primase solamente uno. En oposición a la Constitución federal, necesitaba un poder de dirección política divido en dos: por un lado, hacer las leyes e imponer tributos y, por otro lado, gobernar, administrar recursos y satisfacer necesidades a través de la atribución de cada función a un sujeto diferente entre los cuales debía generarse una relación recíproca de equilibrio y limitación ${ }^{136}$. No obstante $-y$ pese a las diferentes perspectivas teóricas-, ambos procesos fijaron los parámetros mediante los cuales se desarrollará el moderno constitucionalismo.

Empero, y a pesar de los esfuerzos e ímpetus revolucionarios y los avances alcanzados con las declaraciones de derechos y los límites al poder de los gobernantes contenidas en los textos jurídicos antes analizados, será precisamente en aquel estado del arte en que las fuerzas conservadoras retomarán impulsos en búsqueda de una vía de resistencia en contra de los pensamientos revolucionarios burgueses, la noción de soberanía popular, legalidad constitucional y Estado de derecho.

Así, a través de la Restauración se vuelve a contraponer la idea de "pacto" entre el Rey y el reino. Pacto en el cual ahora, por lo menos, se establecerán límites al poder real, ya que luego de aquel proceso ideológico y revolucionario se vuelve inverosímil pensar en la idea de un poder, sin la aplicación de ciertas restricciones. Sin embargo, dichos límites sólo poseían un carácter aparente que no garantizaba la libertad de todo un pueblo, sino más bien solamente permitía mantener ciertos privilegios de grupos o estamentos sociales favorecidos que se negaban a renunciar a ellos. Fruto de aquel proceso de contragolpe político, el nuevo pacto se concretiza

\footnotetext{
135 DiPPEL (2005) pp. 189 y 190.

${ }^{136}$ FiORAVANTI (2014) Pp. 39 y 70.
} 
habitualmente en las denominadas "cartas otorgadas"137. Estas cartas fueron descritas por Adolfo Posada como documentos de constitucionalismo atenuado $y$ deformado que desconocen el principio de la autonomía política del pueblo y la necesidad del establecimiento de un régimen jurídico y de garantías del Estado.

En definitiva, el periodo de Restauración se constituye como un intento relativo y fallido de limitación política del poder, puesto que en el nuevo contexto político era inaceptable un poder absoluto unipersonal que además no contara con mecanismos relativos a la división o contención aquella expresión de poder, puesto que las condiciones sociales y políticas demandaban una verdadera protección de los derechos y libertades ciudadanas. Eliminando todo tipo de arbitrariedad o sometimiento.

Como podemos observar, el constitucionalismo post-revolucionario no vivencia una instalación pacífica, dado que las resistencias ideológicas y estamentales del período de la Restauración ${ }^{138}$ realizan importantes esfuerzos por retornar a un camino que ya en esas épocas no tenía retorno, pero del cual poseían sus mejores recuerdos e inmejorables posiciones de poderío. Este fue el impulso que incluso los llevó a convocar el Congreso de Viena, cónclave cuya finalidad esencial fue legitimar y reorganizar el poder absoluto con la finalidad de revivir el Antiguo Régimen, además de restablecer las fronteras de Europa.

Sin embargo, serán otros hechos sociales e históricos los que afianzarán los postulados revolucionarios. No es hasta el arribo de la denominada "Primavera de los Pueblos" que se comienza a poner término a la Europa de la Restauración ${ }^{139}$. Durante el siglo XIX, e impulsado por factores como la crisis económica de 1847, la negación, privación y restricción de derechos y libertades que aparentemente ya se habían alcanzado, la Revolución Industrial, la consolidación de la burguesía, el

\footnotetext{
137 Resulta menester destacar que luego de los movimientos restauradores del régimen absolutista se intenta mantener la lógica del "pacto" entre el rey y la nación debido a la presión que la sociedad ejercía por no perder los derechos y espacios ganados, pero este pacto no se establece a través de Constituciones de origen popular sino que en textos denominados "cartas otorgadas", en los cuales el mismo monarca quien las concedían en favor de sus súbditos, textos del todo contradictorios con su finalidad, ejemplo de ello fueron los casos de Francia en el año 1814 y España en 1808.

138 POSADA (1930) Pp. 112 y 113.

139 Cabe hacer mención que al no ser las monarquías fenómenos de carácter homogéneo no todos los estados europeos finalizaron tal régimen de una manera inmediata y cronológicamente a la par, durante el periodo de 1848 y posteriormente Francia, Alemania e Italia logran cerrar una etapa y modificar aquella forma de gobierno, no obstante en Inglaterra tal corte no se produjo pero se desarrolló un proceso evolutivo en búsqueda de las mismas demandas. Lo anterior debido a las diferencias filosóficas que influenciaron a cada Estado el liberalismo y el nacionalismo-imperialismo no se plantearon lógicamente de la misma manera, ni sus exponentes los defendieron con la misma fuerza en todos los territorios.
} 
surgimiento de una pequeña clase media junto al ejercicio de las denominadas profesiones liberales, se insta el regreso de las fuerzas populares para luchar con la finalidad de consolidar un proceso que había comenzado décadas atrás y el cual profesaban firmemente. De este modo, en el año $1848^{140}$ se desencadenan hechos que pondrán fin a una etapa absolutista y que abrirán las puertas hacia los gobiernos constitucionales y representativos.

El desarrollo del constitucionalismo permitió forjar la herramienta jurídica de mayor valor en la evolución del derecho público: el nacimiento de una Ley superior y fundamental que posee como esencial cualidad "la limitación jurídica del gobierno" ${ }^{\prime 141}$. Asimismo, surge el Estado de derecho con base constitucional como la antítesis de los gobiernos arbitrarios que por siglos dominaron el escenario europeo, lo cual implicó pasar del mero capricho voluntarista de un gobernante al imperio de la ley. Esta última se consagró como el resultado de la voluntad general, la cual tuvo como finalidad primaria garantizar libertad $y$ derechos, equilibrar poderes $y$ establecer funciones determinadas a los órganos del Estado, a fin de dar lugar a un gobierno garante y sujeto al imperio de la ley, lo que dio origen al mencionado Estado de derecho. Desde aquel profundo cambio organizativo, se considerará que todo Estado deberá constituirse en razón de una ley superior. Como bien dice Mcllwain, "todo gobierno constitucional es un gobierno limitado"142. Estos límites serán fundamentales e inalterables y se consagrarán como una tendencia que lentamente se impondrá en toda Europa. En efecto, tal como señala García Pelayo, sólo a fines del siglo XIX se producirá el florecimiento del Derecho Constitucional, el que se presentará como "la fórmula definitiva de la convivencia política"143.

En conclusión, la relación que se fue produciendo entre los conceptos de poder y libertad dieron paso al nacimiento de ficciones políticas y jurídicas que permitieron la consolidación de un pensamiento filosófico. La creación del pacto o contrato social, la soberanía, la nación, los derechos esenciales y los principios, finalmente encontraron la clave de su fortaleza en las leyes fundamentales, esto es en la ley soberana, precepto jurídico que no es ilimitado, pero que tampoco puede ser limitado por

140 Las revoluciones en 1848 son consecuencia de las llevadas a cabo los 1820 y 1830 , fue la tercera oleada revolucionaria, pero que a pesar de los esfuerzos no logra ser exitosa. Si bien Francia logra poner fin a la monarquía de julio e instaura la segunda república, Alemania constituye el Parlamento de Fráncfort y su texto constitucional e Italia presencie la revolución siciliana, todas serán reprimidas por las fuerzas del ejército monárquico que volverán a detener los avances de un pueblo que sólo anhelaba su libertad y respeto.

141 MCLLAWAin (1991) p.37

142 MCLLAWAIN (1991) p. 36

143 García-Pelayo (1984) p. 29. 
poderes particulares ni podrá establecer privilegios particulares. La ley soberana será producto de la voluntad general y tendrá por finalidad establecer y proteger derechos generales, razón por la que será una norma que despersonaliza y objetiviza el poder real, el que se encontrará por sobre el Estado mismo y deberá ser respetada por todos, incluso el órgano estatal, lo que proporcionará el soporte del Estado de derecho.

Asimismo, se forjará la noción de Ley Fundamental emanada de la nación, en la cual se establecerá fundamentalmente que los órganos dejarán de ser meros servidores del rey. En el texto constitucional deberán estar establecidos dichos órganos y determinadas sus funciones en ordenaciones racionales que sean coherentes con las aspiraciones de la nación. A partir de esta construcción normativa, ya no es el pueblo quien se enfrenta al rey, sino que lo es el texto constitucional $^{144}$, lo cual finalmente consagra el constitucionalismo moderno y el Estado de derecho.

\section{b) Limitaciones políticas al poder}

Tal como fue expresado con anterioridad, la limitación del poder se presentó como una imperiosa necesidad que presentaba múltiples vías de contención: algunas jurídicas, como fue analizado, y otras políticas, que tendían principalmente hacia la división del poder impidiendo su crecimiento ilimitado y devastador. Frente a la facilidad con la que se puede extender el poder y la peligrosidad que ello implicaba, no bastaba con la sola re-conceptualización de la norma jurídica y del valor del derecho como instrumento regulador de la vida política y protector de las libertades individuales, sino que fue necesario que mediante él se estipularan otros mecanismos que contribuyeran a la creación de un camino de equilibrios y herramientas que vinculadas unas con otros dieran lugar a un sistema de frenos y equilibrio del poder en todos sus aspectos.

En tal sentido, las teorías de la soberanía nacional y, posteriormente, de soberanía popular -junto con la representación política y la teoría de la división del poder- permiten profundizar el proceso de limitación, lo que unido a la evolución jurídico-constitucional permiten determinar las reglas dentro de las cuales es posible

144 SÁNCHez Agesta (1945) p. 177. 
que el poder se manifieste a través del establecimiento de un sistema de parcelamiento del mismo, de forma tal que la concentración del poder fuera casi imposible. Sin intención de redundar en materias extensamente investigadas, en los párrafos siguientes pretendemos exponer y comprender, desde una perspectiva evolutiva e histórica, los hechos y fundamentos que cimentaron la limitación, división y contención del poder desde el fenómeno político.

En dicha dirección, debemos imperativamente referirnos a la Revolución inglesa y su proceso constitucional, proceso de carácter paulatino que produjo las primeras revelaciones del Estado-Nación y el prolijo desarrollo jurídico del pueblo británico. Dos fueron los factores que concurrieron en tal proceso: el primero, la creación de un derecho común administrado por la Monarquía y, el segundo, el establecimiento de un Consejo Real que se relacionaba con el Monarca y que, en cierta manera, orientaba las decisiones de la Corona y que poco a poco sería dotado de mayores facultades, lo que decantará finalmente en la configuración de un Gabinete. Este se convertiría en el órgano limitador por su carácter representativo del pueblo británico, quien velaba finalmente por sus derechos, dado que los miembros del Gabinete serían ciudadanos legitimados democráticamente que forman parte del Parlamento.

Por su parte, el desarrollo del Parlamento siempre reflejó rasgos de representatividad, dado que si bien los sujetos que asistían a las primeras expresiones parlamentarias no provenían de todos los estamentos o grupos sociales existentes, eran "elegidos". A través del transcurso de la historia, los ciudadanos dimensionarían el poder que podía llegar a ejercer aquel Parlamento como garante de sus derechos y limitador del poder real. A consecuencia de esto, comenzarán a exigir mayor coherencia en la representación del mismo, a través de la extensión del sufragio, lo que fomentó una omnipotente funcionalidad del mismo. La supremacía del Parlamento se consagra entonces mediante dos aristas, ya que crea, modifica y rechaza la ley, y la protege, ya que no hay ninguna autoridad u órgano que posea facultades para anular o pasar por alto nada de lo que surja del Parlamento. De este fenómeno surge la frase de De Lolme: "el Parlamento inglés puede hacerlo todo, menos transformar a un hombre en mujer" ${ }^{145}$.

$\overline{145}$ Citado por Zink (1965) Pp. 31y 51. 
Si bien es posible calificar como excesivamente prudente las modificaciones de Inglaterra, estas fueron de suma trascendencia. Según Edmund Burke, el pueblo británico en su evolución optó por una monarquía hereditaria, y -a pesar de la libertad que poseía en cuanto a tomar el curso que le fuera más oportuno para determinarse políticamente y para hacer ocupar el trono- no creyeron en cambios osados. De este modo, siguieron un sendero pausado y progresivo mediante el cual reconocieron a la Corona como poder indiscutible, pero afecta a límites tales como la fe, la justicia y la policía. Dichos límites fueron considerados perfectamente inteligibles y obligatorios para quienes ejercen poder dentro del Estado ${ }^{146}$, lo cual garantizaría además la delimitación de las funciones que realizaría cada órgano ${ }^{147}$.

La continuidad constitucional de Gran Bretaña exhibe rasgos de suma relevancia. El primero, lo compone aquella capacidad de mantener vivas instituciones que dieron prueba de sus competencias y adaptaciones a los nuevos tiempos políticos, dado que respetaron el Parlamento y la Monarquía. Aún en tiempos de revolución salvaron aquellas instituciones, las que eran símbolo de la devoción y la atracción del pueblo, entendidas como elementos unificadores internos a la Constitución. Dicha virtualidad es descrita por Young de la siguiente manera: vemos a la Corona como aquella amalgama de lo familiar y lo augusto que exalta el afecto del ciudadano y presta un tono íntimo a su lealtad, por ende, al respetar el Parlamento a la Monarquía se potenciaron plenamente de tal modo que dan nacimiento a un régimen de gobierno que se extiende más allá de los mares ${ }^{148}$.

Un segundo aspecto lo compone aquel equilibrio desarrollado entre poderes, razón por la cual Bagehot expone "suele afirmarse que la excelencia de la Constitución inglesa se debe al equilibrio de los tres poderes unidos" ${ }^{149}$. Por consiguiente, lo relevante de la limitación del poder en la historia de Inglaterra es la forma en la que esto se efectúa. Mediante el constitucionalismo británico se reconocen dos factores determinantes: la ley como regla general y el carácter plural del poder. Sin la necesidad de radicalizar una demanda popular, fueron capaces de

\footnotetext{
146 BURKE (1942) p.57.

147 Pero fue en el gobierno del Rey Juan el pueblo británico comenzó su lucha por limitar al monarca, la dictación de la Carta Magna es reflejo de aquellos esfuerzos, limitar al poder real a través del reconocimiento y declaración de los "derechos tradicionales" además de prohibir el establecimiento de impuestos arbitrarios, la Carta Magna constituye a juicio de Crossman "un principio constitucional" y según Burke no es más que la ratificación de la Ley más antigua y permanente del reino, que luego con la Petición de Derechos, se consolidará la idea de derechos como herencia como un patrimonio heredado de sus antepasados. CROSSMAN (1958) p. 51 y BURKE (1942) p. 67

148 YOUNG (1882) p. 46.

149 BAGEHOT (1826-1877) p.3.
} 
comprender que el poder no era nefasto en sí mismo, sino que -por el contrario- era de gran utilidad, empero debía ser contenido por órganos y por el derecho, los cuales ya estaban presentes en la organización política británica y solamente debían ser declarados.

Esta idea de considerarse a sí mismo como un pueblo que limitaba el poder, es posible detectarla en el análisis de Laski, para quien la máxima del equilibrio del poder se funda en el sentido común y en el razonamiento obvio. Por ende, era imposible que los antiguos pensadores no lo hubiesen detectado y que no haya influido en los principios políticos actuales. Según el autor, debido a esto en Inglaterra la limitación del poder del Monarca se establece a través de la Carta Magna o los Bill de Derechos como reflejo del peso de una tradición. La limitación del Gobierno no es más que la expresión de los justos derechos del pueblo ${ }^{150}$. En definitiva, lo que plasma la Revolución inglesa es que mediante la consagración de derechos ya existentes y el mantenimiento de un sistema político monárquico perfectible y equilibrado -mediante la intervención del Parlamento-, la limitación del poder era perfectamente realizable, sin necesidad de arribar a un proceso de suma violencia como lo fuera la Revolución francesa, la cual será denominada por Burke como una "monstruosa escena tragicómica"151.

Siempre un paso adelante, el proceso inglés continuó desarrollando nuevas dinámicas en las relaciones de poder. La teoría del trust constituyó bajo la premisa del "Rey en Parlamento" una nueva organización política de rasgos representativos. Desde este momento, el Rey ya no es en sí mismo el Estado sino cuando se encuentra en el Parlamento, incorporando con ello a su vez al Parlamento como órgano del Estado, razón por la cual éste goza de la facultad de representar al pueblo. La representación política se verá profundizada y extremada en el Reino Unido por las ideas de Burke, Sidney y Blackstone, las cuales se relacionarán con la máxima autonomía del parlamentario, la libertad de juicio y el deber de actuar a favor del interés general de la nación y no de intereses particulares. De esta forma, se consolidó la monarquía parlamentaria y un sistema de pesos y contrapesos políticos y jurídicos que implicaría determinar funciones que se atribuían a cada órgano dentro de un sistema coordinado jurídicamente por derechos y estructuras pre-establecidas, y legalmente reconocidas.

\footnotetext{
150 LASKI (1932) Pp. 13 y 110.

151 Burke (1942) p.46. A juicio del autor fue absolutamente innecesaria y gestada por hombres confundidos e ignorantes que esencialmente confundieron el derecho del pueblo con el poder mismo.
} 
Por su parte, John Locke desde el más puro Liberalismo declaraba que el hombre era esencialmente un ser racional y libre en permanente búsqueda de libertad y felicidad. Estos dos elementos, a su juicio, estaban estrechamente vinculados. Por lo mismo, Locke no podía concebir la libertad sin garantías políticas que la resguardaran, razón por la cual se esforzó en reivindicarlas, pues le atribuía la prerrogativa de ser "la única muralla defensiva"152 contra el poder. Es por ello que desde la doctrina de Locke, sólo la protección de la libertad limitaba el poder. Este autor desconfió tanto de la soberanía popular como de la monarquía, situación que le permitió encontrar la tranquilidad y seguridad del Estado civil en la soberanía parlamentaria. De este modo, será sobre dichas premisas que construirá la teoría del pacto social: una sociedad civil de carácter consensual que tendrá por finalidad la búsqueda de mayor seguridad y protección de sus bienes, de igualdad, equidad y justicia.

A partir de lo anterior, Locke formulará una de sus más importantes propuestas, aquella en la que concibe la necesidad de que el poder se ejerza separadamente, pues esa será la mayor garantía de que este pacto continúe vigente y que las finalidades se alcancen. En esta oportunidad, el autor expone los tres elementos constituyentes de dicha separación: primero, leyes aceptadas, conocidas y firmes que nazcan producto de un consenso y que sirvan de medida justa para resolver los conflictos que surjan entre los hombres; segundo, un juez reconocido e imparcial con autoridad para resolver conflictos de acuerdo a las leyes establecidas; y tercero, un poder que sostenga y respalde las sentencias cuando sean justas, y que las ejecute debidamente ${ }^{153}$.

Por otro lado, Francia elaborará con mucha más crudeza y dificultad las teorías de la soberanía y la representación política, las que en medio de una sangrienta revolución comenzarán a tomar vida. Sin embargo, y a pesar de lo complejo del proceso revolucionario francés, rescatamos las palabras de Crossman, quien señala que la revolución le otorgó la libertad al pueblo francés -una libertad que no encontró ni en el despotismo, ni en la sola declaración de derechos, sino más bien en su unidad de actuación en la voluntad general, a través de la cual pudo realizar un proceso de autodeterminación nacional ${ }^{154}$-. Compartimos tal exposición esencialmente porque el cambio de domicilio del poder y la división del mismo son

\footnotetext{
152 LOCKE (1969) p.5.

153 LOCKE (1969) P. 94.

154 CROSSMAN (1958) p.116.
} 
consecuencia, en gran medida, del empoderamiento del pueblo en su calidad de supremo detentador de la soberanía. En efecto, la representación política y el mandato representativo de forma consciente y por razones histórico-políticas se ven ligadas a una reacción de carácter revolucionaria contra el Antiguo Régimen ${ }^{155}$, el cual había oprimido y vulnerado en sus derechos y dignidades al pueblo francés.

Por su parte, el surgimiento de la nación, según el análisis de Emmanuel-Joseph Sieyès, se sustenta en dos claros caminos vinculados a la reorganización y el origen del poder. Estos consisten, por un lado, en una reivindicación de derechos y dignidades del pueblo y, por otro, en la unificación del poder y del pueblo en un ente abstracto. Bajo un elemento cardinal -la "unidad"-, Sieyès declara la necesidad de aunar a todas las clases sociales dentro de los límites del contrato social, creando una unidad abstracta que denomina Nación, la que define como "un cuerpo de asociados que viven bajo una ley común y están representados por la misma legislatura"156. Luego, una vez constituida esta corporación de ciudadanos iguales en derechos, Sieyès expone la necesidad de unificar la voluntad común de la nación y su ejercicio. Bajo esta premisa, determina que es necesaria la existencia de un gobierno representativo del pueblo, que sea de carácter limitado por la voluntad común nacional y que actúe por delegación de funciones, velando por los cuidados públicos de la comunidad. Junto con lo anterior, la nación deberá autodefinirse y organizarse, tanto en las formas como en las leyes, para lo cual será necesario dotarse de una Constitución ${ }^{157}$.

No obstante, si bien el desarrollo de las ideas de reformulación y creación de nuevo orden se detecta con fuerza en Sieyès, será en Rousseau donde termine de consolidarse y extremarse. Para Rousseau, un convenio social será vano y contradictorio si, por un lado, sólo hay una autoridad absoluta $y$, por otro, una obediencia sin límites. Al establecer la noción del "contrato social", en el cual cada uno se une a todos no obedeciendo a nadie más que a sí mismos, quedando tan libres como antes, da nacimiento a un cuerpo moral y colectivo que se expresa a través de la voluntad general y que tendrá por obligación favorecer a todos sus

\footnotetext{
${ }^{155}$ AbelLÁn (1996) p.169.

156 SIEYÉs (1988) P.40 y 82.

157 SIEYES (1988) Pp. 103 a 106.
} 
integrantes. El ideario de Rousseau, además, no admite posibilidad alguna de lesionar a sus integrantes toda vez que nadie puede perjudicarse a sí mismo ${ }^{158}$.

En los postulados de Rousseau, encontraremos el origen de la supremacía del pueblo como gestor de las directrices del Estado. El autor le atribuye a éste la potestad legisladora, la que se manifestará a través de la voluntad general. Esta nueva y trasgresora postura lleva implícita no sólo el reconocimiento del origen del poder en el pueblo, sino que además impide delegarlo. Éste poder se expresará siempre mediante mayorías, las cuales constituirán su único límite. De este modo, es posible vislumbrar la potencia de las ideas de Rousseau cuando expone: "no hay que preguntar a quién pertenece hacer las leyes, puesto que son actos de la voluntad general y ni el príncipe está por encima de las leyes, puesto que él es un miembro del Estado" ${ }^{159}$. Bajo esta rupturista interpretación de las relaciones de poder, Rousseau declara que el gobierno no es más que un cuerpo intermedio que recibirá órdenes del pueblo en su calidad de súbditos y soberanos, cuya finalidad no es otra que la libertad e igualdad de los ciudadanos. Así, Rousseau sitúa finalmente el origen, fin y objetivo del poder en manos del pueblo, subordinando con ello al ejecutivo. Por tanto, para el autor el límite al poder es el pueblo.

La representación política, como límite al poder, es el tránsito entre aquella democracia directa del mandato imperativo de Rousseau y la democracia representativa de Sieyès. El jacobinismo promulgaba una fuerte participación del pueblo mediante una democracia virtuosa, mientras que Sieyès postulaba una democracia sin soberano, sustentada esencialmente en los derechos del hombre y del ciudadano, mediante un método empírico y iusrracionalista, siguiendo las huellas de Spinoza y Locke. Este último autor, a diferencia de Rousseau, conceptualiza el estado de naturaleza en una sociedad complejamente definida a partir de las relaciones sociales de producción emergente. En este sentido, el Estado no disminuía la libertad de los individuos, sino que la aumentaba, puesto que multiplicaba los medios para satisfacer necesidades.

Tal como describe Maíz, para el jacobinismo el poder estatal podía penetrar el interior del hombre y se ejercía no sólo sobre sus acciones, sino también sobre su voluntad. En cambio, para el abate ninguna forma de poder podía afectar de modo alguno la libertad del ser humano y su privacidad. Es por ello que la participación

\footnotetext{
158 ROUSSEAU (1980) Pp. 38, 41 y 56.

${ }^{159}$ ROUSSEAU (1980) p.62.
} 
directa rusoniana era para Sieyès una configuración bruta que, aplicada en condiciones no idóneas, podía deslizarse hacia formas tiránicas y despóticas. Por su parte, él plantea la noción de representación como la realización de la libertad. Para el abate existían dos voluntades nacionales producto de la representación: una representación extraordinaria o poder constituyente, y una ordinaria o poder legislativo. La segunda era la que daba nacimiento a la voluntad política. En esta dirección, la representación no transmite una supuesta voluntad, ni tampoco la adecua, sino que le entrega forma a una voluntad común, pues para Sieyès la libertad política efectiva no consistía en la participación directa en todos los asuntos de interés público, tal como lo describía Rousseau, sino que estaba restringida y comprendía la posibilidad de realizar una actividad social y económica sin injerencias del Estado.

De este modo, para el abate la representación es la forma de unificar voluntades. Por lo mismo, ella no consiste en la configuración de una pluralidad de minorías participativas. La noción de representación política para Sieyès se sustentaba, básicamente, en el principio de mayorías y respeto a las minorías, basada en la confianza y su correlato, vale decir, la necesidad de vigilancia de los ciudadanos hacia su representante. Es por ello que perdida la confianza el mandato se revoca. Por consiguiente, la representación es electiva respecto de personas que gozan de una cierta calidad. Los diputados representaban a la nación toda y no al cuerpo electoral que los escogió. Por ende, gozaban de independencia ante sus representados ${ }^{160}$.

Sin embargo, al igual que otras construcciones teóricas, la representación política también fue matizada en el siglo XIX con la tercera vía del constitucionalismo, particularmente en Alemania con la construcción de la teoría del órgano o doctrina del Organschaft, propugnadas principalmente por Eric Voegelin, Max Weber, Georg Jellinek, Gierke, Laband y Hans Kelsen. Estos autores atribuyen al representante la calidad de órgano del representado, o sea del pueblo, quien a su vez es órgano del Estado. Mediante esta nueva interpretación, nacerá el Estado soberano y se dará comienzo a un nuevo lenguaje político-jurídico que instituirá la Constitución Estatal y Nacional. Posterior al proceso revolucionario, surgió en Alemania la necesidad de poner la soberanía a salvo de las luchas políticas, de intereses particulares y, especialmente, de la ilimitada-permanente soberanía del pueblo.

160 MAIZ (1991) Pp.71-74. 
Según Fioravanti, lo que buscaba esta cultura constitucional era la "consolidación de un Estado soberano que no se reduzca a un simple contrato entre distintas partes siempre revocables por ellas"161. De esta manera, la soberanía del Estado constituyó el presupuesto para la anulación de la soberanía de carácter político, la del pueblo y la del monarca, reduciéndolos a la categoría de poderes jurídicamente regulados y ordenados por la constitución del Estado. En tal escenario, la protección de derechos ya no era dependiente de la voluntad de asambleas nacionales. Gracias a esta nueva concepción, los derechos estarían protegidos por la ley del Estado, limitada por reglas constitucionales que garantizaban que en su formación participaran poderes limitados.

Conforme a lo expuesto por Gierke, fruto de este movimiento filosófico se formula una distinción entre la persona individual y la persona colectiva. Así, se distinguen los actos privados de los actos públicos, al atribuírseles carácter vinculante a la comunidad sólo a aquellos actos oficiales o públicos. La persona, como cotitular de derecho colectivo, lo será sólo en su condición de ciudadano con capacidad electoral y no como un individuo concreto. Mediante tal interpretación, según Gierke, se toma conciencia de que el poder del pueblo no emana de la suma de derechos individuales, sino que el derecho público proviene de una asamblea que se encuentra constitucionalmente formada ${ }^{162}$.

Los alemanes decimonónicos consideraron primero al grupo y después a la persona individual. Según su visión, el representante no es más que un órgano del grupo. Por ende, el pueblo en las elecciones selecciona a los representantes, pero cumpliendo como función la manifestación de la voluntad del Estado. Así, los representantes lo son del Estado y no del pueblo ${ }^{163}$. En este sentido, Eric Voegelin expresó que son los ciudadanos los que se constituyen a sí mismos como una sociedad política para la acción, agrupación donde surgirán los "dirigentes", quienes actúan en favor de los demás y cuyos actos serán imputados a la sociedad en su totalidad $^{164}$. Por tanto, para Voegelin, la condición sine qua non de la representación es la de articular a la sociedad. Este autor señala que "la sociedad tiene que

\footnotetext{
161 FioRAVANTI (2014) p. 50.

162 GIERKE (1995) p. 193.

163 TORRES DEL MORAL (1982) p.11.

164 VOEGELIN (1968) p. 63.
} 
articularse mediante la creación de un representante que actúe por ella, de lo contrario no puede cobrar existencia"165.

Finalmente, debemos hacer presente que el advenimiento del Derecho Constitucional moderno ciertamente implicó la limitación del poder a través de derechos fundamentales. No obstante, las explicaciones contractualistas y positivistas -respecto del mecanismo a utilizar para lograr tal finalidad- situaron el poder en manos de otros actores protagónicos, ya fuera la nación o el pueblo, los cuales no podían ejercerlo por sí mismos, por lo que debían delegarlo en otros sujetos quienes mediante debates y votaciones alcanzaban la voluntad soberana. El poder era fruto de un diálogo entre variadas manifestaciones populares. En consecuencia, éste debía sortear todo tipo de barreras si deseaba conformarse como tal, lo que tornaba tremendamente complejo que sólo un órgano pudiera atribuirse todo el poder y volver a abusar de él.

En consecuencia, la configuración de la organización política del Estado también significó un mecanismo importante en la limitación del poder. En efecto, la ordenación del mismo encarnó la división del poder, pues ya no se encontraba depositado únicamente en las manos del monarca, sino que ahora el poder del Estado estaba depositado en las manos de la nación o el pueblo, cuyo poder se expresaba a través de la voluntad general. Ella se configuraba por medio de órganos de representación popular, instituciones que ahora poseían la facultad de crear la ley y de poner freno al monarca. Lo anterior, ubicaba al soberano en un sitial de mera ratificación de las normas y dejaba en manos de un poder Ejecutivo el cumplimiento y aplicación de las normas creadas.

La aparición de la representación política, la división de poderes y en general el nuevo ordenamiento gubernamental -del mismo modo que tantos otros elementos políticos relevantes-, acarrearon consigo el comprender y admitir que el ordenamiento jurídico-público tenía como finalidad definir el reparto del poder, lo cual constituyó el único mecanismo válido en la búsqueda de tal propósito. Consecuentemente, los límites políticos, entendidos como proceso de reparto del poder, configuraron el desarrollo de lo que Mirkine-Guetzévitch denominó tiempo después "el problema de la racionalización del poder". En este fenómeno influyeron variados factores, tales como la desconfianza del Ejecutivo y el fortalecimiento del

${ }^{165}$ Voegelin (1968) p.68 
Parlamento, un nuevo trato entre los poderes $y$, finalmente, la regulación en las constituciones políticas de cada Estado de los mecanismos gubernamentales necesarios para el mejor funcionamiento del andamiaje estatal. En este nuevo Estado, las constituciones reflejaron la idea de supremacía del derecho y el hecho de que toda la vida del Estado está basada en él y conforme a él. Entendida como la expresión más razonable y más justa de la voluntad general ${ }^{166}$, la racionalización del poder significó la división y limitación de este último mediante el derecho. Será establecido como las ordenaciones racionales nacidas a través del acuerdo de las voluntades del pueblo reflejadas en órganos representativos que gozaban de legitimidad democrática.

Respecto a este punto, es preciso traer a colación la filosofía de la época que, a nuestro juicio, es expuesta de forma lúcida por Benjamín Constant. En los trabajos de este autor es posible detectar un pensamiento limitativo integral al poder. Prueba de aquello es su frase: "hay que actuar contra el arma y no contra el brazo que la sostiene"; pues hay pesos demasiado fuertes para la mano del hombre ${ }^{167}$. Según el autor, sólo puede existir la soberanía si es de una manera limitada y relativa. Allí donde comienza la independencia y la esfera individual de las personas, finaliza la jurisdicción de la soberanía. Constant sostenía incluso que con la soberanía popular se había creado caprichosamente un poder tan grande que era difícil de controlar, ya que allí donde existe una soberanía ilimitada no hay forma de proteger a los ciudadanos $^{168}$.

Para Constant, no puede existir ninguna autoridad ilimitada, ya sea un rey, el pueblo o la ley, dado que existe un mínimo esencial de derecho que debe ser garantizado y respetado: los derechos individuales, los cuales constituyen un elemento esencial de los hombres. Para lograr aquella limitación de la soberanía, el mencionado autor fijó dos mecanismos: la voluntad general y el equilibrio de poderes. Con ello, reconoce que el problema es la cantidad de poder y no necesariamente quién lo ejerce. Los límites al poder deben existir y ser una garantía, pues estos no son otra cosa que los derechos del hombre que, garantizados por la ley fundamental, deben de ser respetados. Para lograr este cometido, Constant establece que las funciones del Estado deben realizarse de forma separada y

\footnotetext{
166 Mirkine-GuetzeVitch (1934) p. 8.

167 CONSTANT (1989) P. 9.

168 CONSTANT (1989) p.14.
} 
equilibrada ${ }^{169}$, reconociendo incluso a la figura del monarca como un poder neutral y mediador en dicha finalidad. Por tanto, la construcción del Estado moderno significó el establecimiento de un sistema de distribución de funciones regulado y limitado por el derecho. Lo anterior, fue vinculado a una organización del poder al interior del Estado que se expresa en la teoría de la división de poder que analizaremos a continuación.

\section{c) Teoría de la división de poderes como mecanismo jurídico-político de control}

La limitación política, a través de la separación de las funciones del Estado en legislar, administrar e impartir justicia, será otro gran mecanismo de control del poder. Esto se debe a que no solamente se dividió al poder en órganos distintos, lo cual evitó la concentración y el abuso del mismo, sino porque también procuró equilibrarlos de tal manera que todos funcionaran colaborativa y armónicamente, por medio de su mutua limitación. El sistema de equilibrio de poderes, luego denominado check and balance, fue la raíz que consintió el nacimiento del control político interorgánico, del cual emergerá el control parlamentario. Este último se constituyó como la división de funciones que simultáneamente delimitará las relaciones de poder y, a su vez, el rol que cada función adquirirá en cada sistema político, lo cual generará el surgimiento de las formas de gobierno parlamentaria y presidencial. En los estados modernos la distinción entre poderes fue sinónimo de libertad y la razón de ello no se encuentra muy lejos. De este modo lo aseveró Laski, quien expone lo siguiente: "cuando el poder no se divide de alguna manera, tiende, necesariamente, a ser absoluto; y siendo peligroso, por su misma naturaleza, para los mismos que lo ejercen, resulta que debe ser limitado para que los disfruten, sin que les pervierta" (Laski, 1932, p.5)

Parte de la literatura considera que esta concepción de la división de funciones del Estado es la gran herramienta de limitación del poder $y$, a su vez, el instrumento fundamental para la consecución de los objetivos del constitucionalismo ${ }^{170}$. Esta concepción ya se encontraba de alguna manera presente en la polis griega y en la

\footnotetext{
${ }^{169}$ Interpretación del autor que es dable de percibir en las siguientes palabras: "El soberano tiene derecho de castigar, sólo si las acciones son culpables; tiene derecho hacer la guerra, pero sólo cuando la sociedad es atacada; tiene derecho hacer las leyes, pero sólo cuando esas leyes son necesaria, y en tanto en cuanto sean conforme a la justicia" (Constant, 1989, p.13).

170 SolozÁBAL (1981) p.215.
} 
república romana. Así lo habría expuesto Aristóteles, cuando explicaba la prudencia de un buen gobierno y Polibio, con respecto al equilibrio en las funciones de Gobierno $^{171}$. No obstante, esta teoría de la división de poderes sólo se materializaría de forma definitiva con la contribución de Locke y Montesquieu.

Cuando Locke describe el origen o formación de la sociedad civil, simultáneamente diseña y describe tres poderes: Legislativo, Judicial y Federativo. Estos poderes, inicialmente para el autor, no estaban conferidos en tres órganos independientes, pues la función legislativa la detentaba el Parlamento y el Rey; la federativa el Monarca; y la ejecutiva el Monarca y el Consejo, razón por la que no existirá un Poder Judicial independiente ${ }^{172}$. Sin embargo, el autor describe una organización funcional del Estado. En el pensamiento de Locke es conocida la supremacía que se le confería al Poder Legislativo. No obstante, el valor de sus postulados reside precisamente en que respecto a ello sostuvo que el ejercicio y la ejecución situados en las mismas manos era demasiada tentación para la debilidad humana, ya que ésta tiende a aferrarse al poder, pudiendo eludir o aplicar de forma arbitraria las normas. Ésta es la razón por la cual necesitaban estar aquellas funciones depositadas en manos diversas, facultades que tendrán como límite el deber de actuar conforme a reglas dadas y en búsqueda del bien público. Idénticos argumentos sustentarán también la existencia de un poder permanente que cuide y cautele la ejecución de la normas mientras éstas estén vigentes.

En adición a lo ya señalado, Locke establecerá como salvaguardia del pueblo la posibilidad de que este último pueda ejercer su poder supremo mediante la adaptación o cambio a los legisladores del Poder Legislativo, en el evento que ellos actúen de manera contraria a la misión encomendada. De esta manera, la sociedad civil siempre mantiene subordinados dichos poderes a su autoridad suprema: la voluntad colectiva ${ }^{173}$. Finalmente, la construcción teórica de Locke de carácter descriptiva del sistema político inglés reconoció la importancia de la división del poder en funciones, mas no en órganos. Junto con ello, reconoce la existencia de la voluntad soberana como único detentador del poder pudiendo remover o modificar a sus delegados cuando ellos no actuaran conforme a lo requerido por el pueblo, reforzando con ello límites jurídicos y políticos al poder.

\footnotetext{
171 SÁNCHEZ (1945) p.173.

172 SOLOZÁBAL (1981) p.220.

173 LOCKE (1969) Pp. 110 a 114.
} 
La teoría de división de poderes será tratada en profundidad por Montesquieu, quien logrará desarrollarla como un principio general aplicable a todo Estado, en oposición a lo realizado por Locke, quien solamente se limita a dilucidar el modelo inglés poco conciliable con otras organizaciones políticas ${ }^{174}$. A través de su empirismo histórico, el Presidente del Parlamento de Burdeos elaboró un sistema de equilibrios respecto a la conformación de los poderes del Estado. Montesquieu, como tantos otros pensadores liberales, situó al ser humano y su libertad como eje central de protección de los gobiernos. La libertad de las personas dependerá de la tranquilidad con la que viven sin temor de otros o del gobierno. Montesquieu encontrará en la división de poderes una garantía de protección de aquella libertad y el régimen de legalidad, vale decir, del régimen de Estado legal. Al considerar a la ley como una regla general de carácter abstracto y justo, supone necesario cuidar de estas cualidades. Por ende, encomienda su creación a un órgano que pudiera diseñarla libremente y cuyo objetivo sea el porvenir de la nación y no casos o personas particulares, con lo cual se dotará de un carácter neutral y protector de la necesidad de separar al legislativo de otros poderes ${ }^{175}$.

A diferencia de Locke, Montesquieu formula la teoría de la división de poderes señalando que no basta con que los poderes se encuentren separados, sino que también es necesario que las funciones se ejerzan de forma autónoma por órganos y personas distintas. La finalidad de esta división funcional es el equilibrio y la moderación. El criterio de división funcional e institucional de las funciones tenía como fundamento un argumento que reiteradamente estaba presente en los defensores de la libertad, entre ellos Montesquieu: los hombres que detentan poder sienten habitualmente una inclinación a abusar del mismo, motivo por el cual dicha capacidad de detentar poder debe ser limitada y será necesario que "el poder frene al poder ${ }^{\prime 176}$.

Distribuir las distintas atribuciones en tres órganos diferentes implicaba, según el Barón, evitar el peligro de instalar la función legislativa en las mismas manos que la función ejecutiva, lo cual privaría de libertad a los gobernados. Del mismo modo, sostenía la separación del Poder Judicial del Poder Legislativo porque también podía ocurrir que el poder sobre la vida y libertad de los ciudadanos dependiera arbitrariamente de quien lo practique. Así, de no estar separado del Poder Ejecutivo

\footnotetext{
174 CARRE DE MALBERG (1948) p.743.

175 CARRe de MALberg (1948) Pp. 745 y 746.

176 MONTESQUiEU (1972) p.150.
} 
éste se transforma en un poder opresor ${ }^{177}$. Debido a lo anterior, esta división del poder trae aparejada la posibilidad de que éstos se controlen de forma recíproca, lo cual impide que uno de ellos absorba al resto como único detentador con finalidades insanas. Ésta es la raíz esencial de la división de poderes: configurarse como una garantía de la libertad, tal como la calificaba Posada ${ }^{178}$.

Como es sabido, y fruto de la teoría de la división de poderes, Montesquieu fijará los cimientos de los controles políticos y, entre ellos, particularmente del control parlamentario. Es posible evidenciar esto cuando el autor manifiesta que la tarea legislativa no debe incluir la facultad de frenar al Ejecutivo, pero sí tiene la prerrogativa de examinar cómo deben son cumplidas las leyes dictadas por él mismo. Por su parte, los poderes estarán -en principio- en reposo, pero cuando deban ponerse en acción deberán hacerlo de común acuerdo ${ }^{179}$. Con esta argumentación, es dable destacar que el autor considera al órgano legislativo como el más óptimo para realizar una fiscalización de los actos del Ejecutivo y la ejecución de la ley, con lo cual establece la esencia del control político parlamentario, además de dejar de manifiesto que entre los poderes deberá existir una relación de coordinación que no afecte de ningún modo el ideal de división del poder pretendido.

La incorporación de la división de poderes en los Estados no fue una cuestión sencilla, pero su trascendencia es innegable. Su influencia puede percibirse en tres cuerpos jurídicos muy significativos. El primero, en su consagración en el artículo 16 de la Declaración de Derechos del año 1789; el segundo, en su presencia en la constituyente francesa y luego en su texto constitucional de 1791; y el tercero, en la Constitución americana. La Declaración de Derechos incluso llegó a asimilar a la división de poderes con la Constitución. Así lo expresaba el artículo 16 que reza: "una sociedad que en la que no esté establecida la garantía de derechos, ni la separación de poderes, carece de Constitución".

\footnotetext{
177 El Barón de Montesquieu además señala la forma en que deben estar compuestos los tres poderes. El poder judicial debe ser ejercido por personas del pueblo, por un cierto periodo de tiempo, nombradas por procedimientos legales que den forma a un tribunal que sólo durará un tiempo determinado. Por su parte, el legislativo será formado por cuerpos permanentes que den forma a la voluntad general a través de representantes cualificados (nobles), siendo seleccionados por el pueblo; el poder ejecutivo debe estar en manos de un monarca por la rapidez de acción que tal función necesita ${ }^{177}$. Allí es donde esta lógica de separar poderes implica además dividir no sólo el trabajo sino también dividir el poder, con ello inevitablemente el poder se debilita o por lo menos se dispersa lo cual evita la concentración del mismo, por ende, es un poco más factible lograr su control.

178 POSADA (1930) p. 43.

179 MONTESQUiEu (1972) Pp. 155 y 156.
} 
Sin embargo, será en la Constitución americana en la cual se expresará esta teoría en toda su magnificencia a través de las propuestas de los padres fundadores. En efecto, la Constitución americana de 1787 estuvo construida esencialmente como una respuesta a la doctrina de separación de poderes ${ }^{180}$. Los padres fundadores fueron los alumnos más disciplinados de esta nueva visión de la organización gubernamental, lo cual se verá reflejado en las enmiendas presentadas por Madison, toda vez que ellas tuvieron como fundamento esencial la inclusión de mecanismos de control al poder político central. Los americanos fueron capaces de conjugar la división de poderes y controles políticos con el diseño constitucional elaborado, lo cual tuvo por consecuencia una transacción y aplicación atenuada que dio nacimiento a la doctrina de checks and balances ${ }^{181}$.

Empero, esta estructuración del poder no sólo contó con opiniones favorables, sino que también con voces que la cuestionaron. Las primeras opiniones controvertidas apuntaban al origen de la teoría. De este modo, Bertrand de Jouevenel visualizó un error, tanto en la interpretación como en la aplicación del modelo británico -en el cual Montesquieu basó sus observaciones e investigaciones-. La mayor equivocación fue pretender llevar este modelo de organización estatal a Francia, ya que la particular evolución política británica impediría que pudiese imponerse de la misma manera en otro Estado. Por ende, no bastará con instituir la división de poderes en las constituciones o con consagrar órganos separados en su funcionamiento para que tomen la fuerza necesaria para funcionar correctamente ${ }^{182}$.

Desde otra perspectiva, hay quienes no creyeron efectivo que los poderes fueran capaces de controlarse entre sí y así evitar la concentración del poder, ya que vislumbraban la posibilidad de que esta separación fuera de tal dimensión que impidiera el correcto y oportuno funcionamiento de ellos, produciendo simplemente una parálisis de los mismos ${ }^{183}$. A este punto, se sumaban las críticas de Carre de Marlberg, quien profesaba como inconcebible la existencia de poderes que no se relacionaran entre sí. Según este autor, es imposible que el Legislativo no participe en el Ejecutivo y viceversa, puesto que no son independientes entre ellos. Para el

\footnotetext{
180 POSADA (1930) Pp.41 y 42.

Para el autor las primeras etapas del régimen constitucional general que se gesta en reacción al absolutismo, se elabora como un régimen de equilibrios institucionales de poderes a fin de organizar y mantener una estabilidad política y garantizar el goce más o menos limitados de los derechos de los ciudadanos.

181 SOLOZÁBAL (1981) p. 223 y 224

182 De JuUVenel (1974) PP. 366, 367 y 368.

183 Duguit (1926) P. 153. Los argumentos de Duguit además le permitieron determinar que ésta no era una separación de funciones como tal, sino que solamente configuraba una "colaboración de órganos".
} 
autor, la teoría de Montesquieu constituye solamente una descripción del sistema inglés, razón por la cual resaltará que no se trata de un sistema de separación de poderes, sino que del diseño de un sistema de reparto de tipo inglés ${ }^{184}$.

Pese a las múltiples críticas que se pueden analizar respecto a las bondades o deficiencias de la teoría de la división de poderes, tal teoría -junto a otras como la soberanía, la representación política, la doctrina de la corporación y del órgano- tuvo como misión forjar una voluntad general independiente de toda subjetividad ${ }^{185}$. Producto de aquello, se dio origen a un derecho cuyas cualidades esenciales comprendían la abstracción y generalidad. Desde aquel momento el poder se debe someter a la voluntad general, por tanto está regulado mediante el derecho. En este orden de ideas, se configura en una potestad legítima, pero que además debía dividirse. En definitiva, tal argumentación filosófica, política y jurídica permitió concebir al poder como un objeto controlable y divisible que se ajustaba de forma armónica a los derechos esenciales del ser humano.

\section{Los regímenes de gobierno y el control parlamentario}

Como lo adelantáramos precedentemente, la división de poderes no sólo fue un mecanismo efectivo en el objetivo de controlar el poder, sino que simultáneamente dicha diferenciación funcional fijó mecanismos relativos a la forma en la que se relacionarían los poderes entre sí. En virtud de tal diferenciación funcional y las relaciones entre poderes, fue posible además configurar las formas de gobierno. Esto quiere decir que la interpretación del principio de división de poderes, ya fuere con mayor o menor rigidez, forjó las variantes presidencial y parlamentaria en los gobiernos representativos. De este modo, una mayor rigidez en la separación funcional entre el Legislativo y el Ejecutivo favorecería la gestación del sistema presidencial. A contrario sensu, la flexibilidad en tal separación de funciones, vale decir una vinculación o dependencia más estrecha entre los mismos, daría nacimiento a un sistema parlamentario.

\footnotetext{
${ }^{184}$ CarRe de Malberg (1948) p. 773.

185 HELLER (1995) p.87.
} 
Lo descrito anteriormente, responde a una mirada estrictamente teórica y descriptivo-pedagógica respecto de tales formas de gobierno, mas no corresponde necesariamente a las manifestaciones actuales de cada modalidad. En la actualidad, tal como lo analizaremos, se han producido ciertas mutaciones en las formas de expresión de los regímenes de gobierno que crean una determinada desnaturalización en cada uno de ellos. Dicho punto ha sido extensamente analizado por la doctrina e intentaremos, en las siguientes líneas, exhibir las posiciones más relevantes, siempre desde la perspectiva del control parlamentario, tema central de esta investigación.

En la actualidad, resulta complejo desarrollar una descripción categórica o exacta de los rasgos esenciales en los regímenes parlamentario y presidencial. Más complejo aún es señalar las diferencias cardinales entre ellos, debido a que la expresión de sus elementos neutrales hoy se configura y expresa de un modo diverso a su diseño original. La vida política, las guerras mundiales, el sufragio universal, el actuar de los partidos políticos y, esencialmente, las necesidades propias de cada Estado han provocado importantes mutaciones en ambas formas de gobierno. Lo anterior, ha dificultado el establecimiento de una delimitación clara y precisa entre ellos. Dicho esto y en lo que a nosotros respecta, a continuación estudiaremos ambos sistemas, explicaremos las implicancias de sus rasgos relevantes, en relación a sus manifestaciones primigenias, y expondremos someramente aquellas alteraciones que los han modificado. Lo anteriormente mencionado, se realizará con el fin de poder luego analizar cómo el control parlamentario ha sido en ocasiones sujeto activo y en otras pasivo de tales transformaciones. Adicionalmente, intentaremos determinar como objetivo central la forma en que ello ha influido en su propio desarrollo institucional.

En este punto, cabe destacar que sobre las semejanzas y diferencias del control parlamentario entre los regímenes de gobierno, se ha cimentado una de las discusiones más extensas del Derecho Parlamentario relacionada con el origen del control parlamentario y sus expresiones en cada forma de gobierno. Las discrepancias doctrinales relativas a la existencia y dimensión del control en regímenes políticos parlamentarios y presidenciales son profundas. Éstas diferencias han dado origen a dos posturas clásicas, las que se exhiben muy someramente en los siguientes términos: 
1. Los sistemas parlamentarios son la cuna de la fiscalización parlamentaria en virtud de la relación de confianza que liga al Ejecutivo con el Legislativo. Por lo mismo, éste es el sistema donde el control parlamentario se ejerce en plenitud, exhibiendo como principal efecto la exigencia de responsabilidad política y provocando la destitución del jefe de Gobierno y la caída de los gobiernos;

2. Los presidencialismos se configuran mediante relaciones poco amigables o estrictas entre los Poderes Ejecutivo y Legislativo, lo que conlleva a una doble legitimación popular-electoral respecto de ambos poderes. Aparentemente, en este sistema se imposibilita la existencia de un método de fiscalización parlamentaria real $y$, por lo mismo no poseería un mecanismo de exigencia de responsabilidad política efectivo o, en su defecto, de ser existir este mecanismo su exigencia se realizaría a través de ejercicios muy tenues, mediante herramientas rígidas y de difícil aplicación.

No obstante los postulados antes descritos y los que a continuación analizaremos, nosotros a priori sostenemos que la función de fiscalización parlamentaria y la responsabilidad política, como institución, existen en ambos regímenes y en especial en los tiempos modernos. Sugerimos que allí donde existe poder ha de existir control, por ende, tanto en los regímenes presidenciales como parlamentarios -a pesar de existir una intensidad distinta en la distribución de las atribuciones para cada poder del Estado- siempre habrá de existir mecanismos de control. Ciertamente, las formas en la que se ejecuta utilizará vías diversas, pero en términos generales sus efectos son bastante similares. En los párrafos siguientes iremos profundizando el enunciado que planteamos.

Principalmente, el control parlamentario responde al carácter o impronta que en cada Constitución Política y sistema político se establezca o defina como tal. Los mecanismos establecidos para su ejercicio serán probablemente los más apropiados para su realidad política y jurídica. Es por ello que el sentido y alcance que posea el control parlamentario en cada régimen de gobierno dependerá de tal consagración constitucional y de los constructos teóricos de los mismos. Las expresiones del control estarán supeditadas a lo que el constituyente haya planteado como su 
orientación y finalidad. Lo anterior, fijará los límites tanto para los mecanismos de fiscalización como para sus efectos, pero hay que señalar que la realidad parlamentaria siempre puede generar modificaciones de gran relevancia.

Con todo, estimamos firmemente que la fiscalización parlamentaria y la responsabilidad política son instituciones dúctiles, cuyo principal valor es precisamente adecuarse a las necesidades de cada sistema político, por lo que toman vigencia y protagonismo en cada momento histórico que así lo requiera. Por tanto, al gozar de tal relevancia, los frenos y contrapesos estarán siempre presentes en todo ordenamiento democrático y constitucional que aspire a desarrollar una sociedad libre, justa e igualitaria. La dificultad investigativa aparecerá inexcusablemente al intentar analizar teórica y jurídicamente una institución con tal nivel de variabilidad. No obstante, perseveraremos en dicha misión considerando la relevancia democrática, política e histórica de esta institución. En este punto quisiéramos finalizar señalando que coincidimos plenamente en lo dicho por Giovanni Sartori cuando expone que "en la actualidad todos los verdaderos sistemas constitucionales son sistemas de balances y contrapesos"186.

\section{a) El régimen parlamentario}

Sin ánimo de reiterar conceptos de suma conocidos, nos permitiremos describir algunos elementos centrales en torno al sistema parlamentario, a fin de poder exponer las razones que lo vinculan tan estrechamente con el control político y, por ende, con la fiscalización del Parlamento hacia el Ejecutivo. Con ello, podremos describir de la mejor manera posible el desarrollo del control parlamentario y cómo fue tomando forma hasta arraigarse en los sistemas de representación democráticos.

El parlamentarismo es un tipo de gobierno representativo que posee sus orígenes en Inglaterra, el que nace en virtud de la soberanía parlamentaria. El sistema Westminster se gesta fruto de un largo proceso que posee sus primeras manifestaciones en la Declaración de Derechos de 1689 -documento en el que precisamente se robustecen las garantías del Parlamento y se afianza particularmente a la Revolución Gloriosa de 1688, a través de la cual se establece

\footnotetext{
186 SARTORI (1994) p.102.
} 
una comunión entre el trono y el Parlamento-. No obstante, será con el arribo de los Hannover a la Casa Real ${ }^{187}$ que el gobierno parlamentario se consolidará, debido a la gran labor desarrollada por los ministerios de Walpole y la debilidad de la Corona en los reinados de Jorge III, Jorge IV y Guillermo IV. Posteriormente, el gobierno parlamentario se sustentará en las "convenciones constitucionales" ${ }^{188}$, para luego extenderse a casi toda la Europa Occidental.

El sistema parlamentario de gobierno de origen inglés estaba compuesto por tres actores: la Corona, el Gabinete y el Parlamento. Este sistema estaba sustentado funcionalmente en la vinculación entre los poderes Legislativo y Ejecutivo. En este régimen, el poder Ejecutivo y Legislativo se compartían ${ }^{189} \mathrm{o}$, como describe Solozábal, el régimen parlamentario era una variante del sistema democrático caracterizado por la atribución al órgano representativo de una determinada posición en el mismo, posición central pero respecto de la cual derivan unas determinadas relaciones equilibradas con el Gobierno ${ }^{190}$. En el modelo clásico de parlamentarismo, el Poder Ejecutivo estaba integrado por dos cabezas: un jefe de Estado que era irresponsable políticamente (la Corona) y un jefe de Gobierno que debía asumir la dirección política del Estado y, por ende, las responsabilidades políticas de aquella misión. Por su parte, el Gabinete no podía conformarse ni gobernar si no contaba con la confianza del Parlamento ${ }^{191}$. Esto quiere decir que era el Parlamento el que, a propuesta del partido mayoritario, aprobaba o rechazaba la proposición del programa de gobierno que se quería desarrollar. Además, seleccionaba a la persona que debía cumplir el rol de Primer Ministro o jefe de Gobierno ${ }^{192}$, quien debía velar por el correcto cumplimiento de tal programa político $y$, por último, le correspondía conformar su gabinete ministerial. Por tanto, la aprobación o rechazado del

\footnotetext{
187 Básicamente, y como es sabido, la instalación del sistema parlamentario en el Reino Unido fue un proceso gradual que se asienta con la llegada de la dinastía de Hannover a la Corona la que, al no poseer la lengua inglesa, se ve obligada a contar con un Consejo ejecutivo que fue tomando cada vez más prerrogativas hasta que, a finales del S. XVII, se materializa la relación entre los ministros y los representantes de los comunes. A groso modo diremos que el parlamentarismo fue resultado de las luchas que ejercieron los comunes frente al Rey en búsqueda de limitar sus atribuciones y reivindicar el poder en manos del pueblo personificado en el Parlamento.

${ }^{188}$ SILVA (1997) p.415, 416 y 417.

189 SARTORI (2003) p.116. Resulta relevante exponer la razón por la cual Sartori ha llegado a la conclusión de que el poder es compartido por ambos poderes. Lo anterior se plantea en razón, precisamente, der la soberanía del Parlamento y la falsa dependencia mutua o interdependencia y, se grafica claramente en la dificultad que reviste disolver el Parlamento, no así controlar al ejecutivo, lo cual se hace constantemente. 190 SOLOZABAL (1996) p. 42.

191 VeRdugo y GARCía (1988) p. 229.

192 Habitualmente la persona que es propuesta para cumplir tal función será aquel jefe de partido político que haya obtenido la mayoría electora, en consecuencia, es común que el jefe de gobierno sea a su vez el jefe de partido.
} 
programa político y de la persona que ejercería funciones en su calidad de primer ministro o jefe de gobierno, implicaba depositar o inhibir la confianza para dirigir los destinos de la nación, conformándose con ello el Gabinete.

Quien sin lugar a dudas ha analizado con lucidez la forma de gobierno parlamentaria y sus diferencias con el presidencialismo americano es Walter Bagehot, quien expresa precisamente que los americanos de 1787 creían copiar la Constitución inglesa, pero en rigor hicieron lo contrario. El gobierno americano se encuentra dentro del tipo de los gobiernos compuestos, en los cuales la autoridad suprema está dividida entre varios cuerpos políticos y varios funcionarios. Por el contrario, el gobierno inglés se enmarca dentro del tipo de los gobiernos simples, en los cuales la autoridad soberana sobre todas las materias está confiada a las manos de una misma persona ${ }^{193}$. Aquella autoridad suprema, para este autor, estaba compuesta por la Cámara de los Comunes, la cual se encontraba apoyada fuertemente por el sentimiento popular, razón por la que tenía el pleno derecho de gobernar según le pareciese y de tomar las decisiones que estimara pertinentes y prudentes -además de dar las mejores garantías de que ellas no variarían, pues aseguraba la ejecución de las mismas-. Dado que era aquella autoridad suprema la que nombraba al Ejecutivo, podía entonces castigar de la manera más severa su negligencia. Es por ello que dicha autoridad poseía la facultad de derribar al Ejecutivo. Para el autor, aquella posibilidad era una de las mejores herramientas contempladas por la Constitución británica y la denominaba "válvula de seguridad" del sistema parlamentario.

Por otra parte, conforme a los postulados de Bagehot, la Constitución también contemplaba un elemento "regulador" aplicable en el caso de que el Parlamento desempeñara una función caprichosa. Por este motivo, se le otorgaba al ministro elegido por la misma Cámara el poder neutralizador del Parlamento, con el que podía él mismo disolverlo a fin de mantener el debido equilibrio entre poderes.

Como es posible observar, los rasgos más esenciales del parlamentarismo serán la correspondencia entre Ejecutivo y Legislativo -la que se desenvuelve mediante una noción de colaboración entre poderes- y la existencia de medios de acción recíproca

193 BAGEHOT (1826-1877) Pp. 276-277. 
del cual goza cada uno de los poderes sobre otro ${ }^{194}$. De tal modo, se producirá una fusión entre el Poder Legislativo y el Ejecutivo que otorga preponderancia al Ejecutivo mediante el apoyo del o de los jefes de partidos mayoritarios, a fin de cumplir un programa de gobierno. Adicionalmente, esta forma de gobierno se desarrollará de manera comúnmente efectiva en sistemas de carácter bipartidistas. En suma, en el parlamentarismo existirá una íntima relación entre Ejecutivo y Legislativo en virtud del estrecho vínculo que los une, toda vez que la formación del Gabinete y la aprobación de su jefe de Gobierno emanan del mismo Parlamento, con la finalidad de que el Poder Ejecutivo organice y lleve a cabo el programa político. Sin embargo, aquella condición necesaria será al mismo tiempo la que le imponga al Legislativo la facultad de analizar los detalles del programa y criticar las medidas con las que el Ejecutivo desempeña su cargo, por lo que deberá velar por el correcto funcionamiento del Gobierno y por el cumplimiento de las orientaciones políticas, pudiendo ejercer acciones de responsabilidad política en caso de no cumplirse tales propósitos. Es por ello que se ha planteado que en este sistema existe un "asociación íntima entre poderes" ${ }^{195}$.

De esta manera, podemos definir al sistema parlamentario como aquel régimen en el cual un Gabinete Ministerial, responsable ante la representación nacional, dirige la política del país con el grado de independencia que implica tal misión. El régimen parlamentario instará a que ni Gobierno ni Parlamento lleguen a adquirir una preponderancia duradera, y a que el equilibrio entre el Parlamento elegido, el jefe de Estado y el Gabinete Ministerial se verá garantizado por un control permanente de la opinión ${ }^{196}$. Así, el régimen parlamentario básicamente propone la centralidad del órgano representativo. No obstante lo señalado, ello no altera la relación equilibrada y compensada que existe entre ambos poderes, debido a que el Gobierno responde políticamente ante el Parlamento o, lo que es lo mismo, necesita de su confianza para acceder y mantenerse en el poder. Sin embargo, éste es un sistema en que la dependencia fiduciaria del Gobierno respecto del Parlamento es compensada con la posibilidad de disolución de aquél sobre éste ${ }^{197}$. Pese a lo anterior, para Rubio Llorente siempre existirá una relación de subordinación política del Gabinete para con el Parlamento respecto de este punto. Lo anterior, será así no sólo porque deba

\footnotetext{
194 MANZANARES (1970) p.53.

195 CARTER Y HERZ (1964) Pp. 32 y 33.

196 MANZANARES (1970) Pp. 51 y 53.

197 SOLOZÁBAL (1996) p. 44.
} 
respetar las leyes que de éste emanan, sino también porque depende de los recursos económicos que éste apruebe y le conceda, y además está supeditado su juicio en los nombramientos de los miembros del Gobierno, lo que gesta una verdadera relación de supremacía ${ }^{198}$.

En cuanto al control parlamentario, uno de los aspectos principales para nosotros dice relación con la importancia de la confianza parlamentaria, la cual es depositada por medio del voto de la Cámara Popular al Ejecutivo. Este elemento, será constantemente discutido y se expresará en la continuidad o no del Gabinete. Por tanto, la carencia o falta de confianza por parte del Parlamento implicará el ejercicio de un control sobre la gestión del Ejecutivo, el que a su vez puede aplicar la exigencia de la responsabilidad política -lo que se traduce finalmente en la pérdida del poder, es decir, en la imposibilidad de seguir gobernando-. Por su parte, el Gabinete, al formar un órgano colegiado, determinará si los actos ejecutados por un determinado ministro se entenderán apoyados por el colectivo, y realizados en su nombre. Por ende, la responsabilidad de sus integrantes será solidaria ${ }^{199}$.

Los medios a través de los cuales se llevará a efecto dicha responsabilidad serán dos: la cuestión de confianza y la moción de censura. Ambos mecanismos tendrán por finalidad hacer caer al Gobierno. En el primer caso, se realizaría por el rechazo de una propuesta de ley en la cual se haría valer la cuestión de confianza. En el segundo caso, el mecanismo se haría efectivo en virtud de una iniciativa de los miembros del Parlamento quienes, precisamente, someterían a revisión la continuidad o término de la confianza depositada, es decir, se evaluaría la gestión de dicho Gabinete. Sin embargo, como planteáramos precedentemente, uno de los rasgos esenciales del parlamentarismo es la existencia de mecanismos de acción recíprocos. Es por ello que el Gabinete también contará con una herramienta que le permitirá sortear las dificultades políticas de su gestión para así poder hacer frente a las presiones que ejercerá el Parlamento, además de evitar la compleja situación de encontrarse en minoría parlamentaria. Esta arma constitucional es el derecho de disolución del órgano representativo y el consecuente llamado a sufragio universal respecto de las censuras parlamentarias ${ }^{200}$.

\footnotetext{
198 RUBIO (1993) p.250.

199 SiLVA (1997) p. 420.

200 Respecto de este punto, los autores Verdugo y García señalan que éste es un mecanismo que no sólo permite solucionar conflictos políticos inmediatos entre Parlamento y Gobierno sino que además permite
} 
En consecuencia, el sistema parlamentario nace unido al control gubernamental de tal manera que los ha transformado, según parte de la doctrina, en dos caras de una misma moneda. La causa principal de tal vínculo es una raíz común: la "relación de confianza". Es en este sentido en el cual Manuel Sánchez de Dios esboza que el control parlamentario es la lógica consecuencia de la existencia de la relación básica que liga de forma directa e inexcusable al gobierno con el Parlamento ${ }^{201}$. El principio de que el Gobierno descansa en la confianza del Parlamento, vale decir, en la necesidad de contar con una mayoría en el Parlamento que le permita existir y actuar, será el motivo o corolario por el cual el Gobierno esté sometido al control del mismo y a la exigencia de responsabilidad política. Esta misma línea, y sumándose a tal posición, Jordi Xuclá i Costa agrega que el régimen parlamentario se asienta sobre la relación de confianza o relación fiduciaria, la que es presentada como correlato de aquello que se le asigna al Parlamento: la función de control del gobierno ${ }^{202}$.

Una opinión categórica en este punto es la expresada por José Antonio Portero, pues para este autor sólo en los sistemas parlamentarios el control va unido a la exigencia de responsabilidad, lo que se traduce en la posibilidad de derribar gobiernos, lo que lo convertiría en uno de los elementos definitorios del sistema ${ }^{203}$.

Finalmente, Fernando Santaolalla refuerza lo antes expuesto manifestando que de los rasgos esenciales del parlamentarismo, punto definitorio y rasgo característico del mismo, es la "responsabilidad política". De este modo -agrega el autor-, si bien debe existir control del poder Legislativo hacia el Ejecutivo en otras formas constitucionales como presidencialismo y autoritarismos, es en el parlamentarismo donde la responsabilidad política es atributo característico y diferenciador. Este elemento de dependencia de un poder en otro, que lleva implícita la facultad de remoción, se produciría a través de los mecanismos antes señalados, es decir, la cuestión de confianza y la moción de censura ${ }^{204}$.

solucionar conflictos de poderes, en los cuales se juzga necesario un pronunciamiento popular. VERDUGO Y GARCÍA (1988) p.229.

201 SÁNCHEZ DE DIOS (1995) Pp. 36.

202 COSTA I XUCLÁ (2011) p. 36.

203 PORTERO (1998) p. 9. Sin embargo, posteriormente el autor realizará una diferenciación trascendental entre control- responsabilidad y la naturaleza de sus efectos, producto de la cual concluye la total aplicabilidad de dichas instituciones en regímenes presidenciales y parlamentarios, sin perjuicio, de la diferenciación en su regulación y formas de aplicación que establezcan sus marcos reguladores. P. 17.

204 SANTAOLALLA (1984) Pp. 322 y 323. En este punto el autor a modo de paralelo comparativo expresa que en el caso del presidencialismo pueden existir diversos mecanismos de control entre ambos poderes, 
Para comprender mejor la relación existente entre control y la responsabilidad política -y particularmente en el sistema parlamentario de origen británico-, resulta ilustrativo traer a colación a los autores Carter y Herz. Estos autores declaran al Ejecutivo del Reino Unido como uno de los cuerpos colectivos más poderosos de los sistemas democráticos, debido al control que puede ejercer sobre la Cámara de los Comunes. Sin embargo, como contrapartida acepta la responsabilidad de su actuación en pro de toda la Nación, y no como un cuerpo que represente exclusivamente a la mayoría. Es por ello que el Gabinete se mantiene atento a las preguntas del partido de oposición, a la publicidad de sus actos y al cumplimiento del programa gubernamental, de manera tal que realmente existe un equilibrio entre la libertad del gobierno y la vigilancia de las medidas gubernamentales ${ }^{205}$.

Tales declaraciones permiten finalmente percibir que la construcción del régimen parlamentario posee una finalidad existencial y otra funcional. La fusión de poderes tiene una misión existencial, toda vez que de aquella relación nace a la vida política un jefe de gobierno y un itinerario político que dotará de orientación y eficacia la gestión del Ejecutivo. Por otro lado, la fusión de poderes desarrolla un rol funcional respecto de la posibilidad de controlar la gestión administrativa del Estado, pudiendo objetar y -en definitiva- paralizar toda aquella actividad que sea contraria a los fines establecidos por la nación, debiendo asumir la responsabilidad que ello implica, la que se hará valer mediante los mecanismos diseñados para tal efecto. Estos mecanismos pueden ser contrarrestados cuando parezcan improcedentes, por otras herramientas de igual valor entregadas al Parlamento. Todo lo anterior, tiene lugar con la finalidad de equilibrar los poderes de acción de cada poder estatal a modo de ceñirlo a los estrictos márgenes político-nacionales, es decir, a los límites institucionales fijados por la nación soberana.

sin que ninguno de ellos determine responsabilidad política, adicionalmente agrega como elemento esencial que estos poderes son independientes uno de otro lo que impide la existencia de una relación de confianza y dependencia, lo que también justificaría el por qué la responsabilidad política es propia del parlamentarismo. Visión diferente es la que poseemos, por considerar que sí existe responsabilidad política en los sistemas presidencialistas la cual es exigida igualmente por el Legislativo en el ejercicio de rol fiscalizador, función esencial a su institución así lo han señalado la mayoría de la doctrina, y por su parte la existencia de la división de poderes no influiría en ello sino más bien consideramos tendría una orientación complementaria, la cual es cautelar el correcto ejercicio de roles en la administración de un estado sin inmiscusiones improcedentes, obstruccionistas y/o oportunistas que pudieran afectar los equilibrios en un sistema democrático, en un Estado de derecho.

205 CARTES Y HERZ (1964) p.35. 
Pese al innegable significado del parlamentarismo para los gobiernos representativos, constitucionales y democráticos, es posible destacar que su evolución no estuvo exenta de cuestionamientos. Básicamente y fruto del declive del Parlamento, del fortalecimiento del Ejecutivo, el sufragio universal, el surgimiento de los partidos políticos y las Guerras Mundiales, se gestó un fenómeno en los años veinte y treinta que contrapuso al parlamentarismo contra el anti-parlamentarismo.

Uno de aquellos acérrimos anti-parlamentarista fue Carl Schmitt. Este autor denominaba al gobierno parlamentario como "al influido de modo decisivo por la representación del pueb/o"206. Ciertamente para Schmitt, una directa influencia del pueblo en el Gobierno no representaba necesariamente una virtud. Este autor intentaba explicar dicha preponderancia popular como una justificación antigua que radicaría precisamente en el pueblo considerado en su totalidad real, quien debería decidir -como ocurría antiguamente- cuándo todos los miembros de una comunidad podían reunirse.

No obstante, hoy por razones prácticas resulta imposible que todos se reúnan en el mismo tiempo y lugar, o bien preguntar a todos acerca de cualquier detalle. En base a lo anterior, resulta lógico servirse de una comisión electa constituida por personas de confianza -precisamente lo que conocemos como Parlamento-, generando así la escala de confianza.

Por ello, para Schmitt, "El Parlamento es una comisión del pueblo, y el gobierno una comisión del Parlamento", lo que lo hace esencialmente democrático ${ }^{207}$. Sin embargo, será con respecto a aquellos elementos esenciales del parlamentarismo que el autor formulará dos críticas al sistema: $a$. como forma de gobierno y $b$. como forma de Estado. Schmitt las señalará como causantes de la inestabilidad de los gobiernos, pues generan un excesivo dominio del gobierno por el Parlamento -lo que conduce hacia una imposibilidad de gobernar-, situación totalmente opuesta a la división de poderes e inconciliable con la necesidad de un Estado "administrativo eficaz" ${ }^{208}$. Sin embargo, las críticas de Schmitt no sólo fueron dirigidas al sistema de

\footnotetext{
206 DíAZ DE VALDÉS (2001) Pp.75-80. En este artículo el autor realiza un análisis detallado del pensamiento de Schmitt frente al parlamentarismo como sistema de gobierno, las contradicciones que este presenta y principalmente frente a la "falsedad del mandato libre y la soberanía como ficción".

207 SchmitT (1990) Pp. 41 y 42 . Para Carl Schmitt, la concepción de hegemoneidad del pueblo con un solo interés reinante no se basa en la democracia en libertad.

${ }^{208}$ ARAGón (1998) p. 234 a 236.
} 
gobierno sino que al Parlamento como institución. Podría pensarse que tales opiniones situaban a Schmitt como un defensor del presidencialismo, lo cual de ser efectivo en palabras de Aragón Reyes, sólo comprendería una "dictadura presidencial". Si bien las críticas al parlamentarismo pueden ser más variadas que la sola opinión de Schmitt, no será preciso profundizar en ellas puesto que nuestra misión en el presente apartado es ahondar en el desarrollo del control parlamentario.

Como se observa, el respaldo que ha encontrado el control o fiscalización parlamentaria en el régimen parlamentario es muy nutrido. Sin embargo, su actuación jurídico-política no ha sido del todo pacífica. En efecto, su desarrollo se ha presentado fluctuante, llegando a evolucionar en el pasado reciente a formas atenuadas, producto de una regulación normativa rigurosa y de una concepción diversa del poder, del Parlamento, del Ejecutivo, de la organización política del Gobierno y del Estado. Producto de las propias transformaciones que trajeron consigo el sufragio universal y los partidos políticos, el período de post-guerra se vio envuelto en una serie de cuestionamientos a las instituciones políticas clásicas y a las normas jurídicas vigentes.

En este orden de ideas, fue precisamente a causa del uso excesivo y frecuente de la moción de censura, durante finales del siglo XIX y buena parte del siglo XX, que este recurso fue cuestionado. En razón del predominio de posiciones individuales y de la escasa cohesión de los grupos políticos, se facilitó un uso descomunal de dicha moción, lo que provocó una seria inestabilidad en los gobiernos. Producto de aquello, se produjo en el parlamentarismo occidental un movimiento tendiente a corregir este desequilibrio entre la vinculación entre poderes, el que fuera llamado "Parlamentarismo racionalizado o la racionalización del parlamento".

Esta tendencia propone la estabilidad de los gobiernos y la potencialización del Ejecutivo como medio para lograr una mayor eficacia, estableciendo una regulación formal y detallada de las relaciones entre Ejecutivo y Legislativo, estipulando límites y condiciones a los poderes del segundo y, en general, determinando una limitación del uso de los mecanismos de control. El promotor más enérgico de la racionalización fue B. Mirkine-Guetzévitch, quien dirá que esto fue un fenómeno que implicaba convertir los procesos parlamentarios en procesos jurídicos en los textos constitucionales Es por ello que las constituciones debían ser consideradas no como 
alteraciones al parlamentarismo de la época, sino como procesos racionalizantes del mismo. Así, tomaban un carácter jurídico. Dado que el contexto político tendió fuertemente a encuadrar la vida política al derecho, las asambleas constituyentes de la época pretendieron proteger los nuevos Estados de los embates del parlamentarismo excesivo y de las crisis ministeriales demasiado repetidas. En consecuencia, éstas se esforzaron en reglamentar el voto de confianza sin atentar contra la libertad del Parlamento. De tal modo, solamente pretendía otorgar garantías al Gobierno frente a votos prematuros y poco reflexivos ${ }^{209}$.

En definitiva, aquel elemento que se presentaba como primordial al régimen parlamentario -el germen o posibilidad de exigencia de responsabilidad política-, comienza a vislumbrarse, disminuido de conformidad a la adecuación y a las técnicas que trajo consigo el parlamentarismo racionalizado. Las nuevas técnicas se concentrarían en la reducción de la exigencia de responsabilidad al gobierno a supuestos muy concretos y jurídicamente formalizados ${ }^{210}$. Lo anterior, se llevaría a cabo con la clara finalidad de evitar que la responsabilidad del gobierno se viera comprometida constantemente por incidencias de poca relevancia, procurando evitar vacíos de poder e inestabilidad. En este sentido, para Rafael Bustos el parlamentarismo racionalizado constituye un fenómeno que formaliza las causas de exigencia de responsabilidad e introduce requisitos más gravosos para su aplicación, es por ello que dirá que esta constante "racionalización de la vida parlamentaria" ${ }^{211}$ pretende asegurar en la mayor medida posible la estabilidad del Ejecutivo, es decir, dificultar la retirada de confianza.

Tal tendencia de racionalización, cuyo origen está situado en el período de entre guerras marcado por la denominada "crisis del parlamentarismo" o "declinación del Parlamento", esencialmente en la época de Weimar, no sólo provoca modificaciones en la forma de tornar al régimen más jurídico, sino que se convierte en lo que Portero describe como la tendencia común en los demás gobiernos. El arribo de la racionalización nace, en buena parte, gracias a la consolidación de la democracia de partidos, factor tremendamente relevante porque será en torno a dicha democracia

\footnotetext{
209 Mirkine-GuetzeVitch (1934) Pp. 16 a 18.

${ }^{210}$ COSTA I XUCLÁ (2011) P. 36.

${ }^{211}$ BUSTOS (2001) pp. 11-20. El presente autor inclina sus investigaciones hacia la responsabilidad política que veremos en profundidad en las páginas siguientes.
} 
que el parlamentarismo retomará fuerzas, precisamente en atención al protagonismo de los partidos políticos.

Empero, la racionalización parlamentaria, fruto de un aparente colapso del sistema parlamentario, no fue comprendida fácilmente. En efecto, para algunos autores la razón de su entrada en vigor no sólo fue la inestabilidad política. Por ejemplo, para Santaolalla, tal fenómeno de crisis del parlamentarismo fue superada por la realidad. La sola tendencia regularizadora no fue la única causante de la inestabilidad gubernamental sino que, por el contrario, se presentarían otros variados factores y no la sola normativización de las relaciones Ejecutivo-Legislativo. Algunos ejemplos dicen relación con aquellas causas políticas derivadas de la organización de partidos y el contexto social que provocó un limitado éxito del parlamentarismo racionalizado ${ }^{212}$.

Para Portero Molina, a través del proceso de racionalización además se hace posible consolidar una división entre mayorías y minorías parlamentarias, y así se contribuye a la formación de la opinión pública y se acrecienta la motivación del electorado. Por tanto, "será a partir de aquello que la función de control y la exigencia de responsabilidad cobran su auténtico significado en los sistemas parlamentarios de las democracia actuales" ${ }^{\prime 213}$.

En una dirección distinta, Ángel Sánchez Navarro sostiene que tal mecanismo no sólo favoreció la estabilidad democrática sino que además inmovilizó el actuar del Parlamento. Este autor explica que, desde el contexto español, frente a la agravada alteración de equilibrios en las fuerzas políticas, se extremaron las posturas llegando a la "racionalización" como reacción contra la debilidad de los Gobiernos ante asambleas atomizadas $y$ omnipotentes incapaces de asegurar mayorías parlamentarias estables. Por tanto, la racionalización colocaba trabas procesales a su ejercicio, pero esta "maraña de normas" procedimentales que regulaban toda actuación parlamentaria -como las llamaba el autor-, podían llegar a ser claramente disfuncionales al impedir el correcto ejercicio de las funciones asignadas al Parlamento, donde el reglamentarismo asfixia la política.

212 SANTAOLALLA (1984) P. 327.

213 Portero (1998) Pp. 12. Resulta menester aclarar que Portero, de manera alguna, niega que tales factores hayan existido antes, sino que, por el contrario, sostiene que toman fuerza y se formalizan jurídicamente, declarándose y garantizándose con máxima intensidad. 


\section{b) El régimen presidencial}

Corresponde ahora examinar el sistema presidencial y su relación con el control parlamentario. El presente sistema ostenta su origen en el sistema político de Estados Unidos. Los fundadores de la democracia norteamericana, cautivados por la doctrina de la separación de poderes que habían aprendido de los ingleses y conforme a las explicaciones de Locke, manifestaron una extraordinaria fidelidad hacia aquella división tripartita del poder, mediante la cual buscaron robustecer la práctica de la libertad en la Unión, elemento indispensable para el correcto establecimiento de un gobierno según los padres fundadores.

Por su parte, el predominio del Ejecutivo tuvo como fundamento el fortalecimiento de las trece antiguas colonias y la consolidación de una unidad en la jefatura del Estado como símbolo y garantía de la unidad, así como también manifestación del rechazo hacia la monarquía ${ }^{214}$. Dentro de los rasgos esenciales de dicho sistema presidencial, podemos señalar que el jefe de Estado y el jefe de Gobierno se reúnen en una misma persona. Existe en teoría una separación rígida de los poderes constituidos, vale decir, un poder Ejecutivo en manos de un Presidente de la República; un poder Legislativo en manos del Parlamento; y un poder Judicial autónomo. En el sistema presidencial, la persona que encarna ambas jefaturas recibe el nombre de Presidente y es elegido por la ciudadanía mediante sufragio universal. Por ende, éste solamente responderá de su gestión ante dicho electorado ${ }^{215}$.

Un elemento diferenciador respecto al sistema parlamentario es, precisamente, el hecho de que el Presidente mantiene su poder delegado por el pueblo independientemente de si su partido político cuenta o no con mayoría parlamentaria. Esto quiere decir que el Presidente tiene asegurada su permanencia en el cargo durante el período de tiempo establecido en la Carta Fundamental de manera ininterrumpida. El sistema presidencial de origen norteamericano se caracteriza, en definitiva, por responder principalmente a una sensibilidad especial ante los sentimientos populares, por medio del establecimiento de mecanismos de autorrestricciones y de equilibrio entre los poderes. En el régimen presidencial se refuerza la posición de las minorías, a diferencia de lo que ocurre en el sistema

214 SILVA (1997) p.402.

215 VERDUGO Y GARCÍA (1996) p.234. 
parlamentario. En resumen, este sistema se sustenta en una fuerte división funcional del poder en tres poderes esenciales y en una división territorial del poder entre gobierno federal y los gobiernos de los estados, lo que sirve de modelo a otras naciones, principalmente en las repúblicas latinoamericanas ${ }^{216}$.

En efecto, el modelo presidencial fue el modelo que finalmente se impuso en Latinoamérica. Este régimen desarrolló una atracción irresistible en nuestra región. A juicio de Salvador Valencia, esto se desarrolló por las razones que describiremos a continuación. Esencialmente, al igual que en Estado Unidos, los países de América del Sur dejaban atrás su estatus de Colonias. Por consiguiente, los libertadores tuvieron presente el progreso económico impresionante y el sistema político exitoso llevado a cabo por Washington, Jefferson y Adams como un ideal a seguir. La influencia de la literatura política de la época, contenida básicamente en "El Federalista", ingresó con fuerza en las naciones del sur. Una prueba de ello es que en nuestro país, don José Miguel Infante se preocupó por difundir aquellas ideas en su periódico, al que llamó "El Valdiviano Federal"217.

De este modo, en Latinoamérica las guerras de independencia habitualmente finalizaron con la instauración de un régimen presidencial en que se dotaba al presidente de facultades similares a las estipuladas en los pueblos del norte. Sin embargo, cabe hacer presente que desde cierta perspectiva, el interés fue mutuo, puesto que en Estados Unidos algunos presidentes u hombres públicos también presentaron preocupación por delinear una política para América Latina, lo que desembocó en la doctrina Monroe, propuesta en el año 1823.

Como hemos venido señalando, el origen del presidencialismo en Latinoamérica proviene de su ejemplo más cercano e influyente: el modelo norteamericano, un sistema con preeminencia del Poder Ejecutivo que ha pervivido por décadas, a pesar de las dificultades que ha presentado en nuestros pueblos. Lo cierto es que América Latina tiene una fuerte tradición presidencialista, cuyas expresiones son variadas en la práctica y en las Constituciones. Así, la forma presidencial ha adoptado las más diversas formas y combinaciones en cuanto a las relaciones entre órganos políticos $^{218}$. Sin perjuicio de aquello, "nuestro sistema presidencial no ha imitado de

${ }^{216}$ CARTER y HeRz (1964) Pp. 47 a 52.

217 VALENCIA (1979) Pp.42-44.

${ }^{218}$ NOHLEN (1998) Pp. 23 y 24. 
manera servil, se ha adaptado a nuestras condiciones sociales hasta adquirir una configuración peculiar"219, e incluso dentro de la misma región es posible detectar diversos tipos de presidencialismos. Como bien expresa Valencia, el Ejecutivo en los nuevos presidencialismos difiere sustancialmente respecto de aquél que le dio origen. Así, el régimen presidencial de Latinoamérica constituye una tesis diferente con características propias. Por tanto, el régimen presidencial latinoamericano es un régimen original que algunos han denominado como "cesarismo representativo" en virtud de sus particularidades.

Continuando con las ideas enunciadas anteriormente, y pretendiendo argumentar las diferencias existentes con el presidencialismo de Estados Unidos, recurrimos a los postulados de Humberto Nogueira, quien puntualiza precisamente que nuestra región realizó diversos ajustes en la recepción del régimen presidencial norteamericano. Nuestro territorio latinoamericano fortaleció las facultades del Presidente en desmedro del Parlamento y estableció un sistema de gobierno sumamente centralizado, además de otorgar fuertes funciones legislativas al Ejecutivo, confiriéndole una calidad de órgano colegislador. En este sentido, conforme a lo señalado por este autor, los presidentes de Latinoamérica disponen de ciertas facultades que no posee el mandatario del norte. De tal modo, las principales diferencias se expresan en la iniciativa de ley, la iniciativa exclusiva en ciertas materias de ley, la posibilidad de convocar a legislatura extraordinaria, la participación en el debate parlamentario a través de sus ministros, el veto parcial y la delegación de facultades legislativas en el Presidente de la República ${ }^{220}$. Es por estas potestades que, en términos generales, los presidentes gozan de la capacidad de orientar el trabajo legislativo del Congreso, poderes de los que no goza el Presidente de Estados Unidos.

En efecto, el régimen constitucional latino optó notoriamente por un sistema presidencial con una trascendental preponderancia del presidente, que luego fue adquiriendo fisionomía propia. Por ende, construir comparaciones estrictas entre el sistema presidencial norteamericano y el de Latinoamérica no siempre es posible, como tampoco es dable, en otras ocasiones, formular cotejos entre los presidencialismos de la región, debido a las diferencias que ellos presentan.

${ }^{219}$ VALENCIA (1979) p.69-72.

220 Nogueira (1985) Pp. 89-92. 
Una de las diferencias más importantes entre los estilos de presidencialismos norteamericano y latinoamericano, a juicio de Cox, Morgenstern y Wolfson, es lo referente a la integración que el Ejecutivo ha desarrollado en la legislatura. Un ejemplo de aquello es que un congresista puede ser designado Ministro de Estado. En América Latina, el Presidente y el Congreso cuentan con amplias facultades para fijar la agenda legislativa, cosa que no ocurre en Estados Unidos. En general, estos autores se refieren a la integración de poderes, cuyo resultado es que el locus del poder se ha visto modificado 221.

Por tal motivo, seguiremos estas opiniones e intentaremos no realizar una comparación de modelos presidenciales por resultar inoficioso. Ciertamente, el presidencialismo teórico norteamericano fue el referente sistémico al universo latinoamericano pero, como lo expusiéramos precedentemente, en la actualidad los regímenes en América Latina se expresan de forma diversa y sus características son disímiles a las norteamericanas. Por ello, estimamos que se torna complejo esperar un comportamiento a lo menos parecido entre corrientes tan desiguales. La primera gran diferenciación o modificación del presidencialismo es precisamente su variante original de Estados Unidos y sus manifestaciones latinoamericanas, llegándose a hablar incluso de más de cuatro tipos de presidencialismos: el puro, el atenuado, el aproximado al parlamentarismo, el gobierno colegial, etc. No obstante, las diferencias no quedan allí. Nuestra región exhibe una pluralidad de aristas como las diversidades en el desarrollo económico, en la cultura política, en el desarrollo educacional, en el desarrollo científico técnico, en las experiencias políticas y en la diversidad de ideologías y de sistema de partidos políticos, elementos que tornan imposible otorgar una visión unitaria del régimen presidencial, por lo que pueden solamente señalarse rasgos generales ${ }^{222}$.

Como lo dijéramos anteriormente, en el diseño presidencial norteamericano el Presidente de la República, al ejercer la doble función de jefe de Estado y de Gobierno, reúne en su persona importantes facultades como, por ejemplo, nombrar a los ministros o jefes de cartera como funcionarios de su exclusiva confianza. Si bien el Presidente teóricamente carece de facultades legislativas, siempre puede sugerir

${ }^{221}$ COX ET AL. (2001) p.389.

222 Nogueira (1985) p. 95. 
un programa legislativo en el mensaje anual ante el pueblo. Además, posee potestad reglamentaria, conduce la política exterior, es Comandante en Jefe de las Fuerzas Armadas, tiene derecho a veto contra las leyes votadas en el Congreso y prepara el presupuesto de la nación. En términos generales, el sistema presidencial latinoamericano se expresa básicamente en la legitimidad autónoma del cargo presidencial. Sus amplias facultades $y$, en general, la ausencia de control institucional o su deficiencia, en principio imposibilita el juego de cheks and balances, siendo ésta una de las principales diferencias respecto del presidencialismo de Estados Unidos ${ }^{223}$.

Pese a lo anterior, como todo sistema político que ha sido creado por el hombre, el presidencialismo también ha manifestado serias dificultades respecto de sus características esenciales, particularmente en los rasgos del liderazgo del presidente, en el ejercicio de sus amplias facultades y en las problemáticas que ello genera con los pesos y contrapesos y el necesario control parlamentario. En este orden de ideas, hemos de exponer básicamente las críticas sostenidas por Juan Linz respecto del presidencialismo de América Latina.

Para Linz variados son los elementos conflictivos. Por un lado, la doble función que el Presidente reúne en su persona, lo que le confiere grandes poderes reales y legales. Así, no sólo es dueño del Ejecutivo, sino que además el gabinete es de su exclusiva confianza. Por otro lado, su autoridad se extiende al Parlamento, bajo la forma de facultades colegisladoras ${ }^{224}$. Por consiguiente, al atribuir el Poder Ejecutivo a un solo individuo, el sistema mismo tiende a brindarle una mayor hegemonía y a concentrar en él una magnitud mayor de autoridad. Por su parte, el Parlamento -dada su composición colectiva- refleja de un modo vago y difuso la legitimidad popular que ha recibido por la misma vía que el Presidente, razón por la cual en un régimen presidencial el Parlamento no sólo tiene menos poderes, sino que existe en su interior una dinámica de disminución de los mismos.

En síntesis, para el autor existe una complejidad en la doble legitimidad democrática que se produce en el presidencialismo, porque en un régimen presidencial tanto el Presidente como los legisladores gozan de legitimidad democrática y es posible que la mayoría de ese Parlamento pueda representar a la

223 SerRafero (1998) p.171.

224 LINZ ET AL. (1990) Pp. 16-17. 
opción política contraria a la de la figura del Presidente. En dichos casos, ¿quién está bajo la base de principios democráticos, mejor legitimado para hablar en nombre del pueblo? ${ }^{225}$. Al derivar ambos de la votación popular en elecciones libres con alternativas y con posiciones definidas, siempre se crea la posibilidad de la configuración de un conflicto latente que es posible que irrumpa dramáticamente. Es por ello que al no existir principios democráticos que puedan resolver dicho conflicto, dice Linz, no es azar que los militares hayan intervenido en el pasado como "poder moderador" en las repúblicas presidenciales latinoamericanas. Así, la doble legitimidad a la que Linz se refiere generaría problemas de superioridad democrática. En igual sentido, se expresa Valenzuela cuando expone que, en los regímenes presidenciales, se producen "legitimidades en competencia" 226 : Ejecutivo y Legislativo pueden reclamar su propio mandato electoral para ejercer poderes diferenciados y ocasionalmente superpuestos. Por tanto, las relaciones entre ellos oscilarán entre cooperación o confrontación, lo que provoca diversos problemas. No obstante, respecto a este punto y de conformidad a lo expresado por Mario Serraferro, creemos que no es posible olvidar que aquellos mandatos tienen objetivos diferentes: uno implica crear la Ley y el otro ejecutarla. Por ende, no se debieran fomentar discrepancias. Así, lo que efectivamente debiera crear dificultades no es la doble legitimidad sino la "legitimidad desequilibrada" 227.

Sin embargo, las críticas de Linz no finalizan allí. El autor visualiza otros problemas en el presidencialismo que se expresan en el mandato fijo presidencial y en los ejecutivos fuertes, conceptualizados en la personalización del poder. Tales características del presidencialismo promueven lo que el autor define como la regla "todo al ganador", situación que implica que aquel que gana la presidencia obtiene el poder suficiente para dirigir la administración pública y la agenda política del Gobierno y del Parlamento. Este arreglo democrático impone un juego de suma cero, en el que nuevamente no hay esperanzas de cambios en las alianzas políticas, y de acuerdo al cual los perdedores no tienen más opción que esperar cuatro a cinco años para poder intentar obtener el poder, ya que en este sistema no poseen influencia alguna. Esta modalidad, finalmente, exacerba la tensión y polarización electoral, elementos que pueden gestar un ambiente de violencia e ilegalidad.

\footnotetext{
225 LINZ ET AL. (1990) p.48.

226 VALENZUELA (2008) p. 25

227 SERRAFERO (1998) p. 175.
} 
Por otra parte, señala Linz, los equilibrios políticos y jurídicos son débiles frente al fuerte poder Ejecutivo con amplias facultades -como hemos enunciado en los párrafos anteriores-, toda vez que en el caso de que el Presidente gobernante sea intransigente no existen los mecanismos que prevengan e inhiban dificultades mayores. Por el contrario, el único mecanismo para destituir a un Presidente es el Impeachment, proceso básicamente incierto y lento que puede producir sus efectos tardíamente. Finalmente, dichos factores pueden posibilitar una crisis del régimen en su conjunto, lo que puede acarrear una compleja inestabilidad política ${ }^{228}$. En definitiva, un presidencialismo puede gestar una situación insostenible sin salida, fecundando una crisis de mayor envergadura, pues estos regímenes tienden a originar una lógica confrontación, precisamente porque los adversarios del Presidente ven a un jefe de Estado exitoso como un obstáculo para sus propios intereses y a un Presidente fracasado como a alguien a quien deben evadir ${ }^{229}$.

Aquellas cualidades que Linz califica como deficiencias de la forma presidencial, son los mecanismos que efectivamente buscan evitar que presidentes con poderes tan amplios puedan convertirse en dictadores. Conforme a lo señalado por Nogueira, aquellas características configuran técnicas constitucionales, es decir, el mandato de duración fija, la no reelección inmediata y la acusación constitucional constituyen principios fundamentales en la limitación de un poder que se configuró con poderes sumamente extensos ${ }^{230}$.

En este mismo orden de ideas, podemos vislumbrar en los análisis de Bruce Ackerman otros argumentos que igualmente tienden a exponer arduamente las aparentes deficiencias del presidencialismo. Estas debilidades se concentrarían en el hecho de que en este sistema de división de poderes, el Ejecutivo y el Legislativo se configuran en momentos electorales diversos, lo cual puede provocar que el necesario apoyo parlamentario requerido para gobernar y gestionar un plan de gobierno resulte ser un factor desconocido.. Lo anterior, puede ocurrir de forma inmediata en un proceso electoral, o bien puede llegar a acaecer en momentos electorales diferenciados y, al largo plazo, provocar diversos efectos. Desde esta perspectiva, puede ocurrir en un primer escenario, que el Presidente no cuente con el suficiente apoyo parlamentario, es decir, que su partido político o coalición sea

\footnotetext{
${ }^{228}$ LINZ (2013) Pp. 23-26.

${ }^{229}$ VALENZUeLa (2008) Pp. 22 y 23.

230 Nogueira (1985) p. 94
} 
minoritaria. En esta situación puede adoptar dos modalidades de acción: a.- frente a la debilidad parlamentaria se enfatiza la necesidad de arribar a constantes negociaciones, que pueden no ser del todo beneficiosas desde la perspectiva ciudadana y desde las legítimas aspiraciones del Presidente o, $b$.- pueden generarse rupturas constitucionales debido a la contienda en que pueden incurrir los poderes, conflicto en el cual, mediante herramientas constitucionales a su disposición, ambos poderes pueden hacer de la vida política un momento sumamente difícil, gestando con ello una crisis de gobernabilidad.

En el otro escenario, vale decir en el caso de que exista total coincidencia entre Ejecutivo y Legislativo en términos ideológicos-partidistas, o sea que el Presidente posea mayoría parlamentaria, se provocaría una autoridad absoluta. En esta situación, el partido político o mayoría gobernante aspirará en un tiempo relativamente breve de mandato a realizar todas aquellas políticas públicas que estime necesarias, actuando probablemente de forma maximalista y errática. En dichas circunstancias, los pactos no serán necesarios y la gestión del Presidente podría no tener límites, lo que a su vez igualmente podría crear situaciones de desequilibrio institucional entre poderes. Todo lo anterior, se ve agudizado si consideramos que en la actualidad, según Ackerman, la tendencia políticopresidencial se ha dirigido justamente hacia un excesivo "culto de la personalidad", lo cual, unido a un período fijo de mandato, hacen del control, la denuncia y la remoción de un mal líder un negocio difícil de alcanzar. Es por ello que a juicio del autor, en los sistemas presidenciales los ciudadanos estarían atrapados por presidentes respecto de quienes han perdido la confianza, estando casi impedidos de solicitar su remoción $y$, en definitiva, se encontrarán forzados a asumir crisis institucionales mayores ${ }^{231}$.

Continuando con lo anterior, y siendo un punto relevante en nuestra investigación la relación entre presidencialismo, control parlamentario y la posibilidad de exigir o no responsabilidades políticas por la gestión de gobierno, es menester tratar lo referente a la existencia de un período fijo de ejercicio del cargo. Este período impide aparentemente que el Presidente sea cambiado, aun en casos extremadamente difíciles e incluso cuando ha perdido la confianza de su partido y de

${ }^{231}$ ACKERMAN (2007) Pp. 12 a 21. 
sus aliados. Esta situación se agrava si consideramos la excesiva rigidez del proceso político de Impeachment.

Con todo, nuevamente Linz plantea que la existencia de rigidez en los procesos políticos y jurídicos en los regímenes presidencialistas dificultarían mayormente el ejercicio de las atribuciones fiscalizadoras y de control del parlamento, lo que derivaría en graves conflictos políticos y sociales que podrían desencadenar el potencial "quiebre" de los sistemas democráticos, lo que en consecuencia impediría el correcto desarrollo de una "estabilidad democrática" en estos países ${ }^{232}$. Una propuesta similar plantea Sebastián Linares, quien sostiene que los presidencialismos son formas de gobierno más durables, a consecuencia precisamente de la rigidez en las salidas institucionales a las crisis, lo cual produciría períodos de "supervivencia sin gobernar"233.

Por ende, las formas de terminación de un gobierno presidencial serían variadas e impredecibles. Es por ello que puede ocurrir que un Presidente combativo pueda sentirse tentado a hacer uso de sus poderes de tal forma que sus oponentes no estén dispuestos a esperar pacíficamente que termine su período e, incluso aún con la renuncia bajo presión, es probable que se genere una crisis política mayor. De tal modo, a juicio de Thibaut, debido precisamente a la primacía del Ejecutivo y en virtud de una organización estatal extremadamente centralizada, es posible identificar como una de las críticas empíricas e históricas de los presidencialismos latinoamericanos la falta de formación de un checks and balances eficiente ${ }^{234}$. En definitiva, institucionalmente América Latina no habría heredado un correcto checks and balances en comparación con el sistema norteamericano, especialmente debido a las amplias facultades concedidas a la figura del presidente. Por lo tanto, la responsabilidad política del mandatario y de sus ministros ante el Parlamento sería teórica en los casos en los que se establecía ${ }^{235}$, lo que produciría más que contrapesos, verdaderos bloqueos solamente solucionables mediante acuerdos poco probables.

\footnotetext{
232 LINZ ET AL. (1990). P.49.

233 LINARES (2011) Pp. 9-44.

234 THIBAUT (1993) p. 230

235 NOHLEN Y FERNÁNDEZ (1998) p.119.
} 
En lo que a nosotros respecta, cabe señalar que en el régimen presidencial tipoideal el Presidente es irresponsable políticamente ante el Congreso y sólo responde de sus actos ante la nación que lo ha escogido por sufragio universal. Sin embargo, el Congreso puede obligarlo a dimitir mediante el Impeachment o Acusación Constitucional, procedimiento empleado para hacer efectiva la responsabilidad en virtud de determinados ilícitos ${ }^{236}$. En este sentido, se ha dicho que en rigor en un régimen presidencial no existe responsabilidad política directa del Gobierno y un control parlamentario que recurra a sus últimas consecuencias. Empero, en un régimen presidencial el Impeachment o la acusación en Juicio Político se configura dentro de la responsabilidad constitucional del Gobierno como un control interorgánico muy peculiar, de conformidad a la doble legitimidad democrática de la cual gozan Parlamento y Gobierno. En consecuencia, estas instituciones resultan ser una excepción a la separación de poderes, imponiendo a juicio de Zúñiga, una responsabilidad constitucional de naturaleza jurídico-política: jurídica porque se basa en conductas constitutivas de ilícitos constitucionales, y política porque los órganos que admiten la acusación y que la juzgan son políticos, actuando con amplio margen de libertad o discrecionalidad, responsabilidad que se caracteriza por poseer causales de imputación, personal o subjetivas y que es encausada en procedimientos de "justicia política".

En opinión de Zúñiga, la responsabilidad constitucional del Gobierno en un régimen presidencial, es consecuencia de un principio republicano en virtud del cual existe una concepción vicarial del poder político. Mediante esta concepción, se impone un deber al poder que implica actuar orientado hacia la realización del interés público, al bien común, respecto de lo cual además descansa la confianza de la comunidad política. Así, la responsabilidad en un sistema presidencial encarna la virtud cívica republicana que comprende una ética mínima exigible a los servidores públicos $^{237}$.

Lo anterior, se encuentra en perfecta armonía con las primigenias motivaciones que tuvo presente el constituyente de 1787 cuando creó el Impeachment como un procedimiento que permitiera destituir a altos cargos del poder Ejecutivo o Judicial cuando incumpliesen gravemente sus deberes constitucionales. En dicho contexto, se

236 VERDUGO Y GARCÍA (1996) p. 235.

237 ZÚÑIGA (2006) Pp.2, 3 y 15. 
optó por un mecanismo de destitución dotado de barreras formales y sustantivas que impidiesen una utilización que favoreciera la primacía del Congreso ${ }^{238}$. A nuestro juicio, en los sistemas presidenciales -como lo veremos más adelante- se manifiesta una importante utilización del control parlamentario y del ejercicio del juicio político que ha provocado efectos de relevancia política y jurídica.

Para concluir nuestro análisis del sistema presidencial, quisiéramos agregar brevemente que los detractores del presidencialismo han intentado encasillarlo dentro de un modelo de régimen cercano a la dictadura, promotor de inestabilidades político-gubernamentales, que no otorga otras salidas democráticas a sus crisis institucionales que los golpes de estados vividos en Latinoamérica. Ha sido descrito como un sistema rígido, carente de consensos, en el que primaría una supuesta superioridad de legitimidad democrática por parte del Presidente, situación que lo convertiría en un ser poderoso y peligroso que se encontraría privado de controles políticos, es decir, libre de un contra-equilibrio institucional. Expresión de esto son las palabras de Sartori, para quien el presidencialismo por años ha funcionado mal, el sistema ha presentado serias deficiencias, motivo por el cual ha sucumbido en golpes de estado y otras calamidades ${ }^{239}$.

Desde nuestra perspectiva, aquellas expresiones responden a una persistencia teórica, que nace del estricto apego a los tipos teóricos e ideales de las formas de gobierno, así como también de férreas defensas corporativas del parlamentarismo. Estas argumentaciones no responden necesariamente a nuestra realidad política, económica y socio-cultural, la cual si bien presenta dificultades en cuanto al régimen, es fruto de un natural y lento desarrollo de consolidación democrática respecto de pueblos largamente sometidos a gobiernos administrados-tutelados por autoridades foráneas que desconocían nuestros usos y costumbres. Somos herederos de sistemas autoritarios que se constituyeron por largos años en virtud de las dictaduras que se configuran con posterioridad a los golpes de estado acaecidos en esta región, en los cuales precisamente se fortaleció legal y constitucionalmente un excesivo poder al Ejecutivo.

238 BRONFMAN (2005) p. 95.

239 SARTORI (1994) Pp. 99 y 100. 
El presidencialismo en Latinoamérica es fruto de una evolución democrática que, además, depende esencialmente del particular diseño institucional que exista en cuanto al sistema de partidos, sistema electoral y ciertamente al comportamiento de los actores políticos regionales. Es menester considerar -tal como ya lo señalamosque el sistema democrático de Latinoamérica se vio fuertemente debilitado por las dictaduras militares impuestas. Como consecuencia de esto, la democracia como tal se debió re-articular en el proceso denominado "consolidación democrática", el cual hasta la década de los noventas presentaba bajos grados de afianzamiento y numerosas debilidades que lo hacían un proceso parcial y débil. Este proceso además presentaba importantes diferencias entre un país y otro, lo que dificultaría su análisis y desarrollo. Adicionalmente, su consolidación se vería siempre influenciada y mermada por una seria de complicaciones, como lo fueron las crisis económicas que repercutieron en la legitimidad de la estructura de la autoridad política, la falta de una cultura plenamente democrática, la falta de desarrollo socioeconómico y los problemas de gobernabilidad debido a las estructuras políticas vigentes ${ }^{240}$. Todos estos elementos hacen del presidencialismo de nuestra región una forma de gobierno con ciertas particularidades que habrá de moldear los rasgos clásicos de dicho régimen.

\section{c) El control parlamentario, análisis comparativo entre regímenes}

Habiendo revisado ambas formas de gobierno, corresponde cotejar -a modo de conclusión- la relación que existe entre ellas y el control parlamentario a fin de exponer las diferencias y nuevas modalidades que se desarrollan en torno a aquella relación. Este procedimiento se realizará con el objetivo de comprender, de manera más acabada, las modernas expresiones del control parlamentario y la responsabilidad política, derribando algunos supuestos teóricos que han sido utilizados y considerados como tesis dominantes durante largos años. Realizaremos una breve descripción de cada forma de gobierno y su expresión de control respectiva para, luego, exponer aquellos elementos que configuran las modernas expresiones del control.

${ }^{240}$ Cansino (1993) Pp. 734 y735. 
Ahora bien, desarrollaremos este apartado advirtiendo algunas precisiones formuladas por Dieter Nohlen quien expone que no es posible estudiar las formas de gobierno desde sus bondades y tipos-ideales, puesto que aquello conduce a una grave deformación teórica y práctica, así como tampoco pretendemos traer a colación las supuestas experiencias parlamentarias de Latinoamérica porque, tal como expresa el mismo autor, esto implicaría cotejar una realidad con algo que nunca existió ${ }^{241}$. Nuestra finalidad sólo comprende exponer las formas de gobierno y su relación con el control parlamentario desde una perspectiva teórica, para luego cotejarla con las expresiones modernas, evaluando las diferencias y posibles mejorías que tal institución exhibe, ya que -como bien expresa José Fernando Flóreztenemos presente que "no existe en abstracto modelo institucional óptimo"242.

A este respecto, sólo cabe recordar que el sistema político británico, el cual da origen al parlamentarismo, se basa fundamentalmente en la estrecha relación de confianza entre Ejecutivo-Legislativo. Debido a esto, dicha relación de confianza entre ellos se plasma en un constante control que las cámaras ejercerán sobre el Ejecutivo a modo de vigilancia del Gobierno para que éste no se aleje de la línea política escogida por el país mediante la elección de la asamblea legislativa. Asimismo, ésta asamblea -actuando como garante de aquella voluntad populardeberá velar por el correcto funcionamiento de la administración del Estado. La sanción que lleva implícito tal control será la responsabilidad política exigible por el Parlamento a los ministros, quienes son responsables de forma colectiva ante el Parlamento, testimoniando con ello la confianza o desconfianza hacia éstos ${ }^{243}$.

Por su parte, el régimen presidencial en su tipo ideal-teórico, es un sistema que se origina en virtud de una diferenciación funcional de poderes rígida, en la que cada poder realiza su labor sin inmiscuirse en las funciones de los restantes. En este sistema, se produce una selección directa del pueblo en una persona particular que cumplirá funciones determinadas. Esto se puede evidenciar en la figura del Presidente de la República, quien generalmente expone un programa político determinado, debiendo ejecutarlo de la manera más efectiva posible. Dichos rasgos

\footnotetext{
${ }^{241}$ Nohlen (1998) p. 90. Para Dieter Nohlen nunca ha existido verdaderamente la aplicación de una forma presidencial en la región, los intentos ejecutados como el chileno de 1891-1925 a juicio del autor, estuvieron lejos de concretar un régimen parlamentario, en consecuencia nunca fue una realidad sino que sólo un posibilidad $y$, en los casos que existió la voluntad de llevarlo a cabo nunca fue exitoso en términos de estabilidad política.

${ }^{242}$ FLóREZ (2010) p.144

243 Manzanares (1970) Pp. 55 y 59.
} 
imponen que la figura del presidente únicamente responderá y deberá rendir cuenta de sus actos frente aquellos que lo han seleccionado, o sea, frente al pueblo. Este es el motivo por el cual, aparentemente, no existe un verdadero control parlamentario debido a la precaria influencia del Congreso en su gestión. Asimismo, debido a que habitualmente se estipulan mecanismos muy dificultosos para aplicar la responsabilidad política de ministros y del mismo Presidente, el sistema parece ser un régimen inmóvil.

Tal como señala Alejandro Silva Bascuñán, la fiscalización parlamentaria en un régimen presidencial ha de referirse sólo a la corrección y eficiencia administrativa, sin recaer en la inspiración directiva que le corresponde al jefe de Estado. Por otro lado, en el gobierno parlamentario la fiscalización que ejerce la minoría puede alcanzar características de control mediante la cual se examina el acierto de las medidas generales de orientación y la finalidad política propugnada por el gobierno de la mayoría ${ }^{244}$. En teoría, en el presidencialismo estaríamos frente a un sistema que cuenta con una legitimidad autónoma del cargo de Presidente, con amplias facultades del mismo y una ausencia de control institucional ${ }^{245}$. Esta situación lógicamente genera un cuestionamiento teórico cuando los primeros rasgos establecen un orden de separación de poderes. Sin embargo, el segundo es un elemento de desequilibrio entre órganos, el cual no es compensado por la ausencia de control, factores que a juicio de Serrafero imposibilitan el juego de checks and balances, la cual constituye una situación que no es comprensible al analizar el lugar que ostenta el Congreso en los sistemas latinoamericanos. De este modo, la carencia de control tendría más justificación en la falencia de organismos adecuados de información, técnicos y especializados para cumplir una tarea eficaz.

En este orden de ideas, y continuando con lo antes dicho respecto al control en ambas formas de gobierno, en los siguientes párrafos postularemos algunos argumentos que pretenden poner en jaque ciertos supuestos teóricos antes señalados. De esta manera, intentaremos exponer ciertos elementos relevantes que en cierto modo modifican dichos supuestos $y$ que expresan las nuevas manifestaciones del control parlamentario. Básicamente, nos esforzaremos en exponer particularmente las razones por las cuales creemos que el control

244 SILVA (1997) p.436.

245 SerRAFERo (1998) P. 171. 
parlamentario tiene plena aplicación en el presidencialismo, aunque con diversos resultados.

Un primer aspecto que hemos de abordar y respecto al cual plantearemos algunos matices, es la vinculación entre el control parlamentario y la exigibilidad de responsabilidad política. Respecto a este punto, hemos de señalar que han sido expuestas latamente dos ideas centrales: la primera de ellas sostiene que el régimen presidencial se caracteriza por una supuesta rigidez, la cual provocaría un inmovilismo político grave que no poseen los mecanismos necesarios para crear válvulas de escape frente a tales escenarios; la segunda de ellas, señala que el presidencialismo no daría cabida a una verdadera responsabilidad política y que las excepcionales instituciones destinadas a ello, tales como el Juicio Político, comprenden tantas dificultades en su utilización y ejercicio que solamente originan el desarrollo de crisis políticas sin salida lo que en el pasado ha generado quiebres democráticos. A contrario sensu de la flexibilidad que comprendería un régimen parlamentario, -el cual ostenta per se aquellas posibilidades de remover al gobierno-, se hace exigible rápidamente una responsabilidad política del gobierno, por ende, da mayores oportunidades y salidas democráticas a las posibles crisis políticas ${ }^{246}$.

Lo antes descrito constituye un breve resumen de un pensamiento clásico que hemos detallado a lo largo de este apartado, y que a continuación examinaremos expresando en detalle aquellas mutaciones que han experimentado aquellos regímenes $y$, por tanto, que han afectado al control parlamentario -en razón de los cuales las diferencias se han ido diluyendo paulatinamente-. Por tal motivo, estimamos pertinente exponer dichos fenómenos puesto que, sin lugar a dudas, nos entregarán luces importantes para alcanzar una interpretación adecuada de las modernas expresiones del control. Elementos fundamentales para continuar el estudio en los capítulos siguientes.

Los sistemas parlamentarios han sido objeto de múltiples transformaciones al punto de que el mismo control parlamentario y la responsabilidad política, elementos nucleares del mismo, se han visto en jaque. Factores como la racionalización

${ }^{246} \operatorname{LiNZ}(2013)$ Pp. 15 y 16. 
parlamentaria, la disciplina de partidos y el estrecho vínculo existente entre la mayoría parlamentaria y el gobierno, han alterado esencialmente el control ${ }^{247}$.

Dichos motivos impulsan las declaraciones de Francisco Rubio Llorente en el siguiente tenor: "el control parlamentario real que hoy se ejerce sobre los Gobiernos de la Europa Occidental no responde, ni poco ni mucho, al esquema teórico, no obstante, se continúa intentando explicar $y$, lo que es peor, legitimar la democracia" ${ }^{248}$. En la actualidad, en el sistema parlamentario, en palabras de Jiménez de Parga, el gabinete no es un mero Ejecutivo, sino un verdadero gobierno. Es por esta razón, que en términos contemporáneos y a causa del bipartidismo entre otras razones, Gabinete y Parlamento actúan de común acuerdo. Por ende, la responsabilidad ante las Cámaras es más teórica que real. Debido a esto, el gabinete decide, pero el Parlamento y, en último término, el pueblo es quién vigila ${ }^{249}$.

De este modo, hemos de detectar en este argumento el primer signo distintivo de control parlamentario y forma parlamentaria de gobierno de corte teórico-ideal. Este rasgo nos permite finalmente advertir que existen diversos factores que han influenciado sustancialmente la forma en la cual se desarrolla el control. Las nuevas tendencias expresan un ejercicio del control más tenue que, además, rara vez produce como resultado o sanción la aplicación de responsabilidad política, vale decir, es poco probable el ejercicio y aplicación de una moción de censura o de confianza.

Por su parte, el régimen presidencial latinoamericano también se ha visto afectado por algunas transformaciones, al punto que ha experimentado una serie de episodios de juicios políticos que finalmente lograron hacer efectiva una responsabilidad de naturaleza jurídico-política. Estos fueron procesos políticos que en otros tiempos hubieran sido impensados, o sus resultados hubiesen distado bastante de los resultados actuales. Como bien expresa Aníbal Pérez-Liñán, los juicios políticos en los presidencialismos fueron acontecimientos poco comunes en la vida política de la región. Tal era su impracticabilidad que autores como Lijphart se referían a los

247 En el presente párrafo sólo los esbozamos como un causante de las alteraciones del control parlamentario en un régimen parlamentarista pero será en el capítulo siguiente donde ahondaremos su estudio.

248 RUBIO (1993) Pp. 253 y 254.

249 JiMÉNEZ DE PARGA (1983) p.327. 
mismos en el siguiente tenor: "es posible destituir al Presidente mediante el excepcional y poco frecuente juicio político ${ }^{\prime 250}$.

Sin embargo, hace dos décadas ha surgido el Juicio Político como un instrumento poderoso para desplazar a presidentes "indeseables" sin destruir el orden constitucional, lo que, en definitiva, demuestra una nueva forma de resolver las crisis políticas y sustenta una tendencia mucho más amplia para enfrentar los patrones de inestabilidad política en Latinoamericana. La diferencia sustancial radica en el hecho de que, en épocas anteriores los gobiernos elegidos democráticamente también caían, pero como resultado de ello caía también el régimen democrático. Este suceso favoreció la construcción de argumentos arquetípicos, como los de Linz, relativos a la rigidez y la imposibilidad de salir de forma airosa de las crisis. Desde hace unas décadas, determinados contextos muy complejos de crisis políticas provocan la caída de presidentes electos, pero sin desencadenar quiebres en las democracias mediante precisamente la utilización del juicio político. Tal ha sido la magnitud de aquellos procesos políticos, que se promovieron algunos comentarios que detectaban rasgos "parlamentarios" en los presidencialismos, asimilando el juicio político al voto de censura ${ }^{251}$.

Tal como describe el autor francés Armel Le Divellec, la distinción entre sistemas hoy es muy borrosa, puesto que las propias mutaciones que ha experimentado el control parlamentario -unido a las tradiciones nacionales de cada Estado- configuran una institución distinta a la esperada, generando una "ilusión" sobre el control y sus efectos. El autor describe un elemento relevante en torno al régimen de gobierno. Expone que en el parlamentarismo el control es y seguirá siendo un factor de legitimidad del poder delegado en jefe de Gobierno, puesto que mientras no se rompa el acuerdo político inicial bajo un previo consenso del electorado, se mantendrá una dirección política y se conservará el Ejecutivo. Por tanto, en este escenario el control es débil y más concretamente se traduce en que la mayoría cumple una función de apoyo y la minoría una crítica pública -situación muy lejana a los efectos del control concebido idealmente-. Por su parte, en el presidencialismo la autonomía de ambos órganos dota de mayor libertad al Parlamento para controlar, puesto que a priori no tiene el deber de legitimar constantemente al Ejecutivo. Así,

\footnotetext{
${ }^{250}$ LIJPHART (1997) p. 149.

${ }^{251}$ PereZ-Liñan (2009) Pp. 19, 20 y 21.
} 
tendrá mayor movilidad en supervisar y revisar la dirección política. Por ejemplo, y a pesar de dicho contexto, ocurre muy pocas veces en los presidencialismos norteamericanos y latinoamericanos la utilización del impeachment ${ }^{252}$. Respecto de este último argumento, lo señalado en los párrafos precedentes viene a cuestionar aquella afirmación, toda vez que la utilización del juicio político se ha acrecentado en nuestra región.

En dicho contexto, hemos de poder esbozar nuestro primer postulado, el que implica un reconocimiento al hecho de que las democracias latinoamericanas han dado prueba suficiente de que sí poseen la capacidad y los mecanismos para resistir los conflictos entre Ejecutivo y Legislativo. Por consiguiente, en opinión de PérezLiñán, las crisis del presidencialismo pueden ser resueltas por mecanismos múltiples, dentro de los cuales se encuentra el juicio político. Este último, se encuentra además regulado por preceptos constitucionales. En este sentido, el factor mandato fijo ya no sería una dificultad en la estabilidad del régimen, así como tampoco en el mecanismo y sus tiempos. En efecto, "en los últimos quince años ninguna crisis ha puesto en jaque el régimen democrático, razón por la cual el juicio político no es sólo un recurso legal para remover del cargo a presidentes considerados culpables de ilícitos, suele ser un arma institucional que se emplea también contra presidentes que se enfrentan a legislaturas beligerantes" 253 .

De este modo, la utilización del Juicio Político también ha sido la respuesta habitual a fuertes hechos de corrupción y abuso de poder. En cierto modo, su objetivo final ha sido hacer aplicable una responsabilidad de corte jurídico-política, la cual -tal como hemos planteado anteriormente- no estaría contemplada para el régimen presidencial. Sin embargo, como podemos percibir procede de forma diferente, porque su naturaleza mixta estará compuesta por lo jurídico y lo político, lo que no le resta relevancia, a nuestro juicio. Sólo a modo ilustrativo señalamos los nombres de los presidentes destituidos en juicios políticos o en marco de crisis

\footnotetext{
252 Le Dilletec (2010) Pp. 128-130.

253 PÉREZ-LiÑÁn (2009) p.29. Es preciso señalar que el autor formula un análisis que para nosotros es tremendamente asertivo toda vez que, señala que las complicaciones provocadas por la corrupción específicamente en principio no podían ser resueltas por las estructuras fosilizadas de los presidencialismos pero tampoco podían encontrar vías de escape en acciones militares, esencialmente por el repudio que ello implicaría desde una perspectiva internacional, razón por la cual las élites políticas se vieron obligadas a encontrar caminos constitucionales o pseudo constitucionales para resolver las disputas. Ahonda el autor describiendo que, si bien deben existir méritos legales el destino de Ejecutivo fue evaluado por un conjunto de fuerzas institucionales sociales y políticas. Por tanto, las crisis presidenciales distan mucho de ser la fuerza desequilibrante que suponían los críticos del presidencialismo.
} 
presidencial en América Latina, no obstante que la responsabilidad política propiamente tal será analizada en el siguiente capítulo: Fernando Collor de Melo, Carlos Andrés Pérez, Ernesto Samper, Abadalá Bucaram, Raúl Cubas Grau, Luis González Macchi, Otto Pérez Molina y el reciente caso de la presidente Dilma Rousseff.

Finalmente, examinaremos otro elemento de trascendencia. Para llevar a cabo esto, traeremos a colación la definición que el mismo Pérez-Liñán esboza para referirse a las crisis presidenciales, señalando que son "episodios que se caracterizan por niveles muy elevados de conflicto y por la decisión de una rama electa de disolver la otra con el fin de darle nueva forma a su composición" ${ }^{254}$. Por consiguiente, cabe cuestionarse si tomamos o no este concepto y cuál será la diferencia concluyente respecto a las finalidades de los mecanismos del sistema parlamentario, tales como el voto de censura y la cuestión de confianza, y los propósitos perseguidos en el marco de una crisis presidencial. Aparentemente, los objetivos últimos son idénticos, motivo que nos permite seguir sosteniendo que los argumentos comúnmente esbozados, los cuales sustentaban diferencias relevantes entre ambas formas de gobierno, pueden verse debilitados.

No obstante, se debe hacer presente que en un régimen presidencial siempre existe la posibilidad de que una crisis presidencial finalice de diversos modos, dentro de los cuales pueden ocurrir eventos poco democráticos. Lo anterior, constituye un riesgo permanente en nuestros presidencialismos. La clave de la estabilidad del sistema político democrático dependerá de si los mecanismos escogidos están conforme a derecho, es decir, si se encuentran regulados en el ordenamiento jurídico e, idealmente, en preceptos constitucionales como ocurre con el juicio político, a fin de dotar de validez y legitimidad a las decisiones políticas. Por otra parte, si consideramos que el Estado de derecho se encuentra totalmente afianzado en la cultura jurídica de los Estados, no visualizamos dificultades mayores que pudieran volver a desequilibrar el escenario regional y nacional. Prueba de aquello es el hecho de que las caídas de presidentes -tal como ha sido mencionado anteriormente- no han provocado a su vez la caída del régimen democrático. Por esta razón, creemos que este primer aspecto relativo al control y la responsabilidad política, sienta las bases que justifican la noción de que sí existe un efectivo control y responsabilidad

254 PÉREZ-LiÑÁN (2009) p. 84. 
en el presidencialismo, y que sus efectos pueden ser similares al del régimen parlamentario. Ahora bien, hacemos presente que nuestra finalidad no es equiparar los regímenes de gobierno a fin de no reconocer sus obvias diferencias, solamente pretendemos señalar que desde la perspectiva del control parlamentario los matices son cada vez más pequeños, por ende, creemos que aquello demuestra que la institución, en sí misma, se renueva y se refuerza materializando aquella ductilidad que hemos señalado consistentemente.

Esta opinión que es expresada por Rubio Llorente señala que el control parlamentario ejercido en los sistemas parlamentarios de Europa Occidental es muy semejante al del sistema presidencial ${ }^{255}$. Lo más significativo del presente acápite, a nuestro juicio, es la posibilidad de argumentar y sostener fundadamente la factibilidad de arribar -mediante el uso de la fiscalización parlamentaria en el sistema presidencial- a efectos similares en un régimen de tipo parlamentario, vale decir, podemos alcanzar una estabilidad política con los mecanismos constitucionales diseñados para tal efecto, sin la necesidad de igualar mecanismos ni de tener que avanzar en la parlamentarización de nuestra forma de gobierno.

Con estas afirmaciones, esperamos además poder despejar aquellos intentos por reemplazar nuestra organización política por aquella vía parlamentaria, ya que implantar aquellas válvulas de escape o herramientas parlamentarias como la disolución del Parlamento en una forma presidencial no producirá los efectos deseados. Es por esta razón, que habitualmente en América Latina la elección de presidentes y del Parlamento puede no coincidir. Aunque se disolviera el poder Legislativo para modificar de esta manera las mayorías o minorías en él representada -las que pueden producir la paralización del sistema de decisiones políticas-, la sola convocatoria a nuevas elecciones no solucionaría el problema, puesto que las motivaciones para emitir el voto presidencial y parlamentario son distintas $y$, ciertamente, puede incluso replicarse la misma configuración parlamentaria conflictiva ${ }^{256}$. Respecto a este punto, es posible destacar que nuestro sistema político es de rasgos divergentes, ya que se desarrolla confrontacionalmente mediante posiciones doctrinales muy alejadas que en ocasiones impiden un juego democrático armónico. Por ende, hemos de diseñar y perfeccionar un sistema que

255 RUBIO (1993) p. 254.

256 NogueIRA (1985) p. 97. 
nos permita gozar de estabilidad política a pesar de aquellas particularidades, teniendo siempre presente que muchas de dichas conflictividades ideológicas fueron impuestas por los golpes de estado cívico-militares que modificaron en gran medida las realidades políticas de América Latina.

Un segundo argumento que queremos exponer respecto a las nuevas manifestaciones de control parlamentario, lo compone un elemento decisivo en esta materia. Lo anterior, implica analizar el procedimiento para el nombramiento del Ejecutivo, hecho político que comprende un factor crucial en la nueva interpretación del control parlamentario y sus efectos. Intentaremos sostener que, respecto de las formas de gobierno, se está gestando un tipo de control diverso al inicialmente concebido, lo cual implica afirmar que en el sistema presidencial existe controlresponsabilidad $y$, además, que aquel control podrá provenir de diversas fuentes y vías a diferencia de lo que sucede en el parlamentarismo, sistema en el cual las vías de control parecen estar muy acotadas y los instrumentos de control están contemplados específicamente.

En tal sentido, es preciso señalar que en un régimen presidencial el procedimiento de selección del Presidente es directo, por tanto, el control de los electores hacia el Ejecutivo es asimismo directo. En consecuencia, existe un control que proviene en gran medida de parte de la ciudadanía, lo que finalmente produce que el Ejecutivo deba soportar una presión de suma relevancia y lo constriñe a actuar con mayor responsabilidad, situación que generalmente incide en la reducción de las malas prácticas políticas como la corrupción. Por consiguiente, estamos frente a un control social activo y constante, que a su vez exigirá a sus representantes en el Congreso que materialicen sus demandas. En definitiva, requiere de sus congresistas que resguarden sus intereses lo cual finalmente impulsa el control parlamentario. Situación similar puede ocurrir con los Ministros de Estado, puesto que la personalización y protagonismo que alcanzan tales personas respecto de sus carteras en los regímenes presidenciales es muy alta, lo que hace muy probable que la sociedad identifique con claridad los atributos y debilidades de su gestión. Así, parece existir una mayor exposición de su gestión, promoviendo con ello el control respecto de él. 
Por otro lado, en un sistema parlamentario la selección del Ejecutivo se realiza a través del Parlamento, lo que hace más dificultoso para los votantes controlar el riesgo político-ético, situación que se transmite a la responsabilidad política y sus dificultades de aplicación. La ciudadanía en las elecciones nacionales escoge por un partido político o por una unión de partidos políticos, fuerza política que una vez que obtiene el triunfo electoral y arriba al Parlamento escogerá a la persona que encabezará el Gobierno. Sin embargo, las características personales de aquella persona son "desconocidas" para la sociedad. Por tanto, puede ocurrir que dichos atributos personales del futuro jefe de Gobierno no estén en armonía con las necesidades de la coyuntura política, económica y social. Frente ese escenario, la sociedad tendrá un grado de influencia menor, situación que podría fomentar una frustración social y los grados de desafección política podrían aumentar gestando una crisis política.

Por tanto, en un presidencialismo el reproche es más específico y se concreta en la figura presidencial y en caso de reprobar la gestión del Presidente la ciudadanía podría nunca volver a elegir a la persona cuestionada o a su coalición política. Al contrario, en un parlamentarismo los ímpetus pueden provocar discontinuidad o cambios abruptos de gobiernos, lo cual entorpece el desarrollo de la actividad administrativa y las políticas de largo plazo ${ }^{257}$. Tal situación favorece la determinación del sujeto pasivo del control parlamentario en el régimen presidencial, toda vez que al tener sólo la figura presidencial claramente individualizada, los cuestionamientos políticos y sociales van en aquella dirección hasta que la crisis sea resuelta. Las críticas constantes irán minando el liderazgo de una fuerza política o simplemente, apuntarán a que el Presidente sea derribado.

Por su parte, en el sistema parlamentario puede tornarse un tanto más difusa la determinación del sujeto pasivo por parte de la ciudadanía, puesto que el Gabinete al ser colegiado puede diluir entre todos sus miembros a la figura responsable. Es por esta razón, que puede ocurrir que el ejercicio del control se vuelva difuso y no permita que la sociedad civil pueda expresar su rechazo hacia un ministro

${ }^{257}$ LiNz et al. (1990) pp. 1163-1202. Si siguiéramos el planteamiento presentado por los autores, relativo a la forma de hacer efectiva la responsabilidad política en los presidencialismo, podríamos reconocer en la elección presidencial del año 2010, un ejemplo de aquello, pues la derrota de la Concertación con Eduardo Frei, podría configurarse como la manifestación de la ciudadanía sancionando los errores cometidos en el gobierno del ex presidente Frei, sin perjuicio de que se hayan planteado otros diversos y variados factores relacionados a su conglomerado. 
determinado y así darla a conocer, logrando con ello promover acciones políticolegislativas. Tampoco podrá recurrirse con facilidad a las modificaciones en el Gabinete como alternativas para salir de las crisis sociales. Probablemente, el jefe de Gobierno no tendrá la misma autonomía de la cual goza un Presidente al momento de plantearse la posibilidad de realizar cambios ministeriales, situación que puede gestar una crisis mayor ${ }^{258}$.

En este mismo orden de ideas, cabe destacar que en el presidencialismo es muy posible que el control parlamentario y el control ciudadano se relacionen de manera estrecha y que incluso exista cierta armonía con algunos sectores políticos, motivo por el cual la canalización de la protesta social en relación a una política pública o un funcionario de gobierno indeseado puede encontrar eco en el Congreso, provocando efectos inmediatos. Tal como expresa Pérez-Liñán, la protesta popular fortalece la postura de la oposición en el Congreso y además opera como catalizador de las caídas de los gobiernos. La movilización social ofrece el respaldo necesario para dar sustento político a las acciones del Legislativo ${ }^{259}$.

Desde esta perspectiva, la doble legitimidad que expusimos anteriormente como uno de los factores conflictivos del presidencialismo parece convertirse en una bondad del sistema. El vínculo de legitimidad entre sociedad civil, Presidente y Congreso -que nace en el proceso electoral-, empodera a los miembros de la soberanía popular para poder cuestionar tanto al Ejecutivo como al Legislativo, ejerciendo un control que puede generar múltiples efectos de gran magnitud. Tal como señala Mario Serrafero, la movilización ciudadana se ha interpretado como una suerte de juicio político o retiro de confianza realizada precisamente por la población, emergiendo con ello un "accountability vertical"260.

\footnotetext{
${ }^{258}$ Prueba de aquello fue la insostenible situación que debió afrontar el jefe de Gobierno español Mariano Rajoy al no remover a la Ministros Alberto Ruiz- Gallardón y Ana Mato. El mantenimiento de ambos ministros produjo para el gobierno serias dificultades en temas sensibles como el aborto, ebola y la corrupción.

259 PÉREZ-LIÑÁN (2003) p. 162.

${ }^{260}$ SeRRAfERo (2014) p.74. En Chile, particularmente, este escenario político es conocido. Basta recordar dos procesos de movilización ciudadana de grande magnitudes como las protestas estudiantiles del año 2006, las que retornan con más fuerza el año 2011, y, las medioambientales, a través de las protestas contra la termoeléctrica denominada "barrancones" en Punta de Choros y "Patagonia sin represas". Ambas provocaron diversos efectos de gran trascendencia política, jurídica y económica. Gobiernos de izquierda y de derecha debieron remover ministros e implementar políticas públicas que no estaban contempladas, de ninguna manera, en los programas de gobierno. La presión social fue el motor de la alternancia en el poder y la radical modificación de la agenda de Gobierno y legislativa, a tal punto que en la actualidad el sistema político sigue girando en torno a dichas demandas.
} 
Continuando con este planteamiento, una tercera noción en torno a la supuesta discrepancia entre regímenes en relación al ejercicio de control parlamentario, es la forma en cómo se desarrollan las relaciones Ejecutivo-Legislativo. Siguiendo a Shugart, diremos que en un régimen parlamentario el Ejecutivo es jerárquicamente inferior al Parlamento, situación que determina y limita su actuar. Al contrario, en el presidencialismo al ser ambos órganos elegidos de forma independiente por un período fijo, estarían en un supuesto plano de legítima igualdad. Por ende, se generarían incentivos para transar o negociar con el fin de elaborar la agenda legislativa y gobernar. Sin embargo, al presentarse casos de "colapso" en las relaciones entre Ejecutivo-Legislativo, ya sean de jerarquía (parlamentarismo) o con posibilidades de transacción (presidencialismo), la facilidad o dificultad de remediar tal situación dependerá de la estructura del Parlamento, del sistema de partidos y de la posible existencia de mayorías, por lo que la forma de gobierno no determina necesariamente per se la forma del control. Por el contrario, existen otros factores que han de influir. Dichos elementos serán los verdaderos componentes que finalmente favorecerán o no la estabilidad democrática y, en consecuencia, la "rendición de cuentas"261.

En principio, se ha planteado que la relación entre Ejecutivo-Legislativo es un factor determinante en la capacidad de conducción política del gobierno, vale decir, en la efectividad del gobierno, ya que una mayoría divergente en el Legislativo puede producir una parálisis del proceso decisional. Tal como señala Bernhard Thiabut, el Ejecutivo debiera esperar un bloqueo de la contraparte porque pese a las amplias facultades que posee, los presidentes latinoamericanos quedan condenados a la ineficiencia ${ }^{262}$. Generalmente, las interacciones entre Ejecutivo-Legislativo serán factores determinantes en la capacidad de resistencia o de disposición a cooperar o coordinar entre sí. Según el autor, de este modo se presentan dos caminos: por un lado, una dirección que lleva a relaciones adversas entre poderes que generaría una parálisis política; y por otro lado, una dirección que contempla relaciones coordinadas entre los poderes. Esta segunda opción, a juicio de Thiabut, se acerca a un modelo de checks and balances, en el sentido de que el proceso de toma de decisiones estará marcado por negociaciones entre actores gubernamentales y parlamentarios $^{263}$.

\footnotetext{
261 SHUGART (2008) Pp. 355-357 y 359-360.

262 THIABUT (1993) p. 225.

263 THIABUT (1998) p. 141.
} 
En igual sentido se han expresado Cox, Morgenstern y Wolfson, respecto a la diferenciación funcional de las legislaturas democráticas que se insertan en el proceso de toma de decisiones. Para estos investigadores, las legislaturas se clasifican según tres modalidades: las generativas-reactivas, relacionadas principalmente al parlamento europeo; las proactivas-reactivas de Estado Unidos; y las meramente reactivas de Latinoamérica, lugar donde se sigue considerando al Presidente como un "actor central del universo político civil"264. Por esta razón, la capacidad de decisión del Presidente posee un mayor grado de unilateralidad, ya que cuenta con prerrogativas casi imperiales. Tal combinación de antecedentes hará, finalmente, que se produzca una clara oscilación en los mandatos presidenciales latinos. En dicho contexto, el ejercicio de un poder conflictivo es, a su vez, el detonante de los variados fracasos Latinoamericanos. De este modo, dichos presidencialismos se caracterizan generalmente por exhibir presidentes dominantes que neutralizan el checks and balances democrático, situando en un plano de cuestionamiento los pesos y contrapesos y la limitación al poder. No obstante, estos investigadores detectan salidas de escape para esta realidad, motivo por el cual sostienen que presidencias coalicionales y legislaturas negociadoras garantizarían mayores equilibrios y serán evidentemente más democráticas ${ }^{265}$.

A criterio de los autores y desde esta perspectiva, el ejercicio del control parlamentario dependerá en gran medida de las relaciones más o menos amigables que se produzcan entre poderes. Desde nuestra mirada, sostendremos que este argumento es correcto, empero deben de agregarse otros factores que inciden directamente en este aspecto y que nos han sido considerados tales como el sistema de partidos políticos y el sistema electoral, ambos elementos determinantes en la configuración del Congreso, ya que influyen directamente en la forma en la que se desarrollarán las relaciones Ejecutivo-Legislativo. El nivel de apoyo que el Presidente posea en el hemiciclo, fijará la estrategia que el Gobierno ha de adoptar y, por ende, también dibujará el plan de acción o programa de gobierno ante el Congreso. En el caso chileno, esta situación es realmente decisiva porque el sistema electoral binominal que rige en nuestro país hasta el año 2017, es un mecanismo que genera una multiplicidad de particularidades que construyen un Congreso Nacional cuya representación política es sesgada. Mayorías y minorías se relacionan en un plano de igualdad dado que -numéricamente- el sistema binominal favorece la conformación

264 COX ET ALT (2001) p. 171.

265 COX EL ALT (2001) p.387. 
de minorías numerosas o, en su defecto, impediría derechamente la conformación de minorías parlamentarias, generando sólo dos grandes mayorías. Por tanto, quienes están llamados naturalmente a realizar la acción fiscalizadora, esto es, las minorías parlamentarias no están presentes y sólo se encuentra activa en el Congreso una mayoría de oposición, agente político que habitualmente ejercer un rol obstruccionista, paralizando la acción del gobierno.

En lo relativo al sistema de partidos políticos, plantearemos que, según los postulados de Mainwaring y Shugart, la naturaleza del sistema de partidos es la que produce diferencias sustanciales en el funcionamiento de las formas de gobierno. En adición a ello, la disciplina partidaria será un componente nuclear $y$, por lo mismo, debemos de realizar una primera distinción, la cual implica desentrañar si el Ejecutivo cuenta o no con una mayoría parlamentaria. Sólo realizaremos la distinción respecto del presidencialismo, toda vez que en el parlamentarismo debe necesariamente existir una mayoría parlamentaria que dé origen al gobierno. Es por ello que, en tal sistema, la relación entre Gobierno y mayoría parlamentaria es tan estrecha que el control deja de ser una función principal. Así, el control queda depositado exclusivamente en manos de las minorías parlamentarias, con todas las dificultades que ello implica en términos de quórums y barreras procesales. A este respecto, es el parlamentarismo el que resulta más damnificado porque precisamente aquel elemento de estrecha unión entre Ejecutivo-Legislativo es el que favorece o promueve la lealtad y disciplina partidaria enérgica, lo que produce la inactividad en el control parlamentario.

En cambio, los presidencialismos presentan mayores matices en este aspecto. El número de partidos y el grado de fragmentación será pieza clave en el desarrollo del gobierno y sus relaciones con el Legislativo. En este escenario, puede ocurrir que el Presidente goce o no de mayoría parlamentaria y dicha situación generaría dos posibles escenarios. Para el caso de no contar con la mayoría, el Presidente se verá obligado a generar gobiernos de coalición o, por el contrario, tendrá múltiples dificultades al momento de aprobar las leyes. Ahora bien, si tiene mayoría parlamentaria, se presenta la posibilidad de posicionarse en un escenario que puede favorecer relaciones más fluidas, evitando un bloqueo legislativo ${ }^{266}$.

266 MainWaring y SHUgart (2002) Pp. 10-12. 
Un primer escenario, se configura en el caso de que un partido político esté en minoría pero tenga el candidato presidencial más fuerte o que ya posea un Presidente electo. En tal contexto, aunque se gesten coaliciones políticas, aquellas pueden tener objetivos específicos respecto de un determinado proceso electoral o legislativo, mas no necesariamente podrá contemplar un apoyo hacia la gestión administrativa y política del gobierno en su conjunto ${ }^{267}$. De este modo, la disciplina y la lealtad no serán virtudes con gran presencia en el desarrollo político, lo cual evidentemente fomentará el control. En este escenario, las relaciones serán complejas y el ideario político del Ejecutivo se verá restringido a la capacidad negociadora del mismo. El control por su parte, será activo, situación que desde una perspectiva de largo plazo podría fomentar una crisis política, períodos de inestabilidad e, incluso, la ejecución de un juicio político al Presidente de la nación.

Un segundo escenario, comprende la posibilidad de que puedan conformarse coaliciones de gobierno o simplemente electorales de mayoría, y en ambos casos se configura un Ejecutivo de tal característica. Por tal motivo, se daría nacimiento a un gobierno que teóricamente no debiera soportar fuertes críticas como tampoco una acción fiscalizadora decisiva, toda vez que goza de un amplio respaldo en el Parlamento. No obstante y desde nuestra opinión, es preciso considerar otro elemento que dice relación con el número de partidos que integren aquel conglomerado, cuestión que será determinante en cumplimiento del supuesto antes descrito ya que, a mayor número de partidos, mayores son las probabilidades de que alguno de ellos pueda verse mermado en sus particulares aspiraciones -ya sea porque no siente comodidad con determinadas actuaciones el gobierno, o bien no ha podido adquirir un compromiso suficiente con la gestión del gobierno o el pacto-. De esta manera, la coalición gobernante -a mayor número de integrantes- puede estar afianzada sobre acuerdos débiles.

Esto podría dar comienzo a una actividad mayor de fiscalización de los actos del Ejecutivo. Aquellos agentes políticos que integran la coalición -en virtud de su legítima aspiración por posicionar sus ideales o por visualizar sus mejores opciones presidenciales que les permitirían alcanzar el próximo gobierno-, podrían eventualmente distanciarse del Ejecutivo y comenzar un rol opositor. En tal caso, estaríamos frente a un control que provendría igualmente de una minoría, pero que

267 MAINWARING Y SHUGART (2002) Pp. 11 y 13. 
se encontraría comprendido dentro de aquella mayoría que ha pactado con el Presidente. Por tanto, siguiendo este análisis, cabe sostener que en el régimen presidencial se abrirían más posibilidades hacia el ejercicio del control por diversas vías, puesto que el triunfo electoral de un candidato presidencial requiere de la conformación de alianzas políticas, las que no necesariamente serán duraderas en el tiempo.

Ciertamente, las situaciones antes descritas pueden, a su vez, gestar tensiones al interior del Ejecutivo, en el Parlamento y en general en el sistema político. Entonces, el riesgo de la inestabilidad política emerge nuevamente como una sombra amenazadora. No obstante, objetivamente y en lo que a nosotros respecta, tales hechos fomentan el control de la agenda de gobierno y de la agenda legislativa ${ }^{268}$.

Respecto de aquella flexibilidad en las formas de gobierno, tales fenómenos han sido percibidos y explicados -entre otros- por la autora italiana Lucia Picarella, quien plantea una presidencialización y personalización de los sistemas políticos. Según la autora, esta situación se forja por tres razones: a.- los gobiernos más autónomos y el fortalecimiento de los poderes del premier; b.- los partidos políticos que refuerzan liderazgos, con lo que favorecen una mayor autonomía del líder ${ }^{269}$ y c.- la

${ }^{268}$ Sobre este punto nuestro país precisamente exhibe hechos de gran relevancia. Desde los orígenes de la Concertación de Partidos por la Democracia, se produce la unión de un espectro amplio de partidos políticos, ideológicamente diversos, lo que generó las más diversas complicaciones en el desarrollo y las orientaciones políticas de los gobiernos, pero que a pesar de aquello se matizaban las miradas y se consolidó la Democracia de los acuerdo. Sin embargo, estas discrepancias se han incrementado mayormente con la conformación del nuevo pacto político denominado "Nueva Mayoría", fruto de la conexión entre la Concertación y el Partido Comunista, Izquierda Cristiana y el MAS, cuyo objetivo central fue recuperar el gobierno, luego de haberlo perdido por única vez con posterioridad a la dictadura en manos de la derecha nacional coalición denominada Alianza por Chile. Alcanzado el triunfo presidencial, es posible percibir que en el actual gobierno de la Presidenta Bachelet se ejerce de manera constante y clara un fuerte control sobre su administración, entendido el control como una crítica y como la utilización de aquellos mecanismos de influencia en la gestión del Ejecutivo, por parte de los partidos políticos más equidistantes de la coalición, es decir, el Partido Demócrata Cristiano y el Partido Comunistas. Ambos partidos han criticado duramente la gestión de la Presidenta e intentan influir decididamente en la agenda legislativa y en la agenda del mismo gobierno, configurando con ello una especie de minoría gubernamental que pretende re-orientar el camino trazado inicialmente al nacer aquel pacto, formulando críticas y recomendaciones por los medios de comunicación. Dicho antecedente, que pudiera desde un primer análisis parecer complejo, puesto que da nacimiento a un control intracoalición, el que cambia el foco tradicional del control.

269 Prueba de lo expuesto es precisamente el inquieto comportamiento político de los partidos, coaliciones y alianzas políticas que han gobernado en Europa las últimas décadas. Los sistemas parlamentarios europeos han presenciado estilos de dirección política particulares, en Gran Bretaña con el liderazgo de Margaret Thatcher y de Blair, Francia con Sarkozy, Alemania de Schroeder, e Italia con Berlusconi, por su parte España no queda exenta figuras como Aznar, Zapatero y, por cierto, Felipe González. Por su parte, los presidencialismo Latinoamericanos también presentan liderazgos particulares tales como los de: Collor de Melo y Lula Da Silva en Brasil, Menem en Argentina, Fujimori en Perú, y el recientemente fallecido presidente Hugo Chávez en Venezuela, han impreso en esta región sellos muy particulares que alteran de cierta forma el desarrollo político de las instituciones y su equilibrio, precisamente, en las relaciones Ejecutivo-Legislativo. 
concentración de las campañas electorales en características personales del líder, en desmedro del partido y del programa ${ }^{270}$. Por tanto, las concepciones estrictamente teóricas respecto de la noción de los regímenes hoy no son del todo aplicables, debido a las importantes transformaciones que han ido sufriendo, lo que ha provocado que las supuestas diferencias entre dichos sistemas ya no sean tan categóricas. En efecto, los mandatos presidenciales interrumpidos por juicios políticos en las últimas décadas son más recurrentes. Esto configura una novedad que se aleja por mucho de la compleja rigidez sostenida por Linz, lo que gesta una flexibilización del presidencialismo.

En palabras de Serrafero, la renuncia del presidente y los juicios políticos han sido siempre un mecanismo de superación de las crisis presidenciales además de configurar una herramienta que incrementa el poder del Parlamento. Por su parte, la presión social y comunicacional también ha contribuido en el jugo democrático, lo que expresa, según el autor, la retirada de confianza realizada por la población. Es aquí donde surge finalmente un "accountability vertical"271. Este proceso, según Serrafero, además de crear salidas institucionales a las crisis, genera cierta parlamentarización del presidencialismo al exhibir un mayor activismo congresional.

Continuando con el examen de la flexibilización presidencial, Pérez-Liñán aporta importantes argumentos cuando sostiene que las modificaciones han ido en dirección de disminuir los excesivos poderes del Ejecutivo. Por ende, hoy aquella idea que expone una imagen fuerte del Presidente sería una imagen engañosa. Las crisis presidenciales comprenden precisamente una cierta debilidad del Ejecutivo en su capacidad de controlar a los legisladores, en tanto que el Congreso posee poderes específicos para destruir a la figura del Presidente a través de un juicio político o de la declaración de incapacidad. Por su parte, el Presidente rara vez cuenta con la facultad de disolver al Congreso. Por consiguiente, el presidencialismo puro se ha desviado. La tercera oleada democrática ha modificado las concepciones clásicas también del presidencialismo, generando mayores condiciones para la supervivencia de la democracia y para la consecución de la estabilidad política ${ }^{272}$. En este mismo sentido, es bueno destacar en este punto las palabras de Sartori cuando expone que, al pronunciar la voz "parlamentarismo" en la actualidad no estamos hablando

270 PiCARELLA (2009) p.517.

271 SerRAFERO (2014) Pp. 73-74.

272 PÉREZ-LIÑÁN (2003) Pp.158-159. 
únicamente del tipo británico sino que, por el contrario, existen diferentes manifestaciones del régimen debido a sus diversas realidades y a las múltiples formas en las que se relaciona el Ejecutivo con el Legislativo ${ }^{273}$.

En síntesis, al revisar ambos sistemas enfrentamos la disyuntiva planteada por los autores en torno a atribuirle al parlamentarismo un sistema de fiscalización parlamentaria como elemento esencial de su configuración y, por consiguiente, una adhesión de la responsabilidad política, mientras que en el sistema presidencial existiría una privación de tales características o -en su defecto- una aplicación difusa y débil. No obstante, es preciso exponer algunas consideraciones finales que modifican aquellos supuestos teóricos, como ya lo hemos venido expresando. Como bien explica Rodrigo Lloreda, los sistemas de gobierno han variado: "el presidencialismo ha evolucionado y el parlamentarismo se ha deformado"274, en gran medida por la irrupción de los partidos políticos y los medios de comunicación de masas. Por ende, se torna difícil formular juicios absolutos respecto de los mismos. Así, resulta complejo asumir el control parlamentario como un mecanismo que opera automáticamente conforme a estos parámetros.

En consecuencia, y tal como lo expresáramos anteriormente, debatir las bondades de los sistemas de gobierno en el nivel de los tipos ideales conduce a una grave deformación teórica y práctica ${ }^{275}$. El éxito de una forma de gobierno residirá básicamente en las adaptaciones que ésta pueda realizar dentro de los márgenes del tipo ideal, en dirección de los requerimientos políticos y sociales del momento. Cada sistema irá adecuando sus elementos e instituciones relevantes a fin de sortear las dificultades existentes, respondiendo a las necesidades de los tiempos modernos, alterando sus parámetros ideales y abriéndose a otros elementos de gravitación política y jurídica. Tal situación es la que directa e indirectamente influye en la conceptualización del control parlamentario y sus expresiones concretas. De esta manera, podemos señalar que las instituciones que dan cuerpo al trinomio de Gobierno, Partidos y Parlamento, van sufriendo modificaciones a través del tiempo en todos los escenarios estatales y que las formas de gobierno, su ejercicio y regulación, no son la excepción a dichos cambios.

\footnotetext{
273 SARTORI (2003) Pp. 116 y 117

274 LLORENDA (1967) Pp. 30 a 39.

275 NOHLEN (1999) p. 28.
} 
Por consiguiente, existe a nuestro juicio la posibilidad de ejercer el control parlamentario y la de aplicar la responsabilidad política tanto en regímenes presidenciales como parlamentarios. No obstante, su intensidad será diversa y dependerá mayormente de factores políticos y normativos, y no tanto del sistema imperante. Sostenemos lo anterior porque consideramos que estos tres órganos, cuya participación se analizó en los sistemas de parlamentarismo y presidencialismo, en la actualidad se ven limitados por actores superiores al Estado, como los medios de comunicación social y el control social, los que realmente determinan el juego democrático de un país.

A modo conclusivo, nos quedamos con lo expuesto por Rubio Llorente, quien explica que en América los poderes constituidos proceden de una elección popular y desempeñan, en principio, funciones materialmente distintas, por lo que entre dichos poderes no puede plantearse una relación de superioridad o inferioridad, sino de coordinación e igualdad. Por tanto, el fraccionamiento de las tareas estatales y la colaboración entre ellos, aseguran la limitación de cada uno de los centros de poder, dando vida a sistemas de pesos y contrapesos, checks and balances que no se agotan allí, sino que hay un control parlamentario activo -porque basta con la dualidad de sujetos y no necesariamente con una relación de supremacía o de subordinación-. Por este motivo, el autor expresa que "no resulta imposible, y sí perfectamente adecuado al uso común del término, hablar también de un control político en los sistemas presidencialistas" ${ }^{276}$. Respecto de este punto, el autor formula una salvedad: el control será realmente efectivo en la medida de que el Congreso no esté dominado por el partido político del Ejecutivo o que tal partido no tenga la disciplina necesaria para imponer un criterio. Con todo, aunque el Congreso no pueda derrocar al Presidente, dispone siempre de medios para imponer su voluntad. No cabe duda, señala Rubio, que las sanciones serán diversas, pero en el presidencialismo éstas gozan de gran trascendencia porque se configuran mediante una crítica pública en el seno del Congreso, la que se trasladará al electorado como una apelación al pueblo, quien ha de resolver.

De tal modo, siguiendo a Giuseppe Graterol, el control político en general no es una atribución exclusiva del parlamentarismo: en un régimen presidencial el control parlamentario sobre la acción del gobierno es un requisito necesario para la

276 RUBIO (1993) p.247. 
construcción y mantenimiento del sistema democrático y de derecho ${ }^{277}$. Lo anterior porque, en definitiva, "la separación de poderes mejora la rendición de cuentas de los funcionarios electos, y por tanto la información hacia los votantes, pero sólo bajo controles y equilibrios adecuados"1278.

Por consiguiente, el control parlamentario como institución parece reaccionar a las condiciones políticas, dependiendo del marco de las cual puede y debe actuar. En este sentido, su fuerza o debilidad depende de la conexión que se produce entre aquellos elementos, situación que no se encuentra vinculada necesariamente con el régimen jurídico regulatorio de la fiscalización parlamentaria. Este argumento nos permite fortalecer aquella interpretación que hemos sostenido continuamente en el presente Capítulo, que dice relación con aquella cualidad de ductilidad que posee nuestra materia de estudio. El control en ocasiones escapa de toda aquella construcción teórica, su comportamiento se adecua a cada escenario político y a cada sistema de partidos políticos, independientemente del ordenamiento jurídico que lo regule. Si bien el régimen jurídico le impondrá un determinado marco de acción, el control surge cada vez que existen condiciones políticas para producir efectos, situación que depende de los agentes políticos nacionales y de los nuevos medios de control que las sociedades modernas entregan.

Como es posible colegir del presente análisis respecto del control parlamentario y sus nuevas manifestaciones en ambas formas de gobierno, no cabe más que sostener que la realidad política avanza más rápido que la realidad doctrinal y más aceleradamente que el escenario normativo. Por su parte, como lo hemos venido señalando, los métodos clásicos -concebidos para el ejercicio de la fiscalización- han mutado y en la actualidad se presentan con otras aristas en ambos regímenes. Por ende, afrontamos un proceso de metamorfosis del control a raíz del proceso transformador que experimentan ambos regímenes de gobierno, que ha dado pie a la flexibilización de los mismos. En dicho escenario, todas sus manifestaciones se verán afectadas. Con todo, es menester concluir que en ambos regímenes se pueden gestar situaciones relativamente similares en relación al control, las transformaciones del sistema parlamentario fomentan una presidencialización del mismo, por tanto las cualidades o características antes analizadas respecto del control parlamentario en el régimen presidencial, pueden ser examinadas en el

277 GRATEROL (2013) Pp. 9 y 10.

278 PERSON ET ALT (1997) p.1166. 
parlamentario porque las transformaciones han difuminado los rasgos esenciales y han fomentado la generación de patrones políticos similares que inciden directamente en las expresiones del control parlamentario. Por su parte, el régimen presidencial ha extremado las críticas y el control, por ende, los juicios políticos van en aumento y la responsabilidad política se ejerce con mayor habitualidad.

Respecto a este punto, hemos de sostener que el gran valor de la fiscalización parlamentaria es su ductilidad, a través de la cual logra amoldarse a la realidad política de cada Estado y a cada sistema político lo que, en definitiva, la convierte en una institución siempre vigente y en un tema de análisis relevante y contingente en cualquier país y en cualquier momento histórico. He allí una de las razones basales de esta investigación. La flexibilidad con la cual se expresa el control parlamentario es, sin lugar a dudas, su más importante virtud, pero al mismo tiempo su mayor complejidad, toda vez que intentar abarcar en un trabajo investigativo todas las manifestaciones y componentes del mismo resulta ser una difícil labor, la que asumimos responsablemente.

\section{d) Chile, una democracia presidencial reforzada y la necesidad de control}

La presidencia de la República en Chile es, como la describe Bernardino Bravo Lira, la institución más antigua y prestigiosa. De acuerdo a lo descrito por el autor, posee cuatro siglos de vigencia toda vez que la institución se consolida en Chile en el siglo XVII (año 1609), momento desde el cual se ha sucedido casi de forma continuada desde los presidentes de la monarquía ilustrada hasta aquellos que gozaron de mayores poderes, quienes no sólo fueron simples gobernantes, sino que también se instauraron como jefes de Estado ${ }^{279}$. Por consiguiente, aquella acumulación de funciones históricas ha permitido al Ejecutivo gozar de una especial supremacía respecto del Poder Legislativo de manera continua. Es por ello que se ha esbozado por la doctrina la noción de que en nuestro país se ha configurado un presidencialismo muy particular, denominado reforzado o fuerte.

${ }^{279}$ Bravo (1991) Pp.365 y366. 
Los antecedentes constitucionales dan cuenta que desde la Constitución de 1828 se logra consolidar parcialmente la primera forma de republicanismo en Chile. En dicha oportunidad, se intenta someter todos los poderes al imperio del derecho y se establece la división de poderes, lo que además se desarrolla con fuertes tintes liberales. Sin embargo, será en el año 1929 en el que se producirá una serie de golpes de fuerza que promoverán un cuadro de reformas políticas autoritarias, que pondrán énfasis en la promoción del presidencialismo. Por su parte, Renato Cristi y Pablo Ruiz-Tagle describen que a partir del año 1830 el equilibrio del Ejecutivo y el Legislativo se reemplazó por la primacía de la función Ejecutiva, la que anunció un hiper-presidencialismo autoritario, proceso que asignó un lugar preeminente al titular de dicha función y los situó casi por encima del derecho, debilitando así la división de poderes $^{280}$.

Los antecedentes de un presidencialismo fuerte continuaron presentes y pueden detectarse en la formación del texto constitucional del año 1833. En aquella oportunidad, don Mariano Egaña postuló un conjunto de disposiciones que tendían a organizar el Estado aparentemente bajo un republicanismo, pero que verdaderamente contenían bases monárquicas. La influencia de Egaña fue de tal magnitud que, como bien describe Julio Heise, finalmente logró que en el texto constitucional se consagrara un gobierno absolutista y aristocrático, que limitó en todo lo posible la participación del pueblo. No obstante, en la Constitución de 1833 no se diseñó estrictamente un régimen presidencial, pero tampoco se estableció un régimen parlamentario. A juicio de Heise, se creó una formula híbrida que le dio preponderancia y se inclinó claramente hacia el presidencialismo. Así, se postularon presidentes que en un principio eran casi monarcas absolutos, esencialmente por la ausencia de responsabilidad efectiva del jefe de Estado, como explica el autor: "en un comienzo el Ejecutivo lo absorbe todo"281.

A pesar de las potentes facultades presidenciales, lo cierto es que en el caso chileno aquéllas se encontraban reguladas constitucionalmente y se presentaban como el contrapeso más efectivo a la aristocracia. De conformidad a lo señalado, y siguiendo a Carlos Estévez, diremos que la Carta Fundamental de 1833 tenía como objetivo principal eliminar el desorden y la anarquía. Por tanto, crea como mecanismo de solución a dichas necesidades un Poder Ejecutivo fuerte y poderoso.

\footnotetext{
${ }^{280}$ CRISTI Y RUIZ-TAgle (2006) Pp. 93 y 94.

281 HeISE (1950) p. 54.
} 
En este cuerpo constitucional, el Presidente no era un actor pasivo, sino que era el gran elector y presentaba una clara supremacía sobre el Congreso. Según Estévez, tal sistema político podía no ser el más adecuado a los principios republicanos, sin embargo era el modelo que consolidaba el poder, pues creaba una institución que encarnaba la autoridad: el Presidente, quien era el representante del poder público $^{282}$.

Como es conocido, nuestro país no siempre fue gobernado mediante un régimen presidencial. En nuestra historia estuvo presente -en un período no menor- un cuestionado régimen parlamentario de gobierno, que provocó desequilibrios políticos e institucionales al punto de promover un proceso constituyente que otorgara un nuevo código político y que a su vez solucionara dichos problemas. Es por ello que durante el debate constituyente que se originó en torno a la elaboración de la Constitución de 1925, se zanjó la definición del régimen de gobierno con mayor fuerza a través de la conformación de dos tendencias en relación a este punto: a.aquellos que aspiraban a consagrar al presidencialismo como forma de gobiernos y b. - aquellos que apoyaban el régimen parlamentario. Desde esa época los autores ya señalaban que las características y notas definitorias entre uno y otro régimen había que buscarlas en aquellas disposiciones que dividieron a los constituyentes. Éstas fueron fundamentalmente dos: la fiscalización parlamentaria y la responsabilidad política de los ministros ${ }^{283}$.

Como es posible percibir, aquellas diferenciaciones teóricas respecto de los sistemas de gobierno estaban presentes en Chile y fueron asunto de un vasto análisis, del cual nos haremos cargo en el Tercer Capítulo, oportunidad en la cual examinaremos en profundidad los efectos y consecuencia que produjo la instauración fáctica del régimen parlamentario para la fiscalización parlamentaria en Chile. Empero, la Constitución del veinticinco, cuya finalidad era atenuar las complicaciones políticas que el régimen parlamentario había generado en el sistema político nacional, optó por un régimen presidencial fuerte que fue promovido principalmente por el presidente Alessandri.

Si bien el texto constitucional de 1925 entrega importantes facultades al Presidente, tal como describen Arturo Fermandois y García, los ejes constitucionales

\footnotetext{
282 ESTÉVEZ (1942) p. 5 y 6.
}

283 BRAHM et alt (2002) p. 20. 
más desequilibrantes del presidencialismo nacional, es decir, la iniciativa legislativa exclusiva presidencial y la protección de ideas matrices del proyecto de ley, fueron promovidas y consagradas durante el gobierno de Frei Montalva, cuyo acto final de reforzamiento se consolidó en la reforma constitucional de 1970. Ambos mecanismos legislativos, a juicio de estos autores, operaron en Chile como un refuerzo al formidable Poder Legislativo presidencial. Lo anterior, se realizó con el objeto de contrarrestar la presentación de indicaciones inconexas a la problemática central abordada por un proyecto de ley durante el período de 1925-1970. Desde la promulgación de la Constitución de 1925, a través de sus reformas mediante las leyes números 7.727 de 1943 y 17.284 de 1970, se fueron otorgando facultades al jefe de Estado para asumir la más plena responsabilidad en el manejo administrativo, financiero, tributario y presupuestario del país ${ }^{284}$.

Con todo, debemos señalar que en nuestra actual Constitución Política de la República, que data de 1980, igualmente se estableció un régimen de gobierno presidencialista de acuerdo al cual el Ejecutivo cuenta con una gran gama de potestades administrativas, jurídicas y legislativas. Es por ello que finalmente, se ha llegado a denominar al régimen chileno como un régimen ultra-presidencial $o$ presidencial reforzado. Con esta afirmación se ha querido englobar las múltiples atribuciones de las cuales goza el jefe de Estado y respecto de las cuales el contrapeso del Legislativo es muy débil.

Tal como describe Detlef Nolte, siempre ha existido una preocupación en Chile sobre todo por la concentración de poderes en el Ejecutivo y la fortaleza de su presidencialismo, el que -combinado con un sistema multipartidario- implica el riesgo de elegir presidentes con una base política-partidaria minoritaria en el electorado y en el Congreso. Para el mencionado autor, el Presidente es muy fuerte y el Parlamento débil, esencialmente porque en dicho régimen no es posible ejercer un voto de censura o destituir un ministro o al gabinete. Por otra parte, los amplios poderes del Presidente se componen de facultades no legislativas y facultades legislativas. Las primeras le permiten al jefe de Estado declarar los estados de sitio o emergencia, nombrar libremente o con acuerdo legislativo a jueces u otras autoridades de control, nombrar embajadores y determinar ascensos de altos cargos militares. Las segundas, le permiten gozar de la iniciativa de ley exclusiva en

${ }^{284}$ Fermandois y GaRCiA (2009) Pp. 282,283 y 297. 
importantes materias para el desarrollo del país, le entregan la atribución de determinar la situación económica del país a través de la ley de presupuesto, cuenta con la posibilidad de ejercer un fuerte veto, permiten aplicar urgencias en cualquier fase del proceso legislativo y, además, permiten contar con poderes proactivos en la promulgación de decretos-leyes. Así, en términos generales, el Ejecutivo ostenta un enérgico poder de agenda legislativa ${ }^{285}$. En consecuencia, tales atribuciones han sustentado aquellas nociones que plantean que el Ejecutivo es más bien un colegislado ${ }^{286}$.

Es por ello que un poder que goza de tantas prerrogativas deber ser cautelado y controlado, a fin de que se cumplan ciertos principios esenciales, se limiten competencias y se respeten las garantías constitucionales ${ }^{287}$. Lo anterior, no resulta sencillo si consideramos lo analizado con anterioridad respecto de los regímenes presidenciales y las especiales características que contemplan, tales como la figura de jefe de Estado y gobernante reunidas en una misma persona y el mandato popular que se delega por un periodo fijo, el que posee pocos y complejos mecanismos jurídicos para hacer destituir a ministros y al Presidente, lo que dificulta la posibilidad de fiscalizarlo y controlarlo. Todos estos elementos se acentúan en un sistema como el chileno, en el cual las funciones del Ejecutivo están aún más robustecidas.

En este orden de ideas, hay quienes han levantado propuestas que en cierto sentido matizan aquella noción reforzada del presidencialismo. En este sentido, se expresan las palabras de Francisco Zúñiga, quien en esta perspectiva plantea que respecto del escenario nacional- la Constitución de 1980 posee un parlamento racionalizado que ejerce funciones tradicionales y que tiene un claro fin legitimador del sistema político, en el que se debe matizar el predominio y preponderancia del poder Ejecutivo ${ }^{288}$. Lo anterior, se propone considerando que el Parlamento sólo reingresa a la arena política y social chilena con la consolidación democrática de los

\footnotetext{
${ }^{285}$ NOLTE (2003) Pp. 47, 48, 51 y 52.

286 Por tanto, es posible colegir como un antecedente inicial que una de las características más relevantes del presidencialismo reforzado chileno la constituyen los amplios poderes que en materia legislativa posee el Ejecutivo, lo que limita fuertemente al Poder Legislativo. Razón por lo cual las relaciones EjecutivoLegislativo se producen en un plano de aparente desigualdad, pero tal como estudiaremos en los capítulos siguientes veremos que al Congreso, por su parte, ha interpretado sus atribuciones de un modo que lo fortalece y se posiciona con otra impronta que altera las relaciones entre poderes y, en consecuencia, a fiscalización parlamentaria.

287 Godor (2003) Pp. 12 y 14.

288 ZÚÑIGA (1998) p.315.
} 
años noventa, luego de largos años de dictadura cívico-militar y ya en medio de un fuerte presidencialismo imperante.

A pesar de que se ha esbozado la idea de un presidencialismo fuerte, hay autores -como Carlos Huneeus y Fabiola Berríos- que estiman que la situación es diversa. En este sentido, los autores trazan un aspecto relevante en esta materia al plantear que el Presidente no es un actor que domina de sobremanera la marcha del régimen político, sino que tiene que entenderse con el Legislativo ${ }^{289}$. Asimismo, Huneeus y Berrios dirán que, en el caso de Chile, el presidencialismo es un formúla política viable que posee los recursos para permitir el desarrollo de una democracia estable, tarea en la cual el Congreso tiene una activa participación debiendo contribuir al éxito de la democratización.

Sin perjuicio de lo anterior, las críticas al sistema presidencial siguen siendo más fuertes. Precisamente, Oscar Godoy plantea que el régimen ultra-presidencialista consagrado por el texto de 1980, aun modificado en el año 2005, no solamente rompe el equilibrio de poderes, sino que establece una hegemonía abrumadora del poder Ejecutivo sobre el Legislativo ${ }^{290}$. Señala el autor que "el poder presidencial penetra en la esfera legislativa sin una contrapartida compensatoria ${ }^{291 " . ~ E s ~ p o r ~ e l l o ~}$ que las facultades fiscalizadoras del Parlamento carecerían de imperium, pues no poseen de efectos jurídicos de alguna naturaleza, salvo que una acción de éstas derive en una acusación constitucional, frente a lo cual el Ejecutivo sigue estando muy protegido. De este modo, el sistema carece del debido equilibrio de poderes, lo que adicionalmente genera una despoderización legislativa, fiscalizadora y representativa del Parlamento ${ }^{292}$. Si a lo anterior agregamos que en la actualidad el Parlamento se ha convertido en una institución deficientemente evaluada por la ciudadanía, esencialmente por la desconfianza existente respecto de la clase política, creemos que una vía de escape a tal problema puede desarrollarse a través de un correcto entendimiento y ejercicio de las funciones parlamentarias, una debida especialización y una prudente publicidad de las mismas, junto con la ejecución de

\footnotetext{
${ }^{289}$ HUNEEUS Y BERRÍOS (2005) Pp. 383 y 384.

290 LINZ et al (1990). p. 26 y 47.

291 GODOY (2003) PP. 20-23.

292 Se debe tener presente que tales afirmaciones las formula el autor el año 2003, en que presenta y publica tal artículo. Con esto queremos hacer presente que las reformas constitucionales del año 2005 vienen a mejorar tales deficiencias jurídicas y por ende podría alterar las conclusiones formuladas.
} 
un fuerte pero responsable poder de fiscalización que la sociedad civil valoraría, el que podría contrarrestar la "mala imagen de la institución"293.

En un Estado débil como el chileno, el presidencialismo reforzado juega un papel central y afecta de sobremanera el rol del Parlamento y el actuar de los partidos políticos. Por su parte, la Carta Fundamental es la que establece las reglas de tal juego, la que define la estructura institucional y la finalidad del Estado y, a su vez, la que instaura las competencias de las instituciones, pudiendo fomentar o no la democracia y la participación al establecer mecanismos de control y limitación. Empero, tal como lo analizaremos en el Capítulo Tercero, nuestra Constitución Política comprende características muy particulares pues su génesis y desarrollo no gozan de un atributo democrático lo cual, en definitiva, dificulta aún más las bases institucionales del régimen de gobierno chileno, influyendo lógicamente en los controles políticos y sus manifestaciones. Todos estos argumentos nos permiten convenir en la necesidad de ingresar científicamente en esta materia del Derecho Constitucional y Político. Por tal motivo, hemos decidido iniciar la investigación que en el presente trabajo se ha intentado materializar.

\section{Consideraciones finales:}

Como es dable percibir en el presente Capítulo, se ha intentado realizar un recorrido más o menos breve de la evolución del poder, su relación con la libertad y cómo ambos elementos se constituyen como los pilares relevantes -mas no exclusivos- en el surgimiento del Estado Constitucional. Se intentó realizar una explicación parcializada respecto de la limitación del poder a través de herramientas jurídicas y políticas, a fin de detallar cómo aquellas limitaciones se configuran como el elemento central del Estado de derecho.

La presente investigación, además, nos situó en la posición y deber de examinar la división de poderes y el surgimiento de las formas de gobierno en su calidad de antecedente y origen del control parlamentario. Sin embargo, una investigación que pretenda aportar a la solución de las necesidades jurídicas actuales no puede

293 HUNEEUS Y BERRÍOS (2005) PP. 364, 366 y 367. Los autores se refieren a la poca confianza que los ciudadanos tienen del Congreso, lo que da como resultado una limitada legitimación de este organismo en el sistema político nacional y, lamentablemente, señalan que el Congreso no ha tomado en cuenta su baja credibilidad a pesar de tener conciencia de ello. 
solamente limitarse a exponer hechos de suma conocidos. Es por ello que realizamos un apartado que tenía como principal finalidad no sólo exponer, sino también analizar las nuevas manifestaciones del control parlamentario en cada régimen de gobierno, con la finalidad de poder sustentar uno de nuestros objetivos: acreditar la existencia del control parlamentario en el régimen presidencial con efectos similares al control realizado en las formas de gobierno parlamentario.

Si bien las razones por las cuales se originó la necesidad de controlar el poder hoy nos pueden resultar lejanas e innecesarias, cabe destacar que, desafortunadamente, la potencial peligrosidad del poder sigue vigente. Como lo expusiéramos en los párrafos iniciales, la capacidad que posee el poder de concentrarse y luego extender sus brazos sin importar qué garantías pueda estar vulnerando, es un lamentable hecho que infatigablemente puede acaecer. No debemos olvidar lo postulado por Hume, quien expresa que "tan grande es la ambición natural de los hombres que nunca se hartan del poder ${ }^{\prime 294}$. Por lo anterior, este tema sigue siendo relevante en cualquier Estado democrático.

En la actualidad, el control político-parlamentario está íntimamente relacionado con la legitimidad de los sistemas, pero aún pueden existir problemas en el equilibrio entre órganos de poder. El riesgo de los excesos y de los consiguientes bloqueos y autobloques de las instituciones, de los procedimientos de descentralización y de la distinción entre controles constitucionales y para-constitucionales, entre tantos otros tantos aspectos, siguen influyendo directamente en las creencias constitucionales de la sociedad política ${ }^{295}$. Por lo anterior, el control parlamentario y sus expresiones configuran una materia que nunca dejará de ser relevante para las sociedades democráticas.

Las sociedades liberales pasadas se forjaron mediante la prevalencia de equilibrios y transacciones entre los jefes del Parlamento, el Poder Ejecutivo y los grupos influyentes, debido fundamentalmente a la factibilidad técnica y a la necesidad de construir un sistema democrático del poder, en el cual ningún ente pudiera crecer solo, sino que el desarrollo de la sociedad fuera una labor mancomunada en beneficio de toda la comunidad. No obstante, como plantea Charles Wright Mills, así como cambian las circunstancias históricas también cambian los significados de la mecánica del poder: no hay nada mágico ni eterno en los frenos

294 HUME (1953) p. 79.

295 VALDÉS (2009) p. 48. 
$y$ equilibrios $^{296}$. Por ende, es necesario conocer su origen para poder descifrar sus manifestaciones presentes, las que evidentemente serán incomparables con los hechos pasados. Sin embargo, en su esencia compartirán ciertos rasgos, los que nos permitirán vislumbrar nuevas manifestaciones de frenos y contrapesos, labor que intentamos cumplir en el presente capítulo.

Luego del estudio y de las observaciones realizadas a lo largo de este Capítulo, es posible señalar que sólo en tiempos de democracia y bajo una sociedad equilibrada en sus relaciones de poder, se abrirá el espacio en el que verdaderamente los frenos podrán ser dirigidos a los gobernantes. Sin embargo, la dispersión del poder político y económico nos coloca en una situación compleja, puesto que toda la estructura política de la sociedad ha cambiado. Tal ha sido el cambio en nuestro país, que en la actualidad todas aquellas faltas graves a la normativa e institucionalidad política, en cuanto a la regulación del financiamiento de la política -como en tantas otras aristasparecen ser expresión precisamente de lamentables hechos de corrupción. Esto permite corroborar aquella descripción que hiciera Rafael Gumucio cuando expuso que la "supuesta probidad" de la cual gozaba y se jactaba Chile, fundada en argumentos históricos y empíricos medibles en encuestas y otros elementos cuantificables, no era más que la construcción de la "mitología del Chile del siglo $X X^{\prime 297}$. Esta situación nos impone un desafío interesante: continuar investigando sobre la limitación del poder a través del derecho, porque su desarrollo será la única forma en la que se pueda restablecer equilibrios y mantener la estabilidad política.

En la actualidad, ninguna sociedad intenta desestabilizar el poder monárquico, sino que -por el contrario- intentan limitar a sus propios gobernantes escogidos democráticamente. Los niveles en los que se expresa el poder económico y político son múltiples, pero a su vez también son variadas las fuentes de control. En efecto, en estos tiempos los controles políticos más efectivos están situados en localidades soberanas intermedias y en grupos de presión que pueden llegar a presentar su punto cúlmine en el Congreso, como lo expresa Wright. En las democracias actuales, la economía y la sociedad como un todo se escapan al control directo de la política centrada en el Estado.

\footnotetext{
296 WRIGHT (1963) p. 250

297 GUMUCIO (2005) p. 3
} 
En nuestros tiempos aún existe un déficit democrático, debido al desplazamiento de las fronteras políticas que se materializan en organismos internacionales y en economías globalizadas de difícil control. Sumadas al escaso rendimiento representativo de los partidos políticos, el control del poder vuelve a verse desafiado, depositándose en la ciudadanía y en los medios de comunicación mecanismos certeros y eficientes en la labor de control del poder ${ }^{298}$.

Es por ello que siempre resulta necesario fortalecer y aspirar a mejorar las instituciones democráticas en pro de la estabilidad y desarrollo de las naciones, y del bienestar de las personas, a través de la búsqueda de nuevas alternativas que nos permitan cumplir dicha finalidad, la cual esperamos poder alcanzar en la presente investigación.

${ }^{298}$ VALLESPÍN (1999) Pp. 4-6 


\section{CAPÍtULO SEGUNDO}

"El Parlamento y la función de control parlamentario" 


\section{"El Parlamento y la función de control parlamentario"}

En el presente Capítulo se realizará una breve descripción de la evolución e importancia del Parlamento, como órgano esencial en los sistemas democráticos. Particularmente, se analizarán en profundidad las funciones de representación, legislación y control. Procuraremos exponer cómo el desarrollo de esta institución y sus funciones nacen como una manifestación y consecuencia de la necesidad de limitar y controlar al poder político absolutista que durante años se impuso en Europa. Por consiguiente, examinaremos las funciones del Parlamento desde una determinada óptica, cual es, determinar de qué forma ellas se configuraron como una especial barrera al abuso del poder, realizando un especial hincapié en la función de control parlamentario, por constituir dicho control el centro neurálgico de esta investigación.

Ciertamente, en el presente Capítulo nos detendremos con especial énfasis en el análisis teórico del control parlamentario, dilucidando a través de las bases doctrinales españolas, italianas y francesas -desde la cuales se ha desarrollado principalmente el estudio de nuestra materia- el concepto, la naturaleza y los efectos de control parlamentario mayormente utilizados. Además, llevaremos a cabo un examen de todos los componentes que, en razón de aquellas tendencias doctrinales, dan cuerpo al control parlamentario, con la finalidad de deslindar y determinar las diversas nociones en torno al mismo, para finalmente arribar al estudio de la responsabilidad política como eje central en la comprensión e interpretación del control. Estudiaremos las mutaciones de la responsabilidad política y sus modernas expresiones.

Nuestro objetivo en el presente Capítulo implica otorgar de manera descriptiva, toda aquella discusión teórico-doctrinal indispensable para el correcto entendimiento de la institución materia de estudio, a fin de poder sentar las bases metodológicas que nos permitan continuar en el capítulo siguiente, y así comprender y exponer con claridad su aplicación concreta en el escenario constitucional y democrático chileno. 


\section{El Parlamento}

\section{a) Elementos históricos $y$ políticos relativos al origen del Parlamento}

Damos inicio al presente apartado señalando que el objetivo de esta etapa investigativa es examinar las funciones del Parlamento $y$, en especial, la de control parlamentario. Su finalidad no es abarcar el extenso desarrollo histórico del órgano parlamentario, como tampoco sus orígenes, por configurar tales materias objetos de investigaciones jurídicas diversas a la nuestra. Sin perjuicio de lo anterior, será totalmente necesario recurrir a algunos antecedentes históricos específicos que nos faciliten la comprensión del desarrollo de las funciones parlamentarias, como una mera herramienta ilustrativa de la cadena política, en la cual el control parlamentario es un eslabón de gran importancia en la labor de limitar y controlar al poder.

Como bien es conocido, la tradición política de la configuración de los parlamentos se remonta a las Cortes medievales y del Antiguo Régimen, propias de Inglaterra y España. Es preciso señalar que las primeras Cortes con representación y participación de los diversos estamentos que componían la sociedad de la época, fueron las Cortes de León de 1188, reunidas por el monarca leonés Alfonso IX.

Por otra parte, el origen etimológico de la voz Parlamento proviene del vocablo francés parlement, de su raíz parler, que significa hablar. La voz parlement significaría entonces "charla o discurso" y, por extensión, se haría aplicable al grupo de representantes que se reúnen a debatir asuntos concretos, de allí la conceptualización del Parlamento. No obstante, cabe destacar que en Francia la voz parlement comienza a ser acogida con frecuencia en el siglo XII, aplicándose indistintamente a grandes reuniones de señores y obispos y a las sesiones de la Corte Real que tenían por finalidad impartir justicia. Por este motivo, debe tenerse en cuenta que el organismo político francés que constituye el antecedente directo para la institución parlamentaria moderna, no es el "Parlamento" en sentido estricto, sino la asamblea conocida bajo el nombre de "Estado Generales" que se configuró definitivamente a inicios del siglo XIV ${ }^{299}$.

299 ZORRO (1965) p. 20. 
El Parlamento es una institución constitucional esencial que ha contribuido en modelar la evolución del Estado y la organización política. Las primeras manifestaciones del Parlamento pueden detectarse desde muy temprano y se han considerado como precedentes del mismo: el ágora de Grecia, los comicios en Roma, los concilios de la peble y evidentemente el Senado. Por otra parte, también es posible detectar rasgos parlamentarios en la curia feudal del Rey. Empero, es en la Baja Edad Media donde se configuran los Parlamentos estamentales, reuniones entre delegados de estamentos sociales determinados como la nobleza y el clero con la Corona, a fin de determinar o más bien negociar ciertas imposiciones y gravámenes de orden económico que afectaban al pueblo. Las asambleas medievales fueron esencialmente cuerpos consultivos o judiciales, que generalmente cumplieron un rol negociador respecto de las necesidades económicas de la monarquía y las cargas fiscales de ciertas clases sociales, por tanto, sus funciones no eran de orden político.

Durante el Medioevo, se desarrolló la noción de una Constitución mixta, aunque se ha planteado que no habría un claro constitucionalismo como límite al poder. Según Fioravanti, el constitucionalismo primigenio sí existía y, ciertamente, tenía por finalidad limitar al poder. Sin embargo, el objetivo de aquella limitación era diversa, ya que en dicha época existía la finalidad de contener a la autoridad a fin de que no afectara privilegios o determinados acuerdos concordados con ciertos estamentos; así, la limitación al poder cumplía un rol de garantía.

Por el contrario, el constitucionalismo moderno pondrá su acento en el principio de igualdad, mediante el cual alterará la distribución del poder y eliminará los privilegios específicos, consagrando derechos individuales y universales respecto de individuos considerados iguales entre sí ${ }^{300}$. Es por ello que el rol del Parlamento también se verá modificado. Dejará de ser un ente negociador y se configurará como un poder que, a su vez, actúe como contrapoder de e la autoridad en defensa de los derechos de las personas individualmente consideradas.

Durante los siglos XI y XII la realidad socio-política de Europa presentaba similares características, por ende, la configuración política del Estado se caracterizaba por un feudalismo decadente y por monarquías nacionales, proceso en el cual surgen los gérmenes del Parlamento, los cuales se esconden en la Edad Media a través de instituciones tales como el Concilium Inglés, los Estados franceses, las

\footnotetext{
${ }^{300}$ FioRAVANTI (2014) p.18.
} 
Cortes españolas y las Dietas de Alemania, Dinamarca y Suecia, y los Preparlamentini en Italia. En tal contexto, y como lo señaláramos, dichos organismos poseían y desarrollaban fundamentalmente una función financiera que en contadas ocasiones podía derivar en alguna influencia política, y más tarde cumplirían un rol esencialmente judicial. Particularmente en Francia, durante el reinado de San Luis, el aparato monárquico se ve fortalecido y nace fruto de aquel proceso el "Parlamento de París", conformado como un tribunal judicial que poseía algunas funciones políticas.

Con el arribo del Absolutismo, el Parlamento prácticamente desaparece. Con la concepción de la soberanía absoluta y el Estado autoridad, no había cabida para un órgano que pudiera emanar de alguna manera del pueblo y que realizara funciones propias del soberano. Esencialmente, las Cortes, los Estado Generales y las Dietas son quienes mayormente se ven asfixiadas con el poder real. Por su parte, los Concilium ingleses continúan una lenta evolución que les permite consolidarse políticamente con anterioridad a las demás naciones. En el Estado liberal, el Parlamento vuelve a renacer gracias a los postulados del liberalismo. La soberanía hasta entonces depositada en los hombros del Rey se traslada a un nuevo sujeto: la nación, y el representante de ese todo ancho y voluble -que era la naciónencontraba en una institución llamada Asamblea o Parlamento su más legítima representación. Este nuevo depositario de la soberanía, permitía dar existencia e identificar su voluntad con la del pueblo ${ }^{301}$.

Esta institución pudo construirse en torno a una nueva concepción esencialmente racional que crea una representación política que lo faculta a actuar como el representante de la nación toda, como representante del soberano con enérgicas facultades para regular el actuar del poder y crear el derecho. En el desarrollo del Estado liberal, el Parlamento fue -sin duda alguna- la institución que mayormente percibió las trasformaciones socio-políticas. Con el nacimiento del gobierno representativo -como régimen de autoridad colectiva que contenía intrínsecamente la idea de gobierno por asamblea-, se fortalece la facultad de debatir y crear la ley. Decanta el Parlamento como la sede natural de dicho régimen ${ }^{302}$.

\footnotetext{
301 RAMIREZ (1995) p.55

302 MANIN (1998) p.227.
} 
Desafortunadamente, la evolución parlamentaria ha sido de todo menos pacífica. En efecto, volverá a verse mermado en la época de la Restauración, oportunidad en la cual las monarquías constitucionales se tomarán la esfera política reivindicando nuevamente la autoridad del Rey y ciertas facultades, restringiendo con ello las funciones que habían sido depositadas en el Parlamento.

En tal contexto, Francisco Javier Conde expone que los teóricos de la Restauración a favor de la soberanía nacional tenían total claridad en reconocer al Parlamento como órgano representativo; era el detonante de la caída de la Monarquía ${ }^{303}$, moción que era de suyo conocida. Por tanto, las posturas que aspiraban preservar a la monarquía como sistema político, dificultaron la consolidación del Parlamento como órgano representativo del pueblo, mermando sus funciones ante un jefe indiscutible, otorgando pequeñas delegaciones legislativas o simplemente reduciéndolos a órganos consultivos nuevamente. Por su parte, la hegemonía -de la cual los estamentos habían gozado en el Antiguo Régimentambién será objeto de modificaciones, en virtud del protagonismo que adquiere la burguesía, produciéndose así otra mutación, toda vez que caminaremos desde una sociedad estamental a una sociedad de clases. La relevancia que adquiere la burguesía en virtud del poder económico desarrollado en las últimas etapas del antiguo régimen, le permite luego de las revoluciones adquirir además el poder político. Todo este proceso viene a decantar en el hecho de que la configuración del Parlamento no era más que la representación única y exclusiva de los intereses de dicha clase. Se afianza con ello el papel de clase dominante de la burguesía en el desarrollo del Estado liberal-capitalista, por consiguiente, el Parlamento no representa la generalidad de los intereses y mucho menos los intereses de un incipiente proletariado ${ }^{304}$.

Sólo en el siglo XIX, y gracias a las revoluciones democráticas, el Parlamento logra asentarse de forma definitiva en las sociedades europeas con un nivel de preponderancia superlativo. Sin embargo, aquel rol protagónico no perdurará en el tiempo. Posteriormente, se dio lugar a Parlamentos democráticos fundados en el sufragio universal, vinculados al surgimiento de partidos políticos de masas, elementos que sin lugar a dudas incidirán en el desarrollo del órgano representativo. Como bien explica García-Pelayo, el Parlamento no fue un órgano democrático desde

\footnotetext{
303 CONDE (1945) p.17.

304 RAMÍREZ (1995) p. 56
} 
sus orígenes. Sólo comienza a configurarse como instrumento de la voluntad popular general cuando deja de ser una herramienta de la burguesía y con la introducción del voto universal. Por ende, con aquel sufragio universal es que finalmente se "democratiza al parlamento" ${ }^{305}$. Tales fenómenos afectarán fuertemente la vida parlamentaria, debiendo sortear nuevas dificultades en su desarrollo, correspondiendo soportar cuestionamientos en cuanto a su rol y funciones.

En el período de entreguerras sufrirá los embistes de las nuevas transformaciones políticas y de los totalitarismos, debiendo sobrellevar una declinación en su protagonismo, una crisis y la racionalización de sus funciones. En este sentido, podemos hacer presente que fue sustentada vigorosamente la hipótesis que plantea la pérdida de preeminencia del Parlamento en relación a los demás órganos del Estado y, en particular, respecto del Ejecutivo. Lo anterior fue fruto de los partidos políticos y sus dinámicas. Así, el Parlamento se encontraría dominado por mezquinos intereses partidarios y con ello deviene la debilidad en el ejercicio de sus funciones.

Tales fueron las críticas al papel del Parlamento que permitieron sostener lo que García Morillo describe como el paso del parlamentarismo salvaje a un parlamentarismo estructurado, proceso mediante el cual se limitan las funciones de dicha institución, cuyos ejemplos más prístinos fueron la III República francesa y la República de Weimar. Según este autor, hasta la fecha el Parlamento se configuraba como un órgano central del sistema democrático representativo, al punto de sostener la soberanía parlamentaria. Empero, la ausencia de organizaciones políticas capaces de alcanzar mayorías estables, la indisciplina interna de la generalidad de las organizaciones políticas y la absoluta supeditación del Ejecutivo al Legislativo, fueron el caldo de cultivo del cuestionamiento hacia el órgano, el que se encontró imposibilitado de reaccionar y ofrecer una respuesta estructurada al Estado de partidos. Las consecuencias de aquello fueron la inestabilidad gubernamental y la polarización del debate político. Para García Morillo, este declive no es producto simplemente del Parlamento en sí mismo, sino que además influyeron otros factores como la fractura social y ciertos acontecimientos políticos y sociales. Pero, a pesar de aquello, los Parlamentos no fueron capaces de dar respuesta a aquellas problemáticas político-sociales. Es por esto último, que la vía de escape a este fenómeno se produjo a través de la racionalización del mismo, como sinónimo de

305 García-Pelayo (1984) Pp. 190 y 191 
estabilidad gubernamental, formalizando y regulando con sumo detalle las funciones parlamentarias y los mecanismos mediante los cuales hacerlas efectivas ${ }^{306}$.

Por otra parte, tales mutaciones políticas y sociales colocarán los acentos en otros elementos. Los cuestionamientos en torno a la configuración política quedarán atrás. Mediante una nueva configuración social e intelectual, se exigirá un Estado que no sólo garantice libertad y orden, sino que además asegure determinadas condiciones de vida que otorguen dignidad al ser humano. Se produjo el paso del Estado liberal al Estado social y con dicho cambio de concepción, se exige la ejecución de una función distributiva estatal, a través de la cual se garanticen la concreción de los derechos. Desde esta perspectiva, la sociedad no sólo participará activamente en la formación de la voluntad general o como recipiente de derechos y deberes, sino que adicionalmente tendrá una especial participación en la configuración de políticas distributivas y de otras prestaciones estatales ${ }^{307}$. En tal escenario, el Ejecutivo emerge como el poder del Estado que reúne las mejores condiciones para dar respuesta a las necesidades sociales. De allí que el gobierno prime por sobre el Legislativo. No obstante, la función deliberativa continuará en manos del Parlamento cumpliendo un importante rol en la representación de la nación.

Durante la República de Weimar y la experiencia parlamentaria alemana, se producirán la más insigne crítica al Parlamento y al régimen parlamentario. Múltiples son las causas en virtud de las cuales fue fuertemente cuestionado el parlamentarismo. La ajenidad del modelo de gobierno respecto de la esencia e identidad nacional alemana, un régimen parlamentario que además no contaba con el apoyo popular suficiente, y la manipulación de las masas a través de la socialdemocracia, entre otros factores, permitieron poner en jaque la legitimidad del Parlamento por fuerzas anti-sistémicas, las que pretendían derribar el régimen pero que detectaron como centro neurálgico del mismo al Parlamento, motivo por el cual dirigen sus dardos contra él. Es así que plantearon -como crítica central- la inestabilidad del gobierno como consecuencia de la debilidad de las mayorías parlamentarias, debido a la ambigüedad de los partidos coligados en el gobierno y la

\footnotetext{
${ }^{306}$ GARCÍA (1991) p. 120.

307 García-Pelayo (1982) p.48.
} 
renuncia de la socialdemocracia a sus responsabilidades, como también la escasa capacidad de los partidos para gestionar la crisis económica ${ }^{308}$.

Por tanto, la crisis interna en Alemania generará diversos efectos políticos, pero en lo que respecta al Parlamento provocará el cuestionamiento del mismo y sus funciones, esencialmente respecto de la función de control. Luego de veinte censuras a los Gabinetes en menos de veinte años de la República de Weimar, surgirá la necesidad de restringir su capacidad de extensión y alcance de la atribuciones. Ejemplo de aquello lo fue la Ley de Bonn y la creación de la censura constructiva como medio de limitación a la inestabilidad gubernamental, toda vez que Schmitt considerará a la censura como un simple mecanismo de obstrucción ${ }^{309}$.

Finalmente, la República de Weimar se cerrará con la dimisión del Gobierno de Müller el 27 de marzo del año 1930, tras serle retirada la confianza al Canciller por su propio partido. Con ello, se marcará políticamente la caída del gabinete de la Gran Coalición, provocando la censura fundamental en la historia de la República de Weimar y el quiebre de la democracia parlamentaria en Alemania. Definitivamente, el Parlamento deja de tener validez como órgano soberano de la democracia y expresión del voto democrático en las urnas, motivo por el cual será apartado de las decisiones políticas, generándose un desplazamiento de legitimidad en la acción política hacia la Presidencia de la República, las soluciones extraparlamentarias tomarán fuerza, y tal como describe Díez, la "/uz de Weimar se extingue

Por consiguiente, si bien el actor principal durante el siglo XIX fue el Parlamento, durante el siglo $X X$ se produce un proceso de desgaste $y$ asume aquel sitial el Gobierno. El desplazamiento del órgano se debe, fundamentalmente, a aquella excesiva limitación en el ejercicio de sus funciones como mecanismo que buscaba tanto evitar los conflictos indeseados, así como organizar la vida parlamentaria y racionalizar la actividad parlamentaria en sus relaciones con el Ejecutivo.

En este orden de ideas, diremos que la característica de la sociedad moderna demandaba una función estatal más eficiente y efectiva. En dicha dirección, la toma de decisiones políticas y la instrumentalización de las mismas fueron fruto de complejos estudios y fueron aplicados con rapidez -estos elementos no los reunía el

\footnotetext{
308 DÍEZ (1998) Pp. 304,305, 309 y 310.

${ }^{309}$ SiMÓN (2015) p.92.

310 DÍEZ (1998) p. 311.
} 
Parlamento-. Por tal motivo, emerge el Ejecutivo como un órgano especializado que facilita la adopción de las decisiones, con la posibilidad de ostentar los medios técnicos y humanos adecuados para la mejor valoración de las políticas nacionales, de esta manera emergía el Estado Social. Según García Morillo, el Ejecutivo se configura como un órgano unitario y capaz de actuar con el máximo de eficacia y rapidez. A este respecto, podemos nombrar como otro elemento trascendental el giro en el monopolio de la función legislativa. La ley será concebida como un instrumento del cual dispone el Gobierno para ejecutar su política pública, por tanto, la producción de la norma pasó a estar a cargo del Gobierno y no del Parlamento ${ }^{311}$. Tal como fue descrito, quien comenzaba a liderar la dirección del desarrollo del Estado es el Gobierno, y por lo mismo, le corresponde a él coordinar el impulso y producción de la ley.

Con una nueva impronta -y legalmente racionalizado y democratizado-, el Parlamento enfrentará el siglo XXI en una posición política diversa y con nuevos desafíos, pero siempre como el pilar fundamental en el desarrollo democrático de los pueblos. Finalmente, el Parlamento ha sido siempre un termómetro político de la evolución del Estado ${ }^{312}$.

Si bien los Parlamentos modernos se expresaron mediante tres referentes y modelos distintos, cuáles fueron los continentales, el estadounidense y el británico $^{313}$, sin lugar a dudas es el proceso político del Reino Unido el que definirá al Parlamento como un órgano equilibrante del Estado con atribuciones políticolegislativas. Como lo adelantáramos, a diferencia de lo ocurrido en España y Francia, Inglaterra supo mantener de forma constante su maquinaria institucional y parlamentaria, lo que le permitió finalmente constituir un sistema parlamentario de gobierno.

Lo anterior, se debe esencialmente, conforme expresa Zorro, a dos causales. La primera de ellas, se configura en virtud de la gran diferencia que se presenta respecto de la capacidad representativa que logró desarrollar el parlamento inglés respecto de sus habitantes y de su territorio, situación que no fue resulta en Francia, Alemania ni tampoco por España, ya que estas naciones nunca lograron incorporar ciertos distritos rurales, mermando con ello su capacidad de representación. Un

\footnotetext{
311 GARCíA (1991) Pp. 122 y 129.

312 HERNÁNDEZ (2003)p.150

313 HERNÁNDEZ (2003) p.153
} 
segundo elemento, fue la actitud adoptada por los pueblos. Los ingleses se adhirieron tenazmente a sus privilegios y derechos como una realidad declarada precedentemente, y se concentraron en ir en búsqueda de más prerrogativas. No obstante, los demás pueblos descuidaron las garantías obtenidas y el monarca detectó allí la posibilidad de arrebatárselos cuando lo creyó necesario, de acuerdo a sus intereses ${ }^{314}$.

La evolución institucional británica parlamentaria enuncia sus primigenias asambleas en los reinados de Enrique III y Eduardo I. Ellas estaban respaldadas en la aprobación de la Carta Magna como primera gran barrera político-jurídica a las arbitrariedades de la Corona, y por tanto, la antigua premisa "lo que afecta a todos, debe ser aprobado por todos" simboliza la lucha que patrocinó Simón de Montfort junto a los barones de la época, actores a quienes tiempo después se les atribuyeran los orígenes de lo que sería la monarquía parlamentaria. Otro elemento relevante en el desarrollo del Parlamento en Reino Unido, fue el surgimiento de una convicción unificadora, que se concretó en la convocatoria o citación de todos los condados y ciudades de Inglaterra a conformar el órgano parlamentario. Ejemplo de aquello, fue el "Parlamento Modelo" como una expresión de inclusión social que posteriormente será la fortaleza de la institución.

Gracias al modelo inglés y la evolutiva limitación de las prerrogativas monárquicas, paulatinamente comienza a debatirse no sólo respecto de los aspectos económicos en los Parlamentos, sino también acerca de elementos políticos y legislativos. Particularmente, es en el reinado de Enrique IV donde se consolidarán ciertas prácticas parlamentarias, tales como la adquisición de la función legislativa -como una prerrogativa esencial del órgano-, así como también el reforzamiento de algunos privilegios parlamentarios. No obstante, el proceso definitivo que condujo al triunfo del Parlamento se produce en el período de los Estuardos, en el cual se sientan las bases más sólidas para la consolidación del régimen parlamentario. Sin embargo, sólo con la Revolución Gloriosa se pone término a cualquier intento absolutista, proceso que -fruto de las demandas sociales y de la disputa constante del pueblo- culmina con la aceptación por parte de Guillermo de Orange del "Agreements of the people" y el "Bill of Rights", logrando institucionalizar un deseo pero también una realidad político-social que el Reino Unido venía experimentando. Con ello, se produce un verdadero equilibrio entre el Parlamento y el monarca,

314 ZORRO (1965) Pp. 31 y 32. 
disminuyéndose poco a poco los poderes del Rey, poderes que se desplazaron lentamente a una institución consuetudinaria: el Gabinete.

Particular importancia posee la declaración escrita de 1689, la cual logró establecer dos parámetros tremendamente relevantes. En primer lugar, recapitula los desaciertos del reinado de Jacobo II, evidenciando las graves faltas a las históricas atribuciones del Parlamento. En este sentido, expone la Declaración de Derechos, que en reiteradas ocasiones se actuó sin el debido consentimiento del órgano representativo, como también se vio violada la libertad de elegir a los miembros del Parlamento. Es por ello que en cierto modo realiza una suerte de amonestación a las conductas pasadas, advirtiendo la gravedad que ello implicaba en relación a la tradición parlamentaria del Reino Unido. En segundo lugar, realiza una reivindicación y afirmación de sus antiguos derechos y libertades, declarando la ilegalidad de aquellas conductas que en algún modo pudieran afectar la autoridad del Parlamento, fijando límites concretos y expresamente descritos a la monarquía. Por tanto, dicha declaración no tiene por finalidad crear derechos individuales, como tampoco establecer nuevas garantías, sino que -por el contrario-, ratifica derechos y atribuciones que provienen desde tiempos pretéritos, los cuales confirman la autoridad del Parlamento, especificando los límites de la Corona e incluso cumpliendo un rol notificador de los mismos, colocando especial énfasis en la violación de los mismos.

Con todo, y como expone Sartori, el Parlamento tal como lo conocemos hoy nació cuando se estableció como contraparte efectiva como un interlocutor efectivo del soberano, funcionando como puente entre la nación y el monarca ${ }^{315}$. Quien va aún más allá respecto al progreso de este órgano, es Kelsen. Para él las luchas de fines de los siglos XVIII y XIX eran fundamentalmente luchas por el parlamentarismo, permitiendo a los representantes del pueblo una participación decisiva en la formación de la voluntad política, terminando con la dictadura de las monarquías absolutas y los privilegios bajo un aspecto de "soberanía popular"316.

Siguiendo lo analizado por Zorro, diremos que el fortalecimiento del Parlamento persiguió fines como la limitación al poder, siendo el freno a los intentos absorbentes del Estado, dando a conocer las opiniones de la nación y prestando invaluables

315 SARTORI (1992) p. 189.

316 KELSEN (2002) Pp. 36 y 39. 
servicios a favor de la libertad ${ }^{317}$. Con todo, sigue siendo pieza clave del régimen democrático, en virtud de la publicidad.

Para la sociedad moderna, y como bien describe García Morillo, es en el Parlamento donde se debaten públicamente los proyectos de ley y aspectos relevantes de las políticas públicas. Sigue siendo el lugar donde el Gobierno debe explicar sus actuaciones y las razones que justifican este actuar, por ende, constituyen el foro político por excelencia, el que es trasladado a la ciudadanía a través de los medios de comunicación, contribuyendo en la formación de la opinión pública. En nuestros tiempos, dice García, la importancia del Parlamento proviene directamente de las especiales características del sistema democrático, compuesto por negociación, conciliación y búsqueda de fórmulas de transacción, las que siguen siendo desarrolladas en el hemiciclo, a pesar de que el hilo conductor lo lleve el Gobierno ${ }^{318}$.

Así, el Parlamento como órgano de representación continúa cumpliendo un rol de bisagra entre la ciudadanía y el Ejecutivo, a pesar de la preeminencia de éste último e independientemente de la existencia de aquel cuestionado vínculo mayoríaGobierno. Creemos que el contexto político de las sociedades modernas -que se desenvuelven en medio de nuevas tecnologías y un amplio acceso a la información-, provoca el surgimiento de exigencias políticas diversas. En esta dirección, se requiere de consensos políticos que legitimen las decisiones político-legislativas más relevantes para el desarrollo del Estado. Es por ello que deberán realizarse esfuerzos tendientes para alcanzar los altos quórums necesarios, para avanzar en determinadas materias de importancia social. Igualmente, se demanda una mayor congruencia en el actuar político y el actuar privado y, finalmente, se exhorta una responsable deliberación en las temáticas tratadas. Por consiguiente, aquellas exigencias sólo podrán ser llevadas a cabo en el seno del Parlamento y estimamos que son las renovadas funciones las que efectivamente se realizan.

En efecto, la evolución institucional del Parlamento se direccionó en la lógica de constituirse como el órgano que fuera contraparte de la Corona, protegiendo los derechos del pueblo y hablando por ellos, permitiendo que surgiera la voluntad general que se expresa a través de la normas jurídica, que otorgará seguridad y certeza jurídica a la población. Es la institución que hace carne los ideales liberales,

317 ZORRO (1965) Pp. 222 y 224.

318 GARCÍA (1991) p. 124. 
pero también los democráticos. Sentadas estas premisas, nos dice Ramírez que el Parlamento "está llamado a ejercer la función de creación normativa y en su seno se desarrolla el democrático juego entre gobierno y oposición; la primera función orientada como la iniciativa del proceso político nacional y la segunda como el necesario control político del gobierno, en estrecha conexión con la opinión pública a veces unida al Parlamento y otras veces peligrosamente alejada"1319.

En definitiva, el Parlamento se configura como el espacio de legitimación de la representación del pueblo, reflejo del debate social. Es un órgano básico en sistemas democráticos representativos, razón por la cual se le atribuyen las funciones de representar, legislar y controlar. Favoreció el nacimiento del régimen parlamentario, y fue la gran barrera política del Estado autoridad como de otros intentos absorbentes. Su importancia es indiscutida, es por ello que ha tomado denominaciones como el "centro democrático del sistema político"320 o "foro principal de las ideas de la Nación $n^{\prime \prime 321}$, asentándose como uno de los pilares fundamentales de lo que fue el Estado liberal y el Estado democrático, razón por la cual, cada sistema político parlamentario o presidencial adoptará la forma y funciones que sean necesarias para su propia estabilidad político-institucional.

Lo cierto es que el Parlamento y sus funciones son elementales en cualquier sistema político democrático -sea éste presidencialista o parlamentario- y la forma en que se ejerzan sus funciones permitirá evaluar la salud de la democracia actual. Tal ha sido la relevancia del Parlamento y sus funciones, que significativas investigaciones han examinado su actuación como agentes de consolidación democrática, o como sujetos de construcción institucional en países que retornan a la democracia luego de procesos dictatoriales. Básicamente, analizan la relevancia de la elección del primer Parlamento en dichos contextos y el juego democrático que en él se ha de desarrollar como elementos determinantes en el futuro político de aquellos países ${ }^{322}$.

\footnotetext{
${ }^{319}$ RAMiREZ (1995) p. 59.

${ }^{320}$ HUBE et alt (2011) p. 28.

321 QuiNZIO (1993) Pp. 313-322.

322 Di PALMA et alt (1988) Pp. 83 y 84. En este sentido, diremos que el autor abarca en profundidad la importancia de los parlamentos en las consolidaciones democráticas de los estados que han sufrido gobiernos dictatoriales es decir, se examina el rol que juegan éstas instituciones en las transiciones democráticas, sumándose a este análisis podemos destacar los trabajos de Guillermo O 'Donnell y Philippe Schmitter. Junto con lo anterior quisiéramos señalar que respecto a este punto hemos de formular una estudio pormenorizado de la situación nacional en esta metería en el capítulo siguiente.
} 


\section{b) El Parlamento y sus funciones: legislar, representar y controlar}

A modo conclusivo, y como resultado de aquellas transformaciones señaladas precedentemente, podemos decir que fundamentalmente al Parlamento -como conjunto orgánico- se le atribuyen tres funciones esenciales: representar, legislar y controlar, todas provenientes de un mismo ideal político y jurídico, limitar al poder mediante mecanismos legales y populares. Debía expresar la voluntad nacional y ser el espacio de debate de las ideas del pueblo, logrando la convergencia de dichas ideas en acuerdos estables y seguros. No obstante, los Parlamentos modernos han expandido su órbita de atribuciones, realizando más labores que las señaladas anteriormente. A modo de ejemplo, traemos a colación lo expuesto por Alex Solís ${ }^{323}$ quien las ha reunido en siete categorías, siendo estas las siguientes: función legislativa, función financiera y presupuestaria; función jurisdiccional, función administrativa, función constituyente, función de dirección política y representación; $y$, finalmente la función de control político o parlamentario.

También podría reconocérsele al Parlamento otras funciones -algunas de ellas propuestas, por ejemplo, por la Ciencia Política-. En este sentido, Huneeus y Berríos $^{324}$ exponen que dicho órgano tiene influencia en el reclutamiento político, pues es el Parlamento la institución desde donde emergen los dirigentes de los partidos políticos y los candidatos presidenciales. Con todo, como describe Tapia la función legislativa, deliberativa y fiscalizadora son las funciones que preservan y aumentan el sentido de la libertad y bienestar que ofrece la democracia ${ }^{325}$. Con posterioridad a su análisis y en cuanto a la función de reclutamiento, los autores detallan el hecho de ser el Parlamento el lugar de origen de las candidaturas a la presidencia de los partidos y de la República.

Desde nuestra perspectiva, cabe hacer la salvedad respecto a la premisa anterior -relativa a la capacidad del Congreso de generar liderazgos nacionales y partidarios-, toda vez que ello ha ido variando paulatinamente, conforme se desarrolla nuestra democracia y sus instituciones. Hoy, varios de estos altos dirigentes de partidos no provienen necesariamente de dicho nicho ${ }^{326}$. Por su parte, los presidenciables a partir del año 2006 no emanan necesariamente del Congreso.

\footnotetext{
323 SOLÍs (1995) P. 31.

324 HUNNEUS Y BERRÍOS (2005) p.368.

325 TAPIA (1960) p.23.

326 Ejemplo de aquello es el caso del PPD y el que fuera su presidente el señor Pepe Auth, quién fue electo presidente de su partido, sin haber sido parlamentario, aunque con posterioridad presentó su candidatura y fue electo diputado por el distrito No 20.
} 
Tal es el caso de las candidaturas de Michelle Bachelet y Soledad Alvear, ambas militantes concertacionistas, las cuales provenían del gabinete presidencial del expresidente Ricardo Lagos (en las carteras de Defensa y Relaciones Exteriores, respectivamente). Lo anterior se repite en el año 2013, oportunidad en que las figuras más prominentes como candidatos presidenciales en la coalición gobernante (Alianza por Chile) liderada por el presidente Sebastián Piñera, fueron los señores Andrés Allamand (Ministro de Defensa) y Laurence Golborne (Ministro de Obras Públicas).

Particularmente, tanto en el caso de Bachelet como Golborne, ninguno ha ejercido cargo parlamentario en su trayectoria política. No obstante ello, fueron los personajes públicos que gozaban de mayor apoyo ciudadano. Lo anterior, descartaría lo sostenido por Hunneeus y Berríos, quienes postulaban que en un sistema presidencialista la carrera política no se consolida en el poder Ejecutivo, sino que en el Congreso. Como hemos descrito, la coyuntura política, la estrategia de los partidos políticos y los contextos nacionales han alterado aquella máxima y en la actualidad un liderazgo podría emerger desde diversos espacios de poder y no únicamente desde un solo origen.

En un Estado de derecho, el Parlamento es una institución necesaria. Para Johann Allesch, es la clave del sistema político en una democracia participativa y se constituye como la organización representativa de los ciudadanos y de las fuerzas políticas vigentes. Es un colaborador del Poder Ejecutivo en la tarea de conducir el Estado; canaliza los intereses públicos, los cuales gestionará mediante la función legislativa; posee procedimientos deliberantes y hará partícipe a las minorías, mediante procesos abiertos y públicos, con participación de los grupos de interés, permitiendo que esta institución posea un rol protagónico y decisivo en la actividad política. Es por ello que para el autor un Congreso con aquellas características constituye un factor equilibrante de poderes con los contrapesos esenciales para una democracia ${ }^{327}$. No obstante, la práctica parlamentaria puede distar bastante de aquella declaración ideal respecto del funcionamiento de dicha institución y de las manifestaciones de cada función en particular. Por lo mismo, a continuación procedemos a analizar estas facultades y sus posibles dificultades.

${ }^{327}$ AlLesCh (2003) Pp. 30 y 31. 


\section{b.1. La función de representación como fundamento del control}

En el presente apartado, realizaremos un detallado examen relativo a la representación política como soporte esencial en el origen del control parlamentario. Abordaremos los fundamentos históricos, en razón de los cuales emerge como núcleo base. Además, nos haremos cargo del complejo escenario político que experimentan las actuales democracias modernas, sustentadas básicamente en la información, medios de comunicación y nuevas tecnologías. Analizaremos cómo la representación en tiempos de desafección y crisis en la representatividad política, continúa cumpliendo un rol muy determinante en la configuración del sistema político, en la división de poderes y en la construcción de los equilibrios.

\section{b.1.1. Antecedentes históricos}

La representación política fue la alternativa más certera que el pensamiento político liberal y revolucionario detectara para salir de la crisis que el Antiguo Régimen había dejado en gran parte de Europa. Con la Declaración de Ios Derechos del Hombre y su reconocimiento de libres e iguales en dignidad y derecho, se acusó la importancia de considerar al consentimiento, la participación y -fundamentalmente- la voluntad política del pueblo o la nación como elementos fundantes de las relaciones de poder entre Estado y Gobierno. Desde aquel momento, ya no fue posible imponer autoridades de carácter absoluto ni gobernantes fundados en razones hereditarias. Desde la llegada de los procesos revolucionarios y del liberalismo, era imprescindible contar con el consentimiento del pueblo para dar nacimiento a las estructuras de poder. Se produce así un quiebre político, por medio del cual no se aceptará la dominación política. No se aceptará más al Estado autoridad y se da nacimiento con ello a lo que denomináramos en el capítulo precedente los límites políticos al poder.

Es menester recordar que en la época del pacto social, gracias a los postulados de Jean Bodin y Thomas Hobbes, se establece que sólo por la ratificación de un contrato nace el soberano que detenta el poder y ordena la sociedad, el cual no era susceptible de división. Junto con ello, y una vez delegado por el pueblo en una autoridad, ésta gozaba de plena libertad de acción. Así, estos autores reúnen en el concepto de poder soberano todas las atribuciones en las manos de un solo gran detentador, quien no las compartiría con ningún otro órgano. Esta perspectiva 
ciertamente limitaba la posibilidad de instaurar la representación política, pero comenzaría a establecer ciertos límites a la autoridad, principalmente en la creación de la norma.

Según Bodin, la soberanía sólo se podía radicar en un monarca absoluto, el que recibía el poder directamente de Dios mediante un acto especial. La autoridad política representaba un orden racional conforme a la voluntad divina y, por tal motivo, de existir personas con alguna función de carácter pública-representativa, debían ser previamente determinadas y no configuraban más que lugartenientes, o simples depositarios que no poseían soberanía alguna y que debían rendir cuentas de su gestión ${ }^{328}$. Para el autor, la soberanía es el poder absoluto e indivisible que conlleva la facultad de hacer la ley sin el consentimiento de los súbditos. Es perpetúa, por tanto está por sobre el soberano. La plantea como un imperativo categórico de la existencia y de la unidad del Estado. Sin embargo, ella se encuentra limitada por las leyes de Dios y de la naturaleza e incluso por las leyes comunes a todos los pueblos.

Por consiguiente, subordinaba el carácter absoluto de la soberanía a un derecho superior, el que puede ser el bien común u otro valor fijado como fin del Estado. Por ello, el soberano no puede violar el derecho natural. Empero, lo que no es posible es que la soberanía fuera compartida. De acuerdo al pensamiento de Bodin, los Estados Generales no pueden tener participación en la soberanía, dado que en ella no pueden participar otros órganos y mucho menos puede ser controlada por otros poderes. En tal escenario, la noción de contrapesos entre poderes queda absolutamente descartada. En términos generales, el mencionado autor fue un defensor de la monarquía absoluta por la utilidad que ello implicaba, para el momento histórico en el que se desarrollaba, oportunidad en la que el objetivo central era la unificación nacional ${ }^{329}$.

Desde otra perspectiva, Hobbes mediante una filosofía racionalista logrará liberar al hombre de sus fantasmas y miedos constituyendo una manifestación de ateísmo político. Si bien defenderá el poder absoluto, la monarquía planteada por Hobbes es una monarquía social. El poder ya no tendrá por finalidad el derecho divino de los reyes, sino que tendrá por objetivo el interés de los individuos, mediante la conservación y la paz. En la política de Hobbes, el individuo alcanza un

328 BOdin (1985) Pp. 47, 48 y 49.

329 TOUCHARD (1981) Pp. 228-230. 
pleno desenvolvimiento en el Estado autoritario porque sólo en él es posible encontrar la felicidad, el placer y el bienestar. A través de lo estipulado en el Leviatán, el contrato social no se realiza entre soberano y súbditos, sino que entre individuos que deciden entregarse un soberano, mediante el cual se funda la soberanía.

En tal contexto, Thomas Hobbes critica la separación de poderes sosteniendo que la soberanía es absoluta y que el soberano no debía tener ningún límite exterior al poder, porque es soberanamente racional y no tiene el poder de hacer lo que quiera. No obstante, la soberanía tiene un límite interior y es la razón ${ }^{330}$. Por otra parte, en el hipotético escenario de existir representación del cuerpo político en asambleas u otros órganos, estas facultades serían limitadas y las funciones debían estar detalladas en cartas explícitas o en leyes ${ }^{331}$. Dicha concepción de la representación ha sido denominada por Hanna Pitkin como "un concepto vacío de representación ${ }^{\prime \prime 332}$, debido a que el soberano de Hobbes no tiene límites ni deberes para con sus súbditos. El pueblo sólo cumple un rol de autorización, pero luego de aquello pierde total relevancia e influencia. No puede exigir el cumplimiento de ninguna función.

A juicio de la autora, la explicación hobbesiana implicaba que los hombres al suscribir el contrato autorizaban todas las acciones futuras del único detentador del poder, reflejando con ello el probable temor que le provocaba a Hobbes la anarquía o más bien lo que él denominó el estado de naturaleza. Tal interpretación no permite ningún tipo de control por parte del pueblo, pues una vez entregada la "autorización" toda la gestión del poder quedaba a exclusivo criterio del único soberano, sin contar con la posibilidad de cuestionar si aquellas acciones eran o no beneficiosas para la sociedad. Sin embargo, es destacable que -a pesar de aquella debilidad en la representación- con Hobbes se comienza a poner fin a la idea de Constitución mixta de la Edad Media y empieza a tomar fuerza la Constitución de los modernos.

La débil e inexistente representación estrictamente limitada por las labores omnipotentes de un único soberano -sustentado en leyes naturales, herencia consanguínea y documentos imperativos-, fue objeto de grandes variaciones con el arribo de los postulados del liberalismo, antecedentes que hemos analizado en

\footnotetext{
330 TOUCHARD (1981) p. 259-262.

${ }^{331}$ Hobbes (1989) Pp.185 y 186.

332 PITKIN (1985) p. 35.
} 
profundidad en el capítulo anterior. Empero, hemos de recordar que en la época de las revoluciones deberán enfrentarse fuertes desigualdades sociales creadas por las monarquías, organización estatal que si bien había organizado el poder y las fuerzas sociales, subyugaron al pueblo posicionándolo en una situación de total olvido -sin protecciones jurídicas ni sociales-, provocando con ello un profundo cuestionamiento relativo al domicilio del poder y las relaciones de poder, lo que dio lugar a uno de los debates trascendentales de los siglos XVII y XVIII relativo a la relación entre gobernantes y gobernados. Este proceso dejará como resultado la Declaración de Derechos del Hombre y el Ciudadano, la conceptualización de la soberanía de la nación y del pueblo, todos argumentos definitivos para el empoderamiento de la burguesía y para el surgimiento del gobierno representativo y la representación política, teniendo como finalidad -al igual que todo el desarrollo constitucional de la época- limitar al poder, cualquiera fuera su origen, a través de mecanismos legales pero también populares.

En este sentido, las bases doctrinarias se esbozaron en un nuevo y transgresor tenor. Construir el Estado civil implicaba necesariamente desarrollar otro pacto social, el que fuera expuesto de forma brillante en tres etapas por Sieyès: la primera etapa, era la formación de la nación; la segunda, la formación de una voluntad común que pertenece al pueblo, la que -por impedimentos lógicos- no puede ser manifestada por ellos mismos, razón por la cual confían su ejercicio a un grupo de personas determinado, sin perder nunca la propiedad de la misma pues la soberanía gracias a Sieyès es inalienable y sólo cede la parte necesaria estableciendo límites en su ejecución; y la tercera etapa, se configura como consecuencia de una voluntad común representativa, en la cual, los delegados sólo actuarán como mandantes de quienes realmente la poseen ${ }^{333}$.

En virtud de aquella nueva arquitectura política, se modifican los paradigmas filosóficos de la misma, promoviendo una serie de transformaciones que implicaban dejar atrás, por ejemplo, el mandato imperativo y pasar a un mandato representativo. Lo más importante fue que aquella interpretación significó depositar en la nación el poder soberano, como barrera inquebrantable ante los abusos del poder absoluto. La noción de representación de Sieyès descarta la participación directa de todos los individuos que componen la sociedad, porque la libertad efectiva

${ }^{333}$ SIEYÈs (1988) Pp. 103 y 104. 
no consiste en ello, sino que constituye la posibilidad de desarrollarse social y económicamente sin la injerencia del Estado.

En tal escenario, a través de la representación política emanaba una unificación de voluntades que regiría los destinos de la nación. De este modo, la asamblea de diputados expresaba la voluntad de la nación y, por ello, un diputado representaba a la nación toda y no a un cuerpo electoral concreto, lo que implicaba que debía gozar de la necesaria independencia para ello. Así, los Parlamentos representaban los intereses generales de una nación entera. En ese escenario, la representación sería una función-poder que ha sido encomendada y que ha de construir una voluntad 334 .

El Gobierno representativo de Sieyès fomentaba la participación política y el protagonismo de las asambleas como mecanismo de limitación política de la autoridad. Allí había un poder que debía contrapesar y limitar, modificando la antigua triangulación en el ejercicio del poder que estaba compuesta por la autoridad ejecutiva, el Parlamento y el pueblo. En dicha perspectiva, la nación era representada ante el poder. Con la representación liberal, aquella relación triangular es alterada y el Parlamento se configura como un poder en sí mismo que no actúa frente a una autoridad, puesto que él configuraba la autoridad. En este escenario, la nación ya no cuenta con un representante que actúe por ella ante otro, puesto que ahora el Parlamento se convierte en poder-autoridad. Por tanto, la dialéctica es modificada a tal punto que la arquitectura del sistema político clásico no volverá a tomar aquella forma. Los contrapoderes se diluyen y los equilibrios constitucionales se van difuminando.

Punto aparte fueron los postulados de Rousseau, quien desde la vereda de la soberanía popular y la democracia directa formuló una negación aparentemente absoluta de la representación. No la concibe en la función de legislar pero sí en la función de ejecutar. Para el ginebrino, el soberano es uno y es el pueblo, el cual no puede ser dividido ni destruido. Una vez reunido el pueblo no puede haber otra jurisdicción; así lo explica Rousseau "donde se encuentra el representado en plenitud no puede haber representante", súbdito y soberano es una correlación idéntica cuya idea se reúne en un solo término: ciudadano ${ }^{335}$.

334 MAÍZ (1991) Pp. 76-78.

335 ROUSSEAU (1980) Pp. 117 y 118. 
En definitiva, para Rousseau la voluntad general es ella misma o no es nadie. Para los casos en que se establece la representación, ésta solamente implica una simple delegación. Los diputados nunca podrán tomar decisiones definitivas, siempre será necesario que el pueblo las ratifique para darles validez. Pero como ya lo advertíamos anteriormente, a pesar de no admitir que el órgano creador de las leyes pueda ser representado, sí admite para el Ejecutivo representantes que deberán ser seleccionados por el pueblo, y justifica el autor tal apreciación aludiendo a que ellos solamente se limitarán a aplicar o ejecutar la voluntad general, la cual ya se encontraría expresada en plenitud ${ }^{336}$.

Como es dable concluir, es la construcción doctrinal francesa la que permitió dar nacimiento a la representación política como base de gobiernos representativos que gran parte de los estados fueron adoptando, claro que con las lógicas dificultades propias de la época ${ }^{337}$. La representación política como tal, adquirió manifestación normativa concreta en la Declaración de Derechos de 1789 y fundamentalmente en la Constitución francesa del año 1791. Ambos cuerpos normativos consagran expresamente que la soberanía reside en la nación y que es ella únicamente quien delega sus poderes en una asamblea de representantes. En efecto, la Constitución francesa de 1791 así lo contempla en el Título III artículo 2 al señalar que: "La Nación, de quien emana todos los poderes, no puede ejercerlos más

\footnotetext{
${ }^{336}$ Lo anterior, si bien es contradictorio no deja de ser otra de las importantes manifestaciones del pensamiento de quien quebró el esquema tradicional de la comprensión del poder, postulando la soberanía popular conformada por un mandato imperativo y la revocación de cargos. Lo relevante es que gracias al contrato social el poder se radica en el pueblo, otro argumento de fuerza que permite dar nacimiento a la representación política. Rousseau dio lugar a las más duras sátiras sin poder consolidar su anhelada democracia directa, sin embargo deja al mandato imperativo entre otros aspectos para siempre en la retina de los defensores de la democracia directa, quienes en cada período de "crisis" de la representación vuelven a alzar sus argumentos como alternativa de solución.

${ }^{337}$ Pero como toda elaboración política trasgresora fue objeto de diatribas. Así, Duguit y Carre de Malberg son claros exponentes de aquellos cuestionamientos. El primero, declara la inexactitud de la utilización del término "representación política" y el profundo error de la teoría francesa, en cuanto a crear dos sujetos colectivos ficticios representantes y representados, creando con ello además un nexo un vínculo jurídico subjetivo entre ambos que tuvo como consecuencia que se tendiera a encuadrar tal representación en el mandato civil. A criterio de Duguit, debió de haberse creado una relación jurídica objetiva basada sobre el análisis de hechos, se habría comprendido que lo existente realmente es un hecho real y patente de solidaridad, de interdependencia entre representantes y representados que se configura a través de dos factores de solidaridad de similitud, necesidades comunes y aspiraciones idénticas y división del trabajo, los representados ponen la energía y los representantes las funciones. En opinión de Carre de Malberg, los diputados son elegidos pero no comisario, para el autor no hay un mandato hay una relación de confianza, refutando la construcción misma del régimen representativo, expuso que no existe una verdadera representación, toda vez que no hay subordinación entre los sujetos, no existe un vínculo, no existen voluntades, la voluntad de los ciudadanos es inexistente y sólo existirá cuando los representantes la creen, los representantes no pueden querer por los ciudadanos pues son los ciudadanos quienes querrán a través de ellos, no se podrá ejercer responsabilidades ni anular los actos de los representantes, la nación es un ente abstracto o sea es la nada y la nada no se puede representar. Todos estos argumentos le permiten concluir que lo que realmente existe no es una representación, sino más bien un "sistema de organización de la voluntad y de la persona nacional". Duguit (1926) p.121 y CARRE DE MALBERG (1948) Pp. 941 y 942.
} 
que por delegación. La Constitución francesa es representativa: los representantes son el Cuerpo Legislativo y el Rey". En este sentido, cabe destacar que -como bien describe Carre de Malberg- lo que fundó la Revolución Francesa, en virtud del principio de soberanía nacional, es precisamente el régimen representativo ${ }^{338}$.

Siguiendo a Garrorena, diremos que la piedra angular de la ideología burguesa fue precisamente la soberanía nacional, técnica que como ninguna otra permitió legitimar al poder, haciéndolo parecer un mero "mandatario". Esta soberanía nacional es la que actúa y gobierna como nación, lo que además justifica el surgimiento de un mandato nacional, general, libre y ausente de instrucciones ${ }^{339}$. Por ende, todo hombre debía autorizar y consentir en la configuración del poder, dotándolo de legitimidad y validando su actuar.

Con el arribo de las teorías liberales y esencialmente de la mano de la soberanía nacional, nace a la vida política y jurídica la representación política de mandato libre como perfecto mecanismo que amalgamaba dos conceptos que emergen gracias a dicha corriente: nación e interés general.

Cabe destacar que, a través de la representación política, se logra aunar la nueva organización social creada y se consigue formalizar sus tres creaciones políticas: la nación, la voluntad y el interés general. Como explica la profesora María Josefa Rubio Lara, la representación fue concebida como un mecanismo de integración política de los diversos intereses sociales existentes en dicha época. Surge de la necesidad de superar la pluralidad de intereses en un sólo gran interés nacional, cumpliendo dos funciones. Por un lado, obtener el consentimiento de los nacionales $y$, por otro lado, legitimar el poder político, mecanismo integrador que en todos los tiempos -dice Rubio- seguirá buscando la misma finalidad: ser un canalizador de los intereses sociales. El mandato representativo proporciona los argumentos para reconstruir constantemente la unidad del poder y superar la pluralidad de intereses incluso en nuestros tiempos ${ }^{340}$.

En este mismo sentido se encuentran los postulados de Manin, quien sostiene que el gobierno representativo se forja en unos principios fundamentales ${ }^{341}$,

\footnotetext{
338 CARRE DE MALBERG (1948) p. 913.

339 GARRORENA (1991) Pp. 37, 38 y 39.

340 RUBIO (2000) Pp. 115 y 116.

${ }^{341}$ MANIN (1998) p. 17. Los cuatros principios son los siguientes: 1 .- elecciones regulares, 2.- toma de decisiones con independencia de los deseos de los gobernados, 3.- libertad de los gobernados en expresar
} 
principios que según el autor siguen vigentes en la actualidad, a pesar de las diversas formas democráticas adoptadas por los Estados y de las crisis de la institución.

En efecto, la representación política se configura a través de principios fundamentales, entre ellos las elecciones y el mandato libre o mandato representativo. A pesar de que los pensadores clásicos definieron -de manera inmediata- a la elección como el método idóneo para establecer un gobierno representativo, no es menos cierto que dicho mecanismo no garantizó del todo la anhelada igualdad, sino hasta la llegada del sufragio universal ${ }^{342}$. No obstante, se instaura el sistema de gobierno electo bajo la imperiosa necesidad de eliminar el principio hereditario de ocupación de cargos y de legitimar a los gobernantes. Se optó por un método de selección por sobre un verdadero resultado representativo ${ }^{343}$. Pero, sin lugar a dudas, el elemento que permitió establecer una rotunda diferencia con la representación medieval y dio forma al gobierno representativo, fue la restructuración del mandato del vínculo político entre el órgano y la sociedad.

El mandato -como tal- se desarrolló desde dos vertientes antagónicas: por un lado, el mandato imperativo y por otro, el mandato representativo. No es menester insistir en conceptos que reiteradamente han sido analizados por la doctrina respecto al mandato. Por ello, sólo señalaremos que en el mandato de corte iusprivatista, los representantes recibían un título expreso también denominado cuaderno de instrucciones o cuadernos de agravio (cahiers d'instructions), que contenían específicamente las materias a resolver y las funciones a desarrollar. Por ende, el no cumplimiento de dichas instrucciones contemplaba la posibilidad de revocación de sus emisarios y sus mandatos. Producto de la soberanía nacional, se configura un

sus opiniones y deseos sin control de la autoridad y, finalmente 4.- las decisiones públicas se someten a un proceso de debate.

342 Escapa a las posibilidades de este apartado examinar la evolución del voto y sus dificultades. Pero como bien es sabido, en sus orígenes se limitaba la posibilidad tanto de acceder al poder como el derecho a elegir. Variadas fueron las restricciones diseñadas para limitar la participación popular en la selección de sus gobernantes. La posesión de propiedades, saber leer y escribir entre otras fueron algunos requisitos establecidos en aquella época para acceder a un escaño parlamentario o poder tener derecho a voto. En definitiva, durante el Estado liberal fue una prerrogativa sólo de la burguesía, ya que era considerada una función más no un derecho, que ciertamente, estaba contemplado de tal modo porque respondía a las cualidades y condiciones de la burguesía, la cual gozaba de las influencias necesarias para mantener ese orden político. Posteriormente, con el establecimiento del sufragio universal, la representación política cumple un rol más integrador y democratizador de las instituciones. El sufragio será considerado un derecho que no está supeditado a condiciones o cualidades especiales, sino que simplemente el derecho a elegir, se comprende la dimensión pasiva y activa del mismo.

343 MANIN (1998) Pp. 20 y 22. 
mandato de carácter representativo. No existen instrucciones ni ordenes específicas, el representante actúa por un bien público superior de forma libre e independiente. La duración del mandato será fija y no dependerá de voluntades ${ }^{344}$.

Resulta imperante referirse en este punto -sucintamente- a algunos fundamentos del afamado "Speech to Electors of Bristol" del año 1774, de acuerdo al cual se expone claramente lo que sería el nuevo mandato libre. Burke expuso con fuerza sus ideas respecto a la necesidad de la independencia del parlamentario en su gestión, junto a la total libertad de la que debía gozar al momento de actuar en su calidad de tal, y la imposibilidad de quedar ligado a promesas de carácter obligatorias con sus electores. Burke, apoyado en los principios liberales, declaraba ser elegido para representar a una ciudad o a un país, no a electores específica y exclusivamente, reconociendo la necesidad de que mediara entre ellos una fluida comunicación para conocer sus deseos, opiniones y asuntos. Reclama la autonomía del representante, quien debe tener su propia opinión imparcial, un juicio moderado y una conciencia ilustrada, fundamentalmente debido a que el autor reconoce al Gobierno no como una cuestión de voluntad sino de razón y juicio ${ }^{345}$.

De acuerdo a las mutaciones del mandato representativo y de las elecciones, el gobierno representativo toma cuerpo y comienza a desarrollarse como mecanismo que garantizaba la participación del pueblo en el poder. A pesar de aquello, no estuvo exento de cuestionamientos, y uno de ellos lo formula Hans Kelsen cuando expone que la representación política es una simple "ficción" que se crea para legalizar o justificar al Parlamento bajo un aspecto de soberanía nacional, contribuyendo a sustentar argumentos tales como la democracia. Para Kelsen, si bien esta ficción no ha logrado cumplir su cometido justificador, por lo menos ha cumplido otro rol. Ha mantenido el movimiento político de los siglos XIX y XX, presionado por el ideal democrático y por aquella imagen de que el pueblo se determina así mismo en el Parlamento. En palabras de Kelsen, la representación política impidió una hipertrofia excesiva de la idea de democracia en la realidad política ${ }^{346}$, pero que en realidad nunca existió una relación representativa.

En esta misma dirección, según Garrorena, en la época del Estado liberal fue fácil hacer creer en la existencia de una supuesta relación entre representante y

\footnotetext{
344 MARTÍNez (1994) Pp.113, 114 y 115.

345 BURKE (1942) p.312.

346 KeLSEN (2002) Pp. 38 y 39.
} 
representado, debido a la presencia de factores como una población reducida, la aplicación de sistemas mayoritarios y candidaturas personales, la no consolidación de los partidos políticos y la presencia de un Estado abstencionista, todos los que contribuyeron a hacer posible el mantenimiento de una apariencia de un cierto esquema relacional $^{347}$. Por consiguiente, la representación política nace como una barrera al poder pero con importantes debilidades que el tiempo y la evolución teórico-política irán supliendo. Hemos de continuar analizando la evolución de la representación política en su calidad de límite al poder, para luego comprender los embistes que ha ido sorteando hasta arribar a nuestros días.

\section{b.1.2. La representación como fundamento del control parlamentario}

Siguiendo el clásico y conocido fundamento doctrinal, sostenemos que la representación política, al ser el principio que autoriza a los representantes del pueblo -en su calidad de representantes del soberano- a canalizar sus necesidades e intereses sociales, y a crear la ley como expresión de la voluntad general y mecanismo de seguridad política y jurídica, adicionalmente le faculta e impone la obligación de velar por la defensa y primacía de aquella voluntad soberana. Así también le impone el deber de velar por el irrestricto respeto del pueblo y sus garantías mínimas declaradas en los derechos humanos, todas funciones que a su vez le otorgan el derecho-facultad de exigir y verificar que toda actuación del Gobierno tenga íntima relación con aquellos lineamientos establecidos por el mismo pueblo como principales y esenciales, pudiendo -en el ejercicio de la misma función representativa- solicitar toda aquella información que estime pertinente, a fin de conocer cabalmente la acción del ejecutivo. Lo que se pretende es cumplir el rol garante en la defensa de las posibles arbitrariedades, actividad que le es encomendada por el soberano a sus representantes.

Conforme a la precedente descripción, hemos de plantear en este apartado como idea esencial el hecho de que la representación política, como institución, es el fundamento del control parlamentario en sistemas parlamentarios, pero también en sistemas presidenciales. Admitimos que dicha afirmación no comprende una labor sencilla de argumentar, toda vez que conforme a la relación de confianza que da origen al régimen parlamentario, en dicho sistema esta afirmación se da

347 GARRORENA (1991) p.47. 
naturalmente y no comprende un antecedente novedoso. En los parlamentarismos, en virtud de aquel vínculo de existencia y confianza que nace entre Parlamento y Gobierno, se obliga al depositario de la confianza a velar porque sus mandatarios cumplan su cometido correctamente, y, por tanto, ejercerán un constante control de sus actividades. Sin embargo, sostener igual argumento en un régimen presidencial no es una labor menor, principalmente si consideramos que en dichos sistemas existe una doble legitimación (Ejecutivo y el Legislativo son escogidos popularmente). En consecuencia, la razón del control no puede sostenerse en el depósito de la voluntad soberana en órgano, porque el otro de cierta forma también la posee, dado que ambos gozan de la misma legitimidad.

No obstante lo anterior, intentaremos esgrimir los argumentos pertinentes que permitan sostener nuestra hipótesis y así poder corroborar que la representación es el motor indiscutido en cuanto al origen del control parlamentario en sistemas presidenciales como el nuestro. La representación no sólo da origen al poder, sino que también debe legitimar el ejercicio del mismo. En el caso del presidencialismo, el Parlamento continúa en nuestros tiempos representando a una pluralidad de tendencias y opciones sociales-políticas, y mediante sus deliberaciones alcanzará una unificación de voluntades que cubrirá un amplio espectro. Adicionalmente, y a través de la agenda legislativa, velará por la mayor correspondencia posible entre las propuestas del Ejecutivo y el interés nacional. Por su parte, si bien la Presidencia de la República es igualmente elegida democráticamente, ella representa un interés más restringido, sea este proveniente de un partido político en particular o de un conglomerado. Por ende, el programa de gobierno es propio de un sector político y no de toda la universalidad de sensibilidades políticas, a pesar de gozar de una mayoría electoral. Así, el Parlamento continúa configurando una garantía política de representación y equilibrio, que tendrá por objetivo central asegurar que el pueblo sea especialmente representado.

Si consideramos que en tiempos del Estado liberal el Parlamento era la única institución representativa de la nación soberana, como único espacio de participación de los ciudadanos, se refuerza la reflexión que permite suponer que en su calidad de órgano representativo de la nación era él quien ostentaba el derecho de conocer el estado y avance de las políticas llevadas a cabo por el Gobierno, gozando de la facultad de poder exigir la información necesaria para poder evaluar si ellas se 
condicen o no con la voluntad del pueblo ${ }^{348}$. Por consiguiente, desde una perspectiva histórica, el Parlamento se constituye como el único órgano representativo de los intereses sociales y protector de sus garantías mínimas. En definitiva, entendido que son elegidos por el pueblo y que encarnan su voluntad, deben además vigilar la dirección escogida por la política del Estado, a fin de mantenerla en línea con la querida por la colectividad nacional ${ }^{349}$.

Como bien explica Martínez, el control político que debe realizar el Parlamento se justifica en cuanto supremo detentador del poder, en representación del pueblo titular de la soberanía ${ }^{350}$. Con la misión de hacer ejecutar la voluntad soberana, el órgano de representación debe asimismo responder a dicho interés general nacional. El Parlamento, como representante del soberano, podría exigir una rendición de cuentas por parte del Ejecutivo a fin de evaluar el desempeño y su conformidad con las instrucciones del soberano. Ahora bien, tal situación se expresa perfectamente en la época del Estado liberal y, posteriormente, en un Estado democrático que se organice mediante un sistema parlamentario de gobierno -forma de gobierno que se construye mediante una relación de confianza en la cual el Gobierno es un delegado del Parlamento- para ejecutar una política de Estado determinada previamente por la mayoría electa. En consecuencia, el fundamento de considerar a la representación política como fundamento del control parlamentario, goza de total validez en aquel sistema de organización y no amerita mayor abundamiento.

Para mayor comprensión, hemos de traer a colación las explicaciones de Maurice Hauriou, quien argumenta que la relación entre pueblo, Parlamento y Ejecutivo se expresaba mediante un diálogo al cual denomina proceso de "justificación pública" de la representación, proceso que otros autores han denominado como "relación triangular", a través de la cual el pueblo dialoga con el Parlamento expresando sus intereses, y éste -en su rol de representante del mismodialoga a su vez con el Ejecutivo actuando como portavoz y defensor de sus mandantes, orientando de esta manera las acciones futuras del Gobierno. La premisa desde la cual el francés construye tal concepción, nace desde el pensamiento de considerar a los representantes como mediadores. El carácter de ser representantes del pueblo es lo que le impone a estos "escogidos", en primer lugar, el deber de ser un mediador entre el poder y la ciudadanía, y en segundo lugar, el deber de

\footnotetext{
348 ARAGÓn (1998) p.275.

349 MONTERO Y GARCÍA (1984) p. 19.

350 MARTÍNEZ (2000) p.101.
} 
controlar al poder a fin de que no existan abusos de autoridad o extralimitaciones en el actuar de los órganos. Debe custodiar que se mantenga el justo equilibrio en la división de poderes.

Por ello, se constituyen como una especie de garantes de la sociedad cuyo objetivo es prevenir irregularidades que pudieran afectar al pueblo. Junto con lo anterior, serán quienes lleven la voz del pueblo a los espacios de decisión y de definición de los destinos colectivos de índole pública. Mediante este sistema, a juicio de Hauriou, nace precisamente el control parlamentario como un proceso en el cual el Ejecutivo debe rendir cuenta de su gestión mediante preguntas, interpelaciones y comisiones ante el representante del pueblo, el Parlamento. Es en esta oportunidad en la que se le obliga a justificar sus políticas, sustentados fundamentalmente en la necesaria publicidad con la que deben ejecutar sus actos ${ }^{351}$, de allí la denominación del autor como proceso de justificación pública.

Ahora bien, la dificultad de nuestro argumento que considera que la facultad de representación es fundamento del control parlamentario en regímenes de gobierno presidencial, podría eventualmente presentarse en los siguientes términos: en dicho sistema la representación política se expresa en dos órganos diversos, en la elección del Presidente de la República y en la del Parlamento. Ambos gozan de la legitimidad ciudadana para actuar en su representación. Por ende, habría que justificar el control parlamentario en otros elementos como en la teoría de la división de poderes, en los equilibrios, en los pesos y contrapesos del sistema democrático, y no necesariamente en la representación política.

Sin embargo, por nuestra parte creemos que la representación política es también fundamento del control parlamentario en el presidencialismo, porque si bien ella se expresa mediante dos órganos del Estado, no es menos cierto que la configuración del Parlamento tiende a representar con mayor precisión la composición del espectro político nacional. En tiempos donde el pluralismo político cobra cada vez mayor importancia, la posibilidad de reflejar aquella diversidad social en una instancia estatal sólo es posible en el Parlamento, espacio donde además se expresa con mayor factibilidad la participación ciudadana.

${ }^{351}$ HAURIOU (1980) P. 247 Y 248. 
En este punto, seguimos los postulados del profesor Alan Bronfman cuando señala que ningún órgano puede ofrecer al sistema político la representación de la cual goza el Parlamento. Pueden existir otros entes de representación social, pero ninguno tiene el ámbito de cobertura territorial y social que posee la representación parlamentaria salvo, dice Bronfman, el Presidente de la República, el cual también es representante popular. Sin embargo, explica y aclara que al ser ésta una magistratura unipersonal no es capaz de contener en su estructura el pluralismo político que sí recogería la representación parlamentaria ${ }^{352}$. En efecto, desde una perspectiva territorial el profesor Manzella ha expuesto que será, precisamente, el Parlamento el punto de re-equilibrio de las eventuales desigualdades territoriales en las prestaciones sociales. La estructura de elección popular, unida al mandato general, y a escala territorial, sitúa al Parlamento en una posición de supremacía, que le permite coordinar y consensuar los conflictos de interés que se generan en la diversidad territorial del Estado ${ }^{353}$.

Continuando con nuestro análisis, agregaremos que sólo la representación parlamentaria es la que permite la configuración y participación de mayorías y también de minorías sociales y electorales en el desarrollo parlamentario y, como bien es sabido, las minorías políticas son las llamadas -histórica y naturalmente- a realizar el debido control político. Por tanto, el seno parlamentario será el único lugar donde las diversas fuerzas políticas puedan cotejar sus miradas respecto de la dirección política del Gobierno; es el cauce institucional mediante el cual se realizará el control parlamentario, cumpliendo las formalidades legales pertinentes.

En dicho sentido, sólo en la configuración parlamentaria puede realizarse el juego político entre mayorías y minorías sociales y políticas, las que comprenden un requisito esencial para la configuración del control parlamentario. Por el contrario, tal forma de control no es posible divisarla en la institución presidencial, porque al ser un órgano unipersonal, que además forma parte de una mayoría electoral triunfante, sea ésta un partido o un conglomerado político, En dicha agrupación, el Presidente electo depositará su confianza y de acuerdo a ella conformará su equipo ministerial,

\footnotetext{
352 BRONFMAN (2001)p.51.

353 MANZELLA (2002) p.18. Es menester destacar en este punto que el profesor italiano refuerza tal concepción desde la perspectiva de revitalizar al Parlamento como órgano, porque de no sostenerse su relevancia en los procesos de representación política se está en cierta medida negando, por una parte la realidad de la sociedad actual donde existen diversas formas de representación e incluso es dable sostener la "auto-representación" por parte de algunas organizaciones motivo por el cual y por otra parte el no fortalecer el papel que posee en dicha instancia el Parlamento como capaz de aunar todo tipo de expresión social e interés en su seno es restarle protagonismo en las sociedades del siglo XXI.
} 
construyendo un gabinete de exclusiva confianza presidencial que, por provenir de los más diversos sectores, actuará disciplinariamente en el sentido que el jefe de Gobierno indique o en la dirección que los partidos políticos vencedores orienten. Esta situación los sitúa en otro escenario de control. Respecto de ellos no cabe duda alguna que será posible realizar un control, pero de carácter político extraparlamentario, que en ocasiones puede producir efectos más concretos o significativos en la dirección política o en la misma configuración del gabinete de gobierno, crítica que puede ser pública o privada, pero que sin lugar a dudas provoca cambios.

No obstante, dicho tipo de control no está regulado, ni tampoco debe de cumplir ciertas formalidades, y es por ello que estamos frente a otro tipo de control y no al control parlamentario, toda vez que este último control se ejerce en razón de una relación representativa fruto de un mandato que sólo emerge en el Congreso Nacional, que favorece además en un Estado de Partidos que el representantecongresista pueda desligarse de su partido político, pueda romper con la disciplina partidaria y actuar derechamente como un representante de la nación.

Adicionalmente, quisiéramos agregar un elemento de tipo político, pero con connotaciones psicológicas y/o sociológicas porque siempre en la representación va impresa y existe una doble faz, elemento de confianza-desconfianza por parte del electorado. Se produce una delegación en dichos representantes tanto de sus aspiraciones y anhelos. Confían en que harán valer sus intereses, derechos y que velarán por el bienestar colectivo del bien común. Pero también existe un ámbito de desconfianza, lo que impone al mandatario el deber ético de responder a aquella confianza depositada. Existirá un legítimo temor al desentendimiento del representante y la posible deviación de sus acciones. Desde dicha perspectiva, emerge el deber de otorgar la debida información a la ciudadanía respecto del cumplimiento de aquel mandato, sin que ello implique coartar la libertad con la que debe actuar el representante en el ejercicio parlamentario, sino que solamente implica dotar a la población de la debida información que le permita interpretar si las gestiones y políticas públicas están orientadas en el sentido que ellos esperaban. Mismo argumento sustenta el control político en términos generales, ya que los ciudadanos controlarán al parlamentario y podrán denegar su confianza el proceso electoral siguiente, y a su vez, los parlamentarios velarán por el correcto actuar del Ejecutivo. 
En esta dirección, y a pesar de que la arquitectura del sistema presidencial sea diversa a la estructura del parlamentarismo, lo cierto es que la ciudadanía continúa reconociendo en el Parlamento el órgano representativo de su voluntad y el que deberá actuar cumpliendo sus designios. Por lo anterior, comprenden básicamente que mediante él tienen el derecho a conocer la gestión de su gobierno y aspiran que sea a través de este organismo donde se limiten las decisiones que puedan complicar el correcto desarrollo del país. En consecuencia, al integrarse el Parlamento con un mayor pluralismo social, naturalmente serán muchos más los ciudadanos que se sentirán representados, situación que no ocurre con la presidencia. Por ende, existe la noción de que sólo en el Parlamento habrá más ojos que estarán observando y custodiando que la voluntad única del Presidente de la República y su gabinete responda a un programa político y, esencialmente, a los principios constitucionales nacionales, sin atropellar valores cardinales para la sociedad.

Aquella oportunidad informativa que ofrece el Parlamento -como institución- y los parlamentarios -individualmente considerados-, no siempre es posible obtenerla con total invectiva o transparencia respecto de la información que emanará de los órganos gubernamentales, pues la administración del gobierno pondrá los énfasis y hará las entonaciones en las materias, logros y metas que crea estar cumpliendo, y lo expresará de tal forma que siempre se leerá como una inmejorable gestión de gobierno, lo cual no permitirá que la ciudadanía juzgue críticamente la actividad del gobierno, el programa de gobierno y, así tomar las medidas electorales necesarias.

Finalmente y adelantándonos a las materias que se analizarán en la presente investigación, quisiéramos agregar un último argumento en apoyo a nuestro planteamiento relativo a considerar a la función de representación política como fundamento del control parlamentario, tanto en regímenes parlamentarios como presidenciales. En la actualidad, la diferenciación o las barreras entre sistemas parlamentarios y presidenciales cada vez son más difusas y menos estrictas. La vida política democrática de los Estados ha transformado los clásicos diseños de los sistemas democráticos representativos, situación que de alguna manera auxilia nuestro postulado, toda vez que al no existir en puridad ningún sistema, es dable suponer que sus fundamentos también han variado haciéndolos más flexibles en las nuevas orientaciones constitucionales. Así, el eje central de nuestra perspectiva si bien puede ser cuestionable, no expresa ninguna aberración y tampoco altera más 
factores que los que la propia realidad y el ejercicio político y constitucional ya han alterado.

\section{b.1.3. La crisis de la representatividad política y su vínculo con el control parlamentario}

Con el paso del tiempo, la representación política se vio expuesta a profundas controversias y mutaciones fruto del arribo del sufragio universal, los partidos políticos de masas, la configuración de una sociedad de clases, las guerras mundiales, los totalitarismos y el posterior reforzamiento de la democracia. Elementos que, sin lugar a dudas, influyeron directa e indirectamente en el desarrollo del control parlamentario, motivo por el cual pasamos a examinar los rasgos más significativos de aquellas transformaciones y la forma en cómo relacionaron y alteraron el ejercicio del control parlamentario.

Si bien el Estado liberal y el régimen representativo estaban basados en la libertad por naturaleza y en un equilibrio supuestamente armónico de la sociedad, el rol del Estado era asegurar dicha libertad como un garante y restaurador de los equilibrios sociales. Por su parte, el Parlamento tenía como misión fijar las leyes y controlar el actuar del Gobierno, de tal manera que ambos procesos se encontraran conforme a los intereses del pueblo. Ello fue solamente el diseño del ideal del entonces Estado de derecho, pero la realidad exhibió un contexto diferente, la libertad y la igualdad sólo se ejercían en la medida que éstas se encuadraran en el modelo de libre-mercado, pero no en otras esferas sociales. El sufragio era un prerrogativa de la cual solamente gozaba la burguesía, por cuanto la "voluntad general" solo representaba los intereses de aquella clase.

En definitiva, la eliminación del Estado autoridad y de aquel Estado providencia, trajo consigo un otorgamiento de tal nivel de libre desenvolvimiento de los ciudadanos que a su vez engendró un total desamparo del pueblo. Aquella libertad por la cual tanto lucharon los liberales como pueblo, los dejó indefensos frente al desarrollo económico. Lo cierto es que se había forjado una fuerte desigualdad social, dando pie a la configuración de una sociedad de clases dejando atrás la sociedad estamental. Si bien en este nuevo escenario el pueblo era libre, no estaba lo suficientemente protegido y no fue posible establecer un orden. El Estado 
con poca injerencia en lo social no logró restablecer equilibrios $y$, finalmente, se genera el conflicto social.

Por otra parte, con la paulatina incorporación del sufragio universal se traslada dicho conflicto social a las esferas políticas. Los partidos políticos de masas se consolidan y contribuyen en articular una verdadera voluntad general en el Parlamento. Como dice Rubio Lara, la dependencia que generaron los partidos de masas fue valorada como una profundización de los principios democráticos, llegándose a considerar como los únicos organismos capacitados para llevar los pensamientos de los ciudadanos a los representantes ${ }^{354}$. Empero, el actuar de los partidos políticos tuvo de dulce y de agraz, generando múltiples fenómenos que modificarán la construcción política del Parlamento y, por ende, las relaciones entre Ejecutivo y Legislativo.

Durante largo tiempo, los partidos políticos actuaron como clubes, ligas y movimientos políticos. El temor a sus acciones y el desconocimiento del derecho de asociación fueron las causas principales de su invisibilidad jurídica. Será en el período posterior a la Primera Guerra Mundial cuando sus influencias se tornen inevitables, se posicionen socialmente como los verdaderos mediadores entre el pueblo y el poder político, y logren canalizar las inquietudes ciudadanas y llevarlas a las esferas de poder. Los partidos políticos de masas promueven ideologías políticas específicas y programas políticos atractivos y significativos para las clases sociales desfavorecidas, fue así como los vínculos de representación cambiaron y comenzaron a configurarse nuevas relaciones individuo-partido-representante o bien partidorepresentante-individuo. En esta instancia, tal como lo describe Lucas Verdú siguiendo a Triepel, finalizaría la etapa de ignorancia de los partidos y se comenzaría a evaluar la manera de considerarlos dentro de la maquinaria político institucional ${ }^{355}$. Nace así el Estado de partidos, el que a juicio de García Pelayo comprendió dos supuestos: la democracia de partidos y la constitucionalización de los partidos políticos ${ }^{356}$.

Sin embargo, luego del período de entre guerras germinará una actitud hostil hacia dichos partidos políticos y se propondrá su suplantación. En cierto modo, se

\footnotetext{
354 RUBIO (2000) p.122.

355 VERDÚ (1974) p.106.

356 García-Pelayo (1986) p. 29.
} 
añora el viejo orden corporativo-estamental ${ }^{357}$, en razón de las dificultades que emanaron del denominado Estado de partidos: conflictos tales como, el reemplazo del mandato libre por el mandato de partidos; la disciplina partidaria; el vínculo electorado-partido; la conformación de élites partidarias y esencialmente la forma de ejercer la función de gobierno por los partidos triunfantes electoralmente; el financiamiento electoral, entre otros aspectos. Factores que -desde la óptica de nuestra investigación- afectarán directamente al ejercicio del control político parlamentario, toda vez que sus elementos, objeto, sujetos, y mecanismos no serán los mismos desde la llegada del Estado de partidos.

Ciertamente, cabe reconocer que los partidos políticos son los actores protagónicos del sistema de representación pero también son responsables directos e inmediatos del cuestionamiento y del debilitamiento del Parlamento y, por ende, de sus funciones. Este fenómeno dio paso a la "crisis del parlamentarismo", lo que a nuestro juicio no era verdaderamente reflejo de las dificultades del Estado de partidos, sino que representaba realmente el rechazo al sistema democrático. Sin embargo, produjo igualmente consecuencias en la configuración del Parlamento mediante el afamado fenómeno llamado "racionalización parlamentaria", engendrando fuertes transformaciones en las funciones del órgano representativo, particularmente en la función de control que analizaremos en detalle.

En este sentido, lo que se produce finalmente con esta supuesta crisis de la representación, implicaba soterradamente promover un antiparlamentarismo más que definir una problemática del órgano parlamentario. Esencialmente, el fortalecimiento del Parlamento fue tan relevante que le permitió configurarse como una organización democrática, la cual -integrada por partidos políticos- elaboraba la decisión política nacional, además de establecerse definitivamente como la residencia con carácter exclusivo de la representación de la nación soberana. Existía una cierta hegemonía del Parlamento, lo cual arrojaba como saldo a favor de dicha institución el establecimiento de los gobiernos por asamblea en el mundo occidental y la supremacía de la ley, configurando con ello el reinado del Parlamento. Aquel fue el punto de inflexión que generó todo tipo de cuestionamientos, al extremo de llegar a considerar al Parlamento y los partidos políticos que lo integraban, como un lugar nocivo fruto de intereses egoístas ${ }^{358}$. Estas posiciones desembocarán en la pérdida

\footnotetext{
357 VERDÚ (1974) p.27.

358 RAMÍREZ (1995) Pp. 57, 61 y 62.
} 
de protagonismo por parte del Parlamento y, como efecto contrario, se producirá el auge del Ejecutivo. Se persigue con la creación de fuertes ejecutivos un camino hacia una mayor justicia social y una solución a la búsqueda de estabilidad política. En la indagación de una actividad más protectora de parte del Estado, lo que se produce finalmente es la entrega de la dirección política al Gobierno.

Sin perjuicio de lo anteriormente expuesto y en relación al control parlamentario en particular, la doctrina se ha mantenido conforme en indicar a la disciplina partidaria como uno de los factores más fastidiosos y significativos en el debilitamiento de la función de control. Como dijera Rubio Llorente, el Parlamento dejó de estar constituido por átomos libre., Ahora las decisiones ya están tomadas con anticipación, situación en la cual el control no responderá ni mucho ni poco al esquema tradicional $^{359}$.

Por su parte, Montero y García Morillo coinciden en que dentro de las variadas causas de la crisis del control, se encuentran los partidos políticos y la disciplina, pero también las guerras mundiales que re-fortalecieron al gobierno -al Poder Ejecutivo-, provocando finalmente la crisis de la institución parlamentaria y promovieron el carácter superfluo de sus funciones ${ }^{360}$. En definitiva, como expresara Aragón, con la democracia de partidos y con la disciplina el Parlamento se configura como un comité legislativo del Gobierno, situación que afecta el control y principalmente al parlamentario individual, el cual es absolutamente difuminado.

En la actualidad, nuevamente el régimen representativo es cuestionado. Hoy se habla de una "crisis de representación", expresada en la desafección política por parte de la ciudadanía. No habría una identificación con los clásicos partidos de masas ni siquiera con sus modernas manifestaciones electorales; la situación es compleja principalmente en temas como el financiamiento electoral y la demanda de mayores grados de participación ciudadana. Las razones de tal escenario y sus consecuencias son variadas. Una opinión interesante es la del alemán Peter, para quien estamos frente a un déficit del sistema democrático que tiene directa relación con lo que él Ilama deficiencias funcionales del sistema de partidos. Lo anterior, ha provocado el "entumecimiento de la democracia"361, causados básicamente por la falta de real representación de la demografía nacional, las erráticas conductas de sus

\footnotetext{
${ }^{359}$ RUBIO (1993) p.252.

360 MONTERO Y GARCÍA (1984): Pp. 46 y 47.

361 Peter (1991) Pp. 255, 256 y 257.
} 
militantes, la poca visibilización de la oposición, del control parlamentario y la escasa participación ciudadana en los procesos políticos y toma de decisiones, elementos que más adelante volveremos a abordar. O como también lo describe Bobbio, estamos ante una "apatía política" ${ }^{362}$ muy vinculada con el nivel de cultura política del ciudadano y su nivel educacional.

Frente a situaciones de crisis, la soluciones suelen ser extremas. En efecto, habitualmente cuando se plantea una escenario de "crisis" de representación política, es inevitable que se produzca una especie de reivindicación de la democracia directa e incluso de algunas instituciones de la misma o derechamente del mandato imperativo. Giovanni Sartori explica en detalle tal efecto en un artículo titulado: "En defensa de la representación política", instancia en la que denomina como directistas a quienes exigen más democracia o esperan arribar a una democracia semidirecta, mediante una especie de retorno del mandato imperativo. Sartori califica sus peticiones como desastrosamente disparatadas, pues ellas solamente pueden llevarnos a un sistema representativo altamente disfuncional y localmente fragmentado, que pierde de vista el interés general. Una democracia directa con el nivel cultural de la sociedad actual, sólo nos llevaría a la autodestrucción, lo que deja en evidencia la ceguera intelectual y mental de sus proponentes ${ }^{363}$.

Sin embargo, a nuestro juicio, pensar en una democracia directa ciertamente es inviable. No obstante, re-considerar o replantearse cuáles son las vías de participación social en democracias representativas, comprende un sano ejercicio de adaptación a las nuevas demandas sociales y políticas. El vínculo entre la política y la sociedad civil deber ser fortalecido por mayores mecanismos de participación que impidan la desafección del ciudadano.

Por otra parte, y en la búsqueda de las causales más relevantes de aquel supuesto fenómeno de debilitamiento del Parlamento y de sus funciones de representación y su vínculo con la función de control, parece vislumbrarse un factor común mucho más profundo que la sola entrada en acción de los partidos políticos de masas, la disciplina partidaria y con ello la vigencia de la democracia de partidos. Parece surgir una noción que no responsabiliza o culpabiliza la evolución del Estado de partidos como único gran autor de la desgracia del Parlamento, sino que -por el contrario- existirían antecedentes históricos o teóricos que caminan en otra

\footnotetext{
362 BOBBIO (1986) p. 25.

363 SARTORI (1999) p.6.
} 
dirección. En efecto, resulta un tanto complejo pensar que el Parlamento del Estado liberal funcionase dentro de absolutos criterios de libertad y autonomía representativa, dentro de una cuasi perfecta política institucional, estableciendo con ello una articulación funcional de tal esplendor que fijara parámetros inalcanzables por las actuales expresiones representativas y parlamentarias, estándares que además permitiría graficar la supuesta deficiencia existente en las funciones parlamentarias actuales, evidenciando una patente degeneración del modelo.

Desde esta perspectiva, recogemos lo expuesto por Antonio Torres del Moral, quien ha desarrollado principalmente aquella premisa que sostiene lo siguiente: el clásico modelo de representación que dio lugar a la democracia representativa simplemente ha quedado reducido a una hipótesis marginal, cumpliendo una labor en la vida política pero que no se ha realizado nunca en la vida real. Para el autor, nunca existió aquella pureza en el principio representativo como tampoco la supuesta exquisita independencia del representante. Siempre hubo ciertos vínculos, grupos o personas de particular prestigio que lograban imponer determinados criterios, mucho antes de la existencia de los partidos políticos o de los grupos parlamentarios $^{364}$. Sosteniendo básicamente que se ha elaborado una interpretación bastante quimérica de la representación política y del órgano parlamentario y su funcionamiento -ideal utópico que habría impuesto estándares tan altos que siempre será imposible poder alcanzarlos-, no existe una falla sistémica grave. Lo que ocurre habitualmente es el surgimiento de nuevas barreras que han de sortear los regímenes representativos, pero a pesar de tales circunstancias nos inclinamos más hacia la premisa de Norberto Bobbio, quien declara que no estamos frente a la "degeneración" de la democracia, sino más bien estamos frente a la adaptación natural de los principios abstractos de la realidad o de la teoría cuando es llevada a la práctica ${ }^{365}$. Porque, si bien dicho régimen se ha ido transformado a pesar de todas sus dificultades técnicas, jurídicas, políticas y sociales, es el único sistema que ha permitido aunque sea limitadamente la influencia popular en el poder ${ }^{366}$.

\footnotetext{
364 TORRES DEL MORAL (1982) p. 16.

${ }^{365}$ BOBBIO (1986) P. 8.

366 TORRES DEL MORAL (1982) p.8.

Hacemos mención que las palabras del autor toman mayor significación, si son consideradas las duras críticas que éste le formula al mandato representativo y los fundamentos que sustentan la eliminación del mandato imperativo, la eliminación de las instrucciones y revocabilidad del mandato sustentadas en la teoría de la soberanía nacional por no significar una "construcción jurídica correcta".
} 
Continuando con el estudio de la representación política como una supuesta forma ideal, diseñada en términos tales que en la actualidad ha de verse mitigada por una incapaz forma de ejecución, traemos a colación los planteamientos de otro autor que también ha realizado trabajos en esta misma orientación. Para Luis López Guerra, existirían conjeturas equívocas al momento de efectuar una comparación con la supuesta situación ideal que habrían disfrutado estas instituciones en tiempos pretéritos: aquel supuesto pasado mítico de la institución nunca existió. Sostiene el autor que tal época dorada no habría sido efectiva, en razón de que nunca existieron realmente tales parámetros de absoluta autonomía y plena libertad. Es más, de suponer que efectivamente pudieron haber existido todas aquellas condiciones, tampoco era probable que se expresaran con tanta perfección en la vida política parlamentaria, en atención a que siempre existieron grupos sociales más favorecidos que influían en la decisiones de orden público. Aquel ideario en el cual existía una especie de "paraíso" parlamentario que en los tiempos modernos se habría descuidado o abandonado nunca fue tal. La creencia denominada como "ideología parlamentarista" que intenta sustentar un virtuoso Parlamento, incurriría en un claro error.

El mismo autor desmitifica otra de las hipotéticas problemáticas del Parlamento y de su funcionamiento, la denominada "crisis de la representación y del Parlamento", respecto de la cual igualmente niega la posibilidad de que ella haya existido. A contrario sensu, sostiene que lo sucedido realmente no es una crisis sino simplemente la necesidad de comprender que el Parlamento -como todo órgano que debe responder a las coyunturas de la sociedad- necesita de una constante redefinición y adaptación, tanto en la estructura como en las funciones, para hacer frente a tales cambios políticos y sociales ${ }^{367}$.

En este punto, López coincide con aquella tendencia llamada "perspectiva realista" de la institución, esbozada por la doctrina española con exponentes como Luis María Cazorla, J.L Parodí, López Aguilar y García Morillo, que en cierto modo rebaten tanto el ideologismo parlamentario como la crisis del mismo. Proponen una nueva tesis llamada "parlamento estructurado", como contrapunto que responde al parlamentarismo racionalizado, concepción que afirma que el Parlamento ha sido capaz de ponerse a tono con los cambios sociales acecidos, saliendo airoso y fortalecido de tales circunstancias, asegurando su propia estabilidad institucional.

${ }^{367}$ LÓPEZ (2002) Pp. 31 y 32. 
Para estos autores, socavar al Parlamento implica socavar la médula de los sistemas democrático-liberales.

Básicamente, la presente línea interpretativa pretende que el Parlamento sea analizado desde la óptica realista que examine el cómo funciona y no desde cómo debería funcionar; se configura como un examen sensato pero que ha sido calificado como tremendamente optimista mas no satisfactorio por José Asensi Sabater, autor que expresa que tal lectura realista no es más que una lectura estipulativa o convenida, que ignora a la Constitución normativa y las funciones que se le imponen ${ }^{368}$.

Para Asensi, en aquella concepción doctrinal realista existe una interpretación forzada de la Constitución ajustándola a la realidad parlamentaria, lo cual sería del todo incorrecto, proponiendo como alternativa a dicha concepción el llamado "modelo consecuente" del Parlamento. En lo esencial, y a nuestro juicio, no dista mucho de la anterior noción pese a las críticas que formula, toda vez que implica revitalizar la centralidad del Parlamento "tomándose en serio la normatividad constitucional", principalmente por parte de los sujetos que actúan en su interior y fortalecer la labor legislativa. En definitiva, coloca los acentos en la posibilidad de cumplir las funciones parlamentarias con mayor consonancia con la Constitución, devolviéndole el protagonismo a la ley -como norma de origen esencialmente parlamentario-, argumentos que no configuran primicias en el ámbito del Derecho Parlamentario, pero que tampoco se ajustan a la realidad de la vida política de los Estado modernos.

Habiéndose explicado lo anterior y de cierta manera rebatiendo aquellas líneas de pensamiento que pretenden justificar y responsabilizar todas las variaciones del Parlamento, sus funciones $y$, en particular, los vaivenes del control parlamentario en la democracia de partidos y en la disciplina partidaria o en la excesiva primacía del Ejecutivo, pasamos a exponer los argumentos que a nuestro juicio sí componen la tesis que efectivamente explica una sustantividad que es innegable, la que dice relación con la imposibilidad de sustentar o negar las transformaciones que ha sufrido el Parlamento y la función de control. Si bien no estamos por hablar de una "debilidad" de la función de representación y control, sí creemos que dichas funciones han sido re-direccionadas. Su ejercicio hoy busca

${ }^{368}$ ASENSI (2002) Pp. 49, 50 y 51. 
finalidades diversas y se expresa mediante códigos y con un lenguaje político desigual a los clásicamente comprendidos, situación que nos convoca a lo menos a intentar comprender cuál fue el factor o factores que provocaron tal modificación.

En dicha dirección, esbozaremos una hipótesis sostenida principalmente en argumentos de Ángel Garrorena y Giovanni Sartori, que dicen relación con la identificación que se produjo en el Estado liberal con la representación y el poder, produciéndose una simbiosis entre ambos, y debilitándose así la relación dialéctica de la institución -siendo éste el factor de mayor importancia en el debilitamiento del control parlamentario y la posibilidad de su ejecutabilidad-. Esta situación se explica más gráficamente de la siguiente manera: en sus orígenes Parlamento, Corona y pueblo actuaban en una relación triangular. El Parlamento actuaba ante la Corona en representación-defensa del pueblo, llevando a quien constituía el poder la voz y las necesidades de la sociedad; luego, el Parlamento a su vez regresaba al pueblo y mediante sus relaciones territoriales explicaba y rendía cuentas de la voluntad de la Corona e informaba al pueblo de las decisiones de administración pública que se gestaban, cumpliendo además un papel garante en la creación de la ley y la defensa de los derechos. Pero, cuando el Parlamento se transforma en órgano del Estado deja de ser una contraparte ya no actúa ante otro. Hoy actúa ante nadie o -desde otra perspectiva- actúa ante sí mismo, porque él mismo pasa a ser el poder, toda vez que ya no existe una Corona $y$, de existir, sus funciones son radicalmente diversas a las de administración del Estado que inicialmente le competía, provocando una enérgica modificación de la institución parlamentaria como protector de la sociedad y sus diálogos con el poder.

Si a lo anterior le agregamos -como segundo efecto trasformador- la posible identificación gobierno-mayoría parlamentaria, elemento que sí se encuentra vinculado a la existencia de los partidos políticos, la situación se complejiza aún más. Es esencialmente aquí donde se encuentra la dificultad de la función de control parlamentaria, concebida desde su tradicional expresión. La transmutación del diseño del control del antiguo triángulo de poder -Parlamento-Corona-Puebloprácticamente hoy no existe. La configuración de la arquitectura política es diversa, los vínculos del poder también lo son e incluso hoy son más estrechos que en la época liberal. De allí que sostengamos que no existe una total debilidad del control, sino que existe otra modalidad de control, en la cual también concurren complejidades en atención a su ejercicio, debido a que el poder también ha mutado 
actualmente. Está aún más concentrado en el factor económico, encontrando a su vez más espacios de acción lo que motiva con mayor fuerza el presente análisis y examen de la función de control desde dos fases: una horizontal, relacionada al concepto y procedimientos, y otra vertical, relativa a los sujetos del control.

En consecuencia, las instituciones políticas como el Parlamento lógicamente se han desarrollado conforme a las condiciones y necesidades de cada tiempo. Esperar que la vida parlamentaria sea idéntica en cada época de la evolución política es un absurdo, de allí que los juristas debamos buscar los mecanismos y procedimientos precisos que permitan contribuir en la mejora de los mismos, reconociendo los méritos pero también las debilidades del pasado. Como ya lo hemos adelantado, hoy acontece tanto en sistemas parlamentarios como en sistemas presidenciales nuevas relaciones y vínculos de poder, como también la denominada relación mayoría-gobierno, punto central de este análisis, que ha permitido cuestionarse cómo se ejerce control en tal escenario, si desde la concepción más clásica la organización del Estado es diversa. Ya no existe una estructura triangular, la configuración clásica hoy no existe mediante la cual se diseñará toda la estructura del control parlamentario, estamos frente a un nuevo contexto y, en tal atmósfera, el control se expresará de maneras diversas debiendo re-significarse su sentido y alcance.

Lo concreto es que todo sistema de gobierno y de representatividad sigue siendo estructurada por tres instituciones esenciales: Gobierno, Partidos $y$ Parlamento, los que se vinculan a través de relaciones entre Ejecutivo-Legislativo, y continúan dando sustento al sistema democrático y al control parlamentario. En particular, la relación partidos-representación es fundamental. Los partidos políticos son los mediadores en la representación y sin ellos el funcionamiento del sistema político es imposible 369 , a pesar de las dificultades que ellos han generado en el sistema político. Por tanto, y conforme con las opiniones de Torres del Moral, las trasformaciones del sistema son recíprocas, ni los partidos alteraron sustancialmente al sistema de gobierno, ni éste alteró significativamente a los partidos políticos ${ }^{370}$.

Por consiguiente, las alteraciones son producto del normal desarrollo de las relaciones entre ambos. A criterio del autor, la deficiencia se centra con mayor problemática en la democracia interna de los partidos y no necesariamente en sus

\footnotetext{
369 DUVERGUER (1970) p. 135.

370 TORRES DEL MORAL (1982) p.14.
} 
relaciones institucionales, argumento que compartimos, toda vez que muchas de las trasformaciones de la representación política -como del control- tendrán mucha ligazón con las relaciones entre el parlamentario individual y los dirigentes de sus partidos, que en asuntos nucleares del control en sí mismo.

Sin pretender dar una respuesta a las actuales problemáticas de la representación -por no constituir el objetivo central de la presente investigación y por escapar totalmente a nuestra actual finalidad-, únicamente diremos que creemos que las dificultades son mayúsculas y que el financiamiento de la política y la democracia interna de los partidos son factores claves, junto al déficit de participación ciudadana en estas materias. En palabras de López Guerra, esas dificultades no son insalvables y no ponen en tela de juicio a la institución parlamentaria como órgano insustituible en los regímenes democráticos, pues en su seno siguen estando presentes una pluralidad de voluntades, creencias e intereses a pesar de que la idea de la voluntad general ya no sea tan efectiva. Continúa siendo un centro de integración social y territorial ${ }^{371}$.

En este punto compartimos nuevamente el análisis de Ángel Garrorena, para quien el elemento conflictivo y nuclear de la representación es la necesidad de renovar la mentalidad burguesa anquilosada en el sistema político. Se debe modificar lo que el autor denomina "mentalidad cautelar", esto es, dejar de ver al ciudadano con desconfianza de su capacidad pública reduciéndolo a su ámbito netamente privado. En palabras de Garrorena, se debe proceder a la "superación histórica de una mentalidad"; se debe terminar de recorrer el camino iniciado ${ }^{372}$. Desde nuestra perspectiva, efectivamente, el control parlamentario y las instituciones de gobiernos siguen siendo concebidas decimonónicamente. Se les exige cumplir estándares que hoy no pueden cumplir, creando una sensación de insatisfacción constante por la supuesta "debilidad" de sus actos, razón por la cual proponemos referirnos al control como una institución diversa que debe ser re-significada horizontal y verticalmente.

Un elemento neurálgico que se vincula con nuestra labor, implica también determinar en esta materia qué tipo de representación queremos y cómo queremos que se configure el Parlamento, para que así éste pueda responder de mejor manera a nuestras expectativas y necesidades. Pero, tal cuestionamiento implica ingresar en

${ }^{371}$ LóPEZ (2002) p.37. Es interesante destacar que el autor niega la existencia de la posibilidad de continuar creyendo en la oportunidad de dar lugar a la creación de la voluntad general, debido a las mismas limitaciones de la representación política.

372 GaRRORENA (1991) p.89. 
otro aspecto de la representación relativo a lo que entenderemos por representación -lo que escapa a nuestras posibilidades-. Habitualmente nos referimos a ideas, tales como: "hacer presente", "actuar por otro", "sustitución de sujetos", "reflejosemejanza" e incluso "mediación". Si debiéramos de algún modo clasificar las concepciones que de la teoría de la representación política se han ido plasmando, debemos recurrir a quien ha recopilado y aunado de forma muy clarificadora los axiomas de la representación. Ella es la profesora Hanna Pitkin, quien sistematiza las tendencias en torno a la representación, analizándola a través de las siguientes clasificaciones: representación formalista, representación con perspectiva de responsabilidad, descriptiva, simbólica y la de "actuar por". No intentaremos explicar cada una de estas posiciones. Como hemos advertido, no es el objetivo de este apartado constituir todas concepciones latamente tratadas por la doctrina y conocidas en sus elementos esenciales.

Simplemente, diremos que si bien la representación formalista ${ }^{373}$ como la descriptiva ${ }^{374}$ son las ocupan gran parte de la preocupación doctrinaria, nosotros estamos conforme a lo expuesto por la profesora Pitkin, en relación a considerar a la representación como un "actuar por otro" o actuar en nombre de otros. La esencia de la representación es, simplemente, una actividad a través de la cual se representan aquellos intereses que son de mayor importancia para la ciudadanía. Actuar por alguien -para Pitkin- implica deliberar, razonar por alguien, por ende, tal trabajo debe tener razones y poder contar con las justificaciones que lo respalden. En definitiva, para la autora la representación política es "actuar en interés de los representantes de una forma sensible y ante ellos" ${ }^{375}$. Para ella, la actual

\footnotetext{
373 Para Pintkin la representación formalista contempla la existencia de un representante como un sujeto que es autorizado para realizar dicha función, el representante cuenta con un derecho que le permite actuar, recayendo los resultados o efectos de sus acciones en el representado como si el mismo los hubiese realizado. Tipo de representación que Pitkin explica como aquella donde existe una transaccional inicial en la cual no se establece ningún parámetro, por ello se configura como una "caja negra", toda vez que el representante puede hacer lo que le place no hay límites ni deberes con su representado. PITKIN (1985) p.42.

${ }^{374}$ Se relacionan con la idea de similitud, se encuentra unida evidentemente a la necesidad de lograr que el órgano representativo sea un espejo en el cual se refleje la imagen del sujeto que se está representando. Se refiere más propiamente a la existencia de una "relación de semejanza". En esta estructuración, la representación debe tener como objeto formularse públicamente, pues sólo aquello le permita dotarse de su carácter político y la autenticidad ligada a la idea de verosimilitud de imagen logrando una identificación, que permita dar forma a una línea o canal de transmisión de contenidos. Tal pensamiento es el que Pitkin describe como la representación descriptiva. En este caso, el cuerpo representativo debe tener correspondencia o semejanza precisa con lo que se representa, debe producirse un reflejo no distorsionado, debe haber exactitud de imagen con la nación. La representación dependerá de las características del representado, razón por la cual -a criterio de Pitkin- no se configura una actuación por otro, sino una "sustitución" del sujeto, procedimiento en el cual los acentos estarán puestos en la conformación del órgano representativo y no necesariamente en su correcto funcionamiento. PITKIN (1985) Pp. 65 y 67.

375 PITKIN (1985) p.233.
} 
representación es una institución que presenta complejidades. Las características propias del actor (representante), profesión, opiniones y perspectivas serán relevantes; el deber de actuar conjuntamente con el Gobierno y, más difícil aún, el deber de determinar y llevar al debate los intereses nacionales y locales, porque a juicio de la autora el representante tiene una función dual nacional y local, lo cual supone una carga no menor de funciones a realizar ${ }^{376}$.

Sin embargo, tal noción -como toda opinión doctrinal- encuentra su contrapunto en las formulaciones de Francisco Javier Conde. Para el autor, la representación implica dar presencia a algo que constituye una realidad, pero que por sí mismo carece de presencia. Así, el representante es un revelador del representado ${ }^{377}$. Para Conde no se actúa por otro o en su lugar simplemente le constituye como unidad de acción ${ }^{378}$. Autores como Sartori, Garrorena y García Pelayo, comparten el pensamiento de Conde y la noción de "hacer presente", para quienes la representación no es sólo actuar por otro sino que dar presencia al representado.

En conclusión, creemos que fortalecer la representación política implica gestar mayor participación política, proveniente de los más diversos grupos sociales, y que la concepción de la representación sea considerada como un servicio público sensible ante las necesidades, cercano y económicamente sustentado por vías lícitas que no generen conflicto de interés entre la política y el empresariado. Requiere también que los períodos de mandato parlamentario tengan un límite de reelección -para que no sea posible hacer de la política una carrera profesional-, situación que el anquilosamiento de determinadas personas las situaría de manera perpetua en el Parlamento. En ese estancamiento está el riesgo de que el control parlamentario pierda su vitalidad, porque el estar permanentemente en un situación de poder provoca riesgos para la política y para la sociedad. Las personas pierden total conexión con la realidad y aprehenden lo necesario para lucrar de forma desmedida con el aparato público, y así construir relaciones de tal nivel de confianza que les permita mantenerse en tal calidad. Lo anterior, puede fomentar cierta complicidad

\footnotetext{
376 PITKIN (1985) Pp. 243 a 245.

377 CONDE (1945) p.53. En el pensamiento de Conde, el pueblo como realidad social es deficiente, le falta presencia; le falta "actualidad". Es sólo una posibilidad, es una realidad política en potencia y la representación será esa herramienta articuladora entre la realidad deficiente y la realidad perfecta, lo cual justifica además la imputación de las acciones a la comunidad porque es absolutamente representación pura y simple. Para Conde, no existen dos voluntades, sino la posibilidad de actualización (de hacer presente) la voluntad unitaria que ofrece el pueblo.

${ }^{378}$ CONDE (1985) p.57.
} 
entre sus protagonistas, ya que posteriormente imposibilita la realización del debido control de la gestión de quienes considera sus colaboradores.

\section{b.1.4. La representatividad política en el contexto chileno}

Habiendo señalado los elementos más significativos del vínculo entre representación y control parlamentario, es preciso formular algunos breves comentarios respecto de la representación política en el escenario político chileno, situación que sin lugar a dudas influye directamente en la configuración del Congreso Nacional y, por ende, en el desarrollo del control parlamentario. A continuación, revisaremos algunos de los antecedentes más relevantes en esta materia.

La representación fue muy prolífera en un período de la historia nacional, particularmente desde 1960 hasta 1973, en virtud de un conjunto de medidas previamente adoptadas que favorecieron su ejercicio tales como: los procedimientos electorales, el sufragio femenino, la cédula única oficial que garantizaba el secreto del sufragio, la obligatoriedad de la inscripción electoral y la disminución de 21 a 18 años en la edad para ejercer el derecho a sufragio, adicionado al nacimiento de partidos políticos de masas fuertemente ideologizados, pavimentaron el camino de lo que Jorge Tapia explicó como la vigorización de la capacidad representativa nacional ${ }^{379}$.

Se trata de un momento nacional marcado por un fuerte predominio del Parlamento, y por el nacimiento de partidos políticos de suma importancia en la historia de Chile, como lo fuera el Partido Demócrata Cristiano. Dicho partido, obtendría el Gobierno de la mano del presidente Frei Montalva, triunfo que reflejó lo descrito precedentemente a través de una altísima participación social en la vida política, causa de las transformaciones sociales experimentadas. Este proceso, que el presidente Frei llamaría la "revolución en libertad", propondría fuertes reformas en el agro, la minería y en lo social, proceso que se ve fortalecido y claramente animado por una participación social que se presentaba con fuerza ${ }^{380}$.

\footnotetext{
379 TAPIA (1993) Pp. 91 y 92.

380 Situación que queda perfectamente reflejada en las palabras del mismo Presidente en uno de sus discursos el que reza: "Este movimiento y este hombre que está aquí para hablarles, representa la realización de grandes tareas en el porvenir de la Patria. Tareas que significan una revolución en libertad. Una transformación profunda de Chile. Respaldada por la presencia de ustedes nunca como ahora mi voz
} 
En este sentido, las trasformaciones fueron políticas, sociales pero también económicas. La influencia del capitalismo y de partidos centristas y de derecha, intentaron atenuar las exaltadas pasiones representativas de la época, promoviendo reformas constitucionales que disminuyeron el poder del Parlamento, en favor del Ejecutivo. En este contexto, el año 1970 se da inicio con una estructura política modificada que no favorecía precisamente un trabajo cooperativo entre ambos poderes. Se había institucionalizado el conflicto social, elementos que detonarán posteriormente el golpe militar ${ }^{381}$. Sin embargo, hasta esa fecha la democracia gozaba de buena salud y de una participación ciudadana significativa, la representación política era una verdadero mecanismo de participación popular. Reflejo de aquello fue el triunfo del presidente Salvador Allende, gracias a la unión de las diversas fuerzas de izquierda ${ }^{382}$.

Lo anterior, lo hemos señalado a modo ilustrativo como claras manifestaciones de la participación política activa del pueblo chileno, la multiplicidad de partidos y movimientos políticos y de la representatividad del Parlamento como un órgano ciertamente legitimado, proceso que se verá truncado con el advenimiento de la Dictadura Militar. Durante 16 años de dictadura se destruyó la participación popular y se exterminó el sistema representativo.

Sólo con el retorno de la democracia en el año 1990, se reanuda la actividad democrática, pero encasillada en un marco jurídico complejo, compuesto por la Constitución de 1980 y una particular ley electoral que contemplaba un especial sistema mayoritario binominal ${ }^{383}$, el que fuera descrito por Valenzuela como de "dudosa legitimidad" en atención a las especiales características de su creación. Dicho sistema electoral, fue aprobado a través de una "ley de amarre", norma que la dictadura de Pinochet redactara después del plebiscito de 1989. El sistema electoral

ha tenido tanta autoridad, porque es la voz del pueblo de Chile" (Discurso de la Patria joven, Parque Causiño, 21 de junio de 1964. Eduardo Frei M., obras escogidas, p. 294).

381 TAPIA (1993) p.93.

${ }^{382}$ Aquella unión de fuerzas de izquierda queda expresada en los agradecimientos que realizará esa misma noche luego de conocer su triunfo, en el siguiente tenor: "...acepto este triunfo que nada tiene de personal y que se lo debo a radicales, socialistas, comunistas, socialdemócratas a gente del MAPU y del API, y a miles de independientes. Se lo debo al hombre anónimo y sacrificado de la patria; se lo debo a la mujer humilde de esta tierra. Le debo este triunfo al pueblo de Chile, que entrará conmigo a La Moneda el 4 de noviembre..." (Discurso de 4 de septiembre de 1970, Federación de estudiantes Universidad de Chile).

383 Tal sistema comprende que cada distrito o circunscripción elija dos representantes. Por consiguiente, cada lista puede presentar sólo dos candidatos. Mediante este sistema, el umbral para conseguir ambos escaños es demasiado alto, por ende el triunfo de una lista sólo ocurre si logra doblar la cantidad de votos de la contraria. Así, habitualmente ambas listas obtienen un sólo ganador. Para mayor abundamiento en esta materia, es posible revisar: Altman (2004), Auth (2005), Guzmán (1993), Huneeus (2004), Marín (1986), entre otros. 
binominal tenía por finalidad otorgar el $50 \%$ de la representación parlamentaria a la lista que obtuviera al menos un tercio de los votos, forjando así un sistema electoral que operaba como una camisa de fuerza, transformando el pluralismo partidario chileno en un sistema político que se organizaba en torno a dos coaliciones ${ }^{384}$.

Como bien explican Cabezas y Navia, los diseñadores del sistema electoral binominal tenían un objetivo claro: idear los mecanismos que perpetuaran o mejoraran las posibilidades de elección de sus adherentes, favoreciéndoles o asegurándoles una buena representación en la Cámara de Diputados. Se buscaba finalmente alejar al país de la representatividad proporcional vigente en Chile hasta 1973, por considerarla "contraria al progreso nacional" 385 , privilegiando la participación de los partidos más moderados. En suma, favoreció la participación de partidos minoritarios e impidió que un partido mayoritario lograra el control de los escaños parlamentarios, se configura así un seguro contra la derrota y, a su vez, seguro contra las mayorías ${ }^{386}$.

Tal sistema electoral produjo varias dificultades que se pueden agrupar siguiendo al profesor Alan Bronfman. Posee un claro efecto negativo en la proporcionalidad de la representación, favoreciendo la sobrerrepresentación de partidos políticos de derecha y centro derecha y como efecto la subrepresentación de los partidos de izquierda. Otro aspecto negativo, dice relación con el período electoral, debido a que este sistema fomenta la competencia intralista en desmedro de la clásica disputa de partidos, programas e ideologías ${ }^{387}$, fomentando una elección basada en aspectos personales de los candidatos, y no necesariamente en sus programas. Ello, desvirtúa la finalidad informativa y educativa de las campañas electorales en razón de la ciudadanía.

Finalmente, agregaremos lo descrito por Carey y Siavelis cuando exponen que el sistema chileno genera además una tensión entre los candidatos de la misma coalición, porque tanto los incentivos como los alicientes respecto del candidato individual genera peculiaridades, debido a que aquel candidato perdedor debe ser

\footnotetext{
384 VAlenzuela (2005) Pp. 53 y 54.

${ }^{385}$ Historia de la ley No 18.799, p. 49.

386 CABEZAS Y NAVIA (2005) Pp. 32 y 34.

387 BRONFMAN (2001) Pp.53 y 54.
} 
"recompensado" con algún nombramiento en cargos políticos de relevancia en virtud del alto riesgo que implica su desafío electoral ${ }^{388}$.

El sistema binominal no tiene por finalidad constituir mayorías que puedan hacer un Gobierno, sino muy por el contrario, y como dice Tapia, impide la formación de una mayoría magnificando la minorías, expresándose en la alta cantidad de escaños que obtienen -muy superiores a su votación efectiva- ${ }^{389}$. En consecuencia, impide que el Parlamento sea un reflejo verdadero del pluralismo político vigente en la sociedad chilena. Estos elementos, sin lugar a dudas, afectan el desarrollo del control parlamentario porque si bien es cierto que existe una fuerte minoría parlamentaria que ha de ejercer control de forma constante, ella sólo representa la visión política de un sector ideológico de la sociedad, organizada en fuertes cúpulas partidarias que no realiza una crítica constructiva y que sólo aspira la degradación de su adversario. Con dicho sistema, las pequeñas minorías sociales no pueden alcanzar participación parlamentaria, sólo podrán ejercer control social pero nunca parlamentario ${ }^{390}$. Por consiguiente, las diversas orientaciones políticas o las posibles re-direcciones del programa de gobierno propuestas desde una óptica positiva, no provienen del Parlamento sino que habitualmente de la sociedad civil.

Ese es el contexto jurídico en el cual entró en funcionamiento el Parlamento nacional, a través de un sistema electoral que generaba efectos contraproducentes en la vida y viabilidad de los partidos políticos. Provocaba, además, extensas negociaciones, omisiones y abstenciones en determinados distritos y circunscripciones, procesos que, sin lugar a dudas, desgastaban las coaliciones

\footnotetext{
388 CAREY Y SiAVELIS (2003) p.22. Dicho fenómeno es denominado por los autores como el "seguro para los subcampeones" toda vez que, por el sólo hecho de ser candidato considerando el riesgo y dificultad que ello implica en virtud del especial sistema electoral, el cual sólo permite que los dos candidatos de una lista pertenecientes a la misma coalición política puedan triunfar sí y sólo sí obtienen el doble de votos que su contrincante, hecho de tal complejidad electoral que habitualmente los resultados indican que sólo será electo un candidato de cada coalición. Es por ello que el segundo competidor perdedor habitualmente se ve recompensado en su aventura electoral con la designación en un cargo político importante en el gobierno.

389 TAPIA (1993) p. 94.

390 Con el presente párrafo, no pretendemos solicitar ni directa ni indirectamente que la representación política nacional se establezca mediante un sistema electoral que garantice un sistema proporcional de representación descriptiva o -como comúnmente se señala- un sistema que pueda configurar un exacto reflejo de la sociedad en el órgano representativo. Por el contrario, creemos que si bien es necesario eliminar el sistema binominal, su reemplazante debe ser muy bien examinado, de manera tal que responda a la realidad política nacional pero que también permita construir un Parlamento que pueda cumplir cabalmente las funciones de representar, legislar y controlar.
} 
políticas. Sus relaciones internas se veían mermadas, creando en definitiva una proporcionalidad dudosa de la representación ${ }^{391}$.

Tal es el daño que generó el sistema binominal, que incluso autores como Carey y Siavelis lo califican de alto riesgo para la mantención de las coaliciones políticas vigentes. Dicho sistema electoral podría causar el fin de la que antigua Concertación de Partidos por la Democracia, en virtud de las complejidades estratégicas que él mismo comprende ${ }^{392}$. Finalmente, lo que el sistema binominal provocó fue la polarización de la política nacional y creó prácticamente un bipartidismo ${ }^{393}$. Dicha ley electoral permitió la consolidación en el Parlamento de un número suficiente de escaños por parte de la oposición, permitiendo ejercer un poder de veto a las iniciativas legislativas de la mayoría ${ }^{394}$.

En ese contexto se ha desarrollado la vida parlamentaria nacional. Sin embargo, luego de 25 años de vigencia del sistema binominal, el año 2014 el Parlamento chileno aprueba la ley que sustituye dicho sistema por uno de carácter proporcional e inclusivo, el que tiene por finalidad lograr una mayor representatividad, asegurar la representación femenina y disminuir las barreras de acceso a los candidatos independientes. No obstante, aún no ha tenido aplicación práctica, por tanto, hemos de esperar su concreto ejercicio para dimensionar y analizar los efectos que ha de producir en el sistema democrático chileno, y, en particular, en la configuración del Congreso Nacional.

\section{b.2. La facultad legislativa como expresión de control parlamentario}

Dentro del Estado liberal como proceso multiforme, fueron varios los pilares fundamentales que aspiraron a garantizar el respeto, la seguridad, la propiedad y la libertad humana frente a los abusos de poder. Variados fueron los mecanismos que buscaron generar el esquivo control del poder. Así, la ficción de la representación política fue prueba de aquello, lo cual fue posible observar en el análisis precedente,

\footnotetext{
391 VALENZUELA (2005) Pp. 56 y 60.

392 CAREY Y SiaVelis (2003) Pp.7 y 8.

393 NOHLEN (1985) Pp. 82 y 83 . Respecto de este punto, el autor esgrime que un sistema bipartidista solamente puede funcionar cuando no sean tan grandes las distancias ideológicas entre ambos partidos. Lo que a todas luces en Chile no ocurrió ni tampoco ocurre en estos momentos, ya que existe un amplio abanico de tendencias ideológicas.

394 Cabezas y Navia (2005) Pp. 35 y 36.
} 
pero, por otra parte, también lo fue el ejercicio de la función legislativa del Parlamento.

Los motivos por los cuales la creación de la ley fue arrebatada de las competencias de los monarcas, fueron consecuencia natural de los hechos acontecidos. Con las teorías pactistas queda en evidencia que los ciudadanos no desean seguir siendo dominados por razones o motivos teológicos e irracionales, en la era de la razón pura y de la búsqueda de la verdad científica mediante medios razonados y razonables, era necesario otorgar explicaciones lógicas al origen del poder y a las normas que regulaban la relación gobernante-gobernado. Es por ello que con la abstracción del derecho se visualiza una barrera jurídica que limitaba el poder, proceso que fue detallado en el Capítulo anterior y que fue denominado como los límites jurídicos al poder. Con todo, el traspaso de la creación de la ley al órgano representativo y su evolución, consolidó un mecanismo de obstaculización de los deseos arbitrarios de la autoridad, y da nacimiento al Estado de derecho. Mediante el establecimiento del derecho como fruto de la voluntad soberana se permite legitimar el poder.

Ahora bien, en estas líneas intentaremos demostrar que en el desarrollo de la facultad legislativa es posible encontrar manifestaciones del control parlamentario. A este respecto, sostenemos que el proceso legislativo puede configurarse como un espacio de control, motivo por el cual hemos de analizar dicha noción con las respectivas opiniones doctrinales al respecto y sus efectos. En definitiva, tal como lo expusiéramos, es la Ley como expresión de la voluntad de la nación la que deberá ser respetada por el Gobierno al estipular reglas de ejecución de las políticas públicas. Así, se contempla como un mecanismo de control, por ejemplo económico en el caso de la ley de presupuesto.

\section{b.2.1. Evolución de la Ley como control jurídico del poder}

En las siguientes líneas, hemos de explicar someramente el protagonismo alcanzado por la ley, el cual se deberá fundamentalmente a dos factores que repercutirán en la nueva concepción del poder y sus limitaciones, éstos son: un factor científico y otro político. Nos referiremos a aquel desplazamiento en el criterio 
de origen de la misma, el que se produce al momento de racionalizar la creación de la norma, dejando atrás el subjetivismo con el cual fue elaborada cuando dependía de la voluntad real.

Como explica Fernández-Viagas, el proceso científico esencialmente razonado de la época de la ilustración también repercutió en las ciencias sociales. Por ello, se buscaron normas fijas y determinadas que regulen la totalidad de las relaciones sociales y que establezcan claramente las consecuencias de su incumplimiento, garantizando con ello la seguridad jurídica. Desde esta perspectiva, se mira a la ley como un método científico 395 . Por otra parte, quitar de la esfera de atribuciones del monarca la capacidad de dictar la ley, implicaba evitar los atropellos experimentados hasta la fecha. El objetivo era sacar al Derecho de las intromisiones del Rey evitando dejar la formación de la ley a su sola discreción y hacer de ella un mecanismo de protección. De tal importancia es la facultad de crear la ley, que ésta será depositada en el soberano -la nación- y será la expresión de la voluntad general, la cual gracias a la ficción de la representación política, se encuentra reunida y emerge de un grupo de representantes escogidos por el soberano, cuya sede de debate y organización fue y es el Parlamento.

La construcción de una nueva sociedad, llevaba implícita la necesidad de seguridad y para ello era absolutamente necesario eliminar las incertidumbres que la época feudal y la monarquía absoluta habían dejado en el sistema jurídico. Nadie más que el soberano podía gozar de la posibilidad de dictar la ley, porque en él se reunían todos los poderes y no podía ser contradicho. La finalidad era establecer un sistema que asegurara la racionalidad de sus decisiones, convirtiendo al Parlamento en un Dios mecánico capaz de competir en eficacia con el de los creyentes, órgano de representación en el cual a través del debate se llegará a la ley como la verdad expresada en sentido jurídico ${ }^{396}$.

El proceso político llevado a cabo en el Estado liberal, se caracterizó por la preeminente posición de la ley en todo el ordenamiento jurídico. Los límites a la libertad sólo los podía fijar la ley e incluso se le equiparaba con la Constitución, porque al ser la ley expresión de la voluntad general y absoluta, era ella quien debía

395 FERNÁNDEZ-ViAGAS (2008) p. 26.

396 FERNÁNDEZ-VIAGAS (2008) p.30. 
fundamentar todo el sistema, ninguna otra fuente más gozaba de aquella facultad. En este orden de ideas, la ley puede regular cualquier materia con plena fuerza. Su superioridad jerárquica es absoluta, motivo que permitirá que brote simultáneamente la superioridad del órgano parlamentario, porque en definitiva, ley será todo aquello que desee el Parlamento, no importando su contenido ${ }^{397}$. La ley se constituye como la fuente primaria del derecho, sólo ella podía crear obligaciones y derechos, como expresa Rubio Llorente "la ley lo podía todo" y sólo podía ser modificada o derogada por otra ley ${ }^{398}$.

Pero el dominio de la ley por parte del Parlamento, como toda innovación del pensamiento liberal, tampoco fue aceptado con facilidad por la Corona. En efecto, en el siglo XIX -en el período de Restauración- el retorno del absolutismo pretendió, mediante las "cartas otorgadas" devolver al monarca la facultad de legislar, oportunidad en la que las revoluciones burguesas jugaron un papel determinante para zanjar de forma clara tal problemática, defendiendo la garantía que suponía que la creación de la ley debía ser desarrollada sin intervenciones del Ejecutivo. Esto significaba sin intervención del Rey, debiendo ser fruto del debate de la nación representada en el Parlamento. De allí surgirá la función legisladora propiamente tal, definida por García-Escudero Manríquez como: "la función por antonomasia de las asambleas representativas, que significa la participación de los representantes elegidos por el pueblo soberano en la formación de la voluntad general, expresada en la ley"399.

Durante el Estado liberal, como es de suponer, la creación de la ley se desarrollaba conforme a procedimientos en directa coherencia con dicho pensamiento, que -como explica Tudela- respondía básicamente al axioma de considerar al pueblo como homogéneo. Se creaban leyes mediante procedimientos cortos y las normas eran claras, la racionalización y la búsqueda de seguridad jurídica imponía una restricción normativa ${ }^{400}$, lo esencial era que la ley reuniera dos características: la primera, que fuera general, lo que implicaba según Rubio Llorente que se aplicara a todos pero que a la vez fuera creada por todos ${ }^{401}$, obedeciendo

\footnotetext{
397 TUDELA (2001) p. 151.

398 Rubio Llorente (1995) p. 19.

399 GARCÍA-ESCUDERO (2011) p. 220.

400 TUdELA (2001) p.153. Cabe destacar que en su obra el autor expone, que estima que el procedimiento legislativo del Estado liberal es desgraciadamente similar al que perdura en nuestros días.

401 RUBio LLORENTE (1994) p. 26.
} 
reglas de mayoría; y segundo, que fuera razonada o sea, que fuera producto de un debate participativo en el cual los parlamentarios realizaran un trabajo intelectual importante arrojando como resultado el mejor texto normativo posible. La ley, como fuente única y primaria del ordenamiento jurídico, gozó de un sitial privilegiado por un largo período de tiempo. Como se expusiera anteriormente, se divinizó al Parlamento y con él a su función legislativa, pero tal predominio tuvo una fecha de término.

De conformidad al ciclo bélico experimentado a raíz de las guerras mundiales y de los totalitarismos vividos por las sociedades europeas, nuevamente se promueven fuertes transformaciones políticas e institucionales. En los últimos albores de la época decimonónica, primó el valor por principios superiores e inalterables tales como el irrestricto respeto de los derechos humanos esenciales, la voluntad general expresada en el principio de la mayoría efectiva, el sufragio universal, la seguridad jurídica y política.

En definitiva, prima el principio democrático, principio que debía estar contenido y consagrado en un cuerpo legal superior a la ley, que brindara una efectiva protección a los ciudadanos y que no fuera modificable fácilmente por las posibles manipulaciones y fluctuaciones del Parlamento. A partir de esto, comenzará a declinar el rol protagónico de la ley $y$, por ende, del órgano representativo. Se visualiza a la Constitución Política como el único mecanismo jurídico verdaderamente proteccionista de los valores esenciales de un pueblo. La ley deja de poseer una posición primaria como fuente normativa de la protección del ciudadano y del ordenamiento jurídico. Se coronará a la Constitución como precepto fundamental, reguladora y protectora de todo el ordenamiento político-jurídico, y desde aquel momento todos los órganos y facultades -incluyendo obviamente al Parlamentoestarán bajo su imperio y nacerá la jurisdicción constitucional.

Finalizando el siglo XIX y comenzando el siglo XX, las transformaciones continúan pero cambian de orientación. Culminan las reformas políticas y comienzan a surgir las reformas sociales. Con el nacimiento del Estado social nuevamente la relación entre la sociedad y el Estado se ve alterada; durante el Estado liberal planteamos que el eje central era la libertad como antecedente indispensable de la dignidad, por ende, sus valores eran la seguridad, convivencia pacífica y la 
propiedad. Con el arribo del Estado social, la dignidad humana se transformaría en una condición para la libertad, por tal motivo las condiciones sociales en las que desarrollará la nación no son indiferentes ${ }^{402}$.

Según García-Pelayo, de esta manera el Estado liberal se deja atrás y con ello también la justicia conmutativa, porque el Estado social se sustentará en la justicia distributiva. Desde esta perspectiva, el Estado estará preocupado por proteger a la sociedad y pondrá sus acentos en el bienestar social. Con todo, el nuevo Estado social contemplará como premisas indispensables el desarrollo de la vida humana y para ello, deberá asegurará determinados aspectos vitales. En tal escenario, deberá otorgar ciertas prestaciones sociales que no sólo deben estar proclamadas, sino también garantizadas por los textos constitucionales.

Por tanto, ahora ya no se trata de distribuir derechos formales, sino que se trata de distribuir prestaciones respecto de las cuales el Estado asume una responsabilidad. La nación no cambiará, pero sí se modificarán las formas sociales que la conforman. Se habrá de superar la estructura social capitalista por una forma de vida superior, basada en la participación de todos los estratos en los bienes económicos y culturales.

En dicho contexto, se concibe al Gobierno como un órgano más efectivo en su gestión, estimulando su supremacía política e incluso legislativa. De esta manera, se fue desarrollando el pensamiento de que la ley no era la única fuente del derecho y que, por cierto, el Ejecutivo no solamente se debía limitar a aplicarla o ejecutarla, sino que también necesitaba poder crear sus propias normas que le permitieran funcionar de manera más expedita, hacia un gobierno eficiente. Se esperaba del Poder Ejecutivo la posibilidad de aplicar soluciones rápidas y concretas a problemas urgentes de manera racional. Se requería celeridad y unidad de propósitos para solucionar los problemas y no era posible esperar la deliberación ni arriesgarse a la publicidad de un debate parlamentario ${ }^{403}$.

402 García-Pelayo (1982) p. 26.

403 TAPIA (1960) p.20. 
Como consecuencia de que el Parlamento pierde su supremacía, se considera al Ejecutivo como el heredero natural o reemplazante de aquel sitial, surgiendo con ello además la facultad de crear normas jurídicas a través de una potestad colegisladora. Mediante el surgimiento del Estado social, el Ejecutivo se vislumbra como más efectivo pero el Parlamento se configura como ente de participación, a través del cual han de deliberarse participativamente las decisiones del Estado. A su vez, se promoverá la formación de órganos especializados como las comisiones adhoc. En tal contexto, las demandas sociales se plantean al Estado a través de los partidos políticos, organizaciones de intereses o agrupaciones laborales, entrando en interacción la sociedad y el Estado. Por tanto, la democracia igualmente recibirá influencias de tales movimientos, en virtud del Estado de partidos y sus efectos. No obstante, continúa siendo el mejor régimen para enfrentar tales cambios ${ }^{404}$.

Entonces, la ley como gran instrumento jurídico y político, y como fuente primaria del derecho, sufrirá los embistes del desarrollo histórico de la evolución y de las necesidades de las instituciones de la fase de post-guerras. Producto de este giro radical en la concepción de la ley, se transitó hacia una legislación que no tenía un origen ni un debate parlamentario. La ley era producto de las ideas y necesidades del Ejecutivo, proceso en el cual el rol del Parlamento -como expresa Tudela- fue muchas veces puramente testimonial. Tal situación dibujó un escenario político en el cual la norma se constituye como el instrumento jurídico para desarrollar programas ideológicos ${ }^{405}$.

El fortalecimiento del Gobierno y la compleja realidad que impuso consecutivamente el Estado de partidos, fueron una oportunidad para que la norma se viera nuevamente afectada. El mandato de partido implicó dejar a un lado la representación nacional tradicional cercana al ciudadano, los representantes ya no obedecían directamente a la nación, sino que recibían órdenes de las cúpulas de los partidos políticos, quienes ejercían una función de verdaderos canalizadores de las necesidades del pueblo. En principio, y como manifestación de lo anterior, deja de existir el tradicional debate parlamentario. Ya no se producirá un diálogo deliberativo, ahora solamente se traerán a colación posturas ideológicas que cada

404 García-Pelayo (1982) Pp. 50 y 51.

405 Tudela (2001) p. 157. Para Tudela tal fenómeno provoco la pérdida o deterioro de la seguridad jurídica la norma ahora realiza, toda vez que se crearán leyes en abundancia y su finalidad será crear políticas públicas, fomentando una naturaleza tecnocrática de la ley que dificulta su conocimiento por parte de la ciudadanía e incluso por legos. 
conglomerado político ha definido con anterioridad, sin posibilidad de alterar alguna de las decisiones que ya han sido tomadas y definidas por las élites partidarias en otros espacios políticos, es decir, extramuros del Parlamento.

Por consiguiente, el foro de discusión parlamentaria se torna una simple etapa mecánica y obligatoria que no modificará ninguna mirada ni auxiliará la adopción de nuevas interpretaciones. Es sólo un procedimiento que pretende ser participativo, en el cual la ley dejará de ser un producto razonado y pasará a ser el resultado de un equilibrio de intereses. Se produce lo que Rubio Llorente describe como "destronamiento de la ley"406.

En esta oportunidad volveremos a señalar lo dicho respecto de la representación política -en cuanto al comportamiento del Parlamento en el Estado de partidos- y la disciplina partidaria, toda vez que a nuestro juicio el desarrollo de la institución no necesariamente fue un incólume foro netamente racional y deliberativo. Por el sólo hecho de ser una actividad política, ésta siempre debió haberse visto influenciada por las tendencias ideológicas de la época o de las presiones de algunos grupos sociales poderosos, no sería del todo preciso afirmar que la deformación de la ley es resultado exclusivo de la democracia de partidos.

Desde esta perspectiva, surge la necesidad de dotar al Parlamento de procedimientos que estén acordes con la nueva realidad democrática. En esta oportunidad, los procedimientos parlamentarios toman mayor relevancia y, en particular, el procedimiento legislativo, puesto que deberá ser éste el que dé garantías de participación a todas las fuerzas políticas y permita transparentar las decisiones del Parlamento. Desde nuestra visión, el procedimiento legislativo deberá cumplir una serie de requisitos como condición necesaria de la democracia, lo que le permitirá ser un garante de la participación y la representación, y -a su vez- nos permite fundamentar nuestra noción que considera al procedimiento legislativo como medio de control parlamentario.

Así, el procedimiento tendrá por objetivo someter la creación de la ley a una serie de normas que garanticen fundamentalmente la seguridad y la certeza jurídica. Como dice Vicente Garrido Mayol, la norma debe responder a un procedimiento y

${ }^{406}$ RUBio (1994) p.30. 
conocimiento de la realidad fáctica y jurídica en la cual actuará, proceso que deberá ser transparente, generando confianza y aceptación por los ciudadanos ${ }^{407}$. Por ello, y siguiendo a Paloma Biglino, diremos que el procedimiento legislativo impone la concurrencia de requisitos esenciales como: la publicidad, respeto de la voluntad de la mayoría parlamentaria, garantía de participación de todos sujetos interesados y la participación en un plano de libertad e igualdad en el debate de parte de los todos los parlamentarios ${ }^{408}$. Aquellos rasgos esenciales son precisamente los que permiten fundamentar nuestra noción que aspira ligar al procedimiento legislativo con el control parlamentario.

En este orden de ideas y como bien explica García Martínez, el Parlamento como órgano de representación de la nación ha de cumplir mediante él una finalidad esencial, cual es, establecer una relación política con la comunidad política. En este sentido, y en su calidad de cuerpo representativo, los procedimientos como el legislativo han de tener una duración necesaria para que todas las fuerzas políticas puedan plantear a través de ellos sus posiciones. El procedimiento parlamentario es una garantía del acceso de las minorías a la función parlamentaria y, finalmente, la publicidad del procedimiento le permite vincularse con la comunidad y proyectar su trabajo hacia la sociedad, presentando una incidencia directa en la formación de la opinión pública. De esta manera, la conexión entre la publicidad y la opinión pública se ve reflejada en última instancia en el control que ejercerá el cuerpo electoral a través de las elecciones periódicas ${ }^{409}$.

Como es posible percibir, los rasgos cardinales del procedimiento parlamentario favorecen las condiciones necesarias para que pueda desarrollarse el control parlamentario, principalmente, si consideramos que la finalidad última de los mismos será su comunicación hacia la comunidad política y con ello la evaluación de la gestión parlamentaria.

Tal como describe García Morillo, en la actualidad el Parlamento no cumple una función auténtica de producción legislativa como antaño, empero se trata de una atribución que habrá de convalidar, supervisar y velar por su introducción en el ordenamiento jurídico, que mira a la luz de la realidad española y a la relación

\footnotetext{
407 GARRIDO (2010) p.22.

408 BigLiNO (1991) Pp. 73 y 81.

409 GARCía (1987) Pp. 45 a 55.
} 
Gobierno-Parlamento, el cual cumple el rol de un control interorgánico. Mediante éste la mayoría parlamentaria puede, con más propiedad, realizar su función de verificar la actuación del Ejecutivo. Las minorías menos influyentes contarán con poder de influencia, debido a que en las actuales democracias los consensos políticos son tremendamente deseados. Por ello, el Ejecutivo buscará la mayor cantidad de apoyos para lograr la mínima constatación, se generarán diálogos que podrán favorecer la inclusión de algunas de sus peticiones. En ese contexto, el proceso legislativo cumple un rol de mayor relevancia en términos de contra $y$, en definitiva una mayor relevancia en el sistema democrático, porque le otorga publicidad a las posiciones y razones del Gobierno, y de los grupos parlamentarios ${ }^{410}$.

En este sentido, el órgano representativo encuentra en su propia estructura las soluciones necesarias para continuar siendo el espacio político de participación y de construcción del consenso de la nación. A pesar del supuesto debilitamiento de la ley y del Parlamento, la norma continuará siendo un mecanismo efectivo para regular las relaciones entre las personas y seguirá siendo la manifestación de la voluntad general, garantizando de alguna manera la representación y participación del pueblo, además de otorgar grados de publicidad a la gestión política necesaria para la correcta evaluación por parte del electorado de la gestión.

Otro aspecto a considerar en relación a nuestra interpretación que vincula al procedimiento legislativo con el control parlamentario, es la preponderancia que en esta materia posee el Ejecutivo. Es imposible negar que el poder de la agenda legislativa lo posee el Ejecutivo de iure y de facto. Existe una percepción generalizada de que el Legislativo en los tiempos modernos cumple una función marginal en relación a las facultades de las cuales goza el Ejecutivo, ya sea por la posibilidad de utilizar la tramitación de urgencias o por su capacidad de centralizar la toma de decisiones.

En efecto, durante el siglo XX se produce la transferencia gradual de la capacidad de establecer las normas de la legislatura para el Ejecutivo, reduciendo con ello la facultad de orientar las direcciones políticas del Estado por parte del Parlamento. No obstante, el Ejecutivo siempre ha de necesitar el apoyo de la legislatura para gobernar; habitualmente se ve obligado a negociar su agenda para

${ }^{410}$ GARCÍA (1991) Pp. 131y 132. 
poder aprobarla, lo que permite poder formular ajustes a dichas propuestas. El proceso legislativo está sujeto constantemente a cambios y mejoras. Si bien el Ejecutivo podrá utilizar herramientas estratégicas para controlar y aprobar la agenda $^{411}$, ello no será del todo posible conforme a las contantes restricciones que pueden ejercerse en el seno parlamentario, actividad que -a nuestro juiciocomprende una verdadera facultad de control parlamentario. Hemos de aclarar que, en este sentido, nos referimos a las saludables reconsideración y aportación de indicaciones y modificaciones a la tramitación de leyes, y no a aquellas conductas parlamentarias que sólo pretenden ejercer un obstruccionismo parlamentario ${ }^{412}$. Por estos motivos estimamos que mediante la función legislativa en la actualidad se cumplen dos finalidades: una debilitada facultad de dirección política, y otra más fortalecida de control parlamentario.

La dirección política como primera finalidad, es sostenida y desarrollada en profundidad por la doctrina italiana y también por un sector de la doctrina española. Dicha teoría comprende que la función legislativa es una función de indirizzo política o dirección política estatal. Como dice Aragón Reyes, la función legislativa alcanza su máxima expresión cuando ejerce dirección política ${ }^{413}$, puesto que los proyectos de ley de los legisladores también permiten orientar el rumbo de la política nacional. 0 bien, como expresa Andrea Manzella, en el proceso legislativo se configurarán con más fuerza las mayorías y minorías, porque es allí donde existe indirizzo político; es allí por naturaleza donde se produce una contraposición dialéctica ${ }^{414}$ entre las diversas orientaciones políticas. Reconoce que en la actualidad la relación existente entre mayoría-gobierno dificulta el ejercicio de tal rol orientador, lo cual es totalmente congruente con la facultad de la cual goza el Gobierno de direccionar la política a fin de cumplir su programa, posicionándose éste como el mayor instructor.

Otro autor que también se refiere a la capacidad de indirizzo político por parte de la facultad legislativa, es León Martínez, quien considera que existen manifestaciones de impulso político en el procedimiento legislativo. A propósito de lo

411 SilVERIRA Y VAZ (2010) Pp. 1,2 y 3.

412 GONZÁLEZ DE ZÁRATE (2012) p. 189. Para mayor abundamiento en esta materia revisar la obra citada en la cual, el autor señala que las actividades obstruccionistas pueden ser activas y pasivas dependiendo de si las ejercen minorías o mayorías, como también pueden ser técnicas o físicas, la utilización de una u otra dependerá de la finalidad perseguida, no obstante, son conductas que tendrá como objetivo último habitualmente el entorpecimiento del funcionamiento del debate y por ende de las sesiones.

413 ARAGÓn (1998) p 284.

414 MANZELLA (2003) p. 422. 
anterior, entenderemos que la presentación de propuestas y enmiendas en colaboración con otras fuerzas políticas permiten que mediante proyectos normativos se direccionen los destinos públicos ${ }^{415}$. Con todo, es efectivo que la ley tuvo y tiene en menor medida en la actualidad- una función de dirección política. Ello se ha visto debilitado -como lo señaláramos anteriormente- por el reforzamiento del Ejecutivo, además de las reservas legales existentes, motivo por el cual opinamos que al no poder instituirse al Parlamento como el único promotor de la política pública, quedando esta función supeditada a las decisiones del Ejecutivo, se verá obligado a ejercer con mayor fuerza y rigurosidad el control parlamentario de las normas que ya no emanan de él. No obstante lo anterior, sí puede reorientar en los casos que estime pertinente y con ello redirigir los itinerarios políticos del Gobierno. A nuestro juicio, un ejercicio de control fortalecido en el proceso legislativo, le permite nuevamente al Parlamento influir en las direcciones políticas del Estado.

La segunda finalidad de la función legislativa como expresión del control parlamentario, encuentra sustento en las declaraciones del profesor Sartori, quien expone que el Poder Legislativo del Parlamento nace precisamente como un "control político $^{\prime 416}$. Este control no solamente buscaba arrebatarle al Rey la capacidad de crear la ley, sino que además aspiraba a que el gobernante quedara sometido a la misma, rasgos nucleares que encontraban asidero teórico en el Estado de derecho y la división de poderes -todos mecanismos que el constitucionalismo fue instaurando a fin de proteger a los ciudadanos limitando al poder-. Como bien explica el autor antes señalado, el ideal último y razón de ser del constitucionalismo se resume en la protección de la ley, por contener como presupuesto base el sometimiento de los gobernantes a las mismas leyes. Desde nuestra perspectiva, la función legisladora es y se presenta como manifestación del control parlamentario no sólo por ser en sí misma una barrera de las acciones de la autoridad, sino porque además el procedimiento legislativo es el espacio en torno al cual se debatirá gran parte de la política nacional y se desarrollarán las políticas públicas, y, en general, los lineamientos políticos de mayor trascendencia para el pueblo.

Con todo, el procedimiento legislativo aún otorga la posibilidad de debatir y formular enmiendas por parte de todos los sectores políticos, provenga de donde provenga el proyecto de ley, a fin de orientar y señalar directrices en los sentidos

\footnotetext{
415 MARTÍNEZ (2000) p.139.
}

416 SARTORI (1992) p.193. 
más acordes a la voluntad y necesidades de los ciudadanos. Junto con lo anterior, es un medio ordinariamente público que además aporta información a la sociedad a través de la cual pueden evaluar la gestión de sus representantes. En este sentido se ha expresado Aragón, cuando describe que el control de la norma no necesariamente es jurídico. Cuando tal control de la norma lo realiza un órgano político y con criterios políticos de valoración, dicho control no puede de ninguna manera ser conceptuado como jurídico, sino como político ${ }^{417}$.

Por su parte, la producción normativa se configura como un espacio en el cual creemos que todos los actores políticos del órgano representativo pueden ejercer un rol fiscalizador, porque tiene un derecho de participar, a estar presentes y a expresar sus posibles indicaciones, sea en comisión o en el pleno. Es la instancia en la cual se puede generar un contrapeso a la gran potestad legislativa del Ejecutivo, razón por la cual además contribuye en la revitalización de la división de poderes y en la aplicación de los pesos y contrapesos del sistema democrático. En igual sentido, sectores de la doctrina francesa se han expresado por esta interpretación. En efecto, para Armel Le Divellec el control y la legislación están íntimamente vinculados porque a la hora de legislar se está ejerciendo control, concepción que el autor reconoce como compleja, puesto que adoptar esta mirada implica abandonar ideas tradicionalmente adquiridas ${ }^{418}$.

Ahora bien, sostener lo antes descrito implica seguir una interpretación amplia del control parlamentario, noción doctrinal que permite suponer que el Parlamento tiene como rol genérico la limitación, el control y la fiscalización. En consecuencia, todas sus actividades parlamentarias y todas sus competencias están dirigidas directa o indirectamente a realizar alguna forma de control ${ }^{419}$, argumento que profundizaremos en detalle cuando tratemos al control como función en particular ${ }^{420}$. Sin embargo, en esta etapa de la investigación diremos que seguir tal línea doctrinal permitirá concluir que todas las funciones parlamentarias tendrán en su seno rasgos de control, incluso la función legislativa. En este sentido, conforme a lo descrito por Giuseppe Graterol, estamos por sostener que "no existe una teoría

\footnotetext{
417 ARAgon (1986) p.14.

418 LE DiVELLEC (2010) p. 130.

419 GARCÍA (1988) p. 66.

${ }^{420}$ Sin embargo, desde ya diremos que esta interpretación amplia del control parlamentario es sostenida por Manuel de Dios Sánchez, Manuel Aragón Reyes, Rubio Llorente y León Martínez y en el plano nacional por Francisco Zúñiga Urbina.
} 
absoluta del poder, ni una única forma de controlarlo"^21, por tanto, la concepción de la función de control parlamentaria ha de adaptarse a las dinámicas actuales en las relaciones Legislativo-Ejecutivo; la mutación del poder impone la necesidad de que el control parlamentario pueda adoptar peculiares mecanismos. En ese orden de ideas, es posible comprender que allí donde el Parlamento tenga una oportunidad de controlar, debe hacerlo.

\section{b.2.2. El control parlamentario en la ley de presupuesto nacional}

Conforme a lo expuesto anteriormente, hemos de graficar y profundizar nuestra conjetura de considerar al procedimiento legislativo como sede de ejecución del control parlamentario, especialmente, en lo que relativo a la aprobación del presupuesto de la nación, considerando la relevancia y envergadura de la materia. Teniendo presente lo descrito precedentemente -en cuanto al poder de agenda del Ejecutivo y las debilidades de la función parlamentaria-, hemos de concordar que la elaboración de la ley de presupuesto esencialmente está entregada al Ejecutivo, y por tanto, la participación de las fuerzas políticas de mayoría y de minoría sólo podrá efectuarse en el respectivo debate legislativo, proceso que -según nuestra miradapuede configurar una gran oportunidad para examinar la eficiencia y eficacia de la gestión de la administración del Estado, conforme su desempeño económico.

En definitiva, en el marco del proceso presupuestario, se obtiene particularmente información de tal magnitud para los parlamentarios que permite abrir espacios que pueden orientarse en dos sentidos: por una parte, se puede realizar una evaluación respecto del futuro cumplimiento del programa político y, en cuanto a ellos, formular los análisis comunicacionales que se estime pertinentes; 0 , por otra parte, pueden detectarse ciertos aspectos en relación con los actos del Ejecutivo de tal peso que, a su vez, puedan originar otros procedimientos de control parlamentarios específicos.

Respecto de este punto, cabe recordar que la función económica o financiera relativa a la aprobación de impuestos, gastos e ingresos del Estado, es aquella función tradicional y esencialmente ejercida por las antiguas asambleas

421 GRATEROL (2013) p.6. 
representativas estamentales, incluso mucho antes que la facultad legislativa. En efecto, en las asambleas predecesoras a los Parlamentos modernos se desarrollaba la función legislativa como una función subsidiaria a la función financiera, toda vez que la actividad primordial de dichos organismos era la de emitir (o no) una autorización que permitiera otorgar o aumentar los subsidios o tributos previa solicitud de los monarcas para el cometido de sus fines. Esta instancia desde aquella época comprendía un espacio de negociaciones entre los estamentos y la Corona, ya que las asambleas a cambio de otorgar dicha autorización -la cual comprendía obtener nuevos recursos o aumentar los ingresos de los monarcas-, solicitaban el establecimiento o aprobación de ciertas disposiciones, configurándose con ello la única oportunidad en la que era posible obtener ciertas garantías normativas para la sociedad estamental, a cambio de la aprobación de los fondos solicitados.

Tal es la relevancia de la función financiera, que Santaolalla la define como "una de las funciones definitorias por excelencia de los Parlamentos" ${ }^{422}$. En la actualidad, el ejercicio de la función financiera sigue siendo uno de los aspectos más relevantes en las relaciones Parlamento-Gobierno, puesto que a través de tal debate en torno al presupuesto general de la nación se produce la relación más directa entre el programa de gobierno y su aplicación efectiva, vale decir, su viabilidad presupuestaria $^{423}$. Ciertamente, la designación de recursos será determinante en la gestión que ha de ejecutar la administración pública, y por ello será concluyente en la realización y cumplimiento del programa de gobierno propuesto a la ciudadanía por el Gobierno electo. En consecuencia, repercutirá en la evaluación que la sociedad civil realice respecto de la gestión del gobernante. Como bien dice Melado, "el presupuesto es la expresión numérica del programa político"1424, ya que es la función que ha definido históricamente al Parlamento y -a su vez- al desarrollo de la democracia.

Ahora bien, debemos señalar que la actividad legislativa que se realiza mediante la aprobación de la ley de presupuesto ha sido definida y clasificada según varios autores ${ }^{425}$ como una función financiera o presupuestaria, es decir, la tratan de forma autónoma y separada a la función de control. A partir de eso, podemos

\footnotetext{
422 SANTAOLALLA (1984) p. 196.

423 GUTIERREZ et alt (2001) p.75.

424 MELADO (2007) p. 163.

${ }^{425}$ En este sentido José y Ángel Antonio de Alonso, Santaolalla, Solís, Bronfman, Cordero y Aldunate.
} 
deducir que al realizar dicha distinción respecto de las otras funciones -y especialmente de la función de control-, existen dos posibles interpretaciones. La primera de ellas, podría significar una estrategia metodológica a fin de analizar de forma separada y en detalle tal función, debido a la relevancia de la misma sin importar aquello que se pueda generar en su desarrollo. Así, existen posibles ámbitos de control parlamentario y ello no entorpece su análisis aislado. La segunda de ellas, podría dejar de manifiesto un juicio que considera como funciones diversas a la función financiera respecto de la función de control, lo cual implicaría comprender que entre dichas funciones no existe relación alguna y que no cabe la posibilidad de ejercer control parlamentario mediante su tramitación.

No obstante, estos mismos autores se muestran contestes respecto a la gran importancia que tal proceso contempla en la relación Parlamento-Gobierno, y resaltan el diálogo que ha de realizarse entre mayorías y minorías. En este sentido, exponen José y Ángel Antonio de Alonso que la discusión de la ley de presupuesto es el momento parlamentario más importante, pues allí está en juego la orientación política del Estado al establecer una prelación de necesidades a satisfacer y el montante económico destinado al efecto. Tan relevante es dicha instancia que permite además calibrar la fuerza que posee el Gobierno en el Parlamento ${ }^{426}$.

Por consiguiente, desde nuestra perspectiva, creemos que la denominación que otorgan a esta función los autores arriba indicados, no sería un obstáculo para entender a dicho procedimiento legislativo como una instancia de control parlamentario, dada la trascendencia política que posee y la posible influencia que podría tener en la ejecución del programa de gobierno, es decir, en los actos del Ejecutivo, actos que -como veremos más adelante- son el objeto central del control parlamentario.

Como prueba de aquello, tenemos el debate sobre la ley de presupuesto del año 2012 -generado en el Congreso Nacional durante el año 2011-. En dicha oportunidad, el tono de las conversaciones fue extremadamente beligerante, generando una serie de amenazas provenientes de la oposición del momento (Concertación de Partidos por la Democracia), tendientes a no aprobar la mencionada ley. Por su parte, el presidente Piñera debió discutir el tema en

${ }^{426}$ ANTONIO DE ALONSO (2002) Pp. 182 y 186. 
reiteradas ocasiones en su domicilio particular, junto a sus ministros, hasta altas horas de la madrugada. Incluso debió suspender una de las salidas del país y retornar con suma urgencia. En este escenario, una de las críticas de la oposición fue la falta de transparencia en la información entregada por el Ejecutivo en relación a la ley de presupuesto, falta de información tan compleja, que los parlamentarios del bloque opositor redactaron un documento titulado "anuncios sin respaldo" -el que fue difundido con máxima publicidad-, a través del cual evidenciaban las debilidades políticas del proyecto y expresaban una fuerte crítica. Otro aspecto mayormente cuestionado en tal oportunidad -generando el quiebre entre ambos poderes-, fue el relacionado con el presupuesto destinado a Educación, materia de suma relevancia nacional, toda vez que nuestro país aún desarrollaba un acalorado debate social, académico y político en torno a las demandas ciudadanas que exigían una reforma al sistema educacional.

La situación política era compleja, y tal fue el nivel de la discusión que el oficialismo finalmente formula un ultimátum a la oposición, mediante el cual planteaban la posibilidad de resolver algunas partidas presupuestarias a través del Tribunal Constitucional, arista que provocó más revuelo político. En virtud de aquello, ingresaron al debate los ex Presidentes de la República -particularmente Ricardo Lagos Escobar-, haciendo un Ilamado al orden y emite declaraciones solicitando que se restablezca el diálogo amigable, solicitando que se descarte la vía jurisdiccional constitucional por la gravedad política que ello implicaba.

En consecuencia, la ley de presupuesto se sitúa en un lugar político de suma importancia, configurando un espacio de control político de gran trascendencia para el sistema democrático, puesto que en ella se materializa la gestión pública del Gobierno. Es la oportunidad en que la oposición podrá conocer de forma certera las políticas públicas y las orientaciones programáticas de su contendor; tendrá acceso a las finanzas públicas y así supervigilará el gasto que en ellas se invierte. Adicionalmente, es el momento en el cual muchos gozarán de una visibilidad mediática superlativa, y por tal motivo varios parlamentarios querrán plantear una crítica, una discrepancia o incluso propondrán alguna alternativa. Suele ser un momento clave para el Congreso y para el control político. El manejo político que se realice de ello podrá fortalecer o debilitar al Ejecutivo. Por otra parte, pondrá en evidencia las capacidades y debilidades de la oposición, considerando el nivel técnico 
que el análisis de dicha norma requiere. Por lo dicho anteriormente, concluimos que la ley de presupuesto configura uno de los momentos parlamentarios más significativos del control, pero aclaramos que no necesariamente permite obtener grandes modificaciones en el texto mismo, empero, gesta un momento político en el cual el control -entendido como crítica y corrección de la acción del Ejecutivo- se expresa en plenitud.

Por nuestra parte, hemos de señalar que la idea en cuanto a la estrecha relación control-presupuesto ha sido desarrollada por la doctrina. En efecto, existen interpretaciones en dirección de contemplar al proceso presupuestario como una instancia de control parlamentario. En dicho itinerario, encontramos lo expuesto por Gutiérrez, Lujambio y Valdés quienes señalan que en un sistema de separación de poderes, el Congreso no juega un papel meramente constructivo en la definición del presupuesto, sino que especialmente ejerce un papel de control-autorización, como también juega un papel de control-inspección, puesto que en regímenes de división de poderes cabalmente responsable es impensado no ejercer el debido juego de equilibrios y contrapeso en aquella función. Es impensado no ejecutar mediante el monitoreo congresional constante un control a los actos del Ejecutivo de contenido económico $^{427}$.

En armonía con lo antes descrito, podemos traer a colación la descripción que realiza Ana Isabel Melado, quien afirma que en el debate presupuestario hay control, señalando que cualquier observador de la vida diaria del Parlamento podría constatar que los procedimientos parlamentarios son, generalmente, multifuncionales. De acuerdo a esto, el proceso presupuestario y la información contenida allí puede activar otros procesos de control e incluso puede proporcionar el sustento para formular propuestas alternativas de actuación política, o bien redactar un futuro programa de gobierno. Para la autora, no hay en rigor procedimientos parlamentarios de control porque el control es simplemente una perspectiva desde la que puede analizarse toda la actuación parlamentaria, o una función que todo auténtico Parlamento desempeña mediante el ejercicio de toda su actividad. Por consiguiente, durante la tramitación del presupuesto el control ha de poder ejercerse mediante una crítica de la actividad de la administración pública y, más trascendente aún, se da la posibilidad de incidir sobre la potestad de dirección política del

427 Gutierrez et alt (2001) Pp. 81 y 82. 
Ejecutivo. Para Melado, es de toda lógica jurídica y política que pueda el Parlamento expresar sus opiniones y observaciones concretadas en enmiendas en dicho proceso presupuestario $^{428}$.

Por su parte, hay quienes señalan que, a pesar de las insuficiencias que poseen las Cámaras en el debate mismo y en su capacidad de evaluar los resultados y objetivos del Presupuesto, sigue siendo dicha instancia un ámbito de control donde más podría avanzar el Parlamento, ya que si bien no se definirán ciertas materias de gasto podrá por defecto analizar la eficacia de la gestión del Gobierno. Para Martínez, el control que realizan las Cámaras en el proceso financiero es un modelo del parlamentarismo racionalizado que persigue corregir los excesos en las funciones encomendadas al Ejecutivo, por parte de la mayoría parlamentaria ${ }^{429}$.

En nuestro escenario nacional, la ley de presupuesto se encuentra regulada por la Constitución Política de la República. En sus artículos 65 y 67 señala que la ley de presupuesto es delineada por el Ejecutivo y presentada por el Presidente de la República al Congreso Nacional, debiendo tener su origen en la Cámara de Diputados, tres meses antes de la fecha en que debe comenzar a regir. Por su parte, el Congreso cuenta con un plazo de sesenta días para debatirlo y de no ser aprobado en dicho plazo, comenzará a regir el presupuesto presentado por la Presidencia. Como bien expresan Bronfman, Cordero y Aldunate, el retraso por parte del Congreso en el despacho de la ley de presupuesto acarrea como consecuencia la aprobación tácita del proyecto presentado por el Presidente de la República ${ }^{430}$.

En cuanto a las facultades que posee el Congreso en tal proceso, éstas parecen ser muy débiles. Así, el inciso 2 del artículo 67 expone respecto de los ingresos que, "El Congreso Nacional no podrá aumentar ni disminuir la estimación de los ingresos; sólo podrá reducir los gastos contenidos en el proyecto de Ley de presupuestos, salvo los que estén establecidos por ley permanente". Respecto de los gastos, declara el inciso 4 del artículo 67 que "No podrá el Congreso aprobar ningún nuevo gasto con cargo a los fondos de la Nación sin que se indiquen, al mismo tiempo, las fuentes de recursos necesarios para atender dicho gasto". Con ello, queda en evidencia las debilitadas atribuciones que en esta materia posee el

\footnotetext{
428 MELADO (2007) Pp. 164 y 173.

429 MARTÍNEZ (2007) p. 138.

430 Bronfman et alt (2013) p. 376.
} 
Congreso, sin perjuicio de aquellas especiales negociaciones ${ }^{431}$ que puedan producirse, peticiones que se someten a dilatadas conversaciones en las que habitualmente se producen solicitudes regionales o distritales, las que se utilizan como herramientas de apremio frente al Ejecutivo a cambio del voto favorable de la Ley. Es por ello que existe una atenuada posibilidad de orientar la dirección política del Gobierno.

No obstante, existe un factor que puede generar una diferencia respecto de aquellos supuestos de debilidad que indicáramos arriba. El único elemento que ha de poder provocar una situación distinta en la tramitación de la ley de presupuesto es la composición del mismo Congreso, y con ello nos referimos al hecho de que el Gobierno cuente o no con mayoría parlamentaria, o como dice Graterol, examinar si estamos o no frente a un presidencialismo mayoritario ${ }^{432}$. La posibilidad de no contar con la mayoría parlamentaria necesaria para aprobar dicha ley sitúa al Ejecutivo en una situación compleja que lo obliga a negociar con mayor flexibilidad ${ }^{433}$. Lo anterior, desde un primera aproximación parece un tanto extraño si consideramos que conforme al artículo 67 de la Constitución Política de la República, el presupuesto presentado por el Ejecutivo ha de aprobarse tácitamente a pesar de que el Congreso no lo apruebe en el plazo indicado.

Empero, no basta para el Gobierno con la sola aprobación del presupuesto, sino que además debemos tener presente que todas las demás leyes de la agenda legislativa del Ejecutivo sean consideradas como parte del programa de gobierno y han de tramitarse en el Congreso. En consecuencia, quebrar las relaciones entre ambos poderes por la sola aprobación del presupuesto, puede significar para el Ejecutivo una pésima estrategia política. Por tanto, en cuanto a esta ley si bien las facultades legales de los parlamentarios pueden verse disminuidas, el contexto político ha de ser un factor transcendental a la hora de llevarse a cabo su

${ }^{431}$ En esta materia ver: DöRING (2001) Pp. 146 y 147. Oportunidad en la que señala mecanismos o formas en las que se puede producir la influencia legislativa.

432 GRATEROL (2013) p. 4. Frente a este punto, señala el autor que estamos en presencia de un presidencialismo mayoritario cuando un partido de gobierno además de ostentar el poder ejecutivo, goza de un bloque parlamentario mayoritario.

433 A modo de ejemplo, podemos señalar el debate presupuestario que debió enfrentar el Presidente Piñera particularmente el año 2013 cuando no poseía mayoría parlamentaria, oportunidad en la que fueron rechazadas las partidas presupuestarias de Salud y Educación. Esta situación incomodó a tal punto al Gobierno que instó a que el Presidente de la República desde una gira internacional en Turquía hiciera un llamado a actuar con "seriedad y responsabilidad" a los parlamentarios. Información contenida en el diario online "La Tercera" disponible en: http://www.latercera.com/noticia/politica/2012/11/674-4942869-pinera-por-ley-de-presupuesto-quiero-llamar-a-los-parlamentarios-a-actuar-en.shtml. Página web visitada con fecha: 11.08.2015. 
tramitación, la cual puede generar condiciones diversas en su relación GobiernoParlamento.

\section{b.2.3. El rol de las mayorías y minorías en el procedimiento legislativo}

El control parlamentario en la creación legislativa es realizado esencialmente por minorías -qué duda puede caber al respecto-, pero debemos agregar que desde nuestra perspectiva también es realizado por las mayorías. Si partimos del entendido que el Gobierno goza de un derecho y deber de dirigir la dirección política nacional, debemos de asumir lógicamente que intentará materializar su programa político mediante políticas públicas que en muchas ocasiones deben tomar forma de Ley. Es en esa circunstancia donde se gesta el poder de agenda, pero también la posibilidad de evaluar y examinar a través del debate parlamentario-legislativo dichas direcciones políticas del Ejecutivo. En ese momento se está controlando las intenciones político-legislativas del Ejecutivo y podrán enmendarse o corregirse en el sentido que se estime prudente, tanto por las minorías como por las mayorías. En este sentido se han expresado Sartori, Aragón Reyes, Garrido Mayol, GarcíaEscudero, etc.

Continuando esta línea interpretativa, resulta relevante traer a colación el argumento sostenido por José Tudela, quien refuerza la idea de control en el ámbito legislativo reivindicando la labor de las minorías parlamentarias en dicho proceso y expone que habrá que coincidir en la extraordinaria importancia que poseen la minorías parlamentarias si se desea mantener la esencial vinculación entre Ley y Democracia. Para el autor, el procedimiento legislativo es el gran momento de publicidad, y produce la conexión más significativa con la opinión pública. Debe ser el lugar de encuentro entre lo político y lo ciudadano, dando vida al principio democrático ${ }^{434}$. En este mismo orden de ideas, a juicio de María Asunción García, dos serían los rasgos centrales de la facultad legislativa como expresión de control parlamentario en el procedimiento legislativo. Por una parte, involucra la participación de la minoría, quien siempre se configurará como ente fiscalizador del proyecto de ley, debiendo garantizarse su participación en todos los espacios y etapas del mismo -a fin de que puedan ejercer una verdadera función de control-.

434 TUdelA (2001) Pp. 176 y 177. 
Pueden formular modificaciones y hacer presente todas aquellas cuestiones que consideren que no coinciden con el espíritu de la nación. Por otra parte, el procedimiento al ser público permite que la opinión pública observe desde el inicio hasta su resultado final las acciones de los parlamentarios ${ }^{435}$, pudiendo evaluar la gestión de todos sus intervinientes y el resultado de la norma. En definitiva, sigue ejerciendo un rol democrático en las complejas sociedades actuales.

Sin embargo, estimamos necesario pormenorizar nuestra opinión respecto al control parlamentario de las mayorías en el proceso legislativo, mediante dos situaciones: por un lado, cuando en el sistema parlamentario la mayoría parlamentaria es a su vez quien habitualmente conforma el Gobierno, existe entre ambos un vínculo que es evidente; y por otro lado, cuando en un sistema presidencial la mayoría parlamentaria y Presidencia de la República coinciden en un mismo partido o conglomerado político, se configura lógicamente una afinidad en su relación.

En este contexto y siguiendo a García Escudero, diremos que efectivamente el control parlamentario en la función legislativa no es sólo una función propia de la minoría, sino que lo es también de la mayoría, toda vez que tal grupo parlamentario realizará un conjunto de gestiones tendientes a exigir al Ejecutivo que se realicen todas las labores necesarias para llevar a cabo el programa de gobierno del cual la mayoría parlamentaria también forma parte -o a lo menos lo comparte ideológicamente-, y respecto del cual se han comprometido con la ciudadanía. Lo anterior, implica necesariamente la presentación de iniciativas de ley y su aprobación debiendo estar orientadas de tal forma que permita alcanzar el fin estipulado en el programa, de lo contrario deberán realizar las modificaciones que estimen necesarias para hacerlo lo más amónico posible ${ }^{436}$.

Ahora bien, si debiéramos indicar la razón u el origen del fenómeno planteado precedentemente, ciertamente nos remontaríamos como antecedente obligatorio al surgimiento y desarrollo del Estado de partidos. Tal como describe García-Pelayo, el

435 GARCÍA (1988) Pp. 73 y 74.

436 GARCíA-ESCUDERO (1999) p.25. Lógicamente la autora se considera la existencia de control por parte de la mayoría parlamentaria en el entendido del sistema parlamentario español, en el cual, la mayoría que se configura en el Parlamento es quien está ejerciendo a la vez el Gobierno, por ende, la evaluación que la población realice respecto del ejecutivo tendrá directa relación con la apreciación que se formule respecto del partido político de mayoría parlamentaria y su gestión. Todo lo anterior fruto y consagración de la estrecha relación de confianza entre la mayoría y gobierno expresión básica del parlamentarismo. 
actor o el sujeto del poder se ve modificado, puesto que desde aquel momento los partidos políticos toman total primacía en la actividad política. Por ello, las decisiones del Estado estarán fuertemente influenciadas por los intereses de dichos grupos organizados, generando un problema en la distribución del poder ${ }^{437}$. En tal contexto, serán los partidos políticos los que manejen la actividad y la agenda política, como instrumento para la obtención del poder. De esta manera, pondrán especial interés en el actuar de sus líderes y del Gobierno por constituir el único mecanismo a través del cual expresar sus demandas y mantener el poder. De allí emanan dos ideas centrales: por una parte, la noción de orden de partido y disciplina del voto; y por otra parte, la idea de control extensivo en cuanto al sujeto activo del control, es por ello que ejercerán control las mayorías y minorías parlamentarias, porque en el fondo ambas responden a una dialéctica partidaria.

Por consiguiente, creemos que el compromiso y responsabilidad que asume el parlamentario para con sus electores de quienes depende la continuidad en el cargo, hace previsible suponer que fomentará su preocupación en cumplir con lo prometido, ejerciendo incluso presiones a sus aliados en el Gobierno para que ello ocurra, toda vez que el éxito de la actividad del Gobierno es también el triunfo de la mayoría parlamentaria que forma parte del o de los partidos políticos que están en el Ejecutivo. Por ende, la evaluación del Gobierno incide en cierta medida en la apreciación de su propia gestión. Su esmero porque se cumplan las promesas electorales será alta, lo cual lo llevará a controlar activamente a sus compañeros de filas. Punto aparte es el de las minorías, las cuales ejercerán control a todo evento, es decir, tengan o no un vínculo con el Ejecutivo. Su sola condición de minoría parlamentaria la obliga a realizar su papel primario, el del ser el ente controlador. Empero, siempre ambos sujetos controladores están motivados por una lógica partidaria común propia del Estado de partidos; tal como lo dijéramos anteriormente, dicha actividad cohesionada y disciplinada, les permite posicionar su intereses y mantenerse, o en su defecto, intentar alcanzar el poder.

437 García-Pelayo (1982) Pp. 13 y 14. 


\section{b.2.4. La función legislativa en Chile y sus manifestaciones como control parlamentario}

Desde una primera óptica, nos referiremos al origen de la iniciativa legislativa, toda vez que se ha sostenido que nuestro país responde a un sistema presidencial reforzado 438 en una democracia protegida. Variados autores ${ }^{439}$ lo han llamado régimen ultra-presidencial, gobierno presidencial de ejecutivo vigorizado, presidencial reforzado o súper-presidencial, en el que la producción normativa proviene con mayor fuerza del Ejecutivo frente al cual el "sistema de pesos y contra pesos" toma mayor relevancia ${ }^{440}$. Lo correcto es que en nuestros tiempos la ley no emana exclusivamente del Parlamento. Muy por el contrario, el Parlamento cumpliría un rol colegislador junto con el Ejecutivo, órgano que estaría monopolizando tal función. La Ley, como disposición normativa de carácter general en la actualidad es elaborada por diversos órganos, hoy es una actividad del Estado en su conjunto ${ }^{441}$.

Por otra parte, otro fenómeno que afectaría a la función legislativa y a su vez al control de la misma, es la excesiva abundancia de normas elaboradas por diversos órganos, situación que fuera denominada como "legislación motorizada" por Schmitt. Tal marea legislativa o inflación legislativa, ha provocado la carencia de prolijidad del texto normativo. La norma ya no sería un resultado de un trabajo depurado, se habría producido una decadencia en la calidad técnica de su creación, lo que imposibilitaría un correcto control de todos los textos normativos.

Lo anterior, configura una situación supuestamente anómala de suma trascendencia a la hora de analizar la función legislativa y el control parlamentario chileno, pues el elemento empírico a analizar comprendería dificultades especiales a

${ }^{438}$ Respecto de esta materia es recomendable ver: BULNES (1988). Documento en el cual la autora se refiere al Parlamento como un órgano colegislador junto al Ejecutivo y se refiere al jefe del gobierno y de estado como un presidente de la república "vigorizado".

${ }^{439}$ Cea, José Luis; Godoy, Oscar; Valenzuela, Arturo; Bulnes, Luz; Linz, Juan; en sus respectivas obras han sido algunos de los autores que se refieren en profundidad al régimen presidencial chileno y sus particularidades, reuniendo en sí mismo el presidente las calidades de jefe de gobierno y jefe de estado, analizan las nutridas facultades de que goza el presidente de la república y como estas facultades se relacionan con el poder legislativo, particularmente su calidad de colegislador y su facultad de iniciativa exclusiva, causa de la declinación de la función legisladora propia del parlamento. Algunos por su parte explican tal fenómeno señalando que esto sería el fundamento principal de la mayor profundización y ejecución de la facultad fiscalizadora.

440 Godoy (2003) Pp. 7-23.

441 ARAgón (1998) Pp. 255 y 261. Es importante subrayar que el autor expresa que tal escenario no obstaría a la necesidad de regresar a un equilibrio clásico en el cual el legislador legisla y el gobierno sea sólo un auxiliar no un suplente. 
considerar, porque el ejercicio del control en un sistema de aquellas características colocaría al ejecutor del mismo en un gran aprieto, y al investigador en el deber científico de comprobar tales hechos, examinando la veracidad de tal corriente y cómo ella influye en la ejecutabilidad del control.

Conocidos son los argumentos que señalan las "limitaciones" que posee el Congreso en la función legislativa, en razón del régimen de gobierno presidencial nacional. En efecto, Tapia expone que bajo la Constitución de 1980 "el Presidente es el gran legislador" 442 , y manifestación de aquello son las amplias materias de iniciativa legislativa exclusiva del Presidente de la República, y el sistema de urgencias. En este sentido, Valdés y Soto señalan que esta disyuntiva entre Ejecutivo y sus poderes monopólicos en materia legislativa $-y$ frente a un Congreso con reducidas capacidades-, ha intentado ser salvada por diversas vías como el fortalecimiento de la capacidad técnica de esta institución, creando el sistema de asesorías legislativas que sirvan de contrapeso al rol del Ejecutivo ${ }^{443}$.

En concordancia con lo anterior, podemos graficar en las palabras de Hernán Ampuero la visión generalizada respecto de la primacía de la facultad colegisladora del Ejecutivo, en razón de herramientas legales como las urgencias y la imposición de plazos, como también por el conocimiento de datos, información y en general la cabal comprensión que posee el Ejecutivo de la globalidad de las necesidades sociales en desmedro del Parlamento. El análisis formulado por Ampuero comprende los años 1990 al año 2010, espacio temporal en el cual el 78,4\% de las leyes aprobadas provenían del Ejecutivo y sólo un $10,5 \%$ provenían del Parlamento ${ }^{444}$.

Para Alejandro Vergara Blanco, la posibilidad del Presidente de intervenir en la formación de la ley va más allá de la iniciativa y veto, influye en el contenido y la decisión del texto adoptado. El autor plantea que el Gobierno actuaría además a través de su "longa manu", o sea, mediante su grupo parlamentario que siempre o casi siempre apoyará sus iniciativas o contribuirá en su negociación y veto ${ }^{445}$. Agrega que el Ejecutivo es quien posee en lo concreto mejores condiciones de formular proyectos de ley. No obstante, dichas apreciaciones si bien plantean una realidad,

\footnotetext{
442 TAPIA (1993) p. 116.

443 VALDÉS Y SOTO (2009) P. 55.

444 AMPUERO (2013) Pp. 39 y 40.

445 VeRGARA (1993) p.139.
} 
omiten un elemento a nuestro juicio esencial, debido a que si bien el Ejecutivo tendría una capacidad de iniciativa fortalecida legalmente en cuanto a las materias que puede normar $y$ en las herramientas para redactar buenas iniciativas legislativas, se enfrenta a un requisito esencial y limitador: siempre requiere de la aprobación de las leyes en sede parlamentaria. No basta tener hipotéticamente toda la información si finalmente serán los parlamentarios quienes la examinarán, modificarán y serán ellos quienes establezcan o acuerden el texto final de la norma.

Por otra parte, el sistema de urgencias contemplado en el artículo 74 de la Constitución Política de Chile, configuraría un mecanismo de presión del Ejecutivo desde dos perspectivas: por una parte, el Gobierno podría alterar la agenda legislativa al aplicar alguna urgencia, pues los proyectos catalogados como discusión inmediata y de suma urgencia conforme al artículo 192 del Reglamento de la Cámara de Diputados, deben ser ubicados en primer lugar de la tabla de sesión especiales; y por otra parte, obligaría al Congreso a debatir y votar -una vez finalizados los breves plazos especiales- el proyecto de forma inmediata. Sin embargo, ni las normas contenidas en la Ley Orgánica Constitucional del Congreso en sus artículos 26 y siguientes, ni el Reglamento de la Cámara de Diputados en sus artículos 183 y siguientes, traen aparejada sanción específica hacia el órgano parlamentario si no cumplen tales plazos ${ }^{446}$. Es más, el artículo 186 del Reglamento de la Cámara de Diputados establece que, finalizada la legislatura ordinaria o clausurada la extraordinaria, se producirá la caducidad de la urgencia de dicho período, sin ninguna repercusión legislativa ni jurídica. Por su parte, el artículo 187 del mismo reglamento, relativo a la simple urgencia permite que -a propuesta del Presidente de la Cámara y aprobado por la mayoría de sus miembros- puedan prorrogar los plazos. Con todo, si adicionalmente consideramos que el Ejecutivo cuenta siempre con la posibilidad de retirar las urgencias sin mayores secuelas, resulta difícil creer que se configuran en la práctica como un medio de presión irresistible.

Por tanto, las urgencias se presentan más bien como una presión mediática y en nuestro análisis sólo como presión política para el caso de que el Ejecutivo posea mayoría en el Parlamento, toda vez que a la oposición poco le importará contribuir en el cumplimiento de las metas del Ejecutivo. Es más, el proyecto de ley al cual se le ha aplicado alguna urgencia puede ser perfectamente archivado o rechazado o,

\footnotetext{
${ }^{446}$ En este sentido, se ha expresado autores de la ciencia política, especialmente contenido en el análisis realizado por, BERRIOS Y GAMBOA (2006) p. 113.
} 
por el contrario, puede ser aprobado pero en plazos de discusión tan breves que no permitiría un correcto estudio o examen del texto. Por ende, es dable suponer que en tales casos la calidad legislativa realmente no será la esperada, y que el contenido pueda distar mucho de la intención inicial del Gobierno.

Una expresión tangible de nuestra interpretación, dice relación con la actuación de los mismos parlamentarios, quienes no han desplegado una real contienda por modificar el texto constitucional intentando reivindicar una facultad que poseían hasta el año $1973^{447}$-antes del ingreso en vigencia de la Constitución de 1980-, toda vez que esta materia constitucional sólo ha sido modificada en el año 2010 a través de la Ley No 20.447, mediante la cual sólo se ampliaron los plazos de la "discusión inmediata" y "suma urgencia". Es más, desde el año 2008 a la fecha sólo una iniciativa ${ }^{448}$ legal ha planteado despojar al Presidente de la República de tal capacidad. Las restantes iniciativas ${ }^{449}$ sólo han tenido por finalidad que las urgencias no puedan ser utilizadas en períodos electorales. Aparentemente, no existe una incomodidad parlamentaria real en esta materia, o a lo menos así es posible comprenderlo desde la óptica de las propuestas legislativas presentadas. La única limitación, como mencionamos, es que no sean utilizadas como un instrumento electoral, mas no como un mecanismo que altere el normal funcionamiento de la función legislativa o como una presión irresistible hacia los parlamentarios.

En resumen, y habiéndose analizado las aristas anteriores, es posible plantear un cuestionamiento. Es viable hablar de presidencialismo reforzado en este contexto político y jurídico constitucional, cabe preguntarse si es tan incontrastable el actuar del Ejecutivo frente al Legislativo. De la forma en que hemos expuesto la situación, pareciera que no es tan efectivo aquel sustento doctrinal, no obstante, no está la oportunidad en la que hemos de examinar el régimen presidencial reforzado nacional en profundidad. Solamente debemos hacer presente sus rasgos más esenciales,

\footnotetext{
${ }^{447}$ En este punto, cabe hacer mención que hasta 1973 el Presidente de la República podía hacer presente una urgencia pero la calificación de su grado en simple, suma o extrema urgencia o discusión inmediata correspondía a la Cámara, así se consagraba en el artículo 129 del Reglamento de la Cámara y en el articulo 282 del Reglamento del Senado. Con esta información sólo queremos hacer presente que existen antecedentes nacionales que contemplaban la facultad que el Congreso fuera quién en definitiva regulara de alguna manera agenda parlamentaria, pues si bien el Presidente la aplicaba quedaba a criterio exclusivo del Parlamento su calificación y si realmente se le aplicaba o no algún grado de premura.

448 Boletín No 6177-07, información contenida en página web de la Cámara de Diputados, visitada con fecha 22.01.2015: http://www.camara.cl/pley/pley buscador.aspx?prmBuscar=urgencias

449 Boletines No: 6662-07, 7297-07, 7296-07, 8547-07 y 8966-07. Información contenida en página web de la Cámara de Diputados, visitada con fecha 22.01.2015: http://www.camara.cl/pley/pley buscador.aspx?prmBuscar=urgencias
} 
dejando para posibles exploraciones posteriores este tipo de interrogantes. Al efectuar una labor investigativa de esta magnitud, se torna muy recurrente el descubrimiento de nuevas líneas de trabajo, como la que hemos esbozado muy debilitadamente en estas líneas.

Conforme a lo expuesto en los párrafos anteriores, es preciso señalar al respecto dos apreciaciones. Según los porcentajes citados por Ampuero, sin ánimo de justificar la supuesta debilidad del órgano representativo, es preciso recordar que éste reanuda sus funciones sólo el año 1990, luego de largos años de dictadura, factor de mucha relevancia pues gran parte de sus miembros al comenzar su mandato eran "inexpertos" legisladores -no poseían el conocimiento ni la destreza para promover un sinfín de proyectos de ley-. Conjuntamente, es factible suponer que durante el período post-dictadura las necesidades democráticas fueron múltiples y el establecimiento de prioridades fue de suma necesidad, labor que debía ordenar y coordinar el Ejecutivo porque en dicho momento de la historia nacional, era él quien efectivamente poseía "mayor información" y conocimiento respecto de las urgencias legislativas. Creemos que ello explicaría la baja porcentual que expresa Ampuero. Ahora bien, ello no debiera ser la conducta recurrente durante los tiempos de democracia, menos aún en la actualidad.

Como segundo elemento a examinar, hemos señalado la calidad en la producción normativa. La proliferación normativa habría supuesto una baja considerable en la calidad de la norma. Así, la ley ya no es fruto de un resultado depurado, muy por el contrario, puede ser equívoca e ininteligible, provocando el desconocimiento por parte de la sociedad y la dificultad de realizar un control al número tan amplio de normas. Los factores de aquel fenómeno pueden ser de los más diversas índoles, por ejemplo de origen parlamentario o gubernamental. Generalmente la prioridad de un parlamentario es la continuidad en el cargo más que la calidad de su gestión; los esfuerzos personales y económicos se centran en el trabajo local-territorial por sobre otras funciones. En este sentido, el voto es más sensible al trabajo distrital que a la calidad de la legislación lograda por el candidato ${ }^{450}$.

450 VALDÉS Y SOTO (2009) p. 66. 
Por su parte, los equipos parlamentarios son compuestos por profesionales y/o colaboradores que no siempre gozan de la preparación necesaria para apoyar una gestión legislativa, representativa, financiera, política y fiscalizadora. En este sentido, autores nacionales como Valdés y Soto han manifestado su preocupación por la falta de "capacidad técnica" de las asesorías legislativas, generando una relación más desequilibrante entre el Congreso y el Ejecutivo. Todo lo anterior impacta en la opinión pública, graficándose la percepción de un Parlamento que más bien "dificultaría la aprobación de leyes y no como una entidad que las perfecciona tras una deliberación democrática"1451.

Como respuesta a tal fenómeno, dentro de la doctrina nacional también se ha planteado la importancia de controlar o evaluar la norma en todo su proceso legislativo, evitando que el ciudadano padezca de la falta de coordinación y coherencia del sistema normativo. El ciudadano debe estar convencido de la necesidad y función de la misma. La norma debe ser comprensiva, se propone evaluar la norma de forma rigurosa que permita perfeccionar su realización además de su aplicación, examinando si efectivamente alcanza o no los fines propuestos ${ }^{452}$. El profesor Osvaldo Oelckers ha defendido la importancia de la técnica legislativa como el proceso de formación que busca obtener textos legales exactos y de fácil aplicación $^{453}$, entregando una serie de herramientas y mecanismos de mejora, fundamentalmente, en torno a las asesorías legislativas, órganos que en esta oportunidad no abarcaremos.

Desde la doctrina española, la profesora García-Escudero ha trabajado en detalle tal materia reconociendo los avances españoles con la creación de las "Directrices sobre la forma y estructura de legislar de los anteproyectos de ley" sumándose a las tendencia de ckeclisten o Prüffagen de Reino Unido, EEUU y

\footnotetext{
451 VALDÉS Y SOTO (2009) Pp. 53 a 57. Estos autores, en dicho trabajo exponen la implementación de asesorías legislativas plurales que fomenten la competencia, pero que a su vez sean de confianza política de los parlamentarios formando parte de sus equipos internos, diseñan un completo sistema de organización interna, jefaturas, roles, evaluación, remuneraciones, etc. Con ello se han fijado como objetivo mejorar la calidad de las leyes y prestigiar la actividad política, evitar el desvío de fondos y la presión que ciertos grupos puedan ejercer en temas relevantes a legislar.

452 OelCKERS (1998) P. 443.

453 OelCKERS (1993) Pp. 249 y siguientes. En la presente obra el autor realiza un detalla evolución histórica de la facultad legislativa nacional, principalmente hace hincapié en las dificultades de la calidad normativa experimentada en dictadura y la dificultad de remontar las unidades técnicas de apoyo y asistencia de los parlamentarios en tiempos de democracia.
} 
Alemania $^{454}$. Sin embargo, lo relevante para nuestra investigación es señalar que en tal proceso de elaboración de la norma también hay un espacio de control parlamentario. Así lo ha señalado el profesor Oelckers cuando declara que someter a evaluación los proyectos de ley, una ley o cualquier norma jurídica supone controlar $^{455}$.

Quienes se suman a esta interpretación son los autores Paúl y Soto, para quienes la evaluación ex-post de la ley puede realizarse como una función fiscalizadora mediante el mecanismo de las comisiones investigadoras, las cuales luego de la reforma constitucional del año 2005 y la disminución de sus quórums de formación- han cumplido precisamente tal rol $^{456}$.

Ciertamente, estamos ante una interpretación amplia del control parlamentario que prontamente ahondaremos, pero que no deja de tener sustento político y jurídico. La creación de la norma es una oportunidad que poseen los parlamentarios de mayoría y minorías para analizar las intenciones políticas del gobierno, o de los otros grupos parlamentarios, como también fiscalizar si las direcciones del Gobierno dicen relación con las necesidades e intereses ciudadanos y la calidad de la propuesta. Formulan observaciones y modificaciones, participan directamente en el resultado final de las leyes, en el resultado final de la política nacional y, en el caso de ver muy disminuida su capacidad, siempre podrán enunciar una crítica pública que produzca consecuencias electorales en el pueblo.

Como bien explica Alejandro Vergara, el procedimiento legislativo y el debate en particular, tienen suma importancia y utilidad, pues a pesar de que la decisión política pueda venir ya tomada o negociada previamente, siempre nace la posibilidad de generar una discusión pública, abierta y transparente de los temas de ley ante la opinión pública colocando en fuego cruzado las ideologías ${ }^{457}$. Desde aquella perspectiva, la función legislativa permite ser una vitrina de las conductas, expresiones, ideologías y pensamientos de la actuación de los representantes. Lo relevante de esta actividad es que sitúa al Parlamento y al parlamentario como una

\footnotetext{
454 García-Escudero (1999) p. 32. En esta materia ver la obra de la autora del año 2014: "Manual de Técnica Legislativa".

455 OELCKERS (1998) p.444.

456 PAÚL Y SOTO (2009) Pp. 597 y 598.

457 VERGARA (1993) p.139.
} 
actor de gran importancia en el sistema democrático nacional que hace carne el sistema de contrapoderes de la división de poderes del presidencialismo.

\section{La función de control parlamentario}

Como fuera expuesto en los apartados anteriores, la relación entre poder y libertad configuraron el binomio que promoviera todo el desarrollo jurídico y político durante siglos. Las explicaciones formuladas en nuestro Capítulo I y la constante reiteración de los hechos histórico-políticos más relevantes del siglo de las luces a lo largo del presente Capítulo, permiten comprender por qué el constitucionalismo moderno ha puesto como eje central de su construcción la limitación del poder mediante los controles políticos y jurídicos. Por tanto, el principal legado que nos dejó la filosofía liberal es precisamente la importancia de poner los acentos en el control del poder; para ello, se diseñaron diversos mecanismos: la soberanía nacional, la representación política, la teoría de la división de poderes, el fortalecimiento de la Constitución, por señalar los más relevantes. Pilares esenciales en el establecimiento del sistema de gobierno representativo y en el surgimiento del principio democrático.

Es por ello que en los Estados democráticos deberá existir como regla inexcusable dos controles: unos jurídicos, que persigan el estricto sometimiento al derecho por parte de los gobernantes como medio eficaz para perseguir los actos antijurídicos del poder; y otros políticos, que velen por la conciliación entre la libertad de la cual debe necesariamente gozar el órgano Ejecutivo en el desarrollo de su gestión y una voluntad más alta que el puro derecho. Será indispensable que la gestión del Gobierno se adecue a la voluntad general ${ }^{458}$. El control parlamentario se enmarca dentro de aquellos controles de orden político, porque si bien estará regulado jurídicamente su finalidad es esencialmente política.

La finalidad del constitucionalismo moderno fue buscar la manera en que el Gobierno de la sociedad obedeciera la voluntad de los ciudadanos. Pretendió evitar que se pasara por encima de los mismos, de sus intereses o de sus derechos de

${ }^{458}$ RUBio (1993) p.244. 
forma arbitraria. En el marco de este objetivo, el Parlamento se constituyó como el garante constitucional de aquel propósito. En este contexto, nace el control parlamentario, según García Morillo como "una técnica jurídica-constitucional encaminada a garantizar que la actuación de los gobernantes responda a la voluntad general"459.

El control parlamentario exhibirá en la época del dieciocho una consagración legal de mayúscula importancia. El artículo 15 de la Declaración de Derechos del Hombre y del Ciudadano señala que "el pueblo tiene derecho a pedir cuentas de su gestión a cualquier agente público". Queda establecido en el texto jurídico más importante del período revolucionario, la rendición de cuentas como un derecho esencial del ciudadano y de carácter inalterable. El soberano goza de la autoridad de demandar y obtener de parte de los agentes del poder las explicaciones e información que consideren pertinentes, a fin de comprender si la dirección política adoptada responde a las necesidades e intereses nacionales.

Primeramente, diremos que el control parlamentario como institución políticojurídica ha desarrollado una labor fluctuante a lo largo de la historia. Tuvo en sus orígenes una fuerte relevancia en la organización del Estado, para más tarde verse debilitado gracias a fenómenos como el parlamentarismo racionalizado, el que busca limitar su capacidad de acción garantizando la estabilidad de los gobiernos, la democracia de partidos y la disciplina partidaria, sucesos que en la actualidad han provocado interpretaciones discordantes del control parlamentario que fluctúan entre la percepción de una herramienta en declive o tremendamente fortalecida.

En este sentido y a modo de ejemplo, Rubio Llorente considera que el control parlamentario sigue existiendo más pujante y vigente que nunca. Como expresa Luis Aguilar de Luque, en las actuales democracias representativas los Parlamentos gozan como nunca antes de mayores medios materiales y jurídicos para realizar la función de control. Para el autor, la supuesta "sensación de déficit" del control deriva probablemente de esperar de las instituciones más de lo que hoy pueden ofrecer ${ }^{460}$, o como expresa Robert Blanco Valdés, el control no está en crisis; por el contrario, goza de una vitalidad y densidad de la que casi siempre ha carecido. De tal manera,

459 GARCÍA (1985) p. 20.

460 AgUiAR DE LUQUe (1997) p.83 
hoy un problema consiste en evitar que él se coma cuantitativa y cualitativamente la actividad política de los partidos ${ }^{461}$. También existen opiniones que se refieren al control parlamentario como letra muerta o derechamente lo condena al fallecimiento. En palabras de Miguel Herrero, estaríamos frente a una institución en franca decadencia $^{462}$.

Desde nuestra perspectiva, el control parlamentario ha debido cumplir un determinado rol en cada época del desarrollo político de los Estados. No es posible esperar que el control del siglo XVII sea similar al decimonónico o al de las actuales democracias modernas, pero aquélla es precisamente una de las virtudes del control porque ha sido capaz de cumplir una finalidad relevante en las más diversas circunstancias. Es una actividad dúctil que se acomoda a las condiciones existentes y que continúa prestando auxilio constitucional. Estas características le permiten -en la actualidad- continuar siendo un elemento protagónico en el escenario jurídico-político nacional e internacional, lo que se debe a su re-valorización, entre otros factores.

Uno de aquellos factores lo expresa Humberto Nogueira al señalar que esta función toma mayor preeminencia por la declinación de la función legislativa. La facultad de crear la ley era esencialmente la gran función realizada por el Parlamento $y$, como se expusiera anteriormente, ha sufrido un proceso de debilitamiento principalmente al quedar gran parte de ella designada al Ejecutivo ${ }^{463}$, lo cual provocaría -por defecto- que otras facultades tomen aquel sitial. Ese sería el caso de la facultad de control.

Otra perspectiva del auge del control parlamentario se debe, según Alexis Solís, a diversas razones autónomas y externas a las demás funciones del Parlamento. Estas causas se basarían en el "potencial" 464 que ofrece a los parlamentarios el ejercicio de esta función de control. Ella otorga la posibilidad de poner en la palestra pública actuaciones de funcionarios de gobierno, que pueden ser desde el estatuto jurídico perfectamente legales pero que -de acuerdo a criterios políticos de responsabilidad política y valores constitucionales- son cuestionables, pudiendo ser reprochadas públicamente, obteniendo con ello el parlamentario o

461 BLANCO (2000) Pp. 35 y 36.

462 HerRero (1997) p.53.

${ }^{463}$ NOGUEIRA (1992) p. 2.

464 Solís (1995) PP. 46 Y 47. 
grupo parlamentario un período de protagonismo mediático, que siempre es bienvenido en personas cuya permanencia en su calidad de honorables depende exclusivamente de la voluntad de sus electores.

Independientemente de cuáles sean los exactos antecedentes de la vitalidad del control parlamentario, desde nuestra perspectiva y en el plano nacional la relevancia de investigar esta institución reviste dos elementos: el primero, dice relación con un factor del cual ya hemos hecho mención y se refiere al sistema presidencial chileno, en el cual el Ejecutivo gozaría de un supuesto reforzamiento constitucional y legal; y el segundo, de acuerdo al cual creemos que en tiempos en los cuales la política parece no ser de interés de los ciudadanos -por el descrédito de la misma-, la instancias de control son un buen mecanismo para hacer frente a las conductas poco acordes con la buena política, pudiendo mediante ellas publicitar las conductas de los representantes y evitar que se repitan acciones similares en el futuro, contribuyendo al desarrollo democrático del país y a la alternancia del poder. En este punto, nos manifestamos contestes con los argumentos de Portero Molina, en el sentido que el fundamento del control se encuentra en dos factores esenciales. Políticamente es una exigencia democrática, y jurídicamente es manifestación de unos derechos o facultades del cargo público de parlamentario. Por ello, no puede dejar de ejercerse y su inactividad, en términos políticos, deteriora la democracia $y$, en términos jurídicos, vulnera derechos del representante y del representado ${ }^{465}$.

\section{a) Dificultades en torno al concepto de control parlamentario}

Continuando con nuestra investigación, corresponde cuestionarnos de forma basal qué debemos entender por fiscalización o control parlamentario. ¿Son estos conceptos semejantes, equivalentes o definitivamente atienden a ideas diversas? Dilucidar dicha pregunta nos coloca en la necesidad de realizar un examen detallado de las nociones que existen en la actualidad en torno al mismo, para poder alcanzar así una comprensión de las tendencias existentes, y luego cotejar aquellas nociones con la legislación nacional, esclareciendo así el particular concepto utilizado en nuestro país. Lo cierto es que estamos frente a un concepto de gran complejidad. Éste no es un concepto unívoco. Como bien describen Montero y Morillo, el término

${ }^{465}$ PORTERO (1998) p. 12. 
"control" carece de rigor técnico tiene múltiples significados y diversidad de sentidos jurídicos que provocan la plurivocidad del término ${ }^{466}$; estamos frente a un concepto con significado equívoco, que provoca importantes discusiones doctrinales en torno a qué debemos entender por tal, lo que impide arribar a un consenso.

Efectivamente, estamos frente ante un concepto que carece de homogeneidad técnica y doctrinal, debido a las múltiples formas en que es comprendido y realizado por las democracias representativas. Recordemos que cada universo jurídico nacional o regional ha desarrollado sus propias teorías conforme a sus propios cuadros normativos y culturales. Como dice Pegoraro, es muy difícil detectar un "ídem sentiré" en la doctrina respecto del control parlamentario, por ende, encontrar una definición común y transversal es problemático y será más complejo aún si luego se desea o se intenta aplicar la conceptología de control a ordenamientos jurídicos tan diversos, o respecto de aquellos que poseen climas jurídicos lejanos a nuestra realidad -como sucede con los sistemas europeos, el británico o estadounidense ${ }^{467}$.

En este mismo sentido se expresa Michel Carducci al exponer que el control no parece reconducible hacia un ideal tipo que permita conceptualizarlo, pues no cuenta con una acción generalizadora. Ni siquiera presenta elementos constantes en su manifestación que permitan construir una categoría, un comportamiento común a toda especie de control parlamentario ${ }^{468}$. Coindice en el análisis Chimentí, quien señala que la doctrina no ha sido capaz de definir control ni tampoco qué es lo que debe hacer el Parlamento, porque no existe un "ídem sentiré". Como claramente exponen los autores, una definición de control exacta o aparentemente correcta es imposible de alcanzar. Desde nuestra perspectiva, debido a la diversidad de la cultura jurídica de cada Estado y por las necesidades democráticas que cada uno posea -toda vez que entendemos el control como mínimo nuclear- podemos señalar que siempre deberá tener por finalidad limitar al poder, pero la forma en que el poder se exprese en cada contexto político lógicamente será muy disímil. En consecuencia, intentar asimilar modelos de control resulta bastante complejo.

\footnotetext{
466 Montero y García (1984) p. 22.

467 Pegoraro (2011) Pp. 151 y 152

468 CARDUCCI (1996) p. 8.
} 
Con todo, alcanzar una especie de unificación del concepto desde nuestro entender es bastante complejo, básicamente, por las transformaciones que sufre de forma constante el régimen de Gobierno, como el control parlamentario en sí mismo mediante la inclusión de factores antiguos como el Estado de partidos, la disciplina partidaria; y otros nuevos, como el acceso a la información, los nuevos parámetros impuesto por la ciudadanía a la política que demandan nuevos diálogos y tratos. A pesar de existir mínimos comunes en la teoría del control, lo cierto es que cada escenario jurídico-político configura su propia noción del mismo. La evidente disolución de los clásicos modelos obliga además a replantearse los esquemas, con el objetivo de hacerlos pervivir y mantener la arquitectura política que ha dado resultados positivos dentro de las dificultades.

No obstante lo anterior, la determinación del concepto del control en un país específico y en lo que a nosotros respecta en cuanto a dilucidar cuál es o qué se entiende por control parlamentario en Chile, implica a nuestro juicio, en primer lugar, examinar la doctrina y, en segundo lugar, la estructura y manifestaciones del mismo. Es así como habrá que esclarecer cómo ha sido regulado, cuáles son sus procedimientos, cuáles son sus titulares, su objetivo y sus efectos, para poder dibujar así una idea de control nacional, cometido que realizaremos a lo largo de la presente investigación.

Nuestra labor en este epígrafe será -principalmente- exponer las tendencias actuales más representativas en torno a la conceptualización de la institución y la naturaleza de la misma, a fin de poder conocer las interpretaciones más relevantes sobre él, para posteriormente cotejarlas con la realidad nacional y analizar si alguna de aquellas tendencias puede ser aplicada al caso chileno con las reservas respectivas, atendiendo a nuestro sistema político y jurídico. Esperamos con ello poder comprender y explicar con mayor profundidad el sentido y alcance de la institución, y vislumbrar las posibles mejorías de ser necesarias. Es importante resaltar y recordar en este punto que uno de los eje centrales de la presente investigación se asienta, principalmente, en conocer los modelos o concepciones que se han elaborado en relación al control parlamentario, por cuanto serán precisamente aquellos elementos los que posteriormente nos permitirán dilucidar cuáles habrían sido los recogidos por la doctrina chilena y llevados al texto constitucional. La importancia de detenernos en un tema meramente conceptual, 
radica en la diversidad de interpretaciones que giran en relación al mismo, provocando múltiples dificultades en su determinación.

\section{a.1. Relevancia en la determinación de un concepto de control parlamentario}

El primer elemento que debemos tener presente, es el histórico, toda vez que el origen del control parlamentario proviene y se desarrolla principalmente en dos Estados con diversas entonaciones. Así, el control posee dos raíces diversas: una inglesa, descrita como to check o to control -expresiones utilizadas para referirse a conceptos como regular, ejercer autoridad o dirigir y que, en general, hace alusión a una acción de supremacía y de dominio-; y otro de origen francés contrôler, que se refería a los términos de comprobar, revisar, verificar, en definitiva. Es una acción de inspección ${ }^{469}$.

Esta primera diferenciación es resuelta por Joaquín García Morillo, quien expresa que a lo menos en España es utilizado el término en su interpretación francesa por resultar más próximo con la regulación constitucional y con la realidad política, declarando que la acepción británica es la más lejana para el universo cultural latino ${ }^{470}$. Compartimos este argumento, toda vez que la primera diferenciación de conceptos en torno a su origen y la forma en la que éste se diseñó y, la forma en que es llevado a cabo en nuestro país, pareciera ser mucho más compatible el galicismo. No obstante, como explica Francisco Zúñiga, el arquetipo de control diferenciado por su origen ha permitido que éste se adecúe a los tipos de gobierno y a los regímenes políticos, es por ello que finalmente puede operar el control en todo sistema político, mas sus alcances en el campo de la responsabilidad serán diferentes en la teoría y en la práctica, a pesar de que en el desarrollo de las democracias representativas actuales, la aplicación teórica de la responsabilidad política pueda ser una ilusión o un espejismo ${ }^{471}$.

\footnotetext{
469 Montero y García (1984) Pp.24 y 25.

470 GARCÍA (1985) p. 50.

471 ZÚÑIGA (1998) Pp. 316 y 322.
} 
En este sentido, diremos que la utilización más extendida por el derecho continental es la derivación etimológica francesa de contrôler. Su uso común representa una actividad de examen que un órgano desarrolla sobre la actividades ejecutadas previamente por otro órgano, respecto de los cuales no necesariamente existe una relación de subordinación pudiendo ser de distintas naturalezas, con el propósito de determinar si los actos realizados están en conformidad con la norma o principio que regula tal actividad ${ }^{472}$.

Como segundo aspecto, corresponde señalar las acepciones que contempla la Real Academia de la Lengua Española para ambos conceptos y los lineamientos semánticos con los cuales ha sido construido el control parlamentario. Ellos son los siguientes: Control: "Comprobación, inspección, fiscalización, intervención". "Regulación, manual o automática, sobre un sistema". Fiscalización: "Acción y efecto de fiscalizar" ${ }^{473}$. Desde una primera perspectiva, se debe señalar que para la Academia pareciera que la voz controlar contiene la de fiscalizar y no habría una diferenciación notoria entre ambos conceptos. Pero no siendo suficiente lo contemplado por la Real Academia de la Lengua Española, indagaremos cómo la doctrina ha explicado e interpretado ambos conceptos y los efectos que con ello derivan.

Cabe destacar, que a pesar de todas las interpretaciones antes expuestas y las que analizaremos a continuación, el profesor Pegoraro ha realizado un esfuerzo en otorgar una definición que él considera genérica de control, que responde a los usos más extendidos y frecuentes que contempla al control, ésta es: "La actividad de verificación, evaluación, examen, revisión supervisión, control, disciplinada por el derecho en cualquier forma esté regulada, llevada a cabo por entidades pertenecientes a las instituciones políticas, en formas diversamente configuradas, sobre otros sujetos que pertenecen a instituciones políticas, a fin de establecer medidas favorables o desfavorables" ${ }^{\prime 74}$.

\footnotetext{
472 Novissimo Digesto ITALIANO IV, p.729.

473 http://buscon.rae.es/draeI/SrvltConsulta?TIPO BUS=3\&LEMA=control. Página www.rae.es. Visitada $7 / 5 / 2012$.

${ }^{474}$ Pegoraro (2011) p. 172
} 


\section{a.2. Clasificación metodológica de los conceptos de control parlamentario}

En el presente apartado, y recopilando lo dicho anteriormente más las discusiones doctrinales analizadas, hemos elaborado una clasificación de los conceptos más utilizados en la literatura nacional y foránea respecto del control parlamentario, producto de lo cual en términos generales podemos agrupar dichas interpretaciones a lo menos en tres planteamientos, que pasamos a describir y examinar:

2.1. Posiciones semánticas que realizan una diferenciación entre la voz fiscalizar y controlar, aludiendo a que no son términos semejantes, relacionadas con el origen del vocablo y el desarrollo del mismo en Reino Unido y en Francia, haciendo hincapié básicamente en la sanción.

2.2. Análisis que haría sinónimos ambos términos, concibiendo al control como una garantía jurídica, realizando una distinción entre una manifestación de control amplio y otra restringida, diferenciación asentada en las diferentes sanciones que cada expresión es capaz de generar, con especial énfasis en disociar al control de la responsabilidad política.

2.3. El control parlamentario como una función construida sobre los cimientos de la concepción de control clásica de control-sanción, pero que formula diferencias en cuanto a la sanción incorporando a la responsabilidad difusa, y concibiendo a la función de controlar esencialmente como una función de información. 


\section{a.2.1. Discusión semántica del concepto de control parlamentario}

Iniciamos esta exposición con los postulados de Humberto Nogueira ${ }^{475}$, quien señala de manera clara que control y fiscalización no son sinónimos. Por un lado, fiscalizar es más bien una crítica, formulada a través de juicios de valor acerca de la conveniencia o inconveniencia de determinados actos, de acuerdo a la idea de bien común; y por otra parte, el control es la revisión de la conformidad del acto con el ordenamiento jurídico dejando fuera apreciaciones discrecionales.

Por su parte, autores como Hube, González y Zárate -también en la misma líneaplantean esta diferenciación entre ambos conceptos insistiendo que no serían sinónimos ${ }^{476}$, ya que controlar y fiscalizar son dos atribuciones parlamentarias trascendentales, pero en lo tocante a su consagración constitucional nacional de forma inconsciente, se ha formulado una diferenciación entre control y fiscalización parlamentaria. Así, el primero tendría por finalidad "encaminar la actuación del gobierno"477, a través del proceso de formación de la ley o en el nombramiento de ciertos cargos, interpretación propia de origen anglosajón. A contrario sensu, la fiscalización consistiría en "analizar la conformidad de un comportamiento a un determinado estándar jurídico-político", interpretación del término que seguiría un sentido galo. En consecuencia, el control tiene como efecto perseguir los actos del gobierno, y la fiscalización presenta como finalidad la de buscar responsabilidades políticas.

Continuando con esta clasificación, hemos de exponer una importante hipótesis elaborada por un estudioso del Derecho Parlamentario, Fernando Santaolalla. Este autor realiza una diferenciación de ambos conceptos, pero no coloca sus acentos en lo semántico de los términos, sino que coloca los énfasis en la restricción de la interpretación del control con la finalidad de que dicha institución responda verdaderamente a un criterio jurídico que entregue mayores seguridades, y así salvar los problemas en torno al mismo. Para Santaolalla, las palabras presión, fiscalización, influencia o crítica -con las cuales habitualmente se refieren al controlson distintas al control propiamente tal, esencialmente porque aquellos conceptos son insuficientes a la hora de conceptualizarlo. Lo realmente determinante en

\footnotetext{
475 Nogueira (1992) p. 49.

${ }^{476}$ HUBE et alt (2011) p. 30.

477 HUBE et alt (2011) pp. 30-31.
} 
términos jurídicos en el concepto de control parlamentario, es el parámetro. Por ello, el control debe ser una acción que tutele ciertos valores y principios protegidos constitucionalmente o el programa de gobierno.

En dicho sentido, el parámetro será los valores y principios establecidos en cada sistema democrático, y las sanciones podrán ser de veto o simplemente correctivas. La finalidad es hacer cesar la conducta incompatible con los principios o valores, es por ello que define al control parlamentario como "una actividad que un sujeto (el controlante) ejerce sobre otro (controlado) para la tutela de ciertos valores que el primero tiene el deber de proteger, actividad que puede consistir en la verificación de si se han respetado los valores o principios protegidos y en la adopción de medidas sancionatorias o correctivas en caso contrario"A78.

Por su parte, León Martínez sigue precisamente los postulados antes expuestos de Santaolalla. Realiza una distinción de ambos conceptos de forma más tajante y expone que el control parlamentario es aquel que involucra sanciones, motivo por el cual hace aplicable la responsabilidad política y sólo puede ser comprendido en sistemas parlamentarios. La fiscalización parlamentaria la entiende como actividad presente en todas las facultades del Parlamento, cuya finalidad es llamar la atención de la opinión pública, sin la aplicación de responsabilidades políticas, sino que solamente como una polarización de las alternativas políticas produciendo efectos en las urnas. Tienen asidero teórico, pero sólo es aplicable a los regímenes presidenciales $^{479}$.

Para Martínez, el concepto jurídico de control parlamentario supone la existencia de un parámetro constitucional determinado por valores y principios, respecto de los cuales los programas políticos deben ajustarse, y expone que en caso de dicho incumplimiento existen sanciones. Una sanción específica es la remoción, porque la noción de controlar está necesariamente ligada a la de responsabilidad. Estos argumentos le permite construir tal distinción entre fiscalización y control, contribuyendo con ello -a juicio del autor- a solucionar aquel común problema doctrinario de hacerlos sinónimos. En esta dirección, se entenderá a la fiscalización de tal manera que pueda provenir de órganos de representación diversos al

\footnotetext{
478 SANTAOLALla (1984) Pp. 198 y 199. Para este autor con esta interpretación cobra valor el concepto jurídico de manera tal que puede asimilarse al control constitucional.

479 MARTínez (2000) Pp. 106 y 107.
} 
parlamentario como aquellos socio-económicos o por los medios de comunicación. Para Martínez, la fiscalización como inspección política es sólo un instrumento sin un fin concreto. El control, por otra parte, es una función que permite perseguir y comprobar la actuación del Gobierno, verificando si se acomoda a las directrices constitucionales para determinar si existe o no el mantenimiento de la confianza otorgada al Gobierno, razón por la cual reduce los mecanismos de control a aquellos que comprueban el mantenimiento o no de la confianza y ponen en marcha la responsabilidad política, todas las demás acciones configuran fiscalización ${ }^{480}$. La doctrina expuesta encuentra fuertes exponentes en la doctrina italiana, como Chimenti, Galeotti, Vergottini y Manzella.

Dentro de la literatura nacional relacionada con esta materia, se encuentra la tesis de Gutenberg Martínez quien -diferenciando ambos términos- sostiene que controlar es un concepto más determinante que el del fiscalizar, porque permite no sólo examinar un determinado acto en cuanto a su correspondencia con el derecho positivo, sino que además posee una capacidad jurídica de generar la nulidad del mismo, en el caso que contravenga la norma. En cambio, la fiscalización que es una forma de control no jurídica, y por lo mismo, no goza de facultades coercitivas; no puede anular el acto fiscalizado, pero sí produce una efectividad política importante. Por ello, el autor concluye que ambos son conceptos asociados, que parecieran tener una relación de género-especie ${ }^{481}$.

A este planteamiento se suman los postulados de Juan Carlos Ferrada, para quien la asimilación o diferenciación entre un concepto y otro se basa en las consecuencias que éstos acarrean, particularmente en la idea de sanción ${ }^{482}$. Concluye que fiscalización sería un término más comprensivo y genérico que incluiría al control, siendo este último de carácter restrictivo, que sólo comprendería aquellos instrumentos que llevan aparejada la exigencia de responsabilidad política, concebida ésta como la sanción aplicable. Solís plantea la posibilidad de evitar estas abstracciones teóricas e interpretar las funciones legislativas a la luz de la praxis y la oportunidad en la que se producen los fenómenos políticos.

\footnotetext{
480 MARTÍNEZ (2000) Pp. 122 y 123.

${ }^{481}$ MARTÍNEZ (1998) p. 30.

482 FERRADA (2002) pp. 461-481.
} 
Pues bien, desde la perspectiva de los autores antes citados, si bien es posible diferenciar ambos conceptos, no existe una interpretación unísona respecto de uno u otro. Todos exponen ideas o nociones diversas para la voz control y para la voz fiscalización. No obstante, permite en cierto modo visualizar las tradicionales compresiones de la institución. Por otra parte, los postulados de Santaolalla y Martínez otorgan importantes elementos en la construcción de un concepto jurídico de la institución. Adicionalmente, ambos autores coinciden en el reconocimiento del parámetro entendido como valores y principios constitucionales o el programa político, como el elemento que definirá al control mismo. Como también se refirieren a la existencia de una sanción -la cual comprende acciones correctivas pero también aquellas que pueden hacer cesar las funciones del controlado-, vinculan al control con la responsabilidad a pesar de que la sanción puede o no ser la destitución.

\section{a.2.2. El concepto amplio del control parlamentario}

Una segunda postura doctrinaria en cuanto al concepto de control parlamentario, es aquella elaborada sobre la interpretación que considera al control parlamentario como una garantía jurídica, que no necesita producir como resultado forzoso la responsabilidad política del Gobierno. Esta doctrina considera al control y a la responsabilidad como conceptos distintos, y detalla que el error conceptual habría sido precisamente confundirlos. Por otra parte, tal concepción del control tampoco diferencia semánticamente las voces de control y fiscalización. En este sentido, al declarar a la fiscalización como garantía jurídica los autores engloban en ella ambos elementos. La garantía jurídica estará compuesta por dos acciones diferentes y no vinculadas: la de comprobación y la sanción. Por consiguiente, puede actuar la primera sin necesidad de la segunda, puede haber control sin producir necesariamente una sanción determinada. En este sentido, el control podrá producir otros efectos diversos, pero no acarreará la responsabilidad política del Gobierno.

La presente apreciación interpretativa ha sido desarrollada latamente por la doctrina española, por la doctrina italiana y -con algunos matices- por la doctrina francesa. A continuación, examinaremos las aristas más relevantes de estos tres pilares argumentativos, con la finalidad de exponer en detalle todos los elementos 
que configuran el control parlamentario desde una premisa amplia, con el objeto de alcanzar el mayor grado de profundidad en el estudio de la misma y sus alcances.

\section{- La doctrina española $y$ el concepto amplio del control parlamentario}

Como explican Montero y García Morillo, el control es un instrumento que se realizará bajo criterios de oportunidad política que deben ser libremente valorados por el Parlamento, órgano que en cuya labor tiene por misión proteger bienes jurídicos tutelados como el correcto funcionamiento de la Constitución y la garantía democrática. Si bien sanción y verificación serán elementos constituyentes del control entendido como garantía jurídica ${ }^{483}$, para estos autores no será necesario que actúen conjuntamente, y argumentarán -como prueba de aquello- precisamente al control parlamentario realizado en el régimen presidencial. Estas premisas son profundizadas por García Morillo en su obra particular, sosteniendo que ha existido una incorrecta identificación entre control y la posibilidad de derrocar al Gobierno, debido a la confusión entre control y garantía, pues el elemento genérico, a juicio del autor, es la garantía jurídica la cual comprende en su estructura los dos elementos antes indicados. El primero, la comprobación de la adecuación de la acción a la norma o principio $y$, un segundo factor, la posibilidad de impedir la continuidad de la acción o sea la facultad de sancionar ${ }^{484}$.

Para García Morillo, el primer elemento es el control parlamentario que puede eventualmente complementarse con el segundo elemento sancionador, pero en general no existirá entre ellos un vínculo imperativo. Desde esta perspectiva, el autor señala que "existirá control desde el momento mismo en que tiene lugar con independencia de cuáles sean sus efectos"A85. En definitiva, el concepto tradicional de control parlamentario es cuestionado. Asimilar control a responsabilidad política será un error en el cual incurre parte de la doctrina italiana como De Vergottini, Mario Galizia, Andrea Manzalle y, lógicamente, parte de la doctrina española como Fernando Santaolalla. Al realizar una convergencia de dos conceptos en un mismo fenómeno -además de continuar realizando un clásica interpretación del control

\footnotetext{
483 Montero y García (1984) Pp. 26,28 y 33.

484 GARCÍA (1985) Pp. 43 y 44.

485 GARCÍA (1985) p.47.
} 
parlamentario-, se niega absolutamente su ejercicio en el sistema presidencial y en definitiva implica confundir conceptos, el control podrá producir una pluralidad de efectos no sólo el sancionador. Lo esencial al evaluar la actividad del Gobierno, es la oportunidad con la cual se realice no sus sanciones, entendiendo que el Parlamento es el foro de publicidad de la actuación de los poderes públicos.

Continuando en la misma línea doctrinal, pero con una construcción diversa encontramos los argumentos esbozados por Manuel Aragón, quien diferencia al control parlamentario en dos sentidos. Por un lado, el control en sentido estricto, mediante el cual el éste llevará implícita la posibilidad de remover al titular del órgano ejecutivo, limitando sus procedimientos al voto de confianza y la moción de censura. Por otro lado, el control en sentido amplio, el cual comprende que el control parlamentario se realiza a través de todas las actividades de las Cámaras destinadas a fiscalizar la acción del Gobierno lleve o no aparejada la sanción. Ciertamente, Aragón se inclina más por la preponderancia de la segunda concepción, por carecer la primera de total utilidad en la actualidad. Además, sostiene que la primera concepción de control no permite aplicar dicha institución parlamentaria en el sistema presidencial. Junto con lo anterior, agrega otro factor que produce la inoperancia del control concebido en sentido estricto: la disciplina partidaria, la cual finalmente ha convertido al control en un imposible, por tanto, para el autor aquella interpretación configura un concepto inútil.

Conforme a los postulados de Aragón, la eficacia del control no descansa en la sanción directa sino también en las sanciones indirectas; no es necesario derrocar al Gobierno también es posible que sea corregido o desgastado electoralmente. Expresa el autor que, "entendido así el control ni siquiera se circunscribe a unos determinados procedimientos sino que puede operar a través de todas las funciones que desempeñe de la Cámara" ${ }^{\prime 486}$. Tal diferenciación en el juicio del concepto de control le ha permitido también a Manuel Aragón desarrollar otra distinción, que permite comprender al control desde la perspectiva del funcionamiento actual del Paramento. Es así como expone que existirá control por el Parlamento, cuando los actos de control deban expresar la voluntad general de la Cámara -entiéndase aquellas que implican responsabilidad política-. Además, existirá un control en el Parlamento, que se realizará por los parlamentarios considerados individualmente o

${ }^{486}$ ARAGÓn (1998) p.287. 
por grupos parlamentarios. Este control, a pesar de que sus acciones no produzcan una sanción efectiva, envuelve todas las demás actividades de verificación aunque no produzca efectos negativos para el Gobierno. Sigue existiendo control en la medida que la discusión parlamentaria influya en la opinión pública. Expresa Aragón el "Parlamento, entonces, es el <locus> de donde parte el control, pero la sociedad es el <locus> donde principalmente se dirige, puesto que es allí donde pueden operar sus más importantes efectos ${ }^{\prime 487}$.

Otro autor español que se suma a la interpretación amplia o garantista del control parlamentario es Manuel Sánchez de Dios, quien elabora una concepción aún más extensa, puesto que le atribuye al control una capacidad superior al considerar que éste no sólo se refiere a la vigilancia o a la fiscalización de un actor o actividad, sino que con el control se ejerce también poder. Por ello dirá que "quien tiene el control tiene el poder". El autor expone que el control que se desarrolla en España es evidentemente un control amplio, y en rigor sería imposible adoptar otro por las condiciones fácticas actuales, motivo por el cual los actos del Parlamento podrán tener un carácter polivalente, pudiendo cumplir diversas finalidades mediante un mismo procedimiento. Manuel Sánchez de Dios sostiene que el control parlamentario supone tres funciones: la de información, la de hacer propuestas de orientación y la de sancionar al Gobierno -sanción que puede ser mediante una crítica o bien exigiendo su responsabilidad política- ${ }^{488}$. Dicha distinción implica reconocer que la finalidad del control será principalmente formular críticas $y$, de forma muy excepcional, podrá exigir responsabilidades porque así lo contempla la legislación, mas no necesariamente ello ocurre.

Quien también está por una interpretación amplia del contenido del control es Antonio de Alonso, el cual adicionalmente establece cuáles son los ámbitos en los cuales se expresa un control amplio. Distingue entre un control-orientación que tendría como finalidad la coparticipación con el Parlamento, fijando pautas de comportamiento a la acción del Gobierno y concediendo la habilitación necesaria para que el Ejecutivo realice un determinado cometido. Desde esta perspectiva, podríamos señalar que para este autor la calidad orientativa del control puede asimilarse a la función de dirección política sostenida por la doctrina italiana. Por otra

487 ARAGÓn (1998) p. 288.

488 SÁNCHEZ DE DiOS (2002) Pp. 102 y 103. 
parte, estaría el control-inspección, que tendría por finalidad el aspecto del control propiamente tal, que se ejercerá de forma continuada y ordinaria sobre la acción política del Gobierno, y finalmente, el control-sanción, que comprende su capacidad de eficacia mediante la aplicación de sanciones que pueden implicar incluso el cese del Gobierno ${ }^{489}$.

En consecuencia, como expone Manuel Aragón, la función de control se convierte en la más significativa, la más general, y es capaz de estar en todos los procedimientos parlamentarios de la Cámara ${ }^{490}$, toda vez que -como señala Sánchez de Dios- la actividad de control parlamentario se extiende a todo tipo de procedimientos parlamentarios, pudiéndose decir que, en general, los actos parlamentarios pueden tener un carácter polivalente ${ }^{491}$. O como expresa Rubio Llorente -sin realizar grandes construcciones teóricas en este punto- en su nueva teoría del control, es necesario abandonar la idea de que existen ciertos procedimientos diferenciados de control, por el contrario no hay procedimientos porque el control es simplemente una perspectiva donde toda actuación parlamentaria, función o actividad es control ${ }^{492}$.

Según el autor, lo anterior se debe a la naturaleza dual del Parlamento como creador de la voluntad general, pero también como espacio donde las fuerzas públicas deben de manera permanente verificar el actuar del Gobierno. Por tanto, estamos frente una concepción que en cierto modo desarrolla una lógica absorbente en torno al control parlamentario, al declarar la máxima amplitud del mismo y la posibilidad de estar presente en todas y cada una de las demás funciones parlamentarias. En cierto modo, resta autonomía a las demás atribuciones y concluye generalizando de tal modo la fiscalización que pareciera que el Parlamento sólo realiza control parlamentario.

\footnotetext{
489 Antonio de Alonso (2002) Pp.199 y 200.

490 ARAGÓN (1986) p. 26.

491 SÁNCHEZ DE DIOS (1995) p. 36.

492 RUBIO (1993) p.256.
} 
- La doctrina italiana y el concepto amplio del control parlamentario

En los siguientes párrafos expondremos cómo la doctrina italiana ha desarrollado el criterio de la garantía jurídica como conceptualización del control. Pero antes de entrar de lleno en tal examen, debemos previamente esclarecer algunos elementos particulares que han elaborado los juristas italianos y que determinan e influyen directamente en la construcción dogmática del control.

Un primer aspecto, lo constituye fundamentalmente la contribución jurídicopolítica dada por la creación de una función específica denominada como función de "indirizzo político". Como expresa Manzella, implica la determinación del objetivo político nacional y de la selección de los instrumentos que serán utilizados para ser llevados a cabo ${ }^{493}$. Esta función surge producto de dos voluntades: la del pueblo, en una instancia electoral al emitir un sufragio por uno u otro programa político; y la carácter político-parlamentaria, en la que se definen mediante el mecanismo de confianza parlamentaria los equipos políticos que deberán cumplir tales programas. Por ende, a juicio de Manzella, es un proceso que tiene por finalidad arribar a una síntesis política entre intereses sociales y las mayorías políticas.

Desde esta misma óptica también se han desarrollado trabajos tendientes a sustentar y fundamentar la existencia y manifestación de una "función de inspección", que tendría como finalidad obtener la información y el conocimiento necesario para poder realizar las posteriores funciones de control parlamentario. Es por ello que dentro de aquella función los autores italianos consideran herramientas tales como las preguntas e interpelaciones. Como puede observarse, la construcción italiana elabora dos categorías diversas relativas a la actividad parlamentaria, una de indirizzo político relacionada con las orientaciones políticas, y la otra de inspección, relativa a la capacidad de obtener la información suficiente para poder ejecutar el control. No obstante, incorporaría en ella mecanismos que han sido reconocidos comúnmente como de control. Nos referimos a las interpelaciones y preguntas ministeriales. La particularidad de esta denominación de atribuciones parlamentarias se produce al momento de diferenciar al control del indirizzo y de la de inspección, como a su vez diferenciar la inspección de la función de información, para luego determinar qué es lo que se comprende por control.

${ }^{493}$ MANZELLA (2003) p.410. 
En la labor de distinguir las funciones, Chimentí expone que la función de control es una función de verificación y valoración, por ende, requerirá necesariamente evaluar información. Por esta razón, las funciones de inspección e información tendrían un carácter instrumental respecto de aquella función de carácter autónoma llamada control, diferenciando a cada una de ellas y su diversa finalidad. En el mismo sentido se encuentra De Vergottini, el cual declara que el control y la inspección son distintos, al igual que la función cognoscitiva y la de información ${ }^{494}$, apreciación a la que se suma Lavagna en su obra "Instituzioni di diritto público", en orden a declarar que la función de información e inspección sólo tendrán por objeto recoger antecedentes que pueden ser utilizados con los más diversos fines, tales como los de control parlamentario, pero incluso con fines extraparlamentarios.

La labor desempeñada en dirección a diferenciar y fundamentar las particularidades entre las funciones de indirizzo -información, inspección y control desde una perspectiva procedimental-, ha arrojado como resultado la posibilidad de diferenciar los mecanismos mediante los cuales una y otra se realiza, mas no ha sido útil desde otras aristas -como delimitar al control- porque existe una extrema delgadez entre las fronteras de uno y otro procedimiento, y entre unas y otras funciones, lo que ha provocado una fusión entre las mismas en determinados actos. Por ello, los mismos autores registran aquellas situaciones. Por ejemplo, Manzella expone que el control es una función "in-autónoma" porque debe ser auxiliada por otras funciones ${ }^{495}$, siendo los actos de control también partes o etapas de la función de indirizzo. En palabras de Chimentí, las investigaciones, interpelaciones y preguntas son actividades ambivalentes -de control y principalmente cognoscitivasen búsqueda de dos finalidades diversas: una política y la otra de conocimiento ${ }^{496}$.

Desde nuestra óptica, la posibilidad de que tales funciones se vinculen, forma parte del desarrollo natural de las actividades parlamentarias cotidianas, lo que no diluye la relevancia de la clasificación de los autores italianos, persistiendo en la utilidad de diferenciar procedimientos y finalidades, como a continuación se observará. Podría interpretarse que aquella interpretación responde a una noción

\footnotetext{
494 De Vergottini (1985) Pp. 395 y 397.

495 MANZELLA (2003) p.442.

496 CHIMENTI (2001) p. 202.
} 
amplia del control parlamentario como un proceso que ha de estar presente en todas o casi todas las funciones parlamentarias, cuestión que ya hemos venido tratando.

Continuando con el examen de la concepción de control en la doctrina italiana, es posible percibir de las exposiciones de autores como Galeotti, Ferrari y Chimentí, postulados tendientes a promover la desvinculación entre control y responsabilidad. No obstante, estos autores no hacen mención alguna a la noción de garantía. El fundamento de que el control no se enlaza necesariamente con la exigencia de responsabilidad, se sustenta sobre la base de la finalidad misma del control, orientado netamente a acciones de valoración respecto de determinados actos de Gobierno mediante actos individuales o colectivos, cuyo objetivo está lejos de ser uno de carácter sancionador de situaciones irreversibles. Muy por el contrario, se ejecuta con la clara intención de salvaguardar intereses y valores con una finalidad preventiva-correctiva y no castigadora.

En cuanto a las diferencias entre el control y la responsabilidad, los autores formulan distinciones basadas en criterios diversos a los mencionados por los autores españoles ya citados; sin perjuicio de aquello, la finalidad es la misma: separar la noción de control de aquella sancionadora que la vincula con la responsabilidad política. Así, los argumentos expuestos por Galeotti consisten en reconocer en la función de control elementos de poder, por ende, su ejercicio posee la capacidad de impedir, evitar o eliminar una actividad controlada. En este sentido, el sujeto controlante deberá realizar como primeros movimientos los intentos por salvaguardar principios, normas, intereses y más comprensivamente debe tutelar valores institucionales, frente al despliegue de una actividad o un estado de cosas que pretenda infringirlo. Para el autor, el control puede manifestarse como un medio idóneo para impedir o a lo menos dificultar que determinados actos jurídicos o estados organizativos anormales se $\operatorname{produzcan}^{497}$.

Definido en aquellos términos, para Galeotti no es posible seguir ligando al control a aquellas formas jurídicas que se resuelven mediante mecanismos sancionatorios. Es en atención a aquella finalidad que se debe de inmediato restar del ámbito del control toda aplicación de responsabilidad sobre los actos de una

497 GaleOtTI (1963) p. 43. 
actividad lesiva ${ }^{498}$. Desde la perspectiva de Galeotti, la aplicación de una sanción no remedia el daño causado; no servirá para impedir los efectos dañinos o anormales, porque las actividades lesivas en cuanto a principios y valores son irremediables. Por ello, la prevención es más relevante. En estos términos, la existencia de sanciones en los ordenamientos jurídicos sólo puede producir presiones de orden psicológico, pero no se traduce en una garantía objetiva jurídicamente idónea para restringir actos lesivos.

Al concebir al control parlamentario como una actividad de valoración crítica respecto de la actividad del Gobierno, de forma inherente éste se va a ir vinculando implícita o declaradamente a una decisión que sólo comprende una presión política ejercida sobre el controlado ${ }^{499}$. Por su parte, los postulados de Carlo Chimentí exponen que el control solamente es posible ejercerlo mediante actos de verificación y esencialmente sobre hechos consumados del Ejecutivo, respecto de los cuales -al igual que como expresaba el autor anterior-, las acciones de control del Parlamento no son capaces de provocar mayores modificaciones o de regenerarlos, por ende, la aplicación de sanciones también carece de utilidad.

En consecuencia, para Chimentí el objetivo del control será salvaguardar los propósitos fijados con anterioridad por el mismo Gobierno ${ }^{500}$. En este sentido, el autor formula una distinción en cuanto al ejercicio de la función de control, relativa a distinguirlo o diferenciarlo de aquellas de indirizzo político. Los actos de control son aquellos destinados a impedir situaciones irregulares mediante valoraciones, y por tanto, mecanismos como las interpelaciones son consideradas como actividades de control por Chimentí. En concordancia con esto, el control es una función esencialmente parlamentaria destinada a verificar y analizar las acciones del Gobierno de carácter privativo, o sea, aquellas actividades que se encuentran fuera de las consideradas como de codirección o de las denominadas "actividades de condominio" entre Gobierno y Parlamento, refiriéndose con ello a aquellas que se circunscriben en la función de indirizzo político. Por su parte, la función de control es una actividad de contraposición que tiene por finalidad la crítica y no la caída de la

\footnotetext{
498 GALEOTTI (1963) p.72.

499 CHIMENTI (1974) p.257.

500 En este punto el autor se refiere particularmente al programa de gobierno el cual es definido previamente en el caso italiano en el momento de otorgar la confianza parlamentaria para la gestión del Gobierno, procedimiento que como fue señalado anteriormente se encuentra contemplado dentro de aquella función denominada por los itálicos como función de indirizzo político.
} 
dirección del Ejecutivo, sino que puede contribuir en fomentar el reemplazo de la orientación política de las acciones del Gobierno. Tampoco tendrá como único destinatario la opinión pública, porque allí no pueden producirse estas finalidades. Las segundas, las actividades de indirizzo, son aquellas que comprenden juicios que están encaminados a quitar la confianza del Gobierno, es por ello que de existir una aplicación de la responsabilidad, es más coherente situarla en el marco de esta función y no en la de control, que podrá generar proposiciones y situaciones que son capaces de reconstruir las relaciones entre Gobierno y Parlamento ${ }^{501}$.

En este punto de la exposición, resulta necesario plantear una particular interpretación del control y sus sanciones dentro de la doctrina italiana. El profesor Andrea Manzella expone una importante teoría del control desde la perspectiva de la garantía. No obstante, sus planteamientos difieren bastante de la construcción ideológica expresada especialmente por los autores españoles antes analizados. Expondremos sus argumentos a fin de graficar las profundas diferencias que existen respecto de la postura que aquí se estudia y se expone, evitando con ello posibles errores interpretativos.

En este sentido, el profesor Manzella ha expuesto que la función de control implica una verificación respecto de la actividad de un sujeto político con la finalidad de exigir la responsabilidad institucional, o la responsabilidad difusa, pudiendo adoptar medidas directas e indirectas con el objetivo de restablecer equilibrios e intereses públicos posiblemente trastocados. No obstante, declara el autor que tal interpretación arroja problemas con la responsabilidad al no determinarla, pero contribuye precisamente a diferenciarla de la función garantía constitucional, por constituir elementos distintos. La garantía tiene como finalidad salvaguardar intereses generales, hacer volver a la normalidad constitucional los usos de los poderes públicos; en esta concepción, no es exigible una responsabilidad subjetiva. El desarrollo de la actividad de garantía tendría, por tanto, una calidad abstracta que dice relación con una conducta respecto de un parámetro de legitimidad política. No presenta como necesidad conceptual la búsqueda de la responsabilidad, como sí ocurre en el control parlamentario, procedimiento en el cual se contrasta una acción

${ }^{501}$ Chimentí (1974) p.142. 
y un parámetro determinado constitucionalmente cuyo incumplimiento implica la responsabilidad ${ }^{502}$.

Específicamente, el autor detalla que la garantía constitucional es ingresar a una zona del Parlamento que no consiste en sancionar o anular al Gobierno, sólo pretende o tiende a activar reacciones. Desde esta perspectiva, esta actividad no se desarrollará mediante procedimientos decisionales, sino que se utilizarán exclusivamente aquellos que en la doctrina italiana ha denominado como medios de "inspección" -entiéndase mecanismos como: preguntas, interpelaciones y comisiones de investigación-. En este punto podemos diferenciar que, en la descripción del profesor Manzella, la función de garantía se desarrolla a través de herramientas propias de lo que la doctrina italiana ha denominado como función inspectivacognoscitiva que no tienden a hacer exigible la responsabilidad, sino más bien pretenden gestar reacciones en la opinión pública y en otros partidos políticos ${ }^{503}$.

Como ejemplo, se puede señalar como acciones aquellas encaminadas a "controlar" el sistema de radio-televisión italiana, el cual fue utilizado con mayor preponderancia en los gobiernos de Berlusconi por la directa relación que el Presidente del Concilio poseía en dicha área. No obstante, siguen vinculando al control con la responsabilidad, a pesar de que ésta pueda ser difusa conforme a la realidad gobierno-mayoría que prima también en Italia. Es por ello que podemos colegir que si bien elaboran una teoría en torno a la garantía constitucional no es la misma noción que desarrolla la doctrina española.

- La doctrina francesa $y$ el concepto amplio del control parlamentario

Al igual que las tendencias doctrinales anteriores, la literatura francesa no escapa de aquel análisis recurrente, en relación a las alteraciones y declinaciones que con el tiempo se producen respecto de las funciones del Parlamento $y$, en especial, en cuanto a las transformaciones que ha experimentado el control parlamentario.

502 MANZELLA (2003) p.441.

503 MANZELLA (2003) p.448. 
No obstante, la regulación constitucional y el debate doctrinal francés presentan particularidades de suma relevancia, especialmente en atención a la capacidad que poseen las Cámaras mandatadas expresamente por la Constitución respecto del control y la evaluación de las políticas públicas adoptadas por el Gobierno. En tal sentido, la estructura del control parlamentario galo cuenta con un grado mayor de especificidad. Es decir, el objeto del control se compone de la acción del ejecutivo y la evaluación de las políticas públicas, delimitación que no existe en otras dos legislaciones estudiadas anteriormente, en las que habitualmente el objeto del control se refiere a la gestión del Ejecutivo o los actos del mismo en términos genéricos, regulación tremendamente amplia que -por cierto- ha generado algunos cuestionamientos y dificultades.

Por tanto, desde nuestra perspectiva y conforme a la regulación francesa, el control parlamentario en dicho sistema democrático ha de cumplir dos funciones: una función de crítica y otra función evaluativa. Por tal motivo, la interpretación y significación de sus mecanismos y efectos serán diferentes, es por ello que a continuación formulamos un examen de la misma, con la finalidad de vislumbrar aquellos elementos que la distinguen respecto España e Italia. Inicialmente, es preciso advertir que la interpretación amplia del concepto de control parlamentario en la doctrina francesa, también esboza la noción de que el control se irradia a todas las demás funciones del Parlamento.

Dentro de la literatura francesa, seguiremos lo descrito por Jean-Éric Gicquel, quienes hacen presente que las funciones del Parlamento serán preferentemente: la de votar leyes, controlar la acción del gobierno y evaluar las políticas públicas. Por tal motivo, el Parlamento cumple un doble rol: legislativo y político. Esta situación generaría una relación asimétrica entre los poderes del Estado, sin embargo, tal actividad se encuentra racionalizada debido a la disciplina partidaria de la mayoría parlamentaria. Se disminuye con ello la fuerza del control, estrechando a su vez la asimetría. Ahora bien, para los autores el control se expresa esencialmente a través de dos operaciones: supervigilar la acción del Gobierno y evaluar las políticas públicas. Pero dichas actividades englobarán otras acciones, que van desde la actividad de información hasta participar en la responsabilidad del gobierno. Según Gicquel y Gicquel, en tiempos en que la función legislativa se diluye hay una tendencia a reorientar su rol en razón del control, deviniendo en su segunda 
actividad natural, es por ello que en la actualidad se produce el fenómeno de "legislar menos y controlar más" ${ }^{504}$.

Delcamp, por su parte señala expresamente que el concepto de control es en realidad más amplio y multiforme que el clásicamente comprendido por el purismo jurídico, y eso es lo que constituye una dificultad en torno al mismo. Por tal motivo, una moderna concepción del control permite señalar que él podrá ser ejercido por medios legales o no legales, utilizados por la asamblea tendiente a obtener explicaciones del Ejecutivo, mediante los cuales revisan el funcionamiento de los servicios públicos, el gasto de los recursos públicos y el correcto o incorrecto funcionamiento de la actividad administrativa. Desde esta perspectiva, explica Delcamp que el control es un proceso difuso y continuo, que estará presente en múltiples acciones. Es por ello que a través de los medios de información parlamentaria -aun en ausencia de sanciones legales- se puede controlar la acción del Gobierno, del mismo modo lo sostiene respecto del análisis de los proyectos de ley y del control presupuestario ${ }^{505}$.

Ahora bien, para esta autor la facultad de evaluar las políticas públicas entregada por la Constitución a la asamblea, configura una dificultad pero a la vez fortalece al control. Evaluar no es lo mismo que controlar, por ende, habrá de realizar otras acciones para alcanzar su correcta ejecución. Por ello, se crea el Comité de Evaluación y Control en la Asamblea, porque mediante el mandato constitucional se configura un nuevo campo de acción. Pero, por otra parte, aquel mandato a la vez fortalece el control porque le quita cierta ambigüedad, al clarificar que su objeto en dicha materia es la evaluación favoreciendo la reflexión sobre el mismo.

En este sentido, expone el autor que la mayor fortaleza del control será la publicidad y transparencia con la que se puede llevar a cabo, considerando que él ha de cumplir tres funciones: emitir explicaciones, hacer presente un mal funcionamiento o alcanzar modificaciones en el debate de la ley. Por tanto, respecto de ellas ha de generar un diálogo fluido, no solamente con el Gobierno, sino que debe explicarlo ante la ciudadanía ${ }^{506}$.

\footnotetext{
504 GiCQUel y GieCQUel (2015) Pp. 717 y 718.

505 DelCAMP (2010) Pp. 111 y 112.

506 DelCamp (2010) Pp. 114, 115, 117 y 118.
} 
En opinión de Le Devillec, respecto del control es necesario abandonar ideas tradicionales, puesto que el control se expande a otras actividades. Además, es posible detectar actos de control preventivos, mediante los cuales se cumpliría un rol de vigilancia y verificación, a través de un proceso similar a un acompañamiento en la gestión del Ejecutivo, con el objetivo de evitar el abuso del poder y mejorar sus resultados. También es posible percibir un control posterior, que tendrá por finalidad corregir y castigar. Conjuntamente, habrá de analizar el control desde la perspectiva de los instrumentos que utiliza. En la actualidad el control puede ser ejercido a través de medios formales o mediante medios informales. Los procedimientos formales son oficiales, regulados y públicos, sin embargo, es probable que existan importantes actividades de control en "los pasillos" del Parlamento, acciones informales que pueden generar efectos de mayor trascendencia. Para el autor, el uso de los instrumentos de control no depende de la regulación, sino que de la tradición política de cada sistema, y en tal contexto, el control ya no puede ser medido, toda vez que ha de producir efectos más o menos relevantes dependiendo del tipo de relación que exista entre Gobierno-Parlamento según sus propias tradiciones ${ }^{507}$.

Finalmente, para Le Devillec un factor clave para comprender el control es la "percepción", puesto que dependerá de cada realidad política. Las extensiones que pueda adquirir el control -su mayor o menor reparo- dependerán de la sensibilidad con la cual lo evalúen en cada ordenamiento jurídico. Por ello, a juicio del autor, el control parlamentario no puede ser valorado en razón de la utilización o no de instrumentos jurídicos formales o, en razón de la ocurrencia o no de efectos, en virtud del uso de tales herramientas. Por otra parte, agrega el autor que el control puede recaer sobre objetos diferentes. Por un lado, puede recaer sobre la gestión política general del Ejecutivo y, por otro, solamente puede pretender afectar la política diaria. En el primer caso, la finalidad será influir en la formación del Gobierno y en la dirección política general, intentando alterarlos. Para el caso de afectar la política diaria, la actividad sólo se sustentará en una crítica constante. Dicho análisis le permite al autor, adicionalmente, marcar una diferencia entre regímenes de gobierno, porque en el presidencialismo se realizaría un control a la política diaria y, en el caso del parlamentarismo se ejecutaría un control de gestión política general $^{508}$.

\footnotetext{
507 Le DiveLLeC (2010) Pp. 130 y 131.

508 Le DivelLeC (2010) Pp. 132 a 134.
} 
De este modo, hemos de concluir que para estos autores la interpretación del control es amplia, toda vez que lo consideran presente en múltiples funciones parlamentarias. Tal es la apreciación expansiva del control, de conformidad a lo descrito por los profesores Gicquel. Uno de los clásicos mecanismos de control, como las preguntas parlamentarias -sean escritas u orales-, constituyen para los diputados y senadores medios tradicionales de información, otorgándole un rol orientadorinformador y no necesariamente fiscalizador.

En lo que concierne a la responsabilidad política, esbozan en términos generales que, si bien es cierto que ella es un corolario a la autoridad en democracia, esto es que el Gobierno será responsable ante las Cámaras mediante instrumentos racionalizados como la cuestión de confianza y la moción de censura, la noción de la misma se ha modificado gracias a la relación entre los partidos políticos y las mayorías parlamentarias, que traen aparejada la sumisión al punto de neutralizar su acción y criminalizar las vías políticas. Por tanto, la responsabilidad en términos contemporáneas habrá de medirse electoralmente, porque buena parte del control se realiza por los medios de comunicación a diario. Así, será la nación la que directamente dará o quitará la confianza mediante el voto ${ }^{509}$.

Por su parte, Chantebout explica que para el caso francés el control se ha de ejercer mediante otros mecanismos, como una forma de sobrevivencia. De la misma manera que en la función legislativa, fue derribando los obstáculos acumulados y se fue desenvolviendo de diversas maneras. Es por ello que la estabilidad gubernamental es prevista y la acción del control parlamentario aparece generalmente ineficaz, en razón de la lógica del parlamentarismo mayoritario, debiendo sostenerse al Gobierno. En este contexto, los diferentes procedimientos de control pueden a lo sumo tener algún efecto, empero, la atención estará concentrada en la opinión pública, la que está atenta a los trabajos de la asamblea de atraer la atención de los votantes y hacer presente los errores cometidos por el Ejecutivo, pudiendo incitar el cambio en su voto.

Con todo, según este autor, la real función del control parlamentario en las democracias modernas no es crear problemas al gobierno, pero sí monitorear la administración y ha de obligar al Ejecutivo a corregir sus errores. Lo anterior sólo

509 GiCQUel y GiCQUel (2015) Pp. 719 y 721. 
podrá ser efectivo si los parlamentarios están informados y mientras tal información sea entregada a los electores. Un buen mecanismo adoptado en Francia relativo al control, es la creación del comité permanente de evaluación de las políticas públicas. No obstante, lamentablemente en Francia "el doble mandato y el ausentismo que genera, hace ilusorio el control de las asambleas" ${ }^{\prime 510}$.

Prosiguiendo nuestro estudio del control parlamentario en la doctrina francesa, nos despierta especial interés el análisis realizado por Philip Norton, puesto que plantea importantes matizaciones en la interpretación del control. Este autor expone que el control dependerá, en gran medida, del tipo de Parlamento de que se trate y de la naturaleza de las relaciones entre Ejecutivo y Legislativo. En tal escenario, la efectividad del control obedecerá, en cierto sentido, del uso que le den los presidentes de partido y los líderes en el Parlamento a los procedimientos destinados para ello. Por consiguiente, la capacidad de controlar varía de país en país, toda vez que la regulación constitucional será determinante; así, dos serán los factores fundamentales que lo delimitarán, el régimen de gobierno y el sistema electoral. Otro rasgo de suma trascendencia para Norton, lo constituye la publicidad y transparencia con la que se informa el accionar y el resultado de los instrumentos de control a la ciudadanía, de ello dependerá la efectividad de los mismos.

El autor reconoce diversos tipos de control y múltiples matizaciones, pudiendo generar diversos efectos. Por una parte, expone que podrá existir una oposición extra-parlamentaria la que podría gestar pactos con la oposición oficial, al punto de derrocar gobiernos; por otra parte, el parlamentario individual igualmente es un espacio de control, pudiendo influir fuertemente mediante la prensa en la valoración del Ejecutivo. En virtud de aquellas diversas modalidades, Norton diseña tres tipos de capacidades de control. En un primer lugar, se encuentra la oposición oficial, el partido político de oposición y el parlamentario considerado individualmente que también es de oposición, quienes desempeñan un rol esencialmente controlador ante la opinión pública, pero que no influirán con fuerza en la evaluación de las políticas públicas, ni tampoco en la legislación. Su trabajo es utilizar los mecanismos de control y se concentra sólo en ello. En segundo lugar, se encuentra la oposición al interior del partido de gobierno y las difíciles relaciones entre el partido del Legislativo y el Ejecutivo. En este caso, el control es más eficaz por el poder de veto

${ }^{510}$ Chantebout (2012) Pp. 565, 566 y 571. 
que poseen, puesto que el éxito de la gestión de Gobierno depende exclusivamente de sus propios miembros, de su coalición y lealtad, es por ello que las concesiones y cesiones son más positivas, puesto que la estabilidad de actividad puede verse amenazada. Una tercera posibilidad, la configura una relación transpartido entre Ejecutivo y Legislativo, caracterizada por el compromiso y el espíritu de cooperación, por ende, se basa en una relación no adversaria, sin veto, con un enfoque constructivo propio de las culturas políticas consensuales ${ }^{511}$.

En definitiva, para Norton las relaciones Ejecutivo y Legislativo son complejas, pudiendo existir múltiples modos de control, que además estarán en constante cambio debido a las coyunturas políticas. Habrá diversos tipos de fiscalización y varios mecanismos, pero ello precisamente es la fortaleza del Parlamento, puesto que le permite seguir siendo esencial para la buena salud de los regímenes políticos.

Finalmente, tal como describe Avril y Gicquel, para la doctrina francesa existe una cierta unidad y especialidad respecto de las funciones parlamentarias. Por tal motivo, existe una solidaridad entre las actividades formalmente distintas de la asamblea. De manera tal, que el apoyo político o la oposición a un Gobierno se manifiestan tanto en la deliberación legislativa como también en el ejercicio del control. Por este motivo, ambas funciones son jurídicamente distintas, pero están políticamente conexas, ya que al accionar una reacciona la otra e incluso el procedimiento de una puede servir eventualmente a la otra. Así, la distinción entre la funciones de las asambleas es menos relevante. En conclusión, el término control implicará una actividad que comprende una gran diversidad de operaciones, que va más allá de la sola determinación de la responsabilidad del gobierno o una simple actividad informativa ${ }^{512}$.

511 NORTON (2010) Pp. 19-22.

512 AVRIL et alt (2014) Pp. 182,182 y 325. 


\section{a.2.3. El control parlamentario interpretado como un mecanismo de información}

Nuestra tercera concepción de control parlamentario viene sustentada básicamente por autores como López Guerra, Luis Aguiar de Luque, Antonio Torres del Moral, Giuseppe de Vergottini y, en el escenario nacional, por Francisco Zúñiga. La presente clasificación la hemos configurado en virtud de los siguientes argumentos comunes: confirman la existencia de una vinculación entre control y la responsabilidad política, a pesar de reconocer que en la actualidad tal vinculación no es posible de realizar pero persisten en la idea se responsabilidad. No obstante, vislumbran en la denominada responsabilidad difusa la sanción del control, por tanto, tal noción permite sustentar la continuidad de la estructura clásica del control. Por otra parte, el segundo rasgo definitorio consiste en considerar a la función de información como un instrumento y como fin. En este sentido, la doctrina concuerda en el carácter instrumental de la función de información respecto de las demás funciones, pero además le atribuyen a la información en sí misma, la cualidad de constituirse como "el efecto" del control Parlamentario.

En este contexto, para De Vergottini control será un examen, una valoración pero cuyo parámetro de medición no será el programa oficial del Gobierno y tampoco los valores constitucionales, sino que por el contrario, el parámetro del control es el programa "alternativo" 513 , es decir, el programa de la minoría configurada como oposición. Lo que se realizará mediante el control es una contraposición crítica del programa que se estaría ejecutando por el Ejecutivo y el programa que ofrece la minoría, expresando los beneficios o mejoras que tal programa implicaría. Este control puede ser realizado por mayorías y minorías; por mayorías generalmente en contextos extraparlamentarios obteniendo resultados más eficientes que la realizada por la minoría, y estas últimas en sede parlamentaria.

Esta línea interpretativa sostiene, en términos generales, que es en la capacidad de difusión informativa donde reside la efectiva capacidad controladora del Parlamento. Los fundamentos más genéricos de esta tendencia doctrinal se basan principalmente en dos fenómenos relativos al tradicional control parlamentario: el primero, vinculado a aquella debilidad relacionada a la insuficiencia de los

513 Vergottini (1985) p.396 
mecanismos de control, y el segundo, a la existencia de una estrecha relación entre Gobierno y mayoría, la que, por una parte, asegura la estabilidad del Gobierno mediante la disciplina de partidos pero que modifica los parámetros del pretérito control. Junto con lo anterior, argumentan que el actual control parlamentario ha de ser ejercido en democracias mediáticas, con una alta diversidad de partidos políticos, factores que favorecen la consolidación del pluralismo político y la alternancia del poder. Por tal motivo, el control será esencialmente informar a la ciudadanía.

Dado lo anterior, Luis Aguiar de Luque expresa que la finalidad por excelencia del control es proyectar sobre la opinión pública la acción de Gobierno en sentido estricto, pero también su crítica y las posibles alternativas al mismo; en definitiva, se proyecta ante la opinión pública una determinada imagen de la labor gubernamental como reemplazo a la vigente ${ }^{514}$. Por otra parte, la perspectiva de López Guerra en concordancia con su inclinación hacia una visión "realista del Parlamento", considera que si bien es evidente que sólo una perspectiva estricta o restrictiva del control es la más relevante -porque ella lleva implícita la responsabilidad política-, lo concreto es que la actividad parlamentaria -en razón del vínculo mayoría-gobierno- y la débil actuación de las minorías impiden toda aplicación del mismo y su faz sancionatoria. En consecuencia, el control retoma su importancia para configurarse como un examen continúo de la acción del Gobierno, de manera que se presenta como una especial fuente de información. No obstante, dice el autor, sostener que todas las funciones del Parlamento constituyen control, porque mediante ellas se realizaría supuestamente un examen y una discusión pública que también contribuye en el control, implica cooperar y favorecer en la hipertrofia del concepto en la cual estaría sumido $^{515}$.

En esta misma dirección se encuentran los fundamentos de Giuseppe De Vergottini, para quien también el control parlamentario implica un acción de verificación del comportamiento del aparato del Gobierno, respecto del cual emanarán valoraciones que pueden ir encaminadas en dos sentidos: el primero, una simple crítica y el segundo, la eliminación del Gobierno cuando se resuelve que se ha perdido la relación de confianza. Tal interpretación responde, a juicio del autor, a una

${ }^{514}$ AgUiAR DE LUQUe (1997) Pp. 79 y 81.

515 LÓPEZ GUERRA (2002) p. 42. 
concepción tradicional de la función que estaría inspirada en el control jurídico, basada en la relación de confianza y en la conformidad con un programa.

Empero, en opinión De Vergottini, en el contexto actual existe un dualismo funcional que une mayoría-gobierno, que impide tal lógica de funcionamiento clásico del control además de la existencia de una función de inspección distinta a la de control, que cumpliría una finalidad colaborativa con el control pero que a su vez puede estar orientada a fines diversos, en la que se ubicarían las interpelaciones, preguntas e investigaciones. Para el autor, las manifestaciones de control se pueden distinguir en relación al objetivo del mismo, toda vez que un control puede buscar la sola crítica mientras que un control de carácter intenso, además de poder realizar una crítica buscaría limitar la acción del Gobierno, exigiendo la aplicación de la responsabilidad. He aquí la diferencia central de la perspectiva De Vergottini, pues la responsabilidad a la cual se refiere no necesariamente implica remoción ${ }^{516}$, de conformidad a la posible aplicación de una responsabilidad difusa, que tiene por finalidad el debilitamiento del Gobierno.

Es por ello que el control político podrá presentar como consecuencia la responsabilidad política, pero no es su única finalidad o el marco de la institución. Muy por el contrario, puede también producir otros efectos, ya que si bien la remoción es una posibilidad ella no es la única, debido a que la responsabilidad consiste esencialmente en la obligación de someter a un análisis crítico un comportamiento políticamente relevante respecto del cual es posible eventualmente un juicio negativo.

Considerar a la función de control como un mecanismo esencialmente orientado hacia una entrega informativa a la ciudadanía, es una interpretación compartida por la autora italiana María Luisa Mazzoni, quien focaliza la relevancia de la función informativa del Parlamento como herramienta destinada a ejercer el control, vinculando igualmente al control con la responsabilidad política institucional. Pero, le otorga adicionalmente la capacidad de transmitir a la opinión pública la información necesaria para adoptar las decisiones políticas pertinentes.

516 De Vergottini (2010) p. 519. 
Para la autora, la importancia de la información se puede diferenciar en dos aspectos: aquella información que la Cámara necesita, idealmente exacta e imparcial para desarrollar otras funciones, frente a lo cual debería contar con sus propios y directos canales de obtención de la misma, pues será sólo esa capacidad de obtener información la que le permita desarrollar las demás funciones incisiva y automáticamente $\mathrm{y}$, desde otra perspectiva, porque la pérdida de la capacidad de obtener información trae como consecuencia el menoscabo en el contacto o relación que debe tener con la sociedad y provoca la decadencia del Parlamento como órgano de decisión autónomo y, consecuentemente, insta su subordinación al Ejecutivo.

Respecto de la información y el control propiamente tal, explica Mazzoni que tanto la función de indirizzo como la de control, además de implicar la responsabilidad política del Gobierno, tendría otra importante función que desarrollar: ésta es la de ser una "garantía democrática" ${ }^{517}$ para la ciudadanía, porque sólo mediante esta función de carácter informativo se traslada a la opinión pública los actos y hechos de la autoridad, que de otro modo permanecerían desconocidos para el cuerpo electoral.

En definitiva, los autores antes expuestos vinculan al control con la responsabilidad, pero tal relación se debe principalmente a una noción de responsabilidad que presenta diferencias con la responsabilidad política original o aquella denominada institucional, que es aquella que persigue como finalidad última la destitución. Estas tendencias doctrinales, reconociendo la existencia de tal responsabilidad institucional, son más propensas a seguir una construcción doctrinal esbozada por la misma doctrina italiana -especialmente por Giuseppe Ugo Rescigno relativa a la responsabilidad difusa-, la cual surge como respuesta a la imposibilidad práctica de aplicar la responsabilidad jurídica de remoción del Gobierno mediante los mecanismos de privación de confianza.

Como bien explica Armando Mannino, la opinión más difundida considera que para poder estar en presencia de control, una vez realizada la valoración y en el caso que ésta dé resultados negativos, debe aplicarse obligatoriamente una sanción. Pero, tal sanción resulta de difícil aplicación aun cuando el parámetro con el cual deba medirse la acción sea una norma jurídica rígida o un programa político. Agrega que,

517 MANZZONI (2001) Pp. 243 y 261. 
además, tal sanción es de tal gravedad que en primer lugar, sólo puede ejercerse frente acciones irreversibles y de alto calibre, y en segundo lugar, no servirán para reprimir desviaciones eventuales de menor gravedad, ya sea de una norma jurídica o de la orientación política. Por tal motivo, el control se presenta como una actividad política funcional ${ }^{518}$ constante, que se desarrolla al interior de la Cámaras y que tendrá por finalidad estimular que se mejoren las acciones ejecutadas, tomando en cuenta intereses omitidos o señalando comportamientos que no se adecuan a la ley. Con todo, se convierte en un elemento esencial que aportará información que permitirá formar la opinión pública, desde donde provendrá otra sanción mediante la presión política, forzando dimisiones o ejerciendo su fuerza electoral y cambiando de sujetos políticos, optando, por ejemplo, por la oposición ${ }^{519}$.

En este sentido, la presente concepción de responsabilidad catalogada como responsabilidad difusa, satisface los actuales procedimientos de crítica que comprende el control parlamentario vigente, destinados básicamente a los sujetos de la comunidad social en la cual el operador político se desenvuelve, presentando como base de su configuración el tener presente que siempre la autoridad puede ser juzgada a nivel difuso, a pesar de la legalidad de sus actos, toda vez que quien realiza este examen es el ciudadano ${ }^{520}$.

Por tanto, la presente arista de la responsabilidad difusa permite continuar vinculando control y responsabilidad desde su más clásica concepción jurídica, porque si bien se declara la incapacidad técnica de llevar a cabo una responsabilidad institucional siempre el control concebido como una valoración crítica podrá producir efectos de índole sancionatoria. En este sentido, puede provocar que se adopten acciones por la comunidad como también por los demás sujetos políticos de la esfera pública, acciones que a nuestro entender pueden producir fuertes consecuencias, provengan de los mismos partidos políticos de mayoría o de oposición o por parte de la sociedad civil. No obstante, es innegable reconocer que la concepción de la idea de responsabilidad difusa ha permitido mantener vigente, al menos desde una perspectiva estructural, la visión tradicional de control parlamentario que es la visión que a pesar de las diferencias expuestas, es la seguida por los autores examinados.

\footnotetext{
518 MANNINO (2010) p. 327.

519 MANNINO (2010) p.328.

520 De Vergottini (2010) Pp. 538 y 539.
} 
En el plano nacional, podemos detectar las exposiciones formuladas por el profesor Francisco Zúñiga, quien -siguiendo a López Guerra y De Vergottini- señala que la actividad de control parlamentaria será una actividad mediante la cual se examina la actividad del Gobierno, para analizar si ésta se ajusta o no a lo que el Parlamento estima correcto. Por ende, la piedra angular del control será la publicidad y la crítica, las que no tendrán por finalidad destituirlo pero que sí harán aplicable la responsabilidad difusa, o sea, buscará desgastarlo ${ }^{521}$. Para Zúñiga, esto también implica reconocer al control parlamentario dentro de una concepción amplia del mismo, en razón de la multidimensionalidad de las funciones que realiza el Parlamento, agregando que la configuración de una especial función cognocitivainspectiva se encuentra asociado a ello. En este escenario interpretativo, para el autor es posible igualmente reconocer que los mecanismos de interpelación, preguntas e investigación son propias de esta función inspectiva, las que estarían subordinadas principalmente al control como a otros fines particulares.

Como es dable concluir, los autores antes citados realizan una extensa concepción del concepto control y harían extensivo su objetivo a todas aquellas actividades que realiza el Parlamento -sin distinción alguna-, situación que ha generado algunas discrepancias, particularmente, con la facultad de información. En este sentido, se expresan las opiniones de Portero Molina para quien, por una parte, es necesario diferenciar entre el control parlamentario y la responsabilidad política; $y$, por otra parte, no se debe propender a sostener que toda actividad sea a su vez control.

En un primer aspecto, Portero explica que los fundamentos del control y de la responsabilidad son diversos. El primero, comprende un fundamento jurídico, cual es el de ejercer un derecho del parlamentario, y comprende otro aspecto político, relativo a hacer vigente la democracia. En cambio, la responsabilidad política es una posibilidad que puede o no darse, por ende, no tiene un fundamento ni político ni jurídico; en este mismo orden de ideas, los procedimientos y efectos también serían diversos. El control producirá efectos de naturaleza procedimental. Solamente pone en marcha una actividad, vale decir, activa procedimientos mediante los cuales se ejercen los mecanismos de control -como lo serían las interpelaciones- pero los resultados de aquello pueden ser inciertos y variados, debido a que no obliga al

521 ZÚÑIGA (1998) p. 322. 
Gobierno ni a cambiar sus decisiones ni su dirección. El único efecto claro que podemos señalar, es que proporcionará información de manera continuada y variada a la población ${ }^{522}$. Por su parte, la responsabilidad política posee procedimientos establecidos jurídicamente pero que su sólo ejercicio no produce efectos, sino que una vez activado deberá perseguir un objetivo determinado, es decir, provocarán un efecto categórico en este caso una sanción política.

La presente clasificación podría inducir a error respecto de la función de información y la de control. Para nosotros, informarse o poseer el derecho a obtener información en calidad de representante de la nación -en la función pública de parlamentario-, es diferente a informar a la ciudadanía de las actuaciones del Ejecutivo. En consecuencia, creemos que un escenario lo comprende la obtención de información como elemento tremendamente necesario para poder realizar control por parte de los Parlamentarios; otro escenario distinto, es el derecho a acceso a la información pública por parte de la ciudadanía; y un tercer escenario, lo configura la comunicación que se le pueda entregar a la comunidad respecto de la conformidad o disconformidad de las acciones del Gobierno y las propias por los mismos representantes. Así, hay una información que se hará pública y que estará disponible para que los ciudadanos se informen, y además existirá una información entregada directamente por los congresistas, la que se otorgará con una finalidad persuasiva en el caso de la oposición, con el objetivo de mermar la confianza depositada electoralmente en el Gobierno, pudiendo propender a la alternancia del poder, situación que como más adelante veremos configura la responsabilidad difusa. Empero, por otra parte, existe el derecho a informarse del cual gozan los parlamentarios para desarrollar una correcta función, ya sea de control, legislativa, presupuestaria, etc.

Probablemente dicha confusión puede provenir de un antiguo análisis relativo al acceso a la información y el paso del Estado absoluto al Estado liberal. En el Estado absoluto, además de la irresponsabilidad del soberano, otro patrón común fue la inexistencia de libertad de expresión y el carácter secreto de la función pública. Por ende, la información estatal no tenía carácter público; el secreto era connatural al absolutismo. Por ello, el poder del monarca era tan eficaz puesto que no estaba expuesto al análisis y control social. Dicho secretismo tiene como fundamento el

\footnotetext{
522 PORTERO (1998) Pp. 12 y 13.
} 
origen divino del poder: si el poder deriva de Dios y no del pueblo, sólo debía informar y rendir cuentas a Dios y no al pueblo. Sin embargo, con el arribo del Estado liberal el rol del ciudadano será, precisamente, elegir a la autoridad y controlar el ejercicio del poder, siendo el principal medio de control la misma elección, en ese escenario la posibilidad de elegir, exige que se encuentre garantizado el derecho de expresar opiniones y de informar (por parte de candidatos y votantes).

Por tal motivo, la publicidad de la información fue sumamente relevante. La obtención de información es el medio a través del cual se podrá realizar la evaluación del gobernante, lo cual posibilita la toma de una posición. En este orden de ideas, el disenso provocará finalmente el surgimiento de la oposición. Con todo, es efectivo que el acceso a la información y la libertad de los ciudadanos de informarse posibilita el ejercicio de un control, pero éste es un control social a través del cual velan por el patrimonio público y pueden eventualmente perseguir responsabilidades políticas ${ }^{523}$. Por tanto, habrá de existir un deber estatal de informar a toda la comunidad y a su vez existirá el derecho subjetivo de obtener información, Sin embargo, tal concepción tendrá una finalidad de facilitar el control social sobre agentes públicos, que podrá ser de utilidad a los parlamentarios, quienes gozan de un especial derecho a ser informados en los temas relevantes de la gestión estatal en su condición de representantes de la universalidad. No obstante, ello no implica necesariamente control, toda vez que puede poseer información y no utilizarla como medio de control, sino que orientarla a otro trabajo. En consecuencia, la información es un antecedente necesario del control que, adicionalmente, constituye control en sí misma.

En nuestra opinión, nos inclinamos por una interpretación amplia del control por los siguientes motivos:

En primer lugar, creemos que el control es un instituto esencialmente dúctil, atributo que le permite adecuarse a los regímenes políticos, a las condiciones y realidades políticas de cada país; por tal motivo, el primer elemento a considerar es la imposibilidad de unificar su sentido y alcance, si bien existe un mínimo común en cuanto a consensuar que estamos frente a un control constitucional de carácter

523 Bermúdez y Mirosevic (2008) Pp. 446, 447 y 450. 
político, es dable señalar que su objeto, parámetro, instrumentos y efecto varían en cada Estado.

En un segundo lugar, hemos de concordar que las relaciones entre el Ejecutivo y el Legislativo están matizadas y mediadas, en virtud del desarrollo de los partidos políticos. Por ende, los vínculos políticos entre partidos y entre poderes del Estado, van mutando conforme a la coyuntura política de cada nación. Por tal motivo, las mayorías y las minorías no configuran elementos estáticos. La conformación de coalición de Gobierno y oposición será en ocasiones volátil. En esta misma dirección, cabe agregar que además existirá control político extraparlamentario, que proviene de los mismos partidos políticos del ámbito local, ya sea que no cuenten con representación parlamentaria, o bien que poseyéndola, estimen más eficiente utilizar otros canales y no los institucionalizados para ejercer el control, toda vez que ello genera mayores y mejores resultados. Por ello, los sujetos del control serán principalmente móviles, lo que influirá directamente en el propósito del control, puesto que cada fuerza partidaria aspira a alcanzar objetivos diversos y para ello ha de utilizar los instrumentos de control de múltiples formas. Concluyamos que, en este escenario, los mecanismos de control se adecuarán a la satisfacción de las necesidades del sujeto controlante, y así no necesariamente será utilizado en su sentido clásico. Por tanto, las mutaciones al diseño original del control es abrumador, pero aún bajo este nuevo contexto el control continúa cumpliendo un rol relevante, debido a la capacidad que posee para incidir en la agenda pública.

En tercer lugar, cabe hacer presente que los medios de comunicación, la Web y el empoderamiento ciudadano han generado otras vías de control político, respecto de los cuales nadie ha querido quedar ajeno. Los parlamentarios individualmente considerados los utilizarán activamente, en virtud de réditos políticos que ello les provoca y, por cierto, lo utilizará la ciudadanía de manera tremendamente activa, porque configura el medio de comunicación mediante el cual exponer inquietudes, irritaciones y agradecimientos de forma rápida y directa, e incluso a través del cual podrían recibir una respuesta personalizada. De esta manera, la política se vuelve más cercana y la participación política se hace carne, por consiguiente, de manera indirecta el control fomenta y fortalece el régimen representativo democrático, en el cual la participación es elemento neurálgico. 
En cuarto y último lugar, es posible concluir que la reunión de todos los factores anteriores incide e impulsa la necesidad de ejercer un control fuerte, porque, en definitiva, sigue configurándose como un espacio atractivo desde una perspectiva política y mediática. Si bien sus efectos no serán tan radicales o efectivos como antaño, continúan promoviendo modificaciones de criterio o de políticas públicas de relevancia y, en otros casos, permiten fortalecen la imagen de algún líder político o un jefe de bancada parlamentaria ${ }^{524}$. Es por ello que los parlamentarios optarán por ejercer control en toda función parlamentaria, vale decir, en todo procedimiento sea este debate legislativo, obtención de información o el análisis de la ley de presupuesto.

Ahora bien, una conjugación de éstos cuatro elementos expuestos, configuran los pilares fundamentales en la construcción de una concepción amplia del control parlamentario, como la descrita por la doctrina española, italiana y francesa, pero que ciertamente ha de configurarse con sus propias particularidades en cada país. Por tanto, nos inclinamos por una noción amplia que permite ejercer control por múltiples medios y por diversos actores políticos, interpretación que fortalece e impulsa la revitalización de los regímenes políticos y que, en definitiva, reorienta los contextos históricos.

\section{b) La estructura del control parlamentario}

En la presente etapa de nuestra investigación, corresponde examinar cada uno de los elementos que componen el control parlamentario y las diversas miradas que existen respecto de cada uno de ellos, a fin de poder comprender cómo teóricamente debiera configurarse dicho control.. El debate doctrinal antes expuesto -respecto a la conceptualización del control relativo a lo que debemos entender por tal o, más bien, las concepciones que argumentan el cómo éste ha ido evolucionando hasta llegar a nuestros días sin perder vigencia y continuar cumpliendo su esencial rol de

\footnotetext{
${ }^{524}$ Respecto de este punto, es posible hacer mención ejemplificadora al rol que asumen en cuanto al control algunos personeros políticos, ya sean de Gobierno o de los partidos políticos que no ejercen el Ejecutivo. En esta dirección, creemos útil traer a colación la performance que ha realizado durante todo el Gobierno de la Presidenta Bachelett el Senador y Presidente del Partido por la Democracia Sr. Jaime Quintana, quien desde nuestra perspectiva, siendo un líder de los partidos de la alianza gobernante, ha optado por desarrollar una función crítica, tendenciosa hacia la izquerdisación del programa de Gobierno, actitud que en oportunidades impulsa modificaciones en la agenda legislativa y en el ambiente político del Ejecutivo.
} 
contenedor y limitador del poder-, conlleva adicionalmente la generación de secuelas en la configuración de los elementos del mismo.

Todo proceso de metamorfosis ha de ser compuesto por causas y efectos que se ramificarán a todos los órganos del individuo que sufre tal proceso de cambios, transformaciones que a su vez van creando un proceso concatenado de alteraciones, motivando importantes e interesantes discrepancias por parte de la doctrina, respecto del alcance de cada uno de dichos componentes. Por ello, la interpretación de los agentes de control como del parámetro y sus efectos serán materias de divergencia. En esta oportunidad, hemos decido aunar en tres los elementos del control. Estudiaremos los agentes del control, instancia en la que además tocaremos lo relativo al objeto del mismo; el parámetro; la naturaleza y los efectos del mismo.

Ciertamente, cada interpretación del control antes descrita realizará a su vez una lectura respecto de cada uno de aquellos engranajes del control. Por tanto, será bastante común detectar una orientación en ocasiones ligada entre los pensamientos referentes al concepto y sus elementos, mas no necesariamente serán siempre coincidentes. Tal situación, a nuestro juicio, viene a sumarse a las tantas otras manifestaciones que permiten ir coligiendo que el control parlamentario -como institución- es esencialmente dúctil, cuya configuración dependerá de las necesidades jurídico-políticas de cada Estado y en particular, de la forma en que conviva cada sistema político.

\section{b.1. Naturaleza $y$ efectos del control parlamentario}

Debatir en torno al control, comprende conjuntamente examinar la fiscalización como un poder y una función. Respecto de ello podemos señalar que lo cierto es que el control como poder responde a sus orígenes liberales, a sus experiencias históricopolíticas en las que el Parlamento se configuraba como contraposición del poder de la Corona y detentador pleno de la soberanía, debiendo realizar un control constante sin limitación de tiempos y formas que, de alguna manera, limitará los intentos absorbentes de un ejecutivo monárquico. Con el paso de los años, se mantiene aún en nuestros tiempos el control parlamentario, a manera de corolario de la función de representación de la sociedad, en virtud de la cual sigue detentando la soberanía. 
Hoy ya no es el contrapeso del monarca, ya no se enfrenta al Ejecutivo desde la perspectiva de una competencia de poderes; en la actualidad el control es concebido como una función ${ }^{525}$, cuya manifestación dependerá de la forma en que éste se desarrolle en cada contexto político, en cada realidad política nacional velando por el debido equilibrio de pesos y contrapesos.

El control parlamentario es la función que permite realizar una labor vigilante de las acciones del Gobierno, examinando su correcta orientación conforme a los intereses y necesidades del pueblo; así, el control implicará para el Parlamento un derecho y una obligación. Empero, comprendiendo que estamos frente a una función del parlamento es menester examinar cuál es la naturaleza de dicha institución.

Debemos señalar que no sólo el concepto ha sido un tema complejo de resolver, también lo ha sido la depuración de su naturaleza, en cuanto a si es el control una institución jurídica, política o de carácter ambivalente jurídico-política. Al igual que con lo sucedido respecto del análisis del concepto de control parlamentario y del parámetro, del mismo modo las consideraciones que aquí se expondrán marcarán sus diferencias y fijarán, como eje definidor y central, la posibilidad de exigibilidad o no de responsabilidad política. Por ende, los límites también estarán situados de cierta manera en la aplicación de sanciones y en el tipo de sanciones, motivo por el cual la vinculación entre aquellas perspectivas antes expuestas relativas a la noción de control -en muchos aspectos- coincidirá con estos elementos relativos a la naturaleza y su finalidad. A continuación analizaremos las principales inclinaciones teóricas respecto de la naturaleza y efectos del control.

\section{b.1.1. Control parlamentario, función de naturaleza jurídica o política}

Las principales diferencias que se producen en la inclinación por uno u otro sentido son claras. Siguiendo a Gutenberg Martínez, expondremos que la fiscalización política pretende criticar la conveniencia, la oportunidad, la utilidad o desventaja de una actividad determinada del Ejecutivo, sin poner en tela de juicio la competencia o la corrección jurídica del proceder de la autoridad o el órgano. Por el contrario, la fiscalización jurídica lo que pone en duda es precisamente la corrección

525 Carducci (1996) Pp. 9 y 10. 
jurídica del acto, o bien el órgano es incompetente o no se ha cumplido cabalmente el procedimiento jurídico. El control jurídico se ejerce sobre actos específicos; el control político se ejerce sobre el órgano, por ende, es posible analizar toda la actividad que él mismo despliegue. Un control jurídico posee un parámetro formado por normas de derecho, por consecuencia, indisponible. El control político posee un parámetro subjetivo y disponible; será voluntario en contraposición al carácter necesario del control jurídico. El control jurídico exige responsabilidad política, el control político no busca necesariamente una sanción ${ }^{526}$.

Ahora bien, habiendo clarificado las diferencias sustantivas entre uno y otro tipo de control, es posible analizar la forma en que la literatura científica en la materia ha desarrollado ambas visiones.

Aquellos que relacionan y esperan que la fiscalización contemple la posibilidad de exigibilidad de sanciones derivadas de un incumplimiento normativo y que posea una regulación sancionadora más específica, a través de la exigencia de la responsabilidad política, se refieren al carácter jurídico del control. En ese escenario, difícilmente aceptarán que la esencia de la fiscalización sea sólo la posibilidad de ejercerla, generando los más diversos efectos no vinculados a la responsabilidad política, utilizando criterios de oportunidad. Esta posición doctrinal, además, no concibe la posibilidad que el control se ejerza conforme a valoraciones netamente subjetivas, discrecionales y libres. No obstante, a pesar de la claridad y la rigurosidad con la que se expone una noción jurídica respecto de la naturaleza del control, no es la tendencia teórica seguida con mayor fuerza, muy por el contrario la doctrina mayoritaria se ha inclinado a través de los más diversos argumentos a estimar que el control parlamentario es de naturaleza política, como a continuación lo analizaremos.

La interpretación de la naturaleza jurídica del control es seguida por renombrados autores como Martínez Elipe y lógicamente Montero y García Morillo, y por alguna parte de la doctrina italiana ${ }^{527}$. Estos últimos dirán que el control parlamentario es una subespecie de control jurídico y a su vez es un tipo específico de control constitucional $^{528}$, de allí nacería su condición jurídica propiamente tal. No obstante,

\footnotetext{
526 MARTínez (1998) Pp. 36 y 37.

527 En esta materia especialmente Manzella y De Vergottini.

528 MONTERO Y GARCÍA (1984) p. 25.
} 
es posible hacer presente que los controles constitucionales pueden ser jurídicos y políticos, por tanto, la sola regulación constitucional no conlleva como consecuencia necesaria que todos los controles sean jurídicos o sub especies del mismo. Basta recordar que los controles políticos están positivizados pero, tal como iremos exponiendo, su objeto, parámetro y valorización serán más bien políticos.

Particularmente, para García el control parlamentario es jurídico y se desarrollará bajo criterios de oportunidad, dentro de un contexto de libertad de valoración, pero sobre la base o más bien encuadrado en un marco jurídico que establezca límites. Para el autor, carece de total fundamento colocar como puntos antagónicos la legalidad con la oportunidad de la fiscalización, pues ambos son puntos diferentes de una escala entre cuyos extremos hay un continuo ${ }^{529}$. Dicha línea interpretativa puede visualizarse en lo esbozado por Martínez Elipe, quien expresó un concepto del control claramente sancionador. Por ende, no es extraño que luego señale que el control proviene de un concepto jurídico que supondrá la existencia de un parámetro jurídico constitucional, que determina valores y principios, por tanto, los programas de gobierno deberán ajustarse a ello ${ }^{530}$.

En definitiva, podemos concluir que los argumentos que sustentan una naturaleza jurídica del control, conllevan además una noción de parámetro jurídico y de efectos jurídicos o institucionales, por ende, siempre estará presente la posibilidad de ejercer la responsabilidad política, a pesar de que todos coincidan en que ella es impracticable en la vida parlamentaria actual. Respecto al punto anterior, queremos señalar que desde nuestra perspectiva, tales nociones tienden a aferrarse fuertemente a la clásica concepción del control. Por lo mismo, hacen esfuerzos intelectuales por compatibilizar lo que originalmente fue el control con lo que actualmente se desarrolla por tal, generando una idea de la institución que puede dificultar su análisis.

Expondremos -a modo de ejemplo-, las declaraciones de Xuclá I Costa quien evidencia las problemáticas de aquella posición doctrinal que venimos analizando. El ex-senador español aboga por una separación entre el control y la responsabilidad, y, dando respuesta a las críticas que afirman la pérdida de eficiencia del control parlamentario, señala que tal afirmación es producto de la confusión de ambos

529 GARCÍA (1985) p.62.

530 MARTÍNEZ (2000) p. 109. 
elementos, los cuales son "intrínsicamente distintos" 531 . En efecto, el control parlamentario es realizado por las Cámaras de forma continuada, por medios específicos cuya finalidad es conocer la acción del Gobierno, expresar una opinión y trasladar todo a ello a la opinión pública. Y respecto a la responsabilidad política, ésta es una consecuencia eventual del anterior, que al desarrollarse en una democracia basada en el sistema de partidos, su ejecución será producto de la relación entre mayorías-minorías, que no suele ocurrir pues las normas de disciplina de partidos merman su ejercicio, buscando la estabilidad del gobierno y logrando una primacía del Ejecutivo sobre el Legislativo.

En la dirección opuesta, y respecto de la función de control parlamentario concebida como una función de naturaleza política, podremos observar en los párrafos siguientes que aquellas concepciones que entienden el control desde una perspectiva amplia, también argumentan que es una institución puramente política y que produce efectos de diversa índole. En definitiva, aquella parte de la doctrina que está por sostener la naturaleza política del control se fundamenta en el "principio de oportunidad política", y postularán que el control es una acción que se ejerce de modo continuado intramuros y extramuros parlamentarios, produciendo los más diversos efectos -no sólo renuncias, dimisiones o destituciones-. Estarán por sostener y defender la voluntariedad de su ejercicio, la libertad de apreciación y, en cierto modo, la subjetividad de su examen.

Sin lugar a dudas, quien ha desarrollado en profundidad la idea del control como una institución netamente política es el catedrático español Manuel Aragón Reyes, quien comienza su planteamiento desestimando precisamente aquel fundamento que sostiene que el control es jurídico por el sólo hecho de estar regulado jurídicamente, pensamiento que lo único que provoca es la confusión entre la norma y el fenómeno que regula. Es más, el autor describe que "de sostenerse tal error implicaría creer que la política carecería de normas o que esta no está institucionalizada"532. Tal afirmación, sólo responde a una tendencia actual del Estado de nuestros tiempos que tiende a regular toda actividad humana, a través de fenómenos de "normativización" y la "juridificación de la política"533, lo cual no es un proceso supresor del carácter político de tales fenómenos.

\footnotetext{
531 XUCLÁ I COSTA (2011) P.37.

532 ARAGÓN (1995) p. 159.

533 ARAGón (1986) P. 20-21.
} 
Para Aragón, un control es jurídico cuando hay una valoración jurídica del parámetro, presentando características fijas y determinadas. En estos casos, el parámetro estará compuesto por la Constitución, normas y reglamentos y ciertamente por los valores constitucionales, delimitación en la cual no forman parte el programa político, ni los valores democráticos. Por consiguiente, en el control político el parámetro es una composición libre. No existe un parámetro normativo, objetivo e indisponible. No hay un razonamiento jurídico necesario, porque el control se realiza bajo principios de libertad y de oportunidad, llevado a cabo mediante un juicio valorativo o de adecuación, que tendrá como efecto natural un análisis subjetivo de los mismos, y que además estará orientado hacia el electorado, destinado a provocar reacciones político-electorales más que sancionar o esperar responsabilidades. En esta dirección, el control político se realiza sobre toda de la actividad que ese órgano despliega, siendo el objeto inmediato del control un acto político concreto, una actuación política, en general, e incluso una norma.

En consecuencia, de las palabras del autor podemos destacar que la "subjetividad" del control político será primera característica y factor diferenciado entre ambos controles. De ello deriva la oportunidad con la que se ejecuta, su amplitud, libertad de criterio y de valoración, es por ello que el control político puede recaer sobre simples intenciones ${ }^{534}$, la total voluntariedad que rodea su iniciativa y la relación con la existencia de sanciones pero de carácter "indirecto". En cambio, el control jurídico es "objetivo", sus parámetros están formados por normas de derecho que resultan indisponibles para el actor que controla. Adicionalmente, expone Aragón, el control político produce efectos desde que se pone en marcha, el mero hecho de que se controle al poder puede generar efectos de algún tipo, ésta será la segunda de las fundamentales diferencias con el control jurídico. Luego, en el caso de ser negativo el resultado del control, para el control jurídico se produce inexorablemente una sanción por el carácter objetivo del mismo. En el caso del control político excluye aquel vínculo, por tanto el juicio negativo no necesariamente trae aparejada una sanción de forma automática, no posee efectos sancionatorios per se; sólo excepcionalmente y en los casos en que el propio ordenamiento lo prevea $^{535}$.

${ }^{534}$ ARAGÓN (1986) P. 15.

${ }^{535}$ ARAGÓN (1986) P. 17-18. 
Sin perjuicio de lo anterior, dicha carencia de sanción no significa que el control político no produzca efectos políticos. Operarán pero de manera indirecta, a veces sirve para poner en marcha otros controles, por ende, el control político siempre tendrá "la capacidad potencial" de aplicar sanciones indirectas o posteriores de carácter electoral, social o incluso de obstaculización de procesos futuros. Por ello, en la actualidad el efecto perseguido por el control político no conlleva la necesidad de derrocar gobiernos; los efectos pueden recorrer una amplia escala, alcanzando resultados igualmente potentes. Desde nuestra perspectiva, puede generar efectos políticos-partidistas y políticos-sociales. Los primeros, generarán movimientos al interior del Gobierno en especial de las fuerzas políticas que lo componen y, además pueden afectar las relaciones entre mayoría y minoría. Sin embargo, podrán existir efectos político-sociales que igualmente generarán consecuencias al interior de las fuerzas políticas. En el caso del Ejecutivo incluso pueden promover la salida de autoridades de sus cargos, porque a su vez desencadena o facilita el control social, de manera tal que los efectos pueden ser de gran dimensión.

En esta misma senda, el investigador nacional Alan Bronfman igualmente expresa que la fiscalización es una acción netamente política, cuyos efectos más relevantes será generar mejores marcos normativos y repercusiones mediáticas que influyan directamente en el cuerpo electoral que además, esclarece responsabilidades gubernamentales pero distanciándola de un rol más bien jurídico, dejándola en manos de la justicia ordinaria. lo anterior, implica, una debida aplicación del principio de división de poderes y el respeto irrestricto a los derechos fundamentales, evitando abusos de un poder del Estado ${ }^{536}$. Entonces, para José y Ángel Alonso de Antonio la noción política de la naturaleza del control parlamentario repercutirá en sus efectos y no podrá negarse que su carácter será también político, cuyas consecuencias podrán ser visibles al interior del Parlamento como ad extra. Para estos autores, el posible carácter jurídico del acto analizado o examinado en virtud del control no desvirtúa de ninguna manera el carácter político del efecto que nace de la utilización de un mecanismo de control parlamentario ${ }^{537}$.

536 BRONFMAN (2003) Pp. 105-153.

537 Alonso De ANTONio (2002) p. 199. 


\section{b.1.2. Control parlamentario, función de naturaleza iuspolítica}

Las concepciones antes expuestas respecto de la naturaleza jurídica y política, revisten suma importancia a la hora de realizar un estudio del control. No obstante, la vida parlamentaria y las expresiones del control parlamentario permiten visualizar y reconocer efectos jurídicos, políticos y otros difusos en el ejercicio del mismo, provocando las más diversas reacciones en el mundo político y jurídico. Por ende, han surgido bases dogmáticas diversas que abogan por un especial carácter bifronte de esta institución, en virtud de los siguientes motivos: incuestionablemente es una institución regulada jurídicamente lo cual, ciertamente, no la transforma en jurídica. Empero, no es posible ejercerla sin cumplir o realizar los mínimos jurídicos establecidos en las normas para activar sus procedimientos, por tanto, siempre existirá para su ejecutor un deber normativo al momento de ponerla en ejercicio.

Sin embargo, su finalidad y efectos son básicamente políticos, es decir, aspiran a engendrar efectos políticos de relevancia, esencialmente en la evaluación ciudadana del Gobierno para luego provocar consecuencias electorales, estando siempre presente la posibilidad de derivar hacia una sanción jurídica, que no se constituye como objetivo principal pero que estaría contemplada. En consecuencia, estamos frente a una tendencia que considera al control parlamentario como una institución iuspolítica, que no debe ni puede ser clasificada de forma estricta en una u otra vereda, porque, en definitiva, comprende rasgos de ambas.

La noción iuspolítica del control encuentra sus más relevantes expresiones en los postulados del profesor Galeotti, quien señala que la calificación del control dependerá a su vez de la calificación que el ordenamiento jurídico le da a los objetos sometidos al control, determinación en la cual también será de ayuda conocer cuál es la finalidad del control ${ }^{538}$. La función de control tomará, en consecuencia, la misma calidad que la de su cometido, es decir, la de su objetivo. Desde esta apreciación, la finalidad del control es esencialmente política, pero sus procedimientos son jurídicos. Por tanto, es una institución jurídico-política porque sus finalidades son políticas, pero sus procedimientos se encuentran regulados jurídicamente.

${ }^{538}$ GALEOTtI (1963) p. 37 y 38. 
Así también lo expresa Michel Carducci, cuando señala que la naturaleza del control es política pero necesitará ser procedimentalizado jurídicamente para poder actuar y será, en ese ámbito, donde el Derecho entra a cumplir un papel importante. En este sentido, el autor expone que si bien el control es una función de contenido político, no por ello su actuación puede ser libre y arbitraria ${ }^{539}$. En este mismo orden de ideas se expresan las declaraciones de Manuel Sánchez de Dios, quien también señala que tanto los procedimientos y mecanismos del control parlamentario tienen una naturaleza jurídica ${ }^{540}$ que en parte es constitucional pero que, sobre todo, están regladas por el Derecho Parlamentario. A pesar de esto, de forma posterior el autor desarrolla argumentos con un fin atenuador de tal noción, sobre todo cuando señala que dichas normas son de carácter flexible, para poder adaptarlas a la actividad parlamentaria y a las cambiantes circunstancias.

Finalmente, las apreciaciones de Portero Molina -a nuestro juicio- también sustentan una noción respecto de la doble funcionalidad o la naturaleza bifronte del control parlamentario. Para el autor, el control produce dos efectos. Los primeros son jurídicos, los cuales son de naturaleza "procedimental"541, pero que no ejercen efecto alguno sobre la voluntad del gobierno. Los segundos, son los efectos políticos de índole muy distinta, porque no se pueden medir y son principalmente difusos, inciertos y variados. Hemos de recordar que para Portero la actividad de control parlamentario, implica proporcionar fundamentalmente información continuada y variada sobre la acción de Gobierno, especialmente a un tercer destinatario: el electorado. Con todo, dirá Portero que:" El fundamento de la función de control se encuentra en que es políticamente, una general exigencia democrática $y$, jurídicamente, la manifestación del ejercicio de algunos derechos y deberes integrados al cargo público de parlamentario, sin los cuales su titular no puede hacer efectiva el derecho de los ciudadanos a participar por medio de su representante 1542 .

Desde nuestra perspectiva, y conforme a lo anteriormente expuesto, podemos señalar que el control parlamentario se configura además como una nueva dimensión de la representación política. Se constituye como un elemento que en cierta manera actualiza la democracia representativa, porque tal como lo dijéramos precedentemente, él nace a raíz de la delegación que el pueblo hace de su poder a

539 CARDUCCI (2002) Pp. 86 y 90.

540 SÁNCHEZ DE DIOS (1995) p. 36.

541 PORTERO (1998) P. 16 Y 20.

542 PORTERO (1998) P. 17. 
sus representantes, quienes -por su parte- han de velar por el correcto ejercicio del poder. No obstante, tal función ha sido cuestionada por una supuesta debilidad del órgano y de la representación en sí misma. Sin embargo, creemos que ello no es del todo efectivo, porque siguen existiendo instancias en las que sólo los representantes en interés de la nación pueden actuar. En efecto, sin perjuicio de la posibilidad de realizar un vigoroso control social por parte de la comunidad en colaboración con los medios de comunicación, siempre existirá una amplia gama de materias y procesos en los que la ciudadanía no podrá intervenir o influir -como por ejemplo la aprobación de la ley de presupuesto-, instancias en la que solamente los representantes de la nación podrán obrar por cuenta de sus mandatarios y propender al bien común. Por tal motivo, la participación en importantes asuntos públicos seguirá en manos de los representantes, situación que, en definitiva, revitaliza la noción de control parlamentario.

Ahora bien, de tal exposición es posible advertir que en esta materia se ha optado por la tendencia que describe Aragón, vale decir, aquella que descarta la interpretación que sostiene que por el solo hecho de estar regulada una institución por normas jurídicas -aun sin presentar mayores rasgos jurídicos-, se convierte automáticamente en una institución de carácter jurídico. En este sentido, es posible colegir que existe un consenso en señalar que los procedimientos de control parlamentario son jurídicos, lo que impregnaría tal calidad a la institución, sin embargo, los efectos han de ser políticos, atribuyéndole también dicha condición, lo que genera esta doble calidad.

Sin perjuicio de lo anterior, nosotros estamos por considerar una naturaleza única del control parlamentario de tipo político, toda vez que, si bien él está regulado constitucionalmente y sus procedimientos habitualmente están detallados en normas especiales, tal condición no lo vuelve un control jurídico. Tal como describe Aragón, un control es jurídico porque "jurídico es su parámetro y jurídico es el razonamiento" ${ }^{543}$, ambos elementos ausentes en el control parlamentario. Anteriormente expusimos que el parámetro del control parlamentario es mucho más amplio que los preceptos constitucionales. En su ejercicio ha de aplicarse el criterio de oportunidad y se evaluarán otros instrumentos -como el programa de Gobierno y elementos superiores- como los principios y valores constitucionales determinados

${ }^{543}$ ARAGón (1986) p. 102. 
por la tradición democrática de cada Estado, los que no necesariamente están regulados jurídicamente. En esta dirección, y reforzando nuestro argumento, diremos que la valoración de aquellos no ha de ser jurídica sino subjetiva $y$, esencialmente, libre. El razonamiento por tanto es político. En consecuencia, la configuración del control parlamentario está compuesta en gran medida por factores netamente políticos, y resulta desde nuestra concepción difícil atribuirle otra condición más que una naturaleza política.

\section{b.2. Agentes del control parlamentario}

Es preciso destacar que el control parlamentario forma parte de los controles constitucionales, el cual se expresa básicamente a través de dos ámbitos: uno referido a actos determinados y otro ejercido sobre órganos. En el primero, se examinan medios o actos determinados; en el segundo, se vigilan todas las actividades desarrolladas por un órgano en un momento determinado. El control parlamentario es un control de aquellos que se realiza entre órganos constitucionales, respecto de los cuales puede o no existir subordinación, condición que también ha sido cuestionada por la doctrina y que luego analizaremos. Por consiguiente, el desarrollo del control parlamentario comprende la participación de dos sujetos: un primer sujeto pasivo, o sea, aquel órgano respecto del cual recaerá el control; y un segundo sujeto activo, que es aquel a quien le corresponde ejercer la función de control. Agentes respecto de los cuales Manuel Aragón ha expresado que siempre serán órganos, autoridades o sujetos de poder, es decir, cualificados por su condición "política", pero nunca órganos jurisdiccionales ${ }^{544}$.

\footnotetext{
${ }^{544}$ ARAGÓN (1995) p.144.
} 


\section{b.2.1. Sujeto pasivo y objeto del control parlamentario}

En el presente apartado analizaremos conjuntamente el sujeto pasivo y el objeto de control debido a la estrecha vinculación que existe entre ambos, a fin de lograr una mejor comprensión de los mismos.

Es preciso señalar que el Gobierno, como sujeto del Derecho Parlamentario, ha de tener un comportamiento en ocasiones activo, como es el caso de las iniciativas de ley o en la tramitación de la ley de presupuesto y, en otras ocasiones, actuará pasivamente, cualidad que adquiere precisamente en el ámbito del control parlamentario $^{545}$. Desde una perspectiva estructural y tal como lo hemos podido vislumbrar en torno al debate del concepto de control, queda relativamente patente que el sujeto pasivo del mismo es el Gobierno. Por ende, los actos del Ejecutivo y la administración configuran el objeto de control, el conjunto de acciones que de él emanan y, desde perspectivas más laxas, también lo serán los actos de aquellos agentes políticos que lo apoyen. En tal dirección se encuentra la interpretación del sujeto pasivo del control realizada por Montero Gibert y García Morillo, para quienes el agente pasivo del control no sólo es el Gobierno, sino que también lo es la mayoría que lo respalda -en el caso de que se configure tal situación-, pues ambos entes serán considerados como un todo ${ }^{546}$.

Opinión similar es la expresada por Roberto Blanco Valdés, quien extiende aún más tal noción señalando que el sujeto controlado no se puede reducir a la acción política del Gobierno y de la mayoría que lo apoya -si ése fuera el contexto-, sino que las minorías pondrán en su punto de mira "toda" la actividad del Ejecutivo pudiendo, en tal sentido, dirigir el control a toda acción pública respecto de todas las administraciones y autoridades territoriales, institucionales o corporativas que de alguna u otra manera estén subordinadas al Gobierno; como también estará dirigida a toda actividad pública o privada realizada por los partidos políticos ${ }^{547}$.

Es posible percibir que en cuanto al sujeto y objeto del control, las interpretaciones parecen orientarse en la dirección más amplia posible, es decir, habilitar al control para que extienda sus brazos a la mayor cantidad de actividades

\footnotetext{
${ }^{545}$ Alba (2001) p. 30.

546 MONTERO Y GARCÍA (1984) p. 57.

547 BLANCO (2000) Pp. 43 y 44.
} 
del Ejecutivo. A juicio de Enrique Murillo de la Cueva, las razones de tal escenario expansivo se produce en razón de la doble naturaleza gubernativa y administrativa del Ejecutivo. Junto con ello, cabe afirmar que el Gobierno es un órgano que a su vez está formado por otros órganos, por ende, se debe incluir desde aquella premisa a todo aquel que participa de algún modo apoyando o prestando su colaboración en el ejercicio de la dirección política, para que éste desarrolle su programa ${ }^{548}$. Una interpretación similar es seguida por Solís, quien indica que debe entenderse que el sujeto controlado no sólo se circunscribe al poder Ejecutivo, sino también a los otros poderes, órganos y entes públicos, así como a sus responsables ${ }^{549}$.

La amplitud en la concepción del objeto del control, no queda allí. Como expone el jurista Garrorena, definir el terreno en el cual actúa la fiscalización parlamentaria (ámbito que, según el autor, de ser revitalizado contribuiría en nutrir al control de nuevos contenidos), posee dos aristas relevantes a considerar: una premisa inicial que dice relación con la necesidad de no constreñir el ámbito del control, porque si bien éste debe tener efectos en el Gobierno, no puede ser su único objetivo. Por ello, una segunda premisa implica considerar que nada impide investigar actividades privadas $^{550}$.

En tal contexto, la tarea de delimitar qué es lo que compone al agente pasivo del control señalado en esos términos se complica, puesto que la acción gubernativa tenderá lógicamente a cumplir su programa de gobierno $y$, en dicho cometido, tenderá a extenderse a múltiples potestades y organizaciones de las reparticiones públicas $^{551}$. Sin perjuicio de ello, estamos por seguir la interpretación que indica que el control parlamentario está asignado sobre la actividad gubernamental, y por ello el objetivo del control es conocer la acción del Gobierno, fiscalizarla, expresar una opinión al respecto, y trasladar todo ello a la ciudadanía ${ }^{552}$.

Siguiendo a Manuel Aragón, diremos que al ser un control político no tiene por finalidad controlar las producciones jurídicamente objetivadas del poder, sino controlar a los órganos del poder. En este sentido, la actividad de control se puede

\footnotetext{
548 Murillo de LA Cueva (2011) p. 376.

549 SOLÍS (1995) p. 57.

550 GaRRORENA (1998) Pp. 33 y 34. Respecto de este punto, el autor cita por ejemplo medios de comunicación y su concentración en la propiedad, pues allí radican algunos de los poderes que afectan de manera más directa a la población, respecto de los cuales al Parlamento le corresponde mantener límites.

551 MURILLO DE LA CUEVA (2001) p. 377

552 XUCLÁ I COSTA (2011) p. 36 y 37.
} 
despegar sobre el órgano mismo, o sobre una actuación política general e incluso una norma, pero al realizar ese tipo de control lo que realmente se está controlando es al órgano del que emanan dichas acciones, o a aquel que le son imputables. Así, la finalidad última del control político sobre órganos puede recaer en la actividad general de tal órgano, en una actuación específica o en una norma. Por las mismas características del control, éste puede ser sucesivo o previo, y de tal manera su objetivo puede residir en actividades ya realizadas pero también sobre proyectos ${ }^{553}$.

\section{b.2.2. Sujeto activo o agente controlador}

Como ya se ha indicado, el sujeto pasivo es aquel a quien le corresponde la labor de ejercer el control parlamentario mediante los mecanismos disponibles en cada ordenamiento jurídico, orientados en tal sentido. Esta competencia se encuentra depositada en el Parlamento -como lo expusiéramos latamente en el apartado relativo a la representación política como fundamento del control-, por consiguiente, se configura como una función del Parlamento por ser el órgano que encarna la representación de la colectividad. En consecuencia, quien debe velar por el correcto funcionamiento del órgano del Ejecutivo en relación con las demandas y expectativas del pueblo, será el Parlamento.

Indicar concretamente a quién o a quiénes les corresponde el efectivo ejercicio de tal función, parece ser a primera vista una tarea sencilla de esclarecer. Sin embargo, no lo es tanto. Una respuesta inicial debiera señalar de forma automática que constituyen sujeto activo las "minorías parlamentarias". Así por lo menos lo ha expresado de forma conteste la doctrina y lo grafica Ángel Garrorena cuando señala que la función de control es ordinariamente entregada por las constituciones al órgano parlamentario, y no a sujetos particulares. Pero, en el terreno de los hechos se ha producido un desplazamiento en la titularidad de la función, pasando desde el Parlamento -como órgano- hacia la minoría parlamentaria, quien sería el nuevo

sujeto activo del control respecto de lo cual habría un consenso extendido ${ }^{554}$. En este sentido, se ha señalado que minoría sería todo aquel grupo parlamentario que no

553 ARAGÓN (1986) Pp. 14 y 15.

554 GarRoRenA (1998) Pp. 26 y 27. 
forma parte de la mayoría ${ }^{55}$, conceptualización que determinaría a las minorías parlamentarias, en virtud de criterios netamente numéricos.

No obstante, nosotros estamos por denominar al sujeto activo como "oposición" y no como minoría parlamentaria, en razón de dos elementos de relevancia. El primero, por comprender el término oposición un espectro mucho más amplio que las solas minorías parlamentarias, permitiendo detectar diversos sujetos de control -incluso en los grupos vinculados partidariamente a la gestión del Gobierno-. El segundo elemento, dice relación con la mayor idoneidad de la idea de oposición que se vincula más correctamente con el papel o rol que verdaderamente ejerce en concreto el sujeto activo; esto es, básicamente, ser un ente opositor-crítico de las acciones del Ejecutivo.

Apoyándonos en los lineamientos planteados por el profesor Manzella, sostenemos que entre ambos sujetos existe una diferencia funcional, toda vez que pueden perfectamente existir minorías parlamentarias que no realicen actividades de control por no formar parte de aquellos grupos que actúan como oposición, quienes efectivamente realizan la fiscalización de los actos del Gobierno. Entonces, es dable distinguir a las minorías parlamentarias según su vinculación con otros actores políticos parlamentarios. Según sus actos, puede ocurrir que existan partidos políticos de menor envergadura parlamentaria, es decir, minoría parlamentaria que forma parte de coaliciones políticas mayores -originadas en una instancia previa al periodo electoral o post-electoral debido a razones político-estratégicas-, que se vinculan con otras fuerzas políticas formando alianzas de gobierno. Esta situación las ubica en otro sitial político que el de las mayorías. Si aquel conglomerado además es el gobernante cumplirá lógicamente otro rol, cual es, el de sostenedor del Gobierno, y no se sentirán identificados con los otros grupos minoritarios de oposición, por ende, no realizarán control a pesar de ser un grupo minoritario.

Otra situación particular en torno a las minorías, la configuran las pequeñas minorías, quienes no forman parte de aquellas minorías con mayor protagonismo que pueden ser o no de oposición, sino que ingresan al Parlamento en situaciones coyunturales, como dice Rosario Serra, representando a minorías sociales tales como la raza, lengua o el territorio. Esta condición las coloca en una situación muy

555 SERRA (2009) p. 103. 
diferente y en una desventaja numérica y política al momento de ejercer las herramientas de control, factores que finalmente determinan su participación parlamentaria desde un prisma más colaborativo con el Gobierno, negociador de beneficios particulares en favor de sus representantes, alejándose, por tanto, del posible control parlamentario ${ }^{556}$.

Con todo, el profesor Manzella formula un llamado de atención, señalando que no todo grupo minoritario constituye oposición y que no se debe caer en el equívoco de pensar inmediatamente en las clásicas relaciones de mayoría-minoría, porque aquellas no responden a las nuevas formas políticas; ni a los modernos acuerdos políticos parlamentarios; ni tampoco responden a las múltiples diversidades que surgen al interior del Parlamento ${ }^{557}$. Sin embargo, es muy probable que la condición de minoría coincida con la de oposición. Empero, el autor citado nos entrega otro criterio definidor del sujeto activo; dirá que los números no determinarán las mayorías o minorías, sino que lo que realmente determina a la oposición será su comportamiento 558 .

Por nuestra parte, diremos que un elemento de suma importancia para determinar quién ejerce o no control será el esclarecer cómo se desarrolla la vida parlamentaria y cómo cada fuerza política se relaciona concretamente con el Ejecutivo, ya sea que esté en oposición y en perfecta armonía con el mismo -debido esencialmente al factor dinámico característico de la política y a la diversidad de materias que se tratan en el Parlamento-. Estimamos que deben de ser considerados también elementos como la cohesión de los ejes de izquierda-derecha, las posibles fragmentaciones internas de los conglomerados, la distancia o cercanía ideológicas existentes entre los partidos políticos ${ }^{559}$. Esa última es a veces difusa en la

\footnotetext{
556 SeRra (2009) Pp. 104 y 105.

557 Refiriéndose particularmente al sistema italiano, el autor plantea que sólo en dos momentos del desarrollo político las fuerzas parlamentarias se vinculan y se puede -formalmente- hablar de mayorías y minorías. La primera oportunidad se gesta en el momento de otorgamiento de confianza, situación en la que ciertamente serán los números los que configuran las mayorías y las minorías. El segundo momento se da en el proceso legislativo a través del cual se gesta una natural contraposición dialéctica entre grupos contrapuestos.

558 MANZELLA (2003) Pp. 421 y 422.

559 En este punto es recomendable revisar los expuesto en: GARCÍA Y MARTíneZ (2002) Pp. 331-373.

Documento en el cual las autoras examinan detalladamente el escenario latinoamericano presidencialista y la forma en la que se desarrollan los partidos políticos de oposición, exponiendo los factores que los determinan y aquellos elementos que son especialmente relevantes en su actuar. Es destacable señalar que las autoras concluyen el trabajo sosteniendo que entre mayor es la influencia de la oposición en las decisiones de las políticas públicas del Gobierno, se obtienen mayores grados credibilidad de la institución parlamentaria por parte de la población contribuyendo todo ello finalmente en el fortalecimiento de la democracia.
} 
actualidad, puesto que ellos contribuirán en la articulación y desarticulación de los grupos parlamentarios $y$, como consecuencia de aquello, definirán un comportamiento colaborativo u opositor.

Habitualmente se asocian ambos términos de minoría parlamentaria y oposición como si fueran conceptos sinónimos, lo cual a nuestro juicio es incorrecta. En este punto compartimos lo dicho por Sánchez Narro, quien diferencia ambos conceptos en el siguiente sentido: el concepto de oposición sería esencialmente jurídico-político y, por otro lado, el concepto de minoría sería un término amplio. En efecto, la utilización de la voz minoría se alude frecuentemente a todo tipo de grupo social numéricamente inferior; es así como se habla de minorías étnicas, lingüísticas, sociales, de género, las cuales lógicamente no pueden ser asociadas por el solo hecho de ser "minoría social" a la noción de oposición parlamentaria ${ }^{560}$, ya que responde a condiciones de diferenciación distintas. Para el autor, en la esfera de la vida política y parlamentaria, las minorías pueden identificarse con la oposición en cuanto tienen y representan principios, intereses y valores diferentes a los de la mayoría. Es en esa situación de mínimo común compartido, que fundamentarán y protagonizarán la función de crítica pública de carácter sistemática a la mayoría parlamentaria-gobernante, con la aspiración más o menos realista de llegar a reemplazarla.

Empero, la diferenciación de conceptos aquí planteada no ha sido seguida unánimemente, sino que ha sido mucho más común la unificación de los términos de minoría y oposición -sólo a modo demostrativo exponemos unas referencias-. Para Torres Muro, ambos conceptos son idénticos. En efecto, el autor al referirse a la labor de supervisar políticamente la actividad gubernativa, señala que es una función que le corresponde a los "grupos de oposición" y, posteriormente, agrega que los mecanismos de control -tales como las comisiones de investigación, las preguntas e interpelaciones- son instrumentos de control "de las minorías"561. En consecuencia, a través de las declaraciones de Torres Muro, podemos evidenciar una conceptualización común entre los especialistas en la materia, asimilando los términos de minoría y oposición. Sin perjuicio de aquello, en nuestra opinión ambos constituyen sujetos distintos y lo hemos sustentado precedentemente.

560 SÁNCHEZ (1995) Pp. 42-43.

561 TORRES MURO (1998) Pp. 24 y 25. 
Habiéndose examinado al sujeto activo del control, hemos de analizar otra arista de suma importancia en este ámbito. Habitualmente se ha sostenido durante mucho tiempo que el factor determinante de la crisis del control parlamentario está situado precisamente en este punto, es decir, en la confusión de actores o en la fusión que habría de existir entre ellos (mayoría-gobierno), por sobre todo en gobiernos parlamentarios y cada vez más presente en regímenes presidenciales mediante los presidencialismos mayoritarios. Este fenómeno se origina por la llegada de los partidos políticos de masas, la disciplina partidaria, y en general con el arribo de la democracia de partidos. Así, se ha planteado que en los regímenes donde se produce tal coincidencia entre mayoría parlamentaria y gobierno, se origina una ausencia de control parlamentario graficado en frases como "nadie se fiscaliza a sí mismo" o la dificultad del "autocontrol", o como expresa Ramón Soriano, entre mayoría y Gobierno existe una "correa de trasmisión" ${ }^{562}$.

Por tanto, no cabría hablar de control parlamentario por parte de las mayorías parlamentarias cuando coinciden -ideológicamente o a razón de alianzas políticascon el Gobierno, porque a su vez lo configuran y son parte del mismo. En consecuencia, es probable que apoye la gestión del Ejecutivo por coincidir partidariamente o por lealtad programática en virtud de un compromiso político, motivo por el cual sus esfuerzos estarán situados en apoyar aprobando leyes que le sean requeridas, entre otras diversas gestiones. Estará muy lejos de ser su principal acción o preocupación realizar la fiscalización del mismo, quedando, en consecuencia, el control en manos principalmente de la oposición, quienes lo ejercerán con miras a la alternancia del poder, a través de la crítica oportuna y constante a la gestión de Gobierno.

Desde nuestra perspectiva, no es posible adherir irreflexivamente a la aseveración anterior, porque las relaciones políticas han variado. Los vínculos, lealtades y relaciones entre mayoría-Gobierno han cambiado, incluso es posible decir que en las democracias modernas la mayoría parlamentaria puede no estar refleja en el Ejecutivo; puede ocurrir que existan presidentes minoritarios o jefes de gobierno de minoría. En este sentido, cabe distinguir entre mayorías que no forman parte del Gobierno y las mayorías que sí forman parte del Gobierno. Respecto de las primeras, no habrá duda alguna sobre su probable inclinación hacia el ejercicio de una fuerte

562 SORIANO (2001) p. 3. 
función fiscalizadora, principalmente, haciendo gala de la fuerza numérica de la cual gozan. En el segundo caso, la situación es un poco particular porque puede ocurrir que la preocupación por mantener el poder y obtener reelecciones los motiven a fiscalizar el correcto cumplimiento del programa de Gobierno. Sin embargo, siempre estará latente la posibilidad de que primen las disciplinas y el control se anule. La importancia de este asunto es de alta razón, por lo cual pasaremos a continuación a examinar dicho contexto.

Respecto de las mayorías que se encuentran ligadas al Gobierno, reiteramos en el mismo criterio esbozado precedentemente. En cuanto a la necesaria diferenciación de los términos minoría y oposición -en directa relación con la imposibilidad de definirlos o clasificarlos a priori por una sola configuración numéricadiremos que los roles que ha de ejercer cada grupo parlamentario variará conforme a múltiples factores e incluso en virtud de intereses coyunturales. Sostenemos entonces que lo que definirá a la oposición será el comportamiento y no el número de personas que la ejecuten.

Estimamos también preciso reforzar en esta instancia otro planteamiento que exhibiéramos cuando tratamos la función legislativa, oportunidad en la que señalamos que en el procedimiento legislativo era del todo posible el ejercicio del control por parte de la mayoría, opinión compartida por Tudela, Aragón Reyes, García Martínez y García Escudero. Este argumento lo seguimos sosteniendo en esta etapa de la investigación; desde nuestra óptica, las mayorías vinculadas al Ejecutivo también forman parte de los sujetos activos del control parlamentario, noción que se ve fuertemente reforzada con la interpretación amplia del concepto de control, en virtud del cual se ha señalado que toda función parlamentaria implica -en cierto grado- fiscalizar la acción del Gobierno y que toda acción constituye fiscalización. Por tanto, creemos que tal amplitud de criterios permite también extenderlos a los sujetos del control.

En este contexto, sostener que la mayoría ejercerá control parlamentario implica reconocer además que sus actuaciones presentarán una naturaleza e intensidad diferente al realizado por la oposición ${ }^{563}$. Incluso para De Vergottini la gestión fiscalizadora que realiza la mayoría parlamentaria será aún más eficiente y

563 SERRA (2009) p. 101 
expedita que la realizada por la oposición, en virtud de que esta mayoría no debe utilizar los mecanismos establecidos legalmente para el control, no se verán limitados ni obstaculizados por quórums o requisitos o procedimientos legales o reglamentarios. Su fiscalización se expresará directamente al interior de los partidos políticos de gobierno ${ }^{564}$, provocando en ocasiones fuertes transformaciones en la composición del Gobierno y en las orientaciones políticas del mismo. Desde otra perspectiva, agrega el autor, la mayoría cuenta efectivamente con un parámetro para medir la gestión del Gobierno -el programa de Gobierno-, facilitando la formulación de observaciones. En este sentido, ellos sí deben esforzarse por cumplir tal programa, no así la minoría, quien al realizar la actividad de control coteja las acciones del Ejecutivo con su propio programa alternativo o simplemente evidencia de las acciones del Gobierno, sin ánimo de realizar una evaluación de su cumplimiento sino que su finalidad solamente es la de sustituirlo. La actividad controladora será, en consecuencia, sólo un pretexto para promoverse como su alternativa $^{565}$.

Así además lo exponen Montero y García al declarar que tanto mayorías como minorías ejercerán control: las minorías tenderán a que el Gobierno se acerque a su posición, y la mayoría exigirá el cumplimiento del programa en base al cual han adquirido la confianza de la ciudadanía. En este escenario, la minoría formulará una crítica porque se realiza lo que no se debe y la mayoría criticará cuando no se cumple ${ }^{566}$. En estas actividades evidentemente se presentarán diferencias: las mayorías las realizarán de manera más reservada, sin buscar una proyección comunicacional pero siempre lo ejecutarán incluso cuando el Gobierno goce de mayor autoridad; y las minorías, por el contrario, buscarán una mayor publicidad, porque como lo analizáramos anteriormente, para estos autores el destinatario final del control es un tercero, es el cuerpo electoral.

\footnotetext{
${ }^{564}$ La perspectiva planteada por el De Vergottini presenta manifestaciones concretas en nuestro escenario nacional. Las presiones que se han ejercido tanto a los Gobiernos de la Concertación de Partidos por la Democracia como las observadas en el gobierno de la Alianza por Chile, han sido evidentes principalmente vinculadas a cambios de gabinete, modificación de la agenda del Gobierno, entre otras. En la actualidad, se vislumbran claras advertencias en materias de reformas políticas al interior de la Nueva Mayoría en el actual Gobierno de la Presidenta Bachelett, provenientes particularmente del Partido Demócrata Cristiano, en relación a la reforma tributaria, reforma educacional y la denominada agenda valórica. Presiones que además no han gozado de discreción, toda vez que el timonel del PDC no ha tenido reparos en formular públicamente sus reticencias con las materias en cuestión y las condiciones de su posible aprobación.

565 VeRGOTTINI (2010) p. 520.

566 MONTERO Y GARCÍA (1984) Pp. 51 y 52
} 
En esta misma dirección, podemos también reconocer en el plano nacional un similar planteamiento. Gutenberg Martínez entrega una interpretación que permite entender al control como una acción realizable tanto por minorías como por mayorías. Para el autor, el control gubernamental en regímenes democráticos representativos es ejercido por las minorías de forma abierta, y por las mayorías de manera mesurada. En efecto, estas últimas lo harán de forma más reservada y discreta pero realizarán control. Para el ex-congresista, los matices se presentarán en la intensidad del control proveniente de minorías o mayorías que responderá a múltiples factores, dentro de los cuales señala al tipo de gobierno democrático, al sistema de partidos, su disciplina y coherencia, gobiernos de mayoría o minoría, gobiernos monopartidistas o de coalición ${ }^{567}$.

Sin lugar a dudas, quien expresa un planteamiento diverso en aras de sustentar la noción de control por parte de las mayorías incumbentes en el Gobierno, es Antonio Embid -catedrático de Zaragoza-. Este autor, siguiendo una posición de la doctrina alemana esbozada por Schneider y $Z{ }^{568}{ }^{2}$, parte de la base de la necesidad de comprender al control parlamentario desde una conceptualización diversa a las comúnmente declaradas. Para estos autores el control se reduce a la sola capacidad de tomar propias decisiones. Por tal motivo, el control por naturaleza corresponderá a la mayoría, toda vez que en un sistema democrático sólo las mayorías podrán votar y definir los lineamientos políticos; podrán tomar las decisiones. Esta situación además fue fortalecida con la adopción del Parlamento racionalizado, el cual en búsqueda de la estabilidad de los gobiernos ha puesto en manos de la mayoría todas las posibilidades de uso de las herramientas de control, orientando insensiblemente la búsqueda de fórmulas mayoritarias, pudiendo -incluso- acordar el derribo del Gobierno, en atención a que la presente concepción considera que la articulación de la mayoría no es estática y originaria, sino que se va definiendo mediante procesos continuos $^{569}$.

Por tanto, resulta razonable sostener que existe un verdadero control por parte de las mayorías parlamentarias, función que ciertamente presentará características especiales en cuanto a la intensidad y sus procedimientos, pero respecto de la cual

567 MARTínez (1998) Pp. 17 y 18.

568 En relación con estos autores y a fin de comprender tal concepción del control es preciso ver: SCHNEIDER Y WOLFGANG (1989).

569 EMBID (1992) Pp. 11 y 17. 
es imposible negar los efectos que puede producir. Continuando con aquella noción que determina a la oposición, según el comportamiento del agente político y no en virtud de factores numéricos, no resulta complejo detectar en ciertas oportunidades un rol opositor proveniente de partidos políticos o parlamentarios particulares que forman parte de la mayoría, sea gobernante o no. En ocasiones sus críticas u observaciones gozan de mayor dureza que las realizadas por la oposición de minorías, generando más repercusiones programáticas o de remoción de agentes de gobierno.

Como lo describiéramos al tratar el concepto amplio del control desde la doctrina francesa, traemos a colación lo señalado por Norton cuando explica que existen distintos modos de controlar al Ejecutivo. La fiscalización puede provenir de agentes extraparlamentarios, desde un parlamentario individual, de grupos sociales, o de parte de los miembros de partidos políticos de coalición de Gobierno, o de aquellos que no forman parte del mismo. Ante tal escenario, plantea el autor que la oposición será más eficaz, precisamente, cuando proviene desde el interior de la alianza de Gobierno, puesto que gozan de un fuerte poder de veto y otros mecanismos de presión. Dichas herramientas y la necesidad de permanecer unidos otorgándole estabilidad al mandato presidencial, fomentará el desarrollo de concesiones, por ende, los efectos del control serán más nítidos ${ }^{570}$.

Lo descrito precedentemente, se manifiesta conteste con una idea bastante más general que ha venido primando en el desarrollo de esta investigación, la que dice relación con una interpretación amplia del control parlamentario. Es precisamente desde aquella apertura doctrinal relativa a la noción de control, desde donde es dable ampliar la concepción de los elementos que forman su estructura. Por ende, es factible sostener -a nuestro juicio y tal como lo han expuesto connotados autoresque las mayorías parlamentarias realizan control parlamentario.

${ }^{570}$ NORTON (2010) Pp. 19 y 20. 


\section{b.3. Parámetro del control parlamentario}

El parámetro del control parlamentario es aquel canon, margen, unidad de medida o criterio que deberá tener en cuenta el sujeto activo -el agente controladoral momento de realizar fiscalización, sea esta última entendida como una valoración, un examen o un juicio. Para algunos autores, es precisamente en este elemento donde se encuentra ubicada la piedra angular de toda la institución. Es inexcusablemente este elemento el que fijará la línea divisoria entre un control jurídico y sus efectos sancionatorios, vale decir, la aplicación o no de responsabilidades políticas. O por el contrario, instituirá una arquitectura de control más bien política, que produciría efectos desde que se inicia su ejercicio y respecto de los cuales el margen de variabilidad es bastante más amplio, pudiendo igualmente estar presente la responsabilidad política pero de manera muy excepcional -como última ratio del control, toda vez que ella no es el objetivo central del ejercicio del control parlamentario-.

Con todo, en el presente apartado describiremos ambas tendencias doctrinales, aquellas que proponen una noción jurídica y las que postulan una visión política del parámetro y sus respectivos efectos. En una primera etapa, seguiremos las valiosas declaraciones del autor italiano Armando Mannino, quien nos permitirá describir en detalle cómo se deslinda cada inclinación teórica. Posteriormente, realizaremos un análisis acabado de tales concepciones, a través del estudio de otros exponentes emblemáticos en el Derecho Parlamentario y, en particular, importantes estudiosos del control parlamentario. En consecuencia, centraremos nuestro examen en las dos concepciones más significativas respecto del control parlamentario: las interpretaciones jurídica y política.

Conforme a las declaraciones de Mannino, y considerando que el control parlamentario es una verificación de la actividad desarrollada por un sujeto por parte de otro sujeto controlador conforme a un parámetro, será precisamente la determinación de tal parámetro el factor decisivo que nos indicará cuál será la orientación que tome dicha institución, y por ende la que adopte el intérprete. La primera noción de parámetro está integrada por una opinión tradicional y muy difundida en la doctrina, la cual dirá que el control parlamentario tiene un componente jurídico lo que conlleva que la verificación que ha de realizarse por el 
sujeto controlante -mediante el ejercicio del control parlamentario- debe alcanzar un hallazgo que implique necesariamente la violación concreta del parámetro.

Por consiguiente, y desde esta perspectiva el parámetro será un norma rígida, la que por el hecho de ser infringida impondrá además una obligación al sujeto controlante, concerniente en adoptar una sanción respecto del sujeto controlado. Esta sanción debe ser de cierta gravedad o envergadura, como la aplicación de la responsabilidad política y/o las destituciones o dimisiones. No obstante, para Mannino si bien dicha sanción es ejemplificadora, no sirve para alterar la irreversibilidad de los daños o problemas ocasionados entre los sujetos del control Parlamento-Gobierno, careciendo de utilidad concreta. En una segunda óptica del parámetro, estima que la verificación que se debe realizar por parte del sujeto controlante mediante el control parlamentario tiene un componente de carácter político, lo cual implicará prescindir de la vinculación inmediata entre la valoración y el hallazgo de una violación, sino que -por el contrario- comprende que la actividad de valoración sea una actividad discrecional, mediante la cual tanto la oportunidad en la que se realiza como la aplicación o no de una sanción es libremente juzgada a través de criterios políticos.

Es por ello que el tipo de sanción que podrá aplicarse no será imperiosamente la responsabilidad política. Por el contrario, podrá provocar otro tipo de presiones o críticas que pueden alcanzar ciertos resultados aún más efectivos que las destituciones o dimisiones. Para el autor italiano, en estos casos en que el control es entendido como un control político, el parámetro estará constituido, por ejemplo, por el programa político del Gobierno, razón por la cual las consecuencias de su ejercicio se vuelven muy singulares dado que el programa de Gobierno ostenta cierta movilidad. La presente interpretación considera al parámetro un elemento moldeable no determinado, pero sí lo considera una parte integrante del indirizzo político. Por ello, la valoración realizada podrá ir reprimiendo y re-direccionado dicho programa, previniendo desviaciones eventuales. La verificación en este caso se transforma en una invitación al Gobierno para adoptar medidas o modificar las adoptadas, sin perjuicio de las presiones políticas que ello pueda generar como efectos colaterales $^{571}$.

571 ManNino (2010) Pp. 326 y 327. 
Habiéndose expuesto las dos posibilidades interpretativas respecto del parámetro como elemento del control, corresponde ahora examinar las manifestaciones doctrinales de destacados investigadores en la materia que sustentarán una u otra noción, y que nos permitirá arribar a nuestras propias conclusiones. En este sentido, Manuel Aragón Reyes se inclina por un control de carácter netamente político. Nos explica que efectivamente existen dos tipos de parámetros: unos jurídicos y otros políticos. Los primeros están jurídicamente objetivizados, mientras que los segundos son de carácter subjetivo, disponible y no necesariamente preexistente o pre-determinados. No es posible asociar a una regla o a una norma, de allí que el control parlamentario goce de tal nivel de voluntariedad, pues el agente controlante decide libremente el momento de ejercerlo, gozando adicionalmente de absoluta libertad de criterio. Por ello, nos dirá Aragón que el órgano parlamentario -al ser un órgano político- puede recurrir a las normas pero las interpretará políticamente. En este orden de ideas, podrá recurrir por ejemplo a la Constitución como un parámetro, no obstante su interpretación será política y no jurídica porque él en sí mismo se sustenta en motivos políticos. Por tanto, no utilizará un método jurídico como le correspondería a un juez ${ }^{572}$.

Podemos señalar que para el autor el parámetro estará compuesto esencialmente por principios que podrán ser libremente valorados; quien controle será finalmente quien coloque el límite al parámetro, así, la voluntad del agente controlante puede evaluar una actuación del Gobierno como "inoportuna", como carente de "confianza"573. Respecto a esta concepción del parámetro, hay que señalar que la libertad valorativa a la que se refiere el autor es posible aplicarla cuando el procedimiento de control establecido en cada cuerpo normativo constitucional le reconoce, a su vez, libertad en la conformación del parámetro, es decir, si efectivamente le concede la posibilidad de utilizar criterios puramente políticos o de oportunidad porque es posible que exista una regulación normativa que imponga la utilización de un parámetro normativo, proceso en el cual debe cotejarse la conducta con el canon, ahora bien, si seguimos al autor siempre ha de poder valorarse o interpretarse esa confrontación libremente.

572 ARAGón (1995) p. 150 y 151

573 ARAgón (1986) Pp. 15 y 16. 
Desde la otra vereda conceptual, cabe señalar primeramente que cuando hablamos de control parlamentario estamos analizando una categoría del control constitucional, control que debiera entenderse como una actividad dotada de efectos jurídicos la que consistiría en la evaluación de la conformidad de un determinado acto o de un conjunto de actos desarrollados por un sujeto que está investido en una función constitucional, con un parámetro calificable normativo o regulatorio, pudiendo aplicarse posteriormente las medidas necesarias para eliminar las disconformidades eventualmente detectadas ${ }^{574}$. Es decir, cuando hablamos de control parlamentario estamos hablando originalmente de una expresión del control constitucional que inicial y comúnmente se ha vinculado con un control jurídico, por ende, con un parámetro normativo que implica la aplicación de sanciones reguladas legalmente.

Ahora bien, como toda manifestación doctrinal, ésta expresa los más diversos matices sin alejarse de la noción jurídica de la misma. En este sentido, recogemos lo analizado por Zárate ${ }^{575}$, quien inicialmente advierte que la fiscalización y el control son procesos o mecanismos a través de los cuales podemos hacer exigible la responsabilidad política como finalidad primaria, aunque no sea su único propósito. Tal proceso implica realizar actos de determinación y comprobación de las acciones de un agente público, conforme a la normativa vigente y a un programa político. No obstante, para Zárate la sanción no sería un elemento esencial del control político o fiscalización, pueden existir ambos sin la necesidad de aplicar una determinada sanción. Empero, agrega que de existir y tener que aplicar una sanción ésta puede revestir una variedad de formas, mas no las clásicas como dimisiones o destituciones.

En consecuencia, como es posible advertir y como hemos expuesto latamente la noción estrictamente jurídica ha sido matizada con el correr de los años, hasta llegar a nuestros días a través de una conceptualización mucho más amplia. Lineamientos doctrinales que de alguna manera expone Joaquín García Morillo cuando explica que el control será jurídico, en consecuencia, su parámetro también lo será. Sin embargo, a fin de poder sustentar tal declaración, explica que a pesar de ser un control de legalidad, aun el más riguroso de aquellos tendrá siempre un sesgo

\footnotetext{
574 ENCICLOPEDIA GIURIDICA (1988) p.1.

575 ZÁRATE (2009) pp. 62-69.
} 
subjetivo, y para aminorar tal situación se crean los criterios de interpretación, porque a pesar de la libertad de la cual efectivamente puedan detentar, siempre existirán restricciones o acondicionamientos legales como límites a aquella actividad de valoración ${ }^{576}$. Lo relevante para Joaquín García es reducir la ambigüedad y arbitrariedad con la que pueda realizarse la actividad de control, por ende, propone el establecimiento de ciertos márgenes que acoten la movilidad del agente controlador.

Respecto de esta orientación de corte más bien jurídico, es posible señalar que su configuración siempre ha de ir ligada a elementos subjetivos o valóricos. En definitiva, los autores que colocan al ordenamiento jurídico como parámetro igualmente agregan un elemento no normativo, pero la diferencia no se encuentra depositada allí, como fue expuesto anteriormente. La diferencia está marcada por la sanción que acarrea el parámetro jurídico, el que suele ser de mayor envergadura que el del parámetro político. Sin embargo, lo cierto es que, aun considerando el elemento jurídico como relevante, han de incorporar igualmente elementos subjetivos.

Muestra de aquello lo constituyen las expresiones de Alex Solís, cuando señala que el propósito del control es determinar si las acciones del Poder Ejecutivo y de otros órganos o entes públicos, así como las de sus funcionarios, se adecuan al ordenamiento jurídico así como también a establecer, si la actividad de la administración pública en general está orientada por las expectativas de la voluntad popular $^{577}$. En igual sentido, y en palabras de Gutenberg Martínez, el control es un juicio de valor formulado a la luz del examen de un determinado acto de Gobierno, hecho en correspondencia con el ordenamiento jurídico y con principios consensualmente aceptados por la sociedad que dicen relación con el bien común ${ }^{578}$.

En esta dirección, podemos concluir que el parámetro puede estar constituido por unos márgenes políticos, como lo serían los principios o valores constitucionales y el programa político del Gobierno ${ }^{579}$. O, en su defecto, ha de estar conformado por un canon jurídico que involucra a una norma jurídica específica. Ahora bien, por nuestra

576 GARCÍA (1985) p.61 y 62.

577 SOLÍs (1995) p.56 y 57.

578 MARTÍNEZ (1998) p. 30.

579 SANTAOLALLA (1984) p.200. 
parte creemos que cualquiera que sea la composición del parámetro, la valoración del mismo será política, por tanto, sostenemos que el control parlamentario -al ser básicamente un control político- realizará consecuentemente una valoración de la actuación del Gobierno subjetiva y netamente política, que además se realiza en virtud de criterios de oportunidad que también son políticos.

A mayor abundamiento, graficaremos lo expuesto plasmando las diferencias que se producen en cuanto al parámetro entre el control político y el control jurídico, a fin de demostrar la marcada propensión política que posee el control parlamentario.

Si bien ambos controles aspiran a un objetivo común, como lo es la limitación de las arbitrariedades del poder, el control jurídico particularmente se concentra en reprimir el incumplimiento de la Constitución, el restablecimiento de la fuerza normativa y la supremacía de la misma. Aquella defensa constitucional, se realiza a través de una justicia o jurisdicción constitucional, la que posee normas y procedimientos especiales ${ }^{580}$. En tal sentido, para que exista la jurisdicción constitucional como medio de control jurídico, es menester que existan tribunales que ejerzan potestad para conocer y resolver los conflictos constitucionales con la clara finalidad de dotar de eficacia a las normas constitucionales, especialmente, en relación a la protección de los derechos fundamentales. A pesar de que la composición de los mismos generen discrepancias, puesto que -tal como dice Rubio Llorente- son tribunales jurisdiccionales pero con componentes políticos, porque el sujeto controlado habitualmente es un órgano político ${ }^{581}$. Su actividad es jurídica, por ende, su parámetro y razonamiento se ajustarán procedentes legales.

En tal escenario, y siguiendo a Nogueira, diremos que el control jurídico es un control interórgano, que se caracteriza básicamente por configurar un control objetivo, porque existe un orden normativo preexistente, mediante el cual se realiza la valoración del objeto sometido a control. Esta valoración estará basada en razones jurídicas. Junto con lo anterior, el control jurídico es un control en el que el órgano controlante es independiente, imparcial y calificado; es un control necesario, lo que implica que el órgano controlante debe ejercerlo cuando es solicitado y, en el caso de

\footnotetext{
${ }^{580}$ Cappelletti (1986) Pp. 14 y 15.

581 RuBio (1992) p. 13.
} 
verificar una infracción, debe emitir un fallo. Así, los órganos que ejercen control jurídico son generalmente verificadores de limitaciones preestablecidas ${ }^{582}$.

Por tanto, en lo que a nosotros respecta, corresponde traer a colación lo descrito por Aragón, cuando narra que el parámetro en el control jurídico lo componen "normas abstractas, predeterminadas, que le vienen impuestas al órgano controlante y que éste se limita a aplicarlas a cada caso"583. Por ende, para este autor el parámetro está compuesto por normas jurídicas o, más exactamente, por el derecho en su expresión objetiva, vale decir, por el ordenamiento jurídico. Por tal motivo, el control jurídico será objetivo y su parámetro igualmente lo será.

En conclusión, las limitaciones institucionales del poder están a su vez institucionalizadas en dos tipos de control, uno político y otro jurídico. El primero, es subjetivo y su ejercicio es voluntario, por un órgano, autoridad o sujeto de poder que en cada caso se encuentra en relación de supremacía o jerarquía respecto de otro. Mientras que el segundo, posee un carácter objetivo basado en razones jurídicas, y su ejercicio es necesario en cuanto que el órgano que lo ejerce siempre ha de emitir una decisión, ha de resolver los casos en que se solicite su intervención, dicho órgano será independiente e imparcial, dotado de una especial competencia técnica para resolver asuntos de derecho constitucional ${ }^{584}$. Así surge la jurisdicción constitucional, la que poseerá un ámbito de acción y parámetros de valoración previamente determinados por el Derecho, debiendo limitar su campo de razonamiento e interpretación a los mismos. En cambio, el control político gozará de un ámbito de acción más amplio porque si bien posee elementos jurídicos procedimentales previamente señalados, su ejecución, valoración e interpretación serán eminentemente políticos.

Por consiguiente, es muy probable que las finalidades fiscalizadoras de la oposición no se encuentren contempladas precisamente en una norma. El objetivo de la oposición será normalmente intentar romper la cohesión de los grupos mayoritarios, debilitar al Gobierno y buscar posicionarse como una alternativa del mismo, materias que lógicamente no están reguladas porque precisamente constituyen fines políticos. Intentar suponer que el control ha de cotejar una acción

\footnotetext{
582 NOGUEIRA (2003) p.46.

583 ARAGÓN (1986) p.106.

584 ARAGÓN (1986) p. 96.
} 
de gobierno frente a una causal legal para poder actuar en términos generales, es un equívoco conceptual. Como también lo es fijar únicamente en el programa de gobierno el parámetro, pues como lo sustenta De Vergottini, a la minoría-oposición no le interesa que el Gobierno cumpla a cabalidad tal carta de navegación, sino por el contrario, hará notar que su propio programa -el que denomina programa alternativo $^{585}$ - es el más idóneo de allí paras que se proponga como alternativa del poder. Desde nuestra perspectiva, el parámetro no puede ser solamente el programa, no porque a la oposición no le importe su cumplimiento (es muy probable que la oposición se encargue de hacer público todos y cada uno de los puntos de flaqueza del Ejecutivo ${ }^{586}$ ), sino porque creemos que un programa político de gobierno no comprende la totalidad de las voluntades de la ciudadanía; es por ello que principios más generales como los valores constitucionales o el bien común pueden representar mayormente a la sociedad.

Nuestra opinión dice relación con lo planteado por Manuel Alba. La flexibilidad debe caracterizar al programa político de Gobierno, el cual si bien es su carta de navegación y su compromiso con el electorado, no podrá ser absolutamente determinante para la actividad administrativa del Gobierno, fundamentalmente porque dicho programa fue elaborado como una "foto fija" que pretende poner de relieve un ideal político que a su vez ha mirado la construcción de una sociedad idílicamente, que no responde ni está preparado para los hechos y situaciones imprevistas que puedan ocurrir ${ }^{587}$. Por ello, ceñirse estrictamente al cumplimiento o no de un programa configura también una situación poco ajustable a la realidad política; comúnmente, los Gobiernos tendrán dificultades de diversa índole: política,

\footnotetext{
585 De Vergottini (1985) p.396.

${ }^{586}$ Respecto de esta materia, es posible traer a colación todas aquellas repercusiones mediáticas que se producen principalmente en los primeros días de asumido un nuevo gobierno, debido a la instalada costumbre electoral por parte de los candidatos presidenciales que implica ofrecer a la ciudadanía, el cumplimiento o adopción inmediatamente una vez arribado al poder, de algunas medidas dentro de un período de tiempo establecido. Es así como han surgido por ejemplo: "las primeras cincuenta medidas para los primeros cien días de Gobierno de la actual presidenta Bachelet", publicadas en: http://michellebachelet.cl/programa. Respecto de ellas, la oposición puede de manera más efectiva cumplir un rol fiscalizador de dicha parte del programa, de estimarlo oportuno, esencialmente por la proximidad en el tiempo en la que deben ser cumplidas las mismas y por la latencia pública de la cual serán objeto. Pero respecto de la totalidad del programa sólo será posible controlarlo, una vez avanzados los años de Gobierno. De lo contrario, existe la posibilidad de que las críticas formuladas con las que se espera generar daños políticos, se inviertan en su contra, configurándose así un riesgo muy alto para la oposición, porque al formular tales observaciones, de cierta manera ésta advirtiendo a la coalición gobernante de sus posibles carencias o puntos de debilidad, pudiendo ésta reaccionar oportunamente y revertir dichas insuficiencias, colocando ahora a la oposición en un mal pie comunicacional. Situación que es descrita por el profesor Roberto Blanco Valdés como el fenómeno de "Juegos de espejos invertidos". Blanco (2000) Pp. 38 y 39.

${ }^{587}$ ALBA (2001) p. 21.
} 
económica y social, que podrán influir en dicho cumplimiento, a pesar de que todos los esfuerzos se centren en tal cometido.

Por consiguiente, si bien es cierto que la ejecución del programa de gobierno se realizará bajo criterios de movilidad y flexibilidad, no es menos cierto que tal contexto fomenta e impulsa el derecho de la oposición de controlar y, por otra parte, evidencia el carácter político del mismo control, toda vez que aquella situación generará muchos rasgos de improvisación en la gestión pública. Por ende, se abrirán con mayor probabilidad puntos de flaqueza, espacios que la oposición deberá detectar, pudiendo aplicar o utilizar el criterio de oportunidad, en virtud del cual podrá ser muy efectivo el control. En definitiva, el programa de gobierno se convierte en un parámetro del control de máxima importancia, porque precisamente su movilidad será a su vez fuente de control. Así, el cumplimiento o incumplimiento del mismo será la causa que impulse del control, además de ser el estándar en virtud del cual se ha de evaluar la gestión del Ejecutivo, actos de la Administración respecto de los cuales recaerá la fiscalización.

Junto con lo anterior, hemos de sostener que el parámetro del control está conformado por principios y valores constitucionales. Tal como describe Pereira Menaut, la Constitución es "el límite del poder, por medio del Derecho, asegurando una esfera de derechos y libertades para ciudadano" ${ }^{588}$. Desde luego, hay otros elementos que están presentes en la Constitución, los elementos políticos. La sujeción del poder no sólo responde a elementos normativos contemplados en la Ley Fundamental, sino que también está limitado por principios y valores consagrados en la misma. Tal como describe Hauriou, dotar a la Constitución de supralegalidad implica que todas las demás normas la deben respetar, pero no sólo en su letra, sino que además en su espíritu, es decir, en sus principios constitucionales ${ }^{589}$.

En consecuencia, la Constitución es un ordenamiento jurídico-político que se enfrenta a una realidad viva en permanente tensión, conforme a las circunstancias sociales. En ella se genera el espacio donde lo jurídico y lo político se entremezclan; por tal motivo la interpretación de la misma ha de gozar de ambos elementos, lo cual le otorgará la ductilidad necesaria para enfrentar los nuevos contextos sociales. Entonces, principios y valores enumerarán cláusulas generales o finalidades del

\footnotetext{
588 PEREIRA (1998) p. 23.

589 HAURIOU (1971) p. 326.
} 
código político, que podrán o no estar positivizados en el texto constitucional ${ }^{590}$. Sin embargo, han de cumplir un rol orientador, una función informadora y crítica del ordenamiento jurídico ${ }^{591}$, a pesar de la flexibilidad y las múltiples circunstancias que pueden generar mediante una pluralidad de acciones respecto de los mismos. Tal como describe Peces-Barba, no es posible ocultar la dificultad que tiene un término como el de los valores constitucionales, que poseen tantas connotaciones emotivas y una textura tan abierta. Empero, ellos gozan de un núcleo central formado por la reflexión racional y por la tradición histórica de la cultura democrática ${ }^{592}$. Por tal motivo, han de ser elementos considerados por el sujeto controlante, esencialmente, por la amplitud de los mismos, la correspondencia que ellos poseen con la tradición democrática de cada Estado y por la utilidad que ellos representan para el análisis subjetivo del control político.

Por consiguiente, al fijar a la norma fundamental como el parámetro del control, el control político igualmente gozará de dicha doble calidad jurídica-política. Será jurídico, toda vez que sus procedimientos están positivizados y será político, porque su parámetro y valoración poseerá aquella orientación política. Este fundamento fortalece la noción que se ha sostenido, al decir que la valoración del objeto en el control político es eminentemente subjetiva, vale decir, se aplican razones políticas en virtud del principio de oportunidad. En esta dirección, la voluntariedad del mismo implica que el sujeto controlante sea libre de ejercerlo o no, y que luego su valoración implique o no sanciones ${ }^{593}$. De aquella premisa, hemos de señalar que el control político se desarrollará como un acto de limitación que garantizará valores y principios constitucionalmente relevantes en el sistema democrático, por tal motivo sus rasgos esenciales han de permearse de aquellas características propias de los principios, valores e instrumentos políticos como el programa de gobierno. En consecuencia, de allí que sus rasgos esenciales sean: subjetivo, libre y voluntario.

\footnotetext{
${ }^{590}$ Respecto de este punto, es posible señalar el particular caso español, ordenamiento constitucional en el que aquellos valores se encuentran normativizados. Lla Constitución Política contempla en su artículo 1.1 . una regla jurídica en la que se enuncian "los valores superiores" del ordenamiento jurídico: libertad, justicia, igualdad y pluralismo político. Es por ello que gozan de una estructura jurídica precisa, de manera tal que se configuran como reglas prescriptivas, es decir, vinculantes, obligatorias, eficaces y expresivas de un contenido material. Regulación jurídica poco frecuente en los textos constitucionales. FREIXES Y REMOTTI (1992) p. 100.

${ }^{591}$ FREIXES Y REMOTTI (1992) Pp. 98, 100, 101.

592 PeCES-BARBA (1987) Pp. 379 y 385.

593 ARAgón (1986) p. 100.
} 


\section{El rol de la responsabilidad política en la configuración del control parlamentario}

Del análisis de los elementos precedentes -relativos al control parlamentario-, es posible concluir que si bien existen varios factores que delimitan el control parlamentario y sus manifestaciones, uno de aquellos pilares decisivos es la forma en la que se concibe la responsabilidad política. Es por ello que a continuación examinaremos las aristas más relevantes de esta institución, a fin de poder revelar cómo ha ido evolucionando desde sus concepciones más clásicas hasta las modernas expresiones en el sistema parlamentario y en el sistema presidencial.

Como fuera expuesto es nuestro Capítulo anterior, la lucha por la limitación del poder, la consagración de la libertad individual y el respeto de los derechos fundamentales fueron la razón de existir de los movimientos filosóficos de los siglos XVIII y XIX, procesos que edificaron el legado más trascendental para las democracias modernas: el control político y jurídico del poder, mediante el establecimiento de límites concretos para quienes detentan el poder, y por el establecimiento de determinadas consecuencias para quienes no cumplieran con los nuevos mandatos políticos y jurídicos emanados del pueblo soberano. En definitiva, con el surgimiento del Estado de derecho y constitucional se instaura la garantía del sometimiento de los detentadores del poder a la legalidad vigente, restringiendo el poder a través del derecho.

Por su parte, las limitaciones al poder en el ámbito político se desarrollan mediante el surgimiento de la representación política la cual, además de dar a la nación soberana el protagonismo en la toma de decisiones, presupone la facultad de que los representantes pueden pedir que se les rinda cuentas respecto de las acciones del Gobierno, en tanto sujeto legitimador del ejercicio del poder. Por ello, la noción de responsabilidad nace básicamente como la "obligación de responder"594. Por tanto, con el control y división del poder las autoridades no podían actuar arbitrariamente y tendrán límites jurídicos, pero también límites políticos, y dentro de aquellos límites políticos nace la obligación de rendir cuentas, la que implicaba explicar $y$ justificar sus actos debiendo estar éstos en armonía con los designios populares. Aquellos fueron los elementos constitutivos del nacimiento de la

${ }^{594}$ Bustos (2007) p. 142. 
responsabilidad, institución que trajo consigo determinadas consecuencias como la transparencia de la gestión pública y, básicamente, la pérdida del poder mediante la destitución de los cargos públicos como mecanismo sancionador.

Empero, los fundamentos que favorecen el nacimiento de la responsabilidad política fueron variados. Nosotros los reuniremos en dos rasgos esenciales: uno de orden filosófico y otro de orden histórico. Los argumentos filosóficos se encuentran relacionados con la condición humana y en el apartado precedente señalamos que el respeto a la persona humana, su dignidad y libertad fueron el fundamento para determinar la titularidad de derechos, pero también sirvieron para determinar una serie de deberes jurídicos, políticos e incluso morales. Será precisamente el nacimiento de dichos deberes jurídicos, políticos y morales la oportunidad donde la responsabilidad jurídica encuentre fundamento jurídico y filosófico. Se sustenta en el respeto de la dignidad humana y, en este sentido, se dirá que la libertad es el presupuesto causal esencial para que se pueda hablar de responsabilidad.

En suma, la responsabilidad nace como un efecto causal de la libertad. En este orden de ideas, se expresa que todo acto humano es por esencia un acto libre, racional y voluntario porque es realizado de manera consciente en pleno ejercicio de la razón y la libertad, y por ello puede ser calificado moral y jurídicamente. Así, dependiendo de la naturaleza del acto, éste podrá ser evaluado de conformidad al criterio que corresponda, oportunidad en la que se analizará el objetivo o la finalidad del acto mismo. En consecuencia, un acto podrá ser lícito o ilícito, justo o injusto, digno o indigno, moral e inmoral, y ello dependerá del parámetro conforme a cual se mida, pudiendo estar establecido ya en el ordenamiento jurídico o en las propias exigencias de la naturaleza humana ${ }^{595}$. En virtud de tal motivo, los actos políticos podrán ser evaluados conforme a los estándares que se establezcan en tal sentido, produciendo las consecuencias políticas pertinentes.

Por otra parte, es menester revisar el relevante antecedente histórico en el que se encuentra inmersa la responsabilidad, proceso que se desarrolla esencialmente en el constitucionalismo británico con el surgimiento de las monarquías limitadas o constitucionales que emanan inicialmente con posterioridad a la Revolución Gloriosa, a través de las cuales se produce principal y paulatinamente

595 GÓMEZ (1997) p. 6. 
la limitación de los poderes del Rey por parte del Parlamento. Lo anterior provoca en términos generales- una mutación constitucional que comprendía forjar una soberanía parlamentaria, que conllevaba la necesidad de que el Gabinete ministerial para conformarse pendiera de la aprobación de la mayoría parlamentaria reinante, situación que dio lugar a una estrecha relación de dependencia entre el órgano Parlamentario y el Gabinete.

Sin embargo, dicha relación no siempre caminó por el sendero correcto. Es por ello que el Parlamento necesitó de mecanismos que le permitieran de algún modo detener las actuaciones desvirtuadas de los fines nacionales, provenientes de un Primer Ministro o del Gabinete en su conjunto, situación que en dicho contexto sólo podía ser enfrentada y mitigada mediante el impeachment, institución que derivaba de la época medieval -momento histórico en el cual el órgano representativo ejercía funciones en calidad de órgano judicial-. Por ende, el impeachment estaba destinado a hacer efectiva una acción penal contra cualquier persona, juzgando en única instancia, pero tenía en realidad como finalidad un móvil político. Por ello, se presentaba como la única herramienta limitadora.

Como lo expresáramos anteriormente, con el advenimiento de las monarquías constitucionales tales mecanismos no cumplieron los objetivos queridos y, por lo mismo, dicha institución -una vez alcanzados los propósitos democráticos- fue perdiendo valor. En este sentido, si bien el impeachment de origen inglés sirvió para que el Parlamento influyese sobre algunas decisiones del Rey, su propio perfeccionamiento jurídico forzó su reemplazo por medios más adecuados, para exigir la responsabilidad política por un lado y las responsabilidades jurídicas por otro. A pesar de que durante el desarrollo constitucional de Inglaterra se reviviera en algunas oportunidades el impeachment, esencialmente en el período de los Estuardos, y producto de una lucha de poder entre la Corona y el Parlamento, lo cierto es que esta institución reduce su utilidad y es reemplazada por otras de mayor nitidez, lo cual -sumado a la supremacía parlamentaria y a la rigidez de los procedimientos- termina por desplazarla por completo ${ }^{596}$. En consecuencia, Inglaterra adoptó como mecanismo limitador y sancionador en tiempos de monarquías constitucionales una herramienta de carácter dual, el impeachment,

596 Bronfman (2005) Pp. 91,92 y 93. 
juicio que analizaba conductas penales pero que poseía finalidades políticas, el cual por sus propias debilidades caerá en desuso.

Como bien expone Benjamín Constant, una vez superado el poder absoluto del monarca surgen otros órganos que asumen el ejercicio del poder político. En dicha dirección, los gabinetes ministeriales heredaron en cierto modo las facultades que le atribuían poderes que igualmente podrían ser desempeñados de una manera contraria a los intereses populares. En ese orden de ideas, también era posible que los ministros cometieran abusos respecto del poder legal que detentaban y será evidente que sólo los representantes de pueblo están en situación de juzgar si existió o no tal abuso, y sólo un tribunal especial que posea una autoridad específica puede pronunciarse sobre dicho abuso 597 .

En efecto, en la búsqueda por solucionar aquellos problemas y en virtud de la transformación política que produjo la llegada de la limitación constitucional del poder, explica Diez-Picazo, se produce un total desuso del impeachment, debido precisamente al surgimiento del parlamentarismo y sus transformaciones, lo que finalmente termina por sustituir esta herramienta por una nueva noción: la de responsabilidad política. Con la primacía del Parlamento, los ministros comienzan a seguir al pie de la letra las orientaciones de la mayoría parlamentaria y se producen las dimisiones de sus cargos precisamente cuando pierden aquella vital voluntad política parlamentaria. En este nuevo escenario político, no era necesario cometer un ilícito específico y recurrir a un juzgamiento de carácter penal para cesar las funciones de un funcionario que se extralimitara. Bastaba la ausencia de confianza de la mayoría parlamentaria. Fue de esta manera como se va dejando de lado la obediencia respecto de las orientaciones recibidas conforme al "criterio político" del Rey, para pasar a ejecutar y cumplir las instrucciones u orientaciones del Parlamento.

Por consiguiente, el elemento fundamental del surgimiento de la responsabilidad política fue el desarrollo de la soberanía parlamentaria, la cual permitió que se produjera una diferenciación entre la responsabilidad penal y la responsabilidad política. Así, fue gracias al desarrollo político de Inglaterra que establece "que el mal gobierno y el abuso del poder no dan lugar necesariamente a

597 CONSTANT (1989) p. 89. 
una ilicitud penal" 598 , demostrando finalmente que es posible lograr que las responsabilidades penales y las políticas existan en un mismo ordenamiento, pero caminan por carriles separados y provocan sanciones diversas, en atención al objetivo y naturaleza de los actos que se califiquen como impropios o incorrectos.

Tal proceso evolutivo de los ingleses dejó de lado un juicio con matices penales para arribar hacia una limitación político-jurídica, mediante un control parlamentario; dicho control nace como el gran mecanismo de control democrático, el cual le permite en cierto modo al Congreso delimitar el marco jurídico y político dentro del cual debe desarrollar el ejercicio del poder político. Como explica Gómez, al Parlamento le corresponde ejercer un control político y jurídico sobre las actuaciones del Gobierno para evitar el abuso del poder, toda vez que aquél se encuentra facultado por un marco jurídico habilitante establecido por la Constitución Política ${ }^{599}$. Mediante el control político-parlamentario, se busca determinar qué es lo justo políticamente, verificando si los actos del gobernante están o no acordes con el bien común. He allí una vez más la importancia del Estado de derecho como la razón y justificación de la limitación del poder político, evitando arbitrariedades, aplicando finalmente responsabilidades jurídicas y políticas a quien detenta el poder.

En consecuencia, el Estado de derecho impuso límites al poder en el orden jurídico, pero también impuso consecuencias que pueden derivar en sanciones: tal efecto es la responsabilidad política de gobernantes para con el constituyente primario, quien es la verdadera y única fuente del poder político. En suma, la responsabilidad política quedará delimitada, en líneas generales, conforme al marco de legalidad constituido por el ordenamiento jurídico y las instituciones que correspondan, de manera que la honestidad, tolerancia y el respeto hacia los derechos del pueblo no dependerán de la virtud de los individuos que desempeñen cargos públicos, sino que están dados por reglas y principios establecidos constitucionalmente ${ }^{600}$.

Con todo, con el desarrollo de los modernos Estados democráticos constitucionales se establece normativamente y se consolida una cultura política que implicaba comprender el hecho de que los gobernantes si bien deben ejercer sus

\footnotetext{
598 DíEZ-PICAZO (1996) p. 61.

599 GÓMEZ (1997) Pp. 9 y10.

600 PEÑA (1998) p. 140.
} 
derechos, también deben respetar y cumplir sus deberes políticos y jurídicos. De esta manera, se encuentran compelidos a respetar de modo irrestricto el ejercicio legítimo del poder, la legalidad vigente y los derechos fundamentales, obligándose a dar respuestas por sus actos políticos en el ejercicio del cargo. Como nos dice Napolitano, en tiempos de democracia comprometerse políticamente implica actuar con disponibilidad, con responsabilidad y sobre todo con autenticidad ${ }^{601}$.

Por consiguiente, la responsabilidad política surge ligada a la perspectiva de legitimidad, es decir, sólo una vez que la actividad política se justifica y persigue objetivos moralmente aceptables, respetando límites jurídicos, nace con ello la responsabilidad. Como nos explica Peña, el término responsabilidad remite etimológicamente a la palabra "respondere", que significa responder o rendir cuentas de algo, por alguien y ante otros. La noción responsabilidad política por su parte, se referirá a la obligación que tiene el gobernante, en tanto representante de la voluntad popular, de responder de su gestión frente a los electores ${ }^{602}$. Es por esto, que para Peña un político responsable es quien antepone su tarea pública a cualquier consideración, moral o religiosa referida a su vida privada, de lo contrario faltaría a las exigencias de la ética política.

Con el diseño del sistema de responsabilidad política, finalmente, se logran dos objetivos: por una parte, prevenir comportamientos inadecuados en el seno de los estratos dirigenciales de la Administración pública, toda vez que ningún ministro desea ser sustituido, razón por la cual se esmerará en establecer mecanismos de control interno sobre su departamento previniendo o corrigiendo a tiempo las posibles desviaciones de poder; $y$, por otra parte, permite contemplar sanciones políticas para aquellos comportamientos políticos inadecuados ${ }^{603}$. No obstante, si bien estas declaraciones representan la percepción más elemental de la responsabilidad, dicha institución ha de mutar de tal modo que sus expresiones modernas, si bien rescatan la idea de "responder, explicar, dar a conocer", se ven alteradas dados los elementos configuradores tales como, sujeto activo, pasivo y el objeto de la misma.

\footnotetext{
${ }^{601}$ NAPOLITANO (2010) p. 270.

602 PEÑA (1998) p.128.

603 Bustos (2007) p. 143.
} 


\section{a) Criterio de oportunidad}

El nacimiento de una responsabilidad política, como alternativa a la responsabilidad penal, implicó necesariamente definir y diseñar una arquitectura propia en base a elementos diversos a los conocidos. La nueva responsabilidad política habrá de delimitarse en virtud de otros parámetros. En este sentido, se dirá que el estándar de medición de la responsabilidad política será el criterio de oportunidad. Sin lugar a dudas, este criterio es el punto que zanjará sus profundas diferencias con los restantes sistemas de responsabilidad. La tremenda relevancia de la consagración de tal criterio, que caracterizará y dará cuerpo a la responsabilidad política, se encuentra en directa relación con aquel nexo causal que une al ejercicio del control político parlamentario con dicha responsabilidad. Ambos conceptos se relacionan de tal manera que es imposible pensar en uno sin incorporar al otro; es por ello que Moncoroa expone "no existe responsabilidad política sin control, $y$ tampoco existe el control sin responsabilidad política" ${ }^{604}$. Sin perjuicio de aquello, hay voces como la de Sánchez Agesta que señalan que el "control es un término más amplio que el de responsabilidad, porque la exigencia de responsabilidad determina siempre un control, pero no todo control implica la posibilidad de deducir responsabilidad política"605.

En este orden de ideas, hemos de recordar que todo el control parlamentario descansa a su vez en el principio de oportunidad político, vale decir, que de no ejercer el control parlamentario en los tiempos políticos relevantes, pierde toda su utilidad y, por consiguiente, sus posibles sanciones carecen de sentido y provecho. No obstante, como bien sabemos existirán ciertos rasgos que marcarán diferencias respecto de la noción de control y sus posibles sanciones, las que variarán de conformidad al sistema político imperante, empero, siempre habrá de existir control y responsabilidad. El punto central -como bien expone Sánchez Agesta- es el hecho de que pueden o no estar vinculados.

Es dable recordar, además, que fue el constitucionalismo inglés el que permitió establecer que la legalidad no era el único criterio posible a la hora de enjuiciar a los gobernantes; muy por el contrario, existirá dicho criterio de

\footnotetext{
604 MOCOROA (2014) p. 137.

605 SÁNCHEZ (1960) p. 40.
} 
oportunidad como mecanismo de valoración de los hechos, el cual lógicamente traerá aparejada sanciones pero de orden político, porque dicho criterio significa que no se aplicarán estándares morales o jurídicos. La oportunidad valorará si los hechos o actuaciones se ajustan a ciertos valores y objetivos políticos. Es por ello que DiezPicazo expresa que una actuación política puede ser perfectamente moral o jurídica, pero políticamente inoportuna. O a la inversa, una actuación puede ser políticamente oportuna pero contraria a las normas morales o jurídicas ${ }^{606}$.

Es decir, utilizar un criterio de oportunidad política implica realizar una valoración subjetiva condicionante de la acción del Gobierno, al haber fijado líneas de actuación por parte del Gobierno habitualmente en el programa de gobierno, permitirá que ellas mismas operen como un marco habilitante permitiendo posteriormente su grado de ejecución formando un juicio, un criterio que determinará o no la aplicación de la responsabilidad política ${ }^{607}$. Finalmente, la responsabilidad política se enmarca en procedimientos políticos que se determinan por criterios de procedencia también políticos. En rigor, suele tratarse de principios que no están escritos y son parcialmente indeterminados, se trata de términos vagos y ambiguos, tal es el campo amplio de acción que el reproche puede ir dirigido contra quien causó el hecho como contra otros sujetos vinculados ${ }^{608}$.

Queremos detenernos en este punto, a fin de profundizar ciertos aspectos que dicen relación con la laxitud del criterio. Es de gran importancia hacer hincapié en la amplitud de elementos a utilizar, ya que si bien se ha descrito anteriormente que el programa de gobierno contribuye como parámetro en la aplicación de tal criterio, no es menos cierto que la ocurrencia de hechos políticos reprochables puede escapar con creces a la sola ejecución de un programa. Por ende, no será el único antecedente a considerar. Estimamos de suma importancia traer a colación las palabras de Luis Sánchez Agesta en esta materia: la responsabilidad política no ha de recaer sobre hechos descritos con anterioridad en una norma, sino por el contrario recaerá sobre actos ejecutados legítimamente, por consiguiente, esta atribución de competencia, que es la responsabilidad de carácter constitucional, comprende una amplísima libertad de decisión ${ }^{609}$. Este tipo de responsabilidad no

\footnotetext{
606 DÍEZ-PICAZO (1996) p.72.

607 Alonso de Antonio (2002) p. 199.

${ }^{608}$ MONCOROA (2014) p. 134.

${ }^{609}$ SÁNCHEZ (1960) p. 38.
} 
comprende determinar una culpa por hecho, la comisión u omisión de conductas punibles, sino que implica la ponderación de si ese arbitrio o facultad que se le concede al político gobernante ha sido utilizado o no con acierto y oportunidad, es determinar que su actuación esté vinculada al servicio del bien común en un orden político concreto.

Siguiendo los postulados de Constant, sostenemos que la necesidad de que la responsabilidad política se encuentre estrechamente ligada con criterios de oportunidad y esencialmente de discrecionalidad, dice relación con la imposibilidad fáctica de regular todas aquellas conductas que puedan ser constitutivas de infracciones políticas. Por ello, creemos profundamente en lo descrito por el autor cuando declara que "si todas las formas de perjudicar al Estado tuvieran que ser descritas y especificadas en una ley, el código de responsabilidades se convertiría en un tratado de historia y de política y aun así sus disposiciones sólo tratarían del pasado. Los ministros encontrarían fácilmente nuevos medios de eludirlas en el porvenir" ${ }^{610}$. Junto con lo anterior, el mismo autor establece que además está presente la posibilidad de que el ministro pueda hacer el suficiente daño al Estado sin apartarse un ápice de la letra de la ley, y en consecuencia, la Constitución debe contemplar los mecanismos para reprimir dicho mal.

A nuestro juicio, y como lo señaláramos anteriormente, he aquí el gran rasgo distintivo de este tipo de responsabilidad respecto de las restantes responsabilidades (civil, penal, administrativa), toda vez que ella se examinará y se aplicará conforme a este criterio de oportunidad, el cual -a nuestro juicio- comprende necesariamente dos elementos. El primer aspecto es la pertinencia o la celeridad con la que se debe ejecutar frente a hechos políticos negativos, vale decir han de ser examinados dichos hechos en el momento en que acontecen o dentro de un plazo muy menor de tiempo principalmente en atención a la misma velocidad con la que se desenvuelve la vida política ${ }^{611}$.

\footnotetext{
${ }^{610}$ CONSTANT (1989) p.90.

${ }^{611}$ Durante el año 2015 hemos sido testigos presenciales de lo trascendente de la materia en estudio y los nocivos efectos que puede generar en un sistema político sus equívocas interpretaciones. Los hechos ocurridos con los denominados casos o aristas Penta, Caval y SQM son un claro ejemplo de las debilidades existentes en la concepción de la responsabilidad política en Chile. Una lenta reacción tanto del Ejecutivo como por parte de los partidos políticos, dieron lugar a una crisis política e institucional de magnitud. El descrédito de las instituciones y del sistema en su conjunto son fruto del enfado de una ciudadanía a la cual no le han hablado con la verdad y transparencia y que además percibe un ambiente de total impunidad política. La falta de decisión política y la carencia de oportunidad política nos ha situado en un
} 
El no esclarecer o sancionar inmediatamente hechos cuestionables políticamente, genera diversas reacciones y todas negativas para la estabilidad democrática de los pueblos; en un sentido, se puede producir un malestar social bajo el prisma de la impunidad, puede suceder que la ciudadanía interprete que el actuar incorrecto de las autoridades puede ser concebido como hechos indemnes, por ende, es posible creer que existen personas respecto de las cuales -independientemente de la gravedad de sus actos- no deberán responder por los mismos. En otro sentido, no actuar con oportunidad política y analizar hechos políticos relevantes y cuestionables, genera mayor desprestigio de la casta política. Los niveles de desafección seguirán aumentando y, en general, el sistema como tal se verá debilitado.

El segundo aspecto distintivo es la inexistencia de tipos políticos sancionables. $\mathrm{Si}$ bien es cierto que las constituciones políticas han de regular y establecer procedimientos y algunas causales graves respecto de las cuales el control parlamentario ha de actuar con mayor fuerza y la responsabilidad política será una consecuencia obligada, existirán un sinfín de acontecimientos de relevancia que no estarán contemplados en la norma, precisamente por la imposibilidad fáctica de aquello, situación que desde nuestra perspectiva no impide en modo alguno verificar las posibles responsabilidades que de ellos emanen, básicamente por la trascendencia que los mismos pueden tener en el desarrollo de la administración pública y en la percepción que la ciudadanía adquiere de los mismos. Cabe señalar respecto de este punto, que hemos de ahondar en los párrafos siguientes respecto de aquellos postulados que tratan los tipos de responsabilidad $y$, en particular, la responsabilidad difusa.

La responsabilidad política, por su propia naturaleza e imprecisión y de conformidad al criterio de oportunidad, habrá de generar variados puntos de inflexión, algunos en relación con su propia naturaleza política, su estrecha vinculación con el control parlamentario y sus conocidas expresiones presidencialesparlamentarias, y otros relacionados con el análisis relativo al cómo se interpreta en la actualidad la responsabilidad política.

complejo escenario, respecto del cual sólo podremos dimensionar sus reales alcances en los procesos electorales sucesivos. 
Respecto de esta materia, será necesario considerar dos aspectos; el primero, aquel que coteja a la responsabilidad jurídica con la política y aquella tendencia que analiza los efectos de la responsabilidad política en tiempos modernos, esencialmente, la sanción que de ella deriva. En atención a este primer punto, tenemos que señalar que la responsabilidad política ha sido considerada como una responsabilidad de carácter no jurídico, por no contemplar una sanción jurídica clara y definida, fundamentalmente porque no existe una relación jurídica principal en la que se pueda enmarcar una relación de responsabilidad. Debemos de tener presente que en una relación jurídica el sujeto debe o no ejecutar una conducta determinada, es decir, existe un marco jurídico que también está determinado. En cambio, en la responsabilidad política, el sujeto de hecho deviene responsable, independiente de si está o no obligado a alguna cosa específica o si ejecuta o no una conducta establecida y, además, no existe una sanción previamente determinada, lo que se traduce en que la responsabilidad política se configura en virtud de una relación de inspección o de rendición de cuentas, mediante el pronunciamiento de un juicio político, que eventualmente puede devenir en una consecuencia negativa ${ }^{612}$.

Tal separación entre la responsabilidad jurídica y la política es también sustentada desde otras ópticas que consideran que esta última no exige para su aplicación un nexo causal, es decir, no se abarcan solamente los hechos cometidos por el sujeto responsable, sino que también se consideran aquellos actos respecto de los cuales ha debido tener tutelados por estar bajo su cargo, pero que no ejecuta necesariamente la persona que es responsable. Junto con lo anterior, la responsabilidad política tampoco hace referencia alguna a la capacidad que debe poseer alguna de las partes.

En este tipo de responsabilidad no existe una tipificación específica de obligaciones, sino que se trata de un conjunto de obligaciones que dimanan del ejercicio de un cargo, y por ello se da la existencia de supuestos abiertos e indeterminados, a diferencia del principio de máxima taxatividad de la responsabilidad jurídica ${ }^{613}$. Una argumentación importante en este acápite es la esbozada por el profesor Francisco Zúñiga, quien expone que la responsabilidad constitucional se origina precisamente por la infracción a la Constitución, lo que

612 Rescigno (1967) Pp. 46 a 49.

613 MonCOROA (2014) p. 145. 
podría asemejarla bastante con una responsabilidad jurídica más que a una política. Sin embargo, sucede que aquellas infracciones son por su naturaleza ilícitos que invitan a interpretaciones creativas o que se enmarcan dentro márgenes de libertad interpretativa de órganos políticos, por ende, lo que finalmente pasa es que se utilizan formas judiciales por órganos políticos para llegar a expedir decisiones políticas, concluyendo finalmente que la responsabilidad del Gobierno -por lo menos en Chile- es un mixtum jurídico-político ${ }^{614}$.

Desde nuestra perspectiva, entendemos que estamos frente a una responsabilidad que abarca hechos políticos y que, por ende, producirá consecuencias o sanciones de orden político, pero que habitualmente estará regulada por normas jurídicas que determinarán ciertos procesos a través de los cuales el examen de ponderación ha de aplicarse. Efectivamente, es una institución netamente política pero se vincula al derecho por su necesaria regulación normativaconstitucional y por el establecimiento de sus procedimientos más relevantes. Esta responsabilidad, a nuestro entender, tendrá que ser aplicada de manera eficaz, y en este sentido, deberá contemplar a lo menos dos etapas obligatorias: una fase de discusión y otra de sanción.

En este orden de ideas, diremos que independiente de lo que se considere por sanción en cada sistema político, para el caso del juicio político de los regímenes presidenciales, el ente controlador habrá de proceder conforme a mínimos estándares del debido proceso, garantizando derechos y, esencialmente, la igualdad de las partes, respetando el derecho a defensa del sujeto controlado. Por consiguiente, si bien la responsabilidad es de orden político, ella está regulada jurídicamente. No es posible esgrimir su sola naturaleza política como argumento válido para vulnerar derechos garantizados. En consecuencia, la naturaleza política no exime al sujeto controlante de velar por la protección de los derechos fundamentales.

Así, cuando se estime procedente aplicar una medida que acarrea responsabilidad, desde nuestra perspectiva para el caso del juicio político, siempre habrá que recurrir a dos instancias formales: la primera instancia explicativa, en la cual han de garantizarse todos los derechos del acusado e investigar de la manera

${ }^{614}$ ZÚÑIGA (2006) Pp. 47 y 51. 
más detallada posible, a fin de obtener información certera y contundente que permita continuar con argumentos sólidos un proceso sancionatorio. En segundo lugar, se requiere de un examen de ponderación de los hechos, que tendrá por objetivo alcanzar la máxima convicción respecto de la culpabilidad del sujeto controlado, es decir, adquirir la plena convicción respecto del vínculo causal entre los hechos políticos cuestionados y el sujeto controlado. Por tanto, sólo una vez que se han desarrollado correctamente ambas etapas, estamos en condiciones de exigir la responsabilidad y de aplicar sanciones políticas.

\section{b) La sanción en la responsabilidad política}

Como bien expusiéramos en el Capítulo anterior y en relación con la materia que estamos analizando, es menester recordar que la responsabilidad política ha sido discutida en torno a la viabilidad de su aplicación tanto en regímenes parlamentarios como en los sistemas presidenciales. En este orden de ideas, hemos de vislumbrar la directa relación que ello posee en cuanto a la sanción que la misma ha de alcanzar. Sin querer ser reiterativos, debemos recordar que la responsabilidad política nace ligada al sistema parlamentario inglés, en virtud del cual la moción de censura y la cuestión de confianza eran las sanciones naturales, a pesar de que posteriormente la práctica parlamentaria ${ }^{615}$ contribuyera en la nula aplicación de las mismas. Por su parte, el sistema presidencial -producto de sus mismos elementos constitutivos como la tajante división de poderes- carecería de una verdadera aplicación de la responsabilidad política, manifestando como única fuente de origen de la misma el juicio político, cuyos rasgos distan bastante de la clásica comprensión de la misma.

Empero, y de conformidad con lo visto en el Capítulo precedente, tales clasificaciones o límites conceptuales relativos al control parlamentario y la responsabilidad han ido mutando, provocándose una construcción arquitectónica diversa a la clásica, por tanto, la responsabilidad y las sanciones han sido alteradas de tal forma que han de presentarse de formas diversas. En este orden de ideas y, en virtud del desarrollo de los sistemas de gobierno, se han configurado dos interpretaciones respecto de este tipo de responsabilidad, los que en resumidas

${ }^{615}$ Principalmente el parlamentarismo racionalizado y la intervención de los partidos políticos básicamente la disciplina partidaria y la vinculación mayoría-Gobierno han debilitado e incluso impedido la aplicación de las sanciones tradicionalmente conocidas. 
cuentas buscan armonizar la realidad política y las actuales expresiones de la misma, expresiones que pasamos a exponer:

I. En primer lugar, detectamos una noción restringida y negativa de la responsabilidad política, que sólo comprendería la aplicación de una sanción determinada como lo es la destitución del Gobierno o la dimisión-renuncia del acusado (o responsable políticamente). Por ello, la responsabilidad política tal como la conocemos está ligada indisolublemente al sistema parlamentario, debido a su estrecha relación con la confianza parlamentaria. La aplicación de la responsabilidad no será más que la retirada de confianza otorgada, la cual traerá aparejada la pérdida del cargo público que se ocupaba; por tanto, la finalidad última de la responsabilidad política será desembarazarse del político indeseado ${ }^{616}$. Este tipo de concepción contempla sujetos, procedimientos y sanciones previamente determinadas en normas jurídicas, las que habitualmente se enmarcan en un tradicional sistema parlamentario. La responsabilidad se asocia a un tipo específico de sanción: ésta es la renuncia al cargo público, como el único correctivo al hombre ansioso de poder.

II. En segundo lugar, una noción amplia y positiva que comprende que los alcances de la responsabilidad política son más amplios que la sola destitución del Gobierno o la privación del oficio público. Esta perspectiva, se busca producir consecuencias que no necesariamente se reducen a la dimisión, sino que pretenden alcanzar o producir otros efectos de igual o mayor gravedad que el clásicamente diseñado. Una concepción amplia de la responsabilidad implica que pueda ser llevada a cabo por el Parlamento como órgano de aplicación de la justicia política, independiente del sistema de gobierno imperante, e incluso que pueda ser ejecutada por sujetos activos distintos al mismo cuerpo parlamentario, por ejemplo, por la propia opinión pública. Dicha interpretación permite utilizar mecanismos diversos a los contemplados en las regulaciones jurídicas. Como bien expresa Peña, el sujeto político es responsable en cuanto se le considera capaz y porque se le ha encomendado hacerse cargo de regir una determinada comunidad conforme a ciertos valores y fines, es por ello que su responsabilidad no puede limitarse a sólo rendir cuentas sino que se entiende como una actitud propia de quien aceptó

${ }^{616}$ GARCÍA (1998) p.86 y87. 
tomar decisiones, ocuparse de lo público y, por ende, hacer frente a la gestión pública. Así, una gestión pública ha de medirse por el cumplimiento de sus objetivos salvaguardando valores y fines de la sociedad ${ }^{617}$. Una interpretación implica el reproche público y social como también la no participación electoral o el voto en rechazo a quienes han presentado conductas reprobables, la gama de actores se expande y con ello también las sanciones.

Respecto de este punto, hemos de traer a colación al autor italiano que con mayor profundidad describe tal diferenciación, diseñando dos modelos diversos de responsabilidad política, designándoles un nombre y características particulares. Nos referimos a Giuseppe Ugo Rescigno, quien establece la separación entre responsabilidad política institucional y difusa. La primera de ellas, responde a una concepción restringida y negativa y la segunda, a una concepción amplia y positiva de la responsabilidad política.

Para el autor la expresión institucional se manifiesta como una cualidad inherente al individuo, es decir, aquel sujeto dotado de poder político está facultado para hacer valer la responsabilidad respecto de otro sujeto político, mediante procedimientos y mecanismos institucionales. Será un dispositivo político que es conocido por sus signos y sus características, y que se llevará a cabo ante la comunidad, en virtud de una relación política entre dos sujetos determinados, en el cual uno está sujeto al otro -el cual adicionalmente goza de un fundamento que estaría contenido en una convención entre estos sujetos, que nace mediante una relación de confianza- ${ }^{618}$. Desde otra vereda, ha de exponer que existe una responsabilidad política difusa que comprenderá la posibilidad de formular -mediante la crítica ciudadana- una presión política de tal magnitud que produzca los más diversos efectos políticos y electorales.

La responsabilidad difusa deberá contar con ciertos presupuestos esenciales para su posible aplicación, tales como, la existencia sin condiciones de la libertad de opinión y de crítica como garantía fundamental; por otro lado, deberán existir variados mecanismos institucionales para remover al detentador del poder, los que pueden y deben ser utilizados como consecuencia de la crítica formulada por la

617 PEÑA (1998) p. 128.

618 Rescigno (1967) p. 55. 
sociedad. Junto con ello, la responsabilidad difusa implica necesariamente la existencia de una debida conciencia por parte de la comunidad política, respecto de la facultad que poseen mediante el ejercicio de la crítica, actuación que se puede expresar en la modificación o cambio de los equilibrios políticos existentes.

Empero, Giuseppe Ugo Rescigno señala que para que ella pueda operar será necesario poder contar con la debida publicidad de los actos del Gobierno, además de unos verdaderos instrumentos institucionales que, efectivamente, puedan hacer remover al detentador del poder por vías diversas a los procedimientos legales ${ }^{619}$. Lo anterior, se configura como condiciones necesarias que tiene por finalidad posibilitar que la sociedad pueda realmente acceder a la información necesaria, para practicar una presión fundamentada que produzca las consecuencias esperadas.

Así, la responsabilidad difusa se encuentra fuertemente vinculada con la idea de democracia porque, finalmente, ella se compone por aquel juicio negativo que pueden realizar los ciudadanos respecto de la actuación de los gobernantes que se expresa en un estado de opinión pública, que puede además traducirse en un comportamiento electoral, esto es, no votar a un determinado actor político. No obstante, el uso de la responsabilidad difusa presenta ventajas por las escasas barreras de exigencia de la misma, pero es también posible reconocer sus debilidades y aspectos que pueden ser debatibles.

En este orden de ideas, vale recordar que la responsabilidad difusa no presenta un sujeto activo concreto $y$, por tanto, puede dirigirse sobre todo sujeto que ejerce un cargo público. Su ámbito de aplicación es extremadamente amplio. Como bien describe García Morillo, la responsabilidad difusa finalmente lo que busca es que mediante la opinión pública se ejerza una presión de tal magnitud e intensidad que genere que la permanencia en el cargo se haga insoportable, provocando un costo político de tal dimensión que haga preferible hacer abandono del mismo. En definitiva, una forma difusa de ejercer la responsabilidad política crea la dificultad de determinar el sujeto contra quien se dirige, el motivo y esencialmente los propósitos de su ejercicio. Sin embargo, a pesar de las problemáticas que describe García, la responsabilidad difusa y su objetivo principal no dista mucho de la descripción que el mismo autor otorga a la responsabilidad política, señalando que "responsabilidad

${ }^{619}$ Rescigno (1967) Pp. 117 a 119. 
política es en realidad el útil invento para evitar la enojosa alternativa de tener que seguir soportando a un incompetente o, en caso contrario, no tener otra salida que encarcelarle"620.

Por su parte, la responsabilidad institucional no se encuentra exenta de dificultades en su aplicación. Posee fuertes barreras de acceso, toda vez que comprende la reprobación por parte de un órgano del Estado respecto de otro órgano del Estado, configurado por un esquema arquetípico basado en el depósito de confianza $^{621}$. Por consiguiente, debe de ser ejecutado por sujetos previamente investidos, mediante procedimientos regulados y respetando ciertos quórums establecidos, garantizando estabilidad jurídica pero dificultando en lo concreto su aplicación; baste recordar aquí las problemáticas en la relación gobierno-mayoría que en los párrafos anteriores explicáramos, y que han hecho casi imposible la exigencia de responsabilidad política en los sistemas parlamentarios.

Continuando con los importantes estudios de Ugo Rescigno, corresponde destacar una interesante apreciación respecto de las diferencias que existen entre ambos tipos de responsabilidad, las cuales -a juicio del autor- no sólo se reduce a la sanción. La responsabilidad política institucional buscará aplicar un sanción negativa determinada en la ley: la dimisión. Por su parte, la difusa pretenderá alterar los equilibrios políticos existentes mediante habitualmente procesos electorales. Los sujetos de la relación también serán disímiles, en la institucional tanto el sujeto pasivo como el activo están previamente determinados en Parlamento-Gobierno. En la difusa éstos son más amplios, puede ocurrir que el sujeto activo sea toda la comunidad política y el sujeto pasivo no sólo el Gobierno, sino todo aquel que luche por detentar el poder; en la difusa los hechos a criticar no están determinados, no existirá un tiempo ni una forma única, los acontecimientos serán analizados de conformidad a la oportunidad política. Entonces, la responsabilidad institucional será esporádica e irregular y la responsabilidad difusa por el contrario será continúa y permanente.

${ }^{620}$ GARCÍA (1998) p. 87 y 88.

${ }^{621}$ DíEZ-PICAZO (1996) Pp. 70 y 71. 
No obstante, nosotros estamos por comprender a la responsabilidad política en los términos descritos por Sánchez Agesta, esto es, "como la discusión del acierto de los fines propuestos o de la procedencia u oportunidad de los actos realizados para alcanzar dichos fines por vías que pueden determinar en su caso, de una manera directa o indirecta, la sanción específica de privación del oficio".

La razón por la cual hemos de quedarnos con esta definición, dice relación con el análisis final que se ha alcanzado una vez examinados ambos tipos de responsabilidad, e incluso ambos tipos de sistemas de gobierno. Al detenernos en los efectos o consecuencias de ambos tipos de mecanismos, es posible colegir que ambos pueden producir -muy habitualmente- la renuncia del cargo político que se detenta o la alternancia de la mayoría gobernante. En definitiva, los efectos son similares, opinión que también expresa Ugo Rescigno cuando señala que todas las diferencias que elabora y destaca al mismo tiempo le permiten reconocer que en el fondo el efecto final será prácticamente el mismo en ambas modalidades, porque lo que ha de producirse es el cambio de la mayoría gobernante, es decir, se modificará la titularidad del poder político ${ }^{622}$. A modo de conclusión, nos remitiremos a lo expresado por Francisco Zúñiga cuando expone que la responsabilidad política del Gobierno supone abuso en la utilización o en el ejercicio del poder y se castiga con la privación de éste ${ }^{623}$.

Retomando la definición de Sánchez Agesta, diremos que aquella conceptualización favorece una comprensión inclusiva de todos los elementos y expresiones de responsabilidad política, toda vez que no sólo comprende una sanción inmediata y directa o una sanción específica o difusa, sino que ha de referirse a diferentes procedimientos que han de concluir en sanciones directas e indirectas, destacando que en la exigencia de responsabilidad política no sólo participan órganos que tienen la facultad directa como el Parlamento, sino que también participan órganos políticos e instituciones sociales a las que está permitido discutir estos esos fines, en cuanto a la conveniencia u oportunidad de las decisiones del Gobierno ${ }^{624}$.

\footnotetext{
622 Rescigno (1967) p. 129.

623 ZÚÑIGA (2006) p. 43.

624 SÁNCHEZ (1960) p. 39.
} 
En conclusión, creemos que las declaraciones de Sánchez Agesta permiten comprender que la responsabilidad política ha de ser sólo una y que podrá ser exigida mediante vías directas e indirectas, pero que finalmente siempre va a producir dos sanciones: la privación del cargo público o la derrota electoral de un conglomerado político. Así, podemos señalar de forma arriesgada que en lo relativo a la responsabilidad política en sistemas presidenciales y parlamentarios no existen en la actualidad diferencias de envergadura. Lo que ha de variar significativamente en uno u otro será el momento en el cual ha de ser ejecutadas las sanciones y los lugares políticos en los que se llevará a cabo, más la solución es la misma debido a que, frente al abuso del poder y a las conductas políticamente reprochables no hay más solución que el alejamiento del funcionario, partido político o conglomerado político del poder.

En este mismo sentido, nuestra argumentación se ajusta y es coherente con las realidades democráticas modernas, en las que los medios de comunicación social y la publicidad e información de los actos del Gobierno, provocan un conocimiento masivo de los mismos con bastante rapidez. Por ende, asienten la posibilidad de que se emita una opinión de apoyo o de reproche hacia el Gobierno de manera oportuna, veloz y esencialmente pública. Finalmente, hemos de señalar que esta interpretación permite concebir sujetos pasivos y activos de las más diversas índoles, pudiendo con ello salvar las deficiencias que la relación mayoría-gobierno ha provocado en los regímenes democráticos en general $\mathrm{y}$, en particular, en el régimen parlamentario. Por tanto, creemos que será la opinión pública quien forzará la aplicación de sanciones que, de otro modo, no sería posible aplicarlas. En esta misma dirección, es posible incluir otro factor relevante en esta materia, considerando que esta definición al ser amplia se refiere a todo órgano político. En definitiva, la presente conceptualización, al poseer características amplias, nos permite hacerla extensible a todo tipo de sistema político, favoreciendo su ejecución al contemplar vías directas e indirectas, comprendiendo a los procedimientos tradicionales como aquellos procesos de las democracias modernas $y$, esencialmente, contemplando una sanción genérica perfectamente aplicable en los distintos regímenes, evitando con ello la creación y debate de diferenciaciones que como hemos podido examinar carecen de sentido práctico. 
Resulta necesario referirnos en este punto al rol que les compete a los partidos políticos en este asunto, particularmente en nuestro sistema presidencial en que la participación de los militantes de los respectivos partidos políticos de gobierno en la administración del Estado es muy abundante, incorporación que transforma a los partidos en actores relevantes de la responsabilidad política. Quisiéramos destacar que, frente a hechos como el abuso del poder y la corrupción, la sociedad anhela la aplicación de sanciones jurídicas pero también políticas $y$, en este sentido, los partidos políticos tienen un rol relevante que cumplir. Es preciso señalar que éstos poseen dentro de su orgánica interna instituciones tales como los tribunales supremos, encargados de hacer valer los principios y valores de cada organización partidaria, y por tanto poseen la facultad de hacer los llamados de atención que estimen necesarios, como asimismo aplicar las sanciones que estimen procedentes de oficio o a petición de partes, respecto de militantes que realicen conductas políticamente reprochables, situación que extrañamente podemos visualizar en Chile. Por consiguiente, entendiendo a la responsabilidad política como una institución amplia, estamos por sostener que los partidos políticos han de promover y aplicar con mayor rigurosidad su normativa e instituciones internas, a fin de prevenir o sancionar a sus personeros responsables de actos censurables con el objetivo de fortalecer la democracia nacional pero juntamente con ello vigorizar su propia legitimidad popular.

\section{c) La responsabilidad penal como elemento distorsionador de la responsabilidad política}

Con el desarrollo de las democracias modernas han aparecido nuevos conflictos en torno a la responsabilidad. En la actualidad, existe una corriente proveniente de la práctica política que ha intentado diluir la responsabilidad política, argumentando razones y fundamentos propios de la responsabilidad jurídica. Como bien explica García Morillo, los juicios de oportunidad han cedido protagonismo ante los juicios de legalidad ${ }^{625}$, práctica que tiene como única finalidad, según el autor, eludir la responsabilidad política. En este sentido, lo que ha expuesto García Morillo dice relación con la desaparición de la aplicación de principios de oportunidad siendo sustituidos por parámetros de legalidad. Por ello, desaparecería el elemento

${ }^{625}$ GARCÍA (1998) p. 82. 
discrecionalidad, llevándose consigo a la responsabilidad. Dicha táctica política busca simplemente trasladar el terreno de lo político hacia lo jurídico, lugar donde el estándar probatorio y de criterio es tremendamente diverso al político, situación que simplemente finaliza en la inaplicación de sanciones políticas.

La situación antes descrita fue un problema que ya manifestó dificultades en el pasado. Creemos que a ello se referiría Constant cuando expresaba que los tribunales ordinarios debían juzgar a los ministros cuando fuesen culpables de ilícitos jurídicos, pero no sería apropiado que se pronuncien sobre causas políticas, porque el espíritu de la jurisprudencia es diverso en cuanto a quién debe resolver sobre la naturaleza de los grandes problemas que se presentan en la dimensión pública y nacional. Porque en definitiva, la responsabilidad política tiene dos finalidades: quitar el poder al ministro culpable, y mantener en la nación -mediante la vigilancia de los representantes- la publicidad y la libertad, mediante un espíritu de control que presente un interés por mantener la correcto aplicación de la Constitución y una participación en la vida política ${ }^{626}$. El carácter republicano de la responsabilidad política busca hacer aplicable tanto al gobernante y al servidor público, una concepción vicarial del poder político, en virtud del cual se encomienda al poder que realice el interés público, es decir, el bien común, el cual es confiado por la comunidad política, por el pueblo a los detentadores del poder. Se espera que se proyecte cierta virtud cívica en una ética pública mínima exigible a los servidores públicos $^{627}$.

En efecto, estamos frente a una nueva situación de lata complejidad en torno a la responsabilidad, o así por lo menos lo ha definido Bustos de conformidad a dos elementos relevantes. El primero, dice relación con un insuficiente control parlamentario y la debilidad en poder concretar sus etapas: de denuncia, debate, explicación y sanción si procede. El segundo, implica comprender que la administración pública ha tenido un crecimiento explosivo que hace imposible ejecutar un debido control, las nuevas formas de corrupción que pueden llegar a ser tan sutiles que hacen muy difícil su detección, y finalmente la ausencia de control en áreas de la gestión administrativa. Pero no bastando sólo con aquellas complejas situaciones, ha de considerarse la que -a juicio de Bustos- es la de mayor gravedad,

${ }^{626}$ CONSTANT (1989) Pp. 97 y 103.

627 ZÚÑIGA (2006) p. 70. 
ésta es, la confusión en el ámbito político entre la responsabilidad penal y la responsabilidad de carácter política, considerando que la primera es una responsabilidad subjetiva por culpa o dolo y la segunda, una responsabilidad subjetiva que además de la culpa o dolo incluye la responsabilidad in vigilando e in eligendo.

Por otra parte, las exigencias probatorias para adquirir un grado de convencimiento son tremendamente diversas. Por un lado, la penal requiere una fijación nítida y firme de los hechos hasta lograr un convencimiento judicial de culpabilidad, y la política requiere sólo un convencimiento político-moral de tal culpabilidad. Otro aspecto de suma relevancia es la diferencia en cuanto al criterio aplicable. En la responsabilidad penal, es el ordenamiento jurídico penal que contempla conductas claramente tipificadas, por su parte. En la responsabilidad política, como lo dijéramos anteriormente, crear un código de conductas políticamente incorrectas es inviable, y por ello que el criterio de oportunidad ha de ser el elemento determinante, porque estamos frente a un juicio que se realizará de conformidad un "código de conducta", que por cierto está vinculado a la moral, a la ética y la probidad pública. De esta confusión ha de surgir el mayor error conceptual descrito por Bustos, cual es confundir o asimilar la inocencia política con la inocencia penal. De entender una similitud entre ambas figuras, además de todas las complicaciones antes descritas, se producen dos fenómenos preocupantes: una descompensación en la prevención del abuso de poder y de la corrupción, y la posibilidad de que los responsables políticos puedan desempeñar sus cargos como quieran, siempre que sus conductas no configuren la comisión de un delito ${ }^{628}$.

Desde nuestra perspectiva, diremos que compartiendo el análisis del Bustos en cuanto a la lamentable confusión ${ }^{629}$ que existe en la casta política nacional en cuanto a la judicialización de las conductas políticas reprochables, hemos de convenir en el

628 Bustos (2007) Pp. 145 a 148.

629 Una muestra -a nuestro juicio- de aquella confusión, se expresa en los parámetros establecidos por los partidos políticos nacionales respecto de los casos de corrupción. En este sentido, es posible señalar que los partidos que conforman la centro derecha nacional declaran reiteradamente que un hito determinante para poder analizar políticamente a sus militantes es la ocurrencia de la formalización de cargos en los tribunales penales, es decir, la tesis propuesta implica no sancionar políticamente ni llevar a análisis los casos de personeros políticos que no han sido debidamente formalizados e incluso de serlo también han expresado que ha de esperarse el pronunciamiento judicial de culpabilidad o inocencia para poder actuar políticamente. Situación que a lo menos deja claro el desconcierto en el cual se encuentran considerando que los casos de mayor connotación pública son tremendamente reprochables políticamente y no se han realizado ni siquiera suspensiones de militancia. En la vereda opuesta la Nueva Mayoría no posee aparentemente criterios más efectivos, desde centro izquierda ni siquiera hay declaraciones que puedan esclarecer su postura. 
plano nacional en lo siguiente. Si bien existen en la actualidad diversos hechos constitutivos de ilícitos penales y tributarios ${ }^{630}$, es preciso que respecto de ellos se realicen investigaciones judiciales que puedan desarrollarse con tranquilidad y sin obstrucciones para poder arribar con ellas a la verdad $y$, por consiguiente, a las culpabilidades e inocencias que procedan. Lo anterior, no debe ser influenciado por poderes políticos o fácticos, a fin de que no ocurran consecuencias innecesarias e indeseables como la politización de la justicia, a pesar de que García Morillo estima que éste es un hecho inevitable, porque finalmente hay un desplazamiento de la sede parlamentaria a la judicial ${ }^{631}$. Este escenario presentó su caso más simbólico e importante de los últimos años en el desarrollo político italiano. Es preciso recordar, en este punto, que la operación "Manos Limpias" en Italia ${ }^{632}$ fue la operación más significativa que la justicia llevara a efecto en contra de una corrupción sistémica entre el mundo político y empresarial, que por años se había desarrollado en toda Italia.

Este proceso, finalmente, implicó que los políticos rindieran cuentas pero no ante el Parlamento o ante el pueblo, sino ante la justicia. Como describe Jorge Gutiérrez, los procesos penales se transformaron en procesos políticos ${ }^{633}$. La razón de esta corrupción institucionalizada fue causada -a juicio de Giovanni Salvi- esencialmente por la ausencia de control en las decisiones del poder y la imposibilidad que imponía el sistema electoral italiano en cuanto a la alternancia del poder, y la ausencia total de oposición, situación que finalmente provoca la ausencia de responsabilidad política toda vez que las faltas existían y eran evidentes pero no existieron hasta que

${ }^{630}$ Con ello nos referimos a las denominadas "aristas SQM y PENTA" entre otros.

631 GARCíA (1998) p. 103.

632 El desarrollo del proceso denominado manos limpias en Italian, comienza el 17 de febrero del año 1992, oportunidad en la que en virtud de la investigación de un hecho que es políticamente irrelevante como el juicio por pensión de alimentos del hijo del connotado político de apellido Craxi es posible detectar una red de corrupción. Tal suceso político se inicia en la provincia de Lombardía en la comuna de Milán, lugar donde se encontraría la cárcel de San Vittore lugar que sería la residencia de cientos de políticos condenados por ilícitos penales. La investigación fue liderada por un parmente fiscal llamado Antonio di Pietro quien con total dedicación y profesionalismo formalizó aproximadamente 1500 casos (entre ello altas autoridades del ejecutivo y legislativo italiano como Craxi, Altissimo, Cariglia, Andreottí) de tal gravedad y conmoción pública fue la investigación manos limpias que se produjeron casi 30 suicidios de personas relacionadas directa o indirectamente con algún hecho delictual, cayendo con ello el liderazgo que por más de veinte años detentaban los partidos más tradicionales de la política italiana estos son, el partido socialista italiano y el partido demócrata cristiano. Todo aquel proceso si bien tuvo intentos por arribar a una solución institucional ello no fue posible, incluso a pesar de la gravedad de lo hechos existieron intenciones de aprobar una ley denominada "borrón y cuenta nueva" que pretendía establecer ciertos grados de impunidad y protección de las autoridades políticas, la cual no llego a buen puerto. No obstante, si se modificaron mecanismos políticos que tendían eliminar los elementos que habían promovido o potenciado la corrupción es por ello que se realiza una modificación del sistema electoral a la fecha mayoritario.

633 GUTIÉRREZ (2006) p. 3 
fueron penalmente visibles ${ }^{634}$. Esta opinión la comparte Domingo de Silos Manso, quien expone que al no existir alternancia del poder la corrupción impregnó Italia. Frente a una lamentable inactividad del Parlamento, el proceso mani pulite sólo fue la chispa en una estructura que parecía ser sólida pero que estaba carcomida ${ }^{635}$.

Con todo, lo más relevante en esta materia es comprender -como bien describe Diez-Picazo- que la responsabilidad penal y la política ni se implican ni se excluyen, porque un hecho puede ser jurídicamente ilícito y políticamente inoportuno y viceversa. El perverso resultado de la confusión es la posibilidad de que una anule a la otra, lo que se produciría equívocamente cuando existe una absorción de la responsabilidad penal por la política, cuando se estima que lo políticamente reprobable es, en sí mismo, constitutivo de un delito ${ }^{636}$. En este sentido, no debe olvidarse que finalmente las sanciones que emanan de la responsabilidad política deberán tener por finalidad un componente reactivo, destinado a la segregación del ente incumplidor, y otro componente proactivo que se vincula con una cuestión educativa y formativa de la gestión pública ${ }^{637}$.

La responsabilidad no debe limitarse al Presidente o jefe de Gobierno, sino a la clase política en su conjunto, y no debe permitírseles a los actores políticos que fomenten aquella vinculación entre la responsabilidad penal y la política, porque en el fondo de aquella interpretación se esconde una clara intención de evadir las posibles consecuencias de sus actos. En este punto, existe un fenómeno denominado por Salvi como un "carácter pre-judicial penal de la política", en virtud del cual se esperan resultados del juicio penal antes de actuar políticamente, y por otra parte -al ser tan ineficaces las sanciones políticas y administrativas- coloca al juez penal como el único "políticamente responsable", invirtiendo los roles de acusado y acusador. Finalmente será el juez el que tendrá sobre él el peso de aplicar sanciones que suplan las debilidades del sistema político. En definitiva, se produce una verdadera "suplencia" del poder judicial ante los otros poderes del Estado, considerándose que debiera ser otro el poder del Estado que sancione el desborde del poder, además de

\footnotetext{
634 SALVI (1994) Pp. 20 a 23.

635 MANSO (1994) p. 163, 165 y 167.

636 DíEZ-PICAZO (1996) p. 80.

637 MONCOROA (2014) p. 131.
} 
recordar que los poderes punitivos debieran actuar como ultima ratio no sólo porque fracase la prevención y el control ${ }^{638}$.

El problema mayor se presenta ante la cuestión de si, conforme a la legislación penal nacional, no existe una clara tipificación de ciertos delitos de corrupción; o que ellos posean penas muy bajas; o que los elementos del tipo posean un gran complejidad probatoria, lo que coloca finalmente al político responsable en un escenario tremendamente beneficioso y en un caso de cierta impunidad penal, que sumado a las inexistentes repercusiones políticas de sus mismos partidos políticos, produzcan un sentir social que hace presumir una desprotección ante el poder.

En nuestro país precisamente pasamos por aquel momento en el que las instituciones y la responsabilidad penal y política se han puesto a prueba. Ahora bien, no es un proceso aislado. Muy por el contrario, la responsabilidad política como tal ha sido reconsiderada en otras arquitecturas políticas, las que aproximadamente diez años atrás experimentaron las dificultades que el abuso del poder generó en el ejercicio de una función pública determinada. La ausencia de un efectivo control y la corrupción fueron los elementos que desencadenan en Inglaterra y en Italia con mayor trascendencia, promoviendo fuertes procesos de rearticulación institucional que concluyen en resultados jurídicos diversos.

En el caso inglés la relación entre dinero, política y responsabilidad dio lugar a la elaboración de uno de los textos más relevantes en cuanto a una nueva concepción de la responsabilidad, el informe Nolan. Su finalidad fue fijar las normas de conducta para la vida pública e implicó regular y establecer nuevos parámetros entre el Ejecutivo, el Parlamento y el dinero, estableciéndose un conjunto de medidas tendientes a sancionar el cohecho, los sobornos y las conductas reprochables-. De este documento emanan siete principios, y dentro de ellos se redefine a la responsabilidad política de la siguiente manera "los que ocupan cargos públicos son responsables de sus decisiones y de sus acciones ante el público y deben someterse al escrutinio que sea apropiado para su cargo"639.

638 SALVI (1994) Pp. 26 a 29.

639 INFORME NOLAN (1996) p. 24. 
El mencionado instrumento declara con toda claridad la directa relación existente entre responsabilidad política y transparencia, estipulando la necesidad de que la aplicación de la responsabilidad se realice con la mayor celeridad posible, señalando un conjunto de medidas que tendrán por finalidad lograr un correcto equilibrio entre el desarrollo político y el desarrollo laboral privado. Así también regula el sano equilibrio en los nombramientos de los funcionarios de Gobierno, estableciendo la necesidad de que participen militantes e independientes. Podemos concluir señalando que de este Informe han de emanar dos principios esenciales en la nueva configuración del orden político. Por una parte, existe un principio de proporcionalidad que dice relación con los nombramientos en los cargos del Ejecutivo, la capacitación, el establecimiento de código de conducta y la limitación del lobby y de los presentes que pueden recibir agentes públicos. Por otra parte, se construye el principio de responsabilidad política que ha de regir toda la acción pública pero principalmente entre Ejecutivo y Parlamento, que establece una relación entre ellos sometida esencialmente a la transparencia.

En Chile, se ha desarrollado a menor escala un informe que tiende a proponer esencialmente respecto de las mismas materias del Informe Nolan, una serie de mecanismos de solución. Para ello se constituye el año 2015 un "Consejo asesor presidencial contra los conflictos de interés, el tráfico de influencias y la corrupción", que tiene por finalidad determinar, proponer los mecanismos necesarios para prevenir la corrupción, regular los conflictos de intereses y establecer marcos más transparentes en el financiamiento de la política. Este informe fue analizado por el Ejecutivo respecto del mismo engendró una serie de proyectos de ley que han sido presentados por el Ejecutivo al Parlamento ${ }^{640}$, respecto de los cuales se está desarrollando el debate legislativo necesario, debiendo producirse efectos concretos en un tiempo razonable.

640 El informe se encuentra disponible en: http://consejoanticorrupcion.cl/informe/ 


\section{Consideraciones finales}

En resumen, en el presente Capítulo hemos realizado una descripción evolutiva que pretendió abarcar el proceso en virtud del cual nace la función de control parlamentario. Procuramos exponer las principales transformaciones de la institución, como también englobar sus modernas manifestaciones. Esencialmente, nuestro objetivo comprendió otorgar los argumentos teóricos más relevantes, en razón de los cuales se ha construido la teoría de control parlamentario. Para ello recurrimos a las tendencias doctrinales más significativas elaboradas en España, Italia y Francia.

En conclusión, el segundo Capítulo se centra básicamente en el estudio del concepto de control parlamentario y los elementos que lo configuran, con la expresa finalidad de comprender aquellas nociones doctrinales generales, que pudieran orientar el análisis que habrá de llevarse a cabo en el tercer Capítulo, vale decir, apoyar teóricamente aquella labor de dilucidar cuál es el concepto de fiscalización parlamentaria en el ordenamiento jurídico constitucional nacional.

Con una finalidad metodológica, focalizamos nuestro trabajo en la creación de una clasificación de los conceptos más relevantes de control parlamentario, a fin de simplificar su estudio y ordenar criterios. Producto de aquella labor emanaron tres grupos de conceptos. En el cumplimiento de dicha misión adquirimos la convicción que el concepto amplio de control, es aquella definición que se impone con fuerza en la doctrina jurídica y política, por tanto, nuestra investigación se concentró en dicha interpretación. A mayor abundamiento, hacemos presente que -en nuestra opiniónla concepción francesa es la noción de control parlamentario que contempla elementos de mayor interés y que entrega manifestaciones de suma relevancia a cotejar con el contexto chileno. Desde nuestra perspectiva, la conceptualización que realizan los exponentes galos, en cuanto a considerar al control como un proceso y la distinción que realiza entre función de crítica y función de evaluación, constituyen un aspecto a considerar en el apartado siguiente.

Para finalizar el proceso metodológico, se procedió a realizar un detallado examen de la responsabilidad política, toda vez que ella ha sido considerada el pilar fundamental del control parlamentario y elemento diferenciador en las expresiones 
de cada régimen de gobierno. Por tanto, analizar el estado del arte de la responsabilidad configuraba un antecedente determinante para comprender al control parlamentario en las democracias modernas. En dicha dirección se expusieron los factores de mayor trascendencia como: el criterio de oportunidad, la sanción y su vínculo con la responsabilidad penal. Adicionalmente, se analizó en profundidad la opinión de Ugo Rescigno, cuyo trabajo fue muy orientador para configurar y entender un nuevo sistema de sanciones políticas, del cual extraemos algunos elementos direccionales. 


\section{CAPÍTULO TERCERO}

"El control parlamentario en el Derecho Constitucional chileno" 


\section{"El control parlamentario en el Derecho Constitucional chileno"}

Al hablar de control parlamentario estamos frente a una institución que está en permanente movimiento en el ámbito jurídico en general. Nuestro país no escapa de aquel fenómeno; en efecto, ya hemos hecho presente en los capítulos anteriores que, a nuestro juicio, una de las características más significativas del control es precisamente su ductilidad. Por tanto, estudiar el control parlamentario en el Derecho Constitucional nacional implica analizar un proceso que también es evidentemente evolutivo. En virtud de aquella condición, en el presente Capítulo nos proponemos realizar una serie de consideraciones en cuanto a la forma en que el control parlamentario se ha desarrollado como institución del Derecho Constitucional y como expresión de la vida política nacional. Nuestro objetivo no es realizar un estudio metodológico histórico de esta materia de investigación, sino que el camino que esperamos trazar en esta oportunidad implica únicamente describir y analizar algunos acontecimientos históricos relevantes en torno a la conformación de los textos constitucionales chilenos y al contenido de los mismos, pudiendo destacar los rasgos más significativos del control parlamentario, para finalmente construir nuestro concepto.

En tal proceso descriptivo, hemos de realizar un examen de las fuentes doctrinales más importantes en la materia, para comprender mediante aquellos relatos las motivaciones que existieron en cada momento histórico para diseñar el control parlamentario. Sin perjuicio de aquello, nuestro ideario se centra básicamente en utilizar la dogmática jurídica y especialmente el método exegético respecto de los textos constitucionales y, de esta manera, realizaremos un análisis sistemático de la legislación constitucional respecto del control parlamentario.

Por consiguiente, mediante este tercer Capítulo pretendemos clarificar algunos elementos que nos permitan establecer cuáles han sido los rasgos más sobresalientes en cuanto a la expresión del control parlamentario a lo largo de nuestro Derecho Constitucional. En este sentido, y a través del análisis crítico de algunos hechos políticos relevantes, además de examinar esencialmente la normativa constitucional aspiramos a arribar a una síntesis preliminar respecto de las características del control parlamentario, lo cual nos permitirá vislumbrar elementos 
relevantes en la comprensión de la institución, su desarrollo actual y generar una posible conceptualización.

Dicho lo anterior, y examinando cuál fue la presencia de la noción de control del poder $y$, en especial, la de control parlamentario en el desarrollo del derecho patrio, es preciso subrayar lo descrito por Ruiz-Tagle cuando señala que nuestro Derecho Constitucional ha sido esporádico y circunstancial; no obstante, a pesar de aquellas características su fundamento más importante y duradero se ha sustentado en principios republicanos, democráticos y liberales. Esencialmente, destaca la necesidad permanente de contar con una Constitución escrita como medio de limitación del poder, el reconocimiento del pueblo ciudadano como sujeto del poder constituyente, el imperio de la ley y la participación política a través del sufragio universal $^{641}$.

Cabe hacer presente que -en opinión de Roldán- el constitucionalismo chileno comienza en 1810 y tuvo lugar con la instalación de la primera Junta de Gobierno con el objeto aparente de que rigiera el país durante el cautiverio del Rey de España Fernando VII. Según Roldán, la historia constitucional nacional se puede dividir en cuatro períodos. El primero, abarca los años 1810 a 1814; el segundo, los transcurridos entre 1817 y 1833 ; el tercero, los transcurridos entre 1833 y 1874 ; y el cuarto, de 1874 hacia adelante. Hay que exceptuar los años 1815 y 1816 , porque durante ellos fue restablecido el dominio español, período correspondiente a la Reconquista ${ }^{642}$.

Uno de los rasgos característicos del desarrollo histórico nacional fue, precisamente, contar con un ordenamiento fundamental escrito. Tal como describe Pfeffer, antes de concretarse la independencia de España ya habíamos sancionado tres Reglamentos constitucionales. Según este autor, el modelo para la elaboración de dichos textos fue preferentemente Europeo y el basamento ideológico fue el imperante en aquella época en todo el mundo, es decir, el liberalismo político y económico. No obstante, nuestras constituciones -a juicio de Pfeffer- fueron nominales, puesto que no estaban en consonancia con la realidad jurídico-política y, además, su elaboración habitualmente fue apresurada. A pesar de aquellas limitaciones, dichas Cartas promulgadas por Carrera, O'Higgins, Freire, Pinto, Prieto

641 RUIZ-TAGLE (2006) p.80.

642 ROLDÁN (1924) p.56. 
y Alessandri nos han dado estabilidad política y han formado una autentica tradición constitucional dando forma a nuestra conciencia política básica ${ }^{643}$.

En este mismo orden de ideas se expresa Verdugo cuando señala que nuestro país, si bien no ha vivido dentro del más puro constitucionalismo, no se puede sentir ajeno a los principios del constitucionalismo moderno: soberanía nacional, división de poderes, responsabilidad de los gobernantes, garantías constitucionales, supremacía constitucional; todos tuvieron en un comienzo una concreción precaria, pero siempre estuvieron contenidos en los textos constitucionales. En efecto, a pesar de no materializar exitosamente dichos principios, persistentemente existió el ánimo de contar con una Constitución escrita que los contemplara; aquel fue un elemento que caracterizó gran parte de nuestro desarrollo histórico nacional y que contribuyó en la creación de una tradición jurídico-constitucional nacional, rasgo que en el concierto internacional nos posicionó como una excepción dentro de América Latina porque presentábamos antecedes únicos de estabilidad respecto del régimen de gobierno representativo y del orden constitucional establecido ${ }^{644}$.

Para Bernardino Bravo, el constitucionalismo del siglo XIX y hasta el año 1920 comprendió dos elementos fundamentales: por un lado, será tomado de autores y modelos franceses y estadounidenses, promulgando principios como la división de poderes y las garantías individuales; y, además, pondrá especial énfasis en estos países el reconocimiento de la religión católica como oficial del Estado ${ }^{645}$. Por tal motivo, es posible detectar ciertos elementos tendientes al equilibrio de poderes $y$ control del poder en las primeras expresiones jurídicas chilenas, a pesar de que aquellas fueran habitualmente intenciones más teóricas que concretas.

Con todo, el constitucionalismo nacional se destacó por depositar una confianza ciega en las leyes escritas; un sistema normativo escrito que reflejara las ideas en boga sería capaz de crear ciudadanos rectos. En múltiples oportunidades se pasó por alto el nivel cultural y la realidad social de los chilenos que, en ocasiones, forzaba la aplicación de principios que no comulgaban con la tradición cultural nacional. En este sentido, la teoría constitucional chilena estaba inspirada en fundamentos orgánicos y dogmáticos alejados de la realidad nacional. Es por ello que la aplicación de los principios constitutivos del nuevo ordenamiento jurídico, institucional y social en

\footnotetext{
643 Pfeffer (1987) Pp. 64-65.

${ }^{644}$ Verdugo (2014) Pp.141 y 142

645 BRAVO (1992-1993) p. 305.
} 
Chile tuvo dos caras. Por un lado, se promovían y difundían una serie de derechos y beneficios ciudadanos que representaban un desafío para la organización del Estado, esencialmente, la defensa de la libertad. Pero por otro lado, se evidenciaba la falta de información e inexperiencia en el desarrollo de estas materias que, unido a un exceso de libertad, podrían acarrear el desorden en el plano privado y público, gestando una suerte de desgobierno ${ }^{646}$.

La evolución histórica nacional puede separase en dos etapas denominadas Patria Nueva y Patria Vieja, procesos políticos que iremos analizando en profundidad en las páginas siguientes. En una y en otra etapa los intentos por reglamentar la vida política y social de Chile fueron constantes. En dicha dirección, es posible detectar las primeras manifestaciones en el año 1811 extendiéndose hasta 1830 a través de diversos esfuerzos jurídicos, dando origen a un período que es conocido como el de "ensayos constitucionales". Según Fernando Campos, la historia constitucional de Chile, propiamente dicha, empieza con la Patria Vieja no porque durante tres siglos en los cuales fuimos Colonia hayan sido una página en blanco, sino que por el contrario, fue en ese período en el cual nos preparamos para lo que venía. Sin embargo, la historia de esos siglos no fue escrita por chilenos; fue la voluntad española la que dominó ${ }^{647}$.

Ahora bien, la limitación temporal relativa a examinar el control político y parlamentario a partir del proceso denominado Patria Vieja dice relación con una circunstancia determinante, puesto que sólo en aquella época surgen expresiones jurídicas propias, surge el Derecho patrio y las primeras manifestaciones constitucionales. Sin embargo, cabe destacar que conforme a lo expuesto por Javier Barrientos, en la época indiana existieron formas de detener los abusos y arbitrariedades de los gobernantes mediante una fiscalización jurisdiccional de los actos gubernativos, fiscalización que se realizaba a través de la apelación gubernativa, mecanismo cuya finalidad era fiscalizar la actuación de los gobernantes, razón por la cual se constituía como la gran institución protectora de los vasallos. Según Barrientos, tal apelación desapareció con la llegada del Chile republicano lo que dejó a los ciudadanos por largo tiempo inermes frente al ejercicio del poder, situación aún de mayor gravedad que en la época indiana, toda vez que el desarrollo

646 OCARANZA Y OCARANZA (2010) Pp. 78,79 y 82, 83.

647 CAMPOS (1977) p.325. 
de la administración y la burocracia estatal pueden generar complejos escenarios para el pueblo ${ }^{648}$.

Por consiguiente, el constitucionalismo será precisamente aquel factor que modificará la concepción de que el control del poder existía hasta el arribo de la República a Chile. Básicamente, con el desarrollo del constitucionalismo se alteran los centros neurálgicos del poder, vale decir, son modificados los fundamentos y orígenes del poder, razón por la cual se le atribuye al Parlamento -en su calidad de órgano de representación popular- la facultad de dar forma a la voluntad popular a través de leyes que regularan la vida social y política de las sociedades. Según Barrientos, serán precisamente aquellos fundamentos los que motivarán las circunstancias que arrebatarán la facultad protectora de los ciudadanos que le correspondía a la jurisdicción, para otorgársela al Parlamento. El constitucionalismo sostenía que las garantías de las personas estaban suficientemente cauteladas estando consagradas en la Constitución y en las Leyes, respecto de las cuales la autoridad debía de ajustarse velando por ello el Parlamento.

Desde aquella época la limitación al poder estará presente en los textos constitucionales a través de instituciones diversas y con matices propios dependiendo del momento político que experimentaba nuestra nación. Poco a poco fue incorporada en preceptos constitucionales que reconocían expresamente la institución y sus mecanismos. Durante los tiempos de la colonia, el control se desarrollaba mediante instituciones foráneas; el juicio de residencia fue su máxima expresión. Con la instalación de la República, el control se diluye y se deposita en varios órganos para vivir su período de esplendor en el llamado "parlamentarismo a la chilena". Luego, se suscitaron una seguidilla de hechos políticos complejos que a su vez exaltaron el uso de la fiscalización, para finalmente desencadenar el quiebre institucional de 1973. Con el golpe de Estado, el escenario político nacional gira en ciento ochenta grados, ya que todas las instituciones democráticas se eliminan y se da inicio a una larga dictadura cívico-militar, época en la que los controles políticos fueron inexistentes.

Durante los tiempos de dictadura, se procedió a elaborar un nuevo texto constitucional encargado a la Comisión de Estudios de la Nueva Constitución Política (CENC). El año 1990 finalmente comenzará una etapa de transición democrática con

${ }^{648}$ BARRIENTOS (1992-1993) Pp. 117 y 118. 
una nueva Carta Fundamental y con nuestro primer Presidente elegido democráticamente. En aquel Código Político la fiscalización si bien no fue objeto de grandes transformaciones, no obstante, estaba presente.

Con todo, las instituciones políticas de control en nuestro régimen político -según Zúñiga- se configuran a partir de una dialéctica de continuidad y ruptura de tal manera que el juicio político entronca con el juicio de residencia del Derecho Indiano y con el instituto de la acusación constitucional. Empero, es con la Revolución de la Independencia que el impeachment se incorporó a nuestros textos constitucionales, específicamente en su modalidad británica en la Constitución de $1833^{649}$. Por tal motivo, la doctrina nacional ha considerado que los orígenes constitucionales respecto de la fiscalización parlamentaria surgen más nítidamente en la Constitución de 1833 y, en particular, con las reformas constitucionales del año 1874. En este sentido, para Ferrada ésta será la oportunidad en la que se establezca un verdadero rol fiscalizador de las Cámaras ${ }^{650}$.

En nuestra opinión, la noción de controlar al poder estaba presente a través de instituciones foráneas desde los tiempos de la Colonia, la cual paulatinamente se fue concretizando en instituciones de corte nacional hasta configurarse como una función de fiscalización propia del Parlamento, con el paso del tiempo. Pero, ciertamente, su consagración constitucional más clara se produce en la Carta de 1833, oportunidad desde la cual siempre se ha mantenido. No obstante, somos partidarios en sostener que la idea de control o limitación del poder a fin de prevenir abusos y resguardar derechos fue una aspiración permanente en el desarrollo del Derecho patrio.

\section{La limitación al poder en el Derecho patrio $y$ sus primitivas expresiones}

En el presente apartado, nuestro primer objetivo será determinar cuáles fueron las primeras experiencias de control del poder mediante las cuales se contuvieron los abusos del mismo. Para ello, hemos de recurrir a algunas instituciones de la época colonial y del Derecho Indiano, las que por largos años pervivieron en nuestro sistema político-jurídico dejando sus huellas en nuestro Derecho patrio, como también hemos de estudiar las incipientes manifestaciones constitucionales de

649 ZÚÑIGA (1993) p. 705.

650 Ferrada (2002) Pp. 461-481. 
nuestro derecho en la época de la independencia. Como segundo objetivo, examinaremos el desarrollo de aquellas instituciones de mayor relevancia y determinaremos cuál fue su influencia en el ordenamiento jurídico constitucional nacional. En el cumplimiento del presente cometido, realizaremos un recorrido por los primeros textos constitucionales nacionales siguiendo aquella separación metodológica entre los reglamentos constitucionales y los ensayos constitucionales de la Patria Vieja y de la Patria Nueva, es decir, en este acápite alcanzaremos sólo hasta el texto político del año 1828.

Sin ánimo de reiterar hechos de suma conocidos y estudiados en el desarrollo histórico nacional, cabe hacer presente que en esta oportunidad nos concentraremos, especialmente, en determinados hitos sociales, económicos, políticos, jurídicos y culturales significativos para nuestra evolución política los que, por cierto, tienen directa vinculación con nuestra materia de estudio. Lo anterior, con la finalidad de contextualizar la investigación. y con el objetivo de entregar las herramientas necesarias para lograr la mayor comprensión del proceso evolutivo institucional de la fiscalización parlamentaria en el Derecho Constitucional nacional.

La primera etapa que ha de analizarse está compuesta por aquel período de dominio por parte de la Corona española respecto de los territorios del sur, etapa denominada como Chile colonial. Esta etapa se caracteriza por la aplicación del régimen absolutista, en virtud del cual el Rey de España era dueño absoluto de los territorios americanos. Por un lado, realiza algunas divisiones territoriales y da nacimiento a la organización administrativa de la Colonia a través de Virreinatos y las Capitales Generales. Por otro lado, mediante el absolutismo con el cual se gobernaban estas tierras, el Monarca en el cumplimiento de sus labores en América se encontraba asesorado por un real y supremo Consejo de Indias, el que ejercía funciones ejecutivas, legislativas y judiciales, regulando la vida de los ciudadanos mediante reglamentos especiales como las "Reales Cédulas" ${ }^{651}$. El Consejo comprendía una sección especial del Consejo de Castilla y configuraba la más alta autoridad del imperio americano después del Rey.

Pero -como bien es sabido- con la prisión del Rey de España en manos de Napoleón, dicho estado del arte comienza a ser alterado. Se instauran en una primera instancia las Juntas de Gobiernos en las colonias americanas, las que en un

${ }^{651}$ Amunategui (1947) Pp.165-167. 
principio sólo pretendían mantener el orden político del mismo modo que cuando estaba gobernando el Rey, es decir, prometiendo y jurando permanente lealtad al Rey y a la Corona. Aquella intencionalidad sólo persistió durante un tiempo. Luego se dio paso a un proceso independentista promovido por un fuerte descontento criollo fundamentado en diversas causas entre las cuales se pueden señalar el desamparo económico, educativo y cultural. Será el indiscutible rezago en las diferentes áreas de desarrollo social lo que configurará el sentimiento de insatisfacción que alentará a los precursores de la revolución. Por su parte, los criollos chilenos demandaban un mayor grado de participación en las labores administrativas de gobierno, solicitud que se intensifica por la actitud arrogante y soberbia que reciben de respuesta por parte de los propios españoles. Fruto de lo anterior emergerá como consecuencia un lento pero profundo sentimiento de patriotismo criollo que se fortalece en la segunda mitad del siglo XVIII, el cual promoverá la revolución independentista ${ }^{652}$.

Un segundo conjunto de hitos relevantes se produce durante la Patria Vieja, principalmente en los sucesos acaecidos el 18 de septiembre de 1810. En esta oportunidad se da lugar a la Primera Junta de Gobierno, la cual concluye sus trabajos dictando un Acta del Cabildo Abierto, momento en el cual no se declara la independencia, sino que se reconoce lealtad a Fernando VII. No obstante, en palabras de Ruiz-Tagle, se trazan las primeras líneas de una forma de autogobierno en Chile y se comienza a revisar el vínculo colonial con España. En aquella instancia las preocupaciones fueron fundamentalmente dos: regular la libertad de comercio y convocar a un Congreso Nacional, proceso histórico nacional en el cual los acentos estarán puestos en la regulación de la vida social y del sistema político como sinónimo de estabilidad y seguridad nacional. De allí que emanen los diversos ensayos constitucionales como manifestación de las primigenias manifestaciones del Derecho Constitucional chileno.

El tercer momento relevante es aquel producido durante la Patria Nueva, en especial, los hechos ocurridos el 12 de febrero del año 1818, oportunidad en la que se acepta la posibilidad de dar forma a una nueva unidad política nacional y se declara formalmente la independencia de Chile; sin embargo, la forma republicana sólo la adoptaremos debidamente en la Constitución de $1828^{653}$. Durante los años 1814 y 1829 nuevamente se intentará regular la vida política y social nacional a

652 COLLIER (1977) Pp. 21-28.

653 RUIZ- TAGLE (2006) p. 82. 
través de leyes fundamentales, las que serán un reflejo de las influencias literarias y las doctrinas imperantes en el mundo, el liberalismo, federalismo y los ideales revolucionarios harán su ingreso a Chile. Es por ello que el tenor de cada código político estará en directa armonía con aquellos fenómenos.

Sin perjuicio de lo anterior, tal como expondremos más adelante, a pesar de los fuertes deseos de autonomía política, económica y jurídica, el orden político y social nacional siempre estuvo influenciado por una tradición jurídica hispanoindia que en opinión de Dougnac consideraba que por más grande que fuera el poder real, éste siempre se encontraba sujeto al derecho, proscribiéndose la arbitrariedad ${ }^{654}$, argumento que en nuestra opinión permite esbozar que la noción de control del poder siempre estuvo presente en el pensamiento jurídico-constitucional chileno. Es por ello que emerge la necesidad de regular constitucionalmente de forma escrita desde un comienzo el desarrollo organizativo. La concepción del Estado de derecho estuvo presente en el país desde la Colonia, ciertamente, sin una claridad doctrinal con la que se expresaba en otras naciones, pero persiguiendo el mismo objetivo: limitar al poder mediante el derecho. Por tal motivo, hemos de realizar en el presente párrafo una revisión en el Chile colonial relativa a detectar los incipientes mecanismos del control del poder, y en esa dirección hemos de ir dilucidando cómo se fue desarrollando la institucionalidad del control político.

Para comenzar con nuestra descripción y estudio iniciaremos este apartado con el examen del juicio de residencia, como una manifestación hispanoindia heredada de control, dado que es la expresión más significativa del límite al poder que hemos vislumbrado en la época en estudio. Cabe hacer presente que la residencia -como institución de control- nos sitúa en una zona fronteriza entre los límites políticos y los jurídicos, básicamente, por el tipo de responsabilidad que de ella emana. Si bien es un mecanismo de rendición de cuentas que podrá generar una responsabilidad jurídica, adicionalmente, en el período colonial comprendía un impedimento político, vale decir, también se configuraba como una sanción política, toda vez que su ejercicio implicaba evaluar la gestión del residenciado. Producto de ello y en el caso de que dicha valoración arrojara un resultado negativo, el funcionario podía no ser confirmado en su cargo público e incluso podía ser impedido de obtener futuros nombramientos en el aparato gubernamental. Entonces, el Rey finalmente realiza un examen político respecto de la gestión del residenciado, fruto del cual igualmente se

${ }^{654}$ DougnaC (2000) p. 231 y 237. 
aplicaba una sanción política. En las siguientes líneas profundizaremos nuestro postulado

\section{a) El juicio de residencia como expresión de control del poder político en el Chile colonial}

Dando cumplimiento a nuestra primera misión, diremos que en virtud de la tradición jurídica española la primera manifestación de control al ejercicio del poder fue el juicio de residencia. Hemos decidido poner énfasis en el estudio de esta institución porque ha sido considerada comúnmente como un procedimiento de control respecto de aquellos que detentaban el poder. A pesar de que su configuración tuvo matices administrativos-judiciales, mas no esencialmente políticos, su finalidad era fundamentalmente sancionar el actuar incorrecto del detentador del poder y resarcir los daños que ello pudiera causar a la comunidad. Desde nuestra perspectiva, el primer elemento es una sanción política y el segundo un elemento jurídico. Es por ello que ahondaremos las expresiones nacionales del mismo.

Esta institución del Derecho Público Indiano, como explica el profesor Zúñiga, tiene sus raíces bajo medievales en Castilla y León y en el juicio de "purga taula" de la Corona de Aragón. Tal como describe el autor, era un mecanismo que estaba ligado a un juramento que debían prestar los funcionarios de la Corona al asumir sus funciones de observar las leyes y cumplir lealmente sus deberes, y la necesidad de corregir o reparar los yerros u ofensas que causaren. Según Zúñiga, en América Latina el juicio de residencia fue empleado a veces como instrumento de venganza o de pérdida de confianza real ${ }^{655}$. Empero, la trayectoria del juicio de residencia es extensa. Inicia su consagración en Castilla, pero ella es tomada en préstamo desde el Derecho Romano. Por ello, González explica que la residencia como tal "se

redescubre, no se inventa"656; su regulación estuvo muy ligada a las Partidas y a las Leyes de Estilo. Ahora bien, lo considerable para nosotros es -como bien expresa González- que la residencia era un procedimiento a través del cual se revisaba la conducta inicialmente de jueces y luego respecto de algunos funcionarios públicos, cuya finalidad era exigir la responsabilidad que eventualmente pudiera incurrir en el

655 ZÚÑIGA (2006) p.46.

${ }^{656}$ Alonso (1978) p. 194. 
ejercicio del cargo. La consideraba esencialmente un "procedimiento de fiscalización" que fue sumamente quebradiza y sensible a las oscilaciones políticas y administrativas.

Así lo expresa María José Collantes de Terán de la Hera cuando dice que "se trata de un procedimiento de control de la actuación de aquellos que detentan oficios públicos, especialmente los de administración de justicia, al términos de los mismos, que permitía averiguar cuáles de esos sujetos ofrecían suficiente confianza para adjudicarles nuevo cargos, e igualmente, para reparar los daños que hubieren podido ocasionar en el desempeño de sus funciones" ${ }^{\prime 657}$. Conforme lo señalado por la autora, el juicio de residencia representa un medio de exigencia de responsabilidad de los funcionarios y jueces, vale decir, un procedimiento de control.

Para el chileno Sergio Martínez, el juicio de residencia estuvo presente en América desde los primeros años de la colonización en constante adaptación -de conformidad a las variables circunstancias del orden político-administrativo de nuestra nación- manteniendo su presencia en diversos textos constitucionales. Según Martínez, el juicio de residencia se puede definir de la siguiente manera: "Es un medio de control funcionario que supone la radicación del afectado, por un tiempo, en el lugar en que ha ejercido sus tareas, sometido a un procedimiento indagatorio de sus actos, destinado a calificar sus condiciones y a hacer efectivas sus responsabilidades" ${ }^{658}$. Por consiguiente, en nuestra interpretación, el juicio de residencia en América fue una institución bifronte que consecuentemente abarcaba dos dimensiones diferentes: por un lado, es un mecanismo de rendición de cuentas con sanciones políticas como la pérdida del cargo; y por otro lado, una cualidad de orden jurídico, que pretendía resarcir daños y hacer efectiva responsabilidades civiles y penales.

En este mismo sentido se expresan las palabras de otro autor nacional Emilio Jarpa Díaz de Valdés, quien expresa que en Chile se aplicó el juicio de residencia mediante reglas de aplicación general durante todo el siglo XVIII, como una institución destinada a establecer responsabilidades de los afectados y sancionar sus malas actuaciones, y reservado principalmente a la selección de funcionarios probos. Uno de los aspectos más relevantes que nos aporta este autor fue la definición que formula de esta institución, señalando expresamente que es un procedimiento

\footnotetext{
657 Collantes de Terán de la Hera (1998) p.152.
}

658 MARTÍNEZ (1999) p.239. 
administrativo-jurídico complejo que pretendía seleccionar a los funcionarios probos y eliminar del servicio de la Corona aquellos, cuya capacidad y honestidad merezcan reparos. Su finalidad era, en definitiva, determinar responsabilidades funcionariales derivadas de sus actos por cualquier negligencia o dolo, aplicando serias sanciones $^{659}$.

Para mayor comprensión expondremos brevemente el procedimiento del juicio de residencia. Este proceso sólo comenzaba una vez finalizado el ejercicio del cargo, oportunidad en la que debía ser designado el juez residenciador. Para iniciar el proceso indagatorio era necesario que el juez publicara los edictos, a fin de poner en conocimiento de todas las personas la existencia del proceso y la fecha de inicio del juicio para que así las personas pudieran hacer llegar sus quejas por los posibles daños ocasionados. Posteriormente, el juez designaba a sus colaboradores para la realización del juicio. Durante este período procesal se configuraban dos etapas: una primera etapa de orden probatorio, en la cual el juez se podía valer de todos los medios a su alcance para investigar; y una segunda etapa, que se iniciaba con la formulación de cargos que resultaban de la indagación secreta realizada por el juez, momento en el cual se presentaban las quejas de los ciudadanos afectados, para luego proceder a la formulación de descargos. Una vez reunidos todos los antecedentes el juez podía fallar.

Aquel resultado podía ser favorable o desfavorable para el funcionario residenciado. En el caso de ser favorable, era declarado recto y buen ministro, acreedor de los correspondientes ascensos de su carrera. En el caso contrario, el juez debía proponer la aplicación de una pena, siendo las más frecuentes la multa, el destierro, traslado y la inhabilitación temporal o perpetua para servir a la Corona. Luego, el proceso pasaba a la autoridad superior que debía dictar la correspondiente sentencia ${ }^{660}$.

Así, el juicio de residencia como tal era una institución destinada a determinar posibles responsabilidades cometidas -inicialmente- por funcionarios de la Corona en determinados delitos. Por ende, su finalidad era más bien penal y no técnicamente política. El objeto del mismo era el de examinar lo que hubiera hecho mal el funcionario público durante su oficio; es un procedimiento de control sobre la

659 JARPA DíAZ DE VALDÉS (1966) Pp. 8 y32.

660 MARTíNeZ (1999) p. 240. 
diligencia y fidelidad con que los oficiales públicos desempeñan sus oficios ${ }^{661}$. Ahora bien, en cuanto a nuestro Derecho patrio, siguiendo a Sergio Martínez, lo cierto es que nuestro Derecho recoge el juicio de residencia en casi todos los cuerpos legales republicanos a partir de la instalación de la Primera Junta de Gobierno de 1810, permaneciendo vigente hasta la Constitución del año 1925. A pesar de que -a juicio del autor- esta institución en reiteradas ocasiones se ha visto confundida o desvirtuada en sus aspectos esenciales, perdiendo su denominación característica en la Carta de 1833, pero conservando su rigor conceptual ${ }^{662}$.

El proceso del juicio de residencia fue altamente modificado por nuestro derecho patrio en cuanto a algunos requisitos de procedencia, variando respecto al tiempo que debían quedar sujetos los funcionarios a residencia según la jerarquía y el cargo desempeñado, como también la magnitud de su alcance, es decir, a qué tipo de funcionarios era posible residenciar. Empero, es claro que fue el mecanismo utilizado en el Chile colonial para contrarrestar los abusos en el ejercicio del poder; era un procedimiento de orden jurídico-administrativo que analizaba la ejecución de delitos y los daños que ello generaba a la población como antesala o precedente del juicio político o impeachment. Por otra parte, establecía de manera conjunta sanciones políticas, cuyo objetivo era privar al residenciado del cargo público que ejercía o restringir el acceso al mismo. Por tal motivo, su vinculación con nuestra materia es evidente y resultaba necesario plantearlo a fin de dar mayor coherencia y seguir un hilo conductor en nuestra investigación.

\section{b) Reglamentos, ensayos constitucionales y el control político del poder}

El desarrollo constitucional nacional se plasma en dos etapas, la primera de ellas durante la Patria Vieja. Este período media entre el establecimiento de la Primera Junta Nacional de Gobierno del 18 de septiembre del 1810 y el 2 de octubre del año 1814, fecha en la que se produce la batalla de Rancagua que -en palabras de Dougnac- significó el fin, por el momento, del proceso emancipador chileno, volviendo el Gobierno a manos del sector absolutista ${ }^{663}$. Durante estos cuatro años es posible detectar cuatro textos de orden constitucional: 1.- El Reglamento provisorio de la Junta Gubernativa del reino de Chile de 1810 , 2.- El Reglamento de

\footnotetext{
661 Collantes de Terán de la Hera (1998) p. 162 y 167.

662 MARTINEZ (1965) p.130.

663 DougnaC (2000) p. 230.
} 
1811, 3.- El Reglamento constitucional provisorio de 1812 y, 4.- El Reglamento constitucional provisorio de 1814.

A continuación, realizaremos un breve recorrido por aquellos cuerpos constitucionales, examinando los posibles rasgos de limitación al poder existente en aquel período del constitucionalismo chileno. En particular, examinaremos las particulares expresiones del juicio de residencia por la relevancia que dicha institución representa en la evolución constitucional nacional, además de comprender cómo ella va adquiriendo un tinte diverso a su estructura y espíritu original al punto de desnaturalizar su objetivo e instaurarse como un mecanismo de control.

\section{b.1. La Patria Vieja y los Reglamentos constitucionales}

Este período de la historia de nuestro país es, según Collier, el momento en que se presentan y desarrollan las nuevas ideas políticas y las actitudes emocionales patrióticas que iban a construir los ideales de la Revolución. A juicio del autor, ésta fue sin lugar a dudas la etapa formativa de la Revolución chilena. Durante los años 1810 y 1833 se desarrollan las ideas políticas de mayor trascendencia para la Revolución y la Independencia; la teoría política en sí misma fue el gran aliado de las nuevas transformaciones, configurándose como el instrumento insigne para planear las acciones contra España y también contra Perú. Esencialmente, durante la Patria Vieja se introduce en nuestro país la imprenta y se produce la fundación de un puñado de periódicos, lo que permitió publicar y difundir de forma masiva los nuevos ideales. El ingreso de literatura política se debe en gran medida a las acciones de O 'Higgins. La pequeña intelectualidad criolla estaba representada por autores como Vera, Irisarri, Egaña, Salas y Gandarillas, quienes dan forma a temas como la justificación de la independencia y el desprestigio de España, entre otros. No obstante, durante la Patria Vieja en la conciencia política de la "elite" criolla gobernante en Chile permanecen algunos sectores de la aristocracia que, si bien rendían pleitesía a los nuevos ideales, en el fondo nunca les incomodó vivir bajo el régimen colonial, sectores que posteriormente apoyan el período de Reconquista, entre 1814 y $1817^{664}$.

664 COLLIER (1977) Pp. 123-125. 
La Patria Vieja es -en opinión de Infante- el período en que Chile por primera vez se sometía a la experiencia del autogobierno. Fueron los años en los que se produjeron una serie de eventos patriotas, realistas, republicanos y monárquicos, que con sus ideas y planteamientos forjaron la primera identidad patria de lo que posteriormente será el Chile republicano ${ }^{665}$.

Prueba de aquella intención autonómica chilena es la configuración del primer Congreso Nacional, el cual realiza su primera sesión el 4 de julio del año 1811 . Su primera obra fue la dictación del Reglamento para el arreglo de la autoridad ejecutiva provisoria, sancionado el 14 de agosto del mismo año, cuya finalidad era regir provisionalmente hasta el retorno de Fernando VII. Dicho documento evidenció las debilidades de aquella época. Si bien depositaba la autoridad máxima en manos del Congreso, no lograba organizar ni dividir los poderes y tampoco establecía derechos o garantías individuales; así, se diseña un Ejecutivo débil que luego generará momentos de inquietud ${ }^{666}$.

El Congreso de 1811 tenía -según Galdames- representación de todos los intereses y anhelos del país exceptuando la clase baja del pueblo, la que sólo asistía como mero espectador de las trascendentes decisiones que en él se adoptaban. Tal era la representación que, según este autor, ya se configuraban las grandes tendencias políticas: nacionales, conservadoras, realistas y radicales ${ }^{667}$. Según Infante, lo más importante era que el Congreso Nacional se autodefinía, a través de lo cual pone de manifiesto la necesidad de dividir el poder y determinar las esferas de acción de cada uno de ellos ${ }^{668}$.

Por su parte, los primeros razonamientos del Congreso fueron sucintamente los siguientes: determinar la duración de los cargos diligenciales, delimitar los poderes que ha de ejercer cada poder del gobierno -separando al Ejecutivo del Legislativo o bien realizando divisiones administrativas entre provincias y, esencialmente-, existió una profunda preocupación por la dictación de una Constitución nacional como un código completo. Sin perjuicio de aquellos objetivos, es de suma relevancia detectar que durante la vigencia de aquel Congreso se estableció dentro de sus prácticas políticas la implantación -en términos claros- de una fiscalización sobre los actos del gobierno que correspondía a cada ciudadano. Para estos fines, decretó la publicidad

665 INFANTE (2014) p. 41.

666 CAMPOS (1977) p.328 y 329.

667 GALDAMES (1881-1941) Pp. 157, 171 y 199.

668 INFANTE (2014) p. 91. 
de todas las sesiones mediante carteles y abrió las puertas del Congreso para todo aquel ciudadano que quisiera asistir a los debates ${ }^{669}$.

Por ende, podemos señalar que desde las primigenias manifestaciones asambleístas nacionales, la noción de fiscalización de los actos del poder estuvo presente. Por cierto, no estaba encomendada a los miembros del Congreso pero representaba la idea de límite al poder, cuya barrera era precisamente los incipientes derechos sociales, es por ello que se expresa más bien como un control social puesto que se trasladaba a la misma sociedad el derecho-deber de informarse y analizar el actuar de sus autoridades. Desde una premisa más bien teórica estábamos frente a una especie de control difuso emergente que aspiraba a instalarse como uno de los pilares de la construcción de la futura República. Es dable tener presente que en dicho momento el Congreso era la máxima representación de una autoridad de origen "nacional" y es por ello que su funcionamiento debía ser abierto al pueblo, puesto que hasta ese momento gran parte de las decisiones y directrices políticas eran debatidas y formuladas por autoridades de la Corona o designada por ella, por cierto, muy lejanas a la población chilena.

No obstante, es relevante destacar algunos elementos del discurso de instalación de aquel primer Congreso, formulado por Camilo Henríquez, el cual evidenciaba claros rasgos independentistas. En efecto, en aquella perorata su autor ya hacía referencia a la "nación chilena". El argumento central de aquel sermón fijaba como eje fundamental aquella condición de incertidumbre en la que se encontraban las colonias americanas al estar geográficamente tan alejados de los territorios españoles. Por ello, Henríquez plantea aquel posible escenario de anarquía que podría producirse frente a la ausencia del Rey. Expondrá que "Sí: las naciones tienen recursos en sí mismas; pueden salvarse por la sabiduría y la prudencia"670. El autor en aquel discurso reclamará abiertamente el derecho de los pueblos de defender y sostener la libertad de la nación, la religión, la propiedad y el honor de las familias. En razón de aquellos argumentos no promueve directamente la desvinculación con la Corona española, pero era imprescindible poder organizarse y continuar con el normal funcionamiento del pueblo. Es por ello que será necesario regular nuestra realidad política y dar estabilidad al sistema nacional, por tanto, Camilo Henríquez expresará que: "Más, como tan grandes bienes no pueden alcanzarse sin establecer por medio de nuestros representantes una constitución conveniente a las actuales

669 GALDAMES (1881-1941) p. 192

670 HenRíquez (1960) p. 3. 
circunstancias de los tiempos, esto es, un reglamento fundamental que determine el modo con que ha de ejercerse la autoridad pública"671.

En consecuencia, una vez tomado prisionero el Rey de España, el pueblo chileno siguiendo la misma teoría filosófica y política propugnada en aquellos tiempos en Europa sostiene y adhiere a la secularización del poder. Recordemos que, según lo descrito en el Capítulo I, expusimos que una vertiente de las teorías divinas del origen del poder sostenía que el poder provenía del pueblo, quien lo delegaba a su vez en el Rey. En consecuencia, la teoría del pacto ingresa a Chile y se comprendió que una vez tomada presa la autoridad absoluta el poder debía retornar al pueblo y desde allí reorganizar el orden político ${ }^{672}$. En aquel momento el pueblo -en términos teóricos- creía estar representado en el Congreso, por ende, en una primera instancia del desarrollo político del país se sostuvo que el poder era ejercido por el Congreso Nacional. Es en virtud de aquel pensamiento respecto del cual comienza a gestarse la idea del autogobierno, reconociendo inicialmente la autoridad de la Corona, para luego cuestionar aquel paradigma y dar inicio a un proceso revolucionario que luego declarará la independencia nacional, la soberanía popular y el gobierno representativo.

Por consiguiente, la Patria Vieja se inicia formalmente en 1810 con la Primera Junta de Gobierno, la que tuvo por finalidad ratificar la lealtad al Rey Fernando VII frente a su captura. No obstante, poco a poco irán emergiendo posturas más radicales que plantearán derechamente la independencia de Chile. Con todo, durante esta etapa se dará lugar al cambio de mentalidad en los habitantes del país; surge la necesidad de establecer un régimen independiente y autónomo de la Corona Española, influenciado por las ideas de la Ilustración, la Revolución francesa y Norteamérica en virtud de los viajes de los criollos chilenos a Europa y el contrabando comerciante. El proceso de independencia emerge verbigracia del descontento social, económico y cultural del pueblo, el que implicó erradicar, paulatinamente, la institucionalidad colonial, como también emprender un camino de organización gubernamental propio. En esa dirección, hubo quienes esperaban cambios graduales liderados esencialmente por $\mathrm{O}$ 'Higgins y otros que promovían modificaciones radicales, representadas en la figura de José Miguel Carrera. Todo ello generó fuertes discrepancias en la población entre los ciudadanos que estaban a

${ }_{671}$ HenRíquez (1960) p.3.

672 cf.supra, p.28. 
favor de la independencia y aquellos que estaban por mantener el vínculo de dependencia con la realeza española ${ }^{673}$.

La experiencia vivida durante estos cuatro años distó mucho de ser una experiencia feliz para el pueblo chileno. Se produjo un fracaso en la incorporación de las instituciones liberales como también existió un cuadro de inestabilidad política, sucesos que finalmente hacen cuestionar si Chile estaba preparado para la doctrina revolucionaria. Durante la Patria Vieja primó la incertidumbre. La misma idea independentista no constituía un ideal deseado por la universalidad del pueblo chileno y prueba de aquello fueron los constantes enfrentamientos entre las fuerzas patriotas dirigidas por José Miguel Carrera y el liderazgo de O’Higgins. Las indecisiones entre el actuar de ambos y la falta de coordinación gestan la reorganización de los movimientos realistas, los que finalmente se enfrentan en una heroica batalla el 1 y 2 de octubre del año 1814, oportunidad en que los revolucionarios pierden la partida en manos de los realistas. Con ello, se pone fin en opinión de los historiadores a la Patria Vieja con el denominado Desastre de Rancagua y se instaura el período de Reconquista ${ }^{674}$.

Durante la Patria Vieja los ideales políticos indicaban que las nociones como soberanía popular y Gobierno representativo debían quedar establecidas públicamente en forma de Constitución escrita, texto en el cual se debían establecer otras normas de regulación social. Tal como describe Collier, una Ley Fundamental gozaba de importancia fundamental para los chilenos porque ella encarnaba el contrato social. En este contexto, explica el autor, Chile no escapa de las estructuras tradicionales, es por ello que seguirán como referente constitucional los códigos políticos de Estados Unidos y la Constitución española de 1812 (la influencia de esos textos fue evidente) y uno de los principios fundamentales que se intentaba instaurar en nuestro país fue la incorporación del principio de división de poderes; la noción de equilibrio de poderes fue sagrada. Para Collier los chilenos "consideraron sus diversas constituciones documentos sagrados que eran, de algún modo misteriosos, eficaces por sír675. En el imaginario nacional existía una interpretación mediante la cual se planteaba que las leyes eran la herramienta mediante la cual se construye una sociedad mejor, por tal motivo, durante esos cuatro años de experiencia

${ }^{673}$ El movimiento que buscaba la autonomía nacional debió enfrentar diversas Batallas entre las que se encuentran: Yerbas Buenas, El Roble, el Quilo, Membrillar y la Batalla de Quechereguas.

674 COLLIER (1977) Pp. 91, 92, 98 y 99.

675 COLLIER (1977) p. 175. 
revolucionaria fueron cuatro nuestros ensayos constitucionales, textos que pasamos a analizar.

El Reglamento para el arreglo de la Autoridad Ejecutiva provisoria de Chile del 14 de agosto de 1811, fue obra del primer Congreso que hubo en el país. Por tal motivo y dado que dicho órgano era el depositario de la soberanía y del poder, gran parte de las funciones que eran ejercidas por la Corona eran delegadas al Congreso como único soberano ante la imposibilidad del Rey de ejercer su autoridad. En este sentido, el Real Patronato y las relaciones internacionales, por señalar algunos ejemplos, fueron otorgados a dicho órgano. Sin embargo, el presente Reglamento tuvo una corta vigencia: el 4 de septiembre del mismo año, al mediodía, don José Miguel Carrera dirige con éxito la primera intervención militar y, en virtud de aquel proceso, la Junta Ejecutiva y el Congreso quedan a su merced. Por tal motivo, y con el objeto de plasmar su sello de legalidad, designará una nueva Comisión para que redacten un texto reglamentario diverso ${ }^{676}$.

En cuanto a lo que nosotros respecta en relación con el control del poder, cabe destacar que en el presente texto se realizan importantes esfuerzos por dividir y limitar los poderes públicos. A pesar de que no lo señaló expresamente, sí distinguió las cuatro ramas tradicionales de los poderes del Estado ${ }^{677}$. Básicamente, en el texto del año 1811 se contempló una supremacía parlamentaria que más tarde será debilitada a través de un Ejecutivo fuerte propuesto y ejecutado por O'Higgins. En efecto, el Preámbulo del Reglamento señalaba que: "El Congreso Representativo del Reino de Chile, convencido íntimamente, no sólo de la necesidad de dividir los poderes, sino de la importancia de fijar los límites de cada uno sin confundir ni comprometer sus objetos, se cree en la crisis de acreditar a la faz de la tierra su desprendimiento, sin aventurar en tan angustiada premura la obra de la meditación más profunda: quiere desde el primer momento consagrarse sólo a altos fines de su congregación; pero no está en sus alcances una abdicación tan absoluta antes de constituir la forma sólida de gobierno en los tres poderes, cuyo deslinde es el paso prolijo y más espinoso en todo Estado".

Además, contemplaba en su artículo 10: "El Congreso, como único depositario de la voluntad del reino, conocerá exclusivamente del cumplimiento o infracción general de la ley". Por su parte, el artículo 40 rezaba: "El Congreso por la representación

676 Pfeffer (1987) Pp. 51 y 52.

677 DOUGNAC (2000) p. 238. 
inmediata y general del Reino, asegura su confianza y demanda la seguridad de opinión que se reserva el mando de las armas...". Con todo, el Reglamento establecía un gobierno Ejecutivo de tres miembros y un Congreso unicameral, el cual ejerce las funciones ejecutivas y legislativas pero al que se le atribuyen mayores atribuciones que a los otros poderes. Principalmente, es posible destacar la clara intencionalidad de consagrar la división de poderes como una herramienta mediante la cual se consigue el límite al poder.

Empero, es preciso tener presente que a pesar de la separación de funciones que establecía el Reglamento y que creaba una Autoridad Ejecutiva, el ejercicio del gobierno interior del país partencia -en los hechos- casi completamente al Congreso, el cual contemplaba la facultad de hacer cumplir la ley, el ejercicio del patronato eclesiástico, el manejo de las relaciones exteriores, el mando de las armas y la supervigilancia del Ejecutivo. En consecuencia, su autoridad quedaba sumamente reducida y quien poseía mayores poderes era el Congreso. Podemos decir que la supremacía del Congreso fue evidente ${ }^{678}$.

En lo tocante al control del poder en relación al juicio de residencia, es posible señalar que se encontraba estipulado en el artículo 16 del Reglamento presentando rasgos tremendamente relevantes. La residencia del artículo 16 señalaba lo siguiente: "Los Vocales nombrados al Despacho Ejecutivo jurarán en el Congreso fidelidad a los grandes objetos que éste proclama y sostiene, y la pureza de sus operaciones, de las que son responsables al reino por las resultas de la residencia que se les tomará, al arbitrio de sus representantes en el tiempo y diputación que deleguen"679. En consecuencia, coloca en situación de residencia a los vocales que integraban la Autoridad Ejecutiva Provisoria por parte de sus "representantes". Convengamos que en aquel Reglamento la voz "representantes" se refería, precisamente, a los miembros del Congreso, por consiguiente, ya en el año 1811 la residencia como medio de control era aplicable a los miembros del Ejecutivo y su verificación le correspondía precisamente el Congreso.

Con todo, expresa Mario Verdugo, en este embrión de ordenamiento constitucional el Preámbulo del mismo contemplaba importantes principios del constitucionalismo moderno y, en particular, consagraba el paradigma de la división de poderes. De esta manera se realiza en el texto reglamentario una diferenciación

678 García-Huidobro (2012) Pp. 236 y 237.

${ }^{679}$ http://www.leychile.cl/Navegar?idNorma=1005318\&r=2. Visitada con fecha: 1.10.2015. 
de funciones y se señala además la importancia de fijar límites a los mismos sin comprometer sus objetivos. Es preciso hacer presente que tal separación de poderes fue el resultado de una exigencia que fue consignada en una nota de fecha 23 de julio de 1811, dirigida por el Cabildo de Santiago a sus diputados, en la cual se exigía con urgencia la separación de funciones Ejecutivo y Judicial del Congreso, solicitud que claramente fue incorporada al Reglamento ${ }^{680}$.

Así, a través de una incipiente división de poderes y la noción española de control mediante el juicio de residencia, se configuraba el control de la autoridad ejecutiva y su gestión desde las primeras formas organizativas nacionales y -a nuestro juicio- se configuraba la principal expresión de control político en la época en la naciente regulación jurídica chilena. Ciertamente, la manera en la que el Código Político regulaba estas instituciones fue muy iniciática, puesto que no existían ideas precisas sobre cómo configurar un Gobierno. Por otra parte, el Reglamento tenía un carácter transitorio para resolver una situación específica, puesto que más tarde habría de dictarse una Constitución definitiva. Sin embargo, poseían el ímpetu necesario para intentar organizar los poderes del Estado en el cumplimiento de tal cometido, ya que se fijaban como parámetro la división de poderes y la limitación de los mismos. El bosquejo constitucional de 1811 -y los siguientes textos- ostentarán como rasgo esencial una de las bases fundamentales del constitucionalismo moderno, cual es, la división de poderes y la responsabilidad en la actuación, por tanto el germen del control político estaría presente y en constante crecimiento.

Tal como fue descrito precedentemente, el Reglamento de 1811 tuvo corta vigencia porque don José Miguel Carrera -insigne representante del movimiento revolucionario e independentista y miembro de una de las familias más ilustres y comprometida con la causa patriota- el 4 de septiembre del año 1811 a las doce del mediodía dirige con éxito su primera intervención militar. Producto de aquello, la Junta Ejecutiva y el Congreso quedan a su merced; la intervención militar se pudo consumar sin resistencia. Ante esto, Carrera consideró de gran importancia otorgarle un sello de legalidad a sus pretensiones y fija como prioridad crear un nuevo orden constitucional. Para cumplir aquella finalidad, designa una nueva Comisión que ha de redactar un nuevo Reglamento. En tal escenario el 17 de octubre del año $\mathbf{1 8 1 2}$ se sanciona el "Reglamento Constitucional Provisorio".

680 Verdugo (2014) Pp. 120 y 121. 
Ahora bien, la Junta de Gobierno se había comprometido con entregar una nueva Constitución a Chile designando para su estudio a una Comisión; empero, ello no se produjo y aquel texto fue diseñado de forma privada por pocas personas, grupo pequeño que se encontraba fuertemente orientado e influenciado por el cónsul norteamericano don Joel Roberts Poinsett. Por esta razón el texto estará fuertemente influenciado por los principios de la Constitución de los pueblos del norte, principalmente, de corte federalista. En este sentido, dirá Verdugo que si bien no es posible considerarla como un texto constitucional formal, sí es un claro avance en comparación con el texto de 1811. En tal reglamento se contemplaban principios relevantes como la soberanía del pueblo, haciéndose mención también a algunos derechos y garantías individuales; se establecía en cierta medida el principio de independencia del poder judicial y la libertad de imprenta ${ }^{681}$, el que fue promulgado en base a un plebiscito.

Para el profesor Bravo Lira, este Reglamento constitucional provisorio fue impuesto por un dictador -el joven sargento José Miguel Carrera- y su plebiscito no fue más que una parodia de consulta popular que no dejó ningún buen recuerdo, por el contrario, contribuyó a exacerbar los ánimos y precipitar el estallido de la guerra civil. Según el autor, fue una forma dictatorial de introducir el constitucionalismo por vía plebiscitaria ${ }^{62}$. Lo cierto es que gran parte de la elite, tanto en Santiago como en las ciudades del sur, veían con poco entusiasmo y mucha desconfianza las pretensiones del joven caudillo, y por ello es la ciudadanía la que le exige a Carrera una Constitución sancionada por el pueblo soberano, para limitar y poner fin a cualquier intento despótico o autoritario del joven líder ${ }^{683}$.

Durante el año 1812, el Gobierno chileno dejaba atrás las protestas de lealtad al Rey y se concentraba en aspectos más prácticos relativos a fortalecer la gestión autónoma. En este escenario, no se realiza una declaración formal de independencia pero dispondrán fuertes limitaciones al poder de la Corona a través de los preceptos constitucionales. Según Collier, los cabecillas criollos fueron oportunistas y nunca declararon públicamente su independencia; se mantuvieron atentos al juego de los acontecimientos $y$, en razón de aquello, planificaron sus acciones. Los más

\footnotetext{
681 Verdugo (2014) Pp. 122 y 123.

682 BRAVO (1992-1993) p. 307 y 308.

683 GARCÍA-HUIDOBRo (2012) p. 238.
} 
conservadores se habían encargado de mantener durante todo ese tiempo a lo menos una relación simbólica con el Imperio ${ }^{684}$.

El Reglamento de 1812 solamente estuvo vigente un año, pero su cometido presentaba rasgos de importancia: dejaba el Ejecutivo en manos de un órgano colegiado compuesto por una Junta de tres miembros e inspirada en la tradicional teoría española. Respecto del origen del poder político, continúa reconociendo la soberanía a Fernando VII pero como bien describe Campos en este cuerpo políticojurídico se establecía por primera vez una doctrina emancipadora ${ }^{685}$. Lo anterior en virtud del artículo 5 de la Carta, el cual dejaba sin efecto todo decreto, providencia u orden que proviniera de autoridades o tribunales de fuera del territorio de Chile. Por su parte, el artículo 16 declaraba que la soberanía residía en el pueblo de Chile. Es por ello que Dougnac lo califica como un Reglamento altamente revolucionario ${ }^{686}$.

En lo que a nosotros respecta, el Reglamento de 1812 hace referencia expresa a la residencia en su artículo I numerando XI donde expone lo siguiente: "El Senado residenciará a los vocales de la junta, y los juzgará en unión con el Tribunal de Apelaciones. Cualquiera del pueblo podrá acusarlos por traición, cohecho y otros altos crímenes; de los que siendo convencidos, los removerá el mismo Senado, y los entregará a la justicia ordinaria para que los castigue según las leyes. Promoverá. la reunión del Congreso. Tres Senadores reunidos formarán el Senado. Llevará diarios de los negocios que se traten y de sus resoluciones, en inteligencia que han de ser responsables de su conducta". Respecto del presente precepto constitucional, cabe destacar dos elementos importantes: primero, se entrega el juicio de residencia al Senado, órgano consultivo del Gobierno y a los Tribunales de Apelaciones. Así, la juridicidad de aquella institución indiana se fortalece. El segundo elemento es una importante variante normativa, puesto que el profesor Sergio Martínez sostiene que éste es el primer texto que hace referencia a la residencia como medio de control del Ejecutivo, sirviendo de antecedente a las leyes fundamentales posteriores, especialmente las de 1833 y de $1925^{687}$. No obstante, desde nuestra interpretación y tal como lo expusiéramos precedentemente, el Reglamento de 1811 sí hace referencia respecto de la residencia en el artículo 16, estableciendo que se le tomará residencia respecto del Ejecutivo. Por tanto, para nosotros el texto de 1812 no es

\footnotetext{
684 COLLIER (1977) Pp. 93 y 110.

685 CAMPOS (1977) p.332.

${ }^{686}$ DOUGNAC (2000) p. 249.

687 MARTÍNEZ (1965) p. 144.
} 
totalmente innovador en cuanto al control del Ejecutivo, toda vez que en el cuerpo normativo precedente aunque no se regula en detalle la residencia ya estaba presente la institución.

Otro elemento relevante que nos entrega el Reglamento de 1812 dice relación con la incorporación de tipos penales como parámetro en virtud del cual procede y se evalúa la residencia. Se contempla la traición, el cohecho y otros altos crímenes, todos delitos que habrían de acreditarse en instancias judiciales, ilícitos que se mantendrán vigentes como causales de residencia y acusación en los códigos políticos nacionales posteriores.

Finalmente, siguiendo a García-Huidobro, el Reglamento de 1812 era imperfecto, acotado y carecía de una técnica jurídica esperable para el texto constitucional que sienta las bases del obrar del Estado. Empero, la dictación del mismo no fue una labor sencilla; fruto de las tensiones interprovinciales que emergen en razón del centralismo de Santiago, perturbaron los fundamentos en virtud de los cuales nace el Reglamento. No obstante, la norma representaba todos los principios liberalesrevolucionarios de las revoluciones atlánticas (norteamericana y francesa). Es por ello que contenía el principio de la separación de poderes -noción propia de la literatura política ilustrada-, el aseguramiento de una serie de libertades, la creación de secretarias de gobierno, garantías en el proceso penal y el debido proceso y, esencialmente, la declaración de la soberanía nacional, como también la clara concreción de una declaración de autogobierno contenida tímidamente en el texto de 1811. Se radicaban las potestades legislativas en Chile, algo que bajo el régimen borbónico estaba estrictamente limitado a la metrópoli. Cabe destacar que el rechazo a la tradición indiana o colonial, cursa efectos aunque ello no fue radical; la herencia histórica no pudo borrarse del todo.

Finalmente, el Reglamento de 1812 representa un hito fundamental, puesto que contenía el germen de los principios políticos de las revoluciones atlánticas que en la práctica significaba la separación de Chile del ámbito de control del Imperio Español. Pero a su vez es un recordatorio de nuestro pasado jurídico colonial que fusionó los principios de construcción política nacional, lo que ha servido como un bloque en la construcción de la identidad jurídica nacional ${ }^{688}$.

${ }^{688}$ GARCÍA-HUidobro (2012) Pp. 239-243. 
A nuestro juicio, sin lugar a dudas el cuerpo constitucional más destacable durante la Patria Vieja fue el "Reglamento Constitucional de 1814", promulgado el 17 de marzo del mismo año, mediante el cual se consagraron una serie de modificaciones que definieron el sistema político chileno y que tendrán una larga duración en nuestra organización estatal; esencialmente, se introducen dos factores determinantes para nuestra materia de estudio.

Cabe destacar que la situación nacional era compleja, por tanto, el presente Reglamento fue sancionado bajo circunstancias de excepción: las fuerzas patriotas habían experimentados serios reveses y la capital estaba abierta a tropas enemigas. En tal escenario, el corregidor don Antonio José Irisarri solicitará al Cabildo de Santiago crear con urgencia un Gobierno fuerte y enérgico, otorgando mayores poderes a un ejecutivo unipersonal ${ }^{689}$.

El Reglamento de 1814 depositó el poder Ejecutivo en un órgano unipersonal denominado Director Supremo, delegándole las absolutas facultades de la Junta de Gobierno y, conjuntamente, le otorgó nuevas y amplias atribuciones. Por otra parte, estableció en sus artículos 5 y 8 la posibilidad de que aquel Director Supremo quedara sujeto al juicio de residencia ${ }^{690}$. La razón de aquellas innovaciones políticas se debió a los difíciles momentos políticos que experimentaba Chile. Las tropas absolutistas se encontraban próximas a la capital y con ello reviven las pretensiones de restablecer el Antiguo Régimen. Es por ello que surge la imperiosa necesidad de dejar de lado los gobiernos colegiados y establecer un sistema que Dougnac define como cercano a la dictadura romana ${ }^{691}$.

Las atribuciones que se entregan al Director Supremo era el poder que había recaído en la Primera Junta Nacional de Gobierno. En este sentido lo describe Roldán, cuando expresa que las facultades eran "amplísimas e ilimitadas, podía adoptar toda especie de medidas" ${ }^{\prime 692}$. En nuestra opinión, serán los primeros rasgos de un futuro presidencialismo reforzado, régimen que marcará el desarrollo político chileno.

A mayor abundamiento, y en relación con el control del poder en el Reglamento del año 1814, citaremos el contenido de dos preceptos constitucionales. En este sentido, el artículo 5 del Reglamento establecía que el cargo de Director Supremo

\footnotetext{
${ }^{689}$ Pfeffer (1987) p. 53.

690 CAMPOS (1977) p. 333.

${ }^{691}$ DOUGNAC (2000) p.259.

692 ROLDÁN (1924) p.66.
} 
duraba dieciocho meses y una vez concluido aquel mandato la Municipalidad unida al Senado determinarán su continuidad o no en el cargo. Por su parte, el artículo 8 señalaba: "Concluido el término de su gobierno, quedará sujeto a residencia, y el juez de ella será elegido por el Congreso, si está convocado o próximo a convocarse, $y$ de no por las Corporaciones" ${ }^{\prime 693}$. Tales preceptos constitucionales, finalmente, establecen algunos factores de interés: el primero es la circunstancia de someter a residencia al Director Supremo, como máxima autoridad nacional y quien lidera al Ejecutivo; un segundo aspecto es el hecho de que si bien quien llevará el proceso es un juez, aquel será designado por el Congreso, entonces son los representantes del pueblo quienes definen el nombre del juez que analizará la gestión del Ejecutivo.

Por tanto, respecto de los textos constitucionales de la Patria Vieja -en opinión de Roldán- no fue posible dictar códigos políticos que organizaran de modo completo los poderes públicos, sino que fueron simples bosquejos constitucionales, lo cual se explica teniendo en cuenta la situación que atravesaba Chile iniciando una guerra con la Península. Por tanto, la atención y preocupación del Gobierno estaba centrada en tales circunstancias y en las faltas de orientación que se produjo entre los patriotas ${ }^{694}$. Sin perjuicio de aquello, es posible percibir que existió una intencionalidad de control del poder e incluso de reparar los daños provocados. Aquel control fue intraórganos, toda vez que como rasgo general de la fiscalización, cabe destacar que ella provenía desde el poder Legislativo hacia el Ejecutivo, puesto que siempre estuvo bajo residencia aquel o aquellas personas que formaban parte del Ejecutivo y sus controlantes estaban en el Congreso. Ahora bien, la arquitectura del Estado y la construcción de los poderes del mismo eran incipientes y difusas, por ende, nuestra percepción dice relación con plantear la existencia de la noción de control entre los mismos poderes a fin de evitar abusos. Indisputablemente, hay rasgos de limitación y equilibrio, sin perjuicio de que ella fuera más bien jurídica que política. Desde esta perspectiva, es posible concluir que en este momento del constitucionalismo la tradición hispanoindiana y sus instituciones jurídicas fueron los mecanismos que los pesadores políticos tuvieron en vista al momento de limitar las arbitrariedades del poder; sin embargo, es posible también detectar influjos de la división de poderes provenientes de otras tradiciones jurídicas, pero que a lo menos en esta época no repercutieron con mayor fuerza.

693 Texto disponible página web: www.bcn.cl, visitada da con fecha 24/09/2015. Link: file:///C:/Documents\%20and\%20Settings/Doctorado-15/Mis\%20documentos/Downloads/download.pdf

${ }^{694}$ ROLDÁn (1924) p. 62. 


\section{b.2. La Patria Nueva y la Independencia de Chile}

La Patria Nueva fue aquel período de la historia de Chile comprendido entre 1817 y 1823, marcado por el triunfo del Ejército Libertador que estaba compuesto por los patriotas en la Batalla de Chacabuco. El presente período nacional fue tan o más complejo que el experimentado durante la Patria Vieja; la severa represión política española por recuperar su poder en las colonias promovió la adopción de una actitud creciente de resentimiento de criollo, el que aumentó abundantemente las filas de los adeptos a la independencia. Por su parte, los cabecillas patriotas estaban más decididos que nunca en continuar la lucha independentista hasta las últimas consecuencias. El año más significativo fue 1816, oportunidad en la que se reanudan las carreras por alcanzar la libertad de la mano de Simón Bolívar y José de San Martín, quienes ponen en práctica una grandiosa estrategia.

Aquel movimiento contemplaba necesariamente involucrar a Chile, puesto que el objetivo final era despojar a los españoles del Virreinato del Perú, asegurándose una base firme en nuestro país. El diseño estratégico de Bolívar y San Martín encuentra eco inmediato en Chile; gracias a la actitud excesivamente represiva del Gobernador de Santiago -don Casimiro Marcó del Pont- figuras legendarias como Manuel Rodríguez y Miguel Neira asumen la resistencia guerrillera en defensa del pueblo. No obstante, la firmeza de estos revolucionarios no producían efectos de largo plazo que pusiera punto final a los abusos del Gobierno.

Por su parte, en Argentina O 'Higgins y San Martín habían consolidado una íntima amistad, relación de la cual nacen planes de liberación más duraderos en el tiempo. En aquella planificación se toma la decisión de que una vez liberado el Gobierno de Chile debía ser confiado en manos de O'Higgins. A comienzos del año 1817 el Ejército de Los Andes abandona Mendoza, cruza la cordillera en dirección a Chile y vence a los realistas en la Batalla de Chacabuco el 12 de febrero. En virtud de aquel triunfo, ingresan a Santiago San Martín junto con O'Higgins, oportunidad en que una asamblea de notables le ofrece el Gobierno al argentino quien declina de aquella oferta y la asume O'Higgins sin vacilaciones ${ }^{695}$.

En consecuencia, con posterioridad a aquel triunfo asumirá el Gobierno don Bernardo O'Higgins Riquelme durante seis años, caracterizado por un estilo militar y personalista, período que finalizará con la abdicación del mismo general. Obtenida

${ }^{695}$ COLLIER (1977) Pp. 213 y 214. 
parcialmente la anhelada independencia, era necesario gobernar en medio de cohesión social pero ello no estaba tan claro. La designación de O 'Higgins no dejó a todos contentos, puesto que aún existían algunos carrerinos que le ofrecerían una fuerte oposición. Por tanto, en opinión de Infante, no existía identidad nacional; tampoco había claridad respecto de la forma de gobierno que mejor se adaptaría a Chile, todo producto del cambio de mentalidad ocurrido en la población fruto de la dureza del régimen colonial impuesto durante la Reconquista y de la maduración de las ideas políticas planteadas en la Patria Vieja. Durante este período, el debate se concentrará entre los independentistas liberales y los que abogan por la participación democrática (Infante y Rodríguez) y aquellos que estaban a favor de una línea más conservadora (O 'Higgins, Egaña y Portales) ${ }^{696}$.

Durante la Patria Nueva, y hasta el año 1830, varios fueron los gobiernos que intentaron otorgar un texto constitucional más estable que regulara la vida social y política de Chile. De allí surgirán las Constituciones y ensayos de los años 1818, 1822, 1823, 1826 y, finalmente, la Carta Fundamental más duradera, la Constitución de 1828. Para autores como Bernardino Bravo Lira, sólo a partir de la Carta de 1818 existe una secuencia continuada que permite hablar en propiedad de constitucionalismo. Según este autor., la lucha por establecer un Estado constitucional en Chile comienza verdaderamente luego de 1818, tras una costosa guerra civil que desembocó en la Declaración de Independencia del 12 de febrero ${ }^{697}$. Con todo, en opinión de Roldán, este segundo período de la historia nacional se caracterizó por una gran inestabilidad política, que es el resultado de aquel cambio brusco en las instituciones nacionales. Así, la organización del país se verá fuertemente modificada; hasta el momento se había basado en la autoridad absoluta del monarca español y ahora iba a reposar sobre el ejercicio de la soberanía nacional ${ }^{698}$.

Después de la Batalla de Chacabuco se pone fin a la dominación española en el norte y centro de Chile. Durante la Patria Vieja el centro de la política nacional buscó reflexionar sobre la relación con España; en la Patria Nueva existía plena convicción en la independencia total. Con fecha 17 de febrero de 1817, mediante un Cabildo Abierto, fue elegido como Director Supremo don Bernardo O'Higgins, quien en el mes de noviembre convoca a plebiscito la Declaración de Independencia del país,

\footnotetext{
696 INFANTE (2014) Pp. 158 y 159.

697 BRAVO (1992-1993) p.306.

698 ROLDÁN (1924) p. 68.
} 
puesto que si bien ella estaba declarada de hecho, a juicio del Director Supremo era menester darle solemnidad y publicidad para efectos internacionales. De esta manera, se lleva a efecto la consulta bajo el control de las municipalidades en todo el territorio sometido a las armas patriotas, el cual consistió en firmar en uno de los dos libros en blanco disponibles a favor o en contra de la declaración. Todo el pueblo -incluyendo mujeres- firmaron a favor de la declaración emancipadora. Finalmente, el 2 de febrero de 1818 se firma en Talca el Acta de Declaración, pero el 12 de febrero fue proclamada y jurada en todos los pueblos la independencia, para el primer aniversario de Chacabuco ${ }^{699}$.

El 17 de abril del mismo año el Cabildo Abierto reunido en Santiago le solicita al Director Supremo que se adopten medidas de orden que estableciera una organización política que estuviera conforme con un régimen representativo; O'Higgins accede a lo solicitado y dicta el 18 de mayo un decreto a través del cual nombra una Comisión redactora de un estatuto fundamental, presidida por don Manuel de Salas, La Comisión elabora un proyecto el mismo año, el que es presentado en el mes de agosto. Una vez finalizado aquel propósito, fue realizado un referéndum convocado por el Director Supremo mediante un reglamento ${ }^{700}$. De acuerdo a dicho reglamento, se debía abrir en todas las parroquias del país dos libros, una para firmas favorables y otro para las adversas. Al verificar los resultados, los libros favorables estaban completamente firmados y los libros en contra constaban vacíos. A juicio de Pfeffer, el Reglamento constitucional de $\mathbf{1 8 1 8}$ puede ser considerado el primer estatuto fundamental de Chile $e^{701}$.

Aquel texto declaraba el principio de soberanía nacional, mediante el cual era posible instalar nuestro propio gobierno y dictar las leyes que nos han de regir. Por otra parte, reconoce el principio de separación de poderes. En aquel documento el Ejecutivo estaba delegado en un Director Supremo con amplias facultades y el Legislativo estaba compuesto por un Senado junto con cinco vocales designados por el mismo Director Supremo. A pesar de su carácter provisorio, tal texto político tuvo una vigencia de cuatro años (casi todo el gobierno de Bernardo O `Higgins).

\footnotetext{
699 PfEFFER (1987) Pp. 53 y 54.

700 CARRASCO (1983) p. 27 y 28.

701 Pfeffer (1987) p. 55.
} 
En lo que a nosotros respecta, y en cuanto al control del poder, es posible señalar que la Constitución provisoria de 1818 fue la primera en establecer la residencia con carácter general, aplicable a todos los funcionarios públicos que terminasen el ejercicio de sus funciones. En el Capítulo III del presente texto constitucional se designaban las atribuciones del Senado dentro de las cuales le encomendaba la observancia de la Constitución, como también el deber de reclamar aquellas infracciones a la Constitución provenientes de ciudadanos o algún cuerpo directamente al Director Supremo. En dicho sentido, es también el Senado quien debe de conformidad al artículo 9.0 designar la comisión que deberá estar a cargo del juicio de residencia. El tenor de aquel artículo es el siguiente: "deberá nombrar una comisión, compuesta de unos de sus vocales y dos individuos del Tribunal de Apelaciones, para que con toda integridad a la brevedad posible, tomen residencia a todos los empleados del Estado, que por delito o sin él terminan las carreras de sus funciones políticas"

Ahora bien, a pesar de que la descripción teórica del Código Político contemplaba una residencia general y le otorgaba al Senado un rol de garante del contenido de la misma, la verdadera situación fue que durante la vigencia de la Carta del dieciocho el Ejecutivo gozaba de amplios poderes y el Senado de facultades muy limitadas. Respecto de la condición jurídica de los ciudadanos, si bien establecía una serie de derechos y deberes en el Título I, en la práctica aquel catálogo de derechos y garantías individuales no logró poner atajo a los atentados del gobierno contra las personas. Aquellos excesos e ilegalidades del gobierno tenían un costo inevitable y la situación se tornó cada vez más insostenible ${ }^{703}$.

Estando el Reglamento de 1818 en plena vigencia durante tres años, comenzaron a vislumbrase por parte del pueblo alguna incomodidades con el mismo. Durante los años siguientes a 1820, Chile experimenta un proceso de aislamiento; estaba preocupado por consolidar el sistema democrático y resolver sus problemas. Sólo cuando ingresa a la arena política Diego Portales volverá a tener presencia internacional y saldrá de su recogimiento político en virtud de la Conferencia PerúBoliviana. Durante estos años se iniciarán nuevas transformaciones, particularmente, luego de la abdicación de O 'Higgins el 28 de enero de 1823. En las siguientes líneas analizaremos el desenlace histórico y jurídico de aquellos años.

\footnotetext{
702 http://www.leychile.cl/Navegar?idNorma $=1005251$

703 BRAVo (1992-1993) Pp. 312 y 313.
} 
En virtud de aquellos cuestionamientos a la Constitución, el Director Supremo don Bernardo O'Higgins- plantea la posibilidad de reformar el texto constitucional. Para ello, con fecha 7 de mayo de 1822, mediante un decreto propone convocar a una Convención Preparatoria. La elección de los miembros se produce casi en el acto y ella entra en funcionamiento el 23 de julio del mismo año. Inicialmente, tal Convención debía convocar a una Corte de Representantes, la que tendría por función redactar el proyecto, pero ello nunca ocurrió. Finalmente, $\mathrm{O}$ 'Higgins opta por declarar a la Convención como el poder constituyente, con fecha 28 de septiembre del mismo año. El proyecto de Constitución fue redactado por el ministro de Hacienda y Guerra don José Antonio Rodríguez Aldea. El texto fue discutido de forma precipitada por la Convención y terminó siendo aprobado el 23 de octubre de $\mathbf{1 8 2 2}$.

Aquel texto recibirá directa influencia de la Constitución española de Cádiz del año 1812 y será considerado por autores como Pfeffer como el documento más significativo para el Derecho Público, porque no sólo se reconocen con singular explicitud todos los principios del constitucionalismo, sino que además -de forma muy particular- exterioriza la necesidad de vincular al texto constitucional con los factores sociales económicos y culturales del medio en el que este estatuto va a regir $^{704}$.

Dicho documento declaraba que la soberanía residía en la nación y contemplaba en su Título I artículo 12 que el Gobierno de Chile sería siempre representativo compuesto de tres poderes independientes: Legislativo, Ejecutivo y Judicial; reconoció como órgano constitucional al Congreso y estableció que el Ejecutivo fuera ejercido por un Director Supremo ${ }^{705}$. A pesar de reflejar el pensamiento de la época y los anhelos republicanos, no tuvo una gran vigencia.

En cuanto al contenido del Código Político, hemos de detectar dos elementos de relevancia en relación con nuestro análisis relativo a determinar la forma en que el constitucionalismo chileno fue limitando el uso abusivo del poder. Un primer elemento de gran relevancia para nuestra investigación es la consagración constitucional de la división de poderes como una institución efectiva en la organización política del Estado ${ }^{706}$; con ello podemos ir vislumbrando cómo la noción

\footnotetext{
704 Pfeffer (1987) Pp. 57 y 58.

705 RUIZ-TAGLE (2006) p. 87.

706 AMUNATEGUi (1947) p.177.
} 
de equilibrio entre poderes, de pesos y contrapesos, irá lentamente penetrando en el constitucionalismo nacional.

Como bien destaca Campos, el gobierno en la Carta de 1822 se declara explícitamente organizado bajo un régimen representativo dividido en tres poderes independientes, Ejecutivo, Legislativo y Judicial ${ }^{707}$. Por otra parte, el Código Político contenía una serie de preceptos muy particulares, básicamente por su ambigüedad. Precisamente el artículo $47 \mathrm{~N}^{\circ} 17$ contemplaba como facultad del Congreso la de "Hacer efectiva la responsabilidad de los funcionarios públicos". El artículo 128 contemplaba la responsabilidad de los Ministros de Estado respecto de las providencias, órdenes y decretos que suscriben y en el caso de obrar conjuntamente con otras autoridades cuando actúa arbitrariamente. Mayor atención merece el artículo 131, toda vez que regulaba una especial acusación constitucional contra ministros. Rezaba el precepto: "Para hacer efectiva la responsabilidad de los Ministros, puesta la acusación, declarará la Cámara de Diputados, si hay o no lugar a la formación de causa; y declarado por la afirmativa, quedará suspenso el Ministro hasta su conclusión, y se pasarán los antecedentes a la Cámara del Senado, que debe conocer y sentenciar según su conciencia, ejerciendo un poder racional y de discreción".

No obstante, la Carta del veintidós igualmente en el artículo 166 5.a entregaba a los tribunales de justicia la atribución de conocer de las residencias respecto de quienes deban darlas. Por ende, mantiene el concepto de residencia general y establece que los juicios de residencia serán conocidos por los tribunales de justicia. Por tal motivo, y de conformidad a lo antes expuesto, Bronfman señala que la presente Constitución tuvo una dualidad de fuentes: la Constitución norteamericana y la de Cádiz. Por tal motivo, se crea una especie de juicio político contra los Ministros de Estado y se mantiene la residencia dentro de las facultades del Tribunal Supremo de Justicia. En el presente texto no se explicitaban las causales de acusación, por lo que para este autor la regulación constitucional patria todavía se encontraba distante del modelo norteamericano ${ }^{708}$.

Desde nuestra perspectiva, la Ley Fundamental del veintidós se caracterizó por su excesiva ambigüedad en materia de control del poder. Si bien contemplaba la residencia y una particular acusación constitucional contra los ministros, ello no

\footnotetext{
707 CAMPOS (1977) p. 342.

708 BRONFMAN (2005) p. 101.
} 
profundizó en ninguno de estos mecanismo. Es por ello que no se establecieron procedimientos ni causales; por consiguiente, no contribuyó en el perfeccionamiento del sistema de controles. No obstante, es preciso resaltar la incorporación de la acusación como institución vinculada al control político y a la determinación de responsabilidad política.

Con todo, cabe hacer presente que -a juicio de García-Huidobro- de los textos constitucionales hasta el momento analizados, los más significativos son las Constituciones de 1818 y la de 1822, puesto que ellas fueron las que reflejaron de manera más nítida el espíritu doctrinario de los revolucionarios independentistas. Libertad, igualdad, propiedad, responsabilidad y seguridad fueron los principios que en términos generales movieron todo el proceso revolucionario de América Latina y que se contemplan en dichos textos. Principalmente, la consagración de derechos políticos clásicos que se plasmaron con mucha fuerza en la mayoría de las cartas de siglo XIX ${ }^{709}$.

La Constitución del año 1823, conocida como la Constitución "moralista", se caracterizó por declarar los derechos fundamentes y sus garantías. Sin embargo, su excesiva reglamentación respecto de los procedimientos legislativos y la reglamentación de la vida privada no le permitieron tener una gran vigencia. Tal era su particularidad que Amunategui la define como "confusa e impracticable", cuyo mayor desacierto fue haber pretendido modificar la idiosincrasia del pueblo chileno $^{710}$. Pero, a pesar de aquellas debilidades, fue la primera Carta Fundamental sancionada por la soberanía popular. El texto tenía como esencial finalidad alcanzar la anhelada estabilidad política y reemplazar los gobiernos dictatoriales que hasta la fecha imperaban. Fue obra de un Congreso constituyente, quien delegó la labor de redactar la propuesta en una Comisión redactora. Contrariamente con lo esperado y a pesar de que aquella Comisión estaba compuesta por seis miembros, su redacción fue obra exclusiva de don Juan Egaña, quien fuera una figura principal de la Ilustración en Chile.

Tal fue la tendencia reglamentarista de los espacios privados por parte de la Carta del veintitrés, que otorgaba dentro de las funciones más importantes del Senado el deber de velar por la moralidad nacional, motivo por el cual resultó

\footnotetext{
709 GARCÍA-HUIDOBRo (2010) p. 401.

${ }^{710}$ AMUNTAGUi (1947) p.179.
} 
impracticable, aumentando el desorden y la anarquía ${ }^{711}$. Como bien nos explica Bravo Lira, esta Constitución tuvo una finalidad ingenua porque pretendió establecer a través de las leyes una formación ciudadana de virtud y hábitos cívicos, es por ello que fue calificada como excesivamente reglista y moralizante ${ }^{712}$. En este sentido, resulta pertinente señalar a modo de ejemplo que el Título XXII llevaba por nombre "Moralidad Nacional", el cual encomendaba la redacción de un código moral que regularía la conducta de los ciudadanos en determinadas épocas de la vida social, formando hábitos, deberes, ritualidades, entre otros. Dichas características mermaron su eficacia y sólo rigió unos pocos meses.

En lo concerniente a nuestra materia de investigación, la Carta de 1823 presentaba una fisionomía particular y contemplaba una serie de normas faltas de coherencia que pretendían de algún modo establecer límites al poder. Respecto de su contenido, es posible señalar que el Título VI -que regulaba el Senado- establecía que este órgano, compuesto por nueve miembros elegidos constitucionalmente con una duración en el cargo de seis años, poseía dentro de sus atribuciones de conformidad al artículo 38 N01: "Cuidar de la observancia de las leyes y del exacto desempeño de los funcionarios". En virtud del mismo artículo 38 N03, era posible "Suspender momentáneamente los actos ejecutivos del Directorio en que reconozca una grave y peligrosa resulta, o violación de las leyes". Así, se contemplaba una especie de fiscalización parlamentaria de orden político al Ejecutivo, tendiente a evitar la trasgresión del Estado de derecho que se intentaba instaurar en la reciente República.

Sin perjuicio de aquello, con la Carta del veintitrés se produce un fenómeno de mayor confusión respecto de las instituciones y la pluralidad de mecanismos de control, toda vez que, por una parte, mientras se gestaba un espíritu tendiente a fortalecer los equilibrios y controles entre poderes, por otro lado, se consagraban normas imprecisas y dispersas. En efecto, del análisis del texto es posible indicar una sucesión de normas que contemplaban diversas formas de control. A modo de ejemplo, el artículo 20 estipulaba que una vez concluido el mandato del Director Supremo, pasará al Senado una memoria de todas las gestiones de su administración para anotar en ellas reparos y observaciones, a fin de proceder a una evaluación que definirá el otorgamiento o el rechazo de la calidad de benemérito y el

${ }^{711}$ CAMPOS (1977) p. 347.

712 BRAVO (1992-1993) p. 315. 
grado del mismo. Por tanto, para concederle tal estimación, homenaje o agradecimiento, era analizada políticamente su gestión. En consecuencia, había un examen de sus acciones la que producía un efecto positivo o negativo, situación similar a la que se puede realizar mediante otros mecanismos de control.

En lo relativo a los Ministros de Estado y respecto de la residencia, el presente texto constitucional en su Título IV establecía dos normas de trascendencia: la primera, el artículo 22 que rezaba: "Cada Ministro responde personalmente de los actos que ha suscrito; e in solidum de los que acordaren en común" y, la segunda, el artículo 25 que estipulaba que: "Concluido su ministerio, no puede ausentarse del país un Ministro hasta cuatro meses después". El artículo 26 señalaba "Para hacer efectiva la responsabilidad de un Ministro actual, declara el Senado si ha lugar a la formación de causa, juzgándole después la Corte Suprema de Justicia bajo principios de prudencia y discreción, sobre lo puramente ministerial". Para Martínez estos preceptos constitucionales establecían un plazo de residencia, y además configuraban el modelo que posteriormente se seguiría en las siguientes Leyes Fundamentales $^{713}$. Empero, estas normas regulaban la residencia y la acusación constitucional de forma separada, es por ello que Bronfman dirá que si bien la Constitución contemplaba la residencia a cargo de un Tribunal que nombrase el Congreso Nacional, establecía procedimientos especiales de remoción para el Presidente y los ministros. Pero tampoco contempló en detalle las causales de acusación ${ }^{714}$.

Para nosotros estos preceptos están consagrando las primeras manifestaciones de la responsabilidad política de los ministros, mas no un juicio de residencia. Si bien es cierto que el artículo 25 establecía un plazo de permanencia en el país donde se ejerció el cargo, está lejos de configurar la residencia tal como la hemos visto en los textos políticos anteriores. Por tal motivo, Zúñiga sostiene que en la "insubsistente" Constitución del veintitrés se contemplaba una responsabilidad ministerial a través de la cual le correspondía al Senado juzgar si había o no lugar la formación de causas en su contra y el juzgamiento ante la Corte Suprema ${ }^{715}$.

Con todo, el artículo 26 precisamente resuelve aquella situación en este sentido; lo que se instaura en la Constitución del veintitrés es un sistema de responsabilidad

\footnotetext{
713 MARTÍNEZ (1965) p.182.

714 BRONFMAN (2005) p. 101.

715 ZÚÑIGA (1993) p. 713.
} 
política que estará compuesta por dos etapas, una sede política que analiza el Senado y otra estrictamente jurídica. A nuestro juicio, Martínez confunde dos instituciones distintas: la residencia y el establecimiento de las iniciales expresiones de responsabilidad ministerial. Básicamente, sostenemos esto porque para Martínez el artículo 25 sólo se aplicaba en el caso de que el ministro estuviera en ejercicio del cargo $^{716}$, lo cual creemos que no es correcto. En armonía con nuestra interpretación, podemos traer a colación las palabras de Bernardino Bravo Lira, quien señala que las normas constitucionales antes citadas le imponían como principal papel al Senado el de fiscalizar ${ }^{717}$.

Esencialmente, sustentamos nuestro análisis en virtud del articulado constitucional, toda vez que en el Título XIII relativo a la Suprema Corte de Justicia, regulando sus atribuciones en su artículo 146 No 6.a establecía el conocimiento: "En las residencias de todo jefe de administración general o gobierno departamental". Por ende, la residencia estaba regulada de manera autónoma en el título relativo al Poder Judicial, aplicable solamente a jefes de la administración general o de gobierno. Sostenemos, además, que aquella ubicación guardaba relación con su naturaleza, en atención a que la residencia era un juicio netamente jurídico de las conductas del funcionario público. No obstante, para Sergio Martínez el problema no se encuentra allí sino que en el Título XXI "De la hacienda pública", que confundió la cuenta indiana con la residencia, error que -a juicio del autor- se repetirá en la Constitución de 1828.

Los escollos de la Constitución de $\mathbf{1 8 2 3}$ fueron múltiples. La República quedaría regida por las reglas que la costumbre tenía consagradas. Una situación de estas características no podía continuar, dada las exigencias del desarrollo político nacional. En medio de este desconcierto comenzaron a emerger las voces que propondrían una modificación en el régimen unitario en orden de avanzar hacia un régimen federal, atendida las particulares circunstancias geográficas nacionales. En este contexto, de la mano de José Miguel Infante, se impulsan las ideas federales y el país es divido en ocho provincias; cada una de ellas tenía derecho a elegir una Asamblea encargada de atender los intereses particulares. A modo de establecer el nuevo sistema de un modo definitivo y legal, en el año 1826 se aprueba por el Congreso una ley según la cual Chile se constituía en un régimen federal,

\footnotetext{
716 MARTÍNEZ (1965) p. 183.

717 BRAVO (1992-1993) p. 316.
} 
oportunidad en la que se acuerda que posteriormente se ha de preparar una Constitución que confirmaría las bases de este régimen. En este escenario, surgirán dos tendencias: las que están a favor del régimen y las que están por un régimen unitario. Las regiones recibieron con júbilo estas decisiones y procedieron a organizarse, pero el ejercicio de las facultades federales era un mecanismo respecto del cual los pueblos no estaban acostumbrados, es por ello que sólo produjo agitación política en todas ellas y trajo muy pronto un desgobierno completo ${ }^{718}$.

Continuando con la evolución constitucional del control del poder en el derecho patrio, cabe analizar un particular proyecto de Ley Fundamental desarrollado el año 1826, el que fuera fuertemente influenciado por el federalismo. Impulsado principalmente por don José Manuel Infante, pretendía promover el sistema federal, básicamente en virtud de la influencia y el éxito político de los Estados Unidos durante aquellos años. Sin embargo, la intención federalista no tuvo resultados positivos en Chile porque las provincias no contaban con los recursos suficientes para llevar a cabo un modelo de este tipo. Como bien describe Amunategui, esta ley no pasó de ser una mera tentativa que fracasó en el acto porque si un solo gobierno no fue capaz de alcanzar la tranquilidad y unidad nacional, menos lo podrían lograr ocho provincias con gobiernos distintos ${ }^{719}$. De hecho, sólo fueron aprobadas algunas leyes que pretendían imponer tal modelo. Más tarde se elaboró un proyecto constitucional, pero desafortunadamente sólo alcanzaron a despacharse algunos artículos, toda vez que el 20 de junio del año 1827 se auto-disuelve el Congreso y su tramitación quedó suspendida. El fracaso de la Constitución de Egaña, en palabras de Eyzaguirre, empujó a la mayoría de los espíritus nacionales hacia el federalismo, encontrando un ferviente paladín en José Miguel Infante, a quien el autor lo describe como un hombre "de espíritu iluso, enamorado ciego de la libertad, a la que sólo veía asegurada en un régimen federal que redujera el mínimo poder el poder del Estado y acentuara la independencia de las provincias y los derechos de los ciudadanos ${ }^{\prime 720}$.

En lo que a nosotros respecta, cabe destacar que el presente Proyecto contenía diversas normas de gran importancia. Si bien no alcanzó a entrar en vigor, instauraba expresamente tres instituciones relevantes para el control del poder y especialmente para el control parlamentario: por un lado, pretendía consagrar la división de poderes como un principio constitucional; por otro, instituía la

\footnotetext{
718 ROLDÁN (1924) Pp. 77-79.

719 AMUNTAGUi (1947) p.183.

720 EYZAGUIRRE (1954) p.85.
} 
responsabilidad política y administrativa de los ministros, contemplando derechamente la acusación constitucional aplicable a ministros, al vice-presidente, a secretarios del despacho y jefes de provincia; y por último, contempla la residencia. Por consiguiente, a pesar de su inaplicabilidad, aquel Proyecto detallaba en profundidad instituciones propias del control parlamentario y las regulaba de manera autónoma a cada una de ellas. A continuación, expondremos aquellos preceptos del Proyecto de Constitución Federal que contemplaban las instituciones antes descritas, a fin de poder analizar el espíritu del constituyente respecto del control del poder y del control parlamentario, en particular, siguiendo coherentemente la historia fidedigna en esta materia.

Primeramente, es necesario traer a colación el Capítulo 3 "De la forma de gobierno y de la división de poderes", en especial su artículo 11 porque aquella norma contenía la división de poderes, expresando que cada poder debía actuar separadamente sin que en ningún caso pudieran reunirse; además de declarar a Chile como una república representativa y lógicamente federal.

En segundo lugar, analizaremos con especial énfasis el Capítulo 5 relativo a la "Cámara del Senado", toda vez que aquel capítulo contemplaba la acusación constitucional contra el Presidente de la República. Así, el artículo 34 señalaba que "Cualquiera de las Cámaras á petición de parte, ó á reclamación de uno de sus miembros podrá conocer en calidad de gran jurado sobre las acusaciones contra el Presidente de la República.- $10^{\circ}$ Si atentase contra la Independencia Nacional y la forma establecida de Gobierno.-2. ${ }^{\circ}$ Por cohecho, soborno activo ó pasivo durante el tiempo de su empleo- 3. ${ }^{\circ}$ Por impedir directa ó iindirectamente la elección de Presidente, Senadores, y Representantes, o su reunión en las épocas designadas por la ley, o el uso de las facultades que ella concede á una y otra Cámara". Como es posible percibir, ya en el año 1826 se instauraba la acusación constitucional, resguardando su origen y finalidad, es decir, reconociéndola como un mecanismo de origen parlamentario porque era depositada en manos de las mismas cámaras que configuran al Congreso; vale decir, el órgano deliberante era el poder legislativo. Por otro lado, la correcta comprensión de aquella institución permitió que su ámbito de aplicación abarcara situaciones más bien políticas, como las contempladas en el numeral uno y tres, y otras de corte más jurídico que comprendían la posibilidad de que quien liderara el Ejecutivo fuera acusado de determinados delitos. 
El frustrado texto constitucional del veintiséis estaba esmerado en regular detalladamente la acusación constitucional. En efecto, el Capítulo $8^{\circ}$ relativo a "Privilegios y facultades del Ejecutivo Nacional" era el espacio donde se profundizaba la regulación de la acusación y se establecía el órgano competente para llevarla a cabo. También señalaba los plazos en el que era posible realizarla, elemento que habría introducido una diferencia sustantiva, toda vez que se permitía acusar al Presidente mientras se encontraba en pleno ejercicio de sus funciones. En este sentido, el artículo 78 exponía que: "El Presidente no podrá ser acusado durante el tiempo de su Gobierno sino ante alguna de las Cámaras, y por los delitos indicados en el art. 34 capitulo 5. ' Esta acusación podrá hacerse en el tiempo de su Gobierno, ó en un año después"; y en el artículo 79 disponía: "Pasado este año que es el término designado á su residencia, ya nadie podrá acusarle por delito alguno cometido durante el periodo de su gobierno".

Adicionalmente, el artículo 35 reconocía la misma facultad anterior de acusación por parte de las Cámaras respecto de los miembros de la Suprema Corte de Justicia, Secretarios del despacho y también los jefes de provincia, en el caso de que contravinieran la Constitución. La extensión de la acusación pretendía ser de tal magnitud, que el precepto constitucional 36 contemplaba la posibilidad de que la acusación también fuera aplicable al Vice-presidente de la nación. Disponía que "Cuando el Presidente ó sus Ministros fueren acusados por actos en que haya intervenido el Senado ó Consejo de Gobierno, solo á la Cámara de Representantes pertenece la facultad de gran jurado. También la ejercerá en los casos de acusación contra el Vice-Presidente, por cualquiera delitos cometidos durante el periodo de su destino".

Sin embargo, a pesar de tratar detenidamente la acusación constitucional, aún persistía la existencia del juicio de residencia. Si examinamos el Capítulo 4 relativo al "Poder Legislativo", en su sección 3a "De las atribuciones del Congreso Nacional" se contemplaba en el artículo 43 no 20 la posibilidad de la cual gozaba el Congreso Nacional de dictar leyes que permitieran decretar juicios de residencia respecto de funcionarios públicos. El tenor literal de la norma señalaba que: "Decretar necesariamente el juicio de residencia á todos los funcionarios públicos que hayan concluido sus destinos, ó dejadolos por reuncia, remocion, ó cualesquiera otros motivos, y señalar por una ley especial la forma de residenciarlos en cada bienio". Por tanto, cabe entonces señalar que en esta materia el constituyente intentó regular 
de manera diferenciada la acusación constitucional y el juicio de residencia, a pesar de que en algunos preceptos se hizo referencia a determinados plazos de residencia. Esta conjetura la sustentamos en el razonamiento que implica comprender que el propósito del constituyente era regular presupuestos jurídicos diversos, e incluso podría interpretarse que la acusación y la residencia eran aplicables a sujetos distintos. Nuestra interpretación es divergente respecto de lo sostenido por Martínez Baeza, para quien siempre se estaría en presencia solamente de la residencia, y aquellas normas fueron el precedente indiscutido de las normas contenidas en las siguientes Cartas Fundamentales ${ }^{721}$.

En tercer lugar, cabe hacer presente que este Proyecto contemplaba la responsabilidad de los Ministros de Estado. En esta dirección es posible destacar dos artículos: el artículo 96, que contemplaba la responsabilidad de cada ministro respecto de los decretos que suscribía y de todos los acuerden en común; luego, el artículo 100, que establecía la imposibilidad de salir del país dentro de un plazo de seis meses, período durante el cual estaba abierto un juicio de residencia. De existir acusaciones, según el artículo 101, les correspondía oírlas a la Cámara de Representantes quienes debían declarar si daba o no lugar a la formación de una causa. De ser afirmativa, la declaración los antecedentes eran derivados a la Corte de Justicia para ser juzgados de lo puramente ministerial.

Comenzando el año 1823, las dificultades del Gobierno de O'Higgins eran evidentes. Se produce su abdicación el 4 de abril del mismo año, oportunidad en la que fue elegido como Director Supremo Provisorio don Ramón Freire, designación que obtiene fruto de la fuerza con la cual dirigió la rebelión contra la dictadura de O'Higgins. No obstante, el General presentaba importantes credenciales militares, empero ellas fueron insuficientes para liderar la nación. Junto a lo anterior, se producen otros elementos que dificultaran la gestión de Freire; el estado de la economía chilena no era saludable, se produce un descenso en la producción y un aumento de los gastos fiscales; se agravó tal situación el crédito contratado en Londres, cuyos intereses eran sumamente altos. Este conjunto de elementos colocan al Gobierno de Freire en problemas serios. Es por ello que el 4 de mayo del año 1827 se produce la renuncia del Presidente General Ramón Freire y asume el mando el Vice-presidente, General Francisco Antonio Pinto.

721 MARTÍNEZ (1965) p.190. 
En ese momento Chile comenzaba a sufrir todos los efectos de una prolongada incertidumbre política; la confusión iba en aumento y la situación se complejizaba. El actuar del Congreso durante los años 1824 y 1829 era prácticamente incapaz de solucionar los problemas. Existía una fuerte frustración al verse imposibilitados de concretar las ideas liberales ${ }^{722}$ y federales por las que se había luchado, se experimentaban tiempos de efervescencia y de partidos políticos, fruto de lo cual la República experimenta lapsus prolongados de desorganización. Por otra parte, y desde una perspectiva positiva, cabe hacer presente que al mismo tiempo se desarrollaba profusamente la prensa nacional. En el año 1827 -cuando llega al Gobierno como presidente interino Francisco Antonio Pinto- el federalismo iba en retirada y la noción de una Constitución federal se diluye. No obstante, el presidente Pinto promoverá la redacción de un texto constitucional influenciado por don José Joaquín de Mora, un distinguido literato español y liberal, quien redactará un texto constitucional, a juicio de Collier, sobresaliente. Durante el mandato de Pinto, la realidad nacional se torna alentadora, se establece un equilibrio sensato entre federalismo y centralismo, el Gobierno fue esencialmente bien intencionado y conciliador, al punto de ser ampliamente admirado el presidente Pinto ${ }^{723}$.

El General Pinto convoca al pueblo para elegir un Congreso Constituyente el que fue designado a través de las elecciones de 1828. Por su parte, el Congreso acuerda delegar tal función en una Comisión de cinco personas, la que a su vez delegó tal función en el oficial mayor del Ministerio de Estado (Interior y Relaciones), don José Joaquín de Mora, quien redactó el texto en un mes, el que fue aprobado por la Comisión y el Congreso Constituyente. La Carta Fundamental fue promulgada el 8 de agosto de 1828. A juicio de Pfeffer, es un hecho indiscutible que los modelos tenidos en cuenta por José Joaquín de Mora para la redacción del proyecto fueron la Constitución de Estado Unidos de Norteamérica de 1787 y la Española de $1812^{724}$. Cabe hacer presente que don José Joaquín de Mora era de nacionalidad española.

\footnotetext{
722 Durante el período 1824 y 1829 se experimentaba fuertemente las formas liberales, representado por: pipiolos, federales y populares, quienes adoptaron las doctrinas comunes a las Revoluciones. Estas fuerzas políticas tenían plena conciencia de que la revolución emancipadora no se basaba solamente en un traspaso de poder político de los españoles a los chilenos. Sino que implicaba la libertad del individuo, sustentado en igualdad, libertad y felicidad. Su principal demanda fue reducir o limitar el poder del Ejecutivo.

723 COLLIER (1977) Pp.271, 272 y 273.

724 Pfeffer (1987) p. 61.
} 
Aquel proyecto fue escasamente modificado por el Congreso, obteniendo su aprobación y luego su promulgación el 8 de agosto del mismo año ${ }^{725}$. Sin embargo, a juicio de Amunategui, esta Carta Fundamental no tuvo el defecto de las anteriores (aprobación), pero la vaguedad de sus disposiciones dio margen a que los gobernantes desempeñaran actividades personalistas, aumentando en cierta manera la crisis social y política. En definitiva, fue una Constitución virtualmente impracticable que determinó la caída del Presidente y terminó por dar origen a la anarquía política ${ }^{726}$.

Nos corresponde proceder al examen de la Constitución que tuviera la mayor duración en el tiempo durante el período de la Patria Nueva. Nos referimos a la Carta de 1828, respecto de la cual es posible destacar que aquel texto presentó varias innovaciones políticas y jurídicas. Según Ruiz-Tagle, fue el primero en declarar a Chile como una República y en utilizar el concepto de Presidente de la República. Además, contiene un catálogo de derechos que enfatiza en la igualdad, la libertad y la propiedad, como también establecerá el derecho de petición y la facultad de publicar opiniones $y$, particularmente importante para nosotros es el establecimiento del procedimiento de acusación constitucional que profundizaba la concepción republicana de Chile y el principio de igualdad constitucional ${ }^{727}$.

El origen de esta Ley Fundamental surge una vez constituido el Congreso constituyente el 23 de febrero de 1828, oportunidad en la que el Ejecutivo mediante un mensaje firmado por el vice-presidente Pinto expresa la necesidad de elaborar un nuevo texto que reemplazará al del año $1823^{728}$. La tendencia política y doctrinal imperante al momento de dar nacimiento a la Carta de 1828 era el liberalismo, el que postulaba principalmente la limitación del Poder Ejecutivo. Consideraban que un Ejecutivo fuerte conducía automáticamente al despotismo y, desde esta perspectiva, el peligro latente era otorgar tantas prerrogativas al Presidente que pudiera configurarse demasiado poderoso. Por ende, un principio que estaba suficientemente claro en aquella época era la necesidad de que "todo poder tenga sus límites". Es por ello que al momento de ser promulgada la nueva Carta, el presidente Pinto esbozará

\footnotetext{
725 EYZAGUiRRe (1954) Pp. 88 y 89.

726 AMUNATEGUI (1947) p.186.

727 RUIZ-TAGLE (2006) p. 90.

728 CARRASCO (1983) p.47.
} 
su alegría por establecer en el texto constitucional las garantías necesarias contra el abuso del poder ${ }^{729}$.

En cuanto a su contenido, el texto político logró mantener la consagración constitucional de instituciones de vital importancia en la configuración del control parlamentario $y$, en general, respecto del control político. En dicha dirección es que fue contemplada de manera expresa la división de poderes. Tal fue la intencionalidad del constituyente que titula el Capítulo V como "De la división de poderes" y particularmente en el artículo 22 la consagra como tal. El cuerpo político que analizamos presentó otra característica de atención para nuestra investigación, puesto que reguló primeramente al Poder Legislativo y en el artículo inmediatamente siguiente se determinaba la configuración del Congreso Nacional a través de dos Cámaras, una de diputados y la otra de senadores.

Para Bernardino Bravo Lira, la circunstancia de que el constituyente haya situado con anterioridad la regulación del Poder Legislativo por sobre el posterior establecimiento del Poder Ejecutivo, configuraba una clara condicionalidad de los poderes presidenciales a la acción reguladora del Congreso. Por ello, según el autor, la Ley Fundamental del veintiocho contemplaba una doble limitación de la gestión gubernativa, realizada por las Cámaras y por las Asambleas provinciales ${ }^{730}$. Por consiguiente, es posible señalar que a raíz del presente texto se realiza un esfuerzo por equilibrar verdaderamente los poderes del Estado, modificando las condiciones hasta la fecha existentes, las que estaban en armonía con una cierta preponderancia del Ejecutivo en manos del Director Supremo. Aquella intencionalidad a la cual hacíamos referencia respecto de instaurar realmente la división de poderes, fue expresada en otros articulados, como por ejemplo en los referentes a las prohibiciones del Presidente. El artículo 85 numerando 3.0 le prohibía conocer causas judiciales bajo todo respecto, así como también el numerando 5.0 imponía la prohibición de impedir de forma alguna las sesiones de las Cámaras, como también el establecimiento de algunas barreras en su labor.

En este mismo tenor, pero más expresamente direccionado hacia limitar el poder del Ejecutivo de manera permanente, se estipuló en esta Constitución la creación de un organismo denominado Comisión Permanente, la cual actuaría en los tiempos de receso del Congreso. Estaba compuesta por un Senador de cada provincia, cuyas

729 COLLIER (1977) p. 281.

730 Bravo (1992-1993) Pp. 319 y 320. 
atribuciones eran precisamente velar por el cumplimiento de la Constitución y las leyes, además gozaban de la facultad de formular al Ejecutivo las observaciones que estimen convenientes, como también prestar o denegar el consentimiento al Ejecutivo en aquellas materias que fuere necesario.

Como lo señaláramos precedentemente, en la Carta de 1828 fue vislumbrada y regulada la acusación constitucional. Los artículos 47 y 48 establecían las atribuciones exclusivas de la Cámara de Diputados y del Senado, dentro de las cuales contemplaba la posibilidad de llevar a cabo acusaciones. En lo particular, el artículo 47 señalaba que le correspondía a la Cámara de Diputados conocer de las acusaciones a petición de parte o en virtud de alguna proposición de alguno de sus miembros, debiendo declarar si había lugar o no a la formación de la causa, para luego formalizar la acusación ante el Senado. De conformidad con la Ley Fundamental, era posible acusar al Presidente de la República, el Vice-presidente, ministros, miembros de ambas Cámaras y los miembros de la Corte Suprema de Justicia. Del mismo modo, tal precepto establecía los delitos en virtud de los cuales era posible dar comienzo a la acusación. Ellos eran traición, malversación de fondos públicos, infracción a la Constitución y la violación de los derechos individuales. Por su parte, el artículo 48 entregaba la facultad de abrir el juicio y conocer de las acusaciones de la Cámara Baja al Senado, quien debía dictar sentencia con la presencia de a lo menos las dos terceras partes de los votos.

Resulta importante destacar que el artículo 81, relativo a los privilegios y facultades del Poder Ejecutivo, hacía referencia a la acusación constitucional, la cual era posible ejercer durante su período de gobierno y además podía ser llevada a cabo en el plazo de un año con posterioridad a la cesación del cargo. En este mismo sentido, el artículo 82 señalaba que, una vez pasado aquel plazo de un año, no era posible formular acusaciones por delito alguno cometido en su gestión. Ahora bien, respecto de este precepto lo interesante es resaltar que el artículo exponía que aquel plazo era "el término de residencia", por ende, es posible inferir una vez más que la acusación y la residencia se encuentran estrechamente vinculadas o confundidas hasta el punto de hacer de ellas un solo mecanismo de control. Sin embargo, en el artículo 128 , relativo a las disposiciones generales del texto constitucional, se expone que: "Todo funcionario público está sujeto a juicio de residencia. Una ley especial reglará el modo de proceder en él". Por tanto, es posible concluir que el juicio de residencia fue regulado de forma autónoma respecto de todo funcionario público, sin 
perjuicio de que se contemplaran otras instituciones de rasgos más específicos para controlar a las más altas autoridades.

Tal como describe Zúñiga, la Constitución de 1828 sigue un modelo de acusación norteamericano. Consagra como atribución de la Cámara de Diputados acusar constitucionalmente y del Senado abrir el juicio político a los acusados por la Cámara $^{731}$. Por otra parte, según Bronfman, esta Ley Fundamental fue la primera en mencionar las causales de acusación, radicando el poder de acusar en la Cámara de Diputados y de condenar o absolver en el Senado. Tales causales fueron traición, malversación de fondos públicos, infracción de la Constitución y la violación de derechos individuales. De tal manera que la institución, si bien es trazada con líneas del modelo norteamericano, siguió marcada como un proceso judicial ${ }^{732}$. A pesar de la incorporación del impeachment, la tradición indiana sigue presente y el juicio de residencia estaba regulado en el artículo 128.

Continuando con nuestro examen de la Carta del veintiocho, se hace imprescindible hacer presente otro precepto que igualmente contribuye en la construcción de una idea de control parlamentario hacia el Poder Ejecutivo. Nos referimos al artículo 84, relativo a los deberes del Ejecutivo, en el cual se estipula en el numerando 3.0 el deber de presentar cada año el presupuesto de los gastos al Congreso Nacional, además del deber de dar cuenta instruida de la inversión del presupuesto anterior. Por tanto, desde la Constitución del veintiocho comienza a tomar forma la figura de la rendición de cuentas ante la nación y la ley de presupuestos.

Otro antecedente relevante lo podemos encontrar en las normas relativas a los Ministros de Estado. En particular nos referimos a los artículos 86, 88 y 89, toda vez que dichas normas regulaban la responsabilidad ministerial y ciertas condiciones directamente vinculadas con el control político del Poder Ejecutivo a través del Legislativo. En un primer lugar, el artículo 86 se hacía cargo y señalaba expresamente la responsabilidad personal respecto de los decretos que firme, y otra conjunta respecto de aquellos que suscribe en común con otros ministros. El artículo 88 contenía una incipiente obligación de rendir cuentas por parte de los ministros; una vez abiertas las sesiones anuales de las Cámaras, los ministros debían dar cuenta de sus respectivas carteras ante el Senado y ante la Cámara de Diputados,

731 ZÚÑIGA (1993) p. 712.

732 BRONFMAN (2005) Pp. 101 y 102. 
por separado. El artículo 89, por su parte, establecerá el juicio de residencia respecto de los ministros contemplando un plazo de residencia de 6 meses.

Dicho lo anterior, es posible colegir algunas consideraciones respecto de esta primera etapa de ensayos constitucionales nacionales. Como primer aspecto cabe señalar que a lo menos en todos los textos, sean reglamentos o la norma constitucional, persistió un verdadero espíritu controlador del poder. Sin perjuicio de que las instituciones diseñadas no fueran claras en cuanto a su naturaleza, lo significativo es la presencia de la división de poderes y del control como un propósito generalizado de manera muy sistemática, puesto que se trataba el control desde la perspectiva del juicio de residencia, la acusación de altos funcionarios públicos, la ley de presupuesto nacional y, especialmente, la responsabilidad de los Ministros de Estado.

Un segundo aspecto, implica hacer presente que existe una fuerte influencia del derecho y las instituciones indianas. Es por ello que el juicio de residencia se conserva de forma constante en todos los textos constitucionales. Sin embargo, de forma muy paulatina e incluso confusa se irá incorporando la acusación constitucional como mecanismo de control político y jurídico del poder. Por ende, en esta etapa del constitucionalismo nacional es posible inferir que mediante el juicio de residencia y otros recursos judiciales, era posible establecer una responsabilidad de los gobernantes por los agravios cometidos a sus gobernados. Respecto de aquella responsabilidad -tal como expone Arancibia- es factible diferenciar tres tipos: 1.- una eminentemente personal de quien ejerce el cargo u oficio público; 2.- otra que gira en torno al daño causado a una víctima, con independencia de la esfera subjetiva (dolo-culpa) de su autor; y 3.- la que se genera el deber de reparar el daño causado. Para Arancibia, la primera responsabilidad radica sobre una autoridad por sus actos, respecto de los cuales respondía personalmente y no institucionalmente ${ }^{733}$.

En consecuencia, desde 1810 a 1833 hubo veintitrés años en los que nuestra vida institucional experimentó un proceso que Estévez define de formación constitucional, en el que se dictan reglamentos y constituciones más o menos perfectas desde el punto vista teórico, pero desconectadas con las realidades de la vida a la que estas disposiciones debían aplicarse, en virtud a la inexperiencia política pero siempre inspiradas en un espíritu de patriótico que aspiraba dotar a la

733 Arancibia (1999) Pp. 57-58 
República de orden, libertad y justicia ${ }^{734}$. En este mismo sentido se expresan las palabras de Andrade, para quien sólo la Carta del 33 será la primera Constitución formal, puesto que en el período anterior sólo se realizaron ensayos constitucionales cuya creación no tenía relación con nuestro desarrollo cultural y político; básicamente, se pretendió que a través de las leyes se modificara la mentalidad y estructura de un pueblo ${ }^{735}$.

En conclusión, desde nuestra materia de investigación podemos decir que en dicho período de desarrollo constitucional, no hubo fiscalización parlamentaria comprendida desde la noción de controlar "los actos del Gobierno", buscándose una finalidad de incidir en las políticas públicas, en la gestión de Gobierno o de influir en la opinión pública, a fin de alterar los equilibrios políticos. Existió, por el contrario, un control jurídico con débiles matices políticos que se desarrolló mediante la acusación constitucional, cuyo objetivo era más bien sancionar desde una perspectiva jurídica penal-patrimonial pretendiendo resarcir daños ocasionados a la ciudadanía.

\section{El control parlamentario en el constitucionalismo de la República}

En las siguientes líneas, nos concentraremos especialmente en examinar el desarrollo constitucional chileno a partir de la conformación de las Cartas de 1833 y 1925. Intentaremos dilucidar cómo estos Códigos Políticos fueron dibujando una forma de limitación de los abusos del poder, para luego analizar cuáles han sido los dispositivos jurídicos específicos relativos a la fiscalización parlamentaria, como un medio de control político y jurídico al poder en el Estado democrático de derecho chileno.

En el presente apartado, realizaremos un análisis detallado del control parlamentario y su expresión constitucional en la historia de Chile. Cabe destacar que -como bien lo expusiéramos en el apartado anterior- entre los años 1811 y 1830 se desarrolló un período de ensayos constitucionales, mediante los cuales se intentaba organizar la sociedad chilena. Sin embargo, dicho objetivo no fue alcanzado sino hasta el año 1830 aproximadamente. Por ende, será con la Constitución de 1833 a través de la cual se logra realizar una organización del Estado y se logra dotar de estabilidad y armonía al sistema político nacional. Como bien

734 ESTÉVEZ (1942) p.5.

735 ANDRADE (1988) p.1. 
describe Heise, el mérito de aquella Carta es precisamente su eficacia, vitalidad, vigencia y la capacidad que tuvo para ajustarse a un Estado social determinado, logrando instituir orgánicamente al Estado conformando una República oligárquica $^{736}$.

\section{a) Consideraciones generales en torno a la Constitución Política de 1833}

Primeramente, señalaremos algunos aspectos relevantes del contexto doctrinal, en virtud del cual se elabora la Carta del 1833. Siguiendo a Amunategui, diremos que esta época se caracterizó por el aumento de la ilustración política en la clase dirigente del país adquirido por la lectura de otras constituciones de procedencia francesa, norteamericana y española. Pero, a pesar de aquello, siguió presente una compleja inexperiencia política que induce a confiar demasiado en la eficacia intrínseca de los buenos preceptos constitucionales de otros Estados, sin considerar su adaptabilidad a las condiciones particulares de Chile. Para este autor, se produjo una ciega imitación respecto de las normas de pueblos mucho más civilizados y completamente diversos al nuestro ${ }^{737}$.

No obstante, existen opiniones contrapuestas a la de Amunategui. En esa dirección hemos de traer a colación la opinión de Carlos Estévez, para quien la Constitución del 33 fue una genuina creación nacional, cuyo fin primordial fue asegurar la tranquilidad y el orden en la República y cuyo principal objetivo fue poner término a los desórdenes políticos, la anarquía y el militarismo ${ }^{738}$. La Constitución de 1833 fue una norma de corte conservador en contraposición al texto liberal de 1828. Cabe hacer presente que durante los años treinta Chile era gobernado por Diego Portales, considerado el espíritu del régimen conservador divulgando un modelo fuerte y centralizado de Gobierno. Si bien Portales nunca prestó especial importancia a la legalidad de los actos, su visóin ciertamente influenció la dictación de la Carta Fundamental y la orientación de la misma. Es por ello que una de las características más sobresalientes de la misma es el establecimiento de una figura presidencial fortalecida a través de múltiples atribuciones, sustentado en la elección de los departamentos, autoridad que además podía gobernar hasta dos períodos

\footnotetext{
736 HEISE (1950) p. 55

737 AMUNATEGUi (1947) p.189.

738 ESTÉVEZ (1942) p.5.
} 
consecutivos e incluso un tercero en determinados casos. En esa dirección, se establece que el Presidente no podrá ser procesado mientras ejerce funciones, sino sólo un año después de haber dejado el cargo ${ }^{739}$.

A pesar de las diferentes opiniones y apreciaciones en cuanto a las características e influencias de la Carta Fundamental en cuestión, lo cierto es que con el transcurso de los años se produjo la urgencia de llevar a cabo ciertas modificaciones a dicha norma, empero el texto constitucional establecía una fecha específica en la cual debían realizarse las reformas: el año 1836. En el año 1831 aquella premura se acrecienta y se expresa concretamente en una solicitud formulada mediante un oficio de la Municipalidad de Santiago, la cual fundamentaba que el texto constitucional no se ajustaba al estado social del país, por consiguiente, era necesario proceder a su modificación. Aquella solicitud fue acogida y se convoca a una "Gran Convención" con el único objetivo de reformar la Constitución.

En aquella Convención se enfrentaron dos proyectos, uno de orden liberal liderado por don José Manuel Gandarillas, y otro más conservador que fuera redactado por don Mariano Egaña. Ambas tendencias contrapuestas aspiraban a diseñar modelos institucionales diversos. Gandarillas, por su parte, pretendía realizar sólo modificaciones a la Carta de 1828 sin alterarla radicalmente. Dentro de sus propuestas, y en directa relación con nuestra materia de investigación, cabe destacar que proponía la supresión de la acusación del Presidente incluso hasta un año después de su mandato ${ }^{740}$. Por otra parte, el proyecto de señor Egaña proponía la dictación de una nueva carta política de espíritu más bien autoritario. Aquel documento contemplaba la posibilidad de consagrar un presidencialismo omnipotente que gozaría de las siguientes facultades: reelección sin limitación, la facultad de disolver a la Cámara de Diputados y oponer veto absoluto a las leyes dictadas por el Congreso, las que no podrían ser presentadas hasta el año siguiente. Pero no contemplaba la responsabilidad del Presidente ante el Parlamento ${ }^{741}$.

\footnotetext{
${ }^{739}$ COLLIER (2008) Pp. 58 y 59.

740 EYZAGUiRRe (1953) p.103.

741 La propuesta de Mariano Egaña, de tilde conservador y tendiente hacia la posibilidad de dotar de ciertas facultades al Presidente de la República a fin de poder disolver el Congreso nacional, tenía como origen su clara influencia británica, país en el cual vivió por 5 años, además de sus estudio y admiración por las instituciones políticas francesas. Para Mariano Egaña, el equilibrio de poderes del régimen parlamentario inglés era el tipo ideal de gobierno e intentará por diversas vías introducirlo directa e indirectamente a nuestro país. A pesar de que su influencia fue evidente el resultado final del texto constitucional, fue más bien una mixtura de ambas opiniones, situación que colocó a Egaña en un claro descontento lo cual lo llevó a redactar un proyecto orgánico el que llamó "Voto particular de Egaña".
} 
Pese a la existencia de aquellas contrapropuestas, el resultado final fue una mixtura de ambas. La Carta Fundamental antes indicada finalmente contempló varios aspectos relevantes desde la perspectiva de las tendencias que ejercieron cierta influencia sobre ella. Cabe hacer presente que, según José Luis Cea, ésta fue una Constitución fuertemente influenciada por la propia experiencia constitucional nacional de los años anteriores, es decir, el influjo más gravitante fue la propia experiencia constitucional adquirida, como también -aunque en menor medida- las ideas del liberalismo y algunos aspectos fundamentales de la Constitución de Estados Unidos, particularmente, aquellos aspectos relativos a la división de poderes con frenos y contrapesos. Asegura Cea que ella es incorporada en nuestra Ley Suprema aunque con una notable reducción de aquellos equilibrios. En definitiva, siguiendo lo planteado por el autor, esta norma fundamental se configuró como un instrumento para construir un gobierno fuerte y centralizado, "centrada en las necesidades de la realidad política chilena de la época; cuyo órgano o resorte principal era el Presidente de la República"742.

Desde la perspectiva del contenido mismo de la Constitución, es posible destacar las declaraciones contenidas en los artículos 2, 3 y 4 . El primero de ellos, definía al gobierno de Chile como popular y representativo; el segundo precepto consagraba a la República única e indivisible como la forma de gobierno nacional; y el tercero, depositaba la soberanía en la nación, la que se delega en las autoridades que la misma Constitución instituyera. Estableció como régimen de gobierno al sistema presidencial, consagrando la posibilidad de reelección del Presidente de la República, pero sólo por un período. Respecto de las relaciones Ejecutivo-Legislativo no contempló la posibilidad de disolver el Congreso y exhibió una total ausencia de responsabilidad del jefe de Estado, pero sí contemplaba la responsabilidad de los ministros y su derecho a asistir a los debates parlamentarios ${ }^{743}$.

Finalmente, la Constitución de 1833 fue promulgada el 25 de mayo del mismo año y estuvo vigente por seis décadas. Como describe Sergio Carrasco, es el texto constitucional de mayor vigencia en la historia del país. Sin perjuicio de aquello, a juicio del autor, su vigor puede ser clasificado en tres períodos: una primera etapa de clara vigencia, en la que conforme a sus disposiciones se caracterizaba por situar al Presidente sobre los partidos políticos representados en el Congreso; un segundo

\footnotetext{
742 CEA (1991-1992) Pp.175 y 176.

743 HeIse (1950) Pp.52.
} 
período que comienza a modificar dicha relación y establece un régimen presidencial de partido; $y$, en último lugar, una tercera etapa denominada "pseudo régimen parlamentario".

El éxito del texto constitucional y su lata permanencia en el tiempo, fue resultado de una mixtura de factores. Tal como describe Collier, los sistemas políticos no son mantenidos solamente por las normas fundamentales. Si bien los poderes constitucionales hicieron posible que los presidentes de Chile gobernaran efectivamente, dentro de márgenes legales y reglas bien establecidas, aquello era resultado de la obediencia que la ciudadanía expresaba respecto del gobierno y las leyes, fruto del empleo de ciertas técnicas adoptadas por la autoridad. Durante la vigencia de la Constitución de 1833 la represión fue el soporte del orden institucional. De esta manera, se evitaron y sancionaron las rebeliones armadas o políticas.

Por otra parte, un factor igual de influyente en la estabilidad del sistema se debe en cierta medida a la influencia que ejerce en la cultura del país la Iglesia Católica. Los liberales de la década de 1820 eran declaradamente anticlericales, pero los conservadores seguían fielmente órdenes religiosas. Tal escenario lo comprendió Diego Portales y lo utilizó como un mecanismo para mantener la estabilidad política y social. Aquellos lazos se verán estrechados con el arribo a la presidencia del general Prieto en septiembre de $1831^{744}$.

Por tanto, el texto político que emerge de la Ley Fundamental de 1833 fue ciertamente más conservador, toda vez que durante los años 1833 y 1865 el único partido político con cierta continuidad fue el Partido Conservador, cuyos militantes habían sido apodados como "pelucones". Por su parte, los liberales -llamados "pipiolos"- intentarán retomar fuerza política y electoral, lo cual irá modificando la cultura política del país. Como consecuencia de aquellas transformaciones, se abrió la puerta para el ingreso paulatino de herramientas del régimen parlamentario, instaurándose incluso un parlamentarismo de facto. En tal contexto, la fiscalización parlamentaria sufre diversas alteraciones que lógicamente la fortalecen de manera superlativa. Así, el escenario político cambiará al punto que el control parlamentario se sitúa como el elemento central en la evolución institucional y democrática nacional.

${ }^{744}$ COLLIER (2008) Pp. 65 y 66. 
Ahora bien, desde una perspectiva jurídica, es menester señalar que si bien en la literalidad del texto estaba contemplado un presidencialismo, en la práctica se interpretaba en un sentido parlamentario. Junto con ello, las reformas realizadas los años 1891 y 1892 terminarían por dirigir el sentido, orientación y la aplicación del Código Político en una clara dirección parlamentaria. Se establece, por ende, un absoluto predominio del Parlamento, carente de mecanismos que dieran la posibilidad de disolverlo, lo que finalmente favorece una excesiva rotativa ministerial $^{745}$. Por ello, al texto de 1833 se le atribuye la capacidad de introducir el germen del parlamentarismo. Como bien explica Heise, dicha Constitución estableció armas constitucionales que se entregaron al Congreso a través de las cuales podían "anular las formidables facultades presidenciales"7"76.

\section{b) Examen de la fiscalización parlamentaria y la acusación constitucional en la Constitución Política de 1833}

Respecto del contenido específico de la Carta Fundamental en relación a la fiscalización parlamentaria, cabe destacar que -según Eyzaguirre- el Congreso disponía de dos herramientas para fiscalizar los actos del gobierno; la primera, era la retención de las "leyes periódicas" y la segunda, el juicio político.

Los juristas del 33, fuertemente influenciados por las ideas anglo-francesas, estimaban absolutamente necesario controlar e intentar frenar el autoritarismo presidencial. Con tal propósito, consagran en el Código Político importantes limitaciones al Ejecutivo, una de ellas fueron las leyes periódicas. Conjuntamente con las bases ideológicas de un gobierno fuerte, se desarrollaba la necesidad de frenar y controlar la autoridad presidencial. En tal sentido se establecen las leyes periódicas, mediante las cuales el Congreso gozaba de la importante facultad de aprobar la Ley de Presupuesto y cada diez u ocho meses autorizar la ley relativa al cobro de contribuciones y las que fijaban las fuerzas de mar y tierra. Por ende, el Presidente debía pedir autorización al Congreso para proceder a su cobro y para destinar a las Fuerzas Armadas, debiendo subordinar sus decisiones a la voluntad del Parlamento.

\footnotetext{
745 CARRASCO (1980) Pp. 63 y 64.

746 HEISE (1950) p.53.
} 
Dichas leyes fueron, sin duda alguna, el fundamento más sólido en la interpretación parlamentaria de la Constitución, y representaron el arma más eficaz que poseía la burguesía chilena para controlar al Ejecutivo e ir lentamente debilitándolo hasta anularlo por completo. Según Heise, a través de ellas se coloca en manos del Congreso "una influencia extraordinaria en la dirección de los negocios del país"'747. En este orden de ideas, las leyes periódicas le permitieron sostener a los pensadores liberales que la Constitución del 33 contaba con verdaderos resortes parlamentarios, hasta llegar al más intenso parlamentarismo chileno.

Por su parte, el juicio político constituía una atribución exclusiva de la Cámara de Diputados que comprendía la posibilidad de acusar ante el Senado a los ministros de despacho, consejeros de Estado, jefes del ejército y armada, intendentes y magistrados de los tribunales superiores de justicia, debiendo juzgar aquellas acusaciones el Senado $^{748}$.

Sin embargo, desde nuestra perspectiva y tal como lo iremos desarrollando a lo largo de este apartado, creemos que en el período en el que rige la Constitución de 1833 la forma en la que se lleva a cabo la fiscalización fue mucho más amplia. No sólo contempló mecanismos como las leyes periódicas y el juicio político, sino que además se hizo uso de la censura ministerial como también de la realización de comisiones investigadoras. Ahora bien, tal laxitud en la fiscalización del Gobierno estuvo fuertemente influenciada por la parlamentarización del sistema político nacional.

La arremetida que el régimen parlamentario produjo en Chile fue el factor clave en la expansión de la fiscalización, pero a su vez fue el causante de las dificultades en las relaciones entre los poderes del Estado, esencialmente, porque su ingreso fue de hechos y no mediante derechos. El parlamentarismo comienza a ser carne en virtud de la aplicación espontánea y no regulada de prácticas e instrumentos de control parlamentario; la falta de regulación jurídica constitucional impidió, por consiguiente, un correcto ejercicio de las herramientas fiscalizadoras, pero promovió un parlamentarismo de hecho. Dicho esto, adelantaremos un análisis y hacemos presente un elemento sobre el cual más tarde profundizaremos y que dice relación con el efecto y evaluación que tal desbarajuste institucional provoca en el sentimiento político y jurídico nacional. El uso abusivo de los mecanismos de control

747 HEISE (1986) Pp. 16 y 17.

748 EyZAguirRe (1953) Pp. 105-106. 
generará en el imaginario colectivo político un equívoco concepto respecto de la fiscalización como expresión del control político, por tanto, se responsabilizará a la institución como el elemento perturbador del sistema político, sin comprender el fenómeno desde una óptica más amplia y abarcadora.

En cuanto al examen de la regulación constitucional de la fiscalización, centraremos nuestros esfuerzos en el estudio particular del artículo $38 \mathrm{~N}^{\circ} 2$ y el artículo $39 \mathrm{~N}^{\circ} 2$, normas que regulaban básicamente la acusación constitucional, a fin de dilucidar cuál fue la noción de fiscalización parlamentaria que primó en el período en el que rigió la norma fundamental de 1833. Esto, nos permitirá continuar construyendo la conceptualización de la fiscalización a lo largo del constitucionalismo nacional. A continuación, realizaremos una descripción y análisis de los elementos más relevantes en torno a la acusación constitucional y los aspectos que generaron la mayor cantidad de conflicto en la práctica parlamentaria nacional.

En primer lugar, abordaremos el precepto constitucional del artículo $38 \mathrm{~N}^{\circ} 2$, el que establecía que la puesta en marcha de la acusación constitucional era una atribución exclusiva de la Cámara de Diputados. Vale decir, la posibilidad de presentar acusaciones con la finalidad de hacer efectiva la responsabilidad de determinados funcionarios públicos,sólo le compete a los parlamentarios de la Cámara Baja, siendo la única autoridad que puede acusar a determinadas autoridades ante el Senado. A pesar de que el contenido del precepto es aparentemente claro, en cuanto a la exclusividad del órgano parlamentario en esta materia, hay indicios que permiten pensar que no lo fue tanto.

En efecto, Jorge Huneeus expone que en los años 1852 y 1853749 existieron solicitudes individuales de acusación constitucional por parte de ciudadanos de la República, quienes presentaron una acusación fundamentados en el derecho a petición igualmente consagrado en la Carta Fundamental. Por tal motivo, según el autor, además de rechazar tal solicitud fue necesario manifestar expresamente que la iniciativa era exclusivamente parlamentaria. Sin perjuicio de aquello, dice Huneeus, un ciudadano podía proponerle a un diputado alguna acusación respecto de un determinado funcionario, de esta manera el parlamentario podía evaluarlo y patrocinarla en el caso de estimarla prudente, dándole curso progresivo conforme los

\footnotetext{
${ }^{749}$ Hacemos referencia a la solicitud de acusación constitucional iniciados por don Ignacio de la Carrera en contra los magistrados de las Cortes Superiores de Justicia por haberle inferido perjuicio en una sentencia confirmatoria.
} 
requisitos constitucionales 750 . Respecto de esta materia, Estévez planteaba una posición diametralmente diferente. Para el autor la Constitución del 33 nada dijo al respecto de quién puede ejercer una acusación, es por ello que frente al silencio de la Ley Fundamental podía considerarse que no sólo le correspondía a uno o varios miembros de la Cámara, sino que además era posible estimar que podía ser activada por cualquier ciudadano o habitante de la República751.

Como segundo aspecto relevante podemos señalar que, durante la vigencia de la Constitución de 1833, la facultad de acusar podía ser ejercida cuando la Cámara sesionaba de forma ordinaria o extraordinaria, sin necesidad de que el Ejecutivo incluya la acusación en la convocatoria. Por ende, es posible colegir que la intencionalidad del constituyente fue estipular la mayor amplitud posible, a fin de que pudieran interponerse acusaciones en todo período legislativo, atendido la naturaleza e importancia de la institución, eliminando barreras temporales que pudieran perturbar el ejercicio de este mecanismo de fiscalización.

Un tercer elemento a examinar es el plazo dentro del cual era posible ejercer la acusación constitucional. Respecto de la figura del Presidente de la República, el artículo 83 señalaba que sólo podía ser acusado durante el plazo de un año una vez finalizado su mandato. Las causales en virtud de las cuales procedía una acusación contra el mandatario eran básicamente "todos los actos de su administración en que haya comprometido gravemente el honor o la seguridad del Estado, o infringido abiertamente la Constitución". Ahora bien, no bastando con esta norma constitucional, el artículo 76 del mismo texto político imponía la obligación al Presidente de mantenerse dentro del país, puesto que le estaba prohibido salir del territorio de la República durante el período de un año una vez finalizado su mandato, sin contar con el acuerdo del Congreso. De acuerdo a ambos preceptos, podemos realizar importantes alcances en cuanto a la irresponsabilidad contemplada constitucionalmente respecto del jefe de Estado y en cuanto al plazo mediante el cual era posible activar una acusación contra el Presidente.

Claramente, en el espíritu del constituyente no estuvo contemplada la idea de sancionar al Presidente por sus actos ilegales o abusivos durante el ejercicio del cargo, por tanto, consagró la irresponsabilidad de la más alta autoridad. La norma constitucional eximía de responsabilidad al jefe de Estado mientras ejercía funciones.

\footnotetext{
750 HUNEeUs (1879) p. 203 y 205.

751 EstéVEZ (1948) p.1.
} 
Respecto de esta materia se expresa Estévez señalando que en la Constitución del 33 los constituyentes realizaron un sacrificio evidente respecto de las ideas republicanas, toda vez que es de la esencia de la República que el Presidente sea eminentemente responsable. Por tanto, eximirlo de las acusaciones constitucionales mientras se encontraba en funciones era un absurdo teórico y una contradicción con la forma de gobierno por la que tanto se esforzaron en instaurar. Sin embargo, a criterio del autor, con estos preceptos quisieron poner a cubierto la autoridad presidencial de toda tentativa que pudiera desmedrarla, creando con ello un grave peligro constitucional porque tal irresponsabilidad no daba salidas institucionales a los casos en que un Presidente actuara contra la Constitución o las leyes, simplemente habría que recurrir a las revueltas armadas ${ }^{752}$.

Según Boronfman, la Constitución de 1833 perfeccionó la regulación del juicio político del texto de 1828. La Gran Convención incorporó autoridades al listado de acusables, distinguió causales para cada uno y excluyó al Presidente durante su mandato. La propia Carta regulaba en detalle el procedimiento ${ }^{753}$. Para Zúñiga, en la Constitución de 1833 era evidente que en cuanto a la acusación el constituyente siguió el modelo inglés. Pero en relación al Presidente de la República -como administrador del Estado y Jefe Supremo de la nación-, el constituyente sigue un modelo mixto inspirado en el instituto de la acusación inglés y en el juicio de residencia del derecho indiano, porque era posible acusarlo una vez finalizada su gestión y por todos los actos de su administración. Por tal motivo, para este autor el talante conservador del constituyente introduce finalmente un principio de irresponsabilidad del Presidente en ejercicio como un elemento de continuidad con el principio monárquico, opinión que comparten Carrasco Albano, Galdames y Roldán. Comenta Zúñiga que este artículo sólo estaba destinado a ser una fórmula, pero la vaguedad de su redacción daba cabida a las apreciaciones más contradictorias sobre los motivos de la acusación ${ }^{754}$.

En este punto podemos decir que, en cierta medida, se regula de mejor manera la acusación constitucional, demostrando cierto avance y adecuación a las tendencias modernas del Estado constitucional; no obstante, la exclusión del Presidente de la República como sujeto acusable durante el ejercicio del cargo implicó retroceder la

\footnotetext{
752 ESTÉVEZ (1948) p. 2.

753 BRONFMAN (2005) p. 102.

754 ZÚÑIGA (1993) p. 713.
} 
senda trazada, tal como describe Zúñiga, significaba dar continuidad a un ideal monárquico, rechazando los principios esenciales del Estado moderno.

En definitiva, el artículo 83 estimula el surgimiento de dos nociones políticas: por una parte, nos recuerda las ideas del despotismo ilustrado y los gobiernos impersonales, mediante los cuales se consagraba la absoluta irresponsabilidad e inviolabilidad de los monarcas absolutos, pensamiento propio de la época colonial nacional que -según Heise- se reactualizó en Portales y en los pelucones. En tal escenario, la instauración de la República se ve debilitada. Por otra parte, generó un efecto colateral que posteriormente forja una seria inestabilidad política. Frente a la imposibilidad de hacer responsable al Presidente, se focalizó la fiscalización del Gobierno en los actos de sus ministros, por consiguiente, la responsabilidad política se hizo exigible respecto de los secretarios de las carteras, de lo contrario el Congreso habría quedado en la imposibilidad absoluta de hacer efectiva la fiscalización y la responsabilidad de los actos de la administración del Estado ${ }^{755}$.

Por otro lado, la posibilidad de cuestionar la legalidad y prudencia de los actos del Presidente de la República una vez finalizada su gestión, parece una reminiscencia de una institución que precedentemente expusimos: el juicio de residencia. Este último precisamente podía ser llevado a efecto durante un período de tiempo específico una vez terminado el mandato. Así, los artículos 83 y 76 se acercan más en naturaleza y finalidad a la residencia y no necesariamente a la acusación constitucional. En este orden de ideas se expresan las palabras de Silva Bascuñán, quien sostiene que la Constitución de 1833 -inspirada fuertemente en instituciones inglesas- consagró la irresponsabilidad del Presidente de la República durante el desempeño de su mandato, posición muy particular que obedecía a la tradición española de los juicios de residencia a los que sometían a los representantes del Rey, luego de terminadas las tareas cumplidas al servicio del monarca ${ }^{756}$. Esta especial regulación permite comprender el porqué de los dichos de Martínez, quien incansablemente nos recordaba -en los pasajes anteriores de este capítulo- que la residencia estará presente durante un largo período en Chile, desde el Derecho Indiano hasta la Constitución de $1925^{757}$.

\footnotetext{
755 HEISE (1986) p. 15.

756 SILVA (1963) p. 94.

757 MARTÍNEZ (1965) Pp. 200 y 207.
} 
Es preciso comentar a este respecto que esta acusación constitucional presidencial fuera del período de ejercicio de funciones, fue incluida en la Ley Fundamental por Vial del Rio, quien la propuso con una clara finalidad: quebrantar el principio monárquico de la absoluta irresponsabilidad del mandatario supremo. Pero más tarde y de forma intencionada aquella solicitud no fue contemplada en la misma forma en que fue expuesta por él. La noción primaria de Vial del Rio pretendía que estuviera regulada en el mismo segmento que la acusación constitucional a los demás funcionarios públicos, pero desafortunadamente se enunció en otro capítulo. Según el autor, este precepto estaba destinado solamente a ser una fórmula; asimismo, la vaguedad con la cual fue establecido daba cabida a muchas apreciaciones contradictorias sobre los motivos de la acusación. Así, el espíritu por eliminar la irresponsabilidad monárquica se vio frustrado porque la responsabilidad aplicable al Presidente se limitaba en tiempo y por determinadas causales. Sin embargo, y a pesar de aquello, para Galdames la idea de hacer responsable al Presidente sí triunfó en la práctica, toda vez que la Cámara de Diputados contaba con las facultades suficientes "para hacer pesar en el gobierno su acción fiscalizadora; $i$ el poder de acusación, tan amplio como se consultaba, le confería indirectamente cierta supervigilancia de todos los servicios públicos" ${ }^{\prime 758}$.

Continuando con esta materia, expondremos los postulados de Jorge Huneeus, quien se manifestaba contrario a la idea de ejercer la acusación constitucional una vez finalizado el mandato del funcionario público por desvirtuar el objetivo central de la misma. Por nuestra parte, nos manifestamos completamente a favor de lo sostenido por Huneeus, de conformidad a la siguiente reflexión: la finalidad u objetivo de la acusación es lograr la "destitución" del autor del hecho infraccional. El objetivo último perseguido al ejercer este mecanismo de fiscalización, es alejar de la administración del Estado a personas que utilicen incorrectamente el poder que se les ha entregado; luego de aquello y una vez resuelta la arista política, deberá ser juzgado por la justicia ordinaria de ser procedente. Por tanto, una vez separado del puesto el funcionario que se intenta acusar, está satisfecha la razón en que reposa el sistema de acusaciones extraordinarias ${ }^{759}$.

\footnotetext{
758 GALDAMES (1881-1941) p.929.

759 Huneeus (18799 p. 208.
} 
Vale recordar que el objetivo principal que perseguía el juicio político era precisamente la destitución del funcionario culpable, tradición política que desarrolló el sistema parlamentario inglés justamente por configurar un método más expedito que el clásico impeachment, el cual buscaba más bien una responsabilidad penal. Por ello, nace un nuevo concepto de juicio en Inglaterra que pretendió sancionar hechos -que no necesariamente configuraban un delito- que podían ser actos o faltas graves al interés del país. De tal manera nace para el sistema británico una responsabilidad especial, una responsabilidad política. En virtud de aquel tipo de responsabilidad de características específicas, habrán de emerger procedimientos especiales que garanticen la factibilidad oportuna de determinarla, y que permitan de manera expedita conseguir la máxima reducción del daño. Por consiguiente, persiguiendo tal finalidad debe ser factible la separación de quien ha utilizado el poder de manera incorrecta de aquel espacio de poder que ostenta, puesto que dicho cargo o función es la fuente del problema. Sólo situado en aquella particular condición pudo problematizar el poder, una vez alejado del mismo los efectos nocivos se detienen, no obstante, tendrá que examinarse los otros efectos que ello pudo generar en tiempos pasados, y habrá de concurrir a responder por los otros tipos de responsabilidades que sus actos pudieron generar.

En consecuencia, carecería de total valor iniciar una acusación cuyo objetivo ya está satisfecho desde una perspectiva política, sin perjuicio de ser necesaria desde la perspectiva de otras responsabilidades. En definitiva, nuestra interpretación respecto de la acusación en la Constitución del 33 es que ella contenía otro propósito diverso al típicamente buscado por medio de la fiscalización parlamentaria. Al parecer, la acusación constitucional estaba dirigida hacia la realización de un tipo de evaluación de una gestión ya terminada, a fin de establecer las posibles responsabilidades penales y civiles que habían provocado los actos del agente público, y en especial, los actos del Presidente de la República, mas no necesariamente la determinación de las responsabilidades políticas que pudieran derivar del ejercicio cotidiano del cargo; es por ello que la finalidad es particular. Con este tipo de reglamentación no es posible formular una crítica a la gestión del gobierno, como tampoco es posible evaluar si la administración del Estado está dirigida hacia el bien común. Por tanto, no será posible alterar las tendencias electorales de la nación. Con todo, estamos en presencia de lo que típicamente es conocido como juicio de residencia y no frente a una acusación parlamentaria de corte jurídico-político. En conclusión, no estamos frente a una herramienta propia de la fiscalización parlamentaria. 
Ahora bien, la misma Constitución en el artículo 38 señalaba específicamente la causal en virtud de la cual era factible iniciar la acusación de los restantes funcionarios públicos -con excepción del Presidente-, cuyas causales implicaban comprometer gravemente el honor o la seguridad del Estado, o infringir abiertamente la Constitución. En el caso de los ministros y los consejeros de Estado, podían ser acusados por crímenes tales como: la traición, concusión, malversación de los fondos públicos, soborno, infracción de la Constitución, por atropellamiento de las leyes, por haber dejado éstas sin ejecución y por haber comprometido gravemente la seguridad o el honor de la nación (figura jurídica que es reiterada en los mismos términos respecto de los ministros en el artículo 92 de la Carta Fundamental). En el caso de los generales del Ejército y Armada, por comprometer gravemente la seguridad y el honor de la nación. En el caso de los intendentes, los crímenes aplicables eran la traición, sedición, infracción de la Constitución, malversación de los fondos públicos y concusión. Respecto de los magistrados de los tribunales superiores de justicia, la causal la configuraba el notable abandono de deberes. He aquí otra compleja contradicción de la Carta Fundamental, toda vez que respecto del Presidente establece causales de mayor ambigüedad jurídica en comparación con el resto de los funcionarios; surge entonces una dificultad en la determinación de qué ha de entenderse por "comprometer gravemente el honor y la seguridad nacional o infringir la Constitución". Todas son causales amplias que le otorgan una importante herramienta a los acusadores, configurando una situación de mayor riesgo si consideramos que el artículo 83 lo hacía responsable por "todos los actos de su administración".

En este escenario creemos que no era necesario detallar o especificar un acto concreto de vulneración constitucional; bastaba con esgrimir aspectos generales de su administración para ejercer una acusación. No obstante, respecto de los demás funcionarios, el Código Político realizaba una clara, detallada y taxativa enumeración de delitos, en virtud de los cuales era posible presentar una acusación.

En resumen, de algún modo el texto constitucional igualmente esbozaba sutilmente un camino mediante el cual debatir la responsabilidad política del Presidente y de su Gobierno. La amplitud de las causales y los actos por los que podía ser acusado, generaban una vía de escape a aquella imposibilidad de juzgarlo, mientras ejercía funciones; a través de una acusación-residencia posterior era posible ventilar elementos cuestionables de su gestión, en relación con el interés del 
país y el bien común. A pesar de que aquel debate se diera tardíamente, constituía el único mecanismo mediante el cual exigir responsabilidad de orden política, empero, tal proceso -a nuestro juicio- sólo tenía una finalidad simbólica porque como lo describimos anteriormente sus efectos no serán los típicamente esperados de una herramienta fiscalizadora.

En lo tocante a la causal de acusación aplicable a cada funcionario, otra arista interesante fue la diferenciación que se producía respecto de la infracción a la Constitución cuando es llevada a cabo por el Presidente de la República y cuando la realiza un intendente. En el primer caso, la Ley Fundamental requiere una infracción abierta de la misma, y en el segundo caso, basta con la sola infracción de la Constitución. Así, el jefe de Gobierno goza de mayor permisividad, puesto que podría interpretarse que en el caso de que el Presidente cometa una infracción de la Constitución y mientras ella no sea abierta o evidente no amerita ser sancionada, en cambio, las acciones de un intendente -quien depende de la voluntad del mandatario-, han de ser más rigurosas, porque respecto de él basta la sola infracción.

Un cuarto factor importante en el análisis de la acusación constitucional en la Constitución de 1833, es su tramitación. Una vez presentada la proposición de acusación constitucional, ésta debía sortear dos etapas: un examen de admisibilidad de la misma y una evaluación por una Comisión de diputados que resolverían si hay o no ha lugar la acusación. En este sentido se expresa Estévez cuando señala que en la Ley Fundamental del 33 se hacía una diferenciación entre a.- analizar si era o no admisible la acusación y b.- declarada admisible se realizaba una deliberación mediante la cual se estudiaba la acusación misma ${ }^{760}$. Tal como describe Huneeus, existía un examen de admisibilidad y un examen de aceptación. Lo relevante en este punto será hacer presente y contrastar la discusión que se gesta en torno a esta doble revisión y ver cómo ello influyó en la fiscalización como mecanismo de control político. En este orden de ideas, los enfoques doctrinales y parlamentarios se posicionaron en dos veredas. Una tendencia consideraba que ambas instancias constituían un mero trámite que no requería un estudio previo de la acusación y que tampoco requería de prueba alguna para darle curso. Desde otra perspectiva, y como opinión mayoritaria, se expresaba la tendencia a considerar que las dos

${ }^{760}$ ESTÉVEZ (1948) p. 12. 
evaluaciones de la proposición constitucional configuraban una valoración más rigurosa y específica.

Un férreo defensor de aquella opinión que estima que el examen del escrito de acusación es más riguroso que un simple examen, era precisamente Jorge Huneeus, para quien el análisis de la proposición de acusación requería cierto estudio, atendida la misma naturaleza del Código Fundamental y de la acusación en sí misma. Para este autor, la acusación constituye un procedimiento extraordinario de determinación de responsabilidades, de allí su especial tratamiento. Por otra parte, al estar regulado en la Constitución su alcance es forzoso debiendo estar orientado hacia un cumplimiento eficaz de las garantías del acusado, a fin de que no se atropellen sus derechos y de que no se utilice esta institución para satisfacer mezquinas pasiones políticas.

Es por ello que Huneeus, finalmente, desarrolla tres puntos que deben estar contemplados en la resolución que acoge la tramitación de la acusación. Estos puntos son: 1.- que la acusación haya sido planteada en tiempo y forma; 2.- que el crimen o simple delito que la motiva exista o que haya por lo menos semi-plena prueba de su existencia, o que el hecho denunciado se presenta con el carácter de delito o crimen; 3.- que el crimen o delito, o el hecho que se presenta con el carácter de tal, sea de aquellos que conforme a la Constitución constituye a la Cámara como el tribunal competente para conocerlo. Pues bien, concibiendo de tal modo la admisibilidad -agrega el autor- en tal etapa de análisis de la acusación será además posible recibir declaraciones de testigos, como también ilustrarse por otros medios de prueba necesarios para formarse conciencia del asunto ${ }^{761}$.

Con todo, para Estévez el procedimiento de acusación en la Constitución era sumamente lento y engorroso. La existencia de dos procedimientos distintos, un procedimiento especial para el Presidente, ministros, generales o almirantes y consejeros de Estado, y otro diferente para los magistrados de los tribunales de justicia, miembros de la comisión conservadora e intendentes, así como la doble admisibilidad de la acusación, sólo generaban mayor lentitud y dejaban por largo tiempo al acusado con el peso de un procedimiento de esta naturaleza. Por otra parte, expone el autor que con la Constitución de 1833 el Senado juzgaba ejerciendo un poder discrecional, ya sea para caracterizar el delito o la pena y por ello, en tal

${ }^{761}$ Huneeus (1879) Pp. 224, 225 y 226. 
contexto, se le entregaba al Senado un poder inmenso y sumamente peligroso. Dicha facultad le permitía crear delitos o dar el carácter de delito a hechos que no lo eran tal, como también podía crear penas nuevas sin limitarse a las establecidas ${ }^{762}$.

Las ideas planteadas precedentemente son, sin lugar a dudas, un aporte innegable en el desarrollo de la acusación como medio de fiscalización. Sin embargo, nos permiten concluir algunas reflexiones respecto de la comprensión de esta institución y sus alcances. Particularmente, el punto número dos nos genera cierta incertidumbre, puesto que aparentemente configuraba un cierto estándar de criminalidad de la acción cuestionada. Así, podría pensarse que para que proceda una acusación ella debería configurar una especie de presunción de culpabilidad del acusado. Sólo una vez adquirida cierta convicción en la realización efectiva de la acción u omisión típica, procedería continuar la tramitación. En tal caso, cabe preguntarse finalmente ¿cuál era entonces la convicción que debía alcanzar el Senado como ente juzgador para el caso de haber proseguido la acusación?

Si consideramos que la Cámara de Diputados sólo valora el mérito de los antecedentes presentados, pero quien en definitiva falla la acusación es el Senado, podrían generarse ciertas suspicacias respecto de cuál ha de ser específicamente la labor de la Cámara Alta. Desde otra mirada, creemos que tal interpretación relativa al examen de la acusación se sustenta en una perspectiva absolutamente jurídica e incluso de corte más bien penalista. Entonces, el autor expone una total juridicidad de la causal y de la valoración de la misma, restando toda posibilidad de evaluar políticamente los hechos que gestan la acusación. Por tanto, a nuestro entender habría una clara intencionalidad de determinar una naturaleza jurídica de la fiscalización eximiéndola de elementos políticos, consideraciones que incidirán concisamente en la conceptualización de la fiscalización parlamentaria, aspecto que trataremos en profundidad en los párrafos finales.

762 EstéVEZ (1948) Pp. 12 y 18. 
A modo explicativo se presenta un cuadro con algunas de las acusaciones constitucionales que se han podido pesquisar durante la vigencia de la Carta de 1833.

ACUSACIONES BAJO LA CONSTITUCIÓN POLÍTICA DE 1833 Claudio Vicuña, Ministro de Estado (26 de septiembre de 1891)

Domingo Godoy, Ministro de Estado (26 de septiembre de 1891)

Ismael Pérez Montt, Ministro de Estado (26 de septiembre de 1891) de 1891) 1891)

Guillermo Mackenna, Ministro de Estado (26 de septiembre de 1891)
APROBADO/RECHAZADO Aprobada: Declarados culpables, a disposición de los tribunales ordinarios para su juzgamiento.

Aprobada: Declarados culpables, a disposición de los tribunales ordinarios para su juzgamiento. Aprobada: Declarados culpables, a disposición de los tribunales ordinarios para su juzgamiento. Aprobada: Declarados culpables, a disposición de los tribunales ordinarios para su juzgamiento. Aprobada: Declarados culpables, a disposición de los tribunales ordinarios para su juzgamiento. Aprobada: Declarados culpables, a disposición de los tribunales ordinarios para su juzgamiento.

Luego de la Revolución de 1891, fueron acusados constitucionalmente los exministros antes señalados, en razón de las siguientes causales: traición, infracción a la Constitución, atropellamiento de leyes, dejar sin ejecución leyes, malversación de fondos públicos y soborno. En términos políticos, los cargos estaban fundados en los siguientes hechos: haber creado una dictadura arbitraria y tiránica tratando de cambiar el modelo republicano y promover la guerra civil; privar del ejercicio de sus funciones al Congreso Nacional y a los tribunales de justicia; impedir la aprobación de las leyes que establecen el gasto de la administración pública y los de las fuerzas de mar y tierra; hacer gastos innecesarios en relación a las fuerzas de mar y tierra; atribuirse funciones más allá de lo establecido en la Constitución y la ley; elegir fuera del marco constitucional a diputados y senadores; nombrar jueces sin las 
formalidades legales establecidas; violación de inmunidades; crear tribunales especiales que aplicaban la ley penal incorrectamente; aplicar tormentos a los ciudadanos; privar a los ciudadanos de sus propiedades, bienes y el libre ejercicio de la industria; violación de domicilio y correspondencia; atentar contra la libertad de prensa y reunión; pagar sobresueldos a los militares; mal uso de los fondos públicos; y practicar reclutamientos forzosos y violentos ${ }^{763}$.

La Comisión especial designada para informar las acusaciones estuvo compuesta por tres parlamentarios, quienes el 10 de diciembre del año 1891 acuerdan por unanimidad recomendar a la Cámara de Diputados dar curso a las acusaciones, puesto que existía mérito suficiente para ello. Una de las particularidades de esta Comisión informante fue, precisamente, su argumentación, toda vez que señalaban que su función era demostrar a la Cámara que en su consideración los ex-ministros habían cometido los delitos en el ejercicio del cargo, por ende existían argumentos plausibles para acusar. Este fenómeno fue política y jurídicamente relevante, en razón de que bajo la Constitución de 1833 el rol de la Comisión no fue solamente realizar un examen de admisibilidad de la acusación, sino que además formularon una apreciación sobre el fondo de la materia. Conjuntamente, exponen que los ministros acusados aceptan ejercer sus cargos públicos y realizan dichas acciones, en virtud de las cuales se les acusa, a sabiendas de que su presencia implicaba la renovación del conflicto entre Ejecutivo y Legislativo, problemática que -en opinión de los informantes- había cesado cuando el Presidente de la República aceptó gobernar con ministros cuyas designaciones eran aprobadas por ambas Cámaras.

Por otra parte, los ministros habrían influenciado la no aprobación de leyes cuyo rol era, esencialmente, mantener las buenas relaciones entre tales poderes del Estado. Los parlamentarios informantes expresaron a la Cámara que era absolutamente imposible que ministros que ejercían sus cargos sin apoyo del Congreso pudieran gestionar sus carteras sin verse reducidos a violar la Constitución. Es por ello que a juicio de dichos informantes, los acusados estaban decididos a cometer tales atentados graves ${ }^{764}$.

763 Documentos relativos a la acusación de los ex -Ministros de Estado (1892) Pp. 3-4.
764 Documentos relativos a la acusación de los ex-Ministros de Estado (1892) Pp. 7 y 8. 
Concluye la exposición de la Comisión aludiendo a que cada uno de los acusados es responsable de los hechos acontecidos, pero que el grado de participación y de responsabilidad deberá ser analizado en el fallo posterior. No obstante, los consideran culpables.

Por su parte, la defensa de los ex-ministros, liderada por sus respectivas cónyuges, se concentró en solicitar la inadmisibilidad de las acusaciones por haber sido ejercidas fuera del plazo constitucional, vale decir, presentadas con fecha del 3 de diciembre del año 1891, oportunidad en la que había expirado el plazo de seis meses contados desde que dejaron el cargo. Según las defensoras, sus maridos habían dejado sus funciones como ministros el 20 mayo de 1891, argumentando que además la Carta Fundamental no regulaba interrupciones que pudieran afectar el cómputo del plazo ${ }^{765}$.

Así, es posible colegir que los juicios políticos del año 1891 estuvieron claramente marcados por un componente netamente político, influenciado por una concepción equívoca del régimen de gobierno vigente, puesto que los parlamentarios acusadores plantearon que los ministros cometieron dichas infracciones, precisamente, porque no contaban con la confianza del Congreso. Es decir, el nexo causal entre la Revolución de 1891 y el atropellamiento de la norma fundamental se debe a la designación arbitraria del gabinete -por parte del Presidente-, fundamento que naturalmente omite un debido análisis de aquella facultad constitucional que le permitía al jefe, en un régimen presidencial, designar a los ministros en razón de su única y exclusiva confianza. Adicionalmente, los hechos en razón de los cuales se les acusa en cierta medida son actos políticos que, si bien se enmarcan en causales establecidas en la Ley Fundamental, su sentido y alcance fue ponderado con criterios que iban en ese tenor.

Con todo, es preciso destacar que la Comisión especial que informó las acusaciones emitió un verdadero juicio respecto del fondo del asunto declarándolos derechamente culpables, sin mayor análisis y sin escuchar ni siquiera a la defensa de los acusados, como tampoco explicó por qué admiten a tramitación una acusación posiblemente fuera del plazo de los seis meses. Ciertamente, el procedimiento fue irregular debido en nuestra opinión a la coyuntura política, pero a la constante

765 Documentos relativos a la acusación de los ex-Ministros de Estado (1892) p.21. 
implantación fáctica y forzosa de un régimen parlamentario inexiste normativamente.

Los acusados redactaron -durante los años siguientes al juicio- una serie de manuscritos en los cuales describieron su interpretación respecto del cariz del debate parlamentario. El señor Claudio Vicuña señaló que el Senado falló en virtud de intereses políticos, porque es un órgano al que le toca sentenciar casi por accidente, de tarde en tarde. Por ende, no se puede esperar de este último tino y acierto al apreciar hechos, quienes además sometieron a análisis acontecimientos fuera del plazo constitucional ${ }^{766}$. Por su parte, José Miguel Valdés dirá que los senadores no fallaron, sino que simplemente copiaron una sentencia que ya había dictado la Comisión acusadora, redactada por el Sr. Zegers. Los acusadores eran enemigos de los ministros $y$, por tal motivo, primó el odio y el rencor ${ }^{767}$.

La situación descrita fue alarmante a tal punto que estimuló comentarios tan asertivos como el señalado por el argentino Ramón González, quien expone que los chilenos quieren aplicar un régimen parlamentario, pero su Constitución Política está en un polo opuesto estableciendo un régimen presidencial con un Ejecutivo que posee facultades excesivas e inamovibles durante su período y que es un mandatario irrevocable por el tiempo de su nombramiento. En palabras de González, en el sistema imperante el Legislativo pretende ser un co-ejecutivo; en ese contexto promueven un Ejecutivo promiscuo que inevitablemente generará trastornos, porque el jefe de Estado no tiene medios para enmendar los errores o evitar los avances del cuerpo colegiado. Expresa el autor que la práctica o la costumbre no pueden estar por sobre la ley escrita; deben respetar el régimen presidencial consagrado. De esta manera comprenderán que, a pesar de querer ejercer por ejemplo un voto de censura, el Presidente igualmente puede decir que conserva sus ministros porque son de su confianza y no reconoce las supuestas facultades del Legislativo. Además, la Constitución no regula el voto de censura. De haber existido aquellas instituciones del régimen parlamentario muy probablemente la Revolución no se hubiese producido $^{768}$.

\footnotetext{
766 VICUÑA (1893) p.8.

767 VALDÉS (1893) Pp. 26-31.

768 GonZÁLEZ (1893) Pp.28-32.
} 


\section{c) Otros mecanismos de fiscalización en la Constitución Política de 1833}

Por nuestra parte, tal como lo expusiéramos precedentemente, sostenemos que la Ley Fundamental del 33 contemplaba algunos otros mecanismos de fiscalización parlamentaria y no sólo se debe reducir el análisis del juicio político. Debemos hacer presente que esta interpretación que tiende a extender la fiscalización a otros instrumentos contemplados en la norma constitucional, dice relación con aquella concepción descrita en el capítulo anterior, la cual considera que la fiscalización es un actividad que puede estar presente en las variadas funciones parlamentarias y que no se acota sólo a la acusación.

En este sentido, el artículo 36 No1 confiaba, como atribución exclusiva del Congreso, aprobar o reprobar la cuenta de la inversión de los fondos destinados para los gastos de la administración pública que debe presentar el Gobierno. Por ende, podemos visualizar una tenue pero existente fiscalización presupuestaria de los gastos de administración del Estado.

En lo tocante a los Ministros de Estado, se establecían algunas normas de interés en materia de control. En esta dirección es dable analizar el artículo 87, norma que contemplaba la responsabilidad personal de los ministros respecto de los actos que firman, y solidaria respecto de aquellos que suscriben o acuerdan con otros ministros. El artículo 88, por su parte, les imponía la obligación de dar cuenta del estado de la nación en lo relativo a cada cartera ante el Congreso una vez que éste abriera sus sesiones. Lo más relevante surge en los artículos 99 al 101, porque parecieran dar lugar a otro tipo de acusaciones, considerando que el precepto 99 establece que cualquier persona puede acusar a un ministro "por razón de los perjuicios que éste pueda haber sufrido injustamente por algún acto del Ministerio". Tal acusación se dirige directamente al Senado, el que decide si hay o no lugar a su admisión. En el caso de declararla procedente conforme a lo estipulado en el artículo 100 , debía procederse a ejercer la demanda correspondiente ante los tribunales de justicia. No bastando con ello, el artículo 101 les impone a los ministros la obligación de cumplir con plazo de seis meses de residencia una vez finalizado el ejercicio del cargo.

En conclusión, durante la vigencia de la Constitución de 1833, se creó una República bastante aparente, se conservaban algunas instituciones propias de la monarquía, se empoderaba al Presidente $y$, en cierta medida, se debilitaba al 
Congreso Nacional. El ideal democrático chileno presentaba características muy especiales, puesto que daba nacimiento a un presidencialismo fuerte mediante el cual el Jefe del Ejecutivo, por ejemplo, gozaba de amplias facultades concentradas en el artículo 82. Sin perjuicio de aquello, en otros preceptos se le otorgan otras prerrogativas en materia legislativa. Así lo demuestra los artículos 45 y siguientes, mediante los cuales se contemplaba un veto absoluto presidencial. Por otra parte, el Código Político daba lugar a una institución muy particular, la comisión conservadora, organismo que entraba en funcionamiento precisamente el día en que el Congreso concluía sus sesiones, cuyas funciones eran específicas tales como velar por la observancia de la Constitución y las leyes, dirigir al Presidente en las representaciones que estime pertinente en dicha dirección $y$, finalmente, prestar o rehusar su consentimiento en todos los actos en que el Presidente lo pidiere.

A nuestro entender, al limitar los poderes legislativos y políticos propios del Congreso, veladamente se debilitaba al órgano mismo. En tal escenario, la consagración del principio de división de poderes y la fiscalización parlamentaria, fueron una aspiración y un ideal que no logró concretarse activamente, porque en gran medida nuestra realidad política y cultural no estaba en condiciones de hacer carne dichos anhelos constitucionales. Además, hemos de tener presente que si bien es posible detectar algunos mecanismos indirectos de control, en este punto la única institución destinada a fiscalizar y a hacer exigible la responsabilidad política fue la acusación constitucional. Por consiguiente, siguiendo a Galdames diremos que el poder presidencial podía ejercerse sin ningún contrapeso, ni siquiera los ministros se configuraban en ese sentido. En efecto, la obligación que pesaba sobre los ministros de firmar algunas órdenes del Presidente tenía por objetivo central comprometer la responsabilidad de los ministros y no comprometía en nada la lenidad con la que era tratado jurídicamente al jefe del Ejecutivo ${ }^{769}$.

769 GALDAMES (1881-1941) p.939. 


\section{d) La Revolución de 1891: etapa parlamentaria y sus mecanismos de control parlamentario en el ordenamiento constitucional chileno}

Al igual que lo ocurrido en Europa nuestro país se vio fuertemente influenciado por un clima político muy especial, promovido por el liberalismo individualista y el parlamentarismo. El trascendental principio político que movilizó el pensamiento de occidente, situando al poder político en manos de la nación, la representación política expresada en el Parlamento y el nacimiento a través de sus debates de la voluntad general, daban origen a una arquitectura política revolucionaria que forjaba la absoluta preeminencia del Poder Legislativo en desmedro del Ejecutivo, fenómeno que se replicó con rapidez en las naciones emergentes de América. Mediante estos postulados, se concedía total prestigio a las asambleas legislativas y plena soberanía a la norma legal. Dicho proceso intelectual, jurídico y filosófico arribó de forma efectiva en los pueblos de América del Sur. La importante influencia anglo-francesa le dará a nuestro Congreso Nacional una preponderancia creciente. Para los grupos políticos de la época, la democracia y el progreso político iban de la mano del Parlamento. Por ello, se procuró aumentar sistemáticamente las funciones del mismo y disminuir las del Ejecutivo. La vida pública en general giraba en torno a los cuerpos legislativos, quienes se constituyeron como la salvaguardia frente al autoritarismo del Ejecutivo ${ }^{770}$.

Con el advenimiento de las nuevas ideas políticas y, en especial con el arribo del parlamentarismo en Chile, surgirán diversas complicaciones institucionales y orgánicas que afectarán directamente el desarrollo de la fiscalización parlamentaria, particularmente, la utilización de los mecanismos de control. Es por ello que nos detendremos en examinar y determinar cómo dicho proceso político incidió en la configuración de la noción de fiscalización parlamentaria en el constitucionalismo nacional, y las repercusiones que ello puede haber generado en la evolución posterior de la misma. Tales hitos históricos fueron la Revolución de 1891 y el ingreso fáctico del régimen parlamentario. Ambos acontecimientos trajeron a nuestro ordenamiento jurídico importantes modificaciones en las prácticas legislativas, en especial, en la fiscalización parlamentaria transformaciones que luego serán empujadas con reformas constitucionales. Alguna de ellas perdurarán hasta nuestros

${ }^{770}$ HeISE (1986) p. 13. 
tiempos, empero, también trajeron serias dificultades en el desarrollo del sistema político, gestando inestabilidad e intranquilidad social.

Durante el año 1886 asume el Gobierno del país don José Manuel Balmaceda, como uno de los principales referentes del liberalismo nacional. Durante los últimos meses de su gobierno dirige el país en medio de fuertes tensiones políticas que enfrentaban al Ejecutivo con el Congreso, básicamente, por la distribución del poder concretizado en las funciones específicas a realizar por cada órgano. Fruto de aquellas discrepancias, se gestará la Revolución de 1891 como culminación de un largo proceso político de dificultades multifactoriales que derivan de los reformas constitucionales de 1870, mediante las cuales se intentaba limitar el poder del Ejecutivo y trasladar atribuciones al Parlamento, especialmente promovido por las leyes periódicas, sin las cuales -a juicio de Fernando Campos- ningún presidente podía gobernar. Las leyes periódicas eran leyes constitucionales de duración periódic que autorizaban el cobro de contribuciones, el mantenimiento de las fuerzas de mar y tierra y la residencia, por ende, daban al Congreso un arma poderosa para influir directamente en la gestión del Gobierno ${ }^{771}$. De tal manera, la negativa del Congreso a aprobarlas el año 1890 desencadenó el conflicto institucional, vale decir, emerge con más fuerza la disputa entre el Poder Ejecutivo y el Poder Legislativo. El presidente Balmaceda, frente a tal ingobernabilidad, decide renovar las leyes del año anterior ante lo cual los partidos políticos de oposición se opusieron férreamente. El escenario fue tan complejo que el jefe de Estado ordena la clausura del Congreso Nacional el 11 de febrero de 1891; en virtud de aquel acontecimiento se dará inicio a una guerra civil que durará seis meses.

Por su parte, Bernardino Bravo Lira explica que las motivaciones de aquella Revolución fueron la pugna por la supremacía estatal que existía entre los partidos políticos y la Presidencia de la República. Para el autor el conflicto no se gestaba entre órganos, es decir, no hubo un roce entre Ejecutivo y Legislativo, sino que entre el Presidente y los partidos políticos que lógicamente estaban concentrados en el Congreso Nacional. Tal rivalidad tenía como fundamento apoderarse de la titularidad en el manejo del Gobierno, situación que desencadena la Revolución, en la cual

${ }^{771}$ ESTÉVEZ (1942) p.9. 
triunfan los partidos políticos, lo que significó finalmente la implantación del parlamentarismo ${ }^{772}$.

Según Eyzaguirre, la Revolución surge en razón de dos aspectos de trascendencia. Uno de ellos es la percepción que del sistema político nacional poseía la aristocracia política; la aristocracia nacional -de origen castellano-vasca- no soportaba la existencia de un régimen presidencial excesivamente autoritario como el que se encontraba vigente en Chile, sólo toleraban su sometimiento en virtud del gran temor que sentían hacia la anarquía. Un segundo factor, se compone por lo que el autor define como emancipación progresiva de la tutela presidencial, provocada por el influjo de las ideas liberales, el desarrollo de la educación y el crecimiento de la opinión pública. Crece la necesidad de disminuir el poder presidencial en beneficio del Congreso; tales objetivos se ejecutan mediante la agitación popular y las reformas constitucionales.

A partir de la Presidencia de don José Joaquín Pérez el Parlamento fue tomando un mayor protagonismo, los movimientos liberales y radicales exigirán una reforma constitucional que actualice el texto a las circunstancias políticas vigentes, su solicitud se sustentaba en la necesidad de democratizar el país. Durante los años 1871 y 1875 se realizarán una serie de reformas que limitarán la reelección del Presidente de la República, disminuirán los quórums para sesionar en ambas Cámaras, indicará incompatibilidades del cargo de diputado y otras funciones públicas como jueces y eclesiásticos, redistribuirá el número de congresistas en razón de la cantidad de habitantes de la población, establecerá la composición del Senado por votación directa, se contemplarán las funciones de la Comisión Conservadora y se regularán determinados derechos humanos como la libertad de asociación y la libertad de enseñanza, entre otros. Por otra parte, con especial interés cabe recordar que en la reforma del 24 de septiembre del año 1874 se instituyen atribuciones especiales del Presidente de la República, entre las cuales se establece el Numeral 6: "Nombrar y remover a su voluntad a los Ministros del despacho y oficiales de sus secretarías, a los Consejeros de Estado de su elección, a los Ministros diplomáticos, a los cónsules y demás agentes exteriores, a los Intendentes de provincia y a los Gobernadores de plaza".

772 BRAVO (1991) p.366. 
Además, se regula en el artículo 92 lo siguiente: "Los Ministros del despacho pueden ser acusados por la Cámara de Diputados por los delitos de traición, concusión, malversación de los fondos públicos, soborno, infracción de la Constitución, por atropellamiento de las leyes, por haber dejado éstas sin ejecución y por haber comprometido gravemente la seguridad o el honor de la Nación".

En efecto, otro elemento que contribuyó directamente en esta disputa por el mando del Gobierno y en la implantación del parlamentarismo, fue originado por algunos acontecimientos jurídicos de importancia. Las reformas constitucionales de 1873-1874 modificaron sustancialmente el régimen presidencial vigente, a tal punto que Campos señala que "quebrantaban el autoritarismo presidencial"773. Con todo, mediante estas reformas se tendió especialmente a disminuir las atribuciones del Ejecutivo y a reforzar el Legislativo; tenían por objetivo principal independizar al Congreso de las influencias del Ejecutivo ${ }^{774}$.

El proyecto de reforma fue redactado por Manuel Antonio Matta, para quien era imprescindible reforzar principios como la separación de poderes, fortalecer garantías políticas ciudadanas, limitar las atribuciones del Presidente y, en general, limitar la esfera de acción de los poderes públicos con barreras infranqueables. Aquellas reformas, efectivamente, consagraron aquellos principios, formulando fuertes modificaciones a la Ley Fundamental: alteraban la composición de la Cámara de Diputados y del Senado; establecían ciertas incompatibilidades; alteraban quórums; $y$, especialmente, limitaban las facultades presidenciales fortaleciendo al Poder Legislativo. Por consiguiente, fruto de la Revolución de 1891, se instaura de manera fáctica un régimen parlamentario, que en opinión de Eyzaguirre se ejecuta sin realizar para ello las reformas constitucionales necesarias, sino que simplemente se interpreta la Carta Fundamental en aquel sentido ${ }^{775}$.

Según Bravo Lira, con la Revolución el Presidente quedó anulado políticamente, se le priva de algunas atribuciones cobrando vida un régimen parlamentario de manera extraconstitucionalmente ${ }^{776}$. Para Heise, ellas afectaron la estructura misma

773 CAMPOS (1977) p.272.

774 AMUNATEGUi (1947) p.194.

775 EYZAGUiRRe (1953) p.163.

776 BRAVO (1991) p.367. En palabras de este autor, en el parlamentarismo chileno los principales actores fueron partidos políticos, quienes vivieron su época de oro, razón por la cual el multipartidismo llega a su máximo esplendor y con él las libertades públicas. Empero, la vigencia de tal régimen dependió en gran medida de la prosperidad económica que vivía Chile en aquellos momentos gracias al salitre. No obstante, el desarrollo social no fue una prioridad, motivando con ello fuertes presiones populares y posteriormente militares, desencadenando nuevos enfrentamientos en 1924. Debilitado el parlamentarismo, es la figura 
del régimen. De ellas surge un Poder Legislativo independiente y fuerte, armado de atribuciones fiscalizadoras, cuya finalidad era equilibrar la relación entre poderes a pesar de que lamentablemente ello no se produjera en lo concreto ${ }^{777}$. Como es posible inferir, con las reformas del año 1873-1874 se otorga la supremacía gubernativa al Poder Legislativo, y -junto con ello- se fortaleció la función fiscalizadora en las líneas que a continuación profundizaremos.

Por tanto, las reformas constitucionales importaron un cambio profundo en la organización ideada por la Constitución del 33, alterando por completo el clásico concepto en cuanto al rol político que correspondía precisamente a cada uno de los poderes del Estado. A través de las reformas, se redujeron las extraordinarias facultades del Presidente y, a su vez, se ampliaron y precisaron las facultades fiscalizadoras. Las reformas estaban llamadas a introducir una modificación en las relaciones entre los poderes del Estado (Presidente y Congreso). Como bien describe Estévez, "hasta entonces ambos poderes habían caminado unidos y hecho juntos la labor de Gobierno, en adelante iban a actuar en planos distintos"1778. Según Andrade, las fuertes críticas al extremo autoritarismo contenido en la Constitución de 1833 impulsaron dichas reformas, las que afectaron la estructura misma del régimen mediante las cuales surge un Poder Legislativo independiente y fuerte, armado de atribuciones fiscalizadoras, con la finalidad de disminuir el Poder del Ejecutivo aumentando el del Congreso y afianzando con ello la libertad ${ }^{779}$.

Como bien ha sido descrito, las tentativas por instaurar un régimen parlamentario en Chile fueron variadas, y se expresaron por diferentes vías durante este período de la historia nacional. El Congreso de 1873 a 1888 quiso establecer un nuevo régimen, cuya lucha -tal como lo expusiéramos anteriormente- finalizó con la Revolución y con el establecimiento del parlamentarismo. Por ende, aquellas transformaciones plasmaron su huella e influencia en múltiples instituciones, pero esencialmente en la fiscalización parlamentaria $y$, particularmente, en los mecanismos de control. Es por ello que a continuación realizaremos un examen de dos mecanismos de fiscalización que, gracias a la Revolución y a la instauración del parlamentarismo, ingresan a nuestro ordenamiento constitucional. Ellas son las interpelaciones y la censura.

presidencial la que vuelve a verse reforzada. Se configura como símbolo del patriotismo republicano y la clave para retornar al régimen presidencial.

777 HEISE (1950) p.82.

778 ESTÉVEZ (1942) p.6.

779 ANDRADE (1988) p.4. 
Desde nuestra óptica, aquel proceso de trasformaciones trajo a nuestro ordenamiento jurídico importantes mecanismos de suma transcendencia para nuestra investigación. Tal fue el fenómeno parlamentario en Chile que se incorporan las interpelaciones ministeriales. Cabe destacar que aquel mecanismo de interrogación -que los parlamentarios podían ejercer respecto de los ministros-, se inicia gracias a un joven diputado conservador, don Manuel Antonio Tocornal, quien introduce este hábito político de conformidad a lo que había observado en Europa. Pero, será en el Gobierno de Aníbal Pinto donde se establezca como un verdadero sistema $^{780}$.

Ahora bien, al referirnos a las interpelaciones parlamentarias es preciso realizar un estudio respecto de su regulación contemplada en el "Reglamento de la Cámara de diputados del año $1846^{\prime \prime 781}$. Particularmente, el Título noveno, numerandos 130 al 132 establecían, en términos generales, las características de esta herramienta de control parlamentario. Dichas normas señalaban algunas particularidades que cabe analizar.

Un primer aspecto, contemplado en el numerando 130 da a entender que los diputados podían interpelar a los ministros en cualquier sesión en la que ellos asistieran, con la única limitación de ajustarse a la materia que éste iba a tratar en aquella concurrencia. Sin embargo, si alguno de ellos quisiera interpelarlo sobre otras materias, debía anunciarlo y el Presidente de la Cámara aplazaba esta solicitud para la sesión inmediatamente siguiente o, en su defecto, en la próxima sesión en la que le correspondía asistir a dicho ministro. La regulación de las interpelaciones era ciertamente amplia, toda vez que se permitía un debate abierto con muy pocas limitaciones a las solicitudes de palabra de los diputados, así a lo menos lo deja de manifiesto el numerando 131. Sin lugar a dudas, el numerando 132 es el precepto que mayor atención nos provoca, puesto que no permitía la votación de una interpelación pero establecía que el proyecto de ley, decretos o las medidas constitucionales que se trataren en virtud de la interpelación se entenderán por acogidos.

Siguiendo a Heise en este sentido, diremos que el Reglamento no contemplaba limitaciones ni respecto de las materias ni respecto del tiempo que debían durar, por tanto, es posible establecer que estábamos frente a un mecanismo de gran alcance

\footnotetext{
780 HEISE (1974) Pp. 61y 62.

${ }^{781}$ Sesiones del Congreso Nacional de 1846. Sesión 8a del 24 de junio de 1846.
} 
político y jurídico. Por consiguiente, la regulación contemplada en el Reglamento de 1846 era bastante problemática respecto de las interpelaciones. Es por ello que durante la presidencia de don Ismael Valdés en la Cámara de Diputados, aproximadamente el año 1895, se propone la modificación del Reglamento a fin de evitar el obstruccionismo parlamentario que provocaban las leyes periódicas y la fiscalización parlamentaria, mediante algunos mecanismos como las interpelaciones. En palabras de Valdés, con esta normativa "El prestijio del Congreso sufria con ésto, pues se veia la facilidad con que impedia gobernar $i$ no se ve mui clara su colaboración en favor del interés nacional"782. En tal contexto, se produce una enmienda al Reglamento en materia de interpelaciones: crea el Título $X$, cuya finalidad era establecer un verdadero mecanismo de fiscalización mas no uno de obstrucción. No obstante, si bien se establecen mayores restricciones en su utilización en los artículos 118 al 121, principalmente, respecto de los plazos que le conceden a los ministros para conocer las preguntas y la información solicitada para que pueda contestar adecuadamente y en lo relativo a su iniciativa. Se concibió que la interpelación era de "propiedad" del diputado, por consiguiente, si éste obtenía la información requerida por otra vía o ya no estimaba pertinente continuar con la solicitud de información, podía desistir de la solicitud.

Sin perjuicio de aquellas modificaciones tendientes a mejorar la finalidad y naturaleza de las interpelaciones, a nuestro juicio, aquellas intenciones sólo estaban presentes en el papel pero no estaban verdaderamente incorporadas en la mentalidad política de la época. Sostenemos este comentario en virtud de las mismas palabras expresadas por Valdés, cuando señala que las reformas al Reglamento, en cuanto a los plazos de las interpelaciones, tienen por finalidad dar un tiempo prudente a los ministros para que obtengan la información necesaria para que de este modo se encuentre en condiciones de entablar "la lucha con el Diputado interpelante $i$ de debatir en iguales armas en el combate que con motivo de la interpelación se empeñe entre ambos ${ }^{\prime \prime 783}$. Por tanto, creemos que las interpelaciones como mecanismo de control parlamentario fueron concebidas como una forma agresiva de fiscalización que gestaba un ambiente de contraposición de ideales y no como una medida constructiva o informativa. Esta concepción se mantendrá en el tiempo y, en definitiva, construirá un imaginario negativo respecto de las mismas, fenómeno que más tarde incidirá directamente en su exclusión de la normativa

\footnotetext{
782 VALDÉS (1906) p.18.

783 VALDÉS (1906) p.172.
} 
constitucional nacional. En la Carta de 1925 no estarán incorporadas, tampoco serán consideradas en la Ley Fundamental del ochenta y sólo volverán al escenario político-constitucional el año 2005, a través de la reforma constitucional.

Junto con lo anterior, surgió otro influjo parlamentario: el voto de censura, no regulado constitucionalmente pero que emanaba de una especial interpretación de la norma fundamental. Se estableció -en la práctica- que si bien el Presidente podía modificar y remover ministros a su sano juicio, éstos no podían permanecer en su cargo si no contaban con una mayoría favorable en el Congreso. De tal modo que de no gozar de confianza parlamentaria, era posible destituir a un Ministro de Estado. Dicho mecanismo comprendía una medida de apremio a los secretarios de Estado para que éstos abandonaran sus cargos y, con ello, lograr rectificar el rumbo político del gobierno y así estar en armonía con el sentir del Congreso. Este mecanismo comenzó a aplicarse desde las postrimerías del gobierno de Bulnes.

En el año 1848, el diputado Miguel Gallo denuncia el excesivo abuso de poder del entonces ministro de Interior y Hacienda -señor Manuel Camilo Vial- al liderar ambas carteras, razón por la cual anuncia el voto de censura a fin de lograr que el Presidente nombrara un Ministro de Hacienda particular, indicación que luego fue votada por 27 votos a favor y 11 en contra ${ }^{784}$. Posteriormente, en el año 1849 fue censurado el gabinete liderado por José J. Pérez para luego continuar una seguidilla de censuras por largos años. A pesar de no estar constitucionalmente regulado el voto de censura, la clase dirigente desarrollaba ciertas interpretaciones que lograron dotarlo de fundamento constitucional. Mediante aquellas censuras, se estaba fiscalizando la conducta de un ministro a fin de evitar la llegada a un juicio político $^{785}$.

La aplicación de la censura, en definitiva, fue una cuestión interpretativa constitucional y respecto de ellas existieron dos tesis contrapuestas. Por un lado, se estimaba que el Presidente de la República poseía normas constitucionales que expresamente consagraban como una facultad presidencial la designación de los secretarios de Estado, de conformidad a su solo criterio y bajo su exclusiva confianza, frente a lo cual el Congreso no poseía ninguna atribución o facultad respecto de aquella materia. Por tal motivo, simplemente no tenía ninguna injerencia ni en la designación ni en la remoción y, para el caso de comprender una cosa

\footnotetext{
784 ANDRADE (1988) p.8.

785 HeISE (1974) Pp.63 Y 64.
} 
distinta, aquello vulneraba gravemente un principio del derecho público, según el cual ningún poder del Estado puede atribuirse más funciones que las estipuladas en la ley.

No obstante, desde otra vereda las mayorías parlamentarias estimaban que la Constitución contenía ciertos preceptos que, interpretados de forma conjunta, creaban un régimen parlamentario ${ }^{786}$ que esencialmente fortalecía la función fiscalizadora. Por tal motivo era posible aplicar las censuras. En este sentido se encontraban las normas que consagraban la irresponsabilidad presidencial y la amplitud en la responsabilidad ministerial, las leyes periódicas y la forma en que se ejercía la función fiscalizadora. Así lo expresa Andrade cuando señala que "en ningún artículo se encuentra la facultad de las Cámaras para censurar a los Gabinetes, para negarles u otorgarles su confianza". Sin embargo, los hechos políticos ocurridos, como la misma Revolución de 1891 y la ideología política imperante tendían a reflejar una mayoría parlamentarista. Es más, según este autor, la influencia parlamentaria fue tan significativa que se estableció la práctica de que el Jefe del Gabinete concurriera a la Cámara de Diputados y al Senado a leer las nóminas de los miembros del gabinete y a exponer su programa de acción. Sólo con el voto de aceptación podía iniciar sus labores ${ }^{787}$.

A pesar de ser una mera cuestión interpretativa la que sustentaba la aplicación de la censura en la vida parlamentaria nacional, la convicción alcanzada por los juristas de la época era concluyente. En este sentido, hemos de exponer algunas de las opiniones de Huneeus que permiten graficar esta situación. Para el autor, la facultad de llevar a cabo censuras por parte de los parlamentarios era incuestionable. Un sistema representativo que contemplaba la posibilidad de interpelar a los funcionarios de la Administración del Estado -por parte de Diputados y Senadores-, es decir, que permite pedir inspeccionar la conducta de los funcionarios, puede también exigir explicaciones para formarse un juicio cabal de los hechos. Puede además manifestar si aquella conducta se acerca o no a la esperada, sin embargo, especifica que sólo le corresponde censurar a la Cámara de Diputados y que sólo ha de recaer en los Ministros de Estado y no en otros funcionarios. Por

\footnotetext{
786 ESTÉVEZ (1942) Pp. 8 y 9.

787 ANDRADE (1988) p.10.
} 
consiguiente, expone Huneeus "No puede, pues, ponerse en duda, ni ante la teoría ni ante la práctica, la facultad de interpelar i de proponer votos de censura"1788.

Cabe señalar que el parlamentarismo criollo pudo ejercer con mayor fuerza los votos de censura debido a la existencia de las leyes periódicas y el poder que ellas le entregaban al Congreso. Según Heise, cada vez que el Ejecutivo pretendió resistir un voto de censura, el Congreso amenazaba con la posibilidad de hacer uso de su capacidad de aplazar el estudio y aprobación de las leyes constitucionales o periódicas. Como describe el autor, dichas leyes fueron el recurso de apremio más efectivo que se aplicaba cuando no surtían efectos las interpelaciones y las censuras. La supremacía parlamentaria era evidente, tales leyes le permitían imponer una línea política al Gobierno porque sin su aprobación se perturbaba gravemente el régimen financiero nacional ${ }^{789}$.

Dicho escenario político y constitucional, finalmente, gestó una imparable rotativa ministerial que sólo produjo inseguridad política. Desde 1831 a 1891 hubo 121 cambios ministeriales, entre crisis parciales y totales. A modo de ejemplo, diremos que entre 1891 y 1924 -en un lapsus de 33 años- ocuparon cargos de Ministros de Estado un número de 530 personas ${ }^{790}$. Aquel elemento dio fundamento a una de las fuertes críticas que se le han formulado a la etapa parlamentaria nacional.

En términos generales, la experiencia parlamentarista chilena no ha sido evaluada positivamente. En palabras de Heise, en Chile el parlamentarismo significó la "dictadura irresponsable del Parlamento" que mal aplicado produjo un desquiciamiento de la función pública. Según este autor, los partidos políticos simplemente se unían con una única finalidad: promover la caída y el nombramiento de ministros, satisfaciendo pequeños intereses o pasiones. En definitiva, la rotativa ministerial, entre otros elementos, hará que el régimen parlamentario provoque inestabilidad política y, por cierto, se debilitará al Gobierno, haciendo imposible configurar una gestión continua y seria ${ }^{791}$. En este mismo sentido se expresa Silva Bascuñán, quien expone que dentro de las razones por las cuales cae el parlamentarismo un factor clave fue el número de partidos políticos existentes y su indisciplina; es por ello que el multipartidismo proyectado en el Parlamento no

\footnotetext{
788 HUNEEUS (1879) p. 211.

789 HEISE (1986) p. 19.

790 ANDRADE (1988) p.11.

791 HEISE (1970) p.107.
} 
contribuyó en forjar una combinación estable y sólida. La deficiencia en el actuar de los partidos políticos se expresaba precisamente en la inestabilidad ministerial ${ }^{792}$.

Por otro lado, contrariamente a lo que se pudiera pensar, los impulsos parlamentarios no estaban precisamente orientados a someter a regulación constitucional instituciones como los votos de censura, sino que -por el contrariosolamente pretendían limitar de alguna manera su ejercicio y finalidad. En el año 1895, cuando se proponen y debaten las reformas al Reglamento del año 1846, la censura nuevamente no fue incorporada y no fueron tratadas constitucionalmente. En efecto, se planteó la necesidad de continuar con esta práctica parlamentaria con algunas restricciones en pos del desarrollo nacional, pero sin ser sometida a una regulación constitucional. En tal escenario, el Presidente de la Cámara, don Ismael Valdés, exponía que si bien era necesario poner término al obstruccionismo parlamentario era conveniente que la Cámara "pueda revocar con relativa facilidad un cambio en el Ministerio, pero que no pueda entrabar la acción del que cuenta con su confianza, impidiéndole gobernar....Hai que buscar cierta facilidad para fiscalizarlo, para hacer efectiva la responsabilidad política, pero evitar que el Ministro quede sujeto al tutelaje del Congreso que a la larga resulta perjudicial para la administración del país"

Tal como hemos dicho anteriormente, con el triunfo de las fuerzas provenientes del Congreso en la Revolución de 1891, se instaura de facto un régimen parlamentario y se utilizan mecanismos de control parlamentario de forma excesiva, lo que produjo una situación de profunda inestabilidad política. Ciertamente, existía una discordancia entre lo sostenido por la Constitución de 1833 y sus reformas, las que planteaban un régimen presidencial y lo ocurrido en el ámbito político. En este sentido, aquella infructuosa intención parlamentaria dice relación con el hecho de no contar con los resortes constitucionales necesarios para poder funcionar; su aplicabilidad de facto evidenció serias carencias normativo-constitucionales, de manera tal que Góngora explica que los políticos -en el año 1906- llegan a la conclusión de que el régimen no marchaba bien porque le faltaban algunos correctivos propios del sistema parlamentario, que no estaban contemplados en nuestro ordenamiento jurídico, como la facultad de disolver la Cámara de Diputados

\footnotetext{
792 SILVA (1963) p.43.

793 VALDÉS (1906) p.16.
} 
con acuerdo del Senado o la facultad del Congreso de introducir aumentos al gasto público $^{794}$.

Por su parte, efectivamente los partidos políticos tampoco contribuyeron en la concreción de un régimen parlamentario. Muy por el contrario, fueron los principales responsables de lo que Estévez califica como "una gestión gubernativa desgraciada", en la que los ministros fueron simplemente "esclavos de sus caprichos"795. Así, el año 1982 aproximadamente se pone término a un régimen de gabinete imperfecto e incompleto jurídicamente. Es por ello que -siguiendo a Loewenstein- diremos que estábamos frente a un proceso de mutación constitucional, puesto que ésta es una "transformación de la realidad de la configuración del poder político, de la estructura social o del equilibrio de intereses, sin que quede actualiza dicha transformación en el documento constitucional, el texto de la Constitución permanece intacto"796. Se produjo un cambio en la realidad constitucional al margen de los procedimientos formales de reforma, por un vía revolucionaria.

En el caso chileno, las normas constitucionales fueron incapaces de dominar de un modo efectivo la distribución de poder, por ende, las prácticas parlamentarias y políticas partidistas, construyeron una realidad diversa a la contenida en el texto. Este cambio informal en las relaciones entre poderes, en último lugar, generaba una incongruencia constitucional. La realidad política configuró la necesidad de enmendar el Código Político en una dirección parlamentarista, empero, ello no ocurrió. Por tanto, la consecuencia que se generó fue una profunda diferencia entre lo contemplado en el Derecho Constitucional positivo y el Derecho Constitucional material $^{797}$.

La dificultad de aquella mutación material configuraba una falta de concordancia con la intención valorativa de la Carta Fundamental, generando un problema con el sistema de la Constitución, porque lo ocurrido con la parlamentarización de la vida política promueve un cambio del sentido y significado del texto. Tal como describe Göran, los crudos hechos son lo que despliegan una virtualidad transformadora, a tal punto que podrá cuestionarse si es una mutación constitucional o un acto

\footnotetext{
794 GónGORA (1994) Pp.78 y 79. Respecto del declive del régimen parlamentario, es preciso decir que este autor también expone como factores la estrecha relación que existió entre el dinero y la política, como también la influencia que ejercieron los problemas doctrinales en materia de religión y educación.

795 ESTEVEZ (1942) p.10.

796 LOEWENSTEIN (1976) p. 65.

797 SANCHEZ (2000) Pp.105, 110,121 y 125.
} 
revolucionario de desafío ${ }^{798}$. Según Adriano Sant'Ana, en el caso de que la alternación a la Constitución sobrepase los límites de elasticidad del texto constitucional, estamos frente a una situación de mutación constitucional inconstitucional por afrontar el sistema constitucional. En consecuencia, se produce un quebrantamiento de la misma, destruyendo la vida de las normas constitucionales en un flagrante irrespeto a la Constitución ${ }^{799}$. La situación nacional comprendía un conflicto abierto con la norma fundamental, la mutación plasmaba una situación límite en la que el dilema era reformar o continuar aplicando interpretaciones ilegítimas que sólo iban a empeorar el escenario político nacional, dejando huellas profundas en la cultura política y jurídica que traerán aparejados serios problemas durante muchos años más.

En definitiva, las ideas revolucionarias, liberales y parlamentarias arribaron a Chile con fuerza. Existía plena convicción en la necesidad de derrocar los rasgos que el absolutismo había dejado en el territorio nacional, lo que se había configurado como elementos sólidos del sistema normativo. Por tal motivo, se consideraba al régimen parlamentario como la fórmula perfecta para derribar los resabios de los gobiernos autoritarios. Sin embargo, olvidaron implantar dos modificaciones de suma trascendencia para el correcto desarrollo parlamentario. Tal como describe Heise, olvidaron que en nuestra nación faltaban dos mecanismos: 1.- la existencia de una sola cámara política, tanto Senado como la Cámara de Diputados podían censurar y; 2.- el Presidente no contaba con la atribución de disolver el Congreso ${ }^{800}$.

Para concluir diremos que, sin lugar a dudas, lo más interesante en la aplicación de estos dos mecanismos de control parlamentario -las interpelaciones y la cesura-, es el hecho jurídico de que ninguna de ellas estaba contemplada constitucionalmente, e incluso en el caso del voto de censura tampoco estaba contemplado en el Reglamento de la Cámara. Sin embargo, como explica Heise, la clase dirigente las reconoció implícitamente de conformidad a la interpretación de algunas normas constitucionales y según los reglamentos camerales, precisamente, porque tal reglamento contenía la posibilidad de remover la Mesa de la Cámara, respecto de la cual era posible plantear cuestiones de confianza, lo que influyó en la aplicación de una interpretación por analogía, es decir, que aquello era igualmente aplicable a los secretarios de Estado. Cabe hacer presente que este Reglamento fue

\footnotetext{
798 ROLLNERT (2014) Pp. 130,138 y 148.

799 SANT'ANA (2012) Pp. 50-52.

800 HEISE (1986) p. 38
} 
redactado de manera muy similar al Reglamento de la Cámara de representantes de Bélgica y tuvo vigencia hasta el año 1904, siendo modificado en varias ocasiones ${ }^{801}$.

Finalmente, podemos inferir que la Constitución Política de 1833 en términos de fiscalización fue de menos a más. Originalmente, el texto nace consagrando un régimen presidencial que le otorgaba enérgicas atribuciones al jefe del Ejecutivo y que, en cierta medida, debilitaba el Poder Legislativo. Por tal motivo, la fiscalización parlamentaria quedaba reducida a la acusación constitucional y otros mecanismos de rendición de cuentas. No obstante, con la Revolución de 1891 y con el ingreso al país de los impulsos parlamentaristas, el estado del arte se ve alterado y modificado en ciento ochenta grados. El profuso ejercicio de interpelaciones ministeriales y el voto de censura, además de otros aspectos políticos, instituyeron en Chile un parlamentarismo de particulares características que se apoyó esencialmente en la fiscalización parlamentaria, como mecanismo de sobrevivencia. Pero, desafortunadamente, se produjo un uso abusivo de las mismas. Tal fueron los excesos de una fiscalización parlamentaria mal entendida que -en definitiva- se implanta una errónea concepción del régimen parlamentario y, en especial, respecto de los mecanismos de control político.

Aquella equívoca comprensión del control parlamentario, será un lastre que perdurará en nuestro país por largos años, impidiendo una regulación constitucional acorde a las necesidades políticas nacionales en materia de fiscalización. Como veremos más adelante, incluso en el debate constituyente de la Comisión de Estudios de la Nueva Constitución de 1980, los comisionados traerán a colación al momento de diseñar el nuevo modelo de fiscalización, ejemplos negativos de la época parlamentaria chilena, fijándolo como aquel parámetro del cual había que distanciarse.

\section{e) Consideraciones generales en torno a la Constitución Política de 1925}

Como fue planteado anteriormente, la conflictiva etapa parlamentaria generó en nuestro país múltiples transformaciones en la configuración del sistema político. Fruto de ello se gesta un ambiente de gran inestabilidad política, razón por lo cual y en búsqueda de mecanismos de solución a dicha compleja situación gubernamental,

${ }^{801}$ Monografías de la Cámara de diputados (1811-1945) p.22. 
se produce el renacimiento de los impulsos presidencialistas, conjuntamente con el surgimiento de ímpetus constitucionales reformistas, especialmente, a través de la figura de un carismático Presidente de la República, don Arturo Alessandri Palma. Diversos elementos desembocan en un cambio constitucional, el cual influyó fuertemente en la configuración del régimen de gobierno y en la regulación de la fiscalización parlamentaria, por ende, modifica e interviene los instrumentos de la misma. Es por ello que en los párrafos siguientes nos detendremos en el análisis de aquel proceso constitucional y sus implicancias para la fiscalización parlamentaria.

Como bien describe Eyzaguirre, "el advenimiento en 1920 a la presidencia de la República de Don Arturo Alessandri marca una etapa decisiva en la historia nacional. Con él suben al poder por primera vez como fuerza política la clase media y las aspiraciones proletarias encuentran eco en las esferas del gobierno" ${ }^{802}$. El presidente Alessandri fue un político carismático e inteligente que supo comprender la necesidad histórica del momento, justamente, proponiendo modificaciones a las categorías constitucionales. Consideraba que era necesario reformar la Constitución y generar un nuevo proyecto que abogara por el presidencialismo, para que barriera con el parlamentarismo tan desacreditado moral, política y socialmente ${ }^{803}$.

Tal fue el atractivo de este político, que durante la campaña del candidato Alessandri se gesta una mística diversa que se transforma en el factor fundamental del triunfo, dando nacimiento a un nuevo estilo de hacer política mediante concentraciones masivas y eslogan. Es así como se dejará atrás la clásica política elitista para abrirse a todos los espacios sociales. Aquella perspectiva descrita respecto de la figura de Alessandri es compartida por Bernaschina y Pinto, para quienes el Presidente fue un atento observador social que supo adelantarse a las circunstancias, siendo capaz de proponer interesantes salidas institucionales a través de las cuales logró el éxito electoral ${ }^{804}$.

Particular importancia tuvo en el triunfo electoral la vinculación de Alessandri con las Fuerzas Armadas. Con posterioridad a 1891, el Ejército estaba derrotado y olvidado, hallándose en situación de pobreza material y atraso técnico. Por consiguiente, emergen desde sus filas inquietudes y críticas; según Cea Egaña,

802 EYZAGUiRRE (1953) p.167.

803 GÓNGORA (1994) p.130.

${ }^{804}$ Creemos imprescindible comentar que, si bien la figura de Alessandri generó un estilo político diverso y atractivo, sólo obtuvo un voto más que su contendor. Así, el señor Barros Borgoño obtuvo 176 votos y Alessandri 177, finalmente logra llegar a la presidencia en virtud de un fallo del Tribunal de Honor, el cual le da el triunfo electoral. 
nacen grupos secretos y logias ocultas que asumieron una posición de reproche frente al manejo indolente de la clase alta. Tales grupos encontraron contención y apoyo en algunos líderes políticos, entre ellos el entonces avezado Senador Arturo Alessandri, quien era un hábil, experimentado y visionario parlamentario capaz de captar con oratoria sus inquietudes. Por aquellas razones, en 1920 los uniformados apoyarán al nuevo presidente Alessandri. Sin embargo, con el correr de los años sus promesas no fueron cumplidas y dichos grupos hicieron valer sus demandas, pero continuaron sin respuesta. De esta manera, comenzará a gestarse un estado de crisis en el sistema democrático nacional, mediante fenómenos políticos hasta entonces desconocidos ${ }^{805}$.

En lo concerniente al tema constitucional, estos autores señalan que mediante la propuesta de un nuevo texto pretendía corregir los problemas que había generado el parlamentarismo. Proponía una división clara en la distribución de atribuciones entre el Poder Ejecutivo y el Legislativo, imposibilitando que pudiera imponerse indebidamente uno sobre el otro, es por ello que plantearía en su proyecto de código político un régimen intermedio ${ }^{806}$.

Alessandri asume como Presidente al 23 de diciembre del año 1920, oportunidad en la que insiste en la necesidad de reformar la Constitución vigente. Empero, las dificultosas circunstancias políticas y económicas nacionales atenúan aquellas intenciones. Al año siguiente, en su mensaje presidencial aminoró sustancialmente los impulsos reformistas, empero, continúa haciendo presente la necesidad de a lo menos modificar la Ley Fundamental. En este sentido, plantea la posibilidad de introducir la disolución del Congreso por lo menos una vez durante su gobierno. En términos generales, el Presidente trazaba la idea y necesidad de armonizar las relaciones entre poderes ${ }^{807}$.

Según describe Silva Bascuñán, el año 1922 el Presidente le encarga al diputado José Maza la redacción de un proyecto de reforma, quien elabora una propuesta que no tendrá ningún efecto, puesto que las circunstancias nacionales lo impedirán. En aquel momento el mapa político era complejo. Tal como narra este autor, la oposición política se mostró desde el comienzo amplia y activa, especialmente luego de las elecciones parlamentarias del año 1921 en las cuales el presidente Alessandri

\footnotetext{
805 CEA (2008) Pp. 29 y 30.

806 BERNASCHINA Y PINTO (1945) p.19.

807 ANDRADE (1988) Pp. 18 y 19.
} 
no logró formar una mayoría en el Senado y sólo dispuso de la Cámara de Diputados ${ }^{808}$. Las luchas políticas adquirieron gran intensidad concentrándose fundamentalmente en una férrea oposición hacia la figura de Alessandri, y, por consiguiente, en los proyectos de gobierno. Dicha oposición se hacía sentir a través de múltiples mecanismos, como por ejemplo la no aprobación de las leyes periódicas. Respecto de este escenario, dice Andrade, el Presidente llegó a tener incluso redactada su dimisión en forma de manifiesto hacia el país. Por tales motivos, no pudo finalmente continuar con su proyecto constitucional, en general se vio restringida y amenazada la continuidad del programa de Gobierno y su mandato.

A pesar de las extraordinarias características del Jefe del Gobierno, primaron las dificultades. En el año 1924 intentará nuevamente reformar la Constitución y planteará la necesidad de poner término al asambleísmo parlamentario, esbozando la necesidad de instaurar un nuevo régimen presidencial sobre bases democráticas, y así dar solución a la cuestión social, pero nuevamente encontró un duro rechazó de parte del establishment; las reformas constitucionales quedaron nuevamente postergadas. Las Fuerzas Armadas presionaron al Presidente para que insistiera en ellas, pero ello nunca fue posible. Sin perjuicio de aquello, fueron legisladas y aprobadas otras normas que provocaron la irritación del Ejército ${ }^{809}$. Esta es la principal razón por lo cual su mandato concluye antes de finalizar el período establecido constitucionalmente, produciéndose un término abrupto a su gestión en el año 1924. El motivo de aquel anticipado cese de funciones se produce a raíz del debate parlamentario en el que se pretendía fijar la dieta parlamentaria. Tal situación gesta un conflicto social que genera estupor e indignación en la opinión pública $^{810}$.

A mayor abundamiento, diremos que en virtud del complicado déficit económico que existía en el país, se hacía cada vez más complejo aprobar el presupuesto nacional, las leyes relativas al gasto público y la legislación social. Múltiples pagos se vieron retrasados durante largo tiempo. Entre los afectados por esta situación, se encontraba la oficialidad del Ejército y de la Armada quienes venían sufriendo como los demás empleados públicos de los bajos sueldos tardíamente pagados, a causa de

\footnotetext{
808 SiLVA (1963) Pp. 49 y 50.

${ }^{809}$ CEA (2008) p.30.

810 ANDRADE (1988) Pp.21, 22 y 23.
} 
los habituales retardos en la aprobación de los presupuestos ${ }^{811}$. Pese a aquellas complejas condiciones políticas y económicas, los parlamentarios legislan y aprueban su propia dieta parlamentaria. Tal situación configuró un difícil escenario entre la presidencia y la joven oficialidad del Ejército, quienes realizaron diversas gestiones de presión para obtener un acuerdo que les permitiera conseguir la aprobación de la ley de presupuesto.

El descrédito del Congreso era irresistible, como también lo era la situación del Presidente de la República que apoyaba tal órgano. Es por ello que finalmente se produce una violenta intervención de la oficialidad superior del ejército el 5 de septiembre de 1924. Mediante este pronunciamiento, se produce un acuerdo entre las partes y se pondrá fin al parlamentarismo nacional ${ }^{812}$. Tal como describe Emilio Bello, la reacción de la opinión pública y de los jóvenes militares era el rechazo hacia un régimen anárquico que esterilizaba la labor del Congreso, al mismo tiempo que entorpecía la marcha regular del gobierno y su estabilidad. La crisis del sistema parlamentario era necesaria para abrir camino a la reforma constitucional sobre la base de la independencia y separación de poderes ${ }^{813}$.

El inusitado movimiento militar finalmente logra un acuerdo con el presidente Alessandri, quien acepta en su gran mayoría las peticiones de los oficiales. En efecto, durante los días 8 y 9 de septiembre se despachan y promulgan una serie de leyes contenidas en el pliego de peticiones de los militares. Pero, a pesar de aquel avance, el mismo 9 de septiembre el Presidente renuncia al cargo y pide autorización para salir del país. La intervención militar y la presión ejercida sobre Alessandri, alteraba superlativamente la noción de República que el mandatario poseía.

Por su parte, las Cámaras no se pronunciaron respecto de la renuncia e incluso en una primera instancia la rechazaban; luego de cierto debate en torno a la conmoción social que ello generaba y a la mayor gravedad que implicaba la renuncia del Presidente para el orden constitucional, le conceden un permiso para ausentarse del país por seis meses. Una vez autorizado, el Presidente busca asilo en la

811 CAMPos (1977) p.307. Hemos de hacer presente que los oficinales del ejército motivados por sus demandas laborales, asisten inusitadamente a las sesiones del Senado en señal de muda protesta por el despacho de otras leyes. En una ocasión, salen de aquel edificio arrastrando sus sables provocando un fuerte ruido, el que será conocido en nuestra historia como el "ruido de sables".

812 EYZAGUiRRe (1953) p. 167.

813 BeLLo (1954) Pp. 7 y 8. 
Embajada Norteamericana ${ }^{814}$. Según Donoso, el malestar de la Armada se debe a la propia actuación del Presidente, hechos que finalmente promueven su renuncia y su asilo, es por ello que expresa el autor "Alessandri dejó así un programa de brillantes promesas sin cumplir ${ }^{\prime 815}$.

En tal escenario, comenzó a funcionar una Junta Militar de Gobierno compuesta por el Inspector General del Ejército y otros representantes de las Fuerzas Armadas, los cuales establecen como imperiosas exigencias del momento proceder a la disolución del Congreso, el alejamiento del presidente Alessandri y la convocatoria a una asamblea constituyente ${ }^{816}$. Sin embargo, el ambiente hostil generalizado no le permitió seguir gobernando, razón por la cual se declaró disuelta el 13 de diciembre. Luego de aquella infructuosa enunciación militar asume un nuevo gabinete especial, pero su duración fue igualmente breve. Así, y en aquel estado de inestabilidad e inseguridad política, con fecha 23 de enero del año 1925 se produce un golpe de Estado en manos de los militares, con la finalidad de convocar a una asamblea constituyente.

En tal desconcertado contexto, la Junta de Gobierno y los presidentes de los partidos de la Alianza Liberal deciden finalmente comunicarse con el presidente Alessandri mediante telegramas, puesto que éste se encontraba en Venecia. Le solicitan que retorne a Chile y asuma nuevamente su cargo, a fin de dar término a su período constitucional. Mediante un telegrama, Alessandri accede regresar a Chile en la medida que se establezca un gobierno civil y se dé comienzo a un proceso constituyente. Fue así como el 20 de marzo de 1925 arriba a Chile y la Junta Militar le entrega el mando del gobierno ${ }^{817}$.

Según Bello, Alessandri fue recibido triunfalmente en medio de aclamaciones delirante de las multitudes. Se le tributó el mayor homenaje que se puede ofrecer a un hombre de Estado y eminente servidor público. Para este autor, la vuelta al poder del mandatario, por obra de los mismos elementos de las Fuerzas Armadas responsables de su accidental alejamiento de la Presidencia, importaba en los hechos el restablecimiento del legítimo gobierno civil y constitucional, demostrando "que la revolución no tuvo por objetivo derrocar al Gobierno, sino el patriótico objetivo de

\footnotetext{
${ }^{814}$ Silva (1963) p. 51. La moción fue aprobada en el Senado con 16 votos a favor y 11 abstenciones, y en la Cámara de Diputados también fue aprobada por 47 votos a favor y 37 abstenciones.

815 DonOSO (1976) p. 273.

${ }^{816}$ BELLO (1954) p.10.

817 ANDRADE (1988) Pp. 24, 25 y 26.
} 
obtener la reforma de un régimen anárquico cuya crisis definitiva era un hecho innegable" ${ }^{\prime \prime 18}$.

Con fecha 4 de abril, el Presidente sostuvo una reunión con diversas personalidades nacionales para tratar la organización de la asamblea constituyente. El 7 de abril, a través de decreto designó una comisión consultiva cuya finalidad era informar respecto de la organización y el procedimiento a que debe ceñirse la asamblea constituyente. Posteriormente, se constituirán dos Subcomisiones: una dedicada a preparar el proyecto de reforma y otra a considerar la manera en que serían aprobados los cambios. La Comisión de reformas realizó un activa labor y fruto de aquello surgen dos proyectos, uno inicial que se llamó "la prueba azul" y una segunda versión revisada que se denominó "la prueba amarilla", respecto de la cual se formularon nuevas y vastas consideraciones, debiendo volver a la Subcomisión para dar cumplimiento a las recomendaciones.

Por su parte, la subcomisión, que tenía por misión determinar el mecanismo para aprobar la reforma constitucional, sufrió diversas complicaciones en cuanto a la forma en que habría de expresarse la voluntad general. Explica Silva Bascuñán que el Presidente estaba tan entusiasmado en el proyecto de reforma que quería hacerlo triunfar en consulta directa al electorado y no a través de debates en una asamblea constituyente ${ }^{819}$, debido a la demora que ello podía generar, a las alteraciones que podía sufrir el proyecto $y$, en definitiva, porque él debía dejar el cargo ese mismo año.

Empero, en las sesiones de la Subcomisión Redactora el número de participantes fue muy reducido. En dicha Comisión no se votaba, solamente se recogían y aunaban opiniones en cuanto fueran compatibles con la idea central de "poner límites razonables a la intervención parlamentaria y a su vez a la excesiva participación partidista" en la administración del Estado. En el desarrollo de la misma, se produjeron fuertes desavenencias entre sus miembros, principalmente, respecto de los fundamentos sustentados por el Presidente quien dirigía los debates y abogaba por el proyecto oficial. Tal fue la magnitud de las diferencias de criterio que el General Navarrete con particular fuerza hace presente a los asistentes la premura de la Constitución, puesto que ella configuraba el mecanismo que evitaría el peligro de no recuperar la normalidad. Además, no acordar un texto implicaba desconocer las

818 BELLO (1954) p. 167 y 168.

819 Silva (1963) Pp. 53, 54 y 55. 
demandas del Ejército y la intervención militar nuevamente sería una amenaza ${ }^{820}$. Finalmente, las sesiones de la Subcomisión de reformas finalizaron en el mes de agosto.

Por ende, era necesario determinar el procedimiento mediante el cual proceder a su aprobación social, pero aquella definición fue compleja y se vio interferida por múltiples factores como, por ejemplo, el término del mandato del Presidente en el mes de diciembre del mismo año 1925, entre otros elementos. Así, se determinó que el mecanismo más correcto a utilizar era una consulta popular. Los resultados de aquella consulta le dan un $43 \%$ de apoyo al proyecto de reforma. Si bien se aprueba la reforma tal apoyo no fue ampliamente mayoritario. El decreto promulgatorio de la nueva Carta Fundamental se suscribe finalmente el 18 de septiembre de 1925, pero entraría a regir treinta días después de su publicación en el Diario Oficial, entrando en vigor el 18 de octubre de $1925^{821}$.

Tal como describe Kelsen, la Constitución chilena de 1925 "es producto de aquel movimiento antiparlamentario que hoy se propaga, también en Europa, por doquier $^{\prime 822}$. Tras una serie de discusiones se instauraba un régimen presidencial que promovía fuertes facultades al Ejecutivo, fruto de una tendencia política masiva. Según el autor, las atribuciones del Presidente en el texto eran excesivas, poseía una influencia decisiva en la tramitación legislativa y en el campo legislativo en general. Pero, en especial, carecerá del derecho de disolver el Parlamento o prorrogar su actividad. Es más, las funciones del Parlamento se determinan por una enumeración taxativa y el Presidente posee una garantía general, situación totalmente opuesta a los regímenes parlamentarios, relegando a un segundo plano al Congreso.

El autor, respecto de la responsabilidad política expresa que en forma coherente con el extraordinario poder que se le entrega al Presidente, la Constitución acentúa la responsabilidad del mismo de forma muy particular -cabe mencionar la causal "actos de su administración que hayan comprometido gravemente el honor y la seguridad del Estado"-, además de establecer especiales quórums. En definitiva, la Constitución chilena seguía aquel problema contemporáneo de restringir el poder del Parlamento, en beneficio del Presidente.

\footnotetext{
820 DONOSO (1976) p. 280.

${ }^{821}$ SILVA (1963) p. 58.

822 KeLSEN (2002) p. 643.
} 
Con la dictación de la Carta del 25 se inicia un período encaminado a robustecer el poder presidencial. Coincidirá con un momento de importantes transformaciones a nivel mundial, respecto de las cuales Chile también recibirá sus influjos, impulsando un cambio social e institucional. Por otra parte, cabe hacer presente que a pesar de los esfuerzos de Alessandri por eliminar el parlamentarismo del texto constitucional, ello no era del todo posible porque conservadores, comunistas y radicales continuaban creyendo en las bondades del régimen parlamentario para el desarrollo político nacional. Desde su perspectiva, sólo era necesario eliminar los rasgos problemáticos del pasado. Particularmente, defendían con fuerza el vínculo de confianza entre el gabinete ministerial y el Parlamento, sosteniendo que mediante el voto de censura se establecía un mecanismo preventivo y con la acusación un instrumento represivo, puesto que el Gobierno necesita un orientador político que lo aproxime a la voluntad del pueblo y los ideales políticos. Por tal motivo, Eyzaguirre expone que la sola Constitución de 1925 no será suficiente para encauzar ni contener la honda mutación nacional ${ }^{823}$. Eventualmente, aquella apreciación dice relación con lo descrito por Donoso, cuando describe que la Carta del veinticinco no fue aceptada por los partidos políticos. En lo concreto no había Congreso en funciones, no era posible seguir el procedimiento de reforma establecido en el texto constitucional de 1833, como tampoco fue aprobado por una amplia mayoría, considerando la alta tasa de abstención ${ }^{824}$.

En consecuencia, la sola incorporación literal del cambio del régimen de gobierno no era suficiente para lograr las transformaciones en la cultura jurídica y política del país. A pesar de los esfuerzos del presidente Alessandri, los partidos políticos de la época continuaron promoviendo un régimen parlamentario $y$, por ello, insistieron en aplicar mecanismos propios del modelo, no obstante estar regulados por una norma fundamental que aspira modificar las nefastas expresiones de un parlamentarismo criollo. Prueba de aquello serán los años de gobierno del militante del partido liberal democrático Emiliano Figueroa -entre los años 1925 y 1927-, en el cual el Parlamento -apenas reinstalado- revive prácticas parlamentarias demostrando su disconformidad con el sistema presidencial instaurado. Cualquier herramienta era utilizada por los partidos políticos para restablecer sus influencias en el gabinete ministerial.

823 EYZAGUiRRe (1853) p.168.

${ }^{824}$ DonOSO (1976) Pp. 272 y 282. 
Con todo, tal como describe Pfeffer, con la Constitución de 1925 se incorporarán importantes innovaciones de fondo. Respecto del sistema de gobierno, se extirpa todo germen del parlamentarismo. Para ello se establece un presidencialismo mediante el cual el Presidente de la República nombra y remueve a su voluntad a los Ministros de Estado. Loa acuerdos que adopte la Cámara de Diputados, ejerciendo la facultad de fiscalización, no afectarán la responsabilidad política de los mismos; se declararon incompatibles las funciones de congresista y Ministro de Estado; se otorgaron amplias atribuciones colegisladoras al Presidente, entre ellas la de sancionar y promulgar la ley, iniciativa exclusiva en ciertas materias; los ministros estaban facultados para defender sus proyectos ante el Congreso; se pone término a las leyes periódicas, con excepción de la ley de presupuesto, que se regula especialmente; se separa la Iglesia del Estado; se incorporan débilmente derechos sociales, lo que constituye un avance significativo; se suprimen órganos como el Consejo de Estado y la Comisión Conservadora, pero se crean otros como los Tribunales Administrativos y las Asambleas provinciales ${ }^{825}$.

En palabras de García-Huidobro, con la Constitución de 1925 se da inicio a un proceso de apertura a nivel jurídico-constitucional. Con la Norma Fundamental, además de garantizar derechos políticos y sociales, se da comienzo a un proceso de apertura y democratización que eventualmente permitiría incorporar a la mujer dentro del proceso electoral con un derecho a voto que fue adquiriendo de forma paulatina, con la reducción de la mayoría de edad de 21 años a 18 y con la concesión de voto a las personas con discapacidad y analfabetas ${ }^{826}$, entre otros elementos que permitirán construir un sistema político más representativo y justo, factores que posteriormente contribuirán en la configuración de una sociedad muy politizada.

Bajo la vigencia de la Constitución de 1925, en términos generales, se produjo un importante progreso económico para Chile, especialmente durante los gobiernos del Partido Radical (presidentes Aguirre Cerda, Ríos y González Videla). Estos gobiernos se caracterizaron por un Estado fuerte, gestor y empresario, bajo el cual se produce el auge industrial del país. Según José Luis Cea, estábamos frente a un Estado socialdemócrata, pluralista y de compromiso entre los partidos. En las tres décadas entre 1932 y 1964 se experimentaron progresos sociales ostensibles en salud y en el crecimiento de los grupos intermedios, como los sindicatos. Sin perjuicio de aquello,

825 Pfeffer (1987) Pp. 26 y 27.

826 GARCÍA-HUIDOBRo (2010) p. 403. 
no fue posible establecer un Estado de Bienestar, puesto que si bien existían las ideas ellas no pudieron ser materializadas por falta de experiencia y capacidad técnica. Por otra parte, tal como describe Cea, no hubo un eje programático claro consolidado en un centro ideológico que perdurara. Cada período presidencial fue diverso. Luego de los gobiernos radicales vendrá un nuevo Gobierno autoritario de Alessandri Palma hasta 1938 y más tarde el populismo del General Ibáñez desde 1952 a 1958, seguido del neoliberalismo de Alessandri Rodríguez desde 1952 a $1964^{827}$.

\section{f) Análisis general de la fiscalización parlamentaria en la Constitución de 1925}

Es preciso comenzar señalando que la Constitución de 1925 no tuvo un alcance totalmente modificador respecto de la de 1833, puesto que esta última se caracterizó por dotar de una sólida organización al país durante casi un siglo, siendo garantía de un orden interno. Muchas de sus normas se mantuvieron en la nueva Carta Fundamental; tal fue la continuidad en el contenido de la misma, que se ha discutido por la doctrina si en 1925 se realizó una reforma o una nueva Constitución.

Tal como se describiera precedentemente, una de las razones que motivaron la dictación de esta nueva Carta fue la existencia de un conflicto relativo a la distribución de funciones, surgido entre el Presidente y el Congreso. Por ello, el tema central que se plantea en el debate constituyente es el problema de resolver si la Carta Fundamental consagraría un régimen parlamentario con predominio del Congreso, o si ella debía establecer el equilibrio o separación de ambos poderes sin la subordinación de facultades, base del sistema presidencial. A pesar de la agitada corriente parlamentaria existente en el país, lo cierto fue reconocer un hecho indiscutible: el régimen parlamentario en Chile había generado una crisis política e inestabilidad, por consiguiente -en opinión del presidente Alessandri y un sector de las fuerzas políticas-, era más prudente establecer un Ejecutivo fuerte que gobierne y administre, y un Parlamento que legisle y fiscalice los actos del gobierno ${ }^{828}$. Sin perjuicio de la intencionalidad del jefe de Estado y de la fuerte influencia que

827 CEA (2008) p.36.

828 BeLLo (1954) Pp. 179 y 180. 
ejercerá en dicha dirección, la realidad jurídica y política no aceptó con facilidad la transformación y los resabios del parlamentarismo se mantendrán vigentes.

Siguiendo aquella definición política, la Constitución de 1925 contenía importantes transformaciones. Esencialmente, estableció como régimen de Gobierno el sistema presidencial; consagró la separación iglesia y Estado; suprimió la Comisión Conservadora, el Consejo de Estado; crea el Tribunal Calificador de Elecciones; contempla como mecanismo de selección del Presidente la elección directa y fija como período de mandato seis años; incluye garantías constitucionales como la propiedad y el carácter progresivo de los impuestos y establece la dieta parlamentaria, entre otras variadas modificaciones. Finalmente, tal y como describe Thayer, con la Constitución de 1925 se buscó fortalecer el poder presidencial, "distanciándose de la especie de caricatura del modelo parlamentario inglés que se había impuesto desde 1891". Por consiguiente, se introducen cambios esenciales en materia de fiscalización parlamentaria. En efecto, con esta Carta Fundamental se produce la eliminación de las funciones políticas y fiscalizadoras del Senado y le son entregadas de forma exclusiva a la Cámara de Diputados; por tanto, será dicha Cámara a la que le corresponderá ejercer la facultad de fiscalizar y de acusar constitucionalmente al Presidente de la República, figura que se mantendría en la carta constitucional siguiente y vigente a la fecha ${ }^{829}$.

Dicho lo anterior, es posible hacer presente que con la Carta del veinticinco se producen una serie de importantes mutaciones para el control parlamentario. Por un lado, se entrega en forma exclusiva la facultad de fiscalización a la Cámara de Diputados, elemento trascendental en la concepción del control políticoparlamentario. Recordemos que bajo la Carta del 33 tanto la Comisión Conservadora como el Consejo de Estado ejercían cierto control, por tanto, ahora sólo será resorte de los parlamentarios y, en especial, de las mayorías parlamentarias la activación del control. Por otro lado, se produce una separación clara respecto de la fiscalización parlamentaria y la acusación constitucional. Tal como veremos posteriormente, se configuran dos vías distintas de fiscalización.

Continuando con lo anterior, es preciso traer a colación algunos de los comentarios de Silva Bascuñán respecto de los rasgos más esenciales de la nueva Ley Fundamental. En este sentido, plantea que la Carta presenta características

829 THAYER (1992) p. 357. 
relevantes, entre las que se encuentra precisamente, una forma más perfecta de sistematización conceptual, que deslinda las esferas de competencia entre ambos órganos -que antes no estaban señaladas- como, por ejemplo, las atribuciones exclusivas de las Cámaras del Congreso. En este mismo sentido, expondrá el autor, otra virtud fue establecer un sistema de relaciones entre los poderes Ejecutivo y Legislativo. En el marco de aquel objetivo, el constituyente delimita las funciones de cada órgano -permitiéndole al Presidente nombrar y remover ministros- contempla incompatibilidades entre los cargos de parlamentario y ministro, concede amplísimas atribuciones al Presidente en materia legislativa mediante la iniciativa, el veto y la posibilidad de colocar urgencias legislativas, etc. ${ }^{830}$

Especial preocupación tuvo el constituyente en cuanto a regular expresamente la separación de los roles que podían ejercer los actores políticos de la época. Es por ello que los artículos 28 y 29 contemplan las incompatibilidades, inhabilidades e incapacidades para ejercer el cargo de parlamentario. El constituyente, en definitiva, fija requisitos y condiciones de elegibilidad. El artículo 28 estipula que no podrán ser elegidos como diputado y senador aquellos cargos propios de la administración pública como ministros, intendentes y gobernadores; también traza una línea de separación con el Poder Judicial, toda vez que se prohíbe postular a los escaños parlamentarios a magistrados de los tribunales superiores de justicia, entre otros. Por otra parte, fija un límite a determinados miembros del mundo privadoempresarial, cuyas sociedades posean contratos con el Estado. La separación entre la política y el dinero fue un aspecto relevante para el constituyente de la época. Por su parte, el artículo 29 profundizará aún más aquellas incompatibilidades, extiende el ámbito de funcionarios públicos que deberán optar por una u otra función. Por tanto, estas instituciones pretendían asegurar la dignidad, la capacidad y la independencia del parlamentario en el desempeño de su cargo y en relación con los demás órganos y autoridades ${ }^{831}$. Esta separación durante la particular vigencia del régimen parlamentario no existía, situación que se configura como un factor determinante en el ejercicio de la facultad fiscalizadora, debido al gran interés que provocaba la posibilidad de acceder a cargos públicos de mayor relevancia política.

${ }^{830}$ SiLVA (1963) Pp. 59 y 61.

831 SILVA (1963) p.17. 
En consecuencia, la nueva Constitución viene a configurar una separación más concreta entre los poderes, por consiguiente, debía a su vez diseñarse una nueva arquitectura respecto de la fiscalización parlamentaria más clara y concreta. En ese camino, se produce la supresión de órganos como el Consejo de Estado y la Comisión Conservadora, instituciones que igualmente gozaban de facultades de control político muy colindantes a la fiscalización parlamentaria. El desafío del nuevo texto constitucional fue arduo. A continuación, examinaremos elementos doctrinales y regulatorios en torno a la forma en que se abordó este tremendo objetivo institucional.

Respecto de los controles políticos, Bernaschina y Pinto señalan que el presidente Alessandri sostuvo con firme convicción su mirada respecto de esta materia y la importancia de ella; así, señalaba que siempre era posible que el Presidente pudiera abusar del poder por el solo hecho de ser hombre. No obstante, existirán las garantías para evitarlo. Desde aquella perspectiva, estipulaba dos mecanismos: el primero era el pueblo, puesto que el Presidente tenía como origen la manifestación de la voluntad popular, por ende, dentro de aquel ideal democrático se debía suponer que el pueblo era ilustrado y no escogería a alguien incapaz. Además, el Jefe de Estado tiene límites constitucionales y debía respetarlos como también resguardar las garantías y libertades. Un segundo mecanismo, era el juicio político. Para Alessandri, la figura del Presidente ha de ser responsable, por consiguiente, puede ser acusado por determinadas situaciones mediante un procedimiento rápido y simple $e^{832}$.

En igual sentido se expresa Eyzaguirre, quien describe que al instaurar el régimen presidencial se dispuso al Parlamento de la facultad fiscalizadora, mediante la cual ha de fiscalizar los actos de gobierno sin afectar la responsabilidad de los ministros. En este mismo orden de ideas, se establece la incompatibilidad entre las funciones de parlamentario y ministro; se crea como única ley periódica la ley de presupuesto nacional, respecto de la cual se otorgaba un plazo de 4 meses para debatirla, y en el caso de no ser aprobada regiría el proyecto presentado por el Presidente. Finalmente, contemplaba la responsabilidad directa del Presidente mientras esté en funciones ${ }^{833}$. Con todo, es posible percibir cómo mediante diversos preceptos constitucionales se marca una línea divisoria entre el parlamentarismo y el

832 BeRnASCHINA Y PinTo (1945) Pp. 24y 25.

833 EYZAGUIRRE (1953) p.169. 
presidencialismo y, adicionalmente, se configura una clara limitación a la facultad fiscalizadora puesto que se esgrime concretamente la irresponsabilidad ministerial, junto con diferenciar los roles de congresista y miembro del gabinete ministerial, de modo tal que no pudiera existir manera alguna o interpretaciones antojadizas que pudieran inducir a una errónea concepción parlamentaria contendida en la Ley Fundamental.

Ahora bien, en este contexto se zanjará además aquella irregular situación que creaba la censura. Este proyecto de Constitución suprime la posibilidad de censuras ministeriales debido a que su utilización no fue más que una lamentable confusión que provocó el régimen parlamentario, el cual creía que las libertades e independencias estaban vinculadas a esta facultad de la Cámara de Diputados, pero verdaderamente aquella herramienta no tenía más finalidad que la de inmiscuirse en el Gobierno. En este proyecto constitucional se diferencian funciones: el Ejecutivo debe administrar y el Legislativo fiscalizar y legislar ${ }^{834}$.

A continuación, realizaremos un análisis sistemático del contenido del texto constitucional, formulando especiales consideraciones en cuanto al control políticoparlamentario que en ella se expresa $y$, especialmente, nos pronunciaremos sobre el régimen presidencial contemplado en la norma fundamental.

En primer lugar, y tal como lo hemos venido señalando, el texto constitucional del veinticinco consagró una serie de atribuciones y obligaciones al Presidente de la República. El artículo 72 de la Ley Fundamental contemplaba un gran catálogo de atribuciones exclusivas. En dicho precepto se contemplaban vastas facultades como la posibilidad de concurrir a la formación de las leyes, la facultad reglamentaria, la posibilidad de nombrar a su voluntad a los ministros, intendentes, gobernadores, embajadores, jueces de los tribunales superiores de justicia, jueces civiles y algunos empleos civiles y militares, entre otras autoridades del Estado. No bastando con establecer tan vasto abanico de atribuciones presidenciales, en materia legislativa puso un especial énfasis. El artículo 46 de la Carta le concedía la posibilidad de intervenir el proceso legislativo e incidir directamente en los tiempos y la agenda del Poder Legislativo, a través de la posibilidad de aplicar urgencia al despacho de un proyecto de ley, ya sea en uno o en todos sus trámites. De esta forma, los plazos de tramitación se veían fuertemente disminuidos. Así, se configuró otra facultad del

834 Bernaschina y PinTo (1945) p.26. 
Presidente determinante en el desarrollo institucional del legislador y que, en definitiva, le permite inmiscuirse en el mismo de manera determinante: el derecho a veto y la iniciativa legislativa exclusiva en las materias de mayor interés nacional. Con esto se comienza a dar nacimiento al denominado poder Ejecutivo colegislador.

Sin embargo y pese a la importante nómina de facultades que se le atribuyen al Ejecutivo en la Carta Fundamental, se diseñan algunos mecanismos que pretenden configurar el contrapeso al Ejecutivo. Uno de aquellos elementos cuya finalidad es equilibrar la figura presidencial armónicamente con el Poder Legislativo, se expresa en el nuevo tratamiento de la ley de presupuesto, toda vez que el nuevo texto constitucional establecía que la gestión financiera le correspondía al Presidente en colaboración con el Congreso, pero evitando en todos los casos que aquella colaboración pueda limitar en alguna forma la libertad de acción del Presidente. El artículo 45 en el inciso segundo le concede la iniciativa exclusiva al Ejecutivo respecto de las materias propias del presupuesto de la nación, precepto que -a nuestro juicio- se encuentra en perfecta concordia con el artículo 72 No 10, el cual le impone el deber de velar por las finanzas públicas. Es por ello que el Presidente deberá, de conformidad al artículo 44 No 4, presentar la ley de presupuesto al Congreso Nacional con cuatro meses de anticipación con el objetivo de analizar el debido equilibrio en las finanzas públicas, proceso legislativo que de no llegar a buen puerto, vale decir, que de no ser aprobado por el Congreso, se entenderá aprobado el proyecto presentado por el Ejecutivo, una vez transcurrido el plazo para su debate.

De esta manera, con el nuevo tratamiento de la ley de presupuesto se generan dos mecanismos de seguridad para el sistema político. Por una parte, se incorpora al Parlamento en el debate de la misma, pero se estipula un plazo para el desarrollo y análisis parlamentarios. Por otra parte, se establece una especie de "sanción" en la eventualidad de que los parlamentarios dilaten injustificadamente su aprobación o se nieguen a aprobarla sin motivos razonables. Tal apremio será la entrada en vigencia de la ley conforme al proyecto presentado por el Ejecutivo. Mediante esta fórmula constitucional, se eliminaban las dificultosas leyes periódicas, se delegaba en el Ejecutivo el rol más activo en las finanzas públicas, pero sin excluir al Poder Legislativo de la posibilidad de incidir en las políticas públicas nacionales y de su rol fiscalizador en materia económica. 
Así queda de manifiesto en las discusiones que se produjeron en la quinta sesión de la Subcomisión de reformas constitucionales, de fecha 1 de mayo de 1925, oportunidad en la que el ministro de Justicia, el señor José Maza, señaló que era totalmente conveniente que el Congreso conociera los gastos que necesitaba la nación, porque era la única forma en que se discutían y clasificaban los gastos fijos y variables; y se eliminaban de esta manera las leyes periódicas propias del régimen parlamentario, punto capital que pondría término al abuso del parlamentarismo y le permitirá al Presidente tener leyes oportunas para administrar correctamente ${ }^{835}$.

En este mismo orden de ideas, es posible señalar otra nueva obligación para el Presidente de la República contenida en la Ley Fundamental. El mandatario, conforme al nuevo texto, estaba obligado a dar cuenta al Congreso al iniciar la legislatura ordinaria de cada año, respecto del estado político y administrativo del país. Por ende, aquella vieja tradición nacional pasaba a convertirse en una obligación constitucional con arreglo al concepto de un régimen presidencial que se instauraba. En este sentido, y como bien describe Estévez respecto a esta rendición de cuentas del Presidente, es "el Mensaje es la expresión del pensamiento del Presidente de la República"1836. Por tanto, se perfila como un momento solemne y republicano mediante el cual el mandatario se dirigía a la nación a través del Congreso, oportunidad en la que se exponían los avances alcanzados por la gestión de Gobierno. Ahora bien, el artículo 77 establecía una figura un tanto diferente en cuanto a la modalidad en la que se debía producir dicha cuenta a la nación, puesto que una vez abiertas las sesiones del Congreso Nacional, el Presidente debía ser informado por parte de sus Ministros de Estado respecto del estado de la nación en lo relativo a cada una de sus carteras, con especial atención a sus presupuestos y la proyección de gastos, para que una vez tomado conocimiento pudiera el Presidente dar su cuenta ante el Congreso.

Desde nuestra perspectiva, y tal como lo expusiéramos en el Capítulo anterior, respecto de la noción amplia de control parlamentario es posible percibir en esta obligación un control político-parlamentario, toda vez que debe concurrir el jefe de Estado ante el Poder Legislativo a rendir cuenta del estado en el que se encuentra la nación, oportunidad en la que las Cámaras podrán tomar conocimiento de los avances y las debilidades de la gestión. En virtud de esta rendición, es posible

\footnotetext{
${ }^{835}$ Actas oficiales de las Sesiones de la Comisión y Subcomisión encargadas del Proyecto de la Nueva Constitución Política de la República (1925) Pp. 68 y 70.

${ }^{836}$ ESTÉVEZ (1942) p.28.
} 
obtener antecedentes generales respecto de las materias que posteriormente pueden convertirse en elemento central de la fiscalización. Esta es la oportunidad en la que se conocen las orientaciones que han de aplicarse en los destinos del país. Por consiguiente, es el momento en el cual la oposición al gobierno ha de poder cotejar el proyecto político propuesto y el programa político ofertado a la ciudadanía, evaluando el nivel de cumplimiento del mismo. Por otra parte, le permitirá a la oposición y minorías políticas proponer su propio programa, gestándose un espacio político en el cual era posible expresar lineamientos alternativos a los aplicados por el gobierno y cómo ellos pudieran generar mejores resultados en el desarrollo económico, social y cultural del país.

Dicho lo anterior, es posible formular una primera aproximación que puede ser un tanto evidente, pero es preciso señalarlo y manifestar sus consecuencias histórico-institucionales. Tal como lo planteáramos anteriormente, un objetivo central del proyecto constitucional de Alessandri era instaurar un régimen presidencial, empero, la arquitectura presidencial nacional se diseña desde una perspectiva reforzada, es decir, las especiales características del régimen de gobierno chileno emergen y comienzan a dibujarse en esta Norma Fundamental con rasgos muy autoritarios. La tendencia constitucional fue fortalecer el poder presidencial a través de numerosas disposiciones constitucionales que han cercenado aquellas facultades parlamentarias, las que según Patricio Uslar habrían servido para imponer su criterio al mandatario. Por otra parte, se conformó un rol colegislador del jefe de Estado que, unido al derecho a realizar observaciones a los proyectos de ley, el veto y las urgencias, le permiten impedir que se legisle en un determinado sentido, con el apoyo de sólo un tercio más uno de las cámaras ${ }^{837}$. Dicho esto, es posible concluir que las facultades del Presidente son abundantes $y$, como iremos analizando en el curso de este apartado, los límites y contrapesos fueron menores.

Punto aparte fue la discusión constitucional realizada por el constituyente en la cuarta sesión de la Subcomisión de reformas, de fecha 20 de abril de 1925, respecto del voto de censura. Frente a este mecanismo de fiscalización el rechazo fue casi unánime. El Presidente de la República solicitaba enfáticamente la eliminación de toda redacción que pudiera dar cabida a los votos de censura. Para el Presidente era indispensable establecer un régimen estricto de estabilidad ministerial, de lo contrario el país seguiría presenciando un período de revoluciones que lo llevaría a su

${ }^{837}$ USLAR (1966) p.20. 
total y completa ruina. Respecto de esta materia, resulta interesante analizar la forma en la que el constituyente evaluó las censuras como mecanismo de fiscalización. La desafortunada experiencia parlamentaria nacional logró, finalmente, responsabilizar de todos los errores cometidos al régimen en sí mismo, sin realizar una autocrítica política o una revisión detallada de la normativa existente y así determinar qué elemento o elementos fueron los que finalmente pudieron haber promovido el complejo escenario político. Al parecer se optó por responsabilizar de todos los males a las herramientas fiscalizadoras, por tal motivo cuando se produce el proceso constituyente, las opiniones de sus integrantes estaban en aquella dirección.

En tal sentido, podemos traer a colación las palabras de don Romualdo Silva Cortés, para quien el ideal democrático era un parlamentarismo corregido. Por ende, mantener los mecanismos de control estimaba que era un mal mayor y un fracaso no finalizar exitosamente los trabajos de reforma constitucional, y mantener al país en un estado deplorable, razón por la cual se declaraba obligado a aceptar lo propuesto por el Presidente. En igual tenor se dirigieron las palabras de don Eliodoro Yáñez, quien estimaba que el parlamentarismo era un régimen ideal de protección de las libertades, pero que había fracasado en Chile. No obstante, dudaba que el presidencialismo tipo norteamericano fuera la solución a nuestros problemas. Sin embargo, frente a tal situación igualmente se inclinaba por suprimir la facultad del Parlamento de derribar ministros. En atención a consideraciones políticas, argumentó que tal procedimiento no correspondía ni a uno ni a otro de los sistemas presidencial o parlamentario ${ }^{838}$.

De forma muy prematura diremos que, conforme a estas declaraciones, es posible plantear que la eliminación del voto de censura instalado de hecho en el sistema parlamentario nacional, así como la restricción en la aplicación de las interpelaciones $y$, en general, la regulación restrictiva de la fiscalización parlamentaria chilena, serán fruto de un cierto temor político. El ejercicio de aquellos mecanismos parlamentarios en la bullada época parlamentaria excedió con creces lo sostenible para un Estado democrático en desarrollo, por consiguiente, respecto de ellos se teje una red de cuestionamientos y prejuicios más o menos sustentados que, en definitiva, sólo consiguen restarle valor a los mismos. Así, su utilización debía ser necesariamente restringida a tal punto de que la fiscalización no produjera más

${ }^{838}$ Actas oficiales de las Sesiones de la Comisión y Subcomisión encargadas del Proyecto de la Nueva Constitución Política de la República (1925) Pp. 62 y 63. 
efectos que la sola recopilación de información. Por tanto, la mala experiencia parlamentaria logró configurar una imagen equívoca de los mecanismos de control y, por ende, de la misma fiscalización a tal punto de prácticamente eliminarla del sistema político.

Producto de aquel fenómeno de "desparlamentarización" nacional, la principal víctima del mismo fue una vez más el control parlamentario. Con todo, con el retorno y reforzamiento del presidencialismo se produce un fenómeno de restricción y disminución del campo de aplicación de la fiscalización parlamentaria. Tal como lo planteamos con anterioridad, con la Constitución de 1925 se configuran de forma separada la fiscalización de los actos de Gobierno y la acusación constitucional. A continuación pasaremos a examinar ambos mecanismos y sus particularidades, a fin de evaluar los efectos que el sentimiento anti-parlamentario produjo en el control y poder sopesar la debilidad con la cual se regulan sus mecanismos.

\section{g) La acusación constitucional en la Carta Fundamental de 1925}

La Constitución de 1925 contemplaba la fiscalización parlamentaria en los siguientes preceptos: artículo 39 No 1 y 2, artículo 42 No1 y artículo 43 No 1, normas constitucionales que a continuación examinaremos detalladamente:

El artículo 39 consagraba las atribuciones exclusivas de la Cámara de Diputados. En ella, el numerando 1 contemplaba la posibilidad de "dar o no lugar a las acusaciones constitucionales", por medio de diez de sus miembros, quienes formularen respecto de los funcionarios públicos que el mismo precepto enumera. Por su parte, el numerando 2 contenía la "facultad de fiscalizar los actos del gobierno". Mediante esta atribución con el voto de la mayoría de los parlamentarios presentes, se podía adoptar acuerdos o sugerir observaciones que se transmitían por escrito al Presidente de la República. Empero, estos acuerdos y observaciones no afectaban de modo alguno la responsabilidad de los ministros y del Presidente. En efecto, aquel acuerdo y aquellas observaciones se entendían por cumplidos una vez que fueran contestados verbalmente por los ministros y por escrito el Presidente de la República, sin importar la oportunidad en la que se produjese dicha respuesta como tampoco el contenido de la misma. 
Según Zúñiga, la Constitución democrática-republicana de 1925 conserva la institución de la acusación en juicio político, combinando herencias institucionales de 1828 y 1833, innovando algunos aspectos como la plena justiciabilidad del Presidente de la República durante su período y estableciendo un quórum exigente para declarar ha lugar la acusación contra el Jefe de Estado y para declarar la culpabilidad. En otra dirección, se establecerá un plazo de arraigo de seis meses para el jefe de Estado y tres meses para los ministros, junto con ello se contemplaba la suspensión de actividades ${ }^{839}$.

El precepto propuesto a la Subcomisión de reformas constitucionales contemplaba la acusación al Presidente de la República, pero estipulaba dos cuestiones de interés: en primer lugar, inicialmente continuaba regulando la acusación constitucional aplicable solamente una vez finalizada la gestión del mandatario, es decir, al igual que la Constitución del 1833 el plazo para interponer la proposición de acusación era de un año, una vez finalizado el ejercicio del cargo. El segundo aspecto interesante lo constituía el numerando quinto del precepto original propuesto, toda vez que concedía la posibilidad de que las acusaciones fueran formuladas por un individuo particular, en contra de los Ministros de Estado, en razón de los perjuicios que ellos le hubieren ocasionado injustamente en virtud del ejercicio del cargo.

El espíritu inicial de la acusación constitucional continuaba la trayectoria seguida por el Código Político anterior e incluso iba más allá de la tradición constitucional nacional. Tales inicios de la norma propuesta, continuaban haciendo carne una costumbre y práctica política proveniente del derecho español de época indiana. Esta situación fue a lo menos llamativa en la evolución jurídica de la nación, principalmente si consideramos que el origen de las reformas constitucionales de los años 1924 y 1925, poseían como objetivo primordial modificar y renovar profundamente el sistema político chileno.

Tal como lo expusiéramos precedentemente, uno de los más importantes defensores de la fiscalización parlamentaria en general -pero de la acusación, en particular-, fue precisamente el presidente Alessandri. En las actas constitucionales queda de manifiesto que la voluntad del Presidente era consagrar la acusación y la responsabilidad del mandatario mientras ejerce el cargo. En este sentido, señalaba el

839 Zúñiga (2006), ver link: http://www.scielo.cl/scielo.php?pid=S0718$\underline{00122006000200003 \& \text { script }=\text { sci arttext. Visitado com fecha: } 17.01 .2016 .}$ 
jefe de Estado en la sexta sesión de la Subcomisión: "No es mi propósito dar al Presidente de la República un exceso de atribuciones que lo hagan árbitro de la vida y de la honra de los ciudadanos; de manera que, si se han ensanchado las facultades administrativas del Ejecutivo, se debe dar también a los ciudadanos, representados en el Congreso, la facultad y posibilidad de llamar al Presidente a terreno de la discreción cuando el Congreso considere que se ha salido de él"1840.

Para el mandatario, la acusación era una válvula de escape de seguridad para el caso en que llegara a producirse una situación sin salida. En la misma sesión, se sumó a la opinión del Presidente la postura de don Héctor Zañartu, quien también consideraba que este mecanismo de fiscalización se configuraba como un contrapeso indispensable para contener al mandatario, cuando quisiera abusar de sus atribuciones. Agregaba Zañartu que contemplar solamente la responsabilidad de los ministros y eximir al Presidente, implicaría implantar nuevamente un régimen parlamentario. Las voces disidentes, lideradas por don Luis Barros Borgoño, Eliodoro Yáñez, Domingo Amunategui y Guillermo Edwards apelaban a la dignidad y prestigio del cargo de jefe de Estado, argumentando sobre las posibles manipulaciones políticas que una herramienta de estas características podía generar.

Para estos miembros de la Comisión constituyente, la acusación implicaba poner al Presidente en tela de juicio de una forma irregular, inverosímil y absurda, desprestigiando con ello la administración del en el interior y en el exterior. Frente a estas apreciaciones, don Roberto Meza, contrarrestando aquellos cuestionamientos, esgrimía que los posibles abusos que se produzcan por la utilización de la acusación podrán subsanarse con una buena regulación. Punto aparte fueron las declaraciones de don Nolasco Cárdenas, quien planteó la posibilidad de activar acusaciones por el pueblo, previniendo el caso de que el Presidente cuente con mayorías parlamentarias que impidieran absolutamente la ejecutabilidad de una acusación ${ }^{841}$.

Dicho lo anterior, creemos que lo nuclear del debate se detecta en las palabras del ministro del Interior don José Maza. De lo expuesto por el jefe de la cartera de Justicia se pueden desprender aspectos significativos en cuanto a la regulación de la acusación constitucional. Lo primero, consiste en la aclaración que realiza respecto del origen o naturaleza de la institución cuando expone que, en definitiva, la

840 Actas oficiales de las Sesiones de la Comisión y Subcomisión encargadas del Proyecto de la Nueva Constitución Política de la República (1925) p.74.

${ }^{841}$ Actas oficiales de las Sesiones de la Comisión y Subcomisión encargadas del Proyecto de la Nueva Constitución Política de la República (1925) p.75, 76 y 77. 
consagración de la acusación constitucional no debe encasillarse en un presidencialismo clásico, pero tampoco ha de asimilarse a instituciones del parlamentarismo puro, sino que ha de implantarse un sistema propio para este país. Lo segundo, es su claro rechazo hacia la regulación de la misma en virtud de los riesgos que ella trae aparejados, puesto que lo que con esta institución se establece no es una responsabilidad política sino una responsabilidad penal. Por tal motivo, se establecerá como contrapartida en esta herramienta fiscalizadora un quórum de dos tercios para poder declarar la culpabilidad, aspecto que fue cuestionado inmediatamente por don Manuel Hidalgo, quien desde aquel momento planteó que aquel quórum era una limitación que constituye una traba que hace ilusoria la acusación ${ }^{842}$.

Con todo, la Constitución de 1925 -continuando el legado de la Carta de 1833 y sus reformas del año 1874- contempló la acusación constitucional de los altos funcionarios de gobierno; en particular, innovó estipulando la acusación respecto del Presidente de la República. En esta materia, dos fueron las modificaciones más relevantes jurídicamente. En primer lugar, precisa que el jefe de Estado será responsable por "los actos de su administración" y no por "todos los actos de su administración", como contemplaba la Ley Fundamental antecesora; y en segundo lugar, imprimía como requisito de aplicabilidad que el Presidente contradijera abierta y gravemente la Constitución y las leyes. Según Silva Bascuñán, la primera modificación se debe a la posibilidad de acusar al Presidente en el ejercicio del cargo, por tanto, ya no será necesario realizar un análisis global de toda su gestión, como ocurría con la regulación contemplada en la Carta del 33, debido a su similitud con el juicio de residencia. El segundo aspecto modificado es el requisito de contravenir la Constitución abierta y gravemente. Con esta redacción, señala el autor, se hace notar la trascendencia e importancia del actuar infraccional a fin de que no pudiese acusarse al mandatario por motivos fútiles, sino que en casos señaladamente graves $^{843}$.

\footnotetext{
${ }^{842}$ Actas oficiales de las Sesiones de la Comisión y Subcomisión encargadas del Proyecto de la Nueva Constitución Política de la República (1925) Pp. 77 y 78.

Es importante hacer presente que, en esta misma sesión, se discutió la posibilidad de incorporar en este precepto la posibilidad de disolver al Congreso. El debate constitucional versó en cuanto a contemplar la facultad del Presidente de disolver al órgano legislativo, como contrapartida a la acusación constitucional presidencial. Sin embargo, no hubo acuerdo en esta materia y se rechazó la posibilidad de estipular tal mecanismo, sustentado esencialmente en un argumento teórico relativo al diseño del régimen de gobierno representativo y republicano, en el cual es el pueblo el llamado a resolver los posibles conflictos entre poderes, toda vez que éste es el soberano en quien reside la voluntad general.

843 SILVA (1963) p.95.
} 
En cuanto a la acusación constitucional, para Estévez la nueva Carta Fundamental realizaba una seria de mejoras a la regulación de la misma y, en especial, a la tramitación. En primer lugar, se realizaba una enumeración clara y taxativa respecto de los funcionarios que pueden ser acusados, por tanto, los que no estaban señalados no podían ser acusados. En segundo lugar, el Código Político del 25 permitía la acusación del Presidente en el ejercicio de sus funciones ${ }^{844}$, consagrando la responsabilidad política del mandatario tal como corresponde en una República. Por otra parte, la modificación en la causal de acusación relativa al mandatario que rezaba "a los actos de su administración", obligaba a quienes desearan acusar al jefe de Estado a precisar uno o muchos actos en la acusación sin que les esté permitido ejercerla por una dirección política general.

Según este autor, en esta materia el constituyente adoptó las medidas necesarias para evitar que tan delicada institución pueda ser mal utilizada, mediante el establecimiento de un número mínimo de 10 parlamentarios para poder ejercerla, y así no dejarla "al libre juego de pasiones e intereses políticos" ${ }^{845}$. Según Silva Bascuñán, esta norma constitucional fue la que produjo el debate más acalorado en la Subcomisión redactora del texto de 1925. Si bien es cierto que la Ley Fundamental, siguiendo a la Constitución del 33 y la reforma del año 1874, mantiene la acusación constitucional de funcionarios públicos de alto rango, no es menos cierto que la decisión de hacer aplicable tal instrumento de fiscalización al Presidente de la República generó múltiples consideraciones.

El defensor más férreo de la aplicación expedita y amplia de la responsabilidad fue el presidente Alessandri, quien lo planteaba como una necesidad indispensable, como el contrapeso imprescindible a la magnitud de los poderes que se le entregaban al jefe de Estado ${ }^{846}$.

En nuestra opinión, la modificación de mayor trascendencia en la Constitución del 1925 fue un aspecto procedimental, puesto que se contempló la posibilidad de acusar al Presidente en el ejercicio del cargo. Con esta innovación constitucional, se

844 Las diferencias entre el texto constitucional del 33 y la de 1925 , en definitiva, fueron las siguientes: con la nueva Constitución fue posible acusar al Presidente mientras ejercía el mandato, vale decir, el plazo para deducirla se modifica. En términos generales, se mantuvieron los delitos en virtud de los cuales era posible activar la acusación, salvo la ampliación de dos términos como la frase "contraria a la Constitución" ahora dice "Constitución y sus leyes", y aquella frase que rezaba que "todos los actos de su administración" fue reemplazada por la frase "los actos de su administración". Ahora bien, el precepto establecía un plazo claro respecto de la acusación del Presidente, no obstante, guardó silencio respecto de los otros funcionarios. En particular, no estipulaba un plazo para gobernadores e intendentes.

845 ESTÉVEZ (1948) Pp. 1 y 3.

846 SiLVA (1963) p.94. 
generan determinados efectos que permiten delimitar de mejor manera esta institución. En un primer término, se aleja del juicio de residencia, por ende deja de lado una tradición colonial propia del derecho indiano, institución cuya finalidad dista mucho de la acusación constitucional propia de regímenes representativos de gobierno. Por otra parte, se configura como un verdadero contrapeso jurídicoconstitucional a las amplias facultades presidenciales igualmente contenidas en el estatuto político. De manera tal que es posible percibir la intencionalidad de introducir un régimen presidencial con todas las implicancias que ello genera, labor no menor para una nación que deseaba fervientemente dejar de lado un régimen parlamentario fracasado. Por consiguiente, siempre estuvo presente la posibilidad de utilizar al juicio político como una expresión de aquel sistema y utilizarlo conforme las antiguas prácticas parlamentarias. Sin embargo, tal situación no ocurrió. La primera acusación se produce el año 1935 contra el ministro del Interior don Luis Salas Romo.

En cuanto al procedimiento y tramitación de la acusación, en la Ley Fundamental del veinticinco se resuelve un aspecto que había sido conflictivo durante la vigencia de la Carta del 33. Nos referimos al examen de admisibilidad de la proposición de acusación. Tal como lo expusiéramos en el análisis relativo a las normas constitucionales que regulaban el procedimiento de acusación de la Constitución anterior, hicimos hincapié en la excesiva rigurosidad con la que se planteaba el examen de los hechos que fundaban la acusación.

Con la regulación de 1925 ello se ve modificado y, en palabras de Silva Bascuñán, "presentada la acusación con el número de firmas reglamentarias, debe seguirse la tramitación correspondiente. No tienen el Presidente de la Cámara ni la Corporación atribución alguna para calificar previamente su fundamento, o sea, para admitir o rechazar la proposición de acusación ${ }^{\prime \prime 47}$. Para este autor, sólo la Comisión compuesta por sorteo e integrada por cinco diputados será la facultada para analizar si los términos del libelo acusatorio imputan al acusado algunos de los hechos descritos en la norma constitucional. Igualmente, será dicha instancia a la que le corresponderá valorar los antecedentes recibidos y la consistencia de los mismos, a fin de determinar la fuerza que ellos adquieren en la formación de la convicción de los parlamentarios, para que así -una vez examinados razonablemente los antecedentes- se pueda estimar o desestimar la continuación de la tramitación de la

847 SiLVA (1963) p. 110. 
acusación. Con este análisis, intenta el autor evitar dos situaciones extremas: por un lado, no es posible recabar tal nivel de información que pudiera configurar una determinación de responsabilidad tan detallada y concluyente que pudiera comprometer el fallo definitivo. Por otra parte, debiera realizar una examinación seria, de manera tan razonada que sólo dé lugar a acusaciones razonables.

Por su parte, la aceptación de la acusación genera la suspensión de las actividades del funcionario desde el momento que se declara ha lugar la acusación. Una vez fallada la acusación por el Senado -y siendo ésta acogida-, procederá la sanción de destitución del cargo. Cabe plantear una inquietud que se ha generado respecto de esta etapa del procedimiento acusatorio, que dice relación con la posibilidad de renunciar al cargo público desempeñado mientras se realiza el procedimiento acusatorio y antes de que se dicte el fallo. Desde una perspectiva, se estimaba necesaria la desvinculación, evitando con ello toda posible interferencia en el proceso. Sin embargo, también se planteaba la imposibilidad de renunciar cuando hay un sumario administrativo en contra de un funcionario, entonces con mayor razón debía estar prohibida la renuncia en casos de ser acusado constitucionalmente.

Con todo, en la Constitución de 1925 se contempló un procedimiento más corto y expedito que en el texto constitucional anterior, en cuanto a la excepcionalidad de este tipo de juzgamiento, en favor del funcionario acusado. En este orden de ideas, nos detalla Estévez un aspecto de suma relevancia en cuanto al fallo y finalidad de la acusación. De conformidad al artículo 42, le corresponde al Senado fallar la acusación que ha sido admitida, porque los crímenes políticos deben ser juzgados por cuerpos de carácter político. Pero aquel juzgamiento seguirá reglas diferentes a las de un tribunal ordinario; su apreciación se debe ajustar a otros criterios, tal como describe el autor, el fallo del juicio político debe estar informado por "/a conveniencia, el honor y la respetabilidad de la nación, con el vicio que se teme de los cuerpos políticos en estas materias, o sea, su inclinación por compadrazgos o mezquinos intereses de partido"1848. Con la Constitución de 1925, el Senado actúa como un jurado, es decir, aprecia en conciencia los hechos que sustentan la acusación, sin sujetarse a normas precisas en materia de prueba. Su papel se reduce a señalar si es o no culpable. El efecto de la declaración de culpabilidad hecha por el Senado será la destitución, pero -según este autor- más importante será el restablecimiento del orden constitucional.

${ }^{848}$ ESTÉVEZ (1948) p. 18. 
A modo de ejemplo, y a partir de la información que fue posible recopilar en las bases de datos de la Biblioteca del Congreso Nacional, hemos elaborado un cuadro explicativo que contempla algunas de las acusaciones constitucionales que se realizaron durante la vigencia del texto constitucional de 1925. Respecto de ellas hemos de analizar en especial dos: la llevada a cabo en contra del ministro Domingo Santa María y una segunda acusación en contra del ministro Edmundo Pérez Zujovic, a fin de poder visualizar y examinar los argumentos utilizados en aquel momento y al tenor que se le pretendía otorgar a esta herramienta de fiscalización y sus efectos.

A continuación se adjunta cuadro resumen de las acusaciones realizadas durante la vigencia de la Norma Fundamental de 1925:

\begin{tabular}{|c|c|}
\hline ACUSACIONES BAJO LA CONSTITUCIÓN POLÍTICA DE 1925 & APROBADO/RECHAZADO \\
\hline Maximiliano Ibáñez, Ministro del Interior (28 de octubre de 1926) & $\begin{array}{l}\text { Rechazada Cámara de } \\
\text { Diputados. }\end{array}$ \\
\hline $\begin{array}{l}\text { Carlos Ibáñez del Campo, Ex Presidente de la República (26 de } \\
\text { octubre de 1931) }\end{array}$ & $\begin{array}{l}\text { Aprobada: Declarados } \\
\text { culpables, a disposición } \\
\text { de los tribunales } \\
\text { ordinarios para su } \\
\text { juzgamiento. }\end{array}$ \\
\hline $\begin{array}{l}\text { Carlos Castro Ruiz Ex Ministro de Hacienda ( } 3 \text { de noviembre de } \\
\text { 1931) }\end{array}$ & $\begin{array}{l}\text { Aprobada: Declarados } \\
\text { culpables, a disposición } \\
\text { de los tribunales } \\
\text { ordinarios para su } \\
\text { juzgamiento. }\end{array}$ \\
\hline $\begin{array}{l}\text { Roberto Parrague, Gobernador del Departamento de Osorno ( } 7 \text { de } \\
\text { noviembre de 1934) }\end{array}$ & $\begin{array}{l}\text { Rechazada Cámara de } \\
\text { Diputados. }\end{array}$ \\
\hline Luis Salas Romo, Ministro del Interior (5 de marzo de 1935) & $\begin{array}{l}\text { Rechazada Cámara de } \\
\text { Diputados. }\end{array}$ \\
\hline Emilio Bello Codecido, Ministro de Defensa (enero de 1936) & $\begin{array}{l}\text { Rechazada Cámara de } \\
\text { Diputados. }\end{array}$ \\
\hline Luis Cabrera, Ministro del Interior (1937) & $\begin{array}{l}\text { Rechazada Cámara de } \\
\text { Diputados. }\end{array}$ \\
\hline Matías Silva Sepúlveda, Ministro de Fomento (1937) & $\begin{array}{l}\text { Rechazada Cámara de } \\
\text { Diputados. }\end{array}$ \\
\hline Luis Salas Romo, Ministro del Interior (1938) & $\begin{array}{l}\text { Rechazada Cámara de } \\
\text { Diputados. }\end{array}$ \\
\hline $\begin{array}{l}\text { Arturo Alessandri Palma, Ex Presidente de la República (4 de abril } \\
\text { de 1939) }\end{array}$ & $\begin{array}{l}\text { Rechazada Cámara de } \\
\text { Diputados. }\end{array}$ \\
\hline Pedro Enrique Alfonso, Ministro del Interior (29 de mayo de 1939) & Rechazada en Senado. \\
\hline $\begin{array}{l}\text { Abraham Ortega, Ministro de Relaciones Exteriores (febrero de } \\
\text { 1940) }\end{array}$ & Rechazada en Senado. \\
\hline $\begin{array}{l}\text { Guillermo Labarca Hubertson, Ministro del Interior ( } 30 \text { de } \\
\text { noviembre de 1940) }\end{array}$ & Aprobada: Destituido \\
\hline Osvaldo Hiriart Corvalán, Ministro Del Interior (6 de junio de 1944) & $\begin{array}{l}\text { Rechazada Cámara de } \\
\text { Diputados. }\end{array}$ \\
\hline Lisandro Cruz Ponce, Ministro del Trabajo (16 de junio de 1946) & $\begin{array}{l}\text { Rechazada Cámara de } \\
\text { Diputados. }\end{array}$ \\
\hline
\end{tabular}




\begin{tabular}{|l|l|}
\hline Alfonso Quintana, Ministro del Interior (agosto de 1952) & $\begin{array}{l}\text { Rechazada Cámara de } \\
\text { Diputados. }\end{array}$ \\
\hline Germán Picó Cañas, Ministro de Hacienda (agosto de 1952) & $\begin{array}{l}\text { Rechazada Cámara de } \\
\text { Diputados. }\end{array}$ \\
\hline Ernesto Merino, Ministro de Obras Públicas (agosto de 1952) & $\begin{array}{l}\text { Rechazada Cámara de } \\
\text { Diputados. }\end{array}$ \\
\hline Rafael Tarud, Ex Ministro de Economía (13 de noviembre de 1953) & $\begin{array}{l}\text { Rechazada Cámara de } \\
\text { Diputados. }\end{array}$ \\
\hline Carlos Montero, Ex Ministro del Interior (29 de julio de 1955) & Rechazada en Senado. \\
\hline Osvaldo Koch, Ministro del Interior (29 de julio de 1955) & Rechazada en Senado. \\
\hline $\begin{array}{l}\text { Santiago Wilson, Ministro de Tierras y Colonización (12 de abril de } \\
\text { 1957) }\end{array}$ & Rechazada en Senado. \\
\hline $\begin{array}{l}\text { Osvaldo Sainte-Marie, Ministro de Relaciones Exteriores (26 de } \\
\text { octubre de 1957) }\end{array}$ & Aprobada: Destituido \\
\hline Roberto Vergara Herrera, Ministro de Hacienda (8 de julio de 1959) & $\begin{array}{l}\text { Rechazada en Cámara } \\
\text { de Diputados. }\end{array}$ \\
\hline Roberto Vergara Herrera, Ministro de Hacienda (mayo de 1960) & $\begin{array}{l}\text { Retirada antes de ser } \\
\text { votada de la Cámara de } \\
\text { Diputados. }\end{array}$ \\
\hline Hugo Gálvez, Ministro del Trabajo (24 de julio de 1962) & $\begin{array}{l}\text { Rechazada Cámara de } \\
\text { Diputados. }\end{array}$ \\
\hline Luis Mackenna Shiell, Ministro de Hacienda (abril de 1963) & $\begin{array}{l}\text { Rechazada Cámara de } \\
\text { Diputados. }\end{array}$ \\
\hline Benjamín Cid, Ministro de Salud (11 de septiembre de 1963) & $\begin{array}{l}\text { Rechazada Cámara de } \\
\text { Diputados. }\end{array}$ \\
\hline Eduardo Simián, Ministro de Minería (9 de febrero de 1966) & $\begin{array}{l}\text { Rechazada Cámara de } \\
\text { Diputados. }\end{array}$ \\
\hline $\begin{array}{l}\text { Domingo Santa María Santa Cruz, Ministro de Economía (13 de } \\
\text { octubre de 1966) }\end{array}$ & $\begin{array}{l}\text { Rechazada Cámara de } \\
\text { Diputados. }\end{array}$ \\
\hline Edmundo Pérez Zujovic, Ministro del Interior (18 de junio de 1968) & $\begin{array}{l}\text { Rechazada Cámara de } \\
\text { Diputados. }\end{array}$ \\
\hline Edmundo Pérez Zujovic, Ministro del Interior (4 de mayo de 1969) & $\begin{array}{l}\text { Rechazada Cámara de } \\
\text { Diputados. }\end{array}$ \\
\hline Patricio Rojas, Ministro del Interior (26 de noviembre de 1969) & $\begin{array}{l}\text { Rechazada Cámara de } \\
\text { Diputados. }\end{array}$ \\
\hline
\end{tabular}

Es preciso hacer presente que realizaremos el estudio de dos acusaciones constitucionales, dirigidas contra ministros del gabinete del presidente Frei Montalva. Fundamentalmente, porque ambas son coordinadas por partidos políticos (radicales y comunistas) que, poco a poco, se fueron configurando como una férrea oposición hacia el Partido Demócrata Cristiano y -en especial- en contra de aquella "vía propia" en conformidad a la cual estaba liderando el gobierno, en razón de sus exitosos resultados electorales. Posteriormente, de ese reproche político nacerán afinidades y luego un conglomerado de partidos de izquierda que, unidos, darán nacimiento a la Unidad Popular y obtendrán la Presidencia de la República de la mano del presidente Allende. 
A mayor abundamiento, es posible destacar en el debate parlamentario que ambas acusaciones -en reiteradas ocasiones- se plantearon como actos políticos dirigidos hacia la Democracia Cristiana, en su calidad de partido político de Gobierno, y en contra del presidente Frei y su programa de gobierno transformador.

En el año 1966 se llevará a cabo la acusación constitucional liderada por el Partido Radical en contra del ministro de Economía, don Domingo Santa María, en razón de las siguientes causales: malversación de fondos, atropellamiento de leyes, dejar sin ejecución determinadas leyes y por comprometer gravemente la seguridad de la nación. Básicamente, se le imputaba la falta de supervigilancia de las empresas estatales y problemas económicos en el desarrollo de ciertas áreas del fomento productivo del país (cebollas, manzanas y papas). Los argumentos de los acusadores se agrupaban en quince hechos los que, analizados por la Comisión parlamentaria designada para tales efectos -según lo indicaban los preceptos constitucionales-, fueron rechazados $y$, por ende, le proponen a la Cámara de Diputados que igualmente proceda a su rechazo.

El diputado que debió informar a la Sala los resultados de la comisión, realizó una presentación que estuvo fuertemente marcada por un sello penal, puesto que el cargo de malversación de fondos era ciertamente un ilícito penal, pero además porque se estimó por gran parte de la Comisión que el atropellamiento de leyes, igualmente, debía asimilarse a un delito, toda vez que ello implicaba realizar infracciones tales como la anticipación, usurpación de funciones, nombramiento ilegal y abuso de autoridad. La tercera causa invocada -dejar sin ejecución determinadas leyes- fue interpretada en idéntico sentido. Por su parte, el cargo de poner en riesgo la nación fue considerado como una expresión del tipo penal traición a la patria. Por tanto, en el seno de la Comisión informadora existió pleno convencimiento que la mayoría de los cargos a través de los cuales se acusó al Ministro de Economía eran de corte penal, en consecuencia, debían analizarse en dicho mérito. Es esa dirección, las pruebas aportadas no eran suficientes para configurar tales delitos.

La excepción estuvo presente mediante el examen de la causal que rezaba "infringir la Constitución", en virtud de la cual la Comisión declaró que sólo aquella causal permitía un análisis político, porque ella consideraba el incumplimiento de cualquier obligación que se encuentre regulada por la Carta Fundamental. Será en dicha oportunidad en la que se investigará la "responsabilidad" del ministro, puesto 
que se examina el tipo de orden que podía emitir en relación al tipo de órgano del cual se trataba (recordemos que se le acusaba de no supervigilar empresas públicas). Fruto de aquel debate, se formula la distinción entre órganos de la administración central y órganos de la administración del Estado, concluyendo que su responsabilidad sólo recae sobre órganos de la administración central, mas no en aquellos dependientes del Estado que poseen entes internos de toma de decisiones. En su defensa, el ministro Domingo Santa María alegará, precisamente, el carácter político con el cual se le ha acusado y la burda finalidad de desprestigiar a un Gobierno exitoso. Incluso considerará la acusación como una buena herramienta para aclarar hechos ante la ciudadanía, esencialmente, sobre la reforma agraria y campesina.

Ahora bien, el debate que se produce en Sala es de suma trascendencia para nuestra investigación, porque hasta el año 1966 aún se expresan dudas en torno a la naturaleza de la acusación constitucional, es decir, se centra el debate entre su arista penal y la arista política. Existieron importantes esfuerzos en fundamentar una u otra interpretación. Por una parte, se intentaba limitar a la acusación a la simple comprobación parcial de una ejecución de delitos, opinión esbozada por el diputado Ansieta, quien además señalaba que en la Carta de 1925 estaba impedido exigir responsabilidades políticas. Por otra parte, hubo voces disidentes como el diputado Naudor, quien arguyó que el juicio era un análisis político y de responsabilidad política del ministro. Desde nuestra perspectiva, la opinión más recurrente entre los parlamentarios fue aquella que sostenía que el juicio político era en parte penal y en parte política.

Respecto del ámbito penal, el proceso parlamentario configuraría un antejuicio calificativo de conductas ilícitas que posteriormente será calificado por los tribunales ordinarios de justicia. En relación a lo político comprendía una tentativa de exigir responsabilidad política, a pesar de las limitaciones contenidas en los preceptos constitucionales, no obstante, siempre generaba efectos políticos. Tal apreciación se ve reflejada en las palabras del diputado Millas, quien expone: "La verdad es que, en las condiciones del régimen presidencial de nuestro país, muchas acusaciones constitucionales que han sido presentadas, no han logrado ser aprobadas, a pesar de sus fundamentos justos. Pero la historia de estas acusaciones constitucionales de los últimos años, demuestra que han surtido ciertos efectos, porque más allá del hemiciclo mismo, más allá de la Cámara, han logrado aquello a que se refieren los 
tratadistas cuando observan que el juicio político implica también una sanción moral. Por eso, es un deber de las fuerzas de Oposición, es un deber de quienes fiscalizamos por mandato de la Constitución, promover, cuando corresponda, para el saneamiento de las instituciones democráticas, el juicio político, aunque no tenga una acogida inmediata"${ }^{\prime 849}$.

Con todo, para nosotros la fundamentación del diputado Gustavo Lorca comprende elementos de suma relevancia, toda vez que el parlamentario esgrime un análisis en el que comenta que en la Carta de 1925 la frase literal del texto "abuso de poder" es la que permite el juzgamiento político, porque a juicio de Lorca "sería un error tremendamente perjudicial para el país sostener que, si el Estado es pésimamente mal administrado y que aun cuando esa mala administración haya motivado cuantiosas pérdidas, por no estar comprometido el honor y la seguridad de la Nación, ningún Ministro, ningún funcionario responsable política ni criminalmente ${ }^{\prime \prime 850}$.

La acusación del ministro del Interior Edmundo Pérez Zujovic -del año 1969- tuvo una connotación muy especial, puesto que ella surge en razón de la matanza realizada a pobladores en la localidad Puerto Montt luego de haberse tomado un terreno que era propiedad privada de la familia Irigon, en manos de las fuerzas de orden público nacional de Carabineros de Chile. Los cargos que le imputan los parlamentarios comunistas y socialistas al ministro se sustentan en que él es el responsable político de Carabineros, y responsable de haber emitido la orden de desalojo, avalando el uso abusivo de la fuerza. Junto con ello, le imputan haberse ido de vacaciones una vez ocurridos los lamentables hechos.

Por consiguiente, las acusaciones fueron las siguientes: infracción a la constitución, abuso de poder y atropellamiento de leyes. En su defensa, el jefe de la cartera de Interior expone que ésta es nuevamente un campaña contra el Gobierno, el cual actuó conforme lo permitido por la ley, señalando que se enfrentaban a una ocupación ilegal denunciada por los dueños de la propiedad; una estrategia organizada para alterar el orden social. Por tanto, no hubo abuso de poder y la acusación carece de fundamento de derecho. Por su parte, la Comisión informante que debió analizar la acusación citó a prestar declaración a múltiples actores, a la

${ }^{849}$ Biblioteca del Congreso Nacional, Acusación constitucional contra Ministro de Economía, Fomento y Reconstrucción, don Domingo Santa María Santa Cruz, p.168.

850 Biblioteca del Congreso Nacional, Acusación constitucional contra Ministro de Economía, Fomento y Reconstrucción, don Domingo Santa María Santa Cruz, p.155. 
familia Irigon -dueña de la propiedad tomada ilegalmente- y a los habitantes que presenciaron tal macabra matanza, fruto de lo cual concluyen que el propietario del terreno sólo habían denunciado la toma y que nunca solicitaron el desalojo. Además, demuestran que los pobladores no estaban armados y que la llegada de Carabineros los tomó por sorpresa.

El aspecto más relevante de la presente acusación, se encuentra sustentada en la utilización del "abuso de poder" como cargo acusatorio. La defensa del ministro alegaba que ésta no era una causal y que el precepto constitucional realizaba una enumeración taxativa de las mismas. Por lo mismo, no era posible aludir al abuso de poder como cargo imputable. Adicionalmente, postulaban que en el contexto político vivido, las tomas ilegales de terrenos constituían un negocio político y económico para desacreditar el programa habitacional del Gobierno. En la vereda de la oposición, los acusadores postularían que si bien el artículo 39 no la contemplaba como causal, sí la señalaba como un parámetro respecto del cual debía fallar el Senado. En este sentido y en virtud de tal postulado, se dotaba de un claro contenido político a la acusación constitucional, elemento que a su vez permitía ampliar los aspectos a examinar, además de abrir la posibilidad de determinar responsabilidades políticas respecto de los Ministros de Estado.

Otro elemento muy revelador, en cuanto a esta acusación constitucional, fue el debate que surgió en torno a la responsabilidad del ministro a pesar de alegar la defensa que el jefe de la cartera de Interior no tenía ninguna responsabilidad en las muertes, ni en la toma de decisiones, ni menos en la cadena de mando. Reiteran majaderamente que los intendentes regionales son quienes coordinan el actuar de Carabineros y que en esta ocasión lo hicieron a petición de la familia afectada. Junto con lo anterior, expresaron que los pobladores habían reaccionado violentamente, por consiguiente, el actuar de las fuerzas policiales se llevó a cabo en el marco de la defensa propia y legítima. Con dichos argumentos, fijan dos puntos de atención: por un lado, abren el debate en cuanto a la "responsabilidad" del ministro, y por otra parte, expanden el foco de análisis, puesto que éste no se refiere exclusivamente a un examen criminal, sino que abre una arista política en relación al mismo. En este orden de ideas, es posible detectar una diferencia respecto de la acusación del ministro Santa María: en esta segunda acusación constitucional, los diálogos producidos en el hemiciclo fueron marcadamente políticos. Finalmente, la Comisión aprobó la acusación por 3 votos contra 2, empero, ésta fue posteriormente 
rechazada en la Cámara de Diputados por 78 votos en contra y solamente 54 a favor.

En resumen, podemos señalar que las acusaciones constitucionales bajo la Constitución de 1925 fueron llevadas a cabo bajo un manto de dudas. No estaba claramente definida ni por la doctrina ni por los parlamentarios cuál era la naturaleza de la acusación, vale decir, no fue resuelto si esta herramienta fiscalizadora era una institución política o jurídica. La literalidad del Carta Fundamental tampoco permitía solucionar aquella problemática, es por ello que a rasgos generales podemos señalar que el nuevo Código Político no logró satisfacer correctamente las necesidades políticas que emanaban en aquella época.

Ahora bien, la utilización del juicio político emerge con mayor fuerza y politicidad durante el Gobierno del presidente Frei, mandato presidencial que era encabezado por la Democracia Cristiana. Esto se dio, precisamente, porque la oposición mediante la fiscalización parlamentaria pretendió cumplir un objetivo específico: desgastar políticamente a la Falange, finalidad que -en términos generales- fue alcanzada, puesto que la oposición logró coordinar sus actos, fortalecer redes y dar nacimiento a un nuevo pacto político de centro izquierda que ganará las elecciones presidenciales siguientes.

Con todo, se puede concluir que con la Constitución de 1925 no fue posible zanjar la dificultad relacionada con delimitar un régimen presidencial fuerte, atenuar la responsabilidad política de los miembros del Ejecutivo ni tampoco transformar al juicio político en un antejuicio criminal. Los hechos acaecidos, los programas políticos transformadores y la realidad cultural y social chilena, esperaba y requería de válvulas de escape de carácter político que pudieran resolver las dificultades. Por tanto, el contexto político, social y económico imponía a la fuerza un rol sancionador de la fiscalización parlamentaria y, en cierta medida, ello sí ocurrió, toda vez que si bien no se aplicaron sanciones específicas a Ministros de Estado, se promovió fuertemente una sanción social y moral, que produjo serios resultados. Podemos inferir que lo ocurrido en nuestro país fue la aplicación de una responsabilidad difusa que en lo concreto logró la alternancia en el poder, debilitando a la Democracia Cristiana electoralmente y favoreciendo la conformación de la Unidad Popular y con ello la vía chilena al socialismo. 


\section{h) El artículo 39 y la delimitación de un concepto de fiscalización}

parlamentaria

La consagración de este precepto en la Constitución de 1925, a nuestro juicio, posee dos vertientes. Por una parte, la tradición política nacional contemplaba una supervigilancia por parte del Congreso respecto de los actos del Ejecutivo. Tal como se contempló en la reforma constitucional del año 1874, se introduce en la Carta de 1833 la vigilancia de la administración pública del Estado por parte de la Comisión Conservadora, órgano que representaba a los miembros del Congreso. Por tanto, he allí un antecedente de nuestro artículo 39 n². Sin embargo, y tal como lo hemos recalcado, la Constitución del 1925 suprimió precisamente dos órganos: la Comisión Conservadora y el Consejo de Estado. Por tal motivo, la tutela por parte del Congreso hacia al Ejecutivo debía ser directo.

El segundo elemento, es la intencionalidad presidencial. Ya hemos hecho mención a la fuerza y convicción con la que el presidente Alessandri promovió la fiscalización parlamentaria y los mecanismos a través de los cuales llevarla a cabo en la Comisión de reformas de la Constitución. Dicho esto, creemos que en virtud de ambos factores, se puede contemplar una fiscalización parlamentaria en el Estatuto Político con las particularidades que, a continuación, examinaremos.

De forma preliminar, exponemos una interpretación del precepto 39 que permite ilustrar nuestro análisis. En palabras de José Bidart, dicho artículo fue una "norma imperfecta e incompleta, de manera que no fue lo suficientemente eficaz para coadyuvar en la relación generalmente conflictiva entre el Presidente y el Congreso Nacional... " ${ }^{\prime 851}$. En armonía con lo que hemos venido planteando en estos párrafos, el autor puntualiza que respecto a la fiscalización parlamentaria no existió acuerdo en cuanto a su consagración constitucional. Su regulación fue simplemente el resultado de una transacción entre quienes estaban por el seudoparlamentarismo y quienes defendían al presidencialismo. Por tal motivo, según Bidart, en tal escenario se produjeron dos situaciones de complejidad: por un lado, pretendía establecer la responsabilidad política de los ministros, lo cual fue en cierto modo desvirtuado por la expresa exclusión que de ello se formuló en relación a la fiscalización; y por otro lado, se produjo una importante confusión entre la fiscalización y la acusación en juicio político. La consecuencia de aquello, es que el artículo 39 no fue una norma

${ }^{851}$ BIDART (2013) p. 19. 
precisa, ya que indujo a muchos errores; el ámbito de la norma era general, toda vez que además no definió qué ha de entenderse por fiscalizar actos de gobierno.

En un primer aspecto, hemos de traer a colación algunos de los pasajes más relevantes del debate constitucional en esta materia llevado a efecto por la Comisión de reformas de la Constitución, a fin de comprender cuál era el espíritu e intencionalidad original de la fiscalización y del alcance de la norma.

El numeral segundo del artículo 39 -fiscalizar los actos de gobierno-, al igual que el numerando primero, también fue promovido por el presidente Alessandri. Durante la tercera sesión de la Subcomisión de las reformas constitucionales, con fecha 24 de abril de 1925, el jefe de Estado presentó la redacción de dicho precepto constitucional expresando con suma convicción la necesidad de establecer una adecuada regulación respecto de la fiscalización parlamentaria, como la única manera de "salvar al país de la hecatombe a que lo ha conducido el abuso del sistema parlamentario". Por ende, esgrimía que como mandatario su deber era luchar con todas sus energías por estas ideas, a las cuales calificaba como salvadoras $^{852}$.

El debate constituyente se centró en el quórum necesario para adoptar acuerdos o sugerir observaciones. Don Manuel Hidalgo hacía presente que los partidos políticos con pequeña representación no podrán hacerse oír y no podrán ejercer de forma efectiva sus derechos de fiscalización. Replicaba el Presidente que estos procedimientos deben prestigiar la fiscalización parlamentaria, puesto que ella ha de realizarse no por personas, sino que por colectividades. Agregaba que, de tal manera, incentiva a la Cámara a realizar política desde una perspectiva nacional, despojándose de intereses pequeños y personales. Llama la atención que frente a tal situación en el desarrollo de la cuarta sesión de la Subcomisión de reforma, el ministro de Justicia de la época, don José Maza, igualmente expresa sus aprensiones respecto del quórum como un elemento que obstaculizaría el ejercicio de la fiscalización. No obstante, el precepto constitucional fue aprobado en el siguiente tenor: "Poner entre las facultades exclusivas de la Cámara de Diputados las siguientes: Fiscalizar los actos del Poder Ejecutivo. Para ejercer esta atribución, la Cámara de Diputados puede adoptar acuerdos o sugerir observaciones al Presidente

852 Actas oficiales de las Sesiones de la Comisión y Subcomisión encargadas del Proyecto de la Nueva Constitución Política de la República (1925) Pp. 56 y 57. 
de la República. No se transmitirán al Presidente de la República sino los acuerdos u observaciones que sean aprobadas por la mayoría de la Cámara... „1853.

Dicho lo anterior, corresponde esbozar algunas ideas relativas a la forma en la que la fiscalización podía ser llevada a cabo, conforme el artículo $39 \mathrm{~N}^{\circ} 2$ y las consideraciones que de ello se derivan.

Por una parte, esta norma establecía que la forma de realizar la fiscalización por parte de la Cámara de Diputados era mediante la aprobación por la mayoría de los diputados presentes de acuerdos o sugerir observaciones que se transmitían por escrito al Presidente. Dichos acuerdos $u$ observaciones no afectaban la responsabilidad de los ministros y podían ser contestados por escrito por el Presidente, o verbalmente por los ministros. Una de las primeras observaciones que puede expresarse respecto de este precepto, es que mediante él se refuerza de manera concreta el régimen presidencial, puesto que declaraba que todos los acuerdos y observaciones debían ir dirigidos directamente al Presidente de la República, quien debía responder personalmente o delegar tal obligación en alguno de sus secretarios de Estado.

Por otra parte, se reitera aquella noción que delega claramente la administración del Estado y la jefatura de Gobierno en la figura presidencial, por ende, él es quien representa al Ejecutivo en su conjunto, debiendo ir dirigida la fiscalización de los actos del Gobierno hacia su persona sin perjuicio de las delegaciones que el mandatario realice posteriormente.

Por su parte, Silva Bascuñán especifica qué debemos entender cuando se hace alusión a la palabra Gobierno. Explica el autor que no se está refiriendo al titular de la soberanía, como tampoco al conjunto de autoridades constituidas, sino que solamente se refiere a la función ejecutiva y administrativa encabezada por el Presidente de la República. Por tanto, los actos del Presidente y los actos de todos aquellos que estén bajo sus órdenes, sean de las más diversas autoridades y reparticiones gubernativas o administrativas que dependan de él, constituyen actos de gobierno y deben ser fiscalizados por la Cámara de Diputados. Es decir, un sentido amplio, son todos aquellos que dependen de la más alta responsabilidad en las funciones de gobernar y administrar.

853 Actas oficiales de las Sesiones de la Comisión y Subcomisión encargadas del Proyecto de la Nueva Constitución Política de la República (1925) p. 64. 
En este orden de ideas, la tesis del profesor Silva se sustentaba constitucionalmente en ciertos preceptos. La Carta Fundamental delegaba especialmente la administración del Estado en la figura del mandatario; así, el artículo 60 señalaba que: "Un ciudadano con el título de Presidente de la República administra el Estado, y es el jefe supremo de la Nación". Por otro lado el artículo 71 rezaba: "Al Presidente de la República está confiada la administración y gobierno del Estado; y su autoridad se extiende a todo cuanto tiene por objeto la conservación del orden público en el interior, y la seguridad exterior de la República, de acuerdo con la Constitución y las leyes". Por tanto, la interpretación de Silva estaba en concordancia con lo señalado por nuestro Código Político ${ }^{854}$.

Adicionalmente, el precepto eximió expresamente de toda responsabilidad política a los Ministros de Estado, ya que la norma señalaba expresamente que los acuerdos u observaciones no afectan la responsabilidad de los ministros. Tal expresión puede comprenderse en el sentido de que la crítica hacia la gestión ministerial no generaba efecto alguno, puesto que, en principio, el funcionario público sólo estaba obligado a responder, pero en el caso de no dar respuesta no existía una sanción. Por ende, no estaba obligado a modificar su gestión y mucho menos a renunciar a su cargo.

El precepto tampoco contemplaba un plazo dentro del cual debía emitirse aquella respuesta. En consecuencia, bastaba con responder sin necesidad de que dicha respuesta fuera oportuna. En nuestra opinión, la ausencia de plazo configuraba una de las más importantes debilidades de la fiscalización en la Carta de 1925, toda vez que la doctrina mayoritaria -analizada en el Capítulo anterior- concordaba en el siguiente aspecto: el control puede desarrollarse por diversas vías y buscar distintos objetivos, no obstante, ha de ser siempre oportuno a fin de que su ejercicio tenga alguna repercusión. Por ello, si sólo se contempla la posibilidad de ejercerlo pero sus efectos eventualmente llegaren en un tiempo desconocido, su uso carecería de total sentido.

En resumen, el artículo $39 \mathrm{~N}^{\circ} 2$ no establecía legalmente la obligación de responder por parte del funcionario criticado $y$, en el caso de querer responder, no contemplaba un plazo dentro del cual efectuar tal respuesta. Sin perjuicio de aquello, la norma fue clara en señalar que la fiscalización era atribución exclusiva de la

${ }^{854}$ SiLVA (1963) Pp. 113 y 114. 
Cámara de Diputados, por defecto privaba al Senado de aquella función parlamentaria.

La utilidad de la fiscalización en este aspecto se ve seriamente cuestionada, debido a que finalmente el ministro de la cartera criticada normalmente seguía adelante con la política adoptada en conjunto con el Presidente, sin tener que modificar aspecto alguno y sin verse personalmente comprometido. Podemos aventurarnos y señalar que, en definitiva, el artículo en cuestión no contempla una verdadera fiscalización porque, a pesar de que se pudiese haber generado un juicio de valor por parte de los diputados respecto de una gestión deficiente en la administración del Estado, en la norma primaba de manera más rigurosa el poder presidencial. La actividad fiscalizadora no inducía ningún cambio de ruta por parte del Gobierno y las cosas seguían su curso normal. Sólo excepcionalmente la ausencia de respuesta podía configurar una posible acusación constitucional, en casos de cierta gravedad. Con este sistema de fiscalización el único fortalecido fue el régimen presidencial; es por ello que el Jefe de Estado mantenía intacta su atribución contemplada en el artículo $72 \mathrm{~N}^{\circ} 5$ de la Constitución: los ministros son nombrados y removidos en virtud de su exclusiva y única voluntad, a pesar de estar siendo cuestionados en su administración. En este contexto jurídico, primó la instauración de un régimen presidencial sobre los equilibrios y contrapesos.

Dicho lo anterior, el presente precepto fue fuertemente criticado por la doctrina, en particular por Andrade, Estévez, Silva Bascuñán, Bidart, Cea, Tapia, etc., por considerar a la norma constitucional débil y ambigua que no permitía ni favorecía el ejercicio verdadero de la fiscalización parlamentaria. Tal como describe Juan Carlos Ferrada, en la Constitución de 1925 se establece una fiscalización parlamentaria "sin efectos políticos directos e inmediatos". Lo anterior, respondería lógicamente al planteamiento formulado por el presidente Alessandri Palma, por cuanto su propósito fue fortalecer al órgano Presidente de la República y generar una excesiva dependencia de los ministros hacia el mandatario. Por ello, sólo le reconoce a la Cámara una facultad restrictiva de crítica política, sin contar con la posibilidad de exigir responsabilidades políticas ${ }^{855}$.

855 FeRrada (2002) Pp. 461-481. 
En consecuencia, desde nuestra perspectiva se establecía constitucionalmente una fiscalización política aparente, toda vez que el poder entregado al jefe de Estado, junto con la excesiva vinculación de los ministros hacia su figura, impedían un verdadero control. Los ministros son de su exclusiva confianza y, sin importar la evaluación de su gestión, continuarán en su puesto hasta que el Presidente así lo desee, cual sea la opinión de la oposición o de la ciudadanía. Por otra parte, los mecanismos de fiscalización eran excesivamente débiles y benévolos, puesto que si bien era posible ponerlos en acción, su ejercicio no generaba repercusiones de interés y mucho menos responsabilidad política.

Sin perjuicio de aquello, hemos querido poner especial énfasis en la tesis sustentada por el profesor Alan Bronfman. El autor realiza un diagnóstico detallado respecto del precepto y su contexto normativo-político y expone tres causas basales que generaron la ineficiencia e ineficacia de la norma, de acuerdo a las cuales dos de ellas encuentran sus orígenes fuera del texto constitucional.

La primera de ellas fue el cambio de carácter de los partidos políticos nacionales. La nueva configuración del sistema de partidos dejaba atrás a los partidos transaccionales-cohesionados; se gestaban partidos ideológicos o doctrinales que hicieron carne la disciplina y la orden de partidos. Se produce, por tanto, una modificación en los rasgos constitutivos de los mismos y, por tal motivo, la prioridad era ejecutar un programa de gobierno partidario. En dicho cometido, no podían existir barreras política ni jurídicas. Por ende, la norma constitucional que regulaba la fiscalización estaba diseñada desde una lógica de transacciones y flexibilidad gubernamental totalmente incompatible con la aplicación dogmática de las ideologías.

La segunda causal externa al Código Político fue, a juicio de Bronfman, el crecimiento del aparato estatal dependiente del Ejecutivo. Nos recuerda el autor que, al igual que en el proceso político europeo, se da comienzo al declive del Parlamento y -como efecto inverso- se fue acrecentando el poder del Ejecutivo. Debido a las complejas circunstancias posteriores a la década del veinte, la ciudadanía exige respuesta a sus necesidades sociales, demandas que el Ejecutivo parece solucionar de manera más eficaz. Por consiguiente, la administración del Estado emprende un crecimiento sostenido, dando lugar a la burocracia estatal mientras que el Poder Legislativo continuaba cumpliendo sus funciones con una "mínima estructura técnica 
y burocrática". De allí que surja una relación desequilibrada que no favorecía el ejercicio de la fiscalización.

Finalmente, el tercer postulado dice relación con el precepto constitucional mismo. En este sentido, el argumento del autor se sustenta en los "limitados efectos jurídicos del artículo 39 No 2". Describe que la tenue proyección jurídica de la norma es el factor que coadyuva en la pérdida de fuerza de la misma. Lo anterior, debido a que no contemplaban un plazo en el cual debían de ser contestadas, lo que a su juicio agudizó la escasa eficacia de la norma ${ }^{856}$.

En términos generales, la situación descrita es intensamente atractiva porque la regulación de la fiscalización parlamentaria, contemplada en el artículo 39 en ambos numerales, de alguna manera trunca su propio ejercicio. Sin embargo, aquello es muy discordante con las intenciones expresadas por el presidente Alessandri en el debate constitucional relativo al precepto. Recordemos que es él quien presenta la redacción de esta norma a la discusión de la Comisión de reformas constitucionales. Mediante una fuerte convicción, expuso sobre la necesidad de controlar a un Presidente que gozaría de tan amplias facultades, pero a pesar de aquello el contexto político y la debilidad de la norma impidió la concreción de su ideal. Con todo, aquel convencimiento no se ve reflejado en el articulado de la institución y, más lamentablemente aún, tampoco fue resuelto por la vida parlamentaria. Tal como describe Silva Bascuñán, "la práctica ha comprobado la ineficacia de la forma de fiscalización confiada a la Cámara de Diputados por el $N^{\circ} 2$ del artículo 39 y, como resultado de esta experiencia, se ha propendido a la formación de Comisiones Investigadoras destinadas a considerar problemas de importancia inquietante para la nacionalidad $^{\prime \prime 857}$.

En definitiva, según este autor, no se produjo un fenómeno avasallador por parte del Parlamento a través de la fiscalización. Por el contrario, se produjo un fenómeno inverso, un presidencialismo exacerbado y omnipotente que debilitó las funciones básicas del Parlamento -especialmente la de fiscalización-, provocando que emergieran otros medios de fiscalización no regulados, como las comisiones investigadoras.

856 BRONFMAN (1991-1992) Pp. 296-299.

857 SILVA (1963) p. 117. 
Cabe hacer presente que, con el correr de los años, se fueron dictando una serie de leyes cuya principal finalidad fue fortalecer la fiscalización parlamentaria. En este sentido, surge en el año 1946 la Ley No 8.707 que permitía que el Senado y la Cámara de Diputados contaran con dos representantes de cada órgano en la Junta Central de Beneficencia Pública ${ }^{858}$ y en los consejos de los organismos fiscales de administración autonómica o semi fiscales, a fin de realizar actividades de control. Sin embargo, la norma tuvo corta vida y fue derogada el año 1961. Luego, en el año 1959, se dicta la Ley No 13.609 que crea la Oficina de informaciones parlamentarias. Dicha norma obligaba en su artículo 5 a todos los servicios de la administración del Estado a remitir sus publicaciones oficiales, estudios y estadísticas. Por su parte, el inciso segundo del precepto imponía la obligación de enviar los informes o antecedentes que fueran requeridos por la Oficina de información o directamente por alguna de las Cámaras. Para otorgar mayor eficacia a la norma, el mismo inciso establecía que el jefe superior del respectivo servicio era responsable por el correcto envío de la información solicitada; de no cumplir tal obligación, era sancionado por la Contraloría General de la República. No obstante, tales normas no cumplen su cometido esencial. Si bien la Ley No 13.609 crea mayor accesibilidad a la información, no logra mejorar la actividad fiscalizadora.

El análisis del precepto $39 \mathrm{~N}^{\circ} 2$ es la etapa investigativa doctrinal donde hemos detectado la mayor cantidad de argumentos que nos permiten ir delimitando -en alguna medida- un concepto de fiscalización parlamentaria en el Derecho Constitucional chileno, bajo la Constitución de 1925. Nos referimos a la aclaración que realiza el profesor Alejandro Silva Bascuñán al examinar que esta facultad del Congreso distingue claramente entre la función de fiscalizar y la de controlar, formulando una explicación bastante contundente entre la diferencias entre ellas y exponiendo por qué el constituyente nacional optó por la noción de fiscalizar.

En tal sentido, expone que, la palabra fiscalizar implica -siguiendo al diccionario- "criticar y traer a juicio las acciones u obras de otro", por ende, para el autor el Congreso actúa como un fiscal frente a las acciones del Gobierno. Es decir, investiga y averigua las acciones de otro -en este caso, las acciones del Ejecutivo-. Por consiguiente, no debe confundirse con la noción de control de los actos de Gobierno. Explica Silva que cuando se fiscaliza y controla se examina y analiza un

\footnotetext{
858 La junta central de beneficencia era una institución semipública, encargada de la administración, dirección y creación de hospitales, asilos, manicomios y casas de socorro.
} 
acto, pero desde veredas distintas. En el primer caso, se evalúa desde un juicio de valor acerca de la conveniencia o inconveniencia sustancial de su contenido, desde un punto de vista no sólo de su conformidad al ordenamiento jurídico positivo, sino además desde su adecuación al bien común. Por otra parte, cuando se controla se busca la conformidad del acto con el ordenamiento jurídico positivo, dejando de lado toda apreciación discrecional respecto de las motivaciones y la persona que lo ha ejecutado 859 .

En conclusión, conforme a los antecedentes expuestos podemos señalar que la aplicación o interpretación que respecto de la fiscalización parlamentaria se concibió por la doctrina y por la práctica parlamentaria, hasta la entrada en vigencia de la Constitución de 1925, fue una interpretación política de la misma. Así, existió una tendencia político-jurídica en la época que impulsaba una noción de naturaleza política de la misma, debido a la importante influencia de las ideas parlamentarias que provenían, esencialmente, del continente europeo. En este orden de ideas, la fiscalización parlamentaria estaba regulada jurídicamente, pero su interpretación y su aplicación fueron concebidas políticamente. De ahí la extensión y laxitud de los mecanismos fiscalizadores contemplados en la Carta Fundamental y, en particular, el ejercicio de mecanismos que no estaban regulados por la misma, como fue el caso de los votos de censura.

Es posible inferir que la excesiva amplitud de su interpretación y su profusa aplicación generaron un efecto diverso al esperado, puesto que se les atribuyó la responsabilidad en la inestabilidad democrática nacional y, por tal motivo, es culpabilizada por todos los males del sistema político. Dicho escenario gestó una reconsideración respecto de las mismas, provocándose el siguiente efecto: las nuevas orientaciones políticas que se esbozan a raíz del debate constitucional de 1925 estuvieron dirigidas hacia el fortalecimiento del Ejecutivo y su equipo ministerial. Se reduce la fiscalización parlamentaria, se acota el campo de aplicación y los mecanismos fiscalizadores. El artículo 39 expresó virtudes y debilidades. Desde una perspectiva positiva, hemos de destacar la diferenciación que se produce entre ellos, en cuanto a establecer la acusación constitucional y la fiscalización de los actos de Gobierno, como mecanismos diferentes. Pero, si bien la regulación de la acusación constitucional fue más clara y detallada, la fiscalización presentó importantes debilidades.

${ }^{859}$ SiLVA (1963) p. 114. 


\section{Apogeo y declive de una revolución política e intelectual nacional}

A continuación, realizaremos un brevísimo análisis respecto de algunos de los factores políticos, sociales y culturales que paulatinamente fueron dibujando los sucesos políticos nacionales de mayor significación para esta investigación. El objetivo es entregar antecedentes que permitan comprender cuáles fueron los factores que inciden, directamente, en el desarrollo político nacional, en la evolución de la fiscalización parlamentaria y, en especial, en el desenlace del golpe de Estado cívico-militar, pudiendo así esbozar nociones generales respecto de los elementos que intervienen en la creación de un nuevo texto constitucional y, particularmente, en la regulación de la fiscalización parlamentaria.

Recapitulando, si bien la Constitución de 1925 modifica las bases institucionales del sistema político estableciendo un régimen presidencial fuerte, lo cierto es que la realidad política distó mucho de aquello. En efecto, el parlamentarismo continuó marcando pautas políticas de manera fáctica, en gran medida por el actuar de los partidos políticos de la época.

Siguiendo lo sostenido por Donoso, diremos que, si bien la Revolución militar de 1924-1925 fue más profunda de lo que aparentó, fruto de ella se produce el surgimiento de una Constitución promovida por jóvenes militares que aspiraban eliminar los vicios del régimen parlamentario frente a la férrea oposición de los partidos políticos. Durante la vigencia de la misma, se presentarán serias dificultades en torno a la sucesión presidencial en el país y la forma de ejercer el poder, puesto que -en cuanto a la literalidad del texto- el presidencialismo era evidente. No obstante, ninguna ley era capaz de desarraigar métodos y prejuicios ya instalados, relativos al parlamentarismo ${ }^{860}$. Por ende, lo que sucede en el ejercicio político cotidiano es la resistencia hacia un régimen presidencial y el continuismo en las prácticas parlamentarias.

Cabe recordar que, durante el gobierno de Emiliano Figueroa, la irrupción del Parlamento fue constante. Desde esta perspectiva, los actores responsables de estas ambivalencias políticas, en cuanto al régimen y sus manifestaciones, fueron los partidos políticos, los que tendieron habitualmente a actuar de forma parlamentaria, formando autoridades circulares, transaccionales o de grupo, a diferencia de lo que

${ }^{860}$ DoNOSO (1976) p.348. 
ocurre con el presidencialismo, en el cual el ejercicio de la autoridad es piramidal $^{861}$. Con todo, el parlamentarismo durante los años 1925-1927 no fue erradicado de las costumbre políticas chilenas. Continuará vigente durante muchos más, generando diversos problemas incluyendo a los gobiernos radicales de Pedro Aguirre Cerda, Juan Antonio Ríos y Gabriel González Videla, caracterizados por fuertes negociaciones y acuerdos entre las cúpulas partidistas lo que, si bien permitió una estabilidad política, produjo serios problemas económicos y sociales.

Cabe hacer presente que fue el General Ibáñez quien sostuvo más fuertemente el presidencialismo y su aplicación tanto en su rol de Ministro de Guerra como de Presidente de la República, evitando la revitalización de los fantasmas parlamentaristas, dándole plena vigencia al texto constitucional y, en especial, a las atribuciones señaladas respecto del Ejecutivo. Esbozaba ideas de independencia del Poder Ejecutivo respecto de los demás poderes -incluyendo el militar-, de eficiencia administrativa, de total autonomía de los partidos políticos y de libertad electoral. En consecuencia, será precisamente esa cualidad la que le otorgará un amplio apoyo ciudadano y político basado en sus eslogan "barrer con los políticos". El presidente Ibáñez es electo en el año 1952, oportunidad en la que se produce un gran cambio en la política chilena, puesto que se unifican todos aquellos anhelos en contar un liderazgo presidencial fuerte que guiará el desarrollo del país hacia un puerto seguro. No obstante, con el presidente Ibáñez lo que realmente emerge es el populismo autoritario que pretendía ligar al mandatario directamente con las masas populares, sin mediar a través de partidos políticos, lo cual puso en riesgo el sistema político de representación y de negociaciones ${ }^{862}$.

El Gobierno de Ibáñez se desarrolla en medio de relaciones muy complejas tanto con los partidos políticos como con el empresariado, quienes quitan su apoyo al Presidente. Por su parte, el Jefe de Estado reaccionó atacando constantemente al Congreso y los empresarios. La situación era compleja e Ibáñez presentó una actitud zigzagueante. Intentó generar redes con la izquierda y la derecha, pero no tuvo buenos resultados; además, enfrentaba diversas protestas sociales que evidenciaban su soledad política. Sus ministros duraban cortos lapsus de tiempo en el cargo y sus constantes fracasos en el Congreso y la represión policial precipitaban su salida del gobierno el año 1958.

\footnotetext{
${ }^{861}$ Donoso (1976) p. 302.

862 CORREA et alt. (2001) Pp.197-200.
} 
Durante los años cincuenta y sesenta, la evolución social chilena estuvo marcada fuertemente por la expansión de la industrialización y una difícil integración social, producto de los oscilantes movimientos de la economía y las complicaciones que ello produjo en la oferta de empleo productivo. Además, las complejidades políticas impedían lograr una representación nacional efectiva. Este conjunto de hechos -a juicio de Cañas- contribuye en caracterizar este período como uno de movilización de creciente politización de los grupos sociales y de debilitamiento del consenso político. En tal escenario, los partidos políticos toman particular preponderancia, puesto que son los canales a través de los cuales los movimientos sociales y laborales se transforman en un actor social relevante. Conjuntamente, un grupo de reformas electorales cristalizan la democracia de masas. Durante todo este lapsus de tiempo predominarán en Chile partidos políticos como el Partido Comunista, Partido Socialista, Partido Radical, Partido Demócratacristiano, y el Partido Nacional por la derecha. Estos conglomerados tuvieron presencia nacional con amplia representación popular, por ende, eran altamente competitivos. Hasta el año 1957 el predominio del escenario político lo ejercía el Partido Radical, pero a partir de los años sesenta tomará ese sitial la Democracia Cristina ${ }^{863}$.

El período comprendido entre 1964 y 1973 es, sin lugar a dudas, el espacio temporal más intenso para la política nacional. Estuvo marcado por una excesiva ideologización antagónica hasta el punto de volverse confrontacional, consumando un lamentable golpe de Estado. Como describe Cea Egaña, en los años en comento los jóvenes y profesionales despertaron ávidos de conocimientos políticos, produciéndose un efecto de fuertes disputas intelectuales desarrolladas, esencialmente, en el año 1968, en los claustros universitarios, oportunidad en que los partidos de centro derecha carecieron de un discurso llamativo. Junto con lo anterior, se dio una desintelectualización desde los sectores conservadores, en parangón con la izquierda que se presenta hiperintelectualizada por el pensamiento socialista y comunista, y también en importante medida por la fuerza de centro que cubría la Democracia Cristiana ${ }^{864}$.

Por tanto, emergieron movimientos obreros y campesinos, estudiantiles y sindicales. La promoción del pueblo era un hecho. El fenómeno de polarización política del electorado, en pocas palabras, se encuentra vinculado a que sectores

\footnotetext{
863 CAÑAS (1997) Pp.28-30.

864 CEA (2008) p.36.
} 
muy significativos de la población, los cuales tendían a buscar su representación en partidos que tenían una postura revolucionaria o conservadora respecto del statu quo imperante. Durante los años cincuenta ante la situación política, económica y cultural nacional comenzaba a gestarse un descontento popular masivo, debido al fracaso de las políticas librecambistas que habían instaurado los gobiernos en esos años. Es por ello que los nuevos proyectos surgen inmersos en ideas que proponen el desarrollo social y la modernización, y la implantación de transformaciones globales a partir de una intervención directa y planificada del Estado. Se trataría de una revolución de las estructuras tradicionales. De este modo, el profundo descontento que recorría al país, condujo el diseño de propuestas altamente elaboradas e imbuidas de optimismo.

Por otra parte, en aquellos años en nuestro país, la población electoral había aumentado exponencialmente. Por ende, aumenta el apoyo popular a las diversas fuerzas políticas, surgiendo un mayoritario apoyo al Partido Socialista y a una naciente Democracia Cristiana (fundada en 1957). De ahí que nazca el concepto de revolución como sinónimo de transformación rápida, decidida y cabal de los órdenes establecidos, modificando criterios y paradigmas. La consigna que nutrió las propuestas -que luego serán gobierno- fueron, a saber: "La Revolución en Libertad", "La Vía chilena al socialismo" y la "Revolución Silenciosa". Los años sesenta, en definitiva, marcan el punto de inflexión político que además gestó un discurso que produjeron determinadas prácticas que se cauterizarán por ser rupturistas ${ }^{865}$.

En aquel contexto, se desarrollarán los gobiernos de los presidentes Frei Montalva y Allende Gossens, liderazgos y gobiernos diversos, pero que compartían un objetivo común: realizar cambios profundos que materialicen la libertad, la igualdad y la dignidad del pueblo. Es preciso señalar que, en aquel escenario político, se produce una fuerte crítica la Constitución de 1925; se proponían cambios estructurales y nuevas tendencias en la arquitectura democrática y constitucional del país. Si bien las propuestas de enmienda constitucional no eran numerosas, eran graves y esenciales, y -sumadas a las conductas e interpretaciones extralegalesfacilitaron la crisis $^{866}$.

\footnotetext{
865 CORREA et alt. (2001) Pp. 238-241.

866 CAÑAS (1997) Pp.35 y 40.
} 
El presidente Frei llega al gobierno con un lema denominado "Revolución en Libertad" que comprendía transformaciones de envergadura, pero de forma pacífica, en la estructura política y económica de Chile. El programa estaba sustentado en la ideología social cristiana que proponía el robustecimiento de las atribuciones del Estado. Aquella propuesta de gobierno comprendía: una reforma agraria, renovación urbana, tributo patrimonial y la chilenización del cobre. Ciertamente, dichas propuestas no pudieron ser concretadas en su totalidad y algunas de ellas se vieron truncadas en su ejecución. Tal escenario de incumplimiento provoca la molestia en las Fuerzas Armadas, esencialmente, por el abandono económico en el que se han visto envueltas. Como consecuencia de ello, en el año 1969 se produce una insurrección castrense conocida como el "Tacnazo" ${ }^{\prime \prime 67}$. Incluso los poderes públicos salían de sus marcos institucionales y recurrían al ejercicio de la presión.

A pocos días del Tacnazo se produce la primera huelga del Poder Judicial. Si bien fue resuelto con rapidez, se evidenciaban las complejidades que los fines de los sesenta dejaba en el país y en el Gobierno, toda vez que la agitación social y política era compleja; el desenfreno marcará el fin del mandato de Frei y grandes convulsiones sociales marcarán la elección del año 1970.

Fruto de los hechos anteriormente descritos, el ambiente político estaba enrarecido. Por su parte, la derecha continuaba debilitada ideológica y socialmente, mientras que la izquierda seguía creciendo fuertemente y la Democracia Cristiana creaba su propio camino de centro. La incorporación de vastos sectores de la población a la actividad política superó las modalidades del accionar partidista, otrora sustentado en la negociación y el acuerdo entre las elites parlamentarias, lo que se

${ }^{867}$ Aquel suceso militar se produce porque el Ejército cansado de las carencias técnicas y económicas, en la tradicional misa del Te Deum, las fuerzas del batallón de Yungay retrasan su salida en el momento de rendirle honores a la comitiva oficial del Presidente, como expresión de su disgusto. Luego de aquello se aplicaron las sanciones correspondientes y se iniciaron conversaciones entre el Ministro de Defensa el señor Marambio y el Ministros de Hacienda con el objetivo de evaluar las mejoras en las remuneraciones del Ejército. Empero, ello no fue suficiente para el Comandante Roberto Viaux, de la primera división del Ejército ubicada en Antofagasta, quien planifica un movimiento militar, un ideario de golpe, el cual fue descubierto, a raíz de aquello es citado a Santiago, oportunidad en la que intenta reiteradamente concretar una conversación con el Presidente Frei, la cual le fue negada constantemente; en atención a aquellas circunstancias adelanta su intervención militar, regresa al norte de Chile y coordina la toma de la ciudad de Tacna. En la madrugada del 21 de octubre de 1969 a las ocho de la mañana toma el mando del Regimiento Artillería de Tacna.

Frente a esta escenografía el Presidente Frei declara clausurado el período de sesiones extraordinario del Congreso Nacional, con el objetivo de decretar el Estado de sitio. Por otra parte, corta los suministros básicos del Regimiento para poder presionar una rendición. Luego de infructuosos esfuerzos para hacerlo desistir, el subsecretario de Salud, el médico militar Patricio Silva, lo convenció de firmar el acuerdo conocido como Acta del Tacna, en él se acuerda la renuncia del Ministro de Defensa y otros altos cargos de las Fuerzas Armadas. Finalmente, el Comandante Viaux es enviado al hospital militar donde es detenido. 
tradujo en un constante enfrentamiento directo. En efecto, el Congreso había perdido protagonismo como espacio de negociación. La velocidad con la que se llevaban a cabo las transformaciones llevó a la polarización de las posiciones políticas. La opción de la Democracia Cristiana y la idea del "camino propio" presentaron altos grados de sectarismos y exclusión, lo que a su vez promovió que las fuerzas de izquierda y la derecha abrazaran posturas más radicales frente a las reformas necesarias.

En este escenario se produce un quiebre al interior de la Democracia Cristiana el año 1969, mismo año en la que se da nacimiento a la Unidad Popular formada por el Partido Comunista, Partido Socialista, Partido Radical, Partido Social Demócrata, Acción Popular Independiente (API) y el Movimiento de Acción Popular Unitaria (MAPU) -recientemente creado por jóvenes demócrata cristianos que se alejaron del partido-. La convergencia de fuerzas de izquierda se aúnan en virtud de las ideas marxistas y socialdemócratas. Se esforzaron por anular sus desavenencias y se aglutinan en el anhelo de realizar profundas transformaciones que Ilevarán hacia una sociedad justa e igualitaria ${ }^{868}$.

En aquel contexto se producen las elecciones de 1970, situación en la cual las fuerzas de izquierda se unen alrededor de un programa de cuarenta medidas, en torno a la candidatura de Salvador Allende. Aquella unificación política -bajo el nombre del candidato Allende- fue cuestionada desde su origen. Tal como describe Donoso, el régimen marxista de la llamada Unidad Popular no fue más que expresión de los resabios del parlamentarismo, fruto de viejos vicios. En el gobierno de Allende se haría una entrega progresiva de las atribuciones presidenciales a las mayorías parlamentarias y a los dirigentes de los partidos políticos; se trataría de deshacer de manera evidente la imagen ancestral construida del Presidente de la República, para dar entrada a La Moneda de un personaje diametralmente distinto y disminuido: "un Compañero Presidente" ${ }^{\prime 869}$.

La Unidad Popular se comprometía con el pueblo chileno a realizar una revolución por cauces institucionales, legales y constitucionales. Se hablaba de la "revolución con empanda y vino tinto", logrando una combinación de lo festivo y lo épico, provocando euforia con el triunfo de 1970. Si bien Allende logra una mayoría de $36,3 \%$ ello no era suficiente para ser proclamado Presidente. Le correspondía al Congreso, según disposición constitucional, la elección definitiva entre las dos más

868 CORREA et alt. (2001) Pp. 256 y 257.

869 DONOSO (1977) Pp. 346 y 347. 
latas mayorías. A pesar de que la tradición política nacional indicaba que se debía ratificar la primera mayoría, tal premisa intentó ser desconocida y se entorpeció el camino de Allende a la presidencia. El clima político, luego de la elección, estaba extremadamente tenso; la balanza la inclinaba la Democracia Cristiana, es decir, sus votos eran los que finalmente permitían ratificar al presidente Allende y es por ello que se ven sumidos en una serie de presiones políticas, hasta que finalmente acceden a ratificar al representante de la Unidad Popular bajo la condición de firmar el Estatuto de Garantías Constitucionales, elaborado por la misma Democracia Cristiana, a fin de generar una salvaguarda ante intento dictatorial por parte de la izquierda.

El presidente Allende es proclamado el 24 de octubre de 1970 concitando la atención internacional, puesto que llegaba al gobierno de forma democrática un presidente marxista. Tal escenario asombró al mundo, toda vez que era un momento en que la polarización de la Guerra Fría había incitado a la izquierda, a través de la Revolución cubana y china a comprometerse a acceder al poder en los países del Tercer Mundo ${ }^{870}$.

Finalmente, cabe destacar que nunca antes se le había condicionado la ratificación de un Presidente a la firma de un acuerdo-compromiso político, situación que ya dejaba entrever la desconfianza con la que iba a gobernar el mandatario de la Unidad Popular. Durante su gobierno, se intentó constantemente deslegitimar la elección y su programa de gobierno. Los obstáculos fueron constantes. Si bien durante el primer año de mandato los resultados fueron positivos, los dos años restantes serían de máxima complejidad. El año 1973 ya se escuchaban voces que advertían un golpe de Estado y por ello el Partido Socialista -intentando revertir esta amenaza- realiza una especial convocatoria a jóvenes soldados para unirse al proceso revolucionario y defender al Gobierno Popular. El llamado no fue en vano y varios militares cercanos y leales al gobierno desactivaron acciones del Ejército en contra del mismo, entre ellos los generales Carlos Prats y Augusto Pinochet. Tal fue la confianza que representaban algunos generales, que el Comandante en Jefe del Ejército Carlos Prats -conocido por su lealtad constitucional- renuncia agobiado por las presiones de los militares, recomendando como sucesor y hombre leal al gobierno revolucionario al General Pinochet.

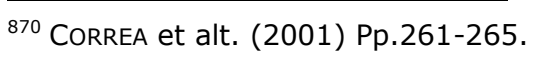


En este contexto, se promoverá con celeridad un complot golpista de civiles y militares que se desarrollaba hace bastante tiempo y con mucha rapidez, liderado por el Almirante José Toribio Merino, por el General de la Fuerza Aérea, Gustavo Leigh, y por el General de Carabineros, César Mendoza, quienes precisaban apoyo en el Ejército para asegurar el éxito de la intervención militar. En tal escenario, días antes del 11 de septiembre se sumará a la estrategia golpista el General Augusto Pinochet quien, en definitiva, tomará el liderazgo de la acción militar y adoptará la postura más severa e inflexible frente a los hechos, liderando posteriormente toda la larga y cruenta dictadura cívico-militar. Por esta razón, Nogueira explica que el golpe militar fue desarrollado orgánicamente por tres ramas de las Fuerzas Armadas, poniendo fin a la etapa institucional de la República democrática chilena. Ahora bien, agrega el autor que en aquel momento había ingresado al país una fuerte polarización ideológica y un bloqueo institucional y político, además de una fuerte crisis económica y social, elementos todos que contribuyeron a la caída del régimen democrático $^{871}$.

El 11 de septiembre el presidente Allende había decidido dar un discurso a la nación y realizar un llamado a plebiscito, con la finalidad de poder consultar al pueblo sobre la continuidad del proyecto revolucionario. Pero, como bien es sabido, aquel discurso nunca pudo ser pronunciado, puesto que durante esa madrugada las Fuerzas Armadas realizaron un ataque militar tan poderoso que no pudo ser contrarrestado ni por el Gobierno ni por las fuerzas sociales y políticas cercanas al Presidente. El Palacio de La Moneda fue bombardeado alrededor de las 11:00 a.m. No hubo contemplaciones ni con el edificio (construcción histórica) ni con sus ocupantes. Sus compañeros fueron tomados prisioneros; otros ejecutados; otros hasta hoy permanecen desaparecidos. Ni siquiera la muerte del mismo Presidente ha sido clarificada. El golpe de Estado fue certero y con él comenzará a ser destruida la viga central que sostenía el andamiaje institucional chileno. Desde el mismo 11 comenzará la reclusión en los hogares de los chilenos; campos de concentración y cárceles serán los mecanismos utilizados con miras a despejar la participación ciudadana, para imponer el sello militar ${ }^{872}$.

871 Nogueira (2008) p.326.

872 CORReA et alt. (2001) Pp.274-276. 
El régimen autoritario en su modalidad burocrática se instaló en Chile y se estructuró en base a la Junta Militar de Gobierno integrada por los respectivos Comandantes en Jefe de las Fuerzas Armadas, dirigida por el General de Ejército Augusto Pinochet. Esta Junta Militar asumió el poder constituyente, ejecutivo y legislativo. El Poder Judicial fue respetado en la medida que legitimara -mediante sus actos- al régimen militar y tolerara el atropello de los derechos humanos. En términos generales, durante los años de dictadura, bajo un férreo control policial y político, se modificaron fundamentalmente las bases sociales y económicas del país a través de un modelo neoliberal, en el cual la autoridad económica gubernamental actuaba sin contrapeso. El apoyo intelectual provenía del gremialismo dirigido por Jaime Guzmán, por la derecha política, por el empresariado más favorecido y por un

grupo denominado "Chicago boys" que promoverán la privatización y la desregulación económica ${ }^{873}$.

\section{Crisis política, Golpe de Estado y fiscalización parlamentaria}

La Constitución Política de 1925 rigió hasta el año 1973, empero, fue modificada en diez oportunidades con la clara finalidad de acentuar el régimen presidencial y modernizar el texto constitucional a los avances nacionales. En el año 1970 fue sometida a la séptima modificación, mediante la Ley $N^{\circ}$ 17.284. La reforma del 23 de enero del año en comento es la modificación más substancial realizada a la Carta Fundamental en materia de fiscalización parlamentaria, por tal motivo pasamos a examinar el contenido de la misma y sus alcances. Del mismo modo, procederemos a analizar los hechos políticos más relevantes ocurridos durante el Gobierno de la Unidad Popular y el golpe cívico-militar, con el objetivo de evidenciar algunos factores claves respecto de la fiscalización y su desarrollo en el Derecho Constitucional nacional.

Durante este particular período de la historia constitucional chilena, es posible distinguir dos etapas desde la perspectiva del ejercicio de la fiscalización. Una primera etapa, que media aproximadamente entre 1970 y 1973, en cuyo período de la política nacional -a pesar de la debilidad jurídica que anteriormente expusiéramos respecto del artículo 48- la Cámara de Diputados le atribuye un valor inesperado y una fuerza política y técnica suficiente a las herramientas fiscalizadoras

873 Nogueira (2008) Pp. 326 y 327. 
contempladas en el Código Político, al punto de poner en jaque la estabilidad democrática. Esgrimiendo interpretaciones meramente políticas, se tendió a utilizar la acusación constitucional con especial énfasis a partir del año $1970^{874}$, razón por la cual aquel proceso político será detallado en profundidad, en las líneas siguientes.

Una segunda etapa histórica nacional comprende el golpe militar del año 1973 y abarca todo el régimen dictatorial, vale decir, los 17 años en el cual la democracia fue inexistente y -por añadidura- también lo fue la fiscalización. En consecuencia, desde ya advertimos que no será posible formular mayores análisis respecto de aquel espacio de tiempo, debido a la inexistencia de control, sino que bastará con ratificar una de nuestras premisas iniciales de investigación: el poder que no es controlado se convierte en peligroso, vulnerador de los derechos humanos y de la institucionalidad democracia ${ }^{875}$.

A modo de introducción, es dable señalar que la etapa institucional chilena, bajo el imperio de la Constitución de 1925, llegará abruptamente a su fin como consecuencia de un golpe cívico-militar que borrará la democracia chilena e implantará un régimen autoritario. En los siguientes párrafos realizaremos una concisa exposición de los factores políticos más relevantes, relacionados con estos graves acontecimientos y su vinculación con la fiscalización parlamentaria -materia de esta investigación-, sin ahondar mayormente en los factores económicos y sociales por dos razones esenciales. En primer lugar, porque son hechos estudiados en profundidad por la literatura nacional, además de comprender muchas aristas que escapan al alcance de esta investigación; y en segundo lugar, porque no constituyen el objetivo central de nuestra investigación.

Es posible precisar que la mayúscula complejidad experimentada en Chile se debe básicamente a una crisis del compromiso del Estado que no pudo satisfacer las demandas sociales, frente al desarrollo de un sistema capitalista dependiente y la existencia de una debilidad política de las fuerzas sociales más relevantes, junto al reformismo industrial democratizante que, política y socialmente, generaron un grave estado de conflictividad.

${ }^{874}$ BRONFMAN (1991-1992) p. 302

${ }^{875}$ Cf.supra, p.18. 
Recordemos que la llegada al Gobierno del proyecto de la Unidad Popular y de la figura de Salvador Allende a la presidencia, fue constantemente impedida a través de diversos mecanismos; la reticencia hacia la vía chilena al socialismo era importante. El Gobierno Popular trajo consigo entre varias otras medidas, entre las cuales podemos mencionar expropiaciones, compra de acciones de la banca, nacionalización del cobre y una fuerte movilización obrera, gestando el desabastecimiento y episodios políticos de violencia lamentables. En definitiva, tal como describe Garretón y Moulian se incoa un proceso de desinstitucionalización, polarización y deslegitimación a través de los cuales se desencadena la crisis del régimen político ${ }^{876}$.

Según Gabriel Salazar, el presidente Allende actuó siempre respetando "tres artículos de fe" que lo llevarían al declive. En un primer término, el mandatario poseía una particular fe en la ley: estimaba que por el solo hecho de ser ley era buena y eficiente. Intentaría realizar una revolución legal, para lo cual le exigió a la Constitución de 1925 que entregara algo que ésta por origen, función y texto no podía dar. La segunda convicción de fe del Presidente, fue confiar en las Fuerzas Armadas chilenas. Para Salazar, tal fue su ingenuidad que obvió las 22 intervenciones militares que en un lapsus de 150 años había ejercido el Ejército, siempre en contra de movimientos democráticos populares. El tercer acto de fe, lo configuró su convicción de gobernar a través del Estado de derecho y de la democracia formal, vale decir, Allende profesaba el desarrollo transformador del Estado, puesto que si los liberales lograron transmutar el inocuo Estado liberal hipertrofiado en un Estado docente, social, empresario y benefactor, estimaba viable crear un Estado revolucionario ${ }^{877}$.

Finalmente, aquellos motivos develan una figura quimérica respecto a la mirada política que el Presidente poseía en cuanto a la arquitectura jurídica y política del Gobierno nacional, los que en cierta medida conspiran a favor del brutal golpe de Estado que pondrá fin a su mandato.

De este modo damos comienzo al estudio de los factores jurídicos y, en especial, a las implicancias de la reforma constitucional. Cabe hacer presente que, según Pfeffer, uno de los propósitos más relevantes de la reforma constitucional del setenta

\footnotetext{
876 GarRetón y Mulian (1979) Pp. 186-190. Para mayor abundamiento de las causas del golpe cívicomilitar y otros factores políticos y económicos revisar obra completa de estos autores.

877 SALAZAR (2009) Pp.160-161.
} 
lo constituía, precisamente, la idea de "racionalizar la función legislativa" y "resolver los conflictos de poder". En este orden de ideas, con la reforma se aprueban dos modificaciones de gran envergadura: en primer lugar, se otorga una facultad exclusiva al Presidente de la República respecto de la proposición de todo el gasto público y previsional y la iniciativa para fijar por ley las remuneraciones en el sector privado. De esta manera, se dotaba al Presidente de la República de las facultades necesarias para llevar adelante una política de planificación económica y social nacional, sin interferencia parlamentaria. En segundo lugar, se permitía delegar facultades legislativas por parte del Congreso al Jefe de Estado. En virtud de ello, se incorporaron al ordenamiento jurídico innumerables decretos con fuerza de ley; prueba de ello fueron los Códigos Tributario, Laboral y Sanitario. Por consiguiente, estas reformas estuvieron básicamente orientadas a racionalizar el procedimiento legislativo $y$, por ende, la función legislativa del Parlamento ${ }^{878}$.

En consecuencia, las nuevas tendencias constitucionales surgidas con posterioridad a la Segunda Guerra Mundial tienen su expresión nacional; la debilidad del Parlamento y el reforzamiento del Ejecutivo son una tendencia de carácter global; el carácter técnico de las leyes y la urgencia de las mismas, requieren enfrentar la gestión de Gobierno con otras herramientas legales y políticas. Es por ello que las reformas de 1970 iban orientadas en esa dirección, alterando la trayectoria constitucional que a la fecha conocía el país.

Continuando con la facultad de fiscalizar, la reforma también modificaba aspectos importantes de la acusación constitucional. Establecía la obligatoriedad al Presidente de permanecer en el territorio de la República mientras ella se conociera; instituía que, una vez iniciada una acusación contra el mandatario, éste no podía ausentarse del territorio nacional salvo que contara con autorización del Congreso, pero una vez que la acusación fuera aprobada -admitida- por la Cámara y pasara al Senado para ser fallada, no podía salir del país bajo ningún respecto.

Según Novoa, el contexto en el cual llegaba a gobernar Allende era muy particular, puesto que existían diversas circunstancias políticas y jurídicas que complejizaron su mandato. Desde una perspectiva jurídica, la Constitución Política de la República contemplaba una amplia gama de atribuciones, especialmente económicas y financieras, depositadas en manos del Presidente; pero a su vez

${ }^{878}$ Pfeffer (1987) Pp. 33 y 34. 
contenía un órgano fiscalizador, la Contraloría General de la República, ente que igualmente gozaba de amplias facultades de control hacia el Ejecutivo, motivo por el cual ostentaba las herramientas para paralizar la gestión del Gobierno.

Desde una perspectiva política, explica Novoa, fueron tres los factores que dificultaron su gestión. El primer factor, lo componían las dificultades en cuanto a sus atribuciones para administrar el Estado. Sus pretensiones se vieron obstruidas por la presencia dentro de la administración pública de un alto número de jefes y funcionarios designados por el gobierno anterior, los que se resistían a dejar sus cargos, apelando a determinados preceptos legales del Estatuto Administrativo. Un segundo factor, fue la actitud adversa que adoptó el Poder Judicial contra el Gobierno de la Unidad Popular, organismo jurídico que estimaba que algunas de las acciones del mandatario atentaban contra principios jurídicos fundamentales, es por ello que en defensa de los mismos no trepidó en extralimitar sus funciones y entrometerse, contra texto legal, en el ejercicio de las funciones administrativas por la vía de conocimiento de reclamaciones de diversa índole. El autor establece como tercer factor jurídico-político -que resulta ser el más relevante para nuestra investigación- la aplicación distorsionada con la que el Congreso -mayormente opositor al Presidente- interpretó los preceptos constitucionales que le concedían la facultad de remover ministros, para el caso de haber cometido delitos graves, o haber trasgredido la Constitución y las leyes ${ }^{879}$.

Según Novoa, el Parlamento utilizó estos instrumentos de fiscalización como el medio para abatir ministros, llegando a imponer una práctica propia del parlamentarismo que le permitía violar la Norma Fundamental y destituir ministros no precisamente a través de votos de censura, sino que mediante reiteradas y sucesivas acusaciones políticas. Por su parte, las acciones de defensa del Presidente respecto de su gabinete eran infructuosas, puesto que el Ejecutivo no contaba con mayoría parlamentaria en ninguna de las dos Cámaras. Por consiguiente, las fuerzas de oposición intentaron holgadamente impedir la aplicación del transformador programa de gobierno.

Respecto de esta primera etapa, es menester traer a colación lo sostenido por Joan Garcés, quien describe como elementos políticos importantes que influyen directamente en el desarrollo del Gobierno de la Unidad Popular dos hechos políticos

${ }^{879}$ NovoA (1978) Pp. 15-22. 
ligados a la facultad fiscalizadora: la caída de la mesa de izquierda de la Cámara de Diputados -por iniciativa de los diputados democratacristianos- y la acusación y destitución de un Ministro de Estado, por iniciativa y resolución de parlamentarios del mismo partido. Para Garcés, aquellos hechos fueron promovidos por dos eventos sociales significativos: por un lado, el asesinato de Edmundo Pérez Zujovic y, por otra parte, la "marcha de las cacerolas" del año $1971^{880}$. Según el autor, tales acontecimientos sirven de catalizadores para los sectores más conservadores de la Democracia Cristiana que motivan actuaciones que sólo empeoran las relaciones ya desgastadas entre ellos y la Unidad Popular ${ }^{881}$.

Al asumir la Presidencia el Gobierno Popular, Allende y la Democracia Cristiana habían acordado que la presidencia del Senado le correspondería a los segundos y la presidencia de la Cámara a la Unidad Popular. No obstante, por los hechos antes descritos -la marcha femenina y la muerte de Zujovic- y habiendo transcurrido solamente ochos meses de mandato, aquel acuerdo se rompe. Las relaciones entre Gobierno y el partido de la falange se habían enfriado, la mesa de izquierda de la Cámara de Diputados fue derribada y reemplazada por una demócratacristiana con respaldo de la derecha. Este último sector político, poseía una línea argumentativa clara, apelaba a la incompatibilidad entre el modelo revolucionario y la institucionalidad democrática, intentando incansablemente cuestionar la legitimidad del Gobierno de Allende mediante un fuerte combate ideológico.

Durante el primer año del presidente Allende, la derecha intentó alterar la estabilidad del Gobierno mediante el instrumento de la acusación constitucional contra ministros. En las tres oportunidades fracasó en su propósito, porque el partido de la falange negaba su apoyo a semejantes iniciativas -incluso cuando fue dirigida contra el ministro de Economía, don Pedro Vuskovic-. Sin embargo, tal como describimos anteriormente, el asesinato de Zujovic y la protesta femenina de las cacerolas, permitieron a los sectores conservadores de la Democracia Cristiana imponer al partido que entablaran un juicio político contra el ministro del Interior. Según Garcés. Este hecho interrumpe la tranquilidad acordada entre ambos sectores

\footnotetext{
${ }^{880}$ La "marcha de las cacerolas" tuvo gran significación social y económica, toda vez que mediante ella se evidenciaban las complejidades en el desarrollo nacional, la cual fue finalizada con la declaración de Estado de emergencia e incluso el toque de queda, profundizando la crisis social. Aquella marcha aparece como un movimiento espontáneo, sin un origen político partidista claro. Por otra parte, el asesinato de Pérez Zujovic quien fuera fundador de la Falange Nacional y del Partido Demócrata Cristiano, Ministro de Obras Públicas y del Interior del presidente Frei Montalva. Su muerte influye decisivamente en la polarización de la política chilena y la radicalización de la misma.

${ }^{881}$ GARCÉs (1972) Pp. 11 y 12.
} 
políticos y da lugar a un enfrentamiento político de alta magnitud. En tal contexto se enfrentará al Gobierno de la Unidad Popular con la Constitución Política de la República; se realizará un alineamiento frente a frente entre el Legislativo y el Ejecutivo por parte del Congreso y de escisión entre el régimen constitucional y el proceso revolucionario, que se materializará en la acusación del Ministro del Interior y su destitución ${ }^{882}$.

Tal escenografía imponía al presidente Allende la adopción de sólo dos vías. La primera, renunciar al programa transformador que lo caracterizó y le dio el triunfo o bien efectuar una paciente gestión -difícil y de largo aliento- que le permitiera materializar sus ideales. Para Allende la opción más clara era continuar con su programa. El triunfo electoral y la tradición nacional hacían prever que la gestión del mandatario podía verse dificultada mas no obstaculizada, toda vez que habitualmente al jefe de Estado electo democráticamente se le era permitido ejecutar sus aspiraciones nacionales. Contemplaba como elemento determinante la cierta similitud ideológica que imperaba en aquel momento, en relación con otros sectores políticos, en consecuencia, confiaba en que -con mayores o menores reticencias- las políticas públicas serían aprobadas. Empero, no contempló como elemento de suma importancia que la oposición nunca pretendió darle una tregua, por el contrario, exacerbaban su supuesta falta de legitimidad y las graves faltas que cometía su gobierno respecto del Estado de derecho a fin de situarlo en una situación sin salida ${ }^{883}$.

No pasó mucho tiempo para que las fuerzas opositoras se unieran y pusieran fin a la vía chilena al socialismo. Pero, antes de ello, las primeras expresiones de rechazo al modelo político que se estaba llevando a cabo fueron la utilización de las herramientas de control parlamentario. La acusación contra el ministro del Interior, José Tohá, incidía en el corazón mismo del problema, puesto que él representaba una importante estrategia en la construcción de la revolución socialista. Como lo esbozáramos, las fuerzas de oposición se alinearon y aquella acusación fue liderada por la Democracia Cristiana, también apoyada por el Partido Nacional y la Democracia Radical, asegurándose con ello mayoría en ambas Cámaras. Por ende, este acto político-jurídico se constituye como la primera amenaza seria a la

\footnotetext{
882 GARCÉS (1972) Pp. 15 y 16

883 NOVOA (1978) Pp. 19 y 20.
} 
estabilidad del Gobierno. La acusación del ministro Tohá fue el puntapié inicial a un trayecto complejo para el Gobierno de la Unidad Popular.

La acusación se sustenta en la "infracción a la Constitución y, el quebrantamiento de las leyes por haberlas dejado sin ejecución y por haber comprometido gravemente la seguridad de la Nación". Pero, a pesar de aquel fundamento jurídico constitucional, lo cierto es que estábamos en presencia de una acusación cuyo tinte principal era de carácter político. Porque en tal contexto social acusar, juzgar y condenar al Gobierno -obteniendo la destitución del Ministro del Interior- suponía una maniobra frente a la cual era muy difícil salir sin sufrir un menoscabo político, ya sea colocando en tela de juicio la constitucionalidad del Gobierno o provocando la pérdida de su posición política ante la ciudadanía. Sin perjuicio de aquello, el Gobierno planteó su defensa desde un plano netamente jurídico-constitucional. En palabras de Garcés, el Gobierno prefirió seguir un camino legal, puesto que ello aminoraba las posibles pérdidas políticas $y$, en cierta medida, evitaba las posibles represalias del Parlamento, paralizando u hostigando al Gobierno mediante otras acusaciones contra Ministros de Estado. La Unidad Popular estaba cierta en que esta acusación era una amenaza concreta sobre una posible ruptura del régimen constitucional y es por ello que actúa con cierta cautela ${ }^{884}$.

Por tal motivo, cuando concurre el ministro Tohá a la Cámara de Diputados a exponer su defensa, desestima cada uno de los hechos por no constituir violaciones a la Norma Fundamental. Agrega que, por el contrario, es la Cámara la que puede incurrir en una grave violación de la Constitución si aprueba una acusación sin un claro sustrato jurídico. Las palabras del Ministro fueron insuficientes y la acusación fue aprobada, quedando suspendido de su cargo hasta el fallo del Senado. Ante el Senado, el 18 de enero de 1971, el jefe de la cartera de Interior plantea la cuestión previa de inconstitucionalidad, pero ella fue rechazada. La acusación sigue su curso y ha de enfrentar un momento especialmente perturbador, los senadores de la Unidad Popular apelando al íntimo y personal criterio de sus colegas -como último resquicio político- solicitan que la votación sea secreta, sosteniendo que de practicarse la votación en aquellas condiciones podía ocurrir que muchos congresistas modificaran su voto, en virtud de la inconsistencia jurídica de la acusación. Pero, lastimosamente, ello no ocurre y la oposición vota abiertamente y de forma pública su aprobación a la

${ }^{884}$ GARCES (1972) Pp. 22 y 23. 
acusación; la minoría se retira de la sesión y el proceso acusatorio queda consumado el 22 de enero de 1971. La acusación contra Tohá es aprobada.

Siguiendo a Garcés, es posible señalar que a pesar de que el presidente Allende acepta la renuncia del ministro Tohá al momento de ser admitida la acusación por la Cámara de Diputados, de manera fáctica éste sigue liderando la cartera de Interior. Esboza el autor que no fue ratificado como ministro de Interior simplemente por una decisión discrecional del Presidente. En esta dirección, y antes de ser juzgado por el Senado, el mandatario expone públicamente su defensa hacia el señor Tohá y expresa que quienes se han salido del margen constitucional son los parlamentarios. Al día siguiente, Allende nombra al señor Tohá como Ministro de Defensa, acto sin precedente en la historia de Chile. Para el autor, estas medidas le permiten al Presidente ratificar sus atribuciones establecidas constitucionalmente, confirmar la irresponsabilidad política de los ministros y denunciar la inconstitucionalidad con la cual han actuado las Cámaras. La oposición, sorprendida por estas medidas, endurece su crítica. Por su parte, el Presidente con su estrategia coloca a la oposición en un "doble jaque"; los promotores de la acusación recurren al Tribunal Constitucional para inhabilitar al señor Tohá en la aceptación del cargo de Ministro de Defensa, empero, su reclamación no fue aceptada y el tribunal le da plena validez a la designación. De esta manera el 28 de enero Tohá era nuevamente Ministro de Estado $^{885}$.

El escenario político era tan complejo en materia de fiscalización que la Cámara de Diputados -con fecha 23 de agosto de 1973- adopta un acuerdo que dirige al presidente Allende, mediante el cual le reprochan al jefe de Gobierno una serie de irregularidades políticas y jurídicas. Lo acusan de quebrantar gravemente el orden constitucional y legal de la República, puesto que no somete al Estado de derecho, viola gravemente la Constitución y las leyes. Lo acusan, además, de no respetar el Estatuto de Garantías acordado con 75 parlamentarios de la Democracia Cristiana y la Unidad Popular al momento de ratificarse en el Congreso su candidatura presidencial como la electa mayoritariamente.

En particular, las Cámaras formulan una fuerte crítica respecto de la usurpación que habría realizado el Presidente respecto de su principal función, la facultad legisladora. Señalan que el Mandatario había adoptado una serie de medidas de gran

${ }^{885}$ GARCES (1972) Pp. 35-38. 
importancia en la vida económica y social del país, las que eran indiscutiblemente materias de ley y que fueron reguladas abusivamente por decretos de insistencia o por simples resoluciones administrativas basadas en resquicios legales. Agregaron además que el Presidente había burlado permanentemente la facultad fiscalizadora del Congreso Nacional, al privar de todo efecto real la atribución que éste poseía para destituir ministros que violen la Constitución y las leyes ${ }^{886}$.

El Mandatario da respuesta al acuerdo de la Cámara el 24 de agosto del mismo año. En aquel documento, hará presente que el medio para cuestionar constitucionalmente su gestión es a través de una acusación constitucional, pero que no poseen las mayorías suficientes para hacerlo $y$, por tanto, utilizan un simple acuerdo que no tiene validez jurídica. Agregará que la mayoría parlamentaria ha desnaturalizado el contenido de la facultad fiscalizadora que el artículo $39 \mathrm{~N}^{\circ} 2$ le otorga, reprochando que los acuerdos y observaciones adoptados deben ser transmitidos por escrito al Presidente y no directamente a los ministros, como se ha hecho, y que aquello no afecta la responsabilidad de los mismos, mientras que sí lo contempla el acuerdo. Finalmente, el Presidente declara al Parlamento como un bastión contra las transformaciones, ya que ha hecho todo lo que está en sus manos para perturbar el funcionamiento de las finanzas y las instituciones, esterilizando cualquier iniciativa creadora ${ }^{887}$.

A mayor abundamiento, se señalan todas las acusaciones constitucionales realizadas en el Gobierno de la Unidad Popular:

ACUSACIONES CONSTITUCIONALES 1970-1973

Eduardo León Villarreal, Ministro del Trabajo y Previsión Social (27

de enero de 1970), causal: atropellamiento leyes; haber dejado sin ejecución leyes

Lisandro Cruz Ponce, Ministro de Justicia (26 de enero de 1971), causal: Atropellamiento leyes; haber dejado sin ejecución leyes

Sergio Ossa Pretot, Ministro de Defensa Nacional (10 de marzo de 1970), causal: Haber dejado sin ejecución las disposiciones legales sobre previsión social de los personales en retiro y de las montepiadas de las Fuerzas Armadas y, especialmente, en cuanto al reajuste de sus remuneraciones, respecto del cual ha dejado sin ejecución la Ley No 17.267.

José Oyarce Jara, Ministro de Trabajo y Previsión Social (23 de marzo de 1971), causal: Atropellamiento leyes; haber dejado sin ejecución leyes.
APROBADO/RECHAZADO Rechazada por falta de quórum.

Rechazada en la Cámara de Diputados.

Rechazada por falta de quórum.

\footnotetext{
886 PfEFfer (1987) p.110.

887 Pfeffer (1987) Pp. 114 y 115.
} 


\begin{tabular}{|c|c|}
\hline $\begin{array}{l}\text { Pascual Barraza, Ministro de Obras Públicas (7 de septiembre de } \\
\text { 1971), causal: Desacato. }\end{array}$ & $\begin{array}{l}\text { Rechazada en el } \\
\text { Senado. }\end{array}$ \\
\hline $\begin{array}{l}\text { Pedro Vuskovic, Ministro de Economía (8 de septiembre de 1971), } \\
\text { causal: Atropellamiento leyes; haber dejado sin ejecución leyes. }\end{array}$ & $\begin{array}{l}\text { Rechazada en la Cámara } \\
\text { de Diputados. }\end{array}$ \\
\hline $\begin{array}{l}\text { Pedro Vuskovic, Ministro de Economía, Fomento y Reconstrucción } \\
\text { (15 de diciembre de 1971), causal: Reiteradas y graves } \\
\text { infracciones a las garantías constitucionales; atropellamiento y } \\
\text { dejar sin ejecutar leyes. }\end{array}$ & Rechazada Senado. \\
\hline $\begin{array}{l}\text { José Toha, Ministro del Interior ( } 28 \text { de diciembre de } 1971 \text { ), causal: } \\
\text { Reiteradas y graves infracciones a las garantías constitucionales; } \\
\text { atropellamiento y dejar sin ejecutar leyes. }\end{array}$ & $\begin{array}{l}\text { Aprobada: } 5 \text { capítulos. } \\
\text { Votación: } 26,26,26,25 \\
\text { y } 26 .\end{array}$ \\
\hline $\begin{array}{l}\text { Hernán del Canto, Ministro de Interior ( } 28 \text { de junio de } 1972 \text { ), } \\
\text { causal: Infracción de la Constitución, atropellamiento de las leyes, } \\
\text { por haberlas dejado sin ejecución y por haber comprometido } \\
\text { gravemente la seguridad de la Nación. }\end{array}$ & $\begin{array}{l}\text { Aprobada: A favor: } 27, \\
\text { Contra: } 14, \text { Abstención: } \\
1 .\end{array}$ \\
\hline $\begin{array}{l}\text { Orlando Millas, Ministro de Hacienda ( } 20 \text { de diciembre de } 1972 \text { ), } \\
\text { causal: Infracciones de la Constitución, atropellamiento de leyes, y } \\
\text { por haber dejado otras sin ejecución. }\end{array}$ & $\begin{array}{l}\text { Aprobada: } 4 \text { capítulos. } \\
\text { Votación: } 31,31,27 \text { y } \\
28 .\end{array}$ \\
\hline $\begin{array}{l}\text { Orlando Millas, Ministro de Hacienda (10 de mayo de } 1973) \text {, } \\
\text { causal: Infracciones de la Constitución, atropellamiento de leyes, y } \\
\text { por haber dejado otras sin ejecución. }\end{array}$ & $\begin{array}{l}\text { Rechazada Cámara de } \\
\text { Diputados. }\end{array}$ \\
\hline $\begin{array}{l}\text { Sergio Bitar, Ministro de Interior y Luis Figueroa, Ministro de } \\
\text { Minería ( } 29 \text { de mayo de 1973), causal: atropellamiento de la ley, } \\
\text { haberla dejado sin ejecución y de infracción a la Constitución } \\
\text { Política del Estado. }\end{array}$ & $\begin{array}{l}\text { Aprobada: } 3 \text { capítulos: } \\
26,16 \text { ( } 8 \text { contra y } 2 \\
\text { abstenciones). }\end{array}$ \\
\hline $\begin{array}{l}\text { Orlando Millas, Ministro de Economía (12 de junio de 1973), } \\
\text { causal: atropellamiento de la ley, haberla dejado sin ejecución y de } \\
\text { infracción a la Constitución Política del Estado. }\end{array}$ & $\begin{array}{l}\text { Aprobada: } 25 \text { votos a } \\
\text { favor. }\end{array}$ \\
\hline $\begin{array}{l}\text { Gerardo Espinoza, Ministro del Interior ( } 26 \text { de junio de } 1973 \text { ) } \\
\text { causal: atropellamiento de la ley, haberla dejado sin ejecución y de } \\
\text { infracción a la Constitución Política del Estado. }\end{array}$ & $\begin{array}{l}\text { Aprobada: } 25 \text { votos a } \\
\text { favor. }\end{array}$ \\
\hline $\begin{array}{l}\text { Carlos Briones, Ministro del Interior ( } 8 \text { de agosto de 1973) causal: } \\
\text { Atropellamiento y no ejecución leyes. }\end{array}$ & $\begin{array}{l}\text { Rechazada Cámara de } \\
\text { Diputados. }\end{array}$ \\
\hline
\end{tabular}

En definitiva, la situación política, económica y social se agudizaba y las dificultades acrecentaron. En palabras de José Luis Cea, los dirigentes de la Unidad Popular sostenían que la Democracia Cristiana -unida a la derecha- se había aliado para impedir el cumplimiento del programa de Gobierno mediante paros nacionales y el rechazo de las iniciativas de ley. No obstante, lo más sensato para Cea era reconocer que lo que sucedía era que la Unidad Popular intentaba exigir la rendición de la oposición por medios políticos, a pesar de ser la fuerza política mayoritaria. En este orden de ideas, el Gobierno Popular intentaba llevar a cabo su programa a través de una revolución de facto, lo cual no fue posible por el "espíritu democrático 
y jurídico mayoritario de la clase política y el profesionalismo de las Fuerzas Armadas $y$ de Carabineros ${ }^{\prime 1888}$. Esta situación provoca serios enfrentamientos en el campo y en la ciudad que finalizan con la intervención militar del 11 de septiembre de 1973, la que según Cea no fue casual ni tampoco el resultado de la acción de un grupo pequeño de uniformados, sino que es incentivada por muchos civiles que, en definitiva, construyen el proceso de quiebre constitucional. Con el golpe cívico-militar se da origen a un gobierno autoritario dictatorial que estará presente formalmente durante 17 años.

Demás está decir que durante el régimen autoritario nacional no hubo control político alguno. Siguiendo a este autor diremos que el poder político se encontraba fuertemente personalizado en la figura del General Pinochet y sólo era contrapesado débilmente por el procedimiento de toma de decisiones de la Junta Militar.

Con todo, el período dictatorial tendrá su fin en el año 1990, pero dejará su legado más significativo: la Constitución Política de la República del año 1980, texto cuyo origen y contenido ha sido fuertemente cuestionado. En este sentido, Francisco Cumplido expone respecto al origen de la misma que La Constitución del año 1980 fue generada por un Gobierno de facto, por una Comisión, designada por el gobierno, de pluralismo limitado; no estaban, por supuesto, todas las corrientes de opinión política existentes a 1973 como componentes de la Comisión que redactó el proyecto... $^{\prime 889}$.

El acto de proceder a la redacción de un texto constitucional, resultaba simbólico para la dictadura, porque tal como describe Fuentes, se trataba de un régimen de facto que progresivamente iba convirtiendo sus acciones en ley. Fue forjando las bases de una institucionalidad. Para la dictadura se trataba de superar la decadencia política de las décadas precedentes; Pinochet representaba múltiples vicios al sistema político, la anulación de los partidos políticos y la eliminación de controles sobre y por el Congreso Nacional. Por tanto, una nueva Carta Fundamental establecía una institucionalidad renovada, una nueva estructura de poder que -según sus creadores- permitía retornar a la esencia chilena. Nos recuerda el autor que las sesiones de la Comisión de Estudios para una nueva Constitución fueron reservadas,

888 CEA (2008) Pp.42 y 43.

${ }^{889}$ CUMPLIDo (1985) p. 87. Recordemos que precisamente el año 1977 renuncian a la Comisión destinada a redactar el proyecto constitucional los destacados juristas, Alejandro Silva Bascuñán, Enrique Evans de la Cuadra y Jorge Ovalle Quiroz, por considerar que la junta militar de gobierno, no contemplaba verdaderamente la intención de restablecer el régimen democrático sino uno autoritario. 
y el resultado de sus trabajos presentado a un Consejo de Estado, el que también fue designado por el Presidente, quien sesionó igualmente mediante sesiones secretas, entregando sus opiniones directamente al alto mando de la Junta Militar, aunque ellas no eran vinculantes. Este órgano fue quien finalizó la elaboración del Código Político ${ }^{890}$.

La importancia de redactar una Constitución fue mayúscula y el General Pinochet realizó sus máximos esfuerzos por "orientar" el sentido de la misma. Es así como el 10 de noviembre del año 1977 envía un memorándum a la Comisión de acuerdo al cual entregaba ciertos lineamientos respecto del contenido. En aquel documento expresaba su preocupación por el establecimiento de un sistema presidencial con una autoridad fuerte, que impidiera que llegasen al poder personas con votaciones minoritarias. También presentaba la modificación sustancial del nuevo Parlamento y el establecimiento de normas que impidieran la intromisión de los partidos políticos en la generación de movimientos gremiales, sindicales, etc. Por su parte, la Comisión recoge las ideas esbozadas en el memorándum, realizando un informe que contenía las ideas básicas y un anteproyecto articulado, el cual fue entregado al jefe de Estado, quien a su vez lo entrega al Consejo de Estado. Finalmente, quienes afinarán la Carta Fundamental será la misma Junta Militar de Gobierno ${ }^{891}$.

La Norma Fundamental fue aprobada en un plebiscito que se desarrolló en un clima de ausencia de libertad de expresión, en el que se consultaron tres materias diversas. Los partidos políticos estaban disueltos, no había registros electorales, ni juntas electorales. Tampoco se pudo contar con apoderados de las opciones contrapuestas en las mesas de sufragio. Había un régimen de emergencia especial, vetando los espacios públicos y medios de comunicación social a aquellos que sustentaban la campaña que se negaba a aprobar la Constitución. Ni siquiera había un Tribunal que se pudiera pronunciar sobre la legitimidad y legalidad del acto plebiscitario $^{892}$.

Con todo, el texto constitucional fue aprobado y promulgado por el General Pinochet el 21 de octubre de 1980, pero entraría a regir el 11 de marzo de 1981. En virtud de los antecedentes antes expuestos, el Código Político presentará -tal como lo describe Carrillo- un notable déficit democrático, debido a su origen espurio y su

\footnotetext{
890 FUENTES (2012) Pp. 27-29.

891 NogueiRA (2008) Pp. 328 y 329.

892 NogueiRA (2008) p. 330.
} 
ausencia de legitimidad democrática, cuya expresión más lamentable fue la hipoteca que supone la tutela militar sobre el régimen político chileno, elementos que le permiten sostener a Carrillo que estamos frente "a una Constitución carente de legitimidad democrática, viciada de origen y, en consecuencia, una Constitución no democrática"1893.

Paralelamente, en el año 1980 mientras se producía la convocatoria a plebiscito los sectores opositores a la dictadura -los que eran expertos en Derecho Constitucional- y que creían firmemente en la democracia, conforman un grupo de estudios constitucionales que tendrá por finalidad redactar una propuesta respecto de un derecho constitucional alternativo. Aquel grupo fue llamado el "Grupo de los 24". Una vez aprobada la Constitución, centran sus concienzudos estudios en el análisis crítico de la misma, emitiendo el documento "Las críticas del Grupo de los 24 " en el cual plasman todos los cuestionamientos relativos al texto constitucional que entraba en vigencia.

Para el Grupo de los 24, la Constitución de la Junta Militar negaba la democracia y -lo que es más grave- cerraba los cambios para instaurar la democracia dentro de los caminos que ella consagra. Bajo el pretexto de "proteger la democracia" de algunos de sus eventuales enemigos, niega la misma cuando desconoce la igualdad de derecho de todas las personas ${ }^{894}$. Las principales críticas de este Grupo de estudiosos señalaban que, con la nueva Constitución, se configuraba un régimen político autocrático y militar en el cual el poder real no residía en el pueblo, quien sólo participaba eligiendo autoridades. El Presidente gozaba de poderes dictatoriales y el Congreso carecía de atribuciones propias. El Presidente no estaba sujeto a ningún control efectivo por parte de los representantes del pueblo, su autoridad no tendría otro contrapeso que el Tribunal Constitucional y las Fuerzas Armadas.

El nuevo texto, según el Grupo de los 24, contemplaba un cesarismo presidencial, aumentando poderosamente las atribuciones del Presidente de la República en relación con un Congreso Nacional minimizado en la nueva Constitución, disminuyendo la representatividad de ambas Cámaras e interfiriendo en la composición de las mismas. Se establecerán restricciones a los parlamentarios, respecto de las cuales se les prohibiría intervenir en conflictos laborales, sociales o estudiantiles; prácticamente, se anulaba la inviolabilidad parlamentaria,

893 CARRILlo (2002) p. 85.

894 "Las críticas del Grupo de los 24" (1981) Pp. 2 y 3. 
entregándole al Ejecutivo el poder de establecer las normas que han de regular el funcionamiento del Congreso. De esta manera, se despojará al órgano representativo de sus funciones inherentes y se dejará totalmente subordinado al Ejecutivo. Los poderes del Presidente serán tan amplios que ningún otro texto los había contemplado. En el Código político original, el mandatario podía disolver la Cámara de Diputados una vez durante su período, podía designar senadores, intervenir en el funcionamiento interno del Congreso, calificar por sí solo las urgencias; podía además convocar a sesiones extraordinarias. Se amplía la potestad reglamentaria e interviene en el proceso de formación de la ley. Por tanto, el menoscabo al Congreso era evidente, esencialmente, en materia de fiscalización puesto que la privaba de todo efecto ${ }^{895}$.

La reducción de la fiscalización parlamentaria tiene, a su vez, otra razón de origen además de la reducción del Parlamento, puesto que el resguardo del control político-constitucional en la Constitución de 1980 estaba depositado en manos del Consejo de Seguridad Nacional. Este órgano estaba presidido por el Presidente de la República e integrado por el Presidente del Senado y la Corte Suprema, por los Comandantes en Jefes de las Fuerzas Armadas y por el General Director de Carabineros. Su función comprendía la posibilidad de "representar a cualquier autoridad" establecida en la Constitución. Tenía opinión frente a hechos o actos que, a su juicio, pudieran comprometer gravemente las bases de la institucionalidad o la seguridad nacional, convicción a la que arribaban mediante acuerdos públicos o privados $^{896}$.

En consecuencia, el control político-constitucional del poder lo posee concretamente un órgano cuya composición es muy vigorosa y difícil de resistir, principalmente, en un momento del desarrollo institucional democrático que comenzaba a caminar por un sendero de larga transición, en el cual los pilares que sustentaban la democracia aún eran débiles en atención a la presencia militar en la política. La facultad de "representar" que tenía el Consejo de Seguridad Nacional estaba evidentemente fortalecida (en contraposición con la del Congreso, el cual solamente podía formular acuerdos y observaciones al Ejecutivo, los que se daban por enteramente cumplidos cuando recibían respuesta de las mismas, sin importar el contenido). Así, la debilidad de la fiscalización parlamentaria como medio de control

895 "Las críticas del Grupo de los 24" (1981) Pp.4 y 5.

896 "Las críticas del Grupo de los 24" (1981) p.8. 
político y constitucional fue evidente, y su valor institucional fue netamente simbólico.

En lo que a nosotros concierne, es posible subrayar que las disposiciones transitorias de la nueva Carta contemplaron, además, la imposibilidad de determinar responsabilidades políticas gubernamentales durante la dictadura, excluyendo expresamente la acusación constitucional. En consecuencia, la investigación parlamentaria de hechos pasados ocurridos durante la dictadura cívico-militar es imposible; la mayor peligrosidad de tal opacidad reinante, es decir, la carencia de control y fiscalización parlamentaria, trajo consigo la falta de la ética pública que sólo produjo como resultado lamentable la corrupción, la cual sólo de a poco -y muy lentamente- hemos podido ir visualizando $y$ detectando, junto con sus desafortunadas consecuencias. Mediante este precepto transitorio, se crea un factor determinante en la inoperatividad del control. Como bien expone Orellana, en tiempo de dictadura no hubo ni libertad de prensa ni fiscalización parlamentaria lo que hacía imposible investigar la extensión del $\operatorname{poder}^{897} \mathrm{y}$, para coronar aquella impunidad política, se prohíbe el ejercicio de la fiscalización parlamentaria de forma retroactiva, vale decir, sólo podía ejercerse respecto de actos posteriores al año 1990, momento en el cual vuelve a desempeñar sus funciones el Congreso Nacional.

Aquella limitación temporal de la fiscalización parlamentaria en la Constitución de 1980 estuvo contemplada en la disposición vigesimoprimera transitoria, letra b), en relación al artículo $48 \mathrm{~N}^{\circ} 2$, respecto de la cual se desprendía que hasta el 11 de marzo de 1990 estaba suspendido el Capítulo V del Congreso Nacional, precepto que interpretado en relación a la acusación constitucional, establecía que sólo se podía ejercer respecto de actos realizados a contar del 11 de marzo de 1990. Esta norma es reafirmada por el artículo 3 transitorio de la Ley Orgánica Constitucional del Congreso Nacional, materia que fue acordada por los Jefes de las Fuerzas Armadas y de Orden Público en la sesión legislativa de fecha 12 de diciembre del 1989. Fue en esa oportunidad en la que estableció el carácter transitorio dicha norma, precepto que fue considerado por los mismos miembros de la Junta Militar como un "resguardo" respecto de los posibles efectos posteriores al retorno de la democracia, y las pasiones políticas que pudieran emerger ${ }^{898}$.

897 Orellana (2004) Pp. 2 y 7.

898 Tribunal Constitucional, Proyecto de Ley y autos en relación, Causa Rol: 91-89. p.38. 
Tal era la preocupación que tuvo la Junta Militar por la perfecta redacción de dicho precepto transitorio, que analizaron latamente la "necesidad" de que el Tribunal Constitucional la declarase Ley del Congreso Nacional como orgánica constitucional, puesto que ello configuraba un importante efecto inhibidor para el fututo Presidente de la República, ante una posible pretensión de eliminar aquel precepto. Por otra parte, la atención también se centró en la fecha que habría de fijarse como punto de partida para las futuras acusaciones constitucionales. En ese contexto, se eximió deliberadamente el mismo día 11 de marzo, fecha en la que asumía el nuevo Presidente de Chile y entraba en funcionamiento el Congreso Nacional, bajo la premisa de la posible ocurrencia de ciertos "hechos" a acaecer aquel día ${ }^{899}$. Es por ello que la limitación temporal corre con posterioridad a tal fecha.

Una vez sometido a control de constitucionalidad el proyecto de Ley Orgánica Constitucional del Congreso Nacional, se presentó una petición de inconstitucionalidad de varios de sus preceptos por destacados juristas nacionales ${ }^{900}$, la cual se refería precisamente a la inconstitucionalidad del artículo 3 transitorio del proyecto en relación con el artículo vigesimoprimero del Código Político, el que limitaba las facultades de la Cámara y el Senado, respecto del artículo 48 № 2.

La contienda constitucional se concentró en dos puntos claves. El primero, hacer presente que la Constitución delegaba en una ley orgánica sola y exclusivamente la tramitación de la acusación constitucional, mas no encomendaba la facultad de fijar límites temporales respecto del ejercicio de las facultades del Parlamento; un segundo aspecto fue la discusión en torno a la instalación del Congreso Nacional y el artículo $19 \mathrm{~N}$ 33, es decir, la imposibilidad de fijar tribunales con posterioridad al acaecimiento de los hechos punibles, respecto de lo cual se planteó que no representaban el mismo significado las voces "establecer" un tribunal e "instalar" al Congreso; por cuanto no era aplicable aquella garantía constitucional.

El fallo del Tribunal Constitucional resolverá las peticiones y declarará en sus numerandos 1 y 2, por una parte, que mediante una ley orgánica -en virtud de su propio carácter- era posible regular otras múltiples materias relacionadas a la función

899 Tribunal Constitucional, Proyecto de Ley y autos en relación, Causa Rol: 91-89. Pp.42 y 43.

900 La petición fue presentada por: Carlos Andrade Geywitz, Francisco Cumplido Cereceda, Humberto Nogueira Alcalá, Jorge Precht Pizarro, Germán Urzúa Valenzuela y Mario Verdugo Marinkovic. Ella pretendía declarar la inconstitucionalidad fundamentalmente de dos aspectos: el primero, la prohibición de acusar constitucionalmente respecto de hechos anteriores al 11 de marzo de 1990 y, el segundo, la instalación de senadores designados. 
legislativa y las funciones de las Cámaras y no solamente las que se establecían en el texto constitucional. Por otra parte, en los considerandos 26 al 30 señaló el Tribunal que efectivamente se vulneraría el artículo 19 No 3 si se establecía la posibilidad de juzgar políticamente a las autoridades por hechos anteriores a la fecha en cuestión, en primer lugar porque el contexto jurídico era diverso y nunca existió un órgano que llevara a cabo juicios políticos, y en segundo lugar porque, si bien la Constitución Política regulaba al Congreso y sus funciones, su jurisdicción nacía con su instalación y no antes, ya que con anterioridad al 11 de marzo de 1990 no gozaba de realidad jurídica.

En este orden de ideas, se expuso que el Congreso Nacional solamente tendría plena vida institucional luego de la fecha indicada, precisamente porque antes estaba sustituido por la Junta de Gobierno. Por su parte, el numerando 31 planteó una tesis que esbozaba una desigualdad y discriminación en la posible aplicación de acusaciones constitucionales anteriores a la fecha ya citada, toda vez que la sanción de aquella herramienta fiscalizadora era la destitución del cargo y, atendido a que se desarrollaría un cambio de Gobierno, podía ocurrir que sólo algunos funcionarios del Gobierno militar continuaran prestando funciones. Por tal motivo, sólo ellos podían ser sancionados y no así los demás servidores del Estado ${ }^{901}$.

De tal modo que, declarados constitucionales los preceptos constitucionales y ley orgánica en cuestión, todas aquellas acciones del Ejecutivo autoritario que fueron realizadas en abierta contradicción a la Ley Fundamental, a las garantías fundamentales y que estaban impregnadas de todo tipo de abuso de poder estarían eximidas de ser fiscalizadas parlamentariamente. Por ende, es imposible determinar responsabilidades políticas respecto de altos mandos del Gobierno militar.

Para finalizar, haremos hincapié en recordar que en la Carta del ochenta se estableció como régimen de gobierno lo que Cumplido denomina como "Cesarismo Presidencial", mucho más poderoso que el Ejecutivo vigorizado contemplado en la Constitución de 1925. La diferencia más trascendental era que en esta oportunidad el contrapeso no lo ejercía el Congreso Nacional, sino órganos técnico-profesionales, como son las Fuerzas Armadas, el Consejo de Seguridad Nacional, el Tribunal Constitucional y los tribunales ordinarios. En consecuencia, la configuración del control parlamentario presenta rasgos de máxima debilidad. En este sentido, es

901 Tribunal Constitucional, Rol: 91-89, Sentencia, Pp. 8 a 12. 
preciso señalar que para Cumplido, aquella configuración institucional podía deberse a dos causas: el temor a la forma como el Congreso había ejercido sus funciones, o a la desconfianza ante el ciudadano ${ }^{902}$.

Compartiendo lo esbozado por el autor, sostenemos que la institución de control y los mecanismos del mismo constituyen una de las expresiones mediante las cuales se sustenta la democracia protegida que, en definitiva, es la que configuró la dictadura. La supervigilancia de las Fuerzas Armadas era el único y concreto control que tuvieron a la vista los miembros del alto mando, la CENC y del Consejo de Estado al momento de realizar el nuevo texto. Por tanto, el espíritu constitucional en virtud del cual se elabora todo el proceso constituyente, no es más que la fachada de una supuesta idea democrática que tenía por propósito devolverle a Chile una institucionalidad jurídica que por años había construido y cuidado, la que fuera suspendida abruptamente por el golpe militar. El objetivo central fue cubrir con un manto institucional y constitucional un régimen autoritario y militar que continuaría perviviendo mediante diversas instituciones y a través de la paralización de otras acciones de pesos y contrapesos políticos, como por ejemplo: el estanco de la fiscalización parlamentaria.

Nuestra realidad nacional luego de la dictadura militar comienza a transitar pausadamente hacia el retorno de la democracia, proceso que será regido por la Constitución Política del año 1980, en la cual se reforzaba un sistema presidencial particularmente vigorizado que pone en jaque al Congreso y sus relaciones mutuas. La transición democrática chilena implicó reformular y reorganizar a las instituciones democráticas hasta la fecha eliminadas, con las virtudes y las dificultades que ello conllevaba. La consolidación democrática implicaba una transición democrática de las instituciones políticas y la transformación de una forma de Estado a otra, el cual se caracterizó por ser un proceso progresivo y muchas veces débil ${ }^{903}$.

Si bien se ha expuesto que Chile transitó exitosamente de forma pacífica y democrática, de una dictadura a un régimen presidencial, no es menos cierto que ello no favoreció la conformación de una democracia sólida. En este sentido, Garretón dirá que se trató de una transición incompleta que dio origen a una democracia restringida, de baja calidad y llena de enclaves autoritarios; la debilidad del sistema democrático nacional obligó a que muchas de las fórmulas e instituciones

\footnotetext{
902 CUMPLido (1985) Pp. 90 y 91.

903 CANSINO (1993) p.723.
} 
que fueron establecidas, fueran resultado de negociaciones entre la oposición y el Gobierno, situación que provocaría la denominada "Democracia de los consensos"904.

Continuando con esta idea, y en palabras de Siavelis, la transición o redemocratización chilena se vio envuelta en una serie de "enclaves de transición y constitucionales" multidimensionales de difícil erradicación, los cuales si bien contribuyen al éxito del modelo de transición democrático, han sido también un arma de doble filo, puesto que han interactuado y combinado para ofrecer fuertes limitaciones a la representación política y al accountability. Lo anterior, en complemento a un complejo sistema electoral binominal, instauró los factores que inciden directamente en la injerencia de las élites partidarias en la configuración del Congreso, fuerzas sociales que ejercerán un fuerte control del mismo y en particular sobre el comportamiento legislativo ${ }^{905}$.

Por tal motivo es que el proceso de transición se realizó "vía transacción", lo cual se tradujo en un paso estable, pero lleno de riesgos e incertidumbres, en el cual si bien el Gobierno contaba con mayorías en las Cámaras, esto no eran suficiente en virtud del número de senadores designados, lo que impedía alcanzar los altos quórums establecidos para aprobar las reformas constitucionales necesarias que fortalecieran la democracia y el control político. Este proceso transicional daría sus primeras luces de consolidación con las reformas constitucionales del año 2005, en las cuales la fiscalización parlamentaria fue objeto de importantes modificaciones que analizaremos posteriormente.

\section{La requlación de la fiscalización parlamentaria en el ordenamiento constitucional original de $\mathbf{1 9 8 0}$}

A continuación, realizaremos un examen detallado del origen y debate de la fiscalización parlamentaria en la Constitución de 1980, texto que sufrirá dos modificaciones de suma relevancia para la organización del régimen $y$, colateralmente, para la fiscalización parlamentaria. Estas reformas son las del año 1989 y las del año 2005.

\footnotetext{
904 GarRetón (1999) Pp.59 y 63

905 SiAVELIS (2009) p. 18.
} 
El estatuto político de 1980 regulaba la fiscalización parlamentaria en el artículo 48, precepto que distinguía como atribución exclusiva de la Cámara de Diputados dos numerales: el $N^{\circ} 1$, que contemplaba la facultad de "fiscalizar los actos del Gobierno, y el N², que trataba las "acusaciones constitucionales". No obstante que las similitudes con su predecesora son bastantes, se consagran algunas diferencias relevantes que analizaremos más adelante. Es preciso recordar que el orden del precepto constitucional en cuanto a situar, en primer lugar, a la fiscalización de los actos de gobierno y, en segundo lugar, la acusación en juicio político se debe -tal como describe Bidart- a la proposición que formulan los miembros de la Comisión de Estudios de la nueva Constitución (CENC), en base a la consideración de que la acusación constitucional venía ser una consecuencia de la fiscalización ${ }^{906}$.

\section{a) Articulo 48 No 1 "Fiscalizar los actos de gobierno"}

Por ahora nos corresponde relatar aquellos elementos de mayor significación política y jurídica, respecto de la historia fidedigna del precepto constitucional e indicar algunas interpretaciones del constituyente, las que nos permitirán dilucidar el espíritu, naturaleza y alcance de la fiscalización en el ordenamiento constitucional nacional.

En primer lugar, diremos como rasgo general que el constituyente de 1980 buscó plasmar en la Carta Fundamental dos propósitos esenciales: en un primer orden, diseñar un sistema presidencial típico e ideal, pero además fortalecerlo; y, en un segundo orden, pretendió evitar cualquier "conflicto" político que pudiera surgir en la relación entre los poderes del Estado, a fin de impedir desequilibrios institucionales, motivo por el cual sacrifica al Poder Legislativo en favor de Ejecutivo. En definitiva, consagra una democracia protegida o tutelada que priva de protagonismo político al ciudadano, favoreciendo la supremacía del Ejecutivo y generando un desequilibrio en relación con el Poder Legislativo, modelo constitucional que desconfía de las ideologías y de los partidos políticos.

La fiscalización parlamentaria diseñada por el constituyente, presentará -al igual que la misma Constitución- características especiales. Sin modificar sustancialmente lo contemplado en la Carta de veinticinco, se produjo un análisis interesante que nos

906 BIDART (2013) p. 21. 
permite comprender el verdadero sentido y alcance de las normas constitucionales. Cabe destacar que algunos miembros de la Comisión de Estudios de la Nueva Constitución (CENC) expresaron especial interés en esta materia, básicamente por el rol que habría de cumplir la fiscalización en el período de transición ${ }^{907}$. Por ello, podemos advertir de forma prematura cuál era la orientación que ésta debía seguir. Así, en el debate constitucional primaron tres elementos, dos políticos y uno jurídico. Tales son: a.- consagrar una tutela (militar) democrática bajo un sistema presidencial vigorizado; b.- no contemplar un sistema de responsabilidad política de los altos funcionarios púbicos e impedir el surgimiento de instrumentos de control propios del sistema parlamentario; y c.- crear una fiscalización esencialmente jurídica, depositada en organismos técnicos y no representativos. De este modo, la fiscalización tendrá un cariz muy particular, muy limitada políticamente y reducida su eficacia. En los siguientes párrafos detallaremos cada uno de estos factores.

Primeramente, nos referiremos a la consagración del sistema presidencial reforzado, debilitando con ello al Poder Legislativo. Sin ánimo de diseñar un modelo de fiscalización parlamentaria acorde a un sistema democrático, se iniciará la discusión de la sesión $N^{\circ}$ 341, con fecha 22 de marzo de 1978, con un discurso introductorio del comisionado Sr. Jaime Guzmán, quien -en términos simplesdelimitará la cancha respecto de lo que finalmente se regulará como fiscalización parlamentaria en la Constitución. Propone utilizar el articulado del Código Político anterior como base desde donde trabajar. En esta dirección, cabe inferir que no existía una intención innovadora, sino que, por el contrario, expresa una voluntad de continuismo. En aquella ocasión, planteó la posibilidad de incorporar al texto constitucional las comisiones investigadoras con imperio, sin embargo, manifestó de inmediato su total rechazo debido a la capacidad que poseían para paralizar la administración pública creando con ello un "elemento perturbador para el sistema político y jurídico" ${ }^{908}$. Esta opinión posteriormente encontrará asilo en los demás miembros de la Comisión, tales como los señores Ortúzar y Lorca, y entonces las comisiones investigadoras quedarán fuera de la Ley Fundamental del ochenta.

\footnotetext{
907 Nos referimos especialmente al Sr. Ortúzar quien expresaba su profunda preocupación por delimitar, esclarecer y precisar las funciones no legislativas del Congreso, en especial, la de fiscalización para el período de transición. Historia de los artículos de la Constitución, Actas Constitucionales, sesión N³41, p. 7.

${ }^{908}$ Historia de los artículos de la Constitución, Actas Constitucionales Sesión N³ 341, p. 8.
} 
En segundo lugar, un rasgo que estuvo presente en todo el proceso constitucional fue la necesidad de establecer normas que imposibilitaran la generación de una fiscalización parlamentaria que arrojara los mismos resultados que en el pasado ${ }^{909}$. En este orden de ideas, se presupone que la fiscalización -de naturaleza eminentemente política de la época anterior- no habría sido positiva para Chile, generando incluso el desprestigio de algunas instituciones como la acusación constitucional. En este sentido, se expresaron los argumentos de los comisionados señores Bulnes, Carmona, Ortúzar, Bertelsen y Lorca, refiriéndose en reiteradas ocasiones a la necesidad de evitar los "abusos del parlamentarismo". El Sr. Guzmán además esgrimió con especial énfasis la incompatibilidad esencial entre la aplicación de la responsabilidad política y el régimen presidencial, habiéndose optado de forma unánime por el presidencialismo reforzado; no cabe posibilidad alguna de contemplarla. En igual sentido se expresarán las opiniones de la comisionada Sra. Bulnes, quien consideraba incompatible reglamentar un sistema de responsabilidad política en un presidencialismo. Para ella, de reglamentarse el juicio político habría de ser esencialmente jurídico penal, administrativo o civil. Agregaba, además, que la regulación de la fiscalización parlamentaria en el texto constitucional predecesor, fue fruto de una negociación con las tendencias parlamentarias, dejando esbozos de parlamentarismo en el texto ${ }^{910}$.

De esta manera, se dio inicio a un debate en el cual los antagonismos fueron protagónicos, no obstante, hubo cierto consenso respecto de la necesidad de que a pesar de consagrar un régimen presidencial, era indispensable establecer la fiscalización parlamentaria. En esta dirección se encontraban las palabras del Sr. Ortúzar, quien estimaba pertinente que el Presidente escuchara la crítica de la Cámara Baja, así como también era necesario estipular plazos para dar respuesta a los acuerdos y observaciones. En definitiva, había que hacer operante el artículo 39 No2.

Pero quien, sin duda alguna, formuló las declaraciones más trascendentes doctrinariamente fue el Sr. Bertelsen al plantear una discusión de suma relevancia en esta materia. El comisionado hizo presente las diferencias que existían entre la

\footnotetext{
909 Tal como lo planteamos en nuestras conclusiones respecto de la Constitución de 1833 y el debate constituyente de 1925, al momento de llevarse a cabo el análisis del control político en la CENC, varios de sus miembros trajeron a colación el complejo escenario que habría gestado la "excesiva utilización" de los mecanismos de control, en particular, en la época parlamentaria nacional, como fundamento suficiente para limitar en la actualidad su regulación.

${ }_{910}$ Historia de artículos de la Constitución. Actas Constitucionales, Sesión N 341, Pp. 9-12.
} 
responsabilidad política y la jurídica, tanto en los criterios a utilizar como en sus efectos. Según el jurista, una naturaleza política de la fiscalización "apunta a determinar o a criticar la conveniencia, la oportunidad, las ventajas o desventajas que una determinada medida gubernativa, una actuación o bien una abstención traen consigo, pero sin poner en tela de juicio la competencia y la corrección jurídica del proceder de la respectiva autoridad u órgano gubernativo; en cambio, la fiscalización jurídica apunta precisamente a esto último, es decir, lo que se pone en duda, lo que se crítica es la corrección jurídica de una actuación, bien sea que el órgano es incompetente, bien sea que no se han cumplido los procedimientos establecidos; en otros términos, la fiscalización de tipo jurídico apunta a un desconocimiento de las exigencias propias del Estado de derecho"1911.

Para el comisionado Bertelsen, era posible que ambos criterios concurrieran conjuntamente, y por tal motivo ambos tipos de fiscalización se entremezclarían sin poder distinguirlos. Resultaba imprescindible diferenciarlos, de lo contrario podía surgir un desorden institucional creando serias consecuencias para el sistema político. En este sentido, expresó que era imperioso que a la Cámara Baja se le atribuyera algún tipo de fiscalización política, porque de lo contrario podía emanar por otra vía, pudiendo ser una vía no conveniente. No obstante, se deben regular, limitar y evitar los mecanismos parlamentarios. En este orden ideas, según el mismo jurista, la fiscalización de carácter político era un hecho inevitable, por dicha razón debía ser contenido jurídicamente.

Tal apreciación coincide, en cierto sentido, con lo planteado por el Sr. Guzmán. Para este comisionado la fiscalización es política en un régimen presidencial cuando ha de ser dirigida hacia la opinión pública del país, cuando es dirigida ante la nación toda. No debe tener por finalidad dar orientaciones al Gobierno, respecto de la forma en que ha de ser conducidos los negocios gubernativos. A nuestro juicio, la frase más significativa es la que señala que: "si se ha concordado en que la esencia de la función fiscalizadora no es perseguir responsabilidades ni políticas ni jurídicas, sino más bien generar efectos de tipo político ante la opinión pública, hasta que la Cámara adopte determinados acuerdos para que tales efectos se produzcan, y muchas veces el más interesado en responder será el Gobierno si advierte que el

\footnotetext{
${ }^{911}$ Historia de artículos de la Constitución. Actas Constitucionales, Sesión № 341, p. 13.
} 
acuerdo de la Cámara de Diputados lo coloca ante la opinión pública en una situación

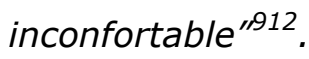

En nuestra opinión, y conforme a lo esgrimido por ambos comisionados, surge de inmediato un cuestionamiento: si existía cierta coincidencia teórica en cuanto al hecho de ser la fiscalización parlamentaria una institución de naturaleza política, por qué se intentaba limitar su ejercicio y efectos mediante recursos normativos. Es más, cabe preguntarse por qué se le pretendía privar de su mayor efecto-consecuencia, ésta es, la exigibilidad de responsabilidad política. Al parecer, la lógica tutelar con la cual concebían y construyeron la democracia nacional impedía que las instituciones básicas de la misma fueran reguladas en su expresión histórica, natural y obvia. Si bien el constituyente tuvo una clara intención de plasmar en el nuevo texto constitucional todos aquellos elementos que teóricamente edifican un régimen democrático y representativo, en los hechos primaron otros factores contradictorios, los enclaves autoritarios y el aparente temor a la participación política y ciudadana. Es por ello que emerge una democracia con rasgos particulares que, esencialmente, regulaba con máxima debilidad el control de origen político-representativo, pero que contemplaba con gran fortaleza el control proveniente de órganos técnicos y militares.

Tal era la preocupación y desconfianza en las instituciones políticas y en el libre juego democrático, que el señor Carmona -durante el desarrollo del debate constituyente- llegó a proponer que en virtud del absoluto desprestigio de que gozaban las comisiones investigadoras, en los casos en que existieran fundamentos plausibles para investigar, un acto debiera realizarse de manera técnica. La Cámara debía remitir los antecedentes al Consejo de Estado, órgano asesor presidencial creado por la Junta de Gobierno, cuyas sesiones y resoluciones eran secretas y compuesto por miembros no electos dentro de los cuales se encontraban incorporados algunos ex Presidentes e integrantes de las Fuerzas Armadas y Carabineros. Por su parte, la comisionada Bulnes, agregaba derechamente que en un régimen presidencial vigorizado como el que se intentaba instaurar no debía existir responsabilidad política; la fiscalización parlamentaria de la Administración sería contraria a tal propósito. Sin perjuicio de aquello, se declaraba partidaria de controles efectivos de la Administración por parte de organismos independientes, y

912 Historia de artículos de la Constitución. Actas Constitucionales, Sesión № 341, Pp. 17 y 18. 
también de un efectivo sistema sobre lo contencioso administrativo que podría conducir al mismo resultado ${ }^{913}$.

Fue en el debate sobre las atribuciones exclusivas del Senado donde se produjo mayor ahondamiento en esta materia. Es decir, nuevamente se esboza la idea de privar de efectos políticos a la fiscalización, una vez más se plantea su naturaleza y finalidad política, pero se esfuerzan en privarlas de las mismas. En esta dirección se encuentran las palabras del Sr. Jaime Guzmán, para quien necesariamente no debía politizarse el juicio político por resultar peligroso para la vida política nacional. Tal era la intencionalidad de juridificar la institución -y a través de ello limitar su naturaleza- que la Comisión planteó la posibilidad de que el juicio político fuera fallado no por el Senado, sino por el Tribunal Constitucional. Finalmente, aquella propuesta no tomó mayor fuerza y se optó por mantener las cosas tal como se habían desarrollado históricamente, precisando la calidad de jurado que ha de tener el Senado ${ }^{914}$, sin mayores atribuciones.

Otro aspecto relevante que fue debatido en la CENC en materia de fiscalización parlamentaria, fue el reducido rol que se le atribuyó a las minorías políticas. Es menester hacer presente que existía plena conciencia en la Comisión Ortúzar respecto de la inexistencia de las mismas, producto del nuevo diseño institucional y constitucional nacional, en especial, en virtud del sistema binomial que entraría en vigor. Hacemos hincapié en este punto entendiendo que las minorías parlamentarias configuran el actor central llamado a realizar la fiscalización. Sin embargo, tal noción clásica del Derecho Político y Parlamentario no fue considerada en nuestro esquema institucional.

Tal como lo analizáramos en el Capítulo anterior, por una parte, el sistema electoral binominal tenía como principal característica impedir la participación de las minorías políticas en los procesos electorales y en su llegada al Parlamento, dando origen con ello a la configuración de dos grandes fuerzas políticas con representación en el hemiciclo; por otra parte, la influencia que ejerce el espíritu del constituyente que igualmente iba en aquella dirección, aparentemente existía la clara pretensión de que ellas no formaran parte del Congreso Nacional, y menos aún que pudieran ser activos controladores de la acción política del Ejecutivo. En este sentido, se expresaba el comisionado Carmona cuando exponía que con la Constitución de 1925

913 Historia de los artículos de la Constitución. Actas constitucionales, Sesión No 353, Pp.16 y 20.

914 Historia de los artículos de la Constitución. Actas constitucionales, Sesión № 353, Pp.39-41. 
cabía la posibilidad de que las minorías arribaran al Congreso e incluso el Presidente podía gobernar sin mayoría parlamentaria. No obstante, con este nuevo texto constitucional aquella situación se elimina. Se consagra un régimen que debe tener una mayoría estable a fin de que pueda funcionar con autoridad y vigor. Por ende, la generación de minoría era una situación "teórica", y para el improbable caso de que se configurara esta minoría creía preciso otorgarles la posibilidad de fiscalizar, voluntad que ciertamente se contradecía con sus mismos dichos y -más concretamente- con los quórums establecidos.

Por tanto, un factor determinante en la limitación jurídica de la fiscalización y la privación de aquel derecho y prerrogativa parlamentaria, fue la influencia que se ejercía de manera normativa en provocar la reducción del escenario políticopartidista. Mediante el sistema electoral binominal y la regulación constitucional de la fiscalización parlamentaria, se pretendió impedir con mucha efectividad que las tendencias políticas minoritarias llegaran al Congreso, y que pudieran ejercer control político. La diversidad y el pluralismo político fue considerado un riesgo. Por tal motivo, la crítica y el control político al Ejecutivo era teoría; si bien se plasmó en lo literal de la norma, ella no iba a tener ningún alcance práctico. En definitiva, se omitía al actor central de la institución fiscalizadora -las minorías parlamentarias- y, para cumplir aquel objetivo, los argumentos expuestos por el constituyente eran simples pero efectivos. Recurrieron a un elemento histórico, la sombra del "nefasto" período parlamentario, y este elemento constituyó el motor que impulsó la satanización de la diversidad política $y$, por tanto, la imposibilidad de actuar políticamente en el Congreso a las minorías sociales y políticas.

Constantemente, en la Comisión Ortúzar se invocaron ejemplos y escenarios en los que la fiscalización ejercida activamente con un sentido político fue la causante de la inestabilidad política y del desastre institucional. Uno de aquellos insignes exponentes era el Sr. Lorca, para quien era menester cuidar los factores que en algún sentido podían poner en riesgo el sistema presidencial diseñado, refiriéndose precisamente a la fiscalización por parte de las minorías. Para el comisionado, la fiscalización activa era sinónimo de régimen parlamentario, por tanto planteaba que había que evitar las posibles aristas que pudieran desembocar en un sistema parlamentario $^{915}$.

\footnotetext{
${ }^{915}$ Historia de los artículos de la Constitución. Actas Constitucionales, Sesión Nº 341, Pp. 22 y 23.
} 
De lo descrito precedentemente, se vislumbra una clara confusión entre el derecho de fiscalizar de las minorías políticas, la fiscalización propiamente tal y los efectos de la misma, como un mecanismo de pesos y contrapesos esencial en un sistema democrático. Aquella confusión no será la única. Prosiguiendo con el debate de las minorías durante el desarrollo de la CENC, el comisionado señor Ortúzar argumentará que las minorías políticas, e incluso un parlamentario, podrán fiscalizar a través del derecho de petición. Evidente resulta la falta de claridad respecto del derecho de información parlamentaria y el de fiscalización. Aunque ambos se encuentran íntimamente ligados, es necesario que entregar herramientas jurídicas diversas mediante las cuales poder ejercerlos, porque pueden además tener objetivos diversos. Si bien habitualmente son parte de un proceso de fiscalización, en ocasiones la recopilación de información puede ser antecedente para el correcto ejercicio de otra función como, por ejemplo, la legislativa. No basta con la sola posibilidad de obtener información si posteriormente no podrá ser utilizada.

Tal era la seguridad del Presidente de la Comisión en cuanto a lo poco pertinente de la regulación de esta materia, que dirá lo siguiente: "se está analizando este problema muy influidos por el sistema político, electoral e institucional anterior, y, en verdad, deben partir de la base de que va a ser diferente, porque toda la mecánica institucional que se está creando tiende a ese objetivo. Expresa que, por de pronto, no será un Parlamento politizado, porque en su generación, podrán influir otros cauces distintos de los partidos políticos exclusivamente, como sucedía con anterioridad $^{\prime \prime 16}$.

En consecuencia, durante el desarrollo del debate constituyente, se contempló una noción muy diversa a la que habitualmente han expresado voces autorizadas en Derecho Parlamentario respecto de la fiscalización parlamentaria. Nos referimos, por ejemplo, a ciertas premisas indispensables como las expresadas por Juan Fernando López cuando explica que "los instrumentos de fiscalización hacen de las minorías necesarios interlocutores en la dialéctica con la mayoría"917. En la Constitución de 1980 se plasmaron ciertas confusiones teóricas, por ejemplo, aquella confusión entre el derecho de información y la función de fiscalización, o bien aquella que responsabilizaba a los mecanismos de fiscalización como causantes de todos los males en la fiscalización, vetando incluso algunos instrumentos por "peligrosos",

\footnotetext{
${ }^{916}$ Historia de los artículos de la Constitución. Actas Constitucionales, Sesión № 341, p.24.

917 LÓPEZ (1988) p. 270.
} 
como las interpelaciones y las comisiones de investigación, además de restringir la participación de las minorías y su llegada al Congreso, eliminando con ello uno de los aspectos esenciales para el correcto ejercicio de una función de control.

En este orden de ideas se expresa Ferrada al exponer que, con la Carta de 1980, el control descansa casi exclusivamente sobre mayorías, lo cual lleva envuelta una contradicción lógica en el sistema. Será frecuente en nuestro sistema electoral que la mayoría parlamentaria sea además la fuerza política que gobierne, por ende, el control parlamentario queda en manos del mismo grupo político. Por ello, se vuelve un sistema ineficaz que además se transforma en lo opuesto, porque se configura como un mecanismo de respaldo y de defensa de la acción del Gobierno ${ }^{918}$.

Respecto de esta materia ya nos pronunciamos latamente en el Capítulo anterior. Desde nuestra perspectiva, la fiscalización parlamentaria es una atribución de todo congresista, por cuanto es perfectamente ejercible por mayorías y por minorías. Siguiendo a Gutenberg Martínez, exponemos que "el control gubernamental se lleva a cabo en todo régimen democrático representativo por la mayoría y por las minorías aun cuando sus procedimientos sean distintos ${ }^{\prime \prime 19}$.

En esta dirección, recordemos que al momento del debate constitucional por la CENC el señor Carmona ya expresaba que existiría cierto derecho preferente de las mayorías al fiscalizar, esgrimiendo "que si la fiscalización se produce por la mayoría, a pesar de que el Gobierno tiene la mayoría, se está ya en presencia de un hecho político de gran consideración dentro del régimen que se quiere concebir" ${ }^{920}$. En consecuencia, es dable concluir que en la historia de nuestra Carta Fundamental existieron argumentos que avalaron y reconocieron el control por parte de las mayorías parlamentarias. Sin embargo, lo ocurrido en el texto original constitucional es una situación extrema, porque aun siendo partidario de la existencia de controles por parte de las mayorías, no es posible diseñar un sistema de control privando de todo derecho a fiscalizar a las minorías. Aquella interpretación "pro mayoría" respecto de la fiscalización, no implicaba extremar los requisitos y quórums para que una minoría no pudiera realizar control. Como bien es sabido, las finalidades y objetivos de aquella expresión del control minoría-mayoría serán distintos, empero todos contribuyen en el perfeccionamiento del sistema democrático. Ahora bien,

${ }^{918}$ FERRADA (2002): [citado 2015-12-18], pp. 461-481. disponible en:

http://www.scielo.cl/scielo.php?pid=S0718-00122002000100025\&script=sci arttext

919 MARTíneZ (1998) p.17.

${ }^{920}$ Historia de los artículos de la Constitución. Actas Constitucionales, Sesión N³ 341, p.22. 
aquella restricción se evidencia en cierta medida en la Norma Fundamental. No obstante, entre otras normas que promovían un desincentivo a la participación política partidista, el verdadero responsable era el sistema electoral binominal

Finalmente, en la Sesión 353 de fecha 19 de abril del año 1978, se acordó invertir el orden del precepto, situando la facultad de fiscalizar los actos del gobierno en el numeral primero, y el juicio político en el segundo. Pero a pesar de aquella "modificación" los demás aspectos centrales siguen caminando por el mismo carril que la sesión anterior. Los tenues esfuerzos del Sr. Bertelsen por insistir en la posibilidad de consagrar "algún derecho" a las minorías con resonancia en la vida pública -incluso propone consagrar algunos derechos-, no producen efectos. Es más, el Sr. Ortúzar puso un drástico final a aquella iniciativa, enfatizando que ese tipo de situaciones jurídicas habría que contemplarlas en la Ley Orgánica Constitucional del Congreso Nacional, porque no se deben abrir espacios para politizar la Cámara Baja, ni arriesgarse a que se utilice la fiscalización de manera desmedida, opinión que comparte la Sra. Romo.

\section{b) Articulo 48 No 2 "Acusación constitucional"}

Respecto de la acusación constitucional, es posible destacar que la Constitución de 1980 sigue los elementos de la institución contemplados en la Constitución de 1925, salvo pequeñas modificaciones. Se establece la posibilidad de que todos los funcionarios acusables lo son en el ejercicio de sus funciones, durante los tres meses siguientes a la expiración del cargo, salvo el Presidente de la República que es acusable durante el plazo de seis meses. Durante la Constitución del 25 sólo era posible acusar a ministros y Presidente; con la nueva Carta Fundamental se suman otros sujetos acusables. Se incorpora la causal de "infracción", la que viene a sumarse a la noción de delito y abuso de poder. Fue agravada la sanción en el caso de declararse la culpabilidad, toda vez que se procede a la destitución y la imposibilidad de desempeñar función pública, sea o no de elección popular, por un término de cinco años. Se trasladan las normas procedimentales desde la Constitución a la Ley Orgánica Constitucional del Congreso Nacional, a diferencia de lo ocurrido en las Constituciones del 33 y $25^{921}$.

921 ZÚÑIGA (1993) p. 715. 
En cuento al debate en el proceso constitucional relativo al juicio político, se dejaba absolutamente claro por el señor Jaime Guzmán en la CENC que su naturaleza era jurídica, y por tal motivo sólo matizaba en determinar si ella era o no de corte penal. Por nuestra parte, sostenemos que la acusación constitucional es una institución que posee una doble naturaleza, política y jurisdiccional a la vez. En los siguientes párrafos profundizaremos sobre este punto.

En la historia republicana chilena la acusación se ha utilizado como una institución de control político, en situaciones graves y extremas, calificadas jurídicamente. Por tal motivo, a juicio de Rodrigo Díaz de Valdés, y como le hemos planteado anteriormente, durante la Constitución de 1925 es el único período en el cual su aplicación e interpretación fue extremadamente amplia. Es por ello que el autor destaca que la acusación fue aplicada como un verdadero juicio de valor o político, alejándose con ello del verdadero espíritu de la Constitución. Por tal motivo, la CENC se esforzó en corregir tales errores técnicos y jurídicos de la Constitución de $1925^{922}$.

Sin embargo, por nuestra parte, consideramos a la acusación constitucional como una institución de naturaleza dual: política y jurídica. Sustentamos nuestra interpretación, principalmente, porque es un instrumento propio de la fiscalización parlamentaria, y, a su vez, posee dicha doble naturaleza, vale decir, la fiscalización es política y jurídica, y aquella cualidad se expande a sus herramientas. Por otra parte, en palabras de Charles Black, la expresión "juicio político" significa acusación o cargos, es decir, el juicio político es el poder o capacidad de formular $\operatorname{cargos}^{923}$. Así, en nuestra disquisición -y para el caso nacional- sostenemos que en el ejercicio de la acusación deben formularse determinados cargos, los cuales proceden respecto de las causales tipificadas constitucionalmente, pero en razón de la comisión de determinados hechos que la configuran, hechos que son políticos. Por ello, mediante el juicio político se evalúan los actos del acusado, empero, aquellos actos son de carácter político y luego se verifica si ellos se enmarcan dentro de parámetros constitucionales. En conclusión, a través de la acusación constitucional, los hechos políticos son cotejados con causales constitucionales. Por ende, la acusación está compuesta por un elemento político, los hechos; y uno jurídico, la norma fundamental. Ahora bien, sin perjuicio de lo anterior, hemos señalado

\footnotetext{
922 DÍAZ de VALDÉS (2013) Pp.99 a 101.

923 BLACK (1975) p. 13.
} 
constantemente que la Constitución Política es también un texto de naturaleza bifronte: jurídica y política. Por tal motivo, muy probablemente las causales en ella contenidas representen dicha condición. En resumen, la cualidad política-jurídica de la acusación es un factor casi inevitable.

Conjuntamente con lo anterior, es posible agregar además que el juicio político es ejercido por órganos que son netamente de carácter político: la Cámara de Diputados y el Senado.

En resumen, nos unimos a la tesis del profesor Humberto Nogueira quien explica que la acusación es un juicio jurídico y político, respecto de autoridades y altos funcionarios del Estado por actos que desempeñan en el ejercicio del cargo, a través de la cual se hace efectiva la responsabilidad constitucional. Constituye, en definitiva, una forma de ejercer justicia política porque la ejerce un órgano político que enjuicia y determina la eventual responsabilidad de la persona. Expresa el autor que la finalidad de la acusación es contener el abuso o desviación del poder, para así resguardar el orden institucional de la República democrática, los derechos esenciales y los cuerpos intermedios ${ }^{924}$.

Por otra parte, en directa relación con la naturaleza de la acusación constitucional, es preciso plantear el debate en torno a la labor que le corresponde ejercer al Senado. La atribución señalada expresamente por el texto constitucional, comprende conocer de las acusaciones y, en este sentido, a la Cámara Alta se la ha delegado la función de "resolver como jurado y se limitará a declarar si el acusado es o no culpable del delito, infracción o abuso de poder que se le imputa". Por consiguiente, emerge el cuestionamiento de si actuó o no un tribunal y, además, cómo debe resolver las acusaciones constitucionales.

Para Charles Black, analizando la regulación norteamericana, expone que al Senado le corresponde "fallar" el juicio político. Aquello implica que la Cámara Alta no debe limitarse al sólo acto de votar la formulación de cargos, sino que además debe aplicar criterios propios de los procesos judiciales, es decir, deben indagar los hechos y la ley sin manifestación de estrechas tendencias partidarias o políticas. Debe primar en la conciencia de cada senador el peligro que comprende el fallo de una acusación, y en la medida de lo posible, debe esforzarse por eliminar todo lo que signifique prejuicio, buscando la imparcialidad, eliminando a priori una actitud cordial

924 Nogueira (2013) Pp.223 y 224. 
o inamistosa con el acusado. Adicionalmente, señala el autor que resolver un juicio político implica asimilar tal acusación a un procedimiento de juicio penal. Por ende, deberían aplicarse criterios penales y se podría resolver con un estándar de mayor calidad, toda vez que correspondería considerar las reglas probatorias para los hechos, el análisis racional del derecho y emitir su declaración de culpabilidad "fuera de toda duda razonable"${ }^{\prime 25}$.

No obstante, en el presidencialismo chileno cabe hacer presente que el texto constitucional original, y luego de las respectivas modificaciones, señalan que quien resuelve la acusación es el Senado. En consecuencia, nuestra Carta Fundamental no utiliza la expresión fallar, como es el caso de los Estados Unidos. Sin embargo, ingresar al análisis de si existen diferencias entre fallar y resolver nos parece una estéril cuestión de nomenclatura, toda vez que a nuestro entender en ambos casos las expresiones engloban la idea de zanjar un conflicto puesto en conocimiento de un tercero. Por ende, nuestra atención la concentramos en la expresión resolver "como jurado", puesto que aquella conceptualización es la que, en definitiva, le resta al Senado la obligatoriedad de resolver conforme a derecho.

Dicho esto, es posible destacar que la Cámara Alta no es un tribunal de derecho, muy por el contrario, dicho órgano es político y está compuesto por una diversidad de individuos que representan variadas profesiones, oficios e ideologías quienes, ciertamente, se esforzarán por realizar una interpretación de los hechos constitucionalmente relevantes así como de las leyes, pero desde sus propios conocimientos y motivaciones políticas, puesto que son esencialmente representantes del pueblo. Por tal motivo, nuestra Carta Magna les otorga la calidad de jurado y no de juez. Empero, aquella condición no lo excluye del deber de respetar el debido proceso, en razón del cual la misma Constitución consagra en el artículo 19 № 3 inc. 6 que: "Toda sentencia de un órgano que ejerza jurisdicción debe fundarse en un proceso previo legalmente tramitado. Corresponderá al legislador establecer siempre las garantías de un procedimiento y una investigación racionales y justos".

En esta dirección, quizás nuestra interpretación es un tanto desalentadora, pero estimamos que los senadores para el caso de resolver la acusación constitucional carecen de criterios objetivos propios de una judicatura especializada. Por ello, son

925 BLACK (1975) Pp. 17 a23. 
considerados un tribunal de carácter excepcionalísimo, e incluso a pesar de proponerles estándares jurídicos como el proceso penal, no debemos olvidar que muchos de ellos son miembros activos y comprometidos con sus respectivos partidos políticos, quienes ejercen habitualmente sus acciones en búsqueda de lograr la alternancia en el poder y alcanzar el poder presidencial. No obstante, la misma Constitución les obliga en su calidad de órgano que ejerce jurisdicción -incluso esporádicamente- a respetar las normas del debido proceso, por tanto, en nuestra opinión no es posible exigirles un estándar jurídico especializado, pero sí se les puede exigir que emitan una "explicación fundada de su resolución".

A pesar de estar tipificadas las causales en razón de las cuales se debe fallar una acusación constitucional, probablemente el análisis carecerá de un examen objetivojurídico de los capítulos acusatorios. Así, es muy factible que la ponderación de la acusación que sea realizada en la Sala, y que se expone verbalmente, sea subjetiva y carezca de fundamentos sólidos, toda vez que además el precepto constitucional contempla conceptos como "infracción o abuso de poder que se le imputa", términos que también favorecen la conceptualización política amplia del texto constitucional.

Por lo anterior, nuestra posición sostiene que la acción que realiza el senador al momento de votar una acusación en Sala es simplemente una resolución en conciencia, la que configura su veredicto, es decir, si declara o no culpable al acusado, en los breves minutos que se le está permitido emitir su palabra. No obstante, debería -mediante un documento escrito- señalar expresamente los motivos, razones y argumentos que le permitieron adquirir la convicción de culpabilidad o de inocencia del acusado para luego recopilar todos aquellos votos escritos, y dar origen a la resolución que zanja el conflicto sometido a su conocimiento. De lo contrario, se estaría vulnerando el debido proceso y a su vez a la misma Constitución Política de la República de Chile.

Adicionalmente, sostenemos que mediante una resolución escrita y fundada, se podría evitar el desconocimiento del acusado respecto de los específicos motivos de su culpabilidad o inocencia, y así impedir que se vea vulnerado en sus garantías mínimas. Por otra parte, se darían a conocer abiertamente los elementos a través de los cuales el Senador realizó su examen jurídico y fáctico de los capítulos acusatorios. 
Con el transcurso de los años la acusación constitucional ha recibo algunas críticas en atención a no respetar las normas del debido proceso, situación que como veremos más adelante tampoco ha sido resuelta en las reformas constitucionales posteriores. Fundamentalmente, dos han sido los argumentos jurídicos que se han planteado en este sentido: en primer lugar, se presenta la opinión de Díaz de Valdés, quien señala que una vez arribada la acusación al Senado, el acusado quedaría en una cierta indefensión en términos probatorios, puesto que el acusado sólo puede presentar pruebas ante la Comisión que se conforma por miembros de la Cámara de Diputados, y posteriormente, no puede incorporar nuevos antecedentes como tampoco podrá objetar la prueba rendida. En definitiva, no existe un plazo para impugnar u objetar la prueba presentada en su contra. Adicionalmente, a criterio del autor, no se contempló con claridad las actuaciones de la Comisión informante y sus criterios, y más preocupante aún es que el tribunal es imparcial y la motivación de pronunciamiento es escasa y débil, principalmente, en el caso de dictaminar la culpabilidad $^{926}$.

La segunda vertiente que cuestiona aspectos de la acusación constitucional es promovida por el profesor Humberto Nogueira, en cuanto a la suspensión de funciones del acusado. El autor, siguiendo lo señalado por la Convención Americana de Derechos Humanos en su artículo 8 y 23, plantea el respeto del principio de inocencia y el ejercicio de los derechos políticos a todos los ciudadanos que se encuentren bajo el imperio de los Estados partes. Por otra parte, considera los pronunciamientos emitidos por la Corte Interamericana de Derechos Humanos, en cuanto al derecho general que le asiste a cualquier individuo de acceder al debido proceso. Atendido tales argumentos, sostiene el autor, suspender derechos en razón de una mera acusación vulneraría la garantía de presunción de inocencia. Según Nogueira la acusación se asimila a un proceso sancionatorio que afecta derechos humanos, por ende, debe regirse por los parámetros del debido proceso y no debería suspender derechos políticos a personas acusadas, sino que solamente podría suspender derechos una vez que se emita el fallo del Senado en virtud del cual se resuelva la acusación constitucional ${ }^{927}$.

\footnotetext{
926 DÍAZ DE VALDÉS (2013) Pp.113 a 116

927 Nogueira (2013) p. 245.
} 
Por nuestra parte, en lo relativo a las críticas, queremos señalar que adherimos a ellas parcialmente. Tal como se ha señalado en estos párrafos y en el Capítulo anterior $^{928}$, la acusación persigue restringir, evitar e impedir que se ponga en riesgo el sistema democrático y constitucional nacional, además de proteger las garantías fundamentales. En tal escenario, en el caso de que algún alto funcionario del Estado ponga, eventualmente, en peligro algunos de aquellos elementos, separar de ese cargo público a aquella persona acusada hasta determinar sus posibles responsabilidades, parece una medida prudente y no gravosa. Con todo, sostenemos que el bien jurídico protegido a través de la acusación es de tan alta importancia que amerita la adopción de medidas de carácter cautelar, las que -sin afectar los derechos del debido proceso- puedan actuar como acciones de prevención.

Sin embargo, tal como lo señaláramos precedentemente, creemos que el fallo de dicha acusación debe ajustarse con mayor rigurosidad al debido proceso, por tal motivo estimamos necesario perfeccionar el contenido y publicidad de aquel fallo. Básicamente, porque la sanción que ha de aplicarse, vale decir, la inhabilitación de cargos públicos por cinco años, es lo suficientemente gravosa para que su adopción se produzca por el solo comentario que se emite en breves minutos en Sala.

En cuanto a la debilidad probatoria que se genera en la segunda etapa del juicio político en el Senado, nos unimos a tales cuestionamientos en torno a la imposibilidad que posee el acusado de acompañar mejores antecedentes que puedan sustentar su defensa. Fundamentalmente, porque es posible que el tenor del análisis de la Comisión informante de la Cámara de Diputados ponga énfasis en elementos que el acusado no consideró como relevantes al momento de contestar, o que se expongan ciertas aristas específicas respecto de las cuales el acusado puede poseer prueba suficiente para argumentar su defensa. En esta dirección, sostenemos que para ello el juicio se divide en dos partes, puesto que ello debiera garantizar que el examen de la evidencia se realice por dos órganos y pueda profundizar, impugnar o mejorar los instrumentos probatorios en razón de los cuales debe resolver el Senado.

En consecuencia, la regulación y espíritu del original artículo 48 fueron planteados de manera bastante confusa. Queda claro que la prioridad central de la CENC fue establecer un régimen presidencial autoritario, sin contrapesos políticos, otorgándole a la fiscalización parlamentaria una naturaleza eminentemente jurídico-

${ }^{928}$ Cf.supra, Pp. 286 y 287. 
técnica, tal como lo describe correctamente Bronfman al expone que "sustituye el concepto de fiscalización política encargada a la Cámara de diputados por mecanismos e instituciones cuyo control se espera más jurídico o técnico, como el Tribunal Constitucional, el Banco Central y la Contraloría General de la República"929. En tal sentido, expone el autor que nuestras dificultades institucionales serían dos: un primer aspecto, lo configuraba la posibilidad de crear conflictos institucionales entre un Ejecutivo fuerte que está por encima de los controles políticos; y un segundo aspecto, sería la imposibilidad constitucional nacional de diseñar un control político flexible que esté acorde a las sociedades modernas.

Una opinión más crítica respecto de la regulación de la fiscalización parlamentaria es la proveniente desde la Ciencia Política. Para esta área de investigación de las ciencias sociales, realizar un examen del texto constitucional y revisar cómo este último ha definido al régimen de Gobierno y órganos como el Parlamento, es considerado como una "errada visión". Así lo expresan Huneeus y Berrios cuando exponen que muchas instituciones no se aplican en la realidad, y que los presidentes tendrían fuentes de poder incluso sacadas de fuera de la misma Constitución. Agregan que la Carta Fundamental de 1980 transformó la realidad política nacional entregando al Presidente una cantidad de atribuciones mayores, lo que produjo el debilitamiento del Parlamento, contribuyendo a fortalecer aquella visión de América Latina que comprende presidentes fuertes y Congresos débiles, lo que afortunadamente ha ido variando con el tiempo y el ejercicio político. Es por ello que con el paso del tiempo el Parlamento toma un rol cada vez más preponderante en el fortalecimiento de la democracia ${ }^{930}$.

En este contexto, cuesta comprender la descripción a la que arriba el profesor Cea en cuanto a la fiscalización parlamentaria contemplado por la Ley Fundamental. El jurista expone que los acuerdos y observaciones "cuyo contendido de adhesión o crítica es esencialmente político, o sea, consecuencia de apreciaciones efectuadas sobre la base de doctrinas, ideologías, o concepciones filosóficas que conducen a los diputados a formular juicios de conveniencia, de mérito o de oportunidad sobre lo obrado o no por el Gobierno......Acuerdos u observaciones que, referidos a los actos del Gobierno, buscan también informar a la opinión ciudadana, orientándola o capacitándola para que asuma posiciones reflexivas acerca de tales actos;....Ante los

929 BRONFMAN (1991-1992) p. 308.

930 HunEeUs y BERRIOS (2005) Pp. 383 y 353 y 358. 
cuales incumbe al Primer Mandatario, confirmar o rectificar a su entera y sola voluntad la conducta del Gobierno, porque la obligación de éste se entiende cumplida por el sólo hechos de entregar su respuesta, sin que en ningún caso la fiscalización afecte la responsabilidad política de los ministros" ${ }^{\prime \prime 31 . ~}$

Desde una primera perspectiva, es racional coincidir con el profesor Cea en el siguiente aspecto: el Presidente puede o no tomar en consideración los acuerdos u observaciones pues goza de tal facultad, como también es correcto que la fiscalización no afecte la responsabilidad de los ministros. Empero, que los acuerdos u observaciones sean fruto de criterios políticos, ideologías o concepciones filosóficas es parcialmente correcto. Ello podrá ocurrir respecto de aquellas tendencias que logran obtener escaños parlamentarios, lo cual tal como lo analizáramos anteriormente sucede respecto de dos tendencias políticas mayoritarias en Chile, es decir, la gran gama o variedades de ideologías no se encuentran necesariamente representadas. Por otro lado, puede ocurrir que el juicio de oportunidad sea emitido, pero aquel planteamiento tenía una respuesta oportuna, por tal motivo la oportunidad se diluía.

Finalmente, esbozamos un cuestionamiento: es posible que aquella forma mediante la cual se desarrollaba la fiscalización lograba verdaderamente informar a la opinión ciudadana, orientándola o capacitándola para que asumiera posiciones reflexivas acerca de tales actos. Estarán realmente interesadas las dos fuerzas políticas que han ejercido el poder de manera constante en Chile en formar un análisis crítico en la ciudadanía, a fin de que ejerzan su potestad electoral en tal dirección que altere los equilibrios políticos vigentes. Sin lugar a dudas durante los años noventa y principios de los dos mil resulta difícil ponerse en aquel escenario.

Para ir concluyendo este apartado y siguiendo la estructura armónica, nos referiremos a nuestro objetivo central de investigación, esto es analizar finalmente si hubo un concepto claro utilizado por el constituyente respecto de la fiscalización. En esta labor seguiremos al jurista Eduardo Cordero cuando responde su pregunta ¿qué es fiscalizar? Comienza por destacar que ni la ley ni su sentido natural han sido claras, por ende, habrá que recurrir al contexto para poder delimitar su alcance. Advierte que éste es diverso al comprendido tradicionalmente, lo que hace su sentido bastante peculiar. La distinción controlar-fiscalizar ha esgrimido que controla quien

931 CEA (1993) p.10. 
vela porque los actos del Gobierno respeten un conjunto de normas que componen el ordenamiento jurídico. Según Cordero, es en resumidas cuentas dar cumplimiento al principio de legalidad y juridicidad contenidos en los artículos 6 y 7 de la Constitución. En cambio, fiscalizar es una acción más amplia porque su objetivo es emitir un juicio u opinión respecto de la conveniencia o la oportunidad de las decisiones adoptadas por el Gobierno. En consecuencia, el concepto de fiscalizar es el que más se acomoda a lo contemplado en la Constitución de 1980, en virtud del contexto y de los medios destinados a la misma. En tal sentido, será aquella posibilidad de "influir en la decisiones políticas, ya sea para confirmar la línea política seguida o para disentir de la misma, de forma transparente y pública frente a la

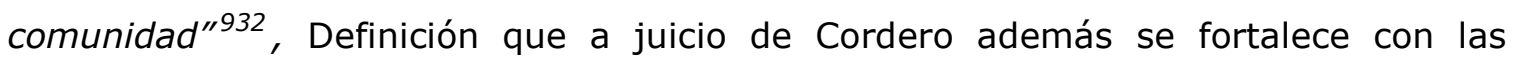
reformas del año 2005.

En dicho escenario, toma mayor sentido lo expuesto por Juan Carlos Ferrada cuando señala una opinión diversa respecto de las distinciones teóricas entre los términos control-fiscalización. Según este autor, la discusión en cuanto a su origen francés o anglosajón e incluso aquellos que matizan según la aplicación o no de sanciones, es realmente improcedente para nuestra realidad, porque la fiscalización parlamentaria en Chile según Ferrada "no tiene efectos inmediatos y cualquiera sea la forma en que se expresa ésta, implica una actividad de relativo control de la actividad política desplegada por los agentes del Estado"933. De allí que pueda utilizarse indistintamente ambos conceptos, sin la necesidad de asociarlo a ninguna sanción.

En consecuencia, respecto de la limitada doctrina que podemos encontrar respecto de este punto en nuestra doctrina nacional, aquellas visiones son contrapuestas, y por tal motivo hemos de seguir analizando más antecedentes que nos permitan aclarar aquel embrollo y aportar un concepto de fiscalización.

Con todo y a modo de conclusión del presente apartado, diremos que las deficiencias del diseño constitucional original de la fiscalización parlamentaria fueron fuertemente cuestionadas por la doctrina jurídica especializada y por importantes voces de las ciencias políticas, básicamente por contener una normativa insuficiente e ineficaz. Su semejanza al modelo del 1925 acarreó los mismos defectos. Fundamentalmente, hacían irrelevante la fiscalización en términos políticos e

932 Cordero (2005) Pp. 516 y 517

933 Ferrada (2002) Pp. 461-481. 
intentabn fortalecer una fiscalización técnica de tendencia jurídica. A pesar de que se establecieron algunas diferencias importantes, tales como liberar al Presidente de dar respuesta personal de los acuerdos y observaciones, entregando tal deber a los ministros $y$, particularmente relevante fue el establecer un plazo de 30 días para que el Gobierno respondiera dichos acuerdos u observaciones, no contempló una sanción en el caso de que no se entregara una respuesta dentro de dicho plazo, o ésta fuera tardía, por ende se entendería como suficiente la sola respuesta y con ello se daba cumplimiento a la obligación. Bastaba con responder; no se calificaba el contenido de tal respuesta. Por consiguiente, el efecto de la fiscalización una vez más es difuso. Elevó a rango constitucional la facultad de pedir antecedentes a diversos $\operatorname{organismos}^{934}$. Por tanto, las pequeñas modificaciones que contemplaba el texto original de la Constitución de 1980, si bien son un avance, no pueden calificarse como suficientes debido a que se incurría en importantes equívocos.

\section{Reformas constitucionales y la fiscalización parlamentaria}

Las reformas constitucionales más significativas al texto de 1980 son las del año 1989 y las del año 2005. Ambas cumplen múltiples funciones jurídicas y políticas que repercutirán fuertemente en el desarrollo del sistema democrático nacional. Por consiguiente, tendrán grado de incidencia importante en instituciones propias del sistema como la fiscalización del poder. No obstante, las reformas del año 1989 serán menos profundas en el cumplimiento de aquel objetivo, debido a las particulares circunstancias que nuestro país experimentaba en dicho año y que más adelante abarcaremos.

Por lo señalado precedentemente, las reformas constitucionales del año 2005 fueran calificadas como las más importantes al texto constitucional y el mayor logro democrático nacional. Tales modificaciones se califican como las más transcendentes para el sistema político-jurídico chileno, básicamente, por dos motivos que pasamos a analizar. Siguiendo a Martínez y Ferrer, diremos que -por un lado- ellas fueron producto de un consenso global por parte de ambos sectores de la política nacional, consenso que nunca se había alcanzado luego de la dictadura. Por otro lado, tuvieron por objetivo esencial democratizar la Norma Fundamental, eliminando lo que la doctrina nacional ha denominado "enclaves autoritarios". Tal como describe

934 MARTÍNEZ (1998) p. 40 y 41. 
Aldunate, las modificaciones fueron conceptuadas como una suerte de final de transición política, que hace desaparecer la tutela militar sobre el sistema democrático ${ }^{935}$.

\section{a) La reforma constitucional del año 1989 y el pacto de transición}

Si bien la Constitución Política fue modificada el año 1989 fruto de un pacto entre el Gobierno y la oposición democrática entonces emergente, sus efectos no fueron los esperados; según Carrillo estas modificaciones sólo aligeran el contenido pero no el vicio de origen, es decir, la ausencia de legitimidad democrática sigue estando presente ${ }^{936}$. Las 54 reformas aprobadas no alteraban la estructura institucional impuesta por el régimen autoritario de Pinochet, de manera que no lograron modificar las disposiciones que más expresamente se referían a la tutela del poder militar sobre el ordenamiento constitucional del país ${ }^{937}$.

Desde una perspectiva política, cabe hacer presente que las reformas del año 1989 tenían un contexto y una finalidad muy concreta, puesto que la oposición de aquellos tiempos (Concertación de Partidos por la Democracia) percibió que sus esfuerzos debían concentrarse en destrabar la posibilidad futura de modificar el texto constitucional. Así, el cálculo estratégico fue llevar a cabo negociaciones que no fueran a buscar una reforma en todos los aspectos críticos, sino simplemente reducir los umbrales para una futura reforma. Aquello se realizó mediante la reducción de quórums necesarios para las enmiendas constitucionales y el aumento en el número de senadores, para así contrapesar a los senadores designados.

Las reformas del año 1989 aumentaban la autonomía de las Fuerzas Armadas y de Orden, aumentaban además el número de senadores de 26 a 38, pero no permitieron avanzar en modificar el mecanismo de designación de algunas autoridades regionales como los intendentes, gobernadores y los consejos regionales. En definitiva, tal como explica Fuentes, lo que aceptó la oposición con estas reformas fue aplicar una tesis gradualista que era la única vía posible para conquistar la democracia, y que sólo después del triunfo de 1988 en el plebiscito, daría paso para diseñar una estrategia política más específica para dar

\footnotetext{
935 Aldunate (2005) p. 67.

936 CARRILLO (2002) p. 86.

937 ROLLA (2002) p. 66.
} 
gobernabilidad democrática al país. Dicha tesis gradualista implicaba, primeramente, aceptar que una vez recuperada la democracia no era factible salirse de las normas contenidas en la Constitución; en segundo lugar, que las condiciones políticas no permitieran plantear una revisión sustantiva Carta; y, en tercer lugar, que la posible reforma comprendería varias etapas, y habría que comenzar por eliminar los enclaves autoritarios y, luego, avanzar en las materias sustantivas ${ }^{938}$.

Tal como describe Nogueira, las reformas del año 1989 fueron el tránsito de la Constitución otorgada a la Constitución pactada. El ministro del Interior Carlos Cáceres, el 29 de abril del año 1989 comenzará una serie de negociaciones que tendrán por finalidad plantear 28 proposiciones de reforma al entonces coordinador de la Concertación de Partidos por la Democracia -don Patricio Aylwin- con el objetivo de establecer los cambios necesarios para llegar a un régimen democrático. Lo anterior fue fruto del triunfo obtenido en el plebiscito del año 1988, en el cual fue derrotado el General Pinochet políticamente, obteniendo sólo un $43 \%$ de los votos que aprobaban la idea que debía mantenerse en el poder por otros 8 años, frente a un 54\% que rechazó tajantemente aquella posibilidad. Luego de varios intentos fallidos, en el mes de mayo se arribará a un acuerdo con muchas reservas por parte de la Concertación, pero que desde un profundo análisis político era la única vía de posibilitar el tránsito del autoritarismo militar a un gobierno democrático ${ }^{939}$.

Pero, si bien las reformas constitucionales cumplen un rol jurídico, también fueron un pilar fundamental en el proceso transicional nacional. En palabras de Godoy, el sistema político alcanzado en Chile fue una democracia protegida bien planificada y coordinada por la élite militar y tecnocrática nacional, pero que una vez alcanzada la liberalización, el restablecimiento de algunas libertades públicas, la decisión de la oposición de participar en el marco de la legalidad creada por la Constitución en el plebiscito de 1988, se plasmaban las bases virtuales del carácter pactado de la transición. Por tanto, la voluntad de las partes se había expresado, pero la reforma constitucional era una condición indispensable para la oposición. Por tal motivo, acordar las reformas fue un cuadro conflictivo de larga data, sin embargo, una vez consensuadas y aprobadas en el plebiscito de 1989 se configura el pacto expreso 940 .

\footnotetext{
938 FUENTES (2012) Pp.52-56.

939 NogueiRA (2008) Pp. 332 y 333.

940 GodoY (1999) Pp. 93 y 103.
} 
Según Raúl Bertelsen, estas reformas fueron el resultado de una transacción en los años iniciales de un nuevo Gobierno, transacción que no generó un gran entusiasmo en los actores políticos que lo acordaron, pero que sí generaba una amplia aceptación por parte de la ciudadanía que participó activamente en la ratificación de la misma. Ahora bien, para el autor con las reformas del año 1989 se rompe una tendencia constitucional nacional, puesto que, esencialmente, las reformas de la Carta de 1833 y 1925 siempre estuvieron dirigidas a fortalecer los poderes del Ejecutivo, en cambio la actual reforma quiebra aquella tradición y disminuye algunas atribuciones. Las modificaciones al texto -calificadas como insuficientes, pero necesarias para profundizar la democracia, en consideración de Bertelsen- no tendrían trascendencia ni relevancia, puesto que aquellos aspectos reformados nunca habían sido utilizados, como la disolución de las Cámaras o la aplicación de estados de excepción. Arguye al autor que, en el caso de existir "normalidad constitucional", preceptos como el original y polémico artículo 8 -o el renovado 19 No 15- nunca se habrían de aplicar. Pero, en el caso de anomalías institucionales o frente a situaciones límites que pongan en riesgo el sistema democrático nacional, estas modificaciones cobrarían mayor sentido y no existirían salidas de emergencia ${ }^{941}$.

En resumen, las reformas de 1989 representan un pacto político forzado pero que permitía transitar a la democracia mediante herramientas jurídicas, institucionales y políticas que no perturbaran los reposados caminos dibujados. El objetivo fue claro y preciso: establecer una serie de condiciones que dieran garantía a todos los sectores políticos $y$, principalmente, militares que en cuanto a las responsabilidades políticas se mantendría un estatus quo y no se verían afectados. Por otra parte, se eliminan algunos elementos que tutelaban militarmente espacios de poder y se disminuyen los grados de amenaza que pudieran quebrar al sistema democrático que nacía.

En ese contexto, en nuestra opinión, la fiscalización parlamentaria no representaba ningún tipo de protagonismo, sino que muy por el contrario fue un elemento que idealmente no debía sufrir modificaciones, toda vez que cualquier enmienda en esa dirección podía significar una amenaza contra los militares, y la transición democrática podría configurarse como un simple anhelo y no como una realidad palpable.

${ }^{941}$ Bertelsen (1989) Pp.600-603. 
A continuación, se señalan las acusaciones que fueron realizadas durante la vigencia de la Carta de 1980 y con anterioridad a la reforma del año 2005.

\begin{tabular}{|c|c|}
\hline $\begin{array}{l}\text { ACUSACIONES BAJO LA CONSTITUCIÓN POLÍTICA DE } 1980 \\
(1980-2004)\end{array}$ & APROBADO/RECHAZADO \\
\hline $\begin{array}{l}\text { Germán Correa, Ministro de Transportes (11 de junio de 1991). } \\
\text { Causal: artículo } 48 \mathrm{~N}^{\circ} 2 \text {, letra b) "Infringir la Constituticón y las } \\
\text { leyes o haber dejado éstas sin ejecución". }\end{array}$ & $\begin{array}{l}\text { Rechazada Cámara de } \\
\text { Diputados }\end{array}$ \\
\hline $\begin{array}{l}\text { Alejandro Hales, Ex Ministro de Minería y Alejandro Foxley, Ex } \\
\text { Ministro de Hacienda (17 de junio de 1994). } \\
\text { Causal artículo } 48 \mathrm{~N}^{\circ} 2 \text {, letra b) "Infringir la Constituticón y las } \\
\text { leyes o haber dejado éstas sin ejecución". }\end{array}$ & $\begin{array}{l}\text { Se tiene por no } \\
\text { presentada, se acoge } \\
\text { cuestión previa. }\end{array}$ \\
\hline $\begin{array}{l}\text { José Pablo Arellano, Ministro de Educación ( } 19 \text { de junio de 1997) } \\
\text { Causal: artículo } 48 \text { letra b) "Infringir la Constituticón y las leyes o } \\
\text { haber dejado éstas sin ejecución". }\end{array}$ & $\begin{array}{l}\text { Rechazada Cámara de } \\
\text { Diputados. }\end{array}$ \\
\hline $\begin{array}{l}\text { Augusto Pinochet, General y Senador designado vitalicio ( } 9 \text { de abril } \\
\text { de 1998). } \\
\text { Causal: artículo } 48 \mathrm{~N}^{\circ} 2 \text {, letra d) p"Por comprometer gravemente el } \\
\text { honor y la seguridad de la Nación" }\end{array}$ & $\begin{array}{l}\text { Rechazada Cámara de } \\
\text { Diputados. }\end{array}$ \\
\hline $\begin{array}{l}\text { Ricardo Lagos, Ex Ministro de Obras Públicas ( } 26 \text { de octubre de } \\
\text { 1998). } \\
\text { Causal: artículo } 48 \text { letra b) "Infringir la Constituticón y las leyes o } \\
\text { haber dejado éstas sin ejecución". }\end{array}$ & $\begin{array}{l}\text { Rechazada Cámara de } \\
\text { Diputados. }\end{array}$ \\
\hline $\begin{array}{l}\text { Jorge Rodríguez Grossi, Ministro de Economía, Fomento y } \\
\text { Reconstrucción ( } 2 \text { de abril de } 2003 \text { ). } \\
\text { Causal: artículo } 48 \text { letra b) "Infringir la Constituticón y las leyes o } \\
\text { haber dejado éstas sin ejecución". }\end{array}$ & $\begin{array}{l}\text { Rechazada Cámara de } \\
\text { Diputados. }\end{array}$ \\
\hline $\begin{array}{l}\text { Luis Bates, Ministro de Justicia (17 de noviembre de 2004). } \\
\text { Causal: artículo } 48 \text { letra b) "Infringir la Constituticón y las leyes o } \\
\text { haber dejado éstas sin ejecución". }\end{array}$ & $\begin{array}{l}\text { Se tiene por no } \\
\text { presentada, se acoge } \\
\text { cuestión previa. }\end{array}$ \\
\hline
\end{tabular}

\section{b) La reforma constitucional del 2005 y la profundización democrática}

La modificación constitucional que finalmente se traduce en la Ley No 20.050 fue inicialmente promovida el año 2001 por dos mociones parlamentarias provenientes cada una de ellas de las fuerzas políticas antagónicas nacionales: por un lado, la propuesta de la Alianza por Chile y, por otro, la propuesta de la Concertación de Partidos por la Democracia. Tales mociones desencadenaron largas negociaciones y desavenencias políticas que dificultaban la posibilidad de llegar a un acuerdo ${ }^{942}$. En

942 El proyecto de la Alianza por Chile presentado por los Senadores Larraín, Chadwick, Romero y Diez correspondió al Boletín $\mathrm{N}^{\circ}$ 2526, y el proyecto presentado por la Concertación de partidos por la 
tal complejo escenario, finalmente se creó una Comisión oficiosa paritaria que se encargó de concordar acuerdos entre ambas fuerzas políticas y el Gobierno. Pero, a pesar de aquellos esfuerzos en coincidir en ciertos aspectos indispensables a modificar, las críticas persistieron. En este sentido, para Martínez y Ferrer a pesar "de los innegables logros en materia constitucional y en la constitucionalización del poder constituido, ni unos ni otros salvan el pecado original de la Constitución de la dictadura: su poder constituyente ${ }^{\prime \prime 943}$.

En efecto, a pesar de las profundas transformaciones de las cuales fue objeto la Carta Fundamental, continuaron voces críticas cuestionando la legitimidad y el origen de la misma, colocando especial énfasis en el mecanismo de reforma que contenía. En esta dirección se encuentran precisamente los comentarios de Kamel Cazor quien considera quimérica la posibilidad de que las reformas legitimen democráticamente al texto constitucional. Si bien la reforma es fruto de un acuerdo institucional compartido por los sectores más relevantes de la política nacional, ello solamente le otorgó mayor eficacia normativa a la Carta Magna, mas no validez democrática, toda vez que ellas fueron llevadas a cabo por un legislador-constituyente que obró mediante un procedimiento establecido por una institucionalidad no democrática, que se encuentra contenido en un Código Político de escasa legitimidad, con un legislador-constituyente configurado por un particular sistema electoral e integrado por senadores designados y vitalicios ${ }^{944}$.

En este sentido se expresa también Rolla, quien señala que "resulta frustrante reconocer que la Constitución vigente es insuficiente y admitir, al mismo tiempo, que no consigue encontrar un camino para modificarla"145, refiriéndose a las sombras que además dejaba el gobierno militar en las normas que reforman la Constitución. Tantas eran las dificultades del proceso de reforma, que el autor se refiere a ello como una "delicada fase de bloqueo constitucional". Por tales motivos, según Cazor, nos encontrábamos frente a un "círculo vicioso" que impide contar con la suficiente justificación de legitimidad para reformar la Carta del 1980. Por tanto, pudiendo llegar a los acuerdos necesarios que permitan obtener los quórums para reformar el texto constitucional, el origen espurio sigue estando presente, y por ello expresa

Democracia patrocinado por los señores Bitar, Hamilton, Silva Cimma, Viera-Gallo se encontraba contenido en el Boletín No 2534.

943 MARTínez y FERRER (2007) Pp. 2, 3 y 17.

944 Cabe recordar que los senadores designados provienen en gran medida de las FFAA y de orden público al punto de denominarse popularmente como "la bancada militar".

945 Rolla (2002) p. 71. 
"...tampoco la Carta de 1980 puede pretender legitimarse a sí misma- a partir de los mecanismos por ella establecidos" ${ }^{946}$.

A modo de contextualizar el escenario político de aquellos años, es preciso señalar que en su primer discurso ante el Congreso Nacional, realizado en el marco de la tradicional cuenta pública anual del 21 de mayo del año 2000, el otrora Presidente de la República, Ricardo Lagos, describiendo el programa político diseñado para su gobierno esboza la idea de llevar a cabo una serie de reformas a realizar al sistema político chileno, reformas legales que, por cierto, implicaban un cambio constitucional.

En razón de tales promesas expresadas por el Presidente de la República -las que además estaban contempladas en su programa de gobierno-, se comienza a vislumbrar la tesis de la reforma-gradualista a la Carta Fundamental. Ahora bien, las declaraciones del presidente Lagos se deben a múltiples factores. Por un lado, tanto él como sus asesores advertían que nuestro país estaba pasando por una situación política muy particular, la que generaba una coyuntura muy favorable hacia la revisión de la Constitución. Por otra parte, por intermedio de algunos congresistas el Gobierno exploró las posibles vías de diálogo existentes entre las fuerzas políticas nacionales (Alianza por Chile y Concertación), y el resultado de aquel análisis fue positivo, por consiguiente, el Ejecutivo concluye que existía un cierto consenso en cuanto a realizar una reforma constitucional. Así, el quórum requerido para la modificación constitucional era un hecho viable.

Como hito trascendente, es preciso destacar que en cuanto a la posibilidad de reformar la Carta Magna, el Gobierno contó con el apoyo político de parte importante de la derecha nacional, situación muy especial y que se debe básicamente al cambio en el escenario político chileno, fruto del debilitamiento de la figura del General Pinochet. Debido a los procesos abiertos en su contra por las cuentas en dólares del Banco Riggs, su detención en Londres y el alza electoral de la Alianza por Chile en los últimos comicios presidenciales, se gesta, en definitiva, el distanciamiento entre la derecha política y la figura del General Pinochet. La derecha nacional se desmarca de las figuras ligadas al golpe de Estado, y -en el fondo- se separa del golpe en sí mismo; de esta manera, configura una nueva impronta política, la que le generó considerables réditos electorales. Por su parte, otro factor determinante en el

${ }^{946}$ CAZOR (2005) Pp.536 y 540. 
proceso de reforma constitucional lo constituye el análisis estratégico que realizó la Alianza por Chile, en cuanto a la conveniencia particular que les generaba como sector modificar algunos de los enclaves autoritarios como mecanismos para aprobar el "test democrático" y así remediar sus críticas permanentes ${ }^{947}$.

De esta manera, la derecha chilena encontraba la vía de escape y el mecanismo perfecto mediante el cual acceder a una reforma constitucional, lo que además sólo le generaba réditos políticos para su coalición, toda vez que mediante la misma era posible, por una parte, blanquear el origen de la Constitución y, por otra, les permitía posicionarse como un sector político verdaderamente democrático. En consecuencia, generaban condiciones favorables para optar al poder y así gobernar al pueblo de Chile.

En este sentido, es posible señalar que las modificaciones al sistema de fiscalización parlamentaria se configuraron como un pilar fundamental en el plan diseñado por aquel sector político, puesto que si gozaban de mayores atribuciones fiscalizadoras, mayor era la posibilidad de visibilizar a sus líderes políticos, evidenciar las diferencias ideológicas y programáticas, y también exponer las posibles mejoras que existirían en la eventualidad de gobernar el país. Por tanto, el fortalecimiento de la fiscalización fue una modificación que, en cierta medida, se produjo en razón de las pretensiones electorales de la derecha, y no necesariamente a partir de una convicción que procurara perfeccionar las relaciones entre poderes, el equilibrio entre ellos, ni menos el perfeccionamiento del accountability.

Por otra parte, las reformas del año 2005 también fueron objeto de críticas desde la perspectiva de la teoría constitucional. En este sentido, el profesor Aldunate desarrolla una serie de observaciones a través de las cuales logra demostrar que, examinada la forma y producto del ejercicio constituyente de la reforma, la Constitución ha visto menguada su importancia como instrumento de institucionalización de la organización político-jurídica fundamental. La falta de prolijidad en la redacción del texto, en el diseño de las instituciones, procedimientos $y$, esencialmente, la pérdida de su función normativa, provoca que dentro del ordenamiento jurídico la Ley Fundamental pasara a ser una ley más, de mayor jerarquía que las otras; la reforma le restó cualquier otro carácter distintivo que no

${ }^{947}$ FUENTES (2012) Pp. 76-80. 
sea el de una debilitada rigidez. Concluye el autor que con la Ley No 20.050 se viene a coronar un proceso de desconstitucionalización de la Constitución ${ }^{948}$.

Ahora bien, a pesar de las deficiencias de origen de nuestra Constitución y su criticada reforma del año 2005, en las siguientes líneas realizaremos un examen respecto de la historia fidedigna en la formación de la Ley No 20.050, con el objetivo de comprender cuál era la orientación que el Congreso Nacional -posdictadura y transición democrática- tenía a la vista respecto de la fiscalización parlamentaria, para luego analizar su concreto resultado final.

Primeramente, hemos de señalar que estimamos que el debate que se produce, particularmente en la Comisión de Constitución, Legislación y Justicia del Senado, es la instancia en la que se manifiesta la discusión más contundente teóricamente, y por ello que centraremos nuestro análisis en aquella etapa. Respecto de este punto diremos que, en términos generales, el impulso reformista impidió la conformación de un verdadero fortalecimiento de dicha función. En resumidas cuentas, al momento de examinar la fiscalización parlamentaria se llevó a cabo un dilatado diagnóstico respecto de la función fiscalizadora y sus efectos, juicio que no necesariamente contribuyó en el perfeccionamiento de la institución porque no se ve reflejado en el precepto constitucional final.

En segundo lugar, mediante aquel debate se examinaron en profundidad otras facultades del Congreso; por ende, no se ciñeron estrictamente a la función fiscalizadora desvirtuando con ello el foco central, el cual era el fortalecimiento de la fiscalización parlamentaria.

En esta dirección, cabe señalar que se vincularon a la fiscalización otras funciones tales como la de información. Ya hemos hecho presente que entre el derecho a la información y el control parlamentario hay una estrecha relación, no obstante, al parecer aquello provocó cierta confusión entre los congresistas y se analizó, de manera conjunta, la función de control y el derecho a información ${ }^{949}$. Este escenario lo intentaron clarificar los Senadores Hamilton y Díez, refiriéndose a los objetivos de los nuevos mecanismos de control como las interpelaciones y las comisiones de

\footnotetext{
948 AldunAte (2005) Pp. 69, 70, 77,79.

949 Tal es la relevancia de la facultad de información, que en ambos proyectos de reforma constitucional presentados por la Alianza por Chile como por la Concertación de Partidos por la Democracia, se denominaban a las comisiones como fiscalizadoras pero expresaban que su finalidad era únicamente la de obtener información. Historia de los artículos de la Constitución. Primer Informe Comisión de Constitución Senado. Sesión 12, Legislatura 345, Pp. 64 y 65.
} 
investigación. Aclaran que el derecho a pedir información debía estar regulado en detalle en otro precepto, principalmente, porque aquel es una atribución de la cual goza tanto la Cámara de Diputados como el Senado y persigue otras finalidades. En cambio, la fiscalización es una función exclusiva de la Cámara Baja, la que además de recopilar información debe controlar los actos del Gobierno. El Senador Díez formula la distinción al señalar que un ministro puede ser llamado por actos de fiscalización, pero también puede ser convocado a prestar información, la que ha de ser utilizada para conocer una situación determinada que se ha de fiscalizar o para dar cumplimiento a las tareas legislativas.

En esta misma oportunidad, emerge la noción de reforzar el derecho de las minorías de poder ejercer instrumentos de fiscalización de manera viable. Se expone la necesidad de precisar que la función fiscalizadora corresponde a la Cámara en su conjunto y no a parlamentarios individualmente considerados. Una vez más fue el senador Hamilton quien planteó la premisa de que los parlamentarios individualmente considerados no pueden transformarse en agentes de fiscalización, por tal motivo han de establecerse quórums razonables ${ }^{950}$.

En tercer lugar, hemos de hacer presente que nuevamente se esboza en el hemiciclo un fundamento -a nuestro entender- incorrecto, el cual denunciaba que aquel vínculo entre política-fiscalización constituía el inconveniente más significativo de la fiscalización. Dicho argumento, se configura como un fenómeno sistemático que estuvo presente en el debate constituyente y que se trae a colación una vez más en la discusión de la reforma constitucional; argumento que en cierto modo contraviene gran parte de la doctrina especializada en la materia, la cual le reconoce al control una naturaleza eminentemente política.

Por tanto, a nuestro juicio, se produce finalmente un desequilibrio entre el sentido de la reforma en esta materia y los efectos democratizadores que ella esperaba alcanzar, versus las reformas aprobadas. Prueba de lo expuesto precedentemente son algunas de las declaraciones y argumentos expresados por determinados congresistas de la época. En este sentido, cabe recordar lo expuesto por el senador señor Díez quien manifestó que "existe conciencia nacional en torno a la idea de que nuestro sistema jurídico necesita con urgencia reglamentar la función fiscalizadora de la Cámara de Diputados para que cumpla la finalidad señalada en la

950 Historia de los artículos de la Constitución. Primer Informe Comisión de Constitución Senado. Sesión 12, Legislatura 345, Pp. 74 a 76. 
Constitución y sea eficiente, seria y creíble por la opinión pública y, al mismo tiempo, no pueda ser usada para producir efectos políticos que dañan a la sociedad en general y a la reputación de muchos agentes públicos, en particular"'1951. Opinión que en cierta manera compartía el Senador Chadwick al sostener "que siempre subsistirá el problema de que, al fiscalizar, la Cámara de Diputados, por tratarse de una Corporación de naturaleza política, se comporte políticamente"1952. Como se puede apreciar, el tinte político del control fue detectado como una dificultad a la hora de regular el control y determinar su objetivo.

Prosiguiendo con el estudio de la reforma constitucional en materia de fiscalización parlamentaria, es necesario plantear otros aspectos interesantes que surgen en el mismo. Se hace referencia a la desnaturalización de los sistemas de gobierno, que desde hace décadas se vienen desarrollando en todos los sistemas democráticos, razón por la cual surge la factibilidad de incorporar instrumentos de fiscalización propios del régimen parlamentario en nuestro sistema presidencial; herramientas tales como las interpelaciones ministeriales y las comisiones investigadoras sin abandonar al régimen presidencial nacional. No obstante, nuevamente harán presente como fundamento moderador a los impulsos reformistas, los nefastos efectos que los instrumentos parlamentarios provocaron en épocas pasadas en Chile.

Tal era la preocupación en este aspecto, que la discusión en Sala del Senado respecto del régimen de gobierno presidencial, el señor Viera Gallo expuso la precaución con la que se debía regular esta función $y$, principalmente, las interpelaciones, toda vez que el período de "anarquía parlamentaria" nacional se desarrolló precisamente en virtud del uso abusivo de la citación de Ministros de Estado para hacer efectiva su responsabilidad. En este mismo orden de ideas, se expresó el señor Fernández quien sostuvo que lo que se estaba analizando era un cambio de fondo en el sistema de fiscalización parlamentaria, puesto que "el introducir instituciones extrañas al sistema político chileno ya en el pasado, como se dijo, han significado trastornos constitucionales de enorme envergadura en el país, y podría darse el caso en estas normas" ${ }^{\prime \prime 53}$. Alegaba el parlamentario que, a pesar de

\footnotetext{
${ }^{951}$ Historia de los artículos de la Constitución. Primer Informe Comisión de Constitución Senado. Sesión 12, Legislatura 345, p. 69.

952 Historia de los artículos de la Constitución. Primer Informe Comisión de Constitución Senado. Sesión 12, Legislatura 345, p. 72.

${ }^{953}$ Historia de los artículos de la Constitución. Primer Informe Comisión de Constitución Senado. Sesión 12, Legislatura 345, p. 112.
} 
limitar el número de veces que podía ser citado un ministro, igualmente se generaba un germen de conflicto entre el Poder Ejecutivo y el Poder Legislativo.

En tal contexto, las reformas en materia de fiscalización fueron acordadas y aprobadas por el Congreso Pleno en la Legislatura 353, el 16 de agosto del año 2005, las que comprendieron los siguientes alcances: se incorporan como mecanismo de control las interpelaciones parlamentarias en la Letra B del artículo 48, a fin de que los parlamentarios pudieran formular aquellas preguntas que estén en relación con las materias propias del cargo; se estipuló expresamente que la asistencia del ministro citado es obligatoria, como también el deber de dar respuesta a dichas interrogantes; se reguló en la letra C) la creación de las comisiones investigadoras, cuya finalidad era la de reunir información relativa a determinados actos de Gobierno, respecto de las cuales se contempla la obligatoriedad tanto de asistencia como de suministrar información, respecto de los Ministros de Estado, los demás funcionarios de la Administración y el personal de las empresas del Estado, o de aquellas en que éste tenga participación mayoritaria. Sin perjuicio de lo anterior, se delegó a la Ley Orgánica Constitucional del Congreso Nacional la regulación del funcionamiento y atribuciones de dichas comisiones, como también la protección de los derechos de las personas citadas. Por otra parte, la modificación constitucional expresó que el resultado de la investigación sería reservado.

Con todo, con las reformas del año 2005 quedarán reguladas las atribuciones exclusivas de la Cámara de Diputados y del Senado en los artículos 52 y 53 de la Carta Fundamental. El artículo 52 contempla dos numerales: el primero, mantiene la fiscalización de los actos de gobierno mediante acuerdos y observaciones, pero en su inciso segundo de la Letra a) formula una salvedad que a nuestro juicio comprende la función inspectiva mas no fiscalizadora. Reza el precepto: "Sin perjuicio de lo anterior, cualquier diputado, con el voto favorable de un tercio de los miembros presentes de la Cámara, podrá solicitar determinados antecedentes al Gobierno. El Presidente de la República contestará fundadamente por intermedio del Ministro de Estado que corresponda, dentro del mismo plazo señalado en el párrafo anterior". Así, se regula el derecho a pedir información constitucionalmente de manera confusa con la fiscalización parlamentaria. Por su parte, las siguientes letras de la norma establecen las citaciones a ministros y las comisiones investigadoras. El numeral $2^{\circ}$ del precepto continuará regulando la acusación constitucional respecto del Presidente de la República, los Ministros de Estado, magistrados de los tribunales superiores de 
justicia, el Contralor General de la República, generales o almirantes de las fuerzas de la defensa nacional y, finalmente, respecto de intendentes y gobernadores.

La evaluación por parte de la doctrina respecto de las reformas tuvo de dulce y de agraz. No obstante, en lo concerniente a la fiscalización parlamentaria, parece ser un balance positivo. A continuación, traeremos a colación algunas opiniones en dicho tenor.

Para Hube, González y Zárate, las reformas del año 2005 vienen a salvar algunas deficiencias constitucionales en materia de fiscalización, ya que permitieron definir más claramente el rol de la Cámara, fortalecer el rol fiscalizador a través de la inclusión de la interpelación y la constitucionalización de las comisiones investigadoras ${ }^{954}$.

Tal como describen Bronfman, Cordero y Aldunate, con las reformas del 2005 el precepto constitucional número 52 no se habría modificado, sino que solamente se habría reforzado. En dicho sentido, tres fueron los alcances más relevantes. En primer lugar, se crean una serie de mecanismos cuya finalidad no sólo es enjuiciar políticamente la acción del Gobierno, sino que además permiten obtener información necesaria a fin de que el juicio político se sustente en antecedentes serios y confiables. En segundo lugar, se constituye una herramienta importante a disposición de las minorías parlamentarias, puesto que podrán alcanzar el quórum necesario para solicitar antecedentes, conformar comisiones investigadoras y citar ministros, a pesar de que no podrán conseguir el quórum para aprobar acuerdos u observaciones. El tercer refuerzo sería aquella definición que configura a la fiscalización como una facultad institucional que ha de ejercer la Cámara de Diputados como órgano, y no sus miembros individualmente considerados ${ }^{955}$.

Una apreciación similar es la esgrimida por Cordero puesto que -para este autorlas reformas constitucionales dan cuenta de un evidente reforzamiento de los instrumentos o medidas fiscalizadoras, mediante los cuales se dota a la Cámara de Diputados y a las minorías parlamentarias de mayor fuerza fiscalizadora, frente a los actos y a la gestión de los complejos órganos que componen el Gobierno. Según el autor, este fortalecimiento de la fiscalización además contribuye a perfeccionar el principio democrático y, en particular, los estándares de transparencia y publicidad

\footnotetext{
954 HUBE et alt (2011) p.29.

955 BRONFMAN et alt (2013) p. 296.
} 
de los órganos del Estado; vale decir, los cambios introducidos engarzan con la incorporación del artículo 8 a las bases de nuestra institucionalidad constitucional ${ }^{956}$.

Por otra parte, voces como las de Francisco Zúñiga y Francisco Vega esbozan un detallado contraste entre lo positivo y lo negativo de la reforma. En un primer orden, bosquejan comentarios críticos en cuanto a la reducción del objeto del control que realiza esta reforma, toda vez que restringe el tipo de órgano que ha de ser fiscalizado. Expresan además el déficit de racionalización que genera en cuanto al procedimiento y derechos de las personas referidas a una investigación, al someter los procedimientos del control político a una ley orgánica. Por otra parte, se utilizan incorrectamente algunos términos al esgrimir la voz "citar" a ministros puesto que el instrumento es "interpelar". Resulta particular una apreciación que los autores realizan respecto de los nuevos mecanismos de control, la cual compartimos plenamente al señalar que las interpelaciones y las comisiones de investigación, se tratan como herramientas que engarzan con la función cognoscitiva o inspectiva, cuya finalidad es básicamente arribar a información exhaustiva.

Pero, sin lugar a dudas, quien grafica los avances conseguidos con la reforma del año 2005 es José Bidart. En palabras del autor, la Comisión de Constitución, Legislación, Justicia y Reglamento del Senado delimita tres conceptos: actos de gobierno, fiscalizar, fundadamente. Respecto de la primera acepción, señala que la expresión "actos de gobierno" incluye al Presidente de la República, Secretarios de Estado, servicios y organismos de la Administración del Estado, las Fuerzas Armadas, además de las empresas del Estado y aquellas en las que tenga participación mayoritaria. Para la segunda acepción, "fiscalizar", declara Bidart que deberá entenderse en el mismo sentido y alcance que el contemplado en la Carta de 1925, es decir, como un juicio valorativo de algún hecho con un carácter político, que tenderá a influir la gestión del Gobierno. En último lugar, la palabra "fundadamente" se enmarca en la respuesta que el Presidente de la República debe otorgar a través de sus ministros, y dicha contestación debe ser fundamentada fortaleciendo de esta manera la eficacia de la facultad fiscalizadora de la Cámara Baja, puesto que la brevedad con la cual debe responder puede perjudicar la calidad y la finalidad de este mecanismo de control ${ }^{957}$.

956 CORDERO (2005) p. 526.

957 BIDART (2013) Pp.29 y 30. 
Por ende, podemos concluir que las distancian de la fiscalización y que, además, no las vinculan necesariamente con la responsabilidad política; vale decir, a través de aquella noción se suman a aquella opinión que considera estos mecanismos como la antesala de una posterior actividad de control, como el precedente de una posible responsabilidad política, pero necesariamente como mecanismos de control propiamente tal. Por otra parte, plantearán como virtud de la reforma el fortalecimiento de su ejercicio por parte de minorías cualificadas, asegurando de tal modo sus derechos de control; en definitiva, las reforman en materia de fiscalización permiten encauzar el régimen político hacia una efectiva democracia representativa ${ }^{958}$.

Una visión igualmente crítica es la esgrimida por Berrios, quien postula que las reformas representan un avance importante, en cuanto aumentan las limitadas facultades del Parlamento en esta materia. No obstante, su impacto puede ser muy menor, principalmente porque los instrumentos siguen siendo limitados. Sin perjuicio de aquello, manifiesta que igualmente amplían la posibilidad de control de la oposición ${ }^{959}$.

Las observaciones esgrimidas por autores como Martínez y Ferrer, constituyen argumentos de suma trascendencia, en cuanto se refirieren al impacto que ellas provocan en el régimen de Gobierno y en el sistema del control y exigencia de responsabilidad del Gobierno. Según los autores citados, las reformas constitucionales estudiadas fortalecen los instrumentos para ejercer la fiscalización, establecen la constitucionalización de las Comisiones de investigación, y contemplan una regulación de la citación de los ministros como un mecanismo de control genérico que no requiere estar vinculado a una investigación específica. Además, consagran una vinculación del Presidente de la República en relación con los acuerdos u observaciones que dirige la Cámara, lo que, en definitiva, constituye un "viaje desde el presidencialismo hacia un semipresidencialismo sui generis"960.

Empero, a pesar de aquel atisbo de virtud, ambos autores persisten en señalar algunas deficiencias respecto de la fiscalización, como la no inclusión de la posibilidad de adoptar acuerdo de sala que pudiera ser puesto en conocimiento de los órganos pertinentes, y la debilidad de la constitucionalización de las comisiones,

\footnotetext{
958 ZÚÑIGA Y VEGA (2005) Pp.307 a 311.

959 BERRÍOS Y GAMBOA (2006) p.30.

960 MARTÍNEZ Y FERRER (2007) p.8
} 
toda vez que su único objetivo sería el de reunir información relativa a determinados actos del Gobiern, convirtiéndose la vigorización de la fiscalización en sede de la Cámara Baja en humo de pajas. Finalmente, postulan que sólo puede valorarse la modificación constitucional desde una perspectiva comparativa en relación al texto original, pero no comprende un avance significativo desde una perspectiva histórica ni constitucional; por tanto, las reformas se quedan a medio camino, estancándose en un semipresidencialismo sui generis y tibio.

Tal como es posible inferir, para ambos juristas la reforma desemboca en la modificación del régimen, vale decir, concluyen que la virtud esencial de aquellas modificaciones fue permitir el ingreso del régimen semipresidencial a Chile, cuestión que a nuestro entender es incorrecta. Ciertamente, la Ley $N^{\circ} 20.050$ se tradujo -en materia de fiscalización parlamentaria- en un reforzamiento de los instrumentos, mas no en un perfeccionamiento de la institución en sí misma. Constitucionalizando mecanismos de control y favoreciendo su acceso a las "minorías" parlamentarias, está lejos de ser la pauta para un cambio de régimen. Un régimen semipresidencial se caracteriza por poseer un ejecutivo dual y una relación entre poderes del Estado, en particular Ejecutivo-Legislativo. Por otra parte, se contemplan instrumentos como la moción de confianza y las censuras, situación muy diversa a la realidad institucional y política chilena.

A pesar de las enmiendas de las cuales han sido objeto la fiscalización parlamentaria, una conclusión inicial implicaría señalar que aparentemente no han sido del todo suficientes. Las deficiencias planteadas por un sector de la doctrina siguen teniendo eco, y, además, existe una cierta incomodidad parlamentaria con la arquitectura actual del control, así lo demuestran algunas iniciáticas legislativas de parlamentarios que persisten en modificar la fiscalización. Sólo hasta el año 2012 existían a lo menos tres proyectos de ley que aspiraban a reformar la institución en sí o a los mecanismos de control. Estos son961: Boletín No 8675-07, No 8554-07, No 8503-07. Lo anterior da cuenta de una preocupación por el tema y la necesidad de perfeccionarla, no obstante, no se vislumbran esfuerzos concretos por finalizar la tramitación de aquellos proyectos de ley o promover el análisis y reflexión sobre la misma.

961 http://www.camara.cl/pley/pley detalle.aspx?prmID=9077\&prmBL=8675-07, Visitado con fecha: 27.12.2012. 
Desde nuestra perspectiva, creemos que es más prudente esperar el desenlace del proceso constitucional que se ha iniciado en nuestro país, a fin de conocer cuál será el rumbo que ha de tomar. Puesto que, si efectivamente se da curso a un proceso constituyente que aspire finalizar con la redacción de un nuevo texto constitucional, será preciso evaluar el régimen de gobierno y, con ello, el sistema de pesos y contrapesos. Por tanto, nada asegura que continuemos aplicando un sistema presidencial de similares características al vigente, ya que la relación EjecutivoLegislativo puede verse alterada. Incluso dentro del abanico de posibilidades que otorga un debate constituyente, podría optarse por otro régimen, o por el mismo pero con adecuaciones, y en todos esos escenarios la fiscalización parlamentaria se verá afectada.

Por otra parte, exponemos las acusaciones constitucionales que se ejecutaron con posterioridad a la reforma constitucional.

\begin{tabular}{|l|l|}
\hline \multicolumn{1}{|c|}{ ACUSACIONES BAJO LA CONSTITUCIÓN POLÍTICA DE 1980 } & APROBADO/RECHAZADO \\
\hline $\begin{array}{l}\text { Yasna Provoste, Ministra de Educación (17 de abril de 2008) } \\
\text { causal: artículo 52 letra b) "Infringir la Constituticón y las leyes o } \\
\text { haber dejado éstas sin ejecución". }\end{array}$ & $\begin{array}{l}\text { Aprobada: Declarada } \\
\text { Culpable, Destituida. }\end{array}$ \\
\hline $\begin{array}{l}\text { Rodrigo Hinzpeter, Ministro del Interior y Seguridad Pública (31 de } \\
\text { agosto de 2011) causal: artículo 52 letra b) "Infringir la } \\
\text { Constituticón y las leyes o haber dejado éstas sin ejecución". }\end{array}$ & $\begin{array}{l}\text { Se tiene por no } \\
\text { presentada, se acoge } \\
\text { cuestión previa. }\end{array}$ \\
\hline $\begin{array}{l}\text { Rodrigo Hinzpeter, Ministro del Interior y Seguridad Pública (2 de } \\
\text { mayo de 2012) causal: artículo 52 letra b) "Infringir la } \\
\text { Constituticón y las leyes o haber dejado éstas sin ejecución". }\end{array}$ & $\begin{array}{l}\text { Se tiene por no } \\
\text { presentada, se acoge } \\
\text { cuestión previa. }\end{array}$ \\
\hline $\begin{array}{l}\text { Harald Beyer, Ministro de Educación (17 de abril de 2013) causal: } \\
\text { artículo 52 letra b) "Infringir la Constituticón y las leyes o haber } \\
\text { dejado éstas sin ejecución". }\end{array}$ & $\begin{array}{l}\text { Aprobada: Declarado } \\
\text { Culpable, Destituido. }\end{array}$ \\
\hline
\end{tabular}




\section{Elementos de la fiscalización parlamentaria en el ordenamiento constitucional $y$ legal nacional vigente:}

En la actualidad, la fiscalización parlamentaria se encuentra regulada en los artículos 52 y 53 de la Constitución Política de la República, en la Ley Orgánica Constitucional del Congreso Nacional y en el Reglamento de la Cámara de Diputados.

A continuación, realizaremos un análisis metodológico respecto de los elementos que componen la fiscalización parlamentaria, e iremos cotejándolos con la regulación nacional vigente $y$, con determinados aspectos empíricos relevantes de la práctica parlamentaria.

\section{a) Los sujetos de la fiscalización parlamentaria}

En el siguiente epígrafe hemos de determinar con cierta certeza quiénes son los actores de la fiscalización en Chile, vale decir realizaremos un análisis normativo y práctico que nos permita exponer de forma fundada quién es el sujeto activo y el sujeto pasivo del control.

Inicialmente, diremos que no cabe duda alguna que el constituyente ha situado a la fiscalización parlamentaria como una atribución exclusiva de la Cámara de Diputados, por tanto, el sujeto activo han de ser los integrantes de la Cámara Baja. Así pues, el artículo 52 reza: "Son atribuciones exclusivas de la Cámara de Diputados: 1) las de fiscalizar los actos de gobierno". Por su parte, el artículo 53 inciso final señala expresamente que aquella función está prohibida para el "...Senado, sus comisiones y demás órganos, incluidos los comités parlamentarios si los hubiere no podrán fiscalizar los actos del Gobierno ni de las entidades que de él dependan, ni adoptar acuerdos que impliquen fiscalización".

Respecto del contenido de estos preceptos cabe formular algunos comentarios. En primer lugar, es posible concluir que el sujeto activo del control lo compone única y exclusivamente la Cámara de Diputados, pero ¿qué alcance ha de tener aquella definición? En un primer examen es preciso señalar que, luego de la reforma del año 2005, respecto de este punto se produce una delimitación de aquella atribución y por 
tal motivo autores como Martínez, Aldunate, Cordero y Bronfman dirán que la función de fiscalizar es una atribución que ejerce la Cámara como cuerpo colegiado; es decir, el control parlamentario es una actividad en la que el sujeto activo no es uno o más diputados individualmente considerados. Para Gutenberg Martínez, el arribo a dicha aseveración implica considerar dos aspectos. Por una parte, el tenor literal de la norma toda vez que ella señala en el inciso primero: "Son atribuciones exclusivas de la Cámara..." y en el inciso segundo que: "Para ejercer esta facultad la Cámara...", por ende, siempre se refiere a la Cámara como un órgano colectivo, no permite el ejercicio por parte de los parlamentarios individualmente considerados ${ }^{962}$. Por otra parte, estima el autor que al estipular el precepto constitucional que los acuerdos u observaciones deben de adoptarse o sugerirse por el voto favorable de la mayoría de los presentes, el sentido de unidad de acción queda de manifiesto ${ }^{963}$.

En nuestra opinión, estimamos que si bien el texto constitucional es claro al señalar que la facultad de fiscalización es una acción que compete a la Cámara de Diputados en su conjunto, razón por lo cual, para realizar un acuerdo u observación debe concurrir el voto de la mayoría de los Diputado presentes. No obstante, creemos que aquel requisito limita la capacidad de acción de los congresistas, toda vez que la Cámara de Diputados en la actualidad está compuesta por 120 Diputados y el año 2018 dicho número aumentará considerablemente. En consecuencia, alcanzar dicha mayoría simple, generalmente, implicará contar con la concurrencia de múltiples voluntades, en este sentido el congresista considerado individualmente, pierde fuerza fiscalizadora como también pierden capacidad de acción las bancadas compuestas por un número pequeño de Diputados. Así las cosas, estimamos que podría establecerse un quórum menor que el de mayoría simple de los presentes, exigiendo siempre la concurrencia de varios Diputados, de esta manera no se quebrantaría a la norma fundamental y se resguarda la concepción de unidad de

962 Respecto de las acciones de control realizables por el parlamentario individualmente considerado, resulta interesante exponer la situación jurídica española, respecto de la cual el parlamentario individual desde hace mucho tiempo posee una débil posibilidad de control y los grupos parlamentarios han tomado el protagonismo, a tal punto que Piedad García-Escudero habla del "Parlamento grupocrático", el cual presenta claras y fuertes expresiones respecto de las facultades legalmente conferidas a los grupos parlamentarios expresadas en el Reglamento del Congreso de los diputados (RDC) y el Reglamento del Senado (RS), es así como por ejemplo: pueden convocar la Junta de Portavoces en el Congreso de los diputados art. 39 del RDC; basta con la propuesta de dos grupos parlamentarios para la creación de comisiones de investigación o estudio en el Congreso de los diputados art. 52 y 53 RDC; a solicitud de dos grupos parlamentarios se puede solicitar votación pública por llamamiento o votación secreta art. 85.1 y 2 RDC; pueden realizar presentación de proposiciones de ley art. 126.1 RDC y art. 108 del RS; propuesta de cierre del debate en Comisión en el Senado art. 116.1 RS, la tramitación del procedimiento legislativo de urgencia puede ser propuesto por dos grupos parlamentarios art. 93 RDC y sólo por un grupo en el Senado art. 133 RS, etc.

963 MARTÍNEZ (1998) Pp. 45 y 46. 
acción. Pero se facilitaría el ejercicio de la función fiscalizadora, reconociendo cierta autonomía a los Diputados para realizar sus labores parlamentarias. Por ende, proponemos que los acuerdos u observaciones puedan ser presentados por un número no menor de diez Diputados, aquella modificación mantendría el espíritu del artículo 52 de la Carta fundamental y, además, equipara el número al mismo requerido para ejercer una acusación constitucional, considerando que la acusación es un instrumento más gravoso. Por consiguiente, disminuyendo el quórum se facilita el ejercicio de ese tipo de fiscalización.

En segundo lugar, es posible sostener que la función fiscalizadora no se encuentra contemplada dentro de las atribuciones del Senado, o dicho de otra manera, la Cámara Alta está imposibilitada de ejercer control parlamentario. Por tanto, al Senado sólo le queda la facultad de obrar como jurado en las acusaciones parlamentarias.

Finalmente, cabe indicar que el sujeto pasivo del control será el Ejecutivo, en particular, la fiscalización recaerá sobre los actos de Gobierno, elemento que analizaremos en profundidad cuando nos refiramos al objeto del control.

Respecto de esta materia es posible realizar dos alcances. El primero, en atención al vínculo minoría-fiscalización debemos recordar lo dicho en el Capítulo anterior en cuanto a las particularidades del sistema electoral nacional, factor que impedía el arribo de verdaderas minorías al Congreso y que, además, influía en la composición de la oposición al Ejecutivo, toda vez que ella no necesariamente será la fuerza política minoritaria en el hemiciclo. Ahora bien, teniendo aquel elemento presente, es posible destacar que la oposición es quien liderará los actos de fiscalización pudiendo ser mayoría o minoría. No obstante, tal premisa igualmente se ha visto alterada en una oportunidad en la vida parlamentaria nacional, cuando el sujeto activo y pasivo no se configuran conforme los cánones clásicos establecidos.

El 16 de marzo del año 1998, la Concertación de Partidos por la Democracia, fuerza política que gobernaba a través de la Presidencia de don Eduardo Frei RuizTagle y que contaba con una leve mayoría en el Congreso respecto del conglomerado de derecha, ejerce una acusación constitucional en contra de Augusto Pinochet en su calidad de General de las Fuerzas Armadas chilenas. Si bien la Concertación no era 
minoría y tampoco era oposición al Gobierno, ejercen esta acusación en virtud de una serie de aspectos netamente políticos en contra de quien había ejecutado el golpe de Estado y liderado la dictadura cívico-militar. De esta manera se intentaban juzgar políticamente los terribles hechos ocurridos en la dictadura, impedir la incorporación del Pinochet como senador vitalicio al Congreso, y así también se pretendía debilitar políticamente a la Alianza por Chile y sus miembros, toda vez que la exposición política del general Pinochet -lograda mediante la acusación- provocaba el surgimiento de una férrea defensa hacia el dictador por parte de la Alianza, evidenciando las cercanías y los vínculos políticos entre dicho colectivo político y el círculo de poder del General, relación que en otras oportunidades se había negado tajantemente.

La acusación constitucional a Pinochet es un caso tremendamente particular que seguiremos utilizando en nuestra investigación, pero que en este punto nos permite marcar una inflexión en los parámetros establecidos habitualmente en relación a los actores del control, puesto que en tal caso los actores de la acusación constitucional fueron atípicos. No fue la minoría ni tampoco la oposición la que activó mecanismos de control, fue precisamente la mayoría gobernante.

El segundo alcance importante respecto del sujeto activo del control, lo configuran los quórums establecidos para poder utilizar una u otra herramienta. Del artículo 52 de la Constitución se desprende que los quórums establecidos para cada mecanismo son diferentes; por ende, activar los acuerdos o sugerir observaciones es el instrumento fiscalizador -desde esta perspectiva- de menor dificultad, puesto que es posible ejercerlo con sólo acuerdo de la mayoría de los diputados presentes. Sin embargo, las interpelaciones y las comisiones investigadoras requieren de quórums de 40 diputados en el caso de las primeras y 48 para las segundas. Empero, para el caso de las acusaciones constitucionales es necesario contar con el apoyo de no menos de 10 ni más de 20 parlamentarios. Por consiguiente, es posible inferir que las acusaciones constitucionales exigen menos quórums que las interpelaciones y las comisiones, lo cual advierte gran interés si consideramos que las acusaciones revisten habitualmente mayor cobertura mediática, y su procedimiento implica detallar claramente las faltas graves o abusos de poder en que se funda. Tal como lo describen los artículos 37 y siguientes de la Ley Orgánica Constitucional del Congreso Nacional y el Reglamento de la Cámara de Diputados en los artículos 304 y 
siguientes, es menester presentar un escrito acusatorio donde se señalen las causas que han de promover la acusación. Por tal motivo la acusación parece configurar un procedimiento que implica cierta rigurosidad.

\section{b) Objeto de la fiscalización parlamentaria}

El artículo 52 de la Constitución reza: "Son atribuciones exclusivas de la Cámara de Diputados: 1) Fiscalizar los actos de Gobierno.". Por consiguiente, el objeto del control político serán los actos del Gobierno.

Nuestra Ley Fundamental trata al Gobierno en el Capítulo IV, oportunidad en la cual estipula en el artículo 24 que "el Gobierno y la Administración del Estado le corresponde al Presidente de la República...". De conformidad a lo señalado en tal precepto constitucional, es posible concluir que el texto constitucional distingue entre Gobierno y Administración del Estado, y por ello se torna indispensable delimitar ambos conceptos y definir si la fiscalización parlamentaria es aplicable a ambos conceptos o sólo a uno. Ahora bien, siguiendo algunas voces autorizadas en Derecho Administrativo plantearemos los rasgos más relevantes en torno a la discusión de este elemento.

Según Enrique Silva Cima, la acción del Poder Ejecutivo puede subdividirse en una acción de Gobierno de contenido político o gubernamental y en una acción ejecutiva propiamente administrativa. La primera, comprende aquellos actos que dicen relación con el gobierno del Estado, ejecutando normas de tipo político; y la segunda, es aquella que tienden a materializar la función administrativa. Ambos gozan de la particularidad de que, a pesar de que provengan de un mismo órgano, los actos de gobierno son competencia del Derecho Político o Constitucional, y los otros serán dominio del Derecho Administrativo. Sin embargo, para Silva Cima esta distinción crea una dificultad, puesto que diferenciar uno y otro será una labor compleja; no obstante, existen elementos que permiten distinguirlos, por ejemplo, las responsabilidades que emanan de ellos son diferentes: los actos de gobierno acarrean una responsabilidad política generalmente discrecional y no reglada; en cambio, los actos administrativos acarrean responsabilidad administrativa, civil y penal. 
Por otro lado, se gesta una disimilitud respecto del control jurisdiccional, puesto que respecto de los actos administrativos siempre habrá una acción que ejercer ante tribunales contenciosos administrativos. En el caso de los actos de gobierno, no habrá posibilidad de ejercer tales acciones. Empero, aun existiendo aquellas diferencias para Silva Cima ellas no obedecen a un criterio formal, toda vez que ambos provienen de un mismo órgano y se materializan de la misma manera, por ende, solamente será la materia la que eventualmente los matice y permita diferenciar uno de otro. Por tal motivo, expresa el autor, la tendencia nacional ha ido restringiendo cada vez más la enumeración de los actos de gobierno ${ }^{964}$. En general, la doctrina ha optado por reducir la categoría de actos de gobierno y extender la noción de acto administrativo.

En igual sentido se expresa Cordero cuando expone que la denominación de acto político o de Gobierno es la más polémica, porque tradicionalmente se ha definido al acto de Gobierno como un acto jurídico de derecho público consagrado por la Carta Fundamental y en virtud del cual los órganos constitucionales disponen de materias o cuestiones de trascendencia para el Estado ${ }^{965}$, sustrayéndolos del control judicial anulatorio quedando en manos del derecho político. Para el autor, aquella noción es incorrecta desde una óptica judicial, porque no es posible concebir la posibilidad de inmunizar determinados actos del control judicial, puesto que tal control es esencialmente pleno y amplio y, además, porque fundamentalmente la ley no los exime. Comulga con esta idea Germán Boloña quien igualmente se refiere a las críticas que esta nomenclatura ha generado en la doctrina, precisamente respecto de la imposibilidad de diferenciarlos. Esgrime que una opción ha sido seguir el modelo francés que establece como indicadores los fines del acto o la importancia de la tarea que trata, empero, ello no ha sido suficiente y la confusión persiste ${ }^{966}$.

Desde la doctrina española se ha tratado en profundidad los actos políticos de Gobierno, toda vez que la legislación expresamente los ha señalado y los ha eximido del control judicial. Para Marcheco, aquella situación jurídica ha significado una dificultad tanto para el Derecho Constitucional como para el Derecho Administrativo, relativa a la conveniencia de marginar del examen jurídico a los actos políticos y

\footnotetext{
964 SiLVA (1995) Pp. 71 a 74.

965 CORDERO (2015) Pp. 259 y 260.

966 Boloña (2005) Pp. 10 y11.
} 
radicar exclusivamente su control en un ámbito político. Explica el autor que aquella noción proviene del derecho francés, particularmente, originada por la jurisprudencia del Consejo de Estado, quienes estimaron que determinados actos realizados por el Poder Ejecutivo en razón de su naturaleza no se sometían al control de la jurisdicción contenciosa administrativa, de manera tal que nace la categoría de actos de gobierno. Esta diferenciación se podía configurar como fruto de tres tipos de análisis: la finalidad del acto, la naturaleza del mismo o una concepción empírica que se evaluará caso a caso. Siempre implicaba un grado de discrecionalidad especial en el acto de gobierno, promoviendo con tal categoría de actos zonas de actuación inmunes, dando lugar a un claro conflicto en el Estado de derecho.

No obstante, explica Marcheco, tal distinción de actos de gobierno sólo persiste desde la perspectiva de la doctrina, pero carece de toda vigencia normativa; ahora bien, la distinción entre uno y otro continuará presente pero sólo basada en la gradación de la discrecionalidad, teniendo en cuenta la densidad normativa. Es por ello que toda actuación será sometida a la legalidad, pero reconociendo la complejidad que implicará ejercer el control de actos políticos ${ }^{967}$.

Con todo, cabe colegir que en cada ordenamiento jurídico será de suma dificultad delimitar los contornos del acto de gobierno, porque poseerán sus propias características. En consecuencia, como describe Saíz será complejo elaborar una teoría con pretensiones generales. Para el autor, en el caso español se ha inclinado por considerar que el acto gobierno será aquel acto colegiado que emerge del actuar del Consejo de Ministros ejerciendo competencias específicas otorgadas en la Ley Fundamental. Respecto de ellos, se podrá ejercer control político y jurisdiccional, empero, los tribunales deberán limitar su actuación a ajustar la actuación al Derecho evitando pronunciarse sobre la voluntad discrecional del poder político o alterar la dirección política contenida en él, puesto que dicho análisis le corresponderá al Parlamento ${ }^{968}$.

La concepción del acto político o acto de gobierno, ciertamente, genera un problema para el Derecho y la doctrina española, porque tal como describe Baena del Alcázar, el Estado de derecho trae consigo la exigencia esencial de que el poder

\footnotetext{
967 MARCHECO (2015) Pp. 4-7 y 45-47.

968 SAÍz (1994) Pp. 226 y 241.
} 
político se someta a las normas jurídicas en el conjunto de sus actuaciones. Es por ello que al inmunizar aquellos actos de carácter político crea una zona fronteriza entre la Política y el Derecho. Básicamente, la mayor dificultad se presenta al momento de tener que distinguir entre un acto político y un acto administrativo. En tal sentido, expone el autor, habrán de utilizarse una serie de criterios para definir uno u otro, como por ejemplo puede aplicarse el principio de que los actos políticos son aquellos que corresponden sólo a las magistraturas más altas del Estado, vale decir, aplicaría un criterio de jerarquía del órgano. Así pues, habrá un requisito subjetivo relativo al órgano del cual proviene. Además de esto, se puede considerar como elemento definidor la naturaleza del mismo, por ende, un acto político será aquel que verse sobre materia política; aquel que tendrá una función política manifiesta, configurándose de esta manera un requisito objetivo. Finalmente, agrega el autor que en cada caso se deberá realizar una interpretación del contexto ${ }^{969}$.

Por tanto, con las modernas interpretaciones del acto político los ámbitos de inmunidad del poder se han reducido a zonas muy pequeñas, a pesar de las dificultades que implica delimitarlos. Sin embargo, persisten algunas visiones defendiendo su existencia. Según Baena del Alcázar, los actos de gobierno se han aminorado debido a la debilidad de la doctrina y a la dificultad de establecer un parámetro claro. Empero, ellos tienen una finalidad de entregar cierta libertad de acción al mandatario y al Consejo de Ministros, puesto que deben existir materias en las que el Gobierno debe decidir con cierto voluntarismo político que no puede estar sometido en su fondo a Tribunales de Justicia ${ }^{970}$. No obstante, aquella interpretación es muy discutible, Francisco García dirá que los actos políticos constituyen una especie de género de los actos administrativos discrecionales, caracterizados por un grado mayor de discrecionalidad política, pero que deberán estar sometida a un control muy reducido porque en no es dable omitir el principio de que todo poder público está sometido al ordenamiento jurídico y ello supone que cualquier autoridad pueda ser controlada judicialmente ${ }^{971}$.

Formulada la distinción entre unos y otros actos, cabe analizar si la fiscalización afecta a ambos o sólo a uno de ellos. Ciertamente, es posible prever dos tesis: la primera, incluiría todo tipo de actos a pesar de la distinción constitucional, y una

969 BAena del Alcázar (1978) Tomo I. Pp. 5, 6,50 y 51.

970 BAena del AlCÁzAR (1978) Tomo II. Pp.15, 18,19 y 36.

971 GARCÍA (2002) Pp. 2 y 3. 
segunda opinión diferenciaría ambos actos aplicando la fiscalización parlamentaria solamente a aquellos actos de Gobierno que emanan directamente de autoridades de Gobierno.

Según Gutenberg Martínez se debe aplicar la fiscalización parlamentaria a ambos actos, porque históricamente se ha realizado de aquella manera. Sin embargo, exceptúa de tal interpretación a aquellos órganos autónomos de la Administración tales como el Banco Central y la Contraloría General de la República y exime de control a aquellos entes de la Administración que no se encuentren bajo la supervigilancia de un ministro ${ }^{972}$. Por tanto, si bien el autor plantea una interpretación amplia de la voz actos de gobierno, aplica un criterio restringido respecto del origen y calidad del órgano del cual proviene el acto, vale decir, considera acto de gobierno todo aquello que provenga de entidades que se encuentran vinculadas directamente al Presidente de la República.

Desde otro sendero, Bronfman, Cordero y Aldunate expresan que el problema en este punto ha sido establecer la expresión Gobierno -que tendría un alcance funcional u objetivo- en cuanto a si se debe considerar como una actividad o si se debe discurrir sobre la naturaleza y tipo de órgano. Para estos autores la distinción inicial entre actos de Gobierno y de la Administración carece de sentido, porque la tendencia mayoritaria considera que los actos de gobierno son actos de Administración discrecionales, por ende, reducen su ámbito de aplicación y -como consecuencia- reducen el ámbito de acción de la fiscalización. Así, la discusión debe centrarse en determinar qué órganos constituyen el Gobierno, atendiendo a que el texto constitucional no contiene una clara delimitación al respecto. Los juristas se inclinan por considerar no sólo los órganos de Gobierno sino que también aquellas entidades de la Administración central y descentralizada y de la denominada Administración invisible. En particular, se refieren a las empresas constituidas bajo formas jurídicas privadas, exceptuando a los Gobiernos Regionales, las Municipalidades y los órganos que gozan de autonomía reconocida constitucionalmente como la Contraloría General de la República, el Banco Central y el Consejo Nacional de Televisión ${ }^{973}$.

972 MARTÍNEZ (1998) p. 48.

973 Bronfman et alt (2013) Pp. 301 a 304. 
El año 2005, en virtud del debate sobre la reforma de la Constitución y en particular la fiscalización parlamentaria, el objeto del control -los actos de gobiernofue un tema latamente abordado por los parlamentarios de la época. Por tal motivo hemos de exponer los argumentos más importantes esbozados en aquella instancia. Un primer aspecto analizado se desarrolló en torno a la discusión relativa a la clásica distinción entre actos de gobierno y actos de administración, en torno a lo cual se planteaba una supuesta ampliación de la fiscalización en cuanto a su competencia, en el caso de aplicarse a ambos actos. Un segundo aspecto fue, en consecuencia, delimitar el alcance de la fiscalización, lo cual comprendería una supuesta expansión del control a determinados órganos. En efecto, en el Primer Informe de la Comisión de Constitución del Senado se acordó que en relación a la denominación "actos de gobierno" se incluirían las actuaciones de las empresas del Estado como también aquellas en las que el Estado tuviera participación mayoritaria, así como las Fuerzas Armadas. No obstante, excluyeron de la fiscalización parlamentaria a los Municipios y los Gobiernos Regionales ${ }^{974}$.

Por nuestra parte, sostenemos que el criterio de diferenciación respecto de qué ha de entenderse por actos de Gobierno es una cuestión relativa al vínculo de dependencia del órgano y no relacionada a la función. Creemos que al ser el Presidente de la República quien lidera el Gobierno, constituirán actos de Gobierno todas aquellas actuaciones que emanen de entidades que deban seguir expresas instrucciones del mandatario; aquellos respecto de los cuales exista una relación de dependencia y subordinación. Desde esta interpretación los actos de gobierno debieran ser aquellos que emanan de autoridades y funcionarios del Estado que han sido designados directamente por el jefe del Ejecutivo. Sin embargo, aquel no debiera ser el único criterio sino el primario, puesto que respecto de las empresas en las que tenga participación el Estado, debido al interés público que ello genera tanto en términos económicos y políticos, también debiera ser sometido a fiscalización. Lo anterior igualmente aplicaría a Televisión Nacional de Chile.

Entonces, si recurrimos a otra fuente normativa para clarificar estos puntos, debemos considerar lo estipulado en el artículo 1 de la Ley № 18.575 Orgánica Constitucional de Bases Generales de la Administración del Estado. De tal precepto podemos inferir que la norma hace una distinción en cuanto a los órganos del Estado

974 Historia de los artículos de la Constitución. Primer Informe Comisión de Constitución Senado. Sesión 12, Legislatura 345, p. 82. 
al señalar en el inciso primero que: "El Presidente de la República ejerce el gobierno y la administración del Estado con la colaboración de los órganos que establezcan la Constitución y las leyes"; y por otro lado, establece en el inciso segundo que: "La Administración del Estado estará constituida por los Ministerios, las Intendencias, las Gobernaciones y los órganos y servicios públicos creados para el cumplimiento de la función administrativa, incluidos la Contraloría General de la República, el Banco Central, las Fuerzas Armadas y las Fuerzas de Orden y Seguridad Pública, los Gobiernos Regionales, las Municipalidades y las empresas públicas creadas por ley".

Por tanto, sería posible sostener que en virtud del inciso segundo del artículo 1, son órganos de la Administración del Estado aquellos que dependen directamente del Jefe de Estado, incluso los órganos descentralizados y autónomos, como la Contraloría General de la República, el Banco Central, Municipios y Gobierno regional. En este sentido, no cabría aplicar aquella exclusión acordada por el legislador al momento de debatir la reforma constitucional del año 2005, mediante la cual convienen expresamente en eximir de fiscalización los órganos autónomos como los descritos en los párrafos anteriores (Municipios y Gobiernos regionales). No obstante, a la luz de la Ley N 18.575 Orgánica Constitucional de Bases Generales de la Administración del Estado, la conclusión podría ser diversa, puesto que la fiscalización alcanzaría a dichos órganos, simplemente porque compone la Administración del Estado. Así las cosas, la norma sobre Bases de la Administración del Estado son más amplias y consagra que la Administración está compuesta por diversos órganos. Sin embargo, estimamos que ello no implica necesariamente que tales órganos deban estar sometidos a fiscalización, toda vez que tal como señalamos en párrafos precedentes, estimamos que el elemento diferenciador para sujetar o no un órgano a control parlamentario, es el vínculo con la presidencia y su rol en la ejecución del programa de gobierno.

En nuestra opinión, nos parece más correcto seguir los criterios establecidos en las actas de la reforma constitucional del año 2005, es por ello que serán actos de gobierno aquellos que emanen de entidades dependientes de las directrices políticas del Presidente -siguiendo el inciso primero del artículo 1-; aquellos que colaboran directamente en la gestión político-administrativa del Gobierno, es decir, aquellos que ejecutan el programa de gobierno. Por ejemplo, el artículo 22 de la misma ley señala que los ministros son precisamente órganos superiores de colaboración del 
Presidente, por ende, igualmente lo serán las subsecretarías y las seremías regionales; así ha de seguirse un criterio de subordinación en todas las demás reparticiones.

\section{c) Parámetro y finalidad de la fiscalización parlamentaria}

Determinar la finalidad u objetivo de la fiscalización parlamentaria, sin lugar a dudas, implica delimitar la naturaleza de la misma situándola en un camino jurídico, político o mixto. Por tal motivo es de suma trascendencia definir este aspecto.

En este sentido cabe recordar que, según lo dicho por Bronfman, Cordero y Aldunate, el objetivo de la fiscalización regulada en la Ley Fundamental nacional es el de "pronunciarse sobre la oportunidad o conveniencia de una determinada decisión adoptada por el Gobierno, así como la de enjuiciar políticamente su gestión, a través de la adopción de acuerdos u observaciones, la solicitud de antecedentes, las constitución de comisiones especiales investigadoras y la citación de los Ministros a fin de recabar información respecto del ejercicio de su cargo, con la finalidad de influir políticamente en la gestión del Gobierno dentro de los cauces institucionales, sin que implique la responsabilidad política de los Ministros... ". No obstante, los autores advierten que en los últimos veinte años la práctica parlamentaria ha desdibujado los contornos de esta facultad, colocándola en un plano de cierta ambigüedad al punto de no existir una clara prohibición de fiscalización por parte del Senado.

De lo anteriormente expuesto, estimamos que -conforme a nuestras apreciaciones- la finalidad de la fiscalización parlamentaria en Chile engloba tres objetivos diversos: 1.- Influir en las decisiones del Gobierno; 2.- Obtener información; 3.- Expresar una crítica respecto de la gestión de la autoridad hacia la comunidad procurando hacer valer la responsabilidad política. Formulamos tal distinción porque consideramos que cada objetivo posee a su vez un instrumento de fiscalización diverso y un destinatario diferente.

Ejercer la fiscalización con la finalidad de influir en las providencias del Ejecutivo constituye una aspiración propia que han de ejercer tanto la oposición como los 
grupos cercanos al Gobierno. Ambas fuerzas políticas poseen legítimas motivaciones para tratar de incidir en las decisiones que adopta el Gobierno. Por una parte, aquellos sectores con representación parlamentaria, sean de mayoría o minoría que forman parte del conglomerado político que posee y ejerce el poder, tenderán a influenciar y orientar la gestión del Ejecutivo, puesto que -tal como expusiéramos en el Capítulo anterior- el vínculo con el Gobierno no impide que se ejerza control. Sin embargo, el tenor de aquel control es diverso debido a que irá orientado a exigir el fiel cumplimiento del programa de gobierno y la agenda legislativa, toda vez que ello es un compromiso adquirido con la ciudadanía. En ese sentido, el cumplimiento devoto y apegado a las propuestas de campaña electoral, constituyen para todos sus miembros el eje central de su actividad, pero además será el indicador mediante el cual se medirá el éxito o fracaso del mandato, y, en consecuencia, la aprobación o rechazo de la fuerza política en su conjunto. Por tanto, aquel sector minoritario o mayoritario que esté en el Parlamento y que comparta afinidades políticas con el Gobierno será quien ejerza una fiscalización directa al Ejecutivo cuya finalidad será necesariamente orientar las decisiones políticas.

Así pues, aquellos mecanismos más discretos comunicacionalmente podrán ser más efectivos a la hora de ejercer control político sobre el Gobierno por parte de sus propios aliados. El "fuego amigo" utilizará instrumentos indirectos que le permitan expresar su preocupación, sin exponer innecesariamente al Ejecutivo al debilitamiento de su imagen. En términos generales, esta fiscalización será soterrada y se ejercerá a través de medios no institucionalizados como mecanismos de control. Empero, hay casos en que las críticas son fuertes y claras y en este sentido podemos traer a colación, a modo de ejemplo, los reproches formulados por el ex presidente Ricardo Lagos a la gestión de la actual Jefa de Estado y el desarrollo de las reformas ejecutadas, en una de las reuniones económicas más trascendentales de nuestro país -ICARE- el 31 de agosto del año 2014. En igual sentido, el año 2015 se expresaron declaraciones por parte de importantes referentes políticos del Partido Socialista de Chile, partido al cual pertenece la presidente Bachelet. La senadora Isabel Allende y el diputado Osvaldo Andrade manifestaron su descontento por la gestión del Gobierno en momentos de crisis. 
Sin perjuicio de lo anterior, habrá igualmente fiscalización en el sentido de reorientar las políticas gubernamentales de parte de la oposición. En el caso chileno, desde nuestra perspectiva las interpelaciones son utilizadas en aquel sentido, es decir, un sentido de influir políticamente en la gestión de Gobierno, por tal motivo tal instrumento de fiscalización gozará de un carácter político. Del examen realizado a la interpelación del 20 de diciembre del año 2010 a la entonces ministra de Vivienda y Urbanismo del Gobierno del presidente Piñera, doña Magdalena Matte y respecto de la interpelación realizada con fecha 26 de noviembre del año 2014 al otrora ministro de Educación del Gobierno de la presidente Michelle Bachelet, don Nicolás Eyzaguirre, podemos concluir que ambas interpelaciones están orientadas en un sentido de crítica política, solicitando una modificación en las decisiones adoptadas por el Gobierno de turno. A continuación fundamentaremos nuestra apreciación. Los sectores de oposición buscarán en los mecanismos más visibles la fórmula de controlar al detentador del poder, a fin de poder informar a la mayor cantidad de población posible de los desaciertos del Gobierno, es por ello que las interpelaciones serán los instrumentos predilectos.

En el primer caso, la interpelación formulada a la señora Ministra Matte tenía como principal objetivo criticar, incidir y re-orientar el "Plan Nacional de Reconstrucción" que se diseñó durante el Gobierno de Sebastián Piñera, con posterioridad al terremoto ocurrido el año 2010. En aquella oportunidad, el interpelante -diputado Latorre, militante demócratacristiano- cuestiona tres aspectos centrales: la carente participación ciudadana y municipal en la construcción de dicho plan, el retraso de las obras y la falta de trasparencia en el otorgamiento de subsidios habitacionales. Por consiguiente, la fiscalización parlamentaria cuestiona la labor ejecutada por el Gobierno del presidente Piñera y la manera en la que es llevada a cabo la reconstrucción. En dicha oportunidad, el diputado dirá que su objetivo es ayudar a miles de familias damnificadas por el terremoto, como también solicitar al Gobierno que reconozca sus errores. El énfasis de esta sesión estuvo puesto en la cantidad de subsidios habitacionales entregados, puesto que había un compromiso de cumplir con 100.000 , pero a juicio de los diputados de oposición ello no se habría realizado y se presentaban errores manifiestos en la forma de realizar la entrega. 
La interpelación del ministro Eyzaguirre marchó en un sentido similar. La finalidad perseguida por la centroderecha fue criticar, influir e incidir de algún modo en la bullada reforma educacional propuesta en el programa de Gobierno de la Nueva Mayoría. La diputada Hoffmann -en su calidad de interpeladora- hará presente al ministro las debilidades de la misma e incluso finalizará su intervención solicitándole derechamente que modifique la reforma, de lo contrario la interpelación no habrá tenido ningún sentido. La politicidad con la que se desarrolla en particular esta interpelación fue indiscutible; la interpeladora incluso trajo a colación la acusación constitucional del ex ministro de Educación Harald Beyer del año 2013, en virtud de la cual el señor Beyer fue sancionado, preguntándole al ministro Eyzaguirre si consideraba justa dicha sanción.

Ciertamente, la interpelación no tenía por objeto analizar la cuestión de fondo que produjo la acusación constitucional realizada el año 2013, ni mucho menos pedirle al señor Eyzaguirre que evaluara el fallo emitido por el Senado en dicha oportunidad, a modo de visibilizar a la problemática educacional, como una materia transversal a todo sector político cuya dificultad es producto de un modelo educativo y no de un ministro en particular. Por el contario, la diputada Hoffmann quizás cumplió solamente lo indicado por Alianza por Chile; dicho de otro modo, el objetivo que se pretendía con esta interpelación era más bien equiparar la situación política vivida por el señor Beyer, configurando un empate político.

En nuestra opinión, si fuese ese argumento uno de los factores que promovieron la interpelación al jefe de la cartera de Educación, el tono político y no jurídico se hace más evidente, en consecuencia, calificar a la acusación como un medio de control jurídico en nuestra legislación y en virtud de este tipo de hechos sería un error. Por cierto, existen fuertes matices políticos que edifican a esta herramienta de fiscalización, como una modalidad mixta entre lo normativo y lo político.

En consecuencia, ambas interpelaciones son realizadas por miembros de la oposición, sector político que mediante este instrumento ha de ejercer una fiscalización cuya finalidad será divergir y reprochar las políticas y conductas adoptadas. Ella tenderá esencialmente a proponer una manera diversa de abordar los asuntos de Estado, propondrá un programa político diverso que prometerá ser más efectivo y eficiente. Por tal motivo, aquel reproche político respecto de la 
gestión estará dirigido a aquellos que poseen el poder, con la clara finalidad de alterar los equilibrios políticos existentes. Así también estará dirigida a la ciudadanía, quienes pueden modificar y provocar la alternancia en el ejercicio del poder. El destinatario del control en este caso es la sociedad en su conjunto, es por ello que la crítica irá dirigida a ellos, como actor ha de ser la comunidad.

Planteamos que una segunda finalidad de la fiscalización es la obtención de información, cuestión que a nuestro juicio no comprende un rol fiscalizador, sino que es un medio a través del cual ha de desarrollarse el control. No obstante, nuestro ordenamiento jurídico lo entiende de manera diversa, como un objetivo de la fiscalización. Prueba de aquello es que el artículo 52 de la Constitución Política en su inciso tercero, el que determina que una de las formas de ejercer la fiscalización parlamentaria es a través de "cualquier diputado, con el voto favorable de un tercio de los miembros presentes de la Cámara, podrá solicitar determinados antecedentes al Gobierno. El Presidente de la República contestará fundadamente por intermedio del Ministro de Estado que corresponda, dentro del mismo plazo señalado en el párrafo anterior". Por tanto, la obtención de información queda comprendida dentro de los mecanismos de fiscalización.

Tal regulación de la facultad de información como símil a la de fiscalizar se ve aún más fortalecida mediante la normativa pertinente a los mecanismos de control, vale decir, cuando la Ley Orgánica Constitucional del Congreso Nacional trata a las comisiones investigadoras -típica herramienta de control en regímenes parlamentarios- como un mecanismo orientado a la obtención de información. En efecto, en el Título $V$ en el artículo 53 de la Ley $N^{\circ} 18.918$, que regula las Comisiones especiales investigadoras, establece que "la Cámara de Diputados creará con el acuerdo de a lo menos dos quintos de sus miembros en ejercicio, comisiones especiales investigadoras con el objeto de reunir informaciones relativa a determinados actos de Gobierno". Por tanto, es posible presumir de la redacción literal de la norma que no se le otorga la facultad de investigar, sino más bien la de recopilar información. Por tal motivo, ellas pueden configurarse como un proceso previo de recopilación de antecedentes, situación que en lo concreto es efectiva, tanto en la interpelación realizada al ministro Beyer como en la interpelación a la ministra Matte. En ambos casos los congresistas interpelantes citaron en su actuación información obtenida en virtud de las respectivas comisiones 
investigadoras de cada temática, es decir, en el primer caso la comisión investigadora sobre el funcionamiento de la educación superior del año $2012^{975}$ y, en el segundo caso, la comisión investigadora sobre seguimiento del proceso de reconstrucción nacional del año $2011^{976}$.

En nuestra opinión, la facultad inspectiva se encuentra lo suficientemente regulada en las disposiciones generales de la Ley Orgánica Constitucional del Congreso Nacional. Los artículos 8 y 9 regulan detalladamente las obligaciones que tienen los organismos de la Administración del Estado, las personas jurídicas creadas por ley o las empresas en que el Estado tenga participación, representación o aportes de capital mayoritario; deberán remitir al Congreso Nacional los documentos que contengan información relevante concerniente a sus actividades.

Por su parte, el artículo 9 contempla expresamente la facultad que poseen las comisiones o los parlamentarios debidamente individualizados en solicitar informes o antecedentes específicos. La misma norma establece la obligación que tienen dichas entidades de proporcionar aquella información; e incluso se permite formular aquella petición no estando en sesiones la Cámara respectiva, siempre que se inserte íntegramente en el Diario o Boletín correspondiente. Continúa la norma estableciendo que los informes y antecedentes serán proporcionados por el servicio, organismo o entidad por medio del ministro del que dependa, o mediante el cual se encuentre vinculado con el Gobierno, con la única salvedad de mantenerse a resguardo aquellos documentos secretos o bajo reserva, respecto de los cuales procede una sesión secreta. Respecto de la función inspectiva, sólo existirá una excepción en el inciso final del artículo 9: se eximen de la obligación de proporcionar informes y antecedentes específicos aquellos organismos de la Administración del Estado que ejerza potestades fiscalizadoras, respecto de aquellos documentos y antecedentes cuya entrega y revelación pueda afectar de alguna manera el desarrollo de una investigación en curso, aun cuando esta entrega se haga de forma secreta o reservada.

975 Información disponible en www.camara.cl, link https://www.camara.cl/trabajamos/comision portada.aspx?prmID=706. Visitada con fecha: 03.2.2016. 976 Información disponible en www.camara.cl, link: sobre seguimiento del Proceso de Reconstrucción Nacionalhttps://www.camara.cl/trabajamos/comision_portada.aspx?prmID=677. Visitada con fecha: 03.2.2016. 
El artículo 9 A continúa igualmente regulando las facultades para acceder a la información pero en otro escenario. El precepto se refiere a empresas públicas creadas por ley, empresas del Estado y las sociedades en que éste tenga aporte, participación accionaria superior al $50 \%$ o bien mayoría en el Directorio. Todas ellas están obligadas a proporcionar los informes y antecedentes específicos que les sean solicitados por las comisiones o por los parlamentarios debidamente individualizados. Respecto de estas entidades es también aplicable la posibilidad de pedir información aun cuando no estén sesionando, caso en el que han de insertarse íntegramente en el diario o boletín correspondiente a la sesión ordinaria siguiente. Respecto de estas entidades, el inciso segundo del artículo 9 A contempla tres excepciones, las dos primeras vinculadas a normas específicas en materia de comercio y mercado de valores -por su carácter de secreto-, y la tercera excepción en virtud de la capacidad de declarar reservada determinada información mediante una ley de quórum calificado, conforme a las causales del artículo 8 de la Constitución Política de la República.

Sin embargo, en los dos primeros casos los parlamentarios pueden persistir en su esmero por obtener tal información, situación frente a la cual las empresas deberán derechamente acceder o, en su defecto, pueden recurrir a la Contraloría General de la República para que ella previo informe de la Superintendencia de Valores y Seguros, resuelva si concurren o no la reserva o secreto.

Finalmente, el artículo 10 fortalece lo antes descrito, puesto que esta norma contempla una sanción para el caso en que no se cumpla debidamente la entrega de la información requerida. Dicha norma declara que los jefes superiores de los respectivos organismos de la Administración del Estado, que haya sido requerido conforme la norma anterior, es responsable del cumplimiento cuya infracción será sancionada previo procedimiento administrativo que corresponda. La medida disciplinaria aplicable es una multa equivalente a una remuneración mensual, la cual se agrava a dos remuneraciones mensuales en caso de reincidencia.

Por consiguiente, cabe inferir dos aspectos: por un lado, la obtención de información por parte de los congresistas en el ordenamiento jurídico en Chile es considerado como un instrumento de fiscalización y, además, las comisiones investigadoras cumplirían un rol informativo. A nuestro juicio, la relevancia con la cual el legislador trata el derecho de información es del más alto reconocimiento, empero, no por ello se ha de equiparar a un mecanismos de control. 
El último objetivo planteado respecto de la fiscalización parlamentaria es el de expresar una crítica respecto de la gestión de la autoridad hacia la comunidad procurando hacer valer la responsabilidad política. Creemos que al alero de esta finalidad es posible examinar especialmente las acusaciones constitucionales.

Las acusaciones constitucionales nacen con una clara finalidad punitiva, pero con el paso de los años ello se va modificando hacia una determinación de responsabilidad política. Nuestra realidad jurídica se encuentra en dicho tenor. Tal como describe Schweitzer, la institución original contemplada en la Constitución de 1833 constituía propiamente un juzgamiento penal, pero con las reformas del año 1874 y el texto de 1925 ello fue modificado dándole a la institución verdaderas características de juicio político con sanción política e independiente del juzgamiento criminal, razón por la cual le permite al autor esbozar que estamos frente una especie de antejuicio de orden político, como trámite previo a la apertura de un procedimiento contra el acusado en tribunales ordinarios de justicia. Por tal motivo, para Schweitzer cuando el Congreso analiza una acusación constitucional juzga un aspecto político y, posteriormente, podrá venir una etapa judicial ${ }^{977}$. Con el transcurso de los años se ha planteado que la acusación persigue una responsabilidad constitucional. Sin embargo, desde nuestra perspectiva la institución comprende una responsabilidad político-constitucional, porque si bien la regulación de la misma y sus causales están contempladas taxativamente en la Ley Fundamental y su procedimiento regulado en la Ley Orgánica Constitucional del Congreso Nacional, los hechos que la sustentan son políticos y el análisis de la misma también lo es.

El artículo 52 en el numeral 2 estipula que es la Cámara de Diputados quien declara si hay o no ha lugar las acusaciones, estableciendo quiénes son los sujetos acusados y las causales en virtud de las cuales se puede acusar. Por tal motivo, podemos señalar que si bien las causales de acusación están establecidas constitucionalmente, su análisis y ponderación serán políticas. En cuanto a la experiencia parlamentaria, las acusaciones presentan una importante inclinación hacia una tendencia política. Así, hemos examinado tres acusaciones constitucionales: la del General Pinochet el año 1998, y las acusaciones de los

977 SCHWEITZER (1972) Pp. 69 a 75. 
ministros de Educación Yasna Provoste y Harald Beyer, el 17 de abril del año 2008 y la el 13 de abril del año 2013, respectivamente.

En el caso del General Pinochet se fundaba la acusación en los siguientes capítulos: causar grave perjuicio a la imagen internacional de Chile, comprometiendo gravemente el honor de la nación; quebrantar el Estado de derecho, comprometiendo gravemente la seguridad de la nación. Estas causales en lo concreto se sustentaron en hechos políticos significativos, es decir, en declaraciones que el General habría pronunciado en el concierto internacional, las que finalmente afectaban la honra del país. Por otra parte -en el contexto nacional-, se basaron en cuestionadas actividades militares en tiempos de transición democrática, como lo fueron el ejercicio enlace, el boinazo, declaraciones en las que amenazaba el orden institucional interno $y$, finalmente, las ofensas conferidas a las víctimas de derechos humanos. Un factor relevante en este proceso acusatorio fue la argumentación de la defensa, puesto que ella sostuvo reiteradamente que el juicio no era oportuno y que la finalidad era, en definitiva, sancionar al General a fin de impedirle que asumiera como senador vitalicio (es posible percibir el interés político que ello generó). La acusación se votó de forma secreta, por el sistema de balotas, dando como resultado el rechazo de la acusación por 62 votos en contra de la acusación, 52 a favor y una abstención $^{978}$.

En el caso de la ex ministra Provoste, quien fuera la primera ministra destituida por medio de un juicio político en vigencia de la Carta de 1980, los capítulos acusatorios fueron: la no corrección de las irregularidades cometidas por el Seremi de la Región Metropolitana, en materia de recursos públicos; no aplicación de sanciones en virtud de infracciones graves a la ley de subvenciones; ignorar los resultados de diversas auditorías que daban cuenta de las irregularidades; y la entrega de información inexacta a la opinión pública y al Congreso Nacional ${ }^{979}$. En el caso del ex ministro Beyer las causales fueron: infringir la Constitución y dejar de

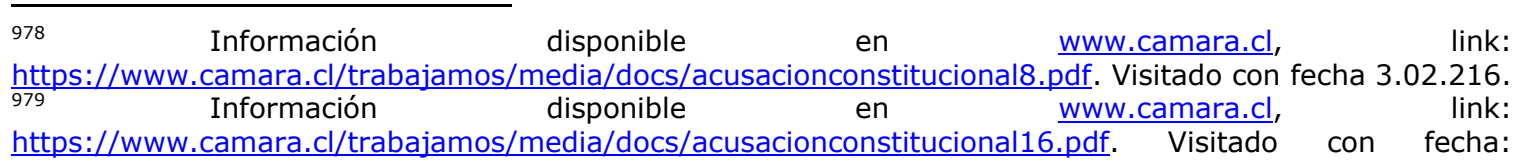
3.02.2016. 
ejecutar las leyes; infringir la probidad; no ejercer el debido control jerárquico; y omisión en el cumplimiento de obligaciones ministeriales ${ }^{980}$.

No obstante la rigurosidad jurídica con la cual se plantearon cada uno de los capítulos acusatorios, es posible formular un factor político que incide directamente en el ejercicio y examen del juicio político, toda vez que ambos ministros asumen la cartera de Educación en momentos en los cuales el modelo educativo nacional era cuestionado en todas sus aristas. Ambas autoridades toman posesión de sus cargos en medio de fuertes protestas sociales, debiendo tomar las riendas de una política educacional viciada y errática. Por ende, los sectores políticos de oposición, conociendo la realidad del sistema educativo y las irregularidades cuyo origen se remonta a tiempos pasados- hacen uso de esta herramienta fiscalizadora entendiendo el complejo contexto político que se experimentaba. Todas estas acciones decantan finalmente en la reforma educacional propuesta por la presidente Bachelet, y se dará comienzo a un proceso de fuerte cambio en las políticas públicas en educación. Por tanto, en todos los casos fueron hitos políticos de relevancia nacional las que promovieron la iniciación del juicio político.

En este sentido se orientan las palabras del profesor Bronfman, quien señala que la acusación contra presidentes no posee un interés partidista o político; en cambio, las acusaciones que se dirigen contra Ministros de Estado "en la experiencia chilena han sido un campo relativamente de lucha política y partidista, como no se trata de autoridades que cuenten, por sí mismas, con legitimidad democrática, las cámaras parlamentarias dominadas por una mayoría contraria al gobierno, disfrutan de mayor libertad para decidir cómo ejercen su competencia. En este contexto, podrían percibir la conveniencia electoral de emplear impeachment para desgastar o destituir rivales políticos ${ }^{\prime \prime 981}$. Coincidimos con el planteamiento del profesor, en el sentido de que las interpelaciones tienen un contenido mucho más político que otros medios de fiscalización.

Lo ocurrido con los jefes de las carteras de Educación es muestra significativa de cómo la coyuntura política genera reacciones en el Congreso Nacional y en la utilización de la fiscalización parlamentaria. En consecuencia, diremos que las

980 Información disponible en www.camara.cl, link: https://www.camara.cl/trabajamos/comision ficha.aspx?prmID=729. Visitado con fecha: 3.02.2016.

981 BRONFMAN (2005) p. 116. 
interpelaciones y la acusación constitucional componen a nuestro entender verdaderos mecanismos de control político, cuyos parámetros están juridificados en el texto constitucional. Sin embargo, la apreciación de los mismos se realiza de manera subjetiva y partidista. Las comisiones investigadoras, los acuerdos y observaciones, en cambio, se identifican en mayor medida con la función inspectiva; se utilizan como medio de obtención de información, por ende, constituyen la antesala de la posterior actividad fiscalizadora.

Concordamos, por tanto, con lo expresado por el profesor Zúñiga para quien la fiscalización parlamentaria es necesariamente un control político con un parámetro subjetivo. Su parámetro no es objetivizado, sino disponible y no necesariamente preexistente, lo que hace una importante diferencia con el control judicial puro, puesto que el control político parte de la libertad de valoración y libertad de decisión del órgano. En otra dirección, el control político es voluntario a diferencia del control jurídico, en el cual el órgano de control decide cuándo y qué controlar. Además, el procedimiento de dos fases que realiza el Congreso con la acusación en juicio político no es puramente una función jurisdiccional, sino una función jurisdiccional-política. De esta manera, el profesor Zúñiga plantea que la acusación en juicio político se perfila con dos caras: jurisdiccional y política. El momento jurisdiccional queda de manifiesto en el conocimiento y juzgamiento del Senado, y la afectación de intereses jurídicos en la esfera subjetiva concreta del acusado. Por otra parte, el componente político está dado por el órgano, sanciones y fines políticos propios de este instituto y por la potestad discrecional de que está revestido el Senado para declarar la culpabilidad $^{982}$.

Finalmente, podemos concluir que nuestro ordenamiento jurídico contempla variadas herramientas fiscalizadoras. No obstante, cada una tiene una finalidad distinta. Los acuerdos y observaciones, como las comisiones investigadoras, cumplen un rol claramente informativo que, a nuestro juicio, no debiera considerarse plenamente mecanismos de control, sino más bien función inspectiva. Las interpelaciones y el juicio político constituyen derechamente mecanismos de fiscalización, los que además harán exigible una responsabilidad jurídica directa o difusa, puesto que siempre su ejercicio ha de provocar repercusiones políticas de relevancia. En esta dirección sostenemos que según el actuar parlamentario y los

982 ZÚÑIGA (1993) Pp. 721 y 723. 
criterios aplicados en el conocimiento de los actos sujetos a fiscalización, se emplean generalmente criterios jurídico-políticos, respecto de los cuales es posible distinguirlos según etapas. En una etapa de conocimiento de los hechos se aplicará un criterio jurídico, el cual permitirá detectar una causal en virtud de la cual justificar el ejercicio de la acción controladora. No obstante, una vez finalizada aquella etapa e iniciado el proceso de valoración, se han de aplicar criterios netamente políticos, de esta manera se dota a la fiscalización parlamentaria en Chile de una doble faz, compuesta por una arista jurídica y una política.

Con todo, hemos querido dejar para el final a una autora que desde la sociología política incorpora en nuestra materia de estudio la naturaleza del control, sus objetivos y finalidades; elementos no menos relevantes que permiten visualizar a la institución desde otro prisma.

Estamos por la idea de caminar hacia un ideal de democracia más participativa, en cuyo desarrollo el control político sea una labor de los actores sociales. Por tal motivo, estimamos que los postulados de J. Marie Moncrieffe otorgan luces en tal camino. Para la autora en las democracias, los gobiernos y la sociedad civil deben apoyar activamente los principios del sistema democrático, principalmente garantizando el ejercicio de derechos políticos, los que suponen un grado de autonomía para las personas, de manera tal que participen adecuadamente de la actividad política. Por otra parte, debe ser ejecutado correctamente el mandato por los gobernantes, consistente en otorgar un bienestar material a los ciudadanos. De cumplirse ambos supuestos y en la búsqueda de lograr un "óptimo" resultado, se requiere de coordinación y garantizar "equilibrios"; el logro de estos objetivos y resultados no se limita solamente al papel de los gobiernos, sino que todos son responsables entre sí. Esto vendría a constituir, según la autora, la naturaleza del accountability ${ }^{983}$.

Bajo dichos supuestos de cumplimiento democrático y participación, presenta diversos factores que favorecerán la realización de ese tipo de rendición de cuentas, tales como: a.- énfasis en la descentralización y el estímulo a los gobiernos locales, consistentes con la participación ciudadana más amplia, lo que puede ayudar a crear instituciones más responsables y un buen gobierno. b.- transparencia como factor

983 MONCRIEFfE (1998) p.393. 
clave, será así como expone que la transparencia es crucial para el accountability" por poseer el potencial de detener prácticas corruptas y otorgar al electorado una percepción más exacta de la política gubernamental; c .- libertad de expresión y de asociación, fomento de la participación ciudadana a través de asambleas locales y en lugares de trabajo, con la finalidad de no concentrar sólo en las elecciones- que suelen ser distantes- la única forma de participación.

En definitiva, plantea que la participación, la representación adecuada y la rendición de cuentas son conceptos sinérgicos. Concluyendo, Moncrieffe propone lo que ella ha definido como una reconceptualización de la responsabilidad política, que consiste en dejar de interpretar la rendición de cuentas como un deber de los gobernantes, sino también un deber en relación a los grupos, facciones sociales, representantes y funcionarios públicos, reconociendo sus respectivas responsabilidades y el deber de exigibilidad de las otras. Sin embargo, reconoce un grado de abstracción de tales medidas, razón por la cual propone otras alternativas específicas que permitan el desarrollo de esta reconceptualización, como por ejemplo mejorar la contribución financiera a los partidos políticos, perfeccionar la posibilidad de hacer presente de llevar a la luz pública la violación de códigos de conducta o el no cumplimiento de funciones de los parlamentarios, cambios institucionales que permitan una mejor representación proporcional de la oposición y otros grupos de interés en la legislatura, además de facilitar formación política y la participación ciudadana ${ }^{984}$.

En resumen, en nuestra opinión, Moncrieffe postula un ideario que es sumamente compartido por los diagnósticos que se han realizado en relación a la desafectación de la ciudadanía y la política, en virtud de los cuales la formación cívica del ciudadano es un factor clave en el mejoramiento de los sistemas democráticos, ya sea que el ciudadano pertenezca a la sociedad civil, sea funcionario público o militante de un partido político. Es vital profundizar la cultura de la participación y del pluralismo político, puesto que sólo a través de ello podremos estimular el ejercicio del control en todas sus dimensiones. Junto con ello, el fortalecimiento y rearticulación de los partidos políticos es otro elemento trascendental. Estos órganos intermedios deberán adecuarse a las nuevas realidades sociales y culturales, perfeccionando principalmente sus vías de financiamiento y

${ }^{984}$ MONCRIEFFE (1998) p. 391. 
visualizando a la sociedad de una forma más adecuada a sus propias demandas, con el objetivo de hacer pervivir el mandato popular. Además, deben revitalizar instituciones como la fiscalización parlamentaria, espacio desde el cual se crean nuevos diálogos institucionales.

Nuestro país, precisamente, se encuentra un estado de crisis política que nos permite realizar cambios relevantes. Las nuevas normas promulgadas tendientes a fortalecer la democracia, transparentar el financiamiento de los partidos políticos, generar mayores grados de transparencia, rearticular a los partidos políticos, nos presentan un desafío nacional que implica asumir con hidalguía la labor en comento y construir un democracia sólida y estable, o por el contrario, ser constreñidos por prácticas políticas añejas que sólo aspiran a mantener un statu quo que básicamente los beneficia personalmente y que pone en riesgo la noción del colectivo, de la comunidad política.

\section{Conceptualización de la fiscalización parlamentaria: propuestas en torno a una nueva concepción}

Habiendo realizado un recorrido por los elementos más trascendentes en cuanto al examen del control parlamentario en el Derecho Constitucional chileno, procederemos a detectar algunas de las dificultades más relevantes en su ejercicio y, a continuación, hemos de esbozar una noción del concepto de control parlamentario acorde a todos los aspectos tratados a lo largo de este Capítulo.

\section{a) El sistema electoral nacional como factor determinante en la fiscalización parlamentaria}

Sin lugar a dudas, uno de los factores de mayor dificultad en la actualidad respecto del control parlamentario, se aloja en un factor que ya tratamos en el Capítulo anterior. Nos referimos al particular sistema electoral binominal, normativa que fue modificada el año 2015 y respecto de la cual aún no podemos evaluar sus resultados concretos, puesto que su aplicación sólo procederá en las elecciones 
parlamentarias del año 2017. La realidad electoral parlamentaria nacional hasta dicha fecha estuvo regida por el sistema binominal, que generaba grandes dificultades en la configuración de los sujetos del control parlamentario en el proceso de configuración de mayorías y minorías, y su desenvolvimiento en relación a la fiscalización.

Desde un primer prisma, debemos señalar que en virtud del principio democrático y del pluralismo político como valor esencial de los regímenes representativos, al momento de configurar el órgano representativo debiera generarse un proceso integrador e inclusivo de las diversas manifestaciones sociales, principio que no sólo debe ser un presupuesto de hecho, sino que además debe estar fortalecido en el ordenamiento jurídico, a fin de contribuir a la ordenación de un Parlamento plural, legítimo y representativo de la ciudadanía, a través del cual solamente pueda ser viable la fiscalización. Como bien expresa Fernando López, el Congreso debe ser un lugar donde las pulsaciones oposicionales de la sociedad encuentren apoyo, garantizando su participación como elemento central del correcto ejercicio de control. Empero, como lo analizáramos en los capítulos anteriores, pueden existir lamentables limitaciones estatales al pluralismo y a tal proceso integrador, expresadas a través de los ordenamientos jurídicos, estableciendo fuertes barreras a la inclusión mediante la normativa electoral, la legislación de los partidos políticos y reglamentos internos de las cámaras. En general, la legislación determinará de manera absoluta la forma o materialización que alcanzarán ambos sujetos del control ${ }^{985}$.

Es dable señalar que el sistema binominal produce extremadas distorsiones de la representación nacional, generando dificultades para los candidatos, los partidos y los dirigentes. Agrega Nohlen que este sistema ha generado una desigual relación entre la población y la cantidad de diputados en virtud de la distribución de los distritos que, en definitiva, produce un efecto de desproporción electoral lo suficientemente grande ${ }^{986}$. Este sistema fue diseñado -como bien expresa Siavelispara sobrerepresentar a la derecha $y$, simultáneamente, reducir el número de partidos políticos significativos en el país. Dicho procedimiento electoral se caracteriza por fijar umbrales electorales muy altos para alcanzar la representación electoral, condición que, en cierto modo, ha promovido la formación de fuertes

985 LÓPEZ (1988) Pp. 61, 66 y 67.

986 NOHLEN (1985) Pp. 82 y 83. 
coaliciones, porque de otra manera sería bastante complejo alcanzar los porcentajes electorales necesarios para obtener un escaño parlamentario.

Por tanto, y en lo que a nosotros respecta, en el marco del sistema binominal se produjeron importantes limitaciones que se ven reflejadas en dos efectos de interés en la investigación: por una parte, aseguraba un alto número de escaños parlamentarios a favor de la oposición, por tal motivo ésta no se configuraban como una minoría en el Congreso, situación que induce a creer que, en principio, se garantizaba un ejercicio de fiscalización fuerte y abundante; y por otro lado, impedía la participación político-electoral de grupos políticos minoritarios, promoviendo la configuración de grandes alianzas político-electorales. Por ello, la política nacional se expresará mediante grandes conglomerados políticos.

Tales alianzas políticas en virtud del particular sistema electoral binominal desarrollaron las más diversas estrategias electorales en atención a que "ganar en plenitud" en tal sistema electoral, implicaba necesariamente obtener un "doblaje" en el distrito parlamentario o en la circunscripción senatorial. De lo contrario cada conglomerado obtenía solamente un escaño respectivamente de los dos que estaban en juego. El doblaje, por su parte, implicaba que los dos candidatos de una lista obtenían el doble de los votos conseguidos por la lista competidora, cuestión que excepcionalmente se producía, por ende, siempre debía ser electo un representante de cada conglomerado.

Adicionalmente, se debe tener presente que las listas electorales son abiertas, presentándose dos situaciones, según Carey y Siavelis. La primera, que se opte por dos candidatos fuertes-poderosos en búsqueda del doblaje, o que se opte por un candidato fuerte y otro bastante más débil a fin de garantizar el triunfo de uno de ellos cuando las posibilidades de "ganar" se vean exiguas ${ }^{987}$. Dicha circunstancia genera -según estos autores- una especial situación, toda vez que al asumir una candidatura se está asumiendo finalmente un "riesgo" que puede ser mayor o menor dependiendo del territorio que se disputa, lo cual ha favorecido la creación de ciertos "incentivos", particularmente de parte de la coalición de izquierda de la Concertación de Partidos por la Democracia, coalición que desde el año 1990 había detentado ininterrumpidamente el Gobierno hasta el año 2010 Estos incentivos se representan

987 CAREY Y SiAVELIS (2003). Pp. 9 y 11 
en ciertos "seguros" ofrecidos a quienes asuman tal aventura, lo que se traducía en palabras de Carey en "seguros para los subcampeones", o como dice Siavelis "pólizas de seguro político" ${ }^{988}$, destinados para aquellos candidatos que no lograban el doblaje electoral. Consistían en la designación en cargos de relevancia administrativa en el Ejecutivo para aquellos candidatos que no obtuvieran un triunfo. Como expresan los autores se premiaba a quienes actuaban con coraje y se recompensaban las causas perdidas ${ }^{989}$.

Por consiguiente, al ser tan improbable la posibilidad de doblar electoralmente, el sistema binominal provocaba una integración forzada de un número importante de parlamentarios de ambas coaliciones. En tal sentido, la diferencia numérica entre congresistas de oposición y congresistas que pertenecen a partidos políticos de Gobierno es minúscula, favoreciendo la existencia de una fuerte oposición que no será necesariamente de rasgos minoritarios y que, fundamentalmente, por la distancia ideológica entre ambos, hacen presumible sostener que la fiscalización se presentaría vigorizada, lo cual ciertamente ha ocurrido y la actividad controladora es abundante, sin que sea necesariamente efectiva. Sin embargo, el sistema binominal excluye a una multiplicidad de movimientos políticos y ciudadanos, limitando la formación de verdaderas minorías políticas en el Congreso. Así pues, el sujeto activo del control no necesariamente será la minoría.

Por otra parte, las profesoras García y Martínez señalan que la capacidad de influencia de la oposición está íntimamente relacionada con su representación efectiva. Las preferencias de los votantes de oposición se ven realmente reflejadas en la legislatura traducidas en escaños parlamentarios y, de esta manera, el sistema electoral determinará la proporcionalidad o desproporcionalidad en la traducción del porcentaje en escaños. Por tanto, para estas autoras, el sistema electoral actuará como primer filtro distorsionador de la capacidad de la oposición ${ }^{990}$. Así, la capacidad

\footnotetext{
988 SiAVELIS (2004) p. 70.

989 Nosotros agregamos que la búsqueda del doblaje por parte de los conglomerados reduce las posibilidades de participar en la vida política a personas que carezcan de presencia mediática o de un historial político relevante, en atención a que la inseguridad que genera el doblaje obliga a los dirigentes políticos a recurrir a sus candidatos más poderosos, condición que lógicamente no cumplirán muchos militantes que en razón de la edad, género, actividad laboral o militancia política en partidos más pequeños, no han podido alcanzar la notoriedad necesaria para poder sobrellevar tal batalla contexto que, en definitiva, impide una verdadera participación política y un recambio en los sujetos políticos. En este sentido, las prioridades estarán puestas en aquellos militantes emblemáticos pertenecientes a las fuerzas políticas más vigorosos.

990 GARCÍA Y MARTÍNEZ (2002) p. 6.
} 
de influencia de la oposición está determinada por su tamaño y por la cohesión de los partidos o miembros que la integren.

Por ende, al poseer nuestro país un sistema electoral tan perverso como el binominal se producía una verdadera alteración de la realidad parlamentaria, y la oposición estaba sobrerepresentada. En tal escenario y siguiendo a las profesoras García y Martínez, en el caso chileno el sistema electoral no era un verdadero filtro que reflejara fehacientemente las inclinaciones políticas de la ciudadanía, puesto que la oposición podía ser numéricamente inferior a las sensibilidades sociales que apoyaban al sector político gobernante, sin embargo, su representación parlamentaria era altísima y en ocasiones casi similar a la coalición de Gobierno. En este caso el sistema electoral distorsionaba la realidad social y fortalecía a los sectores de oposición.

Dicho fenómeno ha de incidir en el tipo de fiscalización que se realizará en el Congreso. Desde nuestra perspectiva, lo más evidente respecto del sistema binominal, es su profundo error en la configuración del Congreso. Un Estado democrático no sólo debe responder y respetar un principio mayoritario, sino que también un principio de minorías. No basta con que los más decidan; aquello es insuficiente. Es imprescindible, como lo expresa Paloma Requejo, respetar un principio de minorías y establecer un sistema que involucre a los menos en los procesos de toma de decisiones. Si bien ellos no definirán nada por lo menos deben poder participar, porque un Estado democrático no sólo es igualdad es además participación, por ende, es también pluralismo. Por su parte, la incorporación de minorías genera otro tipo de diálogos que contribuyen en la legitimidad de las decisiones tomadas ${ }^{991}$.

Por ello, para Requejo será tan importante la protección de las minorías, especialmente la forma a través de las cuales pueden ingresar al Parlamento, pues como lo hemos venido planteando ello depende de la rigidez o flexibilidad de las normas, debiendo adoptarse los correctores que sean necesarios para lograr su participación en el órgano representativo, porque además ello implica no defraudar la voluntad expresada por los ciudadanos. No puede desvirtuarse tan profundamente la representación.

991 Requejo (2000) Pp. 28 y 29. 
En consecuencia, la situación en la que se encuentran las minorías políticas a menudo no es muy ventajosa, por tanto, la función de control se ve a su vez debilitada y por eso los autores han expuesto la necesidad de fortalecerlas. Así lo describe Sánchez Navarro cuando propone una mayor protección y garantía normativa hacia las minorías parlamentarias, planteando primeramente el cambio en la dialéctica entre órganos ${ }^{992}$, lo cual implica dejar de concebir al Parlamento como un todo orgánico que representa a una nación abstracta y homogénea, pasando a reconocer en su interior el pluralismo social, en virtud del cual todas las opiniones presentes en las cámaras manifiestan la voluntad popular, perspectiva desde la cual toda minoría está también legitimada por el pueblo debidamente facultada para realizar un concreto y efectivo control.

También hay quienes hablan de fortalecer o regular los derechos de la oposición. En este sentido, podemos exponer las palabras de Ramón Soriano, para quien el control es asunto de minorías opositoras a la acción de gobierno y los problemas en su ejercicio es un problema que dice relación con la necesidad de democratizar los procedimientos $^{993}$; no bastará con comprender a la democracia como mecanismo para adoptar decisiones legítimas, sino que además se debe establecer o extender a procedimientos que abran puertas, señalando como un ejemplo la necesidad de asegurar normativamente la participación de las minorías en los órganos internos del Parlamento, entre otros. Finalmente, para una solución bastante vigorosa en relación a fortalecer o mejorar las condiciones en las que debe de ser desarrollada la función de control por parte de la oposición, hemos de detectar en los argumentos de Ángel Garrorena una importante aportación. Para el autor es necesaria la constitucionalización de la minoría, así habilitado por ella (la Constitución) y con un estatuto eficaz, podrá cumplir de modo sustantivo la función de "contra-poder"994.

Lo descrito precedentemente da lugar a una fenómeno disciplinar que en palabras de Fernando López se extiende a una disciplina política, electoral y parlamentaria, problemática que sólo encuentra vías de solución mediante una correcta vigilancia de la democracia interna de los partidos políticos ${ }^{995}$. En el sistema

992 SÁNCHEZ (1995) p. 36.

993 SORIANO (2001) Pp. 5 y 11.

994 GARRORENA (1998) p.29. Primordial importancia le atribuye el autor a la regulación de las minorías y un reconocimiento constitucional expreso y claro, como factor determinante en el mejoramiento de la función fiscalizadora y en el fortalecimiento y resurgimiento de la misma, lo que él denomina la "renovación del sujeto del control".

995 LÓPEZ (1988) p. 75. 
político actual existen diversos incentivos perversos que inducen un actuar incorrecto por parte del parlamentario -entendido individualmente-, en relación con el comportamiento excesivamente territorial y asistencialista que asumen con las comunidades a las cuales representan, alejándose a razón de ello de las labores legislativas y de control, propias de su cargo público. Este comportamiento es consecuencia de un temor fundado: no ser nominado o seleccionado por los dirigentes de las cúpulas partidarias en los procesos electorales siguientes, ya sea por factores políticos internos, personales o porque ha reducido sus aprobación ciudadana. Tal situación obliga al congresista a sustentar toda la fuerza de una posible renovación del escaño parlamentario en obtener altas aprobaciones o adhesiones a su gestión por parte del electorado que representa, además de tener que contar con la simpatía de los dirigentes de sus partido político, motivos que promoverán acciones poco coherentes con su cargo. Por ello, pondrá toda su energía en obtener el apoyo ciudadano y en obedecer determinadas órdenes de partido, a fin de poder posteriormente defender su "cupo". Dichas actuaciones muy probablemente desvíen su atención de los temas centrales del Congreso y, por consiguiente, su labor parlamentaria se verá descuidada. En este sentido, la calidad de la fiscalización no será la óptima.

Directamente relacionado con lo ya antes expuesto, es la configuración de otro fenómeno que directa o indirectamente influye en el buen desempeño de las funciones parlamentarias y, en particular, con la fiscalización parlamentaria. Ésta es la denominada "profesionalización de la política", que conforme nos explica el profesor Roberto Blanco Valdés, afecta tanto a mayorías como a las minorías, por ser el desafortunado motor que promueve la disciplina partidaria cuyo objetivo, principalmente, será la mantención en el Gobierno o la incansable búsqueda por obtener el Gobierno. Para el autor, el arribo a la política de personas jóvenes que sólo realizan a lo largo de su vida laboral funciones de carácter político y que, a raíz de ello, han vivido materialmente de la misma ${ }^{996}$, engendra mayores motivaciones a la hora de defender la acción del Ejecutivo o a la hora de ir en su búsqueda, pues en él se encuentra una fuente inagotable de recursos políticos para el partido provocando a su vez que el Parlamento también se establezca como una estación de tránsito para aquellos que tengan otras aspiraciones o finalidades. Estos elementos

996 BLANCO (2000) Pp. 38 y 39. 
directa o indirectamente van en desmedro del objetivo último del control, éste es el control del poder en pos de la protección de los derechos de los ciudadanos.

Sin perjuicio de lo dicho, nos parece interesante exponer las nociones de Manuel Alba respecto a la profesionalización de la política, cuestión que constantemente ha de ser indicada como un problema que afecta al control y, en general, al desarrollo de una buena política. Para Alba tal fenómeno es también respuesta a otro problema aún mayor, porque lo que se refleja con la profesionalización no es más que la respuesta al desentendimiento por parte de los ciudadanos de los asuntos públicos $^{997}$. En tal sentido, para el autor la causa de tal fenómeno ha de tener sus orígenes en el mismo pueblo, que desinteresado en las cuestiones públicas, dejaría todo un campo de acción libre para aquellos individuos pertenecientes a partidos políticos para que puedan disfrutar por períodos de tiempo indeterminados de los frutos que conlleva prestar servicios en lo público.

Dichas declaraciones contienen grandes dosis de veracidad al ser efectivo que los ciudadanos han situado a la política dentro de su escala de prioridades, probablemente en los últimos eslabones. Ahora bien, tal falta de interés no es gratuita o antojadiza. La ciudadanía no se ha desentendido de la política por simple falta de interés, sino porque precisamente vicios como la profesionalización, el financiamiento irregular de la política y la misma organización de los partidos políticos han superado con creces los límites soportables por la sociedad; es por ello que no resulta extraño que se haya perdido la capacidad de convocatoria por parte de los partidos. Se ha configurado una especie de círculo vicioso en la política nacional, en el que se concatenan una serie de nefastos acontecimientos que alejan al ciudadano.

\section{b) Confusión interpretativa entre la función de información $y$ la fiscalización parlamentaria}

Tal como hemos señalado en otras oportunidades, la fiscalización parlamentaria es actividad que está íntimamente relacionada con todas las actividades del Congreso. Sin embargo, no podría llevarse a cabo sin una suficiente información y es

997 ALBA (2001) p. 32. 
por ello que la información es de suma relevancia para realizar cualquier función parlamentaria; empero, ella por sí sola no tendría sentido. Su preeminencia surge cuando está vinculada a otra función como, por ejemplo, la de fiscalizar. Por tal motivo, resulta imperioso que exista una correlación entre la facultad de las Cámaras de ser informadas y el deber del gobierno de informar al Parlamento ${ }^{998 .}$

En nuestra legislación el resguardo a la facultad de solicitar información por parte del Congreso encuentra una debida protección constitucional y legal. Sin embargo, desde nuestra perspectiva, en relación con esta materia creemos que se produce un error recurrente en nuestro Derecho Constitucional, el cual ha sido normar en el mismo precepto el derecho de información junto al derecho de fiscalizar, toda vez que si bien uno es causa necesaria del otro, no constituyen facultades idénticas. El parlamentario siempre ha de requerir información a fin de desarrollar una buena gestión parlamentaria, sea legislar o controlar, por ende, siempre ha de necesitar información. En este sentido, creemos pertinente enmendar aquella situación, dando protagonismo y fuerza jurídica a cada una de dichas facultades de forma separada y autónoma. Eventualmente, podría significar un importante avance modificar los artículos 9 y siguientes de la Ley Orgánica Constitucional del Congreso Nacional, a fin de establecer plazos prudentes en la entrega de la información, con la finalidad de perfeccionar esta función inspectiva.

Como ya hemos señalado en otros párrafos de este Capítulo, desde nuestra perspectiva existe una cierta homologación o fusión de funciones parlamentarias por parte del constituyente, en cuanto a la asimilación que se realiza respecto de la función de fiscalizar y la de informar. En reiteradas ocasiones se ha promovido la idea de mejorar las herramientas de información como sinónimo de perfeccionamiento de la fiscalización, tal como se puede inferir del debate parlamentario en torno a las modificaciones del año 2005. Ahora bien, no cabe duda alguna en el hecho de que una buena calidad en la información recibida por la Cámara le permitirá alcanzar tal nivel de conocimiento que lo dejará en un muy buen pie para desarrollar una labor de control. La información es el motor central que mueve gran parte de la vida parlamentaria. Empero, ambas son funciones diferentes y deben regularse de manera separada, además de contar con mecanismos especiales para cada función.

998 MORA-DONATTO (2001) p.111. 


\section{c) Propuestas para un nuevo concepto de fiscalización parlamentaria}

Lo primero que cabe señalar es que la fiscalización parlamentaria -reflejada en sus diversos mecanismos- es una institución utilizada en nuestra realidad política, independientemente del resultado de la misma. En consecuencia, ha sido considerada como una institución relevante por la cultura jurídica y política nacional. En esta dirección agregaremos que su utilización ha dependido, básicamente, de la coyuntura política imperante en nuestro país. Por tanto, tal como es posible percibir en el desarrollo del presente Capítulo la fuerza o debilidad con la que se ejercen algunos mecanismos de fiscalización y, en especial, las acusaciones constitucionales que fueron pesquisables, se ejecutan principalmente en períodos álgidos de la historia nacional. Prueba de aquello son los hechos acontecidos en el año 1891 bajo la vigencia de la Constitución del año 1833, oportunidad en la que el cien por ciento de las acusaciones presentadas en aquellos años, fueron aprobadas mediante un análisis y procedimientos a lo menos irregular, del cual nos referimos en el acápite correspondiente.

Un segundo momento político relevante para la fiscalización parlamentaria lo compone la nueva regulación de la misma en la Carta Fundamental de 1925, período que analizaremos distinguiendo dos etapas: la primera, que va entre 1925-1969 y un segundo periodo, que comprende los años 1970-1973, según los cuadros explicativos que a continuación se exponen. 


\section{Acusaciones bajo La Constitución Política de 1925 (período 1925- 1969)}

- Rechazada Cámara de Diputados

Rechazada Senado

- Retirada antes de ser votada de la Cámara de Diputados.

Aprobada

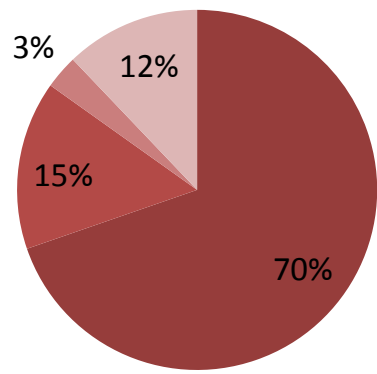

GRÁFICO N¹

Durante los años en comento, es posible señalar que las acusaciones fueron múltiples (33 acusaciones), pero aparentemente sus resultados no fueron significativos, toda vez que la mayoría de ellas fue rechazada. Tal como lo grafica nuestro cuadro explicativo, sólo el $12 \%$ de las acusaciones presentadas fueron aprobadas. Sin embargo, a pesar de que sus efectos sancionatorios no se aplicaran y las dudas en cuanto a su naturaleza y finalidad estuvieran presentes de forma constante, y los cuestionamientos en relación a su rol criminal fueran el eje central de los debates parlamentarios; las acusaciones produjeron efectos políticos de mayúscula trascendencia. Durante los años de Gobierno del presidente Frei Montalva (1964-1970), el juicio político fue dirigido en contra de los ministerios claves en su gestión Economía e Interior, acciones que conjuntamente afectaban a dos de los hombres fuertes del gabinete, los ministros Santa María y Pérez Zujovic.

Las acusaciones ejercidas por el Partido Radical y los Partidos Socialista y Comunista estuvieron orientadas, esencialmente, en dañar la imagen del partido político gobernante, vale decir, su finalidad fue aminorar el liderazgo de la Democracia Cristiana, objetivo que es alcanzado, puesto que si bien no lograron 
destituir a ningún Ministro de Estado, la imagen de la Falange se ve debilitada. Por su parte, la oposición canaliza aquellos esfuerzos configurando un pacto político que se exhibe como la alternativa de cambio popular y social que unida a la fuerte ideologización que experimentaba Chile generaron el caldo de cultivo para la derrota electoral de la Democracia Cristiana.

Por tanto, es posible inferir que el período 1925-1969 a pesar de las dudas en torno a la institución en sí misma y la inaplicabilidad de sus sanciones, la fiscalización parlamentaria propiamente tal fue ejercida con una clara intencionalidad política, que en ese sentido produjo efectos electorales propios de la responsabilidad difusa.

\section{Acusasiones constitucionales bajo la Constitución de 1925 (período 1970-1973)}

Aprobadas Rechazadas

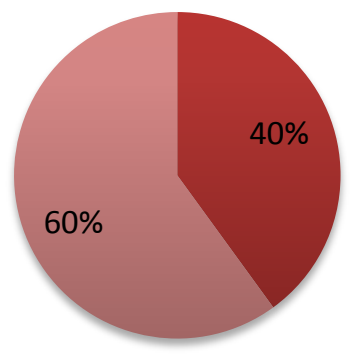

GRÁFICO N²

El segundo período que debemos examinar es aquel que transcurre entre 1970-1973, bajo la vigencia del texto constitucional de 1925. Durante estos tres años la situación varía considerablemente, toda vez que la cantidad de acusaciones presentadas fueron 42 y el número de aprobadas aumenta exponencialmente. Según gráfico, el $60 \%$ de las acusaciones constitucionales fueron aprobadas, fenómeno que se encuentra directamente vinculado a los álgidos momentos políticos que experimentaba nuestro país aquellos años. A diferencia de lo ocurrido en el Gobierno del presidente Frei, Allende no contó con un apoyo parlamentario numéricamente superior a la oposición. Por ende, confluyen diversos elementos que favorecen el ejercicio de acusaciones constitucionales. En ese sentido, es posible señalar que la 
oposición era mayoritaria en el Congreso, existía una profunda disconformidad con el programa de gobierno de la Unidad Popular y, adicionalmente, se cuestionaban los caminos legales adoptados por el presidente Allende y sus ministros, para alcanzar sus objetivos propuestos y comprometidos con el pueblo de Chile.

En ese contexto, la fiscalización parlamentaria emerge como la alternativa institucional más efectiva para hacerle ver al Gobierno que la oposición no estaba de acuerdo con las políticas públicas adoptadas. Ahora bien, en este escenario es posible sostener dos hipótesis: la primera, implica cuestionarse si los mecanismos de control y sus efectos consagrados constitucionalmente eran suficientes para enfrentar un momento político tan complejo. En ese sentido, es plausible sostener tentativamente que dichos mecanismos de control no configuraron las válvulas de escape pertinentes, que gestarán las salidas institucionales óptimas que evitarán el quiebre democrático. Una segunda hipótesis igualmente atendible implica discutir sobre la actitud con la cual enfrenta el Gobierno las acusaciones y las críticas formuladas por el Congreso, puesto que en ocasiones simplemente trasladaban al ministro destituido a otra cartera, eludiendo con ello la sanción adoptada por el Legislativo $y$, en cierto sentido, haciendo oídos sordos a las imputaciones formuladas.

Una respuesta tentativa comprende necesariamente traer a colación el fundamento teórico de la fiscalización parlamentaria puesto que, en definitiva, el control político se delega en manos del Parlamento, en razón de representar la voluntad popular y configurarse como un contrapeso a las amplias atribuciones que posee la Presidencia de la República, actuando como un elemento equilibrante en defensa de los intereses ciudadanos. Ahora bien, como latamente hemos descrito en el Segundo Capítulo, en la actualidad el juego democrático entre mayorías y minorías al interior del Parlamento construye otras realidades fiscalizadoras; el cambio de paradigma entre los partidos políticos y la disciplina partidaria dan forma a nuevas relaciones entre Ejecutivo-Legislativo. En este sentido, cabe destacar que a pesar de las transformaciones teóricas en cuanto a la composición del control político, ha de mantenerse un mínimo esencial, éste comprende hacer subsistir el mandato representativo. Por tanto, se deben realizar esfuerzos por representar la voluntad del pueblo como único detentador del poder. Por consiguiente, la fiscalización expresada como crítica a un programa de gobierno o una determinada política pública, debe 
estar en armonía con lo pretendido por la ciudadanía. En esa dirección es cuestionable el actuar de la oposición política chilena durante los años 1970-1973.

Para el período regido por la Constitución política de 1980 habrán de diferenciarse dos períodos: uno que transcurre entre 1990 y 2004, transcurso de tiempo regido por el texto original de 1980 y las reformas de $1989 ;$ y, un segundo momento, que abarca los años 2005 al 2013, en razón de las profundas reformas constitucionales realizadas el año 2005 y que afectan directamente a la fiscalización parlamentaria.

\section{Acusaciones constitucionales bajo la Constitución de 1980 (período 1980-2004)}

- Rechazada Cámara de Diputados $\square$ Se tiene por no presentada Aprobada

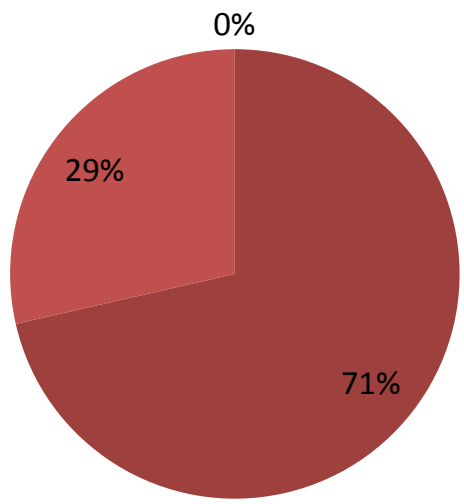

GRÁFICO N³

Durante los primeros años de transición democrática ocurren dos fenómenos de suma importancia que afectan el desempeño de la fiscalización. En primer lugar, existe una expresa limitación constitucional respecto de fiscalizar los actos de gobierno realizados por la Junta Militar, por tal motivo el control sólo puede ser ejercido respecto de las acciones de un Ejecutivo que retomaba funciones de gobierno luego de dieciséis años de dictadura. En segundo lugar, cabe tener presente que los primeros años de transición el actuar de la coalición gobernante (Concertación de Partidos por la Democracia) improbablemente se podía controlar, 
en razón de los siguientes factores: por un lado, la fuerza política gobernante asumía recientemente la dirección de la Administración Pública, en consecuencia, no existía una diversidad de actos de gobierno respecto de los cuales ejercer la fiscalización; por otro lado, el programa de gobierno y las primeras políticas públicas estuvieron orientados, básicamente, en reorganizar el aparato estatal y la Administración Pública $y$, en ese contexto, no existe una amplia gama de actos del Ejecutivo que se configuren como objeto de control de relevancia política; por último, el actuar de los congresistas en el ejercicio del cargo era de carácter iniciático, un gran número de diputados y senadores asumen la representación nacional por primera vez debiendo adquirir los conocimientos necesarios para cumplir correctamente las formalidades propias del actuar legislativo y fiscalizador, proceso de aprendizaje que probablemente dilató la adquisición de una actitud política activa de control. Adicionalmente, debemos recordar que la norma constitucional en sí misma tampoco contribuyó en hacer del control un instrumento atractivo para el complejo momento que sobrevenía en Chile.

Por ende, la acción fiscalizadora ejercida por la oposición estuvo contenida. Tuvo que pasar tiempo para que el Ejecutivo consolidara sus funciones y diera origen a las acciones respecto de las cuales era factible controlar. Así, las acusaciones constitucionales también fueron ejercidas con cierta debilidad. En este sentido, el gráfico $N^{\circ} 3$ da cuenta que durante el período inicial de la democracia chilena y anterior a la reforma constitucional del año 2005 (período 1980-2004), la cual fortaleció la fiscalización, no fue aprobado juicio político alguno. El $70 \%$ de las acusaciones fueron rechazadas.

Una excepción a aquel estado del arte lo constituyó el juicio político dirigido en contra de Augusto Pinochet, el cual a pesar de sus inexistentes efectos sancionatorios generó importantes repercusiones políticas. En términos simbólicos representó la única instancia a través de la cual se cuestionó el actuar del Comandante en Jefe de la Junta Militar; significó interpelar sus constantes y soterradas amenazas tendientes a desestabilizar el régimen democrático, además de evidenciar las múltiples irregularidades ocurridas en su mandato respecto de las cuales se pretendió obtener impunidad tanto para él como para su círculo de confianza directo. 
Por tanto, podemos concluir que el período que media entre 1989 y 2004 el escenario político nacional, durante los primeros años de transición democrática, no admitió un ejercicio pujante de la fiscalización, en razón de los argumentos antes descritos.

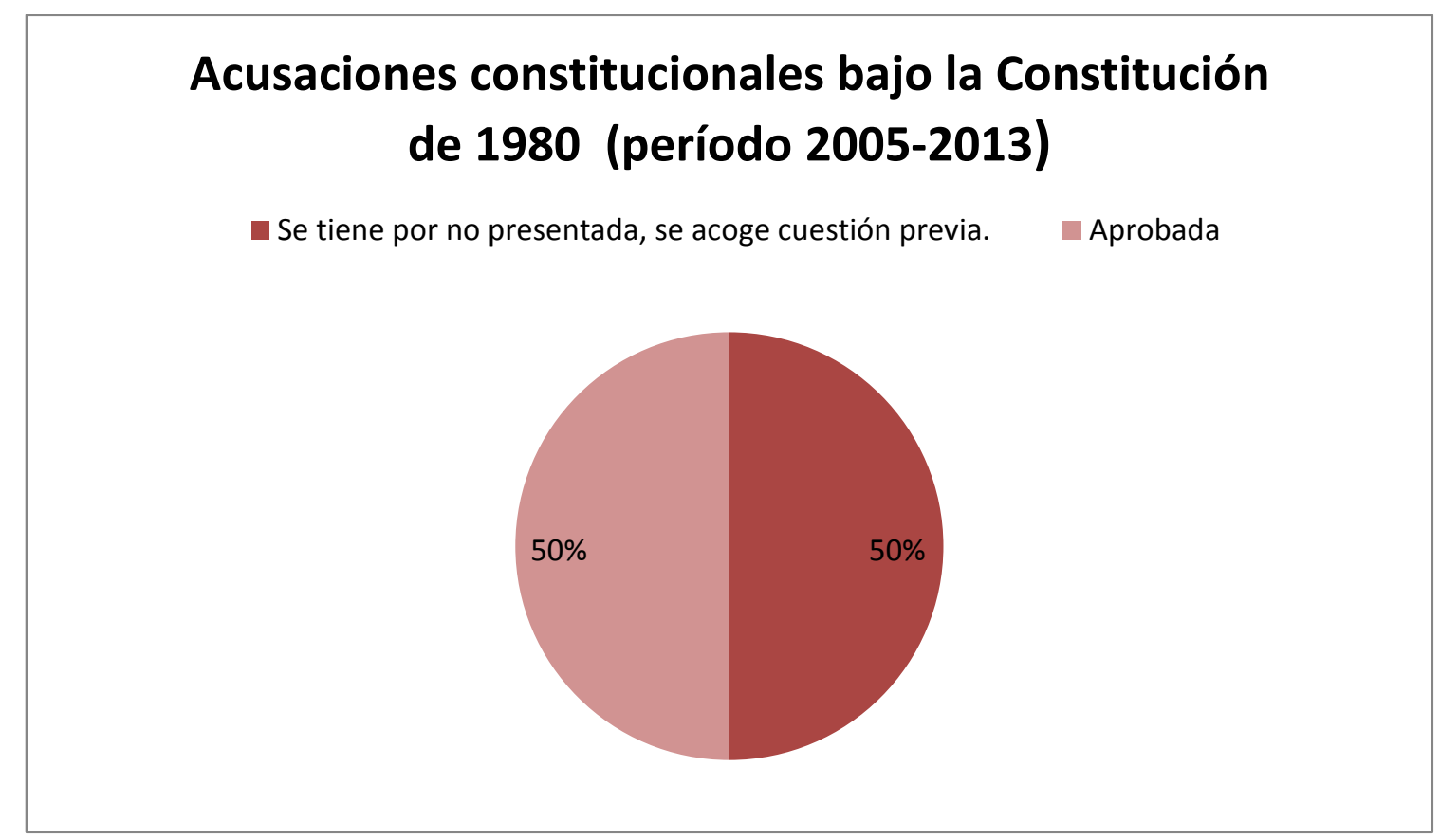

GRAFICO N4

Durante los años que siguieron a la reforma constitucional del año 2005 el escenario político nacional experimentó importantes transformaciones. Por un lado, la Concertación de Partidos por la Democracia ha mantenido el poder desde 1990 de forma continua, lo que genera un vasto conjunto de actos que fiscalizar. Su rol de coalición de gobierno se ha visto desgastada debido a razones coyunturales o a sus propias acciones erráticas, ligadas en ocasiones a hechos de corrupción. La oposición, es decir, la derecha chilena ha logrado modificar su imagen distanciando su vinculación con el golpe de Estado y la dictadura militar. Han levantado como bandera de lucha temáticas ciudadanas como la delincuencia y el desarrollo de la economía, despojando en ocasiones a los partidos de izquierda de sus históricas reivindicaciones. En ese sentido, sus resultados electorales son cada vez más pujantes, llegando a obtener la Presidencia de la República el año 2010 de la mano del presidente Sebastián Piñera. 
En tal sentido, la utilización de la fiscalización por parte de una oposición con amplia representación parlamentaria (a raíz del sistema binominal) configuró desde nuestra perspectiva $y$, sin lugar a dudas, el factor determinante mediante el cual se fue construyendo paulatinamente la derrota de la Concertación y el triunfo de la derecha después de 20 años de gobiernos de centroizquierda. Por consiguiente, la fiscalización parlamentaria durante los años posteriores a la reforma constitucional fue ejercida con fuerza, valiéndose precisamente de las fortalezas que dichas modificaciones establecieron.

Desde una óptica jurídica, la reforma del año 2005 fortalece la eficacia de la fiscalización, elemento que fue leído correctamente por ambas fuerzas políticas nacionales, es por ello que su ejercicio fue brioso arrojando resultados concretos en cada período de gobierno, es decir, durante el gobierno de la Alianza por Chile y de la Concertación, son destituidos -en razón del juicio político- sus respectivos Ministros de Educación. Estas carteras, de conformidad a los sucesos ciudadanos y políticos ocurridos desde el año 2006 con la protesta estudiantil denominada "Revolución Pingüina", constituían un elemento central en el desarrollo de sus programas de gobierno, lo que adicionalmente incidía de manera directa en la percepción social en cuanto a la estabilidad y solidez en la forma de liderar y gobernar el país.

Los resultados contenidos en el gráfico $\mathrm{N}^{\circ} 4$ demuestran que la fiscalización parlamentaria es una herramienta utilizada con fuerza por ambos sectores políticos cuando les ha correspondido ejercer su rol de oposición, toda vez que dicha institución se convirtió en un mecanismo eficaz para debilitar la imagen del gobierno. En este escenario es posible sostener que esta institución recientemente se consolida y comienza a incorporarse al ideario político nacional.

Con todo, analizada la vida parlamentaria en relación a la fiscalización parlamentaria y en especial respecto de la acusación constitucional, cabe formular observaciones en relación con las apreciaciones teóricas y doctrinales en relación a nuestra materia de investigación. 
Por consiguiente, habiendo realizado un análisis político previo corresponde examinar voces doctrinales. Una primera aproximación en cuanto a la noción de la fiscalización parlamentaria es señalar que ha sido seguido uniformemente por la doctrina la voz fiscalización parlamentaria y no control parlamentario; entre los autores más destacados se encuentran los juristas Huneeus, Silva Bascuñán, Estévez, Bronfman, Aldunate, Cordero y Cea. Por tanto, ha sido entendida en términos generales como la posibilidad de influir en las decisiones políticas, ya sea para apoyar la dirección política seguida por el Ejecutivo o para discrepar de la misma, de forma transparente y pública frente a la comunidad; como sinónimo de investigación de las acciones del Ejecutivo, evaluando la oportunidad de las mismas; y, como un juicio de valor de los actos del Gobierno, formulado a la luz de una correspondencia entre el acto, el ordenamiento jurídico y los principios consensuados por la sociedad, que dicen relación con el bien común y la limitación del poder.

Por su parte, la Real Academia de la Lengua Española define fiscalizar como ${ }^{999}$ : "hacer el oficio de fiscal" y "criticar y traer a juicio las acciones u obras de alguien". Por tanto, hemos de concluir que el término más adecuado en consideración a la historia constitucional chilena y a lo señalado por la doctrina es efectivamente el término fiscalización, puesto que existe cierta unanimidad en cuanto a que el rol del Congreso y de la oposición es criticar y juzgar políticamente los actos y la conducta del Gobierno.

Para nosotros la fiscalización parlamentaria comprende una noción más similar a la que expusiéramos en el Capítulo anterior, en torno al sistema francés de control $^{1000}$,: "un proceso en virtud del cual la oposición u otro actor político ha de formular primeramente una crítica oportuna al Gobierno, a fin de incidir en los lineamientos políticos adoptados o proponer los propios; para luego, eventualmente, proceder a hacer exigible la responsabilidad política directa o difusa, con el objetivo de limitar el actuar abusivo del poder y alterar los equilibrios políticos existentes". A continuación, realizaremos un desglose y examen de cada uno de los elementos de nuestro concepto.

999 Información obtenida en www.rae.es, link: http://dle.rae.es/?id=HzaPKXu. Visitada con fecha: 05.02.2016.

1000 Cf.supra, p.226 y siguientes. 
1) Desde nuestra perspectiva el control parlamentario es un proceso, toda vez que ha de requerir de otros elementos predecesores y necesarios, para poder ser ejecutada y producir efectos. Al definir la fiscalización como un proceso, nos permite realizar la distinción entre una primera etapa de la gestión, en la que se sólo formulará una crítica a los actos del Gobierno, realizando un juicio de valor subjetivo en relación a la oportunidad de los mismos; y una segunda etapa consecuencial a la primera, que intentará hacer exigible la responsabilidad política directa a través de una acusación constitucional o difusa mediante otros mecanismos de fiscalización institucionalizados o no institucionalizados.

En este sentido, los mecanismos de obtención de información y sus procedimientos, serán un factor determinante para congresistas porque muy porbablmente sea aquella información la razón o motivo, desde la cual se desencadene un proceso fiscalizador posterior cuyo resultado final podría configurar la exigibilidad de responsabilidad política.

2) La fiscalización parlamentaria es realizada por la oposición y no por minorías políticas, el sujeto activo será la oposición; por ende, podrá ser ejecutada por una oposición que puede concidentemente ser el sector minoritario como también podrá ser ejercida por aquel sector de oposición que se encuentra inmerso al interior del grupo de mayoría en el Congreso Nacional. Es decir, en el presidencialismo nacional la fiscalización puede provenir del grupo minoritario o del grupo mayoritario indistitamente, e incluso, independientemente, de las relaciones de confianza que poseean los congresistas y sus partidos políticos con el Presidente de la República o con la coalición gobernante, toda vez que la motivación para ejercerla se fundamenta en multiples razones políticas, sociales, personales y económicas. Igualmente, hemos incorporado otro sujeto fiscalizador al incluir la frase " $u$ otro actor político", debido a que la fiscalización tal como es conocido provenien además desde los medios de comunicación, redes sociales u otros instrumentos acordes a las democracias modernas. 
En cuanto al sujeto pasivo éste es el Ejecutivo y el objeto sobre el cual reace la fiscalización será, por consiguiente, los actos del Gobierno. En tal sentido, señalamos precedentemente que a nuetsro entender, los órganos cuyos actos serán suceptibles de ser fiscalizados, son aquellos que se relacionan directamente con el Presidente de la República, a través de relaciones de confianza, son aquellos órganos quienes llevarán a cabo el programa de gobierno.

3) Finalmente, incorporamos el objetivo o fin último de la fiscalización, el cual no es solamente la eliminación o modificación de una determinada directriz política, o la destitución de algún personero de Gobierno, sino que además comprende dos elementos distinto: por una parte, ha de cumplir su histórico rol, el cual es limitar el ejercicio abusivo del poder; $y$, en segundo orden, pretende modificar el estatus político vigente. Es decir, se pretende provocar la alternancia en el poder.

En definitiva, cuando plateamos la noción de fiscalización entendida como un proceso ello también comprende el fin con el cual se ejerce la misma, puesto que sus fines se irán cometiendo en la medida que cada etapa, a su vez, vaya cumpliendo su específico objetivo. Si los pasos previos no logran producir los efectos esperados, eventualmente, podrá producrise la consecuencia última, la alternanacia en el poder. En tal sentido, la fiscalización continúa configurandose como un instrumento de vital importancia en los sistemas democráticos. 


\section{Consideraciones finales}

En conclusión, en el presente Capítulo hemos realizamos un recorrido a través de los textos constitucionales de la historia de Chile, a fin de obtener la antecedentes necesarios que nos permitan construir el concepto de fiscalización parlamentaria en nuestro país. Adicionalmente, estudiamos aquellas instituciones que se presentan como el antecedente histórico de la misma.

Para ello fue necesario analizar los aspectos políticos de cada momento constitucional. Conjuntamente, examinamos cómo los congresistas interpretaron y aplicaron dichos textos, particularmente respecto de la acusación constitucional. Tal análisis de casos nos permitió comprender a la institución desde una perspectiva histórica y práctica, evaluando de esta manera su comportamiento. Con especial énfasis se estudiaron determinados períodos de la historia nacional, toda vez que ellos nos aportaron elementos de suma relevancia para comprender la evolución y desarrollo de la fiscalización parlamentaria.

Concentramos un examen acabado respecto de la génesis y modificación de la norma fundamental vigente de 1980, analizando básicamente sus particularidades de origen y su relación con la fiscalización parlamentaria. Procuramos exponer los aspectos más relevantes de las reformas constitucionales que involucraron a la fiscalización parlamentaria. En tal labor realizamos un estudio de cada uno de los elementos que configuran la fiscalización en el plano nacional, esperando haber realizado pequeñas contribuciones. 


\section{CONCLUSIONES}




\section{CONCLUSIONES}

Nuestra labor al comenzar la presente investigación, comprendía esclarecer -en razón de elementos jurídicos, doctrinales y empíricos- los elementos más significativos que permitieran determinar un concepto constitucionalmente adecuado de fiscalización parlamentaria. Determina dicho concepto tenía por objetivo poder cotejarlo con el ejercicio de la misma institución, y, finalmente, otorgar nuestra propia definición.

Adicionalmente, llevamos a cabo un estudio respecto del comportamiento de la fiscalización, focalizado especialmente en las acusaciones constitucionales mediante gráficos y hechos políticos, a través de los cuales adquirimos los conocimientos necesarios para finalmente determinar el concepto de fiscalización y, a la vez, poder crear una conceptualización propia. Esperamos haber contribuido con un eslabón en la cadena que destacados autores nacionales tiempo atrás comenzaron.

Este proceso de investigación nos ha llevado a detectar ciertos factores y componentes que permiten concluir una serie de supuestos de relevancia, detallados a continuación:

PRIMERA: Cabe señalar que, según lo propuesto en el Primer Capítulo, nuestro propósito implicaba describir el vínculo existente entre el control del poder y el constitucionalismo en general. En este sentido, y a pesar de la obviedad de tal relación, resultó menester indicar que el sustento teórico del control parlamentario -en su calidad de control político- se apoya en la limitación del poder. Por consiguiente, el control parlamentario es un medio a través del cual se limita la dirección política y administrativa del Ejecutivo, siendo el límite al poder, a su vez, un elemento fundante del constitucionalismo moderno.

Como bien fue expuesto en el Capítulo primero de este trabajo, la limitación y la división del poder trajeron consigo el establecimiento de controles jurídicos y políticos. Por una parte, las limitaciones jurídicas fueron expresadas a través de textos de suma relevancia como el Bill of Right, la Declaración de los Derechos del Hombre, la Constitución de Estados Unidos y la Constitución francesa. Por otra parte, las limitaciones políticas, fueron expresadas a través del surgimiento de los 
gobiernos representativos, como un mecanismo de limitación de todo uso arbitrario del poder, del Gobierno y sus oficiales. Fruto de aquella metamorfosis jurídicapolítica, se produce el cambio de paradigma en la conceptualización del poder y el control, por consiguiente, emerge el constitucionalismo.

Por otro lado, las normas, la Constitución como ley suprema y el Derecho en general, comenzaron a ser creados por el pueblo. En razón de aquella necesidad de control, la creación y producción del ordenamiento jurídico fue objetivizada. En ese escenario, en virtud de la representación política, el electorado ostentaba el pleno derecho a exigir que sus mandatados explicaran sus acciones y defendieran sus intereses, proceso que se expresaba en el mecanismo de rendición de cuentas y el ejercicio de la responsabilidad política.

Básicamente, a través de esta nueva arquitectura del poder, emerge el Estado de derecho mediante expresiones tales como: los pesos y contrapesos, los equilibrios entre los poderes del Estado, y el control de los poderes políticos, en búsqueda de la limitación del poder; todos instrumentos mediante los cuales se construye el constitucionalismo moderno. Por tanto, el control es un rasgo genético del mismo. A través de este sistema, se otorgaba la protección de los derechos de los ciudadanos y, conjuntamente, se configuraba un importante factor de estabilidad para los gobiernos.

SEGUNDA: Señalamos que una de nuestras premisas iniciales sostenidas en esta investigación, suponía mantener, en nuestra opinión, que el control político encarnado en el control parlamentario estaba presente en todo tipo de régimen de gobierno, porque allí donde existe poder gubernamental ha de nacer un control político-parlamentario que limite su actuar y proteja derechos. Lo anterior, resultaba ser independiente de los posibles matices, conceptos y mecanismos de control parlamentario propios de cada régimen de gobierno. Además, existirán circunstancias y elementos fácticos de orden social y político, diversos a los concebidos teóricamente, los que afectarán el "ideal" desarrollo del control.

En adición a lo esbozado en el Capítulo primero, expresamos algunas incidencias y factores que desnaturalizan a los regímenes de gobierno, lo que ha generado patrones de comportamiento muy similares entre ellos, en cuanto al control parlamentario. Por consiguiente, el control alcanza un objetivo análogo en 
ambos regímenes -tanto en regímenes presidenciales como en modelos parlamentarios-, e incluso podríamos plantear que en la actualidad persigue sanciones idénticas, pero utilizando distintos mecanismos.

Lo anterior, ha generado en la configuración de dicho tipo de control modificaciones al punto de que las tradicionales diferencias entre uno u otro régimen se han diluido paulatinamente, reduciendo al mínimo las brechas en materia de control parlamentario entre regímenes de gobierno. A ello, hay que sumarle como factor la yuxtaposición en la desnaturalización del presidencialismo-parlamentarismo, fenómeno que se une al particular comportamiento de los partidos políticos, en atención a la desafección política, la disciplina partidaria, el vínculo mayoría-gobierno y la influencia que ejercen determinados sistemas electorales.

Es por ello que le atribuimos como una característica esencial al control parlamentario, la ductilidad. En nuestra opinión, esta institución políticaconstitucional goza de la capacidad de adecuarse a la realidad política en la que debe operar. Así pues, se adapta al tipo de regulación jurídica en virtud de la cual debe actuar y al régimen de gobierno en el cual ejerza sus efectos. Por tanto, es posible colegir -tal como lo dijéramos precedentemente- que dicha cualidad (la ductilidad) le permite estar presente en todo régimen de gobierno, independientemente de las complicaciones fácticas y legales que deba sortear.

Conjuntamente, hemos planteado que en razón de la diversidad de formas mediante las cuales se expresa el control parlamentario, se generarán a su vez efectos múltiples, disímiles al derrocamiento de Gobierno o destituciones de ministros. Dicho esto, es posible destacar que en las democracias modernas son variadas las maneras de ejecutar el control parlamentario, inclusive es posible realizarlo mediante otras funciones del Parlamento, y no sólo a través de la especial función de control. De ello derivan importantes y particulares nuevas sanciones, ampliando la gama tradicional de mecanismos de control y expandiendo también las sanciones. No obstante, tales sanciones pueden alcanzar similares efectos a los concebidos tradicional y teóricamente, o incluso en algunos casos pueden ser más efectivos.

Por esta razón, nos unimos a la visión difusa de la responsabilidad política señalada por Ugo Resigno, porque creemos firmemente que las sanciones actuales son de orden electoral, pero también permiten mejorar la función pública. La 
fiscalización que realizan los congresistas es sólo el puntapié inicial de un control mayor que es ejecutado por la ciudadanía y los medios de comunicación.

En consecuencia, desde nuestra perspectiva, las nuevas modalidades de control que nacen en virtud de las modernas relaciones políticas, pretenden conseguir dos finalidades diversas. Tal diferenciación de finalidades de la fiscalización, nos permite sostener que existen dos tipos de propósitos, uno con fines electorales y otro, con fines gubernativos, los que pasamos a exponer:

a) La primera, promueve mayormente la formulación de una crítica constante que suscite la reorientación de las políticas públicas adoptadas por el Ejecutivo y sostenidas por la alianza política gobernante. Vale decir, el objeto del control lo constituye, esencialmente, el programa de gobierno. Fruto de aquella crítica se espera evidenciar las debilidades del gobernante en su calidad individual. De esta manera personaliza los mandatos, mecanismo que en el escenario nacional toma mayor relevancia, puesto que nuestro enérgico presidencialismo coloca en un sitial de suma trascendencia al jefe del Estado. Por tal motivo, debilitar su figura conlleva disminuir la valoración de sus atributos. Así pues, se aminoran sus capacidades y se genera un ambiente de desprotección e inseguridad política.

Adicionalmente, este tipo de fiscalización pretende alcanzar una sanción de largo plazo que proyecta conseguir la alternancia en el poder; por tanto, dice relación con un comportamiento electoral. De este modo, aquella vinculación entre la labor fiscalizadora del congresista y el traslado que de ello se realiza a la ciudadanía -canalizado mediante las nuevas tecnologías y los medios de comunicación-, puede sentar sólidas bases de desafección respecto de un determinado actor político, sea un partido político o un personaje político en particular. Así, su credibilidad y niveles de confianza pueden ser duramente trastocados. Por consiguiente, su rol público como representante del pueblo puede verse afectado, perdiendo los porcentajes electorales que poseía y, a su vez, promoviendo el crecimiento de otras fuerzas políticas. 
b) La segunda finalidad de la fiscalización, comprende fines gubernativos, es decir, tiene por objetivo evidenciar las deficiencias en la conducción política y programática del Gobierno. Entonces, tendrá por fin último exponer con claridad las diferencias ideológicas entre los actores políticos que componen el mapa político de cada país. En este sentido, serán puestas en entredicho las políticas públicas adoptadas por el Ejecutivo. Cuando es cuestionado el modelo que ha de ser instaurado por el gobernante, este tipo de fiscalización es llevada a cabo no sólo en un escenario mediático, sino que además en sede congresional. Por tanto, serán utilizados los mecanismos de fiscalización contemplados en la Constitución, leyes y reglamentos, es decir, mediante las interpelaciones, acusaciones y comisiones de investigación. A través de estas herramientas es posible inspeccionar a fondo la orientación, debilidades y fortalezas de las políticas públicas adoptadas, y una vez recopilada dicha información es posible montar una puesta en escena que permita -a través de vías institucionales- poner en jaque el plan de gobierno personificado en los miembros del gabinete ministerial. Este tipo de fiscalización pretenderá demostrar que el modelo de Estado que diseña el Ejecutivo es erróneo, y que es preciso retomar otra senda para mejorar las condiciones económicas, políticas y sociales.

Lo anteriormente descrito, analizado desde otra perspectiva, permite señalar que el despliegue de la fiscalización favorece la entrega de información hacia la ciudadanía dotándola de mayores y mejores herramientas para discernir y escoger entre las opciones políticas y programáticas que se presentan en un país. Contribuye en hacer efectiva la alternancia al poder, puesto que permite visualizar las alternativas de cambio existentes según las necesidades de cada etapa social y política, por ende, fortalece el sistema democrático. En definitiva, promueve el debido e inexcusable control social. 
TERCERA: Con todo, en este nuevo escenario la configuración de mayorías y minorías es diversa y sus relaciones con el Ejecutivo son absolutamente diferentes, argumento que hace aún más interesante la conformación del Congreso y las expresiones del control. A nuestro entender, las minorías pueden ser de dos tipos: político-sociales y parlamentarias. Las primeras, responden a un concepto amplio que dice relación generalmente con movimientos y demandas sociales que no cuentan con participación-representación en el Congreso, pero que, sin embargo, formulan una constante crítica al gobierno mediante el control social. Adicionalmente, es posible que en algún momento estas minorías puedan acceder a ciertos escaños parlamentarios de forma aislada, lo que los ubica en las denominadas "pequeñas minorías". Esta posición política podrá inclinarse ya sea por ejercer un control parlamentario activo, mucho más intenso que otras minorías, o por el contrario, podrá realizar acciones negociadoras con el Gobierno, lo que se expresará en una actitud mucho más cooperadora.

Las segundas -las minorías parlamentarias-, forman parte de una noción restrictiva y estarán compuestas principalmente por partidos políticos que posean un menor porcentaje de participación. Estas minorías pueden o no constituirse como grupos de oposición, pues, desde nuestra perspectiva, lo que determinará la calificación de oposición respecto de un grupo parlamentario será su comportamiento y no necesariamente el número de miembros ni el conglomerado en el que se encuentran políticamente ubicados. Conjuntamente, estará presente la mayoría parlamentaria, sector político que de igual forma ejerce control. Este último control, a pesar de que la forma en que se realiza es más discreta, posee efectos habitualmente más efectivos.

En colofón, es preciso destacar que las relaciones entre los grupos políticos -con o sin representación en el Congreso- en conjunto con los sectores políticos del Congreso vinculados al Gobierno, sean o no mayoría, presentan un comportamiento especialmente crítico con el Ejecutivo. Creemos que esto se debe al control social que ejerce la sociedad, en atención a la exigibilidad de estándares más altos respecto de la administración del Estado. La ciudadanía demanda gobernantes diligentes, probos y transparentes, situación que exponen de forma fuerte y clara. Por tanto, los sujetos políticos, en razón del mandato representativo, no pueden ni deben ir en otra dirección. Así, la fiscalización se torna indispensable en la gestión de un congresista, puesto que ello lo acerca a su electorado. 
CUARTA: Arribando de lleno a las conclusiones en torno al objetivo central de la presente investigación, es posible comenzar señalando que, en el caso chileno, se han presentado cuestionamientos en relación a esta facultad de fiscalización del Congreso. Se ha sugerido que es preciso definir, o más bien clarificar, su orientación -política o jurídica-, el parámetro, objeto $y$, en consecuencia, su relación con la responsabilidad política; todos argumentos que motivaron la presente tesis.

Principalmente, porque en nuestra opinión existiría un cierto desconcierto sobre la misma y la razón de aquella confusión se gesta en cuanto al diseño de la fiscalización y los mecanismos que ella contempla, y la manera en que ellas son ejercidas por el Congreso Nacional. Fue menester examinar los fundamentos teóricos y las circunstancias prácticas, a fin de determinar los elementos más significativos de la focalización en Chile y, de esta manera, elaborar nuestro concepto.

Como elemento histórico, el frustrado régimen parlamentario que se expresó en el país entre los años 1891 y 1924, dejó huellas en el desarrollo constitucional y político nacional. Durante aquel espacio temporal nuestro país experimentó la aplicación y ejercicio de herramientas fiscalizadoras, tales como el voto de censura, el veto de determinadas leyes y el juicio político. Todos estos instrumentos de fiscalización no estaban regulados en el texto constitucional, pero su ejercicio tenía por propósito esencial implementar un sistema parlamentario que tampoco estaba contemplado en la Carta Magna nacional. Por tanto, era prácticamente imposible, desde una perspectiva jurídica, que aquellas modificaciones fácticas fueran lo suficientemente poderosas como para modificar la realidad normativa vigente. En particular, el voto de censura no estaba contemplado en la Carta Fundamental, no obstante, fue ejercido con fuerza provocando una inestabilidad ministerial de suma relevancia, generando una crisis política de envergadura.

Esta situación política nacional se puede encuadrar dentro de una mutación constitucional porque lo que ocurría en Chile no era una simple interpretación diversa del texto constitucional, sino que -muy por el contrario- se trataba de un actuar derechamente contrario a la norma fundamental.

Aun así, los dos mecanismos de fiscalización descritos no estaban regulados constitucionalmente y configuraban elementos insignes del régimen parlamentario, el cual -tal como hemos dicho reiteradamente- no estaba contemplado constitucionalmente en la República chilena, sino solamente en el espíritu de algunos 
políticos nacionales. Aquel escenario configuró un fundamento de máxima politicidad para la fiscalización parlamentaria en su aptitud general. Desde aquel momento, la institución fue comprendida como una actividad política que generaba, a su vez, responsabilidad política, y que expresaba su mayor sanción a través de la destitución de Ministros de Estado.

El elemento subjetivo, en nuestra opinión, es la interpretación que se instala en la cultura política tradicional chilena. En los textos de 1925 y 1980 se intenta constreñir aquella noción, limitándose el alcance y la naturaleza de la fiscalización. Por tal motivo, se reduce a parámetros y procedimientos jurídicos la utilización de la misma, se señalan explícitamente cuáles serán los mecanismos de control respecto de los cuales se reduce su eficacia y se coarta expresamente la aplicación o exigibilidad de la responsabilidad política, puesto que, tal como lo dice la Carta Fundamental, el ejercicio de determinados instrumentos de fiscalización no afecta de manera alguna la responsabilidad política de los miembros del gabinete ministerial.

Del examen de los procesos constituyentes de 1925 y 1980, es posible convenir que el espíritu del constituyente estaba dirigido a reducir la fiscalización parlamentaria, ya que en ella se personificó a todos los males de una época del acontecer nacional. Los problemas políticos e institucionales generados durante la aplicación fáctica del régimen parlamentario y la posterior inestabilidad democrática, fue atribuida en gran medida a la fiscalización. El análisis de aquel complejo momento en el debate constitucional no arrojó más culpables que a esta sola institución; no se realizaron mayores indagaciones que permitieran detectar otros factores de importancia. Por tal motivo, la reducción de la fiscalización se fijó como objetivo central en los nuevos textos constitucionales.

Por ende, la debilidad regulatoria de la misma se debe -en nuestra opinión- al temor de que el uso de ella pudiera generar similares dificultades políticas conocidas en el pasado. Por tanto, la fiscalización parlamentaria contemplada en el ordenamiento constitucional vigente, es el resultado de una tradición política que utilizó sus mecanismos de manera equívoca, debido a la misma construcción democrática nacional, la cual ha tenido de dulce y agraz. Sin embargo, creemos que la importancia que ella representa para el sistema político de nuestro país es suma. 
QUINTA: A pesar de la disminución en su capacidad de acción durante los años 1970 a 1973, en razón de un determinado momento político, social, intelectual y económico, retoma fuerzas y emerge con nuevos bríos provocando un sinnúmero de efectos políticos y jurídicos de suma importancia, contribuyendo con la crisis nacional que se gestaba y finaliza con el golpe de Estado cívico-militar.

Demás esta recordar que durante los años de dictadura el control -no sólo el político, sino que también el jurídico- fue inexistente y sólo con el retorno de la democracia la fiscalización parlamentaria revive, como tantas otras instituciones. Sin embargo, el contexto nacional era de suma precaución. La transición política y las amenazas soterradas de los militares impidieron el correcto ejercicio de la misma, por tanto, desde 1990 hasta 2004 la practicabilidad de la fiscalización fue más bien un ideal teórico, debido a un factor social y psicológico que impedía ejercer la democracia plenamente. Salvo el excepcional caso de la acusación constitucional contra Pinochet Ugarte.

Una vez que se fue consolidando la democracia y derribados algunos de los enclaves de la dictadura, emergen como un impulso democrático las reformas constitucionales del año 2005 en virtud de las cuales se fortalece la fiscalización parlamentaria. Desde aquel momento la fiscalización ha tomado un cariz diverso -más intenso y eficaz-, que ha mermado la imagen política y la valoración de la gestión de un Gobierno, contribuyendo a la alternancia del poder, circunstancia poco recurrente en nuestro país. Resultado de aquello es que en el año 2008 -durante el mandato de la presidente Bachelet- se produce el juicio político de la otrora ministra de Educación Yasna Provoste, cuyo resultado fue la determinación de la responsabilidad política y su consecuente sanción. Esta situación se repetirá en el Gobierno del presidente Sebastián Piñera, respecto del también ministro de educación, Harald Beyer. Lo anterior, expresión del complejo momento social que experimentaba Chile, en razón de las protestas estudiantiles y la demanda de la ciudadanía por una educación pública, gratuita y de calidad.

En nuestra opinión, el contexto social de forma decisiva motivó e influenció el ejercicio de la función fiscalizadora. Debido a ello, hemos sostenido en nuestro concepto de fiscalización parlamentaria que en las democracias modernas ella es -en sí misma- un proceso, porque se construye en virtud de múltiples elementos políticos, ciudadanos y jurídicos los que conjugados producen como resultado la fiscalización. En nuestra interpretación, cualquiera de aquellos factores puede dar 
comienzo a la activación de los sistemas de control, los que a su vez pueden o no radicarse en el Congreso Nacional mediante dicha función. Por tanto, la naturaleza de la institución posee un tinte político relevante.

No obstante, la fiscalización requiere continuidad en el análisis de sus manifestaciones, prioritariamente con posterioridad a la conformación del Congreso Nacional que tendrá lugar luego del proceso eleccionario del año 2017, en razón de las reformas al sistema electoral.

Por otra parte, es preciso examinar el comportamiento de la cultura política nacional, toda vez que el conjunto de normas promulgadas durante este año que buscan fortalecer el sistema democrático, fomentan la participación política de nuevos partidos políticos y actores de gran relevancia. En esta dirección, la configuración de mayorías y minorías probablemente contribuya en un reordenamiento de las fuerzas políticas $y$, por consiguiente, incidirán en el comportamiento de la fiscalización parlamentaria.

SEXTA: La conceptualización de la fiscalización en nuestro ordenamiento jurídico constitucional, comprende la noción de adhesión o crítica -esencialmente políticasobre la base de doctrinas, principalmente ideologías o concepciones filosóficas, que conducen a los congresistas a formular juicios de conveniencia o de oportunidad sobre lo obrado o no por el Ejecutivo. La finalidad de esto es lograr incidir directamente en la gestión del Gobierno, no solamente plasmar una crítica, sino que también alcanzar efectos de envergadura política mayor, por ejemplo la destitución de Ministros de Estado o el cambio en una política pública contemplada en el programa político de gobierno.

En este sentido, los congresistas mediante los acuerdos u observaciones, los demás mecanismos de fiscalización y la acusación constitucional, no sólo esperan confirmar o rectificar la conducta del Gobierno, sino que conjuntamente demandan la aplicación de sanciones políticas; pretenden la exigibilidad de la responsabilidad política. Sin embargo, la obligación del Gobierno se entiende cumplida por el sólo hecho de entregar su respuesta, sin que en ningún caso la fiscalización afecte la responsabilidad política de los ministros o de las otras altas autoridades del Ejecutivo. 
Dicho lo anterior, es posible concluir que entre lo regulado y lo pretendido existe una aparente contradicción, situación que -en nuestro entender- es consecuencia de la propia evolución histórica de la institución, como también es resultado del espíritu de los congresistas y agentes políticos nacionales, quienes le exigen al presidencialismo chileno reforzado que se comporte de una manera distinta a la diseñada jurídicamente.

Por tal motivo proponemos, por una parte, una nueva conceptualización de la fiscalización parlamentaria chilena, idea que desarrollamos en el siguiente apartado. Exponemos la noción de ajustar la aspiración política, con las prácticas parlamentarias llevadas a cabo en el Congreso Nacional, y la regulación constitucional nacional. Por otra parte, creemos igualmente importante plantear la necesidad de examinar el régimen de gobierno presidencial, y analizar una posible modificación. Nos inclinamos por un régimen semi-presidencial.

SÉPTIMA: En cuanto al Capítulo tercero, quisiéramos exponer sucintamente algunas problemáticas que fueron detectadas en torno a una institución que en nuestra opinión es una consecuencia de la fiscalización parlamentaria, nos referimos a: la acusación constitucional.

En dicho Capítulo, planteamos algunas dificultades que rodean al juicio político. En primer lugar, hicimos presente aquellas debilidades que existen entre el correcto cumplimiento del debido proceso y el actual procedimiento del juicio político. Básicamente, abordamos aquellos cuestionamientos en cuanto a la imposibilidad de ofrecer o impugnar medios de prueba en la segunda instancia del proceso acusatorio, el que es llevado ante el Senado. En segundo lugar, agregamos que -según nuestra interpretación- es menester perfeccionar el fallo o resolución final que emite el Senado en su calidad de jurado, cuando resuelve la acusación, sea de culpabilidad o de inocencia. Estimamos necesario corregir el contenido y razonamiento del mismo, como también la fundamentación de la decisión adoptada.

Por otra parte, en el mismo Capítulo tercero nos referimos a las sanciones que lleva implícita la acusación constitucional, particularmente, nos detuvimos en el examen de la obligación que se le impone a determinados funcionarios públicos de separase de su cargo en el caso de que una acusación sea declarada ha lugar por la Cámara de Diputados y pasar a su análisis al Senado. Respecto de ello, señalamos 
que dicha separación es -a nuestro entender- una medida cautelar que sólo pretende evitar daños de envergadura en la gestión pública, principalmente por el interés público comprometido, por tal motivo no debe ser entendida como una sanción anticipada que vulnera las garantías constitucionales del acusado, sino que solamente es una acción que se configura como una medida preventiva. En este sentido la única sanción efectiva es la contenida en la declaración de culpabilidad del Senado, en razón de la cual queda el acusado destituido de su cargo, y no podrá desempeñar ninguna función pública, sea o no de elección popular, por el término de cinco años. En cuanto a la sanción de la acusación, creemos pertinente evaluar su extensión de cinco años, puesto que parece ser muy gravosa.

OCTAVA: En consecuencia y para finalizar podemos concluir sosteniendo que la conceptualización de la fiscalización en el plano nacional es confusa, puesto que la tradición política chilena ostenta antecedentes y prácticas bastante disímiles, las que al ser contrastadas con lo estipulado y esperado por la regulación constitucional, se torna aún más imprecisa. De conformidad a la costumbre política, los congresistas utilizan fundamentalmente criterios subjetivos al momento de ejercer la fiscalizaicón, pretendiendo obtener de ella consecuencias políticas específicas, mientras que la regulación jurídico constitucional de la fiscalización contempla otro escenario. Básicamente, la regulación de la Carta Fundamental observa un tipo de responsabilidad constitucional objetiva diversa a la responsabilidad esencialmente política que en ocasiones se pretende alcanzar mediante el ejercicio de la fiscalización, la normativa constitucional establece parámetros que están en gran medida objetivizados.

Así las cosas, a través del ejercicio de la facultad fiscalizadora, los congresistas no persiguen la literalidad y espíritu del texto de la Norma Fundamental, la cual contempla, tal como lo señalamos precedentemente, supuestos normados explícitamente. Por el contrario, los congresistas pretenden provocar mediante ella efectos políticos que logren modificar los lineamientos estratégicos del Gobierno y de los partidos políticos que lo conforman, además, de utilizar a los medios de comunicación como instrumento de divulgación de sus críticas al funcionamiento del Ejecutivo y, así llegar a la opinión pública, de manera de influir en las orientaciones político-electorales. Es por ello que, por una parte, a la fiscalización se le puede atribuir concretamente un carácter político y, por otra parte, 
se le restringe a parámetros y supuestos jurídicos. He allí uno de los elementos centrales que configuran la interpretación contrapuesta de la misma institución

Por consiguiente, la conflictividad en torno a esta institución es de importancia, en nuestra opinión, genera una incomodidad constitucional. Toda vez que, se espera de la fiscalización parlamentaria efectos poco viables para el régimen presidencial nacional de carácter vigoroso. En este sentido, es posible cuestionarse: si la regulación de la fiscalización parlamentaria es la insuficiente, o bien es el régimen de gobierno el que no satisface las necesidades políticas que emanan de los congresistas.

Sin perjuicio de lo anterior, desde nuestra perspectiva, para poder ponderar ambas opciones correctamente, habrá que esperar un hecho político relevante, será preciso examinar la configuración del Congreso Nacional del año 2018, mediante el nuevo sistema electoral, el que, probablemente, potenciará una conformación de fuerzas políticas más proporcional $y$, posiblemente, diversas a las históricamente presentes en el hemiciclo. Por tanto, es factible que el comportamiento de mayorías y minorías sea disímil del que hasta ahora conocemos, por ende, el ejercicio de la fiscalización también se podría ver afectado. En tal contexto, podremos examinar un primer aspecto: si las complejidades en el ejercicio de la fiscalización provenían de la tradición o cultura política de nuestros congresistas y de la configuraciòn del Congreso Nacional o si su origen, dice relación con la regulación de la fiscalización y sus mecanismos. Con todo, aquel escenario nos permitirá analizar el comportamiento del régimen presidencial bajo otros supuestos y así, examinar las relaciones entre mayorías, minorías y Gobierno. Por ende, se podrá dimensionar si es el presidencialismo el defectuoso, si es la fiscalizaicòn y su regulaciòn la deifictaria o si, en definitiva, es una complicación de la cultura política nacional.

Finalmente, con el propósito de contribuir en la búsqueda de una solución a la controversia que emerge entre la parctica política y la regulación constitucional en relación a la fiscalizaicón parlamentaria. Sostenemos que de conformidad al concepto que hemos acuñado en esta tesis, varias de las dificultades que hemos esbozado, se verían remediadas si consideramos a la fiscalización como un proceso de carácter inicialmente político-social que puede generar una segunda etapa jurídicaconstitucional y que, ambas etapas unidas, han de generar efectos políticos, electorales y ciudadanos de trascendencia para el sistema democrático. Para ello 
habrá que formular algunas reformas al texto constitucional pero esencialmente habría que depurar la interpretación que poseen los congresistas de la institución.

A modo de conclusivo, queremos expresar que tal como ocurre con la generalidad de las investigaciones, y ésta no es la excepción, finalizamos un trabajo que, si bien responde ciertos cuestionamientos, al mismo tiempo abre otros planteamientos desde los cuales podemos comenzar a trazar nuevas indagaciones, hipótesis y objetivos. Si embargo, esperamos haber dado correcto cumplimiento a los propósitos que nos planteamos al iniciar la elaboración de ésta investigación, la que hemos finalizado con las conclusiones antes expuestas. 


\section{CONCLUSIONI}




\section{CONCLUSIONI}

Il nostro lavoro all'inizio di questa ricerca, voleva chiarire - per effetto di elementi giuridici, dottrinali e empirici - gli elementi più significativi che consentono di determinare un concetto costituzionalmente adeguato di fiscalizzazione parlamentare. Determinare il concetto aveva I'obiettivo di confrontare con l'esercizio della stessa istituzione, e, infine, dare la nostra propria definizione. Questo processo di ricerca ci ha portato a rilevare alcuni fattori e componenti che ci permettono di concludere una serie di ipotesi rilevanti, specificati qui di seguito:

PRIMA: È opportuno rilevare che, come proposto nel Primo Capitolo, il nostro scopo implica che si descriva il nesso tra il controllo del potere e il costituzionalismo moderno. In questo senso, e nonostante l'evidenza di tale nesso, è diventato necessario indicare che la base teorica del controllo parlamentare - nel ruolo di controllo politico - si basa sulla limitazione del potere. Pertanto, il controllo parlamentare è un mezzo attraverso il quale la direzione politica e amministrativa del Potere Esecutivo è limitata, essendo il limite al potere, ma anche, un elemento fondante del costituzionalismo moderno.

Come pure è stato esposto nel Primo Capitolo di questa tesi, la limitazione e la divisione del potere hanno portato la creazione di controlli legali e politici.

Da un lato, i limiti di legge sono stati espressi attraverso testi estremamente importanti come il Bill of Right, la Dichiarazione Universale dei Diritti dell'Uomo, la Costituzione degli Stati Uniti e la Costituzione francese.

Inoltre, i vincoli politici sono stati espressi attraverso l'emergere di governi rappresentativi, come un meccanismo che limita qualsiasi uso arbitrario del potere, del Governo ei suoi funzionari. Come risultato di questa metamorfosi giuridicapolitica si verifica il cambiamento di paradigma nella concettualizzazione di potere e controllo.

D'altra parte, le regole, la Costituzione come legge suprema e il Diritto generale, hanno cominciato ad essere creato dal popolo. A causa di questa necessità di controllo, è stata oggettivata la creazione e la produzione del sistema giuridico. In tale scenario, in rappresentanza politica, l'elettorato ha tenuto il pieno diritto di 
esigere che i mandati spiegano le loro azioni e difendono i interessi, processo che è stato espresso nel meccanismo della responsabilità politica.

In sostanza, attraverso questa nuova architettura del potere, emerge lo Stato di diritto utilizzando espressioni, come ad esempio: pesi e contrappesi, equilibri tra poteri dello Stato e il controllo del potere politico, alla ricerca della limitazione del potere; tutti gli strumenti attraverso i quali è costruito il costituzionalismo moderno. Pertanto, il controllo è una caratteristica genetica dello stesso controllo. Attraverso questo sistema, è stata impostata la tutela dei diritti dei cittadini, e congiuntamente, è stato fissato un importante fattore di stabilità per i governi.

SECONDA: Abbiamo notato che una delle nostre premesse iniziali sostenuti in questa ricerca, a nostro parere, è che il controllo politico incarnato nel controllo parlamentare era presente in tutti i tipi di sistema di governo, perché dove c'è potere governativo verrà fuori il controllo politico-parlamentare, limitando il agire e proteggendo i diritti. Questo, ha dimostrato di essere indipendente dalle possibili sfumature, concetti e meccanismi di controllo parlamentare di ogni sistema di governo. Inoltre, esisteranno condizioni e elementi di fatto di ordine sociale e politico, diversi da quelli concepiti in teoria, che influenzano lo sviluppo di controllo "ideale".

Oltre a quanto disposto nel Primo Capitolo, esprimiamo alcuni incidenti e fattori che denaturano i regimi di governo, che ha generato modelli di comportamento molto simili gli uni agli altri, riguardo al controllo parlamentare. Pertanto, il controllo raggiunge un obiettivo simile in entrambi i regimi (nei regimi presidenziali e in modelli parlamentari) e anche noi potremmo sostenere che attualmente persegue sanzioni identiche, ma con meccanismi diversi.

Questo ha generato nella configurazione di tale controllo modifiche al punto che le differenze tradizionali fra uno o un altro regime sono gradualmente diluiti, riducendo al minimo le lacune nel controllo parlamentare tra i regimi di governo. A tali elementi si aggiungono come fattore la giustapposizione nello snaturamento del presidenzialismo-parlamentarismo, fenomeno che si lega al particolare comportamento dei partiti politici, in vista della disaffezione politica, disciplina di partito, il nesso maggioranza-governo e l'influenza di alcuni sistemi elettorali. 
È per questo che diamo come una caratteristica essenziale al controllo parlamentare, la duttilità. A nostro parere, questa istituzione politica-costituzionale ha la capacità di adattarsi alla realtà politica in cui si deve operare. Quindi si adatta al tipo di regolamentazione giuridica in base al quale agire e al sistema di governo in cui esercitare i suoi effetti. Pertanto, è possibile dedurre (come abbiamo detto precedentemente) che questa qualità (la duttilità) permette di essere presente in qualsiasi sistema di governo, a prescindere dalle complicazioni di fatto e legale da superare.

Congiuntamente, abbiamo sostenuto che a causa della diversità dei modi in cui si esprime il controllo parlamentare, ci saranno anche effetti molteplici, dissimile al rovesciamento del Governo o revoca dei ministri. Detto questo, è possibile sottolineare che nelle democrazie moderne sono vari i modi per eseguire il controllo parlamentare, anche è possibile eseguire il controllo attraverso altre funzioni del Parlamento, e non solo attraverso la speciale funzione di controllo. Ne risultano importanti e specifici nuove sanzioni, ampliando la tradizionale gamma di meccanismi di controllo e anche espandendo le sanzioni. Tuttavia, tali sanzioni possono ottenere effetti simili ai concepiti tradizionale e teoricamente, o anche in alcuni casi può essere più efficace.

Per questo motivo, ci siamo uniti alla visione sfocata di responsabilità politica indicata da Ugo Resigno, perché crediamo fermamente che le sanzioni attuali sono di ordine elettorale, ma anche consentono di migliorare la funzione pubblica. La fiscalizzazione effettuata dal Congresso è solo il inizio di un maggiore controllo che viene eseguito dal popolo e dai media.

Pertanto, dal nostro punto di vista, le nuove forme di controllo che nascono in considerazione della politica moderna hanno l'obiettivo di ottenere due scopi diversi. Tale differenziazione ci permette di sostenere che ci sono due tipi di scopi, uno con fini elettorali e un altro con scopi governativi:

a) Il primo, promuove soprattutto la formulazione di una critica costante che dà origine al riorientamento delle politiche pubbliche adottate dall'Esecutivo e sostenute dalla alleanza politica di governo. Cioè, il oggetto del controllo ciò è costituito essenzialmente dal programma di governo. Come risultato di tale critica si aspetta di vedere le debolezze del uomo di governo nella sua qualità individuale. Così i 
mandati sono personalizzati, meccanismo che sulla scena nazionale diventa più rilevante, poiché il nostro presidenzialismo energico pone il capo dello Stato in un luogo di massima importanza. Per questo motivo, indebolire la sua figura implica ridurre la valutazione dei attributi. Così, le capacità sono diminuiti e si genera un clima di vulnerabilità e insicurezza politica.

Inoltre, questo tipo di fiscalizzazione cerca di conseguire una sanzione di lungo termine che intende svolgere una alternanza al potere; pertanto, relativo al comportamento elettorale. Così, questa connessione tra il lavoro di fiscalizzazione del membro del Congresso e il trasferimento che è fatto per il popolo (canalizzato attraverso le nuove tecnologie e media) può stabilire solide basi di disaffezione per un determinato attore politico, sia che si tratti di un partito politico o di un carattere politico in particolare. Così, la credibilità e i livelli di fiducia possono essere gravemente perturbati. Pertanto, il ruolo pubblico come rappresentante del popolo può essere influenzato, perdendo le percentuali elettorali che aveva, e anche promuovendo la crescita di altre forze politiche.

b) Il secondo scopo della fiscalizzazione ha scopi governativi, vale a dire, ha lo scopo di mettere in evidenza le carenze della politica e il programma del Governo. Poi, avrà lo scopo di definire chiaramente le differenze ideologiche tra attori politici che compongono la mappa politica di ogni paese. In questo senso, saranno messi in discussione le politiche pubbliche adottate dall'Esecutivo. Quando è messo in dubbio il modello che deve essere stabilito dal uomo di governo, questo tipo di fiscalizzazione è realizzata non solo sul piano mediatico, ma anche nella sede del Congresso. Pertanto saranno utilizzati i meccanismi di fiscalizzazione disciplinati dalla Costituzione, legge e regolamenti, vale a dire, utilizzando interpellanze, accuse e commissioni di ricerca. Attraverso questi strumenti è possibile ispezionare a fondo le orientamento, punti di forza e di debolezza delle politiche pubbliche adottate, e una volta raccolte queste 
informazioni è possibile montare una scena che permetta (attraverso vie istituzionale) di mettere a repentaglio il piano del governo incarnato nei membri del gabinetto ad interim di ministri. Questo tipo di fiscalizzazione cercherà di dimostrare che il modello di Stato che progetta l'Esecutivo è sbagliato, e deve riprendere un altro modo per migliorare le condizioni economiche, sociali e politiche.

Come descritto in precedenza, analizzato da un'altra prospettiva, cosente sottolineare che il dispiegamento della fiscalizzazione favorisce la fornitura di informazioni al pubblico, offrendo maggiori e migliori strumenti per identificare e scegliere tra le opzioni politiche e programmatiche che sono presenti in un paese. Contribuisce a far rispettare l'alternanza di potere, perché consenta di visualizzare le alternative di cambiamento che esistono in base alle esigenze di scena sociale e politica, e quindi, rafforza il sistema democratico. In breve, promuove il appropriato e ingiustificabile controllo sociale.

TERZA: Tuttavia, in questo nuovo scenario la configurazione delle maggioranze e delle minoranze è diversa e le relazioni con l'Esecutivo sono molto differenti, argomento che rende ancora più interessante la formazione del Congresso e le espressioni di controllo. A nostra conoscenza, le minoranze possono essere di due tipi: politico-sociale e parlamentare. La prima minoranza risponde a un concetto ampio relativo generalmente ai movimenti e le esigenze sociali che non hanno una partecipazione-rappresentanza al Congresso, ma che tuttavia hanno formulato una critica costante del governo attraverso il controllo sociale. Inoltre, è possibile che ad un certo punto queste minoranze possano accedere isolatamente ad alcuni seggi parlamentari, chiamati "piccole minoranze". Questa posizione politica può realizzare un controllo parlamentare attivo, molto più intenso di altre minoranze, 0 , al contrario, può realizzare azioni negoziando con il Governo, che esprime un atteggiamento molto più cooperativo.

La seconda minoranza (minoranze parlamentari) fanno parte di una funzione restrittiva e sono principalmente composti da partiti politici che hanno una minore percentuale di partecipazione. Queste minoranze possono o non possono costituirsi come gruppi di opposizione perché, dal nostro punto di vista, che determinerà il 
rating di opposizione per quanto riguarda un gruppo parlamentare sarà il comportamento e non necessariamente il numero di membri né il conglomerato in cui si trovano politicamente. Congiuntamente, sarà presente la maggioranza parlamentare e il settore politico che esercitano un controllo allo stesso modo. Questo ultimo controllo, anche se il modo in cui viene fatto è più discreto, ha effetti generalmente più efficaci.

Infine va sottolineato che le relazioni tra i gruppi politici (con o senza rappresentanza al Congresso) in combinazione con i settori politici del Congresso collegate al Governo hanno un comportamento particolarmente critico con l'Esecutivo. Crediamo che questo sia dovuto al controllo sociale esercitato dalla società, in vista della esigibilità superiore per quanto riguarda l'amministrazione dello Stato. Il popolo esige governanti diligenti e trasparenti, situazione che definisce in modo chiaro e forte. Pertanto, i soggetti politici (a motivo del mandato rappresentativo) non possono e non devono andare in un'altra direzione. Così, la fiscalizzazione diventa essenziale nella gestione di un membro del Congresso, perché questo lo porta più vicino al elettorato.

QUARTA: Arrivando pienamente alle conclusioni attorno l'obiettivo centrale di questa ricerca, è possibile iniziare da notare che, nel caso del Cile, sono stati presentati ricorsi in relazione a questa fiscalizzazione del Congresso. È stato suggerito che è necessario definire, o chiarire, il orientamento (politico o giuridico), il parametro, l'oggetto e quindi il nesso con la responsabilità politica; tutti gli argomenti che hanno motivato questa tesi.

Principalmente perché crediamo che ci sarebbe qualche confusione e ciò va collegato al design della fiscalizzazione e ai meccanismi che fornisce, e il modo in cui sono esercitate dal Congresso Nazionale. E 'stato necessario esaminare i fondamenti teorici e le circostanze pratiche per determinare gli elementi più significativi di focalizzazione in Cile, e quindi sviluppare il nostro concetto.

Come un elemento storico, il regime parlamentare frustrato che si è espressato nel paese tra il 1891 e il 1924, ha lasciato il segno sullo sviluppo politico e costituzionale nazionale. Durante questo periodo il nostro paese ha sperimentato la realizzazione e l'esercizio di strumenti di fiscalizzazione, come il voto di sfiducia, il veto di certe leggi e il giudizio politico. Tutti questi strumenti di fiscalizzazione non 
sono stati regolati dalla Costituzione, ma l'esercizio fondamentale è stato quello di implementare un sistema parlamentare che non è stato contemplato nella Costituzione Nazionale. Pertanto, è stato praticamente impossibile da un punto di vista giuridico, che tali modifiche di fatto fossero abbastanza potente per cambiare le regole attualmente in vigore. In particolare, il voto di sfiducia non è stato contemplato nella Costituzione. Tuttavia, è stato esercitato con forza provocando una instabilità ministeriale estremamente importante, generando una grave crisi politica.

Questa situazione politica nazionale può essere inquadrata all'interno di una mutazione costituzionale, perché quello che è successo in Cile non era semplicemente una diversa interpretazione del testo costituzionale, ma al contrario, è stato un atto rettamente in contrasto con la regola fondamentale.

Eppure, i due meccanismi di fiscalizzazione descritte non sono stati regolati costituzionalmente e hanno configurato elementi distinti del regime parlamentare, che -come abbiamo detto costantemente- non erano previsti nella Repubblica cilena, ma solo nello spirito di alcuni politici nazionali. Questo scenario ha creato una fondazione di massima politicità per la fiscalizzazione parlamentare in forma fisica generale. Da quel momento, l'istituzione è stata intesa come un attività politica che ha generato la responsabilità politica ed esprimeva la più grande sanzione attraverso la revoca dei ministri di Stato.

L'elemento soggettivo, a nostro parere, è l'interpretazione che viene installata nella cultura politica tradizionale del Cile. Nei testi del 1925 e del 1980 si tenta di costringere tale nozione, limitando la portata e la natura della fiscalizzazione. Pertanto, tale utilizzo si riduce a parametri e procedure giuridiche sottolineano esplicitamente quali tipi di meccanismo di controllo sarano utilizzati per il quale la sua efficacia si riduce e limita espressamente l'applicazione o esigibilità della responsabilità politica, poiché, come dice la Costituzione, l'esercizio di specifici strumenti di fiscalizzazione non pregiudica in alcun modo la responsabilità politica dei membri del Governo.

Dal esame delle procedure costituzionali del 1925 e 1980, è possibile concordare sul fatto che lo spirito del componente mirava a ridurre la fiscalizzazione parlamentare, perché in quella fiscalizzazione sono stati personificati tutti i mali di un periodo di eventi nazionali. I problemi politici e istituzionali derivanti durante l'implementazione del sistema parlamentare e la conseguente instabilità democratica 
sono stati attribuiti in gran parte alla fiscalizzazione. L'analisi di quel momento complesso nel dibattito costituzionale ha mostrato un unico colpevole: questa istituzione. Non sono state effettuate indagini che permettono di rilevare altri fattori importanti. Pertanto, la riduzione della fiscalizzazione è stato impostata come obiettivo principale nei nuovi testi costituzionali.

A nostro parere, la debolezza regolamentare e 'a causa del timore che potrebbe generare difficoltà politiche simili a quelli sperimentati nel passato. Pertanto, la fiscalizzazione parlamentare prevista nel sistema costituzionale esistente è il risultato di una tradizione politica che ha usato i suoi meccanismi in modo sbagliato a causa della stessa costruzione democratica nazionale. Tuttavia, riteniamo che l'importanza che rappresenta per il sistema politico del nostro paese è una somma.

QUINTA: Nonostante la diminuzione della capacità d'azione nel corso degli anni 1970-1973, a causa di un particolare momento politico, sociale, intellettuale ed economico, riprende le forze ed emerge con nuove prospettive provocando numerosi effetti politici e giuridici importanti, contribuendo alla crisi nazionale e si conclude con il colpo di Stato civile-militare.

$\mathrm{E}^{\prime}$ opportuno rammentare che durante gli anni della dittatura il controllo (non solo politico, ma anche il giuridico) era inesistente e solo con il ritorno della democrazia la fiscalizzazione parlamentare rivive, come molte altre istituzioni. Tuttavia, il contesto nazionale era di massima cautela. La transizione politica e le minacce dei militari hanno impedito il corretto esercizio della fiscalizzazione. Pertanto, dal 1990 fino al 2004 la praticabilità della fiscalizzazione era piuttosto un ideale teorico, a causa di un fattore sociale e psicologico che ha impedito l'esercizio pieno della democrazia. Ad eccezione del caso eccezionale su un'accusa costituzionale contro Pinochet Ugarte.

Una volta che la democrazia è stata consolidata e alcune delle enclavi della dittatura abbattuti, emergono come un impulso democratico le riforme costituzionali del 2005 in base al quale si rafforza la fiscalizzazione parlamentare. Da quel momento, la fiscalizzazione ha preso uno sguardo diverso (più intenso ed efficace) che ha causato l'immagine politica e la valutazione della gestione di un Governo, contribuendo alla alternanza di potere, circostanze poco ricorrente nel nostro paese. Risultato di ciò è che nel 2008 (durante il mandato della presidente Bachelet) si 
manifesta un giudizio politico della Ministro dell'Istruzione chiamata Yasna Provoste, che ha portato alla determinazione di responsabilità politica e la sua conseguente sanzione. Questa situazione si ripete nel Governo del presidente Sebastian Piñera rispetto al Ministro dell'Istruzione, Harald Beyer. Alla luce di quanto precede, espressione del complesso momento sociale che il Cile stava vivendo, nascono le proteste studentesche e la domanda dal popolo per un'istruzione pubblica, gratuita e di qualità.

A nostro parere, il contesto sociale decisamente ha motivato e influenzato l'esercizio della funzione di fiscalizzazione. A causa di questo, abbiamo mantenuto nel nostro concetto di fiscalizzazione parlamentare che nelle democrazie moderne è un processo, perché è costruito sotto molteplici elementi politici, cittadini e giuridici, che quando sono combinate porteranno alla fiscalizzazione. Nella nostra interpretazione, qualsiasi di questi fattori può iniziare l'attivazione di sistemi di controllo, che a sua volta può o non può essere presentata al Congresso Nazionale mediante tale funzione. Pertanto, la natura dell'istituzione ha una sfumatura politica rilevante.

Tuttavia, la fiscalizzazione richiede la continuità nell'analisi delle sue manifestazioni, soprattutto dopo la formazione del Congresso Nazionale, che sarà poi posto il processo elettorale del 2017, a causa delle riforme del sistema elettorale.

Inoltre, è necessario esaminare il comportamento della cultura politica nazionale, dal momento che l'insieme di regole introdotte quest'anno che cercano di rafforzare il sistema democratico promuovano la partecipazione politica di nuovi partiti politici e attori di grande importanza. In questa direzione, la configurazione delle maggioranze e delle minoranze probabilmente contribuisce in un riallineamento delle forze politiche e, pertanto, influenzerà il comportamento di fiscalizzazione parlamentare.

SESTA: La concettualizzazione della fiscalizzazione nel nostro diritto costituzionale comprende la nozione di adesione o critica - essenzialmente politica - sulla base di dottrine, principalmente ideologie o di concetti filosofici, portando i legislatori per dare giudizi di convenienza o di opportunità su quello fatto o non fatto dall'Esecutivo. Lo scopo di questo è raggiungere direttamente influenzare la gestione del Governo, non solo acquisire una critica, ma anche ottenere effetti di maggiore rilevanza politica, per esempio, la revoca dei Ministri di Stato o il cambiamento di una politica pubblica contenuta nel programma politico del Governo. 
A questo proposito, i membri del Congresso attraverso osservazioni o accordi, altri meccanismi di monitoraggio e di accusa, non solo sperano di correggere il comportamento del Governo, ma collettivamente richiedono l'applicazione di sanzioni politiche; cercano l'esigibilità della responsabilità politica. Tuttavia, I'obbligo del Governo è capito soddisfatto per il solo fatto di dare sua risposta, senza incidere sulla responsabilità politica dei ministri o di altre autorità del Potere Esecutivo.

Detto questo, si può concludere che tra quello regolato e sostenuto c'è una apparente contraddizione, situazione che a nosotro parere, si tratta di una conseguenza della evoluzione storica dell'istituzione, e anche è il risultato dello spirito del Congresso e degli agenti politici nazionali che esigono che il presidenzialismo cileno rinforzato sia diverso da quello progettato giuridicamente.

Per questo motivo, proponiamo da un lato una nuova concettualizzazione della fiscalizzazione parlamentare cilena, idea sviluppata nel prossimo paragrafo. Descriviamo la nozione di regolare l'aspirazione politica, con le pratiche parlamentari svolte nel Congresso Nazionale, e la regolamentazione costituzionale nazionale. Dall'altro, riteniamo importante di considerare la necessità di esaminare il sistema di governo presidenziale e analizzare un'eventuale modifica. Siamo a favore di un regime semi-presidenziale.

SETTIMA: Per quanto riguarda il Terzo Capitolo, vorremmo discutere brevemente alcuni problemi che sono stati rilevati intorno ad una istituzione che, a nostro parere, è una conseguenza della fiscalizzazione parlamentare. Stiamo parlando di: un'accusa costituzionale.

In questo capitolo, vi presentiamo alcune difficoltà che circondano il giudizio politico. In primo luogo, vi presentiamo quelle debolezze che esistono tra il corretto adempimento di un giusto processo e l'attuale procedura di giudizio politico.

Essenzialmente, trattiamo queste domande per quanto riguarda l'impossibilità di fornire o sfidare elementi di prova in seconda istanza del processo accusatorio (processo portato davanti a un Senato). In secondo luogo, secondo la nostra interpretazione, noi aggiungiamo che è necessario perfezionare il giudizio o risoluzione finale emesso dal Senato in qualità di giuria, durante la risoluzione della 
accusa, sia di colpevolezza o innocenza. Riteniamo necessario rettificare il contenuto e il ragionamento dello stesso, nonché i motivi della decisione.

Inoltre, nello stesso Terzo Capitolo ci riferiamo alle sanzioni che hanno inclusa un'accusa costituzionale. In particolare, ci siamo fermati sull'obbligo di lasciare la loro carica (imposto su alcuni funzionari della pubblica amministrazione) nel caso in cui un atto d'accusa è stato dichiarato dalla Camera dei Deputati e analizzato dal Senato.

A questo proposito, facciamo notare che tale separazione è -a nostra comprensioneuna misura precauzionale che solo ha l'obiettivo di evitare ulteriori danni nella pubblica amministrazione, principalmente di interesse pubblico. Per questo motivo non deve essere inteso come una sanzione anticipata che viola le garanzie costituzionali degli accusati, ma è solo un'azione che è configurata come misura preventiva.

In questo senso, l'unica sanzione efficace è quella contenuta nella condanna del Senato, motivo per cui l'imputato è rimosso dal suo incarico, e non può svolgere alcuna funzione pubblica, anche se non eletto dal popolo, e per un periodo di cinque anni. Per quanto riguarda la sanzione per l'accusa, riteniamo rilevanti per valutare la sua proroga di cinque anni, poiché sembra essere molto oneroso.

OTTAVA: Di conseguenza, e, infine, possiamo concludere affermando che la concettualizzazione della fiscalizzazione a livello nazionale non è chiara, poiché la tradizione politica cilena ha sfondi e pratiche abbastanza dissimili rispetto ai termini previsti nella regolazione costituzionale. In conformità con la politica di consueto, il Congresso utilizza, essenzialmente, criteri soggettivi quando esercita la fiscalizzazione e cerca di ottenere conseguenze politiche specifiche, mentre la regolamentazione giuridica costituzionale della fiscalizzazione comprende un altro scenario. In sostanza, la regolazione della Costituzione vede un diverso tipo di responsabilità costituzionale alla responsabilità politica che a volte si propone di estendere mediante la fiscalizzazione, la normativa costituzionale stabilisce i parametri che sono in qualche misura oggettivati.

Ecco perché, da un lato, la fiscalizzazione può avere una natura politica e, inoltre, avere limitazioni e ipotesi di legge. Così, attraverso l'esercizio dell'autorità di 
fiscalizzazione, i membri del Congresso non seguono la formulazione e lo spirito del testo della norma fondamentale. Che comprende, come già detto, le ipotesi espressamente regolate. Al contrario, i membri del Congresso hanno lo scopo di causare effetti politici che ottengono modificare i meccanismi del Governo e dei partiti politici, anche utilizzando i mezzi di comunicazione come mezzo di diffusione delle loro critiche, e quindi raggiungere l'opinione pubblica, in modo da influenzare gli orientamenti politici ed elettorali.

Pertanto, il conflitto intorno a questa istituzione è importante, a nostro parere, perche crea un disagio costituzionale e, apparentemente, si aspetta della fiscalizzazione parlamentare effetti impraticabile per il regime presidenziale nazionale di carattere vigoroso, come quello che il nostro paese ha. Così, è possibile mettere in discussione se la regolamentazione della fiscalizzazione parlamentare è insufficiente, o se è il sistema di governo che non soddisfa le esigenze politici del Congresso, in termini di fiscalizzazione parlamentare.

Tuttavia, dal nostro punto di vista, per pesare entrambe le opzioni in modo corretto, dovremmo aspettarci un fatto politico rilevante, è necessario esaminare la configurazione del Congresso Nazionale del 2018, mediante il nuovo sistema elettorale, che certamente stimolerà fortemente una formazione di varie forze politiche alle storicamente presenti alla Camera. E 'quindi molto probabile che il comportamento delle maggioranze e delle minoranze è diverso da quello che sappiamo finora. Pertanto, l'esercizio della fiscalizzazione sarà anche influenzato. Quindi, siamo in grado di esaminare un primo aspetto: se la complessità della fiscalizzazione provenivano dalla tradizione o cultura politica dei nostri membri del Congresso o se l'origine è legata alla regolamentazione della fiscalizzazione e suoi meccanismi. Inoltre, questo scenario ci permetterà di analizzare il comportamento del regime presidenziale, i rapporti tra maggioranze e minoranze e Governo, e così si può concepire se il presidenzialismo è difettoso per gli attuali intenzioni politiche.

Tuttavia, a nostro parere e secondo il concetto che abbiamo coniato in questa tesi, alcune delle difficoltà che abbiamo delineato, ci sono risanati se consideriamo la fiscalizzazione come un processo di carattere inizialmente politico-sociale, che può generare una seconda fase legale e-costituzionale, entrambe le fasi insieme, devono generare effetti politici, elettorali e cittadini di rilevanza per il sistema democratico. Per fare questo dobbiamo fare alcune riforme al testo costituzionale, ma in sostanza 
dovremmo accertare l'interpretazione che hanno i membri del Congresso dell'istituzione.

Come con la generalità della ricerca, e questa non fa eccezione, abbiamo completato un lavoro che, sebbene risponde alcune domende, allo stesso tempo apre altri approcci da cui possiamo iniziare a disegnare nuove indagini, ipotesi e obiettivi. 
BIBLIOGRAFÍA 


\section{BIBLIOGRAFIA}

\section{$\underline{A}$}

ABELLÁN, Ángel Manuel (1996): "Notas sobre la evolución histórica del parlamento y la representación política", Revista de Estudios Políticos (Nueva Época), Número 92 abril-junio, p. 165.

ACKERMAN, Bruce (2007): "Contra el presidencialismo", Revista Claves de la Razón Práctica, Na 178. Pp. 12 a 21.

AGUIAR DE LUQUE, Luis (1997): "La problemática del control en la actualidad" en Ramírez, Manuel (edit.), El debate Parlamentario (Madrid, Editorial Trotta, Fundación centro de estudios políticos y constitucionales "Lucas Mallada", colección estructuras y procesos) p.83

ALBA NAVARRO, Manuel (2001): "Los sujetos del derecho parlamentario. Ponencia general", en Eusko Legelbitzarra (edit.), Instituciones del derecho parlamentario III: "Los sujetos del derecho parlamentario", (Vitoria-Gasteiz, Editorial Eusko Legebiltzarra, Parlamento Vasco, colección informes y documentos) p. 30

ALBERTI, Jaime (1980): "Martínez Marina: derecho y política" (Oviedo, Editorial Graficas Summa S.A.) Pp. 163.164 y 165.

ALDUNATE LIZANA, Eduardo (2005): "El fin de la transición hacia una Constitución de poca importancia. Visión crítica de la reforma de la Ley Na 20.050", en ZÚÑIGA URBINA, Francisco (coordinador), "Reforma Constitucional" (Santiago, Editorial Lexis Nexis).

ALONSO DE ANTONIO, José y Ángel (2002): "Introducción al Derecho Parlamentario", Madrid, editorial Dykinson.

ALONSO GONZALEZ, Benjamín (1978): "El juicio de residencia en Castilla, I: origen y evolución hasta 1480". Anuario de historia del derecho español, Vol. No 48, 193-248.

ALLESCH PEÑAILILLO, Johann (2003): "Presupuestos para un proceso de modernización del Congreso Nacional", Revista de derecho de la Pontificia Universidad Católica de Valparaíso, Vol. No XXIV, pp. 29-58.

AMPUERO VILLAGRÁN, Hernán (2013): "Algunos antecedentes de la función legislativa de la Cámara de diputados de Chile (1990-2010), Revista Enfoques, Vol. XI, No 19, Pp. 39 y 40.

AMUNATEGUI JORDÁN, Gabriel (1947):"Derecho constitucional", (Santiago, Editorial Universitaria).

ANDRADE GEYWITZ, Carlos (1988): "Génesis de las constituciones de 1925 y 1980", (Santiago, Editorial Jurídica, Ediar-Conosur Ltda.) 
ARAGÓN REYES, Manuel (1986): "El control parlamentario como control político". Revista de Derecho Político. Vol. 23, p. 26.

ARAGÓN REYES, Manuel (1986): "La interpretación de las Constitución y el carácter objetiva del jurisdiccional", Revista Española de derecho constitucional. Año 6, Vol. $N^{\circ} 17$, mayo-agosto.

ARAGÓN REYES, Manuel (1995): "Constitución y control del poder, introducción a una teoría constitucional del control" (Buenos Aires, Ediciones Ciudad Argentina, Fundación Centro de Estudios Políticos y Administrativos) p.144

ARAGON REYES, Manuel (1998): "Estudios de derecho constitucional" (Madrid, Centro de estudios constitucional, Colección Estudios Constitucionales) Pp. 255 y 261

ARAGÓN REYES, Manuel (2004): "El papel del rey en la monarquía parlamentaria", Fundación Manuel Jiménez Abad de Estudios políticos y parlamentarios.

ARANCIBIA MATTAR, Jaime (1999):"Responsabilidad de los gobernantes por daños y perjuicios causados a los gobernantes en Chile indiano. Once casos de jurisprudencia (1552-1798), Revista chilena de Historia del Derecho, Vol. No 18, pp.53-83.

ARISTÓTELES (1970): "Política" (trad. Julián Marias y María Araujo, Madrid, Editorial Instituto de Estudios Políticos, primera edición) p.7 y 78.

ASENSI SABATER, José (2002): "El futuro de las funciones del Parlamento" en PAU I VALL, Francesc (Coord.) "El Parlamento del siglo XXI" (Madrid, Editorial Tecnos, Asociación Española de Letrados de Parlamentos) Pp. 49, 50 y 51.

\section{B}

BAENA DEL ALCÁZAR, Mariano (1978):"Los actos políticos del Gobierno en el Derecho Español (I)". Documentación administrativa № 177. ISBN 0012-4494, pp. 5-62.

BAENA DEL ALCÁZAR, Mariano (1978):"Los actos políticos del Gobierno en el Derecho Español (Y II)". Documentación administrativa № 178. ISBN 0012-4494, pp. 5-48.

BAGEHOT, Walter (1826-1877): "La Constitución inglesa" (trad. por Adolfo Posada, Madrid, Editorial la España Moderna, Biblioteca de Jurisprudencia).

BARRIENTOS GRANDON, Javier (1992-1993): "La Fiscalización de los actos de gobierno en la época indiana y su desaparición durante la república", Revista de Estudios Histórico-Jurídico, sección Historia del Derecho Indiano, Vol. No XV, pp. 105-130. 
BELLO CODEISO, Emilio (1954): "Recuerdos políticos; La junta de gobierno de 1925. Su origen y relación con la reforma del régimen constitucional" (Santiago, Editorial Nascimiento).

BERMÚDEZ SOTO, Jorge y MIROSEVIC VERDUGO, Camilo (2008):" El acceso a la información pública como base para el control social y la protección del patrimonio público". Revista de Derecho de la Pontificia Universidad Católica de Valparaíso. Vol. $\mathrm{N}^{\circ}$ XXXI, segundo semestre, pp.436-468.

BERNASCHINA, Mario y PINTO, Fernando (1945): "Los constituyentes de 1925", (Introducción de Aníbal Bascuñán Valdés, Santiago, Editorial Universidad de Chile).

BERRIOS, Fabiola y GAMBOA, Ricardo (2006): "El Congreso nacional chileno y el ejercicio de sus funciones legislativas y fiscalizadoras (1990-2006)", Revista Política (Santiago, Universidad Chile) p. 113.

BERTELSEN REPETTO, Raúl (1989): "Las reformas a la parte orgánica de la Constitución". Revista Chilena de Derecho, Vol.16 N03 (septiembre-diciembre) pp. 599-605.

BIDART HERNÁNDEZ, José (2013): "Antecedentes sobre el establecimiento y reforma de la "atribución exclusiva de la Cámara de Diputados en la fiscalización de los actos del gobierno" en el artículo 52 número 1 letra A de la Constitución de 1980, en Pfeffer Urquiaga, Emilio (edit.) Congreso Nacional, Libro homenaje al profesor Alejandro Silva Bascuñán (Santiago, Editorial Jurídica de Chile) pp. 19-31.

BIGLINO CAMPOS, Paloma (1991): "Los vicios en el procedimiento legislativo" (Madrid, Centro de Estudios Constitucionales) Pp. 73 y 81.

BLANCO VÁLDES, Roberto (2000): "Control parlamentario, oposición política y alternancia en el Estado de partidos (una reflexión a partir de la experiencia española)", en Monreal, Antoni (edit.) La división de poderes: El Gobierno (Barcelona, Institut de Ciències Polítiques i Socials, Universitat de Lleida) Pp. 38 y 39

BOBBIO, Norberto (1986): "El futuro de la democracia" (trad. José F. Fernández Santilla, México, Fondo de Cultura Económica) p. 25.

BODIN, Jean (1985): "Los seis libros de la república" (trad. Pedro Bravo Gala, Madrid, Editorial Tecnos S.A.) p. 72

BOLOÑA KELLY, Germán (2005): "El acto administrativo" (Santiago, Editorial Lexis Nexis) Pp. 10 y 11.

BRAHM GRACÍA, Enrique; BERTELSEN REPETTO, Raúl y AMUNÁTEGUI ECHEVERRÍA, Andrés (2002): "Régimen de Gobierno en Chile ¿presidencialismo 0 parlamentarismo? 1924-1973", (Primera edición, Editorial Jurídica de Chile, Santiago, agosto). p. 20. 
BRAVO LIRA, Bernardino (1991): "Parlamentarismo a la chilena", Revista Chilena de Derecho Vol. 18, N03, septiembre-diciembre, pp.363-373.

BRAVO LIRA, Bernardino (1992-1993):"El primer constitucionalismo en Chile (18111861)", Revista de Estudios Históricos-Jurídicos, sección historia del Derecho Chileno, Vol. No XV, pp. 303-331.

BRONFMAN VARGAS, Alan (2001): "Diez años del funcionamiento del sistema binominal", Revista de Derecho de la Universidad Católica de Chile, Valparaíso, Vol. XXII, p.51.

BRONFMAN VARGAS, Alan (2003): "Las Comisiones Parlamentarias y el Ejercicio de las Facultades Fiscalizadoras", Revista de Derecho de la Pontificia Universidad Valparaíso versión XXIV, pp. 105-153.

BRONFMAN VARGAS, Alan (2005): "El tipo de responsabilidad perseguida en el juicio político", Revista de Derecho de la Pontificia Universidad Católica de Valparaíso, Vol. No XXVI, segundo semestre, Pp. 91 a 93.

BUSTOS GISBERT, Rafael (2001): "La responsabilidad política del gobierno: ¿Realidad o Ficción?; (Madrid, Editorial Colex) Pp. 11-20.

BUSTOS GISBERT, Rafael (2007): "Corrupción de los gobernantes, responsabilidad política y control parlamentario", Revista Teoría y Realidad Constitucional, Vol. No 19 , p. 142.

\section{$\underline{\mathbf{C}}$}

CAAMAÑO DOMINGUEZ, Francisco (2004): "Representación o Participación de las minorías: sobre la determinación de algunos espacios constitucionales útiles a las políticas del reconocimiento", Revista Fundamentos: Cuadernos monográficos de teoría del Estado y derecho público e historia constitucional, ³, Vol. 8, p.10.

CABEZAS, José Miguel y NAVIA, Patricio (2005): "Efecto del sistema binominal en el número de candidatos y de partidos en las elecciones legislativas en Chile, 19892001", Revista de Ciencia Política, Vol. No 45, primavera, pp. 29-51.

CANSINO, César (1993): "La consolidación de la democracia en América Latina: problemas y desafíos", El Congreso de México: Foro Internacional, Vol. 33, N04 (134), octubre-diciembre. Pp. 734 y735

CAÑAS KIRBY, Enrique (1997): "Proceso político en Chile: 1973-1990" (Santiago, Editorial Andrés Bello) Pp.215 y 300.

CAPPELLETTI, Mauro (1986): "¿Renegar de Montesquieu?, La expansión y la legitimidad de la "justicia constitucional". Trad. Por Pablo de Luis Durán. Revista Española de derecho constitucional. Año 6, Vol. Nº17, (mayo-agosto). 
CARDUCCI, Michele (1996): "Controllo e teorie costituzionale" (Padova, Casa Editrice Dott. Antonio Millani CEDAM) p. 8

CARDUCCI, Michele (2002): "El control político derecho comparado e italiano", en PAU I VALL, Francesc (Coord.), "El Parlamento del siglo XXI" (Madrid, Editorial, Tecnos, Asociación Española de Letrados de Parlamentos) Pp. 86 y 90

CAREY John M. y SIAVELIS, Peter (2003): "El "seguro" para los subcampeones electorales y la sobrevivencia de la Concertación", Revista de Estudios Públicos, Vol. 90, otoño. Pp. 9 y 11.

CARRASCO DELGADO, Sergio (1983): "Génesis y vigencia de los textos constitucionales chilenos" (Santiago, Editorial Jurídica de Chile, segunda edición).

CARRE DE MALBERG, Raymond (1948): "Teoría General del Estado" (Trad. José Lión Depetre, fondo de cultura económica, México, primera edición española). P.105.

CARRILlO, Marc (2002): "Las hipotecas de la Constitución de Chile". Revista de estudios políticos, Vol. N¹15, pp. 81-98.

CARTER M, Gwendolen y HERZ H., John (1964): "Gobierno y Política en el siglo XX" (trad. Pedro Aguirre Espinosa, México, Editorial Limusa Wiley, S.A.) p. 32 y 33.

CAZOR ALISTE, Kamel (2005): "Reformas de 2005: ¿Constitución auténticamente democrática? ¿Nueva Carta Fundamental?, en NOGUEIRA, Humberto (coordinador), "La Constitución Reformada de 2005" (Santiago, Editorial Librotecnia, Centro de Estudios Constitucionales de Chile, Universidad de Talca).

CEA EGAÑA, José Luis (1991-1992):"Sobre las constituciones y el constitucionalismo chilenos", Revista de Derecho de la Universidad Católica de Valparaíso, Vol. No XIV, pp.173-190.

CEA EGAÑA, José Luis (1993): "Fiscalización parlamentaria del Gobierno", Revista Chilena de Derecho, Vol. 20, № 1, (enero-abril), pp. 7-20.

CEA EGAÑA, José Luis (2008): "Derecho constitucional chileno, Tomo I" (Santiago, Ediciones Universidad Católica, segunda edición actualizada).

CHANTEABOUT, Bernard (2012): "Droit constitutionnel" (Francia, Editeur SIREY, édition $N^{\circ} 29$ ).

CHIMENTÍ, Carlo (1974): "Il Controllo parlamentare nell'ordenamento italiano", Quaderni della giurisprudenza costituzionale (Milano, Editore Doot. A. Giuffé) p.257

CHIMENTÍ, Carlo (2001): "Compendio di diritto costituzionale italiano e di elementi comparative" Volumen I (Torino, Editore G. Giappichelli, segunda edición) p. 202.

COLLANTES DE TERÁN DE LA HERA, María José (1998): "El juicio de residencia en Castilla a través de la doctrina jurídica de la Edad Moderna", Revista de Historia, Instituciones y Documentos Vol. No 25, pp. 151-184. 
COLLIER, Simón (1977): "Ideas Políticas de la Independencia chilena 1808-1833" (Trad. por Carmen Cienfuegos W. Santiago, editorial Andrés Bello, primer edición en español).

COLLIER, Simón (2008): "La construcción de una República 1830-1865. Política e Ideas" (Trad. Fernando Puercell Torreti, Chile, Ediciones Universidad Católica de Chile, Segunda Edición).

CONDE, Francisco Javier (1945): "Representación política y régimen español" (Madrid, Ediciones de la Subsecretaria de Educación Popular) p.17.

CONSTANT, Benjamín (1989): Escritos Políticos (Trad. María Luisa Sánchez Mejia, Madrid, Centro de Estudios Constitucionales) p. 8

CORDERO QUINZACARA, Eduardo (2005): "La facultad fiscalizadora de la Cámara de Diputados", en ZÚÑIGA URBINA, Francisco (coordinador), "Reforma Constitucional" (Santiago, Editorial Lexis Nexis).

CORDERO VEGA, Luis (2015): "Lecciones de derecho administrativo" (Santiago, Editorial Legal Publishing, segunda edición corregida) Pp. 259-260.

CORREA, Sofía; FIGUEROA, Consuelo; JOCELYN-HOLT, Alfredo; ROLLE, Claudio y VICUÑA, Manuel (2001): "Historia del Siglo XX chileno", (Santiago, Editorial Sudamericana, primera edición).

COSTA, Pedro (2004): "Derechos", en Fioravanti, Maurizio (edit.), "El Estado moderno en Europa" (trad. Manuel Martínez Neira, Madrid, Editorial Trotta S.A.) p.52.

COX, W. Gary, MORGENSTERN, Sacott and WOLFSON, Leandro (2001): "Latin America 's Reactive Assemblies and Proactive Presidents". Comparative Politics, Vol. 33, p. 171.

CRISTI, Renato y RUIZ-TAGLE, Pablo (2006): "La República en Chile, teoría y práctica del constitucionalismo republicano" (Santiago, Ediciones LOM, primera edición).

CROSSMAN, R.H.S (1958): "Biografía del Estado Moderno" (trad. por J.A. Fernández de Castro, México, Fondo de Cultura Económico, cuarta edición en inglés) p.22.

CUMPLIDO, Francisco (1985): "Una salida político constitucional para Chile. Exposiciones y debates del Seminario "Un sistema jurídico-político constitucional para Chile", realizado el 27 y 28 de julio de 1984, Santiago, Chile", (Editorial Instituto chileno de estudios humanísticos, primera edición). 


\section{$\underline{\mathbf{D}}$}

DE JUOVENEL, Bertrand (1974): El Poder (trad. J. de Elzaburu, Madrid Editorial Nacional) p. 129

DE VEGA, Pedro (1985): "Significado constitucional de la representación política", Revista de Estudios Políticos (Nueva época), Número 44 marzo-abril, p.27.

DE VERGOTTINI, Giuseppe (1985): "Derecho constitucional comparado" (trad. Pablo Lucás Verdú, Madrid, Editorial Espasa-Calpe S.A., segunda edición) Pp. 395 y 397.

DE VERGOTTINI, Giuseppe (2010): "Diritto Costituzionale" (Padova, Casa Editrice Dott. Antonio Milani, settima edizione) p. 519

DELCAMP, Alain (2010): La Perception du Contrôle Parlementaire. Comment le rendre plus attractif? , Le Seuil « Pouvoirs », Vol. 3, N 134, pp.109-122.

DI PALMA, Giuseppe, CHAPARRO, Sandra y DEL ÁGUILA, Rafael (1988): "La consolidación democrática: una visión minimalista", Revista Española de Investigaciones Sociológicas, Vol. No 42, abril-junio, pp.67-92.

DÍAZ DE VALDÉS, José Manuel (2001): "Carl Schmitt y el Congreso Nacional Instaurado por la Constitución de 1980". Revista de Derecho de la Universidad Católica de Valparaíso, Vol. XXII, (2001) pp.75-80.

DÍAZ DE VÁLDES, Rodrigo (2013): "Acusación constitucional y debido proceso", en Pfeffer Urquiaga, Emilio (edit.) Congreso Nacional, Libro homenaje al profesor Alejandro Silva Bascuñán (Santiago, Editorial Jurídica de Chile) pp. 99-118.

DÍEZ ESPINOSA, José Ramón (1998):"La democracia parlamentaria en la República de Weimar: entre el mito y la realidad". Investigaciones Históricas. Época moderna y contemporánea. pp. 287-311.

DÍEZ-PICAZO, Luis María (1996): "La criminalidad de los gobernantes" (Barcelona, editorial Critica Grijalbo Mondadori S.A.) P. 61.

DIPPEL, Horts (2005): "Constitucionalismo moderno. Introducción a una historia que necesita ser escrita", Revista Historia Constitucional (revista electrónica), Vol. № 6, ver en: http://hc.rediris.es/06/index.html.

DONOSO LETELIER, Crescente (1976): "Notas sobre el origen, acatamiento y desgaste del régimen presidencial: 1925-1973", (Santiago, trabajo patrocinado por la Oficina Coordinadora de Investigaciones, profesor Jaime Eyzaguirre, de la Facultad de Derecho de la Pontifica Universidad Católica de Chile).

DÖRING, Herbert (2001): "Parliamentary Agenda Control and Legislative Outcomes in Western Europe", Legislative Studies Quarterly, Vol. 26, No. 1, febrero. Pp. 145165. 
DOUGNAC RODRÍGUEZ, Antonio (2000): "El sistema jurídico indiano en el constitucionalismo chileno durante la Patria Vieja (1810-184)", Revista de Estudios Histórico-Jurídicos, Sección historia de los Derechos Patrios Iberoamericanos, Vol. No XXII, PP.225-266.

DUGUIT, León (1926): "Manual de derecho constitucional" (trad. José G. Acuña, Madrid, Editorial Francisco Beltrán librería española y extranjería, segunda edición española) p.25.

DUVERGUER, Maurice (1957): "Los partidos políticos" (España, editorial fondo de cultura económico, primera edición en español) Pp. 420 y 421.

DUVERGUER, Maurice (1970): "Instituciones políticas y derecho constitucional" (Barcelona, editorial Ariel, quinta edición en español).

\section{$\underline{\mathbf{E}}$}

EMBID IRUJO, Antonio (1992): "El control parlamentario del Gobierno y el principio de la mayoría parlamentaria, algunas reflexiones". Revista de las Cortes Generales, Vol. 25, primer cuatrimestre. Pp. 11 y 17.

ENCICLOPEDÍA GIURIDCA (1988): Volumen IX, Tomo I (Roma, Istituto de la Enciclopedia italiana, Fondata da Giovanni Treccani) p.1

ENRÍQUEZ FUENTES, Gastón J. (2006). "El control político como requisito del estado constitucional. Evolución histórica"; Criterio Jurídico. Vol. 6: p. 46.

ESTÉVEZ GAZMURI, Carlos (1942): "Reformas que la Constitución de 1925 introdujo a la de 1833", (Santiago, Editorial Universidad Chile).

ESTÉVEZ GAZMURI, Carlos (1948): "Derecho constitucional. Tomo primero, parte $I I^{\prime \prime}$, (Santiago, Editorial Fundación Publicaciones de la Universidad Católica, escuela de leyes).

EYZAGUIRRE, Jaime (1953): "Historia constitucional de Chile" (Santiago, editorial Universitaria).

\section{$\underline{\mathbf{F}}$}

FERMANDOIS VÖHRINGER, Arturo y GARCÍA GARCÍA José Francisco (2009): "Origen del presidencialismo chileno: Reforma constitucional de 1970, ideas matrices e iniciativa legislativa exclusiva". Revista chilena de derecho, Vol. 36 No 2, pp. 281311.

FERNÁNDEZ-VIAGAS BARTOLOMÉ, Plácido (2008): "El poder legislativo entre la política y el derecho" (Navarra, Editorial Aranzadi S.A.) p. 26. 
FERRADA BORQUEZ, Juan Carlos. "La Reforma Constitucional a la Fiscalización Parlamentaria en la Constitución de 1980: un análisis preliminar" Ius et Praxis [online]. 2002, vol.8, n.1 [citado 2013-04-01], pp. 461-481. Disponible en: http://www.scielo.cl/scielo.php?script $=$ sci arttext\&pid $=S 071800122002000100025 \&$ lng=es\&nrm=iso.

FIORAVANTI, Maurizio (2004): "Estado y constitución", en Fioravanti, Maurizio (edit.), "El Estado moderno en Europa" (trad. Manuel Martínez Neira, Madrid, Editorial Trotta S.A.) p.14.

FIORAVANTI, Maurizio (2014): "Constitucionalismo: Experiencias históricas y tendencias actuales" (trad. Adela Mora Cañada y Manuel Martínez Neira, Bologna, Eduitorial Trotta S.A.)

FLÓREZ RUIZ, José Fernando (2010): "Parlamentarismo frente a presidencialismo. Actualización de un debate crucial para América Latina", Revista de Derecho del Estado, Vol. No 25, diciembre, pp.135-158.

FREIXES SANJUÁN, Teresa y REMOTTI CARBONELL, José Carlos (1992): "Los valores y principios en la interpretación constitucional". Revista española de Derecho Constitucional. Año 12, Vol. N³5, (mayo-agosto), pp. 97-109.

FRIEDRICH, Carl J. (1975): "Gobierno constitucional y democracia; teoría y práctica en Europa y América, Tomo I" (trad. Agustín Gil Lasierra, Madrid, Editorial Gráfica Espejo S.A., Instituto de Estudios Políticos, colección ciencia política).

\section{$\underline{\mathbf{G}}$}

GALEOTTI, Serio (1963): "Introduzione alla teoria di controlli costituzionali" (Milano, Editore Dott. A. Giuffré) p. 43.

GARCÉS, Joan E. (1972): "Revolución, Congreso y Constitución, El caso Tohá" (Santiago, Editorial Nacional Quimantu Limitada, primera edición).

GARCÍA GARCÍA-SOTOCA, Francisco Javier (2002): "Los actos políticos del Gobierno ¿limite negativo de la jurisdicción? Revista jurídica de la Comunidad de Madrid, Vol. No1-14, pp.1-3.

GARCÍA GUERRERO, José Luís (2000): "Democracia representativa y partidos políticos", en López Garrido Diego; Massó Garrote, Marcos y Pegoraro, Lucio (edit.), Nuevo derecho constitucional comparado (Valencia, editorial tirant to Blanch libros) Pp. 576 y 577.

GARCÍA MARTÍNEZ, María Asunción (1897): "El procedimiento legislativo", (Madrid, Publicaciones del Congreso de los Diputados, Dirección de Estudios y Documentación de la Secretaría General, serie IV: Monografías No 10) Pp. 45 a 55. 
GARCÍA MARTÍNEZ, María Asunción (1988): "La actividad legislativa del Parlamento como mecanismo de control político", Revista de las Cortes Generales, España, segundo cuatrimestre Vol. No 14, p. 66.

GARCÍA MORILLO, Joaquín (1985): "El control parlamentario del Gobierno en el ordenamiento español" (Madrid, Editorial publicaciones del Congreso de los Diputados, secretaria general, seria IV: monografías Nº1) p. 20.

GARCÍA MORILLO, Joaquín (1991):"Mitos y realidades del parlamentarismo", Revista del Centro de Estudios Constitucionales, Vol. No 9, mayo-agosto, pp. 115-144.

GARCÍA MORILLO, Joaquín (1998): "Responsabilidad política y responsabilidad penal", Revista Española de Derecho Constitucional, Año 18, Vol. No 52, p. 82.

GARCÍA RUIZ, José Luis (2010): Introducción al Derecho Constitucional (Cádiz, Editorial Servicios de Publicaciones de la Universidad de Cádiz, primera edición) p. 31.

GARCÍA, Fátima y MARTÍNEZ BARAHONA, Elena (2002): "La estrategia política y parlamentaria de los partidos de oposición latinoamericanos: ¿capacidad de influencia o influencia efectiva? Revista Instituciones y Desarrollo, Vol. 12-13. Pp. 331-373.

GARCÍA-ESCUDERO, Piedad (1999): "Consideraciones sobre la iniciativa del Gobierno, Cuadernos de Derecho Público, Vol. № 8 (septiembre-diciembre) p.23

GARCÍA-ESCUDERO, Piedad (2011): "El parlamentario Individual en un parlamento de grupos: La participación en la función legislativa", Revista Teoría y Realidad Constitucional, UNED. Vol. No 28, Pp. 221, 222 y 223.

GARCÍA-HUIDOBRO BECERRA, Cristóbal (2010): "200 años de desarrollo jurídico en el Chile Republicano. Notas para un balance". Revista Chilena de Derecho, Vol. 37 $\mathrm{N}^{\circ} 2$, pp. 401-403.

GARCÍA-HUIDOBRO BECERRA, Cristóbal (2012):"El reglamento constitucional provisorio de 1812: Reflexiones para un bicentenario". Revista Chilena de Derecho, Vol. $39 \mathrm{~N}^{\circ} 1$, pp. 235-243.

GARCÍA-PELAYO, Manuel (1982): "Las transformaciones del Estado contemporáneo", (Madrid, Editorial Alianza S.A., tercera edición corregida y aumentada).

GARCÍA-PELAYO, Manuel (1984): "Derecho constitucional comparado" (Introducción de Manuel Aragón, Madrid, Editorial Alianza S.A., primera edición) p. 29.

GARCIA-PELAYO, Manuel (1986): "El Estado de Partidos" (Madrid, Alianza Editorial S.A.) p. 29. 
GARRETÓN, Manuel Antonio (1999): "Balance y perspectiva de la democratización política chilena", en Menéndez-Carrión, Amparo y Joignant, Alfredo (edit.) "La caja de Pandora, el retorno de la transición chilena" (Santiago, Editorial Planeta Chilena S.A., primera edición) p.59

GARRETÓN, Manuel Antonio y MOULIAN, Tomás (1979): "Procesos y bloque políticos en la crisis chilena de 1970-1973", Revista Mexicana de Sociología, Vol. 41, N 1, Análisis de Coyuntura.

GARRIDO MAYOL, Vicente (2010): "Las garantías del procedimiento pre legislativo: la elaboración y aprobación de los proyectos de ley" (Valencia, Editorial Tiran lo Blanch) p.22

GARRORENA MORALES, Ángel (1991): "Representación política y Constitución democrática", Hacia una revisión crítica de la representación (Madrid, Editorial Civitas S.A., primera edición) Pp. 37, 38 y 39.

GARRORENA, Ángel (1998): "Algunas sugerencias para renovar la función de control parlamentario", Revista Mexicana de Sociología, Vol. 60 № 2 (abril-junio) Pp. 26 y 27.

GICQUEL, Jean y GICQUEL, Jean-Éric (2015): "Droit constitutionnel et institutiones politiques". (Francia, Editeur Domat droit public, LGDJ, lextenso éditions, édition $N^{\circ}$ 29).

GIERKE, Von Otto (1995): "Teorías políticas de la edad media" (trad. Piedad García Escudero, Madrid, Centro de Estudios Constitucionales) p.198.

GODOY ARCAYA, Oscar (1999): "La transición chilena a la democracia pactad". Revista Estudios Políticos N74, pp.79-106.

GODOY ARCAYA, Oscar. (2003):"Parlamento, Presidencialismo y Democracia protegida". Revista de Ciencia Política, Vol. 23, No 2: pp. 7-23.

GÓMEZ TAMAYO, Daniel Fernando (1997): "Responsabilidad jurídica y política del gobernante en la historia de las ideas políticas", Díkaion Revista de Actualidad Jurídica, Vol. No 1. Pp. 5 y6.

GÓNGORA, Mario (1994): "Ensayo Histórico sobre la noción de Estado en Chile en los Siglos XIX y XX" (Santiago, Editorial Universitaria, quinta edición).

GONZALEZ CASANOVA, José (1980): "Teoría del Estado y Derecho Constitucional" (España, Editorial Vincens-Vives, primera edición) Pp. 21, 22 y 24. 
GONZÁLEZ DE ZÁRATE LORENTE, Roberto (2012): "El obstruccionismo parlamentario", Asamblea: Revista parlamentaria de la Asamblea de Madrid, Vol. No 27, PP. 183-202.

GONZÁLEZ, Ramón (1893): "La Revolución de Chile, proceso á los ministros del Gobierno derrocado y el parlamentarismo", (Buenos Aires, Editorial "El Literario" N52, disponible en Biblioteca del Congreso Nacional, Colección Raros y Valiosos, monografías).

GRATEROL STEFANELLI, Giuseppe (2013): "La función parlamentaria de control en la democracia y en un estado de derecho" (Venezuela, Observatorio Económico y Legislativo de CEDICE Libertad, Serie Diálogo Democrático No 4) p.6.

GUMUCIO, Rafael (2005): "Chile: corrupción y poder". Polis: Revista Latinoamericana. No 12, p. 3.

GUTIÉRREZ CHÁVEZ, Jorge (2006): "La corrupción en Italia, la muerte de un régimen" (Madrid, Revista Interdisciplinar Entelequia, primera edición, noviembre.)

GUTIÉRREZ, Gerónimo; LUJAMBIO, Antonio y VALDÉS, Diego (2001): "El proceso presupuestario y las relaciones entre los órganos del poder. El Caso Mexicano en Perspectiva Histórica y Comparada", (México, Editorial Universidad Nacional Autónoma de México, Instituto de Investigaciones Jurídicas, serie Ensayos Jurídicos N02) pp. 81 y 82.

\section{H}

HAURIOU, André (1980): "Derecho constitucional e Instituciones políticas", (trad. José Antonio González Casanova, Barcelona, Editorial Ariel, segunda edición), p. 69 y 70.

HEGEL, Guillermo Federico (1937): "Filosofía del derecho" (trad. De Angélica Mendoza de Montero, introducción de Carlos Marx, Buenos Aires, Editorial Claridad S.A., primera edición) p. 208.

HEISE GONZALEZ, Julio (1950): "Historia constitucional de Chile" (Santiago, Editorial Jurídica de Chile, colección apuntes de clases N03).

HELLER, Hermann (1995): "La soberanía", (trad. Mario de la Cueva, México, Editoriales Fundación, Escuela Nacional de Jurisprudencia, A.C. y Fondo de Cultura Económico, segunda edición) p.85.

HENRÍQUEZ, Camilo (1960): "Escritos políticos de Camilo Henríquez" (introducción y recopilación de Raúl Silva Castro, Ediciones Universidad de Chile). 
HERNÁNDEZ OLIVER, Blanca (2003): "Parlamento y Estado de paridos. La democracia contemporánea". Revista de las Cortes Generales, tercer cuatrimestre No 60. p.150.

HERRERO Y RODRIGUEZ DE MIÑóN, Miguel (1997): "El Estado de partidos y la vida parlamentaria" en Ramírez, Manuel (edit.), El debate Parlamentario (Madrid, Editorial Trotta, Fundación centro de estudios políticos y constitucionales "Lucas Mallada", colección estructuras y procesos) p.53.

HESISE GONZALEZ, Julio (1974): "Historia de Chile. El período parlamentario 18611925", (Santiago, Editorial Andrés Bello).

HOBBES, Thomas (1989): El Leviatán: la materia, forma y poder de un Estado eclesiástico y civil (Trad. Carlos Mellizo, Madrid, Editorial Alianza S.A.) P.87.

HUBE, Constanza; GONZÁLEZ, Jaime; ZÁRATE, Sebastián (primer semestre 2011). "Control político de gobierno y la legislación"; Revista Hemiciclo, Academia Parlamentaria de la Cámara de Diputados, Vol. No 4: p. 28.

HUME, David (1965): "Ensayos políticos de David Hume" (trad. Francisco González Aramburu, introducción por Charles W. Hnedel México, Editorial Herrero Hermanos, SUCS., S.A., primera edición en español).

HUNEEUS, Carlos; BERRÍOS, Fabiola (2005). "El Congreso en el presidencialismo. El caso Chile". Revista Sociedad Argentina de Análisis Político, Vol. 2, No 2: p.368.

HUNEEUS, Jorge (1879): "La Constitución ante el congreso, o sea comentario positivo de la Constitución chilena" (Santiago, Imprenta de Los Tiempos).

\section{$\underline{\mathbf{I}}$}

INFANTE, Javier (2014): "Autonomía, Independencia y República en Chile 18101828" (Santiago, Ediciones Centro de Estudios Bicentenario, primera edición)

\section{$\underline{\mathbf{J}}$}

JARPA DÍAZ DE VALDÉS, Emilio (1966): "El juicio de residencia en Chile durante el siglo XVIII", (Santiago, Memoria para optar al grado de Licenciado en Ciencias Jurídicas, Universidad de Católica de Chile) p. 8 y32.

JELLINEK, Georg (1914): Teoría General del Estado, Tomo primero (Madrid, librería general de vitoriano Suárez, segunda edición alemana) p.459. 
JELLINEK, Georg (1981); "Fragmentos del Estado" (trad. Michael Forster, Miguel Herrera de Miñon y José Carlos Esteban, Madrid, Editorial Civitas S.A.) p.69.

JIMÉNEZ DE PARGA, Manuel (1983): "Los regímenes políticos contemporáneos, Las democracias con tradición democrática" (Madrid, Editorial Tecnos, sexta edición) p.327

\section{$\underline{\mathbf{K}}$}

KANT, Immanuel (1985): "La paz perpetua" (trad. Joaquín Abellán, Madrid, Editorial Tecnos) Pp.14 y 15.

KELSEN, Hans (1988): "Escritos sobre la democracia y el socialismo" (Madrid, colección universitaria, editorial debate) Pp. 215, 216, 221 y 222.

KELSEN, Hans (2002): "Esencia y valor de la democracia" (Granada, editorial Comares S.I.) Pp. 36 y 39

KELSEN, Hans (2002): "Observaciones sobre la Constitución chilena". Anuario de Filosofía Jurídica y Social: sobre la cultura jurídica chilena. Sociedad Chilena de Filosofía Jurídica y Social, Vol. N²0.

\section{$\underline{\mathbf{L}}$}

LARENZ, Karl (1942): "La filosofía contemporánea del derecho y el estado" (trad. E. Galán Gutiérrez y A. Truyol Serra, prólogo del L. Legaz Lacambra, Madrid, Editorial Revista de Derecho Privado) Pp. 34 y 38.

LASKI, J. Harold (1932): "El Estado moderno, instituciones políticas y económicas, Tomo II" (Trad. y prologo por Teodoro González García, Barcelona, editorial Librería Bosch).

LE DIVELLEC, Armel (2010): "Des effets du contrôle parlamentaire". Le Suil Pouvoirs, Vol.3 No134, pp. 123-139.

LIJPHART, Arend (1997): "Presidencialismos y democracia mayoritaria: Observaciones teóricas", en Linz, Juan y Valenzuela, Arturo (edit.) "La crisis del presidencialismo, 1. Perspectivas comparativas", (Madrid, Alianza Editorial, Tomo I).

LINARES, Sebastián (2011): "Treinta años de parlamentarismo-presidencialismo: un balance de de las evidencias". Revista española de Ciencias Políticas, No 27, pp. 944. 
LINZ, Juan (1997): "Democracia presidencial o parlamentaria ¿Qué diferencia implica?", en Linz, Juan y Valenzuela, Arturo (edit.) "La crisis del presidencialismo, 1. Perspectivas comparativas", (Madrid, Alianza Editorial, Tomo I).

LINZ, Juan (2013): "Los peligros del presidencialismo", Revista Latinoamericana de Política Comparada, Vol. No 7, julio.

LINZ, Juan; LIJPHART, Arend; VALENZUELA, Arturo; GODOY, Oscar (1990): "Hacia una Democracia Moderna la opción Parlamentaria", (Santiago, ediciones Universidad Católica de Chile, primera edición) pp. 16-17.

LOCKE, John (1969): "Ensayo sobre el Gobierno civil" (trad. Amando Lazaro Ros, Madrid, Editorial Aguilar S.A.).

LOEWENSTEIN, Karl (1976): "Teoría de la constitución" (trad. Alfredo Gallego Anabitarte, Barcelona, Editorial Ariel, segunda edición) p. 23

LÓPEZ AGUILAR, Juan Fernando (1988): "La oposición parlamentaria y el orden constitucional. Análisis del estatuto de la oposición en España", (Madrid, Centro de Estudios Constitucionales, colección <<Estudios Constitucionales>>) Pp. 61, 66 y 67.

LÓPEZ GUERRA, Luis (2002): "Organización y funcionamiento del Parlamento del futuro" en PAU I VALL, Francesc (Coord.) "El Parlamento del siglo XXI", (Madrid, Editorial Tecnos, Asociación Española de Letrados de Parlamentos) Pp. 31 y 32.

LOUGHLIN, Martín (2010): "Fundation of public law", (New York, Oxford University Press, first published).

\section{$\underline{\text { 느 }}$}

LLORENDA CAICEDO, Rodrigo (1967): "El sistema presidencial de gobierno". (Tesis para optar al grado de doctor en ciencias jurídica. Pontifica Universidad Javeriana) pp. 30 a 39.

\section{$\underline{\mathbf{M}}$}

MAINWARING, Scott y SHUGART, Matthew (2002): "Presidencialismo y sistema de partidos en América Latina", Revista Uruguaya de Ciencia Política.

MAÍZ, Ramón (1991): "Estado constitucional y gobierno representativo en E. J. Sieyès", Revista de Estudios Políticos (Nueva Época), Vol. N 72, abril-junio. 
MANIN, Bernard (1998): "Los principios del gobierno representativo" (versión de Fernando Vallespín, Madrid, Alianza Editorial) p. 17

MANNINO, Armando (2010): "Diritto Parlamentare" (Milano, Giuffré Editore) Pp. 326 y 327.

MANSO, Domingo de Silos (1994): "La revolución italiana", Revista de Política Exterior, Vol. 8 No 37, febrero-marzo.

MANZANARES, Henri (1970): "El régimen parlamentario de Europa occidental", Revista de Estudios Políticos, No 171, p.53

MANZELLA, Andrea (2002): "El Parlamento en el siglo XXI", en PAU I VALL, Francesc (Coord.), "El Parlamento del siglo XXI" (Madrid, Editorial, Tecnos, Asociación Española de Letrados de Parlamentos) p. 18

MANZELLA, Andrea (2003):"Il Parlamento" (Bologna, Edicione Il Mulino, terza edicione) p.441

MARCHECO ACUÑA, Benjamín (2015): "El control jurisdiccional de los actos políticos del Gobierno en el Derecho Español". Revista de Internacional de Estudios de Derecho Procesal y Arbitral, Vol. No 2, pp. 1-50.

MARTÍNEZ BAEZA, Sergio (1965): "La residencia en el derecho patrio chileno", Revista Chilena de Historia del Derecho, Vol. No 4, pp.129-207.

MARTÍNEZ BAEZA, Sergio (1999): "Jueces y Tribunales de residencia en Chile", Revista Chilena de Historia del Derecho, Vol. No 18, pp.239-244.

MARTÍNEZ ELIPE, León (2000): "Fiscalización política del gobierno" (Navarra, Editorial Aranzadi) p.101.

MARTÍNEZ LAGO, Miguel Ángel (2007): "El control parlamentario sobre el presupuesto público", Revista Presupuesto y Gasto Público, Secretaria General de Presupuesto y Gasto, Instituto de Estudios Fiscales, Vol. No 48, PP129-143

MARTÍNEZ OCAMICA, Gutenberg (1998): "Fiscalización Parlamentaria y Comisiones Investigadoras", análisis propuestas. Santiago, editorial Jurídica de Chile- Editorial Andrés Bello.

MARTÍNEZ SIERRA, José Manuel y FERRER, Covadonga (2007): La reforma constitucional en Chile. Jornada sobre orientación y método del derecho del derecho constitucional, Vol. No16. 
MARTÍNEZ SOSPEDRA, Manuel (1994): "Las instituciones del Gobierno Constitucional, sistemas de gobierno y órganos constitucionales" (Valencia, Fundación Universitaria San Pablo C.E.U., segunda edición) p. 117

MAZZONI HONORATI, María Luisa (2001): "Diritto Parlamentare" (Torino, G. Giappichelli, Editore) Pp. 243 y 261.

McLLWAIN, Charles Howard (1991): "Constitucionalismo antiguo y moderno" (trad. Juan José Sólozábal Echavarría, Madrid, Centro de Estudios constitucionales) p.37

MELADO LIROLA, Ana Isabel (2007): "Los instrumentos de control parlamentario de la Ley de presupuestos generales del Estado", Revista Teoría y Realidad Constitucional, Universidad Nacional a la Distancia, Vol. N| 19, pp. 161-195.

MILL, James (1997): "Ensayo sobre Derecho y Política" (trad. Por Víctor Méndez Baiges, Granada, Editorial Comares) Pp. 28,29, 30 у 31.

MIRKINE-GUETZEVITCH, B (1934): "Modernas tendencias del derecho constitucional" (trad. Sabino Alvarez-Gendin, Madrid, Editorial REUS, S.A., primera edición) Pp. 16 a 18.

MOCOROA M., Juan (2014): "El Juicio político como "medida de salud pública"'", Revista Mexicana de derecho constitucional Cuestiones Constitucionales, Vol. No 30, p.137.

MONCRIEFFE, Joy Marie (1998): "Reconceptualizing Political Acconuntability". International Political Science Review, Vol. 19, N017, p. 393.

MONTERO, José Ramón y GARCÍA MORILLO, Joaquín (1984): "El control parlamentario" (Madrid, Editorial Tecnos) p. 19

MONTESQUIEU (1972): "El Espíritu de las leyes" (trad. Mercedes Blasquez y Pedro de Vega, Madrid, Editorial Tecnos, primera edición) Pp. 55 y 63.

MONTORO BALLESTEROS, Alberto (2004): "Poder y formas del derecho (la tensión entre variedad y uniformidad del derecho)", Revista Anales del Derecho, Universidad de Murcia, Número 22.

MORA-DONATTO, Cecilia (2001): "Instrumentos constitucionales para el control parlamentario" (México, Instituto de Investigaciones Jurídicas, Universidad Nacional Autónoma de México).

MURILLO DE LA CUEVA, Enrique Lucas (2001): "El Gobierno como sujeto del Derecho Parlamentario" en en Eusko Legelbitzarra (edit.), Instituciones del derecho parlamentario III: "Los sujetos del derecho parlamentario", (Vitoria-Gasteiz, Editorial 
Eusko Legebiltzarra, Parlamento Vasco, colección informes y documentos) Pp. 376 y 377.

\section{$\underline{\mathbf{N}}$}

NAPOLITANO, Antonio (2010): "Democracia y responsabilidad política", Revista ANALES de la Universidad Metropolitana, Vol. No 10 (Nueva Serie), p. 270

NOGUEIRA, Humberto (1985): "El presidencialismo en la práctica política", Revista Nueva Sociedad, Vol. No 77 mayo-junio, pp. 88-98.

NOGUEIRA, Humberto (1992): "El Congreso Nacional, introducción al derecho parlamentario", (Santiago, editorial Corporación Participa) p. 49.

NOGUEIRA, Humberto (2003):"Tópicos sobre jurisdicción constitucional y tribunales constitucionales". Revista de Derecho. Vol. No XIV, julio, pp.43-66.

NOGUEIRA, Humberto (2008): "La evolución político constitucional de Chile 19762005", Revista Estudios Constitucionales, Año 6, N². Centro de estudios constitucionales de la Universidad de Talca. Pp. 325-370.

NOGUEIRA, Humberto (2013): "Consideraciones sobre la acusación constitucional en la Carta Fundamental vigente", en Pfeffeir Urquiaga, Emilio (edit.) Congreso Nacional, Libor homenaje a Alejandro Silva Bascuñán (Santiago, Editorial Jurídica de Chile) Pp. 223-254.

NOHLEN, Dieter (1985): "El análisis comparativo de sistemas electorales, con especial consideración en el caso chileno" Revista de Estudios Públicos, Vol. 18. Pp. 82 y 83

NOHLEN, Dieter (1998): "Presidencialismo versus Parlamentarismo: dos enfoques contra puestos", en Nohlen, Dieter y Fernández, Mario (edit.), "El presidencialismo renovado. Instituciones y cambio político en América Latina". (Caracas, Editorial Nueva Sociedad, primera edición).

NOHLEN, Dieter (1999): "Presidencialismo vs. Parlamentarismo en América Latina" en Nohlen, Dieter (edit.) "Sistema de Gobierno, Sistema Electoral y Sistema de Partidos Políticos: opciones institucionales a la luz del enfoque histórico-empírico", (México editores Tribunal Electoral del Poder Judicial de la Federación: Instituto Federal electoral, Fundación Fiedrich Naumann) p. 28.

NOHLEN, Dieter y FERNANDEZ, Mario (1998): "El presidencialismo latinoamericano: evolución y perspectiva", en Nohlen, Dieter y Fernández, Mario (edit.), "EI presidencialismo renovado. Instituciones y cambio político en América Latina". (Caracas, Editorial Nueva Sociedad, primera edición). 
NOLTE, Detlef (2003): "El Congreso chileno y su aporte a la consolidación democrática en perspectiva comparada", Revista de Ciencias Políticas, Vol. XXIII, $N^{\circ} 2$, PP.43-67.

NORTON, Philip (2010): "La nature du côntrole parlementaire", Le seuil Pouvoirs, Vol. 3, N 134, pp. 5 á 22.

NOVISSIMO DIGESTO ITALIANO IV: Diretto a Antonio Azora e Ernesto Eula (Torinice, Editrice Unione Tipografica, terza edicione) p.729.

NOVOA MOREAL, Eduardo (1978): "¿Vía legal hacia el socialismo? el caso de Chile, 1970-1973. Colección monográficas políticas $N^{\circ} 1^{\prime \prime}$ (Caracas, Editorial Jurídica Vezolana).

\section{$\underline{\mathbf{0}}$}

OCARANZA, César Darío y OCARANZA, Francisco José (2010):"Los fundamentos ideológicos del derecho político en el Chile de la Independencia (1810-1830): Un caso de vinculación entre el ordenamiento jurídicos y la historia de las ideas". Revista Ars Boni et Aequi, Vol. 6 N02, pp.71-90.

OELCKERS CAMUS, Osvaldo (1993): "La asesoría legislativa" en "Diagnostico histórico jurídico del poder legislativo en Chile 1960-1990" (Valparaíso, Centro de estudios y asistencia legislativa, Universidad Católica de Valparaíso).

OELCKERS CAMUS, Osvaldo (1998): "Aspectos esenciales de la evaluación de los proyectos y de control parlamentario de las normas con rango de ley", Revista de derecho de la Universidad Católica de Valparaíso-Chile, Vol. XIX, P. 443.

ORELLANA VARGAS, Patricio (2004): "Probidad y corrupción en Chile. El punto de quiebre". Polis: Revista Latinoamericana. No 8. Pp. 2 y 7.

\section{$\underline{\mathbf{P}}$}

PANEBIANCO, Ángelo (2009): "El poder el estado, la libertad: la frágil constitución de la sociedad libre" (trad. De Juan Marcos de la Fuente, Madrid, Unión Editorial S.A.) Pp. 27 y 28.

PAÚL DÍAZ, Álvaro y SOTO VELASCO, Sebastián (2009): "Legislar con eficacia: la importancia de evaluar las leyes", Revista Actualidad Jurídica, Tomo II de la Universidad del Desarrollo, Vol. N 19, Pp. 597 y 598. 
PECES-BARBA MARTÍNEZ, Gregorio (1987): "Los valores superiores". Ponencia presentada en las jornadas de la Dirección General de los Servicios Jurídicos del Estado. Fecha 25 de mayo de 1987, disponible en: http://datateca.unad.edu.co/contenidos/551055/COMPLEMENTARIAS UNIDAD DOS/ valores Peces AFD 1987.pdf

PEGORARO, Lucio (2011) "Derecho público comparado, itinerarios de investigación" (Bogotá, Ediciones Facultad de Derecho, Centro de Investigaciones socio-jurídicas, Universidad Libre, primera edición) Pp. 151 y 152.

PEÑA, Javier (1998): "Sobre la responsabilidad política", Revista Internacional de filosofía política, Vol. No 11, p.2

PÉREZ ROYO, Javier (1980): Introducción a la Teoría del Estado (Barcelona, Editorial Blume, primera edición) p. 107.

PÉREZ-LIÑÁN, Aníbal (2003): "Pugna de poderes y crisis de gobernabilidad: ¿Hacia un nuevo presidencialismo?, Latin American Research Review, Vol. 38, No 3, pp.149164.

PERÉZ-LIÑÁN, Aníbal (2009): "Juicio político al presidente y la nueva inestabilidad política en América Latina", (Buenos Aires, Editorial Fondo de Cultura Económico, primera edición en español), pp.

PERSON, Torsten; ROLAND, Gérard y TABELLI, Guido (1997): "Separation of Powers and Political Accountability".The Quarterly Journal of Economics. Vol. 112, No 4, p.1166.

PETER SCHNEIDER, Hans (1991): "Democracia y Constitución" (Madrid, editorial Centro de Estudios Constitucionales) Pp. 255, 256 y 257.

PFEFFER URQUIAGA, Emilio (1987): "Manual de Derecho constitucional, Tomo I: basado en las explicaciones de los profesores Luz Bulnes Aldunate y Mario Verdugo Marinkovic" (Santiago, Editorial Jurídica ConoSur Ltad).

PICARELLA, Lucia (2009) "Presidencialización y personalización en el Sistema Político Español, 1975-2008". Revista Enfoques, Vol. No 11, p. 185.

PITKIN, Hanna Fenichel (1985): "El concepto de representación" (trad. Ricardo Montoro Romero, Madrid, Centro de Estudios Constitucionales) p. 35

PORTERO MOLINA, José Antonio (1998): "El Control Parlamentario del Gobierno". Workin Paper (Barcelona, Universidad Autónoma de Barcelona e Institut de Ciéncies Politiques i Socials). 
POSADA, Adolfo (1930): "El Régimen Constitucional: esencia y forma, principios y técnica" (Madrid, Librería General de Victoriano Suárez) Pp. 112 y 113.

\section{Q}

QUINZIO FIGUEROA, Jorge (1993): "Un Sistema Unicameral para Chile"; Revista chilena de Derecho, Volumen 20, No 2-3: Pp. 313-322.

\section{$\underline{\mathbf{R}}$}

RAMIREZ, Manuel (1995): "Problemáticas actuales del Parlamento", Revista de Estudios Políticos (Nueva Época), Vol. No 87, enero-marzo, pp. 53-79.

REQUEJO, Paloma (2000): "Democracia parlamentaria y principio minoritario, la protección constitucional de las minorías parlamentarias" (Barcelona, Editorial Ariel S.A., primera edición febrero 2000) Pp. 28 y 29.

ROLDÁN, Alcibíades (1924): "Elementos de Derecho Constitucional de Chile" (Santiago, Ediciones Imprenta Laguna y Co., tercera edición corregida y aumentada).

ROLLA, Giancarlo (2002): "Luces y sombras de la experiencia de las transiciones pactadas. Breves consideraciones sobre los límites de la Constitución vigente den Chile". Revista de estudios políticos, Vol. N¹15, pp. 65-80.

ROLLNERT LIREN, Göran (2014): "La Mutación constitucional entre la interpretación y la jurisprudencia constitucional". Revista Española de Derecho Constitucional, Vol. No 101 , mayo-agosto, pp. 125-155.

ROUSSEAU, Jean-Jaques (1980): "Del contrato social" (trad. Mauro Armiño, Madrid, Editorial Alianza, primera edición) p. 30.

RUBIO LARA, María Josefa (2000): "La representación política como proceso recurrente: transformaciones y pervivencia de la representación", Revista Internacional de Filosofía Política, № 16, Pp. 115 y 116.

RUBIO LLORENTE, Francisco (1992): "Seis tesis sobre la jurisdicción constitucional europea", Revista Española de derecho constitucional. Año 12, No 35, (mayoagosto).

RUBIO LLORENTE, Francisco (1993): "La forma del poder" (Madrid, Centro de estudios constitucionales) p.224.

RUBIO LLORENTE, Francisco (1994): "Función legislativa, poder legislativo y garantía del procedimiento legislativo, en Peñaranda, José Luis (Coord.), "V Jornadas de 
derecho parlamentario: El procedimiento legislativo 1994" (Madrid, Publicaciones del Congreso de los Diputados, serie IV monografías N³8) p. 26.

RUBIO LLORENTE, Francisco (1995): "Parlamento y ley", Anuario Jurídico de La Rioja, Vol. No 1 , pp. 15-28.

\section{$\underline{\mathbf{S}}$}

SAIZ ARNAIZ, Alejandro (1994): "Los actos políticos del Gobierno en la jurisprudencia del Tribunal Supremo". Revista de Administración Pública, Vol. №134, mayo-agosto, pp. 225-251.

SALAZAR V., Gabriel (2009): "Del poder constituyente de asalariados e intelectuales (Chile, siglos $X X$ y XXI)". (Santiago, Ediciones LOM, primera edición).

SALVI, Giovanni (1994): "Aspectos de la corrupción italiana, represión y prevención" (Centro de Estudios Públicos, Vol. No 221 primavera)

SÁNCHEZ AGESTA, Luis (1945): "Lecciones de derecho político, II teoría de la constitución" (Granada, Editorial imprenta hijo de Paulino Ventura) Pp. 140, 141 y 142.

SÁNCHEZ AGESTA, Luis (1960): "Gobierno y Responsabilidad", Revista de Estudios Políticos, No 113 , pp. 35-66.

SÁNCHEZ AGESTA, Luis (1966): "Principios de teoría política" (Madrid, Editorial Nacional) p.25

SÁNCHEZ DE DIOS, Manuel (1995): "La esencia del régimen: el control parlamentario del Gobierno". Revista Política y Sociedad. Vol. 20, p. 36.

SÁNCHEZ DE DIOS, Manuel (1996): "La disciplina de los partidos en los grupos parlamentarios del Congreso de los Diputados" Revista de las Cortes Generales. Vol. 39. Pp. $6 y$ 7

SÁNCHEZ DE DIOS, Manuel (2002): "La práctica del control parlamentario en el Congreso de los diputados entre 1977 y 2000", Revista de las Cortes Generales. Madrid, Tercer cuatrimestre Vol. No 57, Pp. 102 y 103.

SÁNCHEZ NAVARRO, Ángel J. (1995): "Las minorías en la estructura parlamentaria". (Madrid, Centro de Estudios Constitucionales) Pp. 42-43.

SÁNCHEZ URRUTIA, Ana Victoria (2000):"Mutación constitucional y fuerza normativa de la Constitución una aproximación al origen del concepto". Revista Española de Derecho constitucional, Año 20, Vol. Na 58, Enero- abril, pp. 105-135. 
SANT'ANA PEDRA, ADRIANO (2012): "La elasticidad del texto de la Constitución como límite para las mutaciones constitucionales". Revista de Estudios Avanzados, Vol. N017, pp. 39-61.

SANTAOLLA LÓPEZ, Fernando (1984): "Derecho Parlamentario Español", (Madrid, Editorial Nacional).

SARTORI, Giovanni (1988): "Teoría de la democracia, 1. El debate contemporáneo" (Madrid, editorial Alianza, versión española de Santiago Sánchez González) p.51

SARTORI, Giovanni (1992): "Elementos de teoría política", (Madrid, editorial Alianza S.A.) Pp. 17 y 18.

SARTORI, Giovanni (1999): "En defensa de la representación política", Revista Claves de la Razón práctica, Vol. N91, p.6.

SARTORI, Giovanni (2003): "Ingeniería constitucional comparada, una investigación de estructuras, incentivos y resultado", (trad. Roberto Reyes Mazzoni, México, Editorial Fondo de Cultura Económico, tercera edición en español) p.116

SCHMITT, Carl (1962): "Diálogos, diálogos de los nuevos espacios. Dialogo sobre el poder y el acceso al poderoso" (trad. Anima Schmitt de Ottero, Madrid, Editorial Instituto de Estudios Políticos) Pp. 65 y 67.

SCHMITT, Carl (1990): Sobre el Parlamentarismo, (Madrid, estudio preliminar de Manuel Aragón. Editorial Tecnos, $1^{\text {a }}$ edición) pp. 41 y 42.

SCHNEIDER Hans-Peter y WOLFGANG Zeh, ed. (1989): "Parlamentsrecht und Parlamentspraxis in der Bundesrepublik Deutschland: ein Handbuch" (Berlín, Walter de Gruyter)

SCHWEITZER, Daniel (1972): "Acusación constitucional, regímenes de emergencia y otros estudios jurídicos", (Santiago, Editorial Andrés Bello).

SERRA CRISTÓBAL, Rosario (2009): Pequeñas minorías y control parlamentario. Corts. Anuario de Derecho Parlamentario, No 21, p.103 y 104.

SERRAFERO, Mario (1998): "Presidencialismo y parlamentarismo en América Latina: un debate abierto", Revista Mexicana de Sociología, Vol. 60, № 2, abril-junio, p.171.

SERRAFERO, Mario (2014): "Flexibilización del presidencialismo en América Latina: ¿un fenómeno nuevo?, Revista de Estudios Políticos (Nueva Época), Vol. No 163, enero-marzo, pp.67-99.

SHUGART SOBERG, Matthew: (first published in 2006, first published in paper back in 2008): "Comparative Executive-lesgilative Relations", Chapter No 18, en R.A.W. 
RHODES, BINDER, Sarah y Rockman, Berta (edit.), "Political Institutions", (Oxford, University Press) pp. 355-357 y 359-360.

SIAVELIS, Peter M. (2004): "Sistema electoral, desintegración de coaliciones y democracia en Chile: ¿el fin de la Concertación? Revista de Ciencia Política, Vol. XXIV No 1. Pp. 59 y 60.

SIAVELIS, Peter M. (2009): "Enclaves de la Transición y democracia chilena". Revista de Ciencia Política, VOL. 29, No 1, p. 18.

SIEYÉS, Emmanuel-Joseph (1988): ¿Qué es el estado llano?; precedido del "Ensayo sobre los privilegios" (Trad. Por José Rico Godoy, Madrid, Centro de estudios constitucionales) p.19.

SILVA BASCUÑÁN, Alejandro (1963): "Tratado de derecho constitucional, Tomo II: La constitución de 1925", (Santiago, Editorial Jurídica de Chile)

SILVA BASCUÑAN, Alejandro (1997): "Tratado de derecho constitucional, Tomo I: principios Estado y Gobierno" (Santiago, Editorial jurídica de Chile, segunda edición) p.402.

SILVA CIMA, Enrique (1995): "Derecho administrativo chileno y comparado: actos, contratos y bienes", (Colaborador Aliro Verdugo Lay, Santiago, Editorial Jurídica de Chile) Pp. 71-74.

SILVEIRA E SILVA, Rafael y VAZ GUIMARAES DE ARAÚJO, Suely Mara (2010): "Apropiación de la agenda legislativa: usurpación o cooperación entre los poderes". En V Congreso Latinoamericano de Ciencia Política. Buenos Aires. Pp. 1-26.

SIMÓN YARZA, Fernando (2015):"La moción de censura: ¿Constructiva u <obstructiva?, Revista Española de Derecho Constitucional, Vol. No 103, enero-abril, pp. 87-109.

SOLOZÁBAL ECHAVARRÍA, Juan José (1981): "Sobre el principio de la separación de poderes", Revista de Estudios Políticos (Nueva Época) Núm. 24 noviembrediciembre.

SOLOZÁBAL ECHAVARRÍA, Juan José (1996): "El régimen parlamentario y sus enemigos (reflexiones para el caso español)", Revista de Estudios Políticos (Nueva Época), Vol. No 93, julio-septiembre.

SORIANO DÍAZ, Ramón (2001): "El parlamento demediado: ¿controla, legisla y representa? Revista Derecho y Conocimiento: anuario jurídico sobre la sociedad de la información y el conocimiento, Universidad de Huelva, Vol. 1. P. 3. 


\section{$\mathbf{I}$}

TAPIA VALDÉS, Jorge (1960): "La Técnica Legislativa", (Santiago de Chile, Editorial Jurídica de Chile, Universidad de Chile). p. 20-23

TAPIA VALDÉS, Jorge (1993): "Funciones y Atribuciones del Parlamento entre 19601990", en "Diagnostico histórico jurídico del poder legislativo en Chile 1960-1990" (Valparaíso, Editado por Centro de Estudios y Asistencia legislativa, Universidad Católica de Valparaíso).

THIBAUT, Bernhard (1993):"Presidencialismo, parlamentarismo y el problema de la consolidación democrática en América Latina", Estudios Internacionales, Instituto de Estudios Internacionales Universidad de Chile, Año 26, Vol. No 102, abril-junio.

THIBAUT, Bernhard (1998): "El gobierno de la democracia presidencial: Argentina, Brasil, Chile y Uruguay en una perspectiva comparada", en Nohlen, Dieter y Fernández, Mario (edit.), "El presidencialismo renovado. Instituciones y cambio político en América Latina". (Caracas, Editorial Nueva Sociedad, primera edición).

TORRES DEL MORAL, Antonio (1982): "Crisis del Mandato representativo en el Estado de Partidos", Revista Derecho Político, No 14 verano, p.8.

TORRES MURO, Ignacio (1998): "Las Comisiones parlamentarias de investigación". (Madrid, Centro de Estudios Políticos y Constitucionales. Cuadernos y Debates No 75), pp. 24 у 25.

TOUCHARD, Jean (1981): "Historia de las Ideas Políticas" (Madrid, Editorial Tecnos, Colección de Ciencias Sociales serie de Ciencia Política, cuarta edición).

TUDELA ARANDA, José (2001): "Calidad y renovación del concepto de ley", Revista de las Cortes Generales, España, primer cuatrimestre Vol. ํo 52, p. 151.

\section{$\underline{\mathbf{u}}$}

UGO RESIGNO, Giuseppe (1967): "La responsabilitá politica", (Milano, Editore Dott. A. Giuffré, Universitá degli studi di Roma, nuova serie 28) Pp. 46 A 49.

USLAR VARGAS, Patricio (1966): "La integración del Congreso Nacional", (Santiago, editorial jurídica de Chile). 


\section{$\underline{\mathbf{v}}$}

VALDÉS CARRERA, José Miguel (1893): "República de Chile, la condenación del Ministro Vicuña y José Miguel Valdés", (París, Imprenta Universal, disponible en Biblioteca del Congreso Nacional, Colección raros y valiosos, monografías).

VALDÉS PRIETO, Salvador y SOTO VELASCO, Sebastián (2009): ¿Cómo fortalecer la labor legislativa del Congreso?; Revista de Estudios Públicos, Nº 114, p. 55.

VALDÉS VALDÉS, Ismael (1906): "Prácticas Parlamentarias" (Santiago, Litografía I Encuadernación Barcelona).

VALDÉS, Diego (2009): "Visión panorámica del constitucionalismo en el siglo XX", (Revista de derecho constitucional europeo, Año 6, No 12, julio-diciembre) p. 24.

VALENCIA CARMONA, Salvador (1979): "El poder ejecutivo latinoamericano", (México, Editorial Universidad Nacional Autónoma de México, Instituto de Investigaciones Jurídicas, primera edición).

VALENZUELA, Arturo (2008): "Presidencias Latinoamericanas interrumpidas", Revista América Latina Hoy, Vol. No 49, ediciones Universidad de Salamanca, pp.15-30.

VALENZUELA, J. Samuel (2005): "¿Hay que eliminar el sistema binominal?, Una propuesta alternativa", Revista de Ciencia Política, Vol. No 45, primavera, pp. 53-66.

VALLESPÍN, Fernando (1999): "El futuro de la democracia", Revista Claves de la Razón Práctica. No 97, noviembre. Pp. 4-6.

VERDÚ, Lucas Pablo (1974): "Principios de ciencia política", volumen tercero: Estado contemporáneo y fuerzas políticas (Madrid, Editorial Tecnos, segunda edición) Pp. 20 y 22.

VERDUGO MARINOVIK, Mario (2014):"Los principios del constitucionalismo clásico en los ordenamientos fundamentales de Chile".

VERDUGO MARINOVIK, Mario y GARCIA BARZELATO, Ana María (1988): "Manual de derecho político, Instituciones políticas, Tomo I" (Santiago, Editorial Jurídica de Chile, segunda edición).

VERGARA BLANCO, Alejandro (1993): "Formación de la Ley y técnica legislativa", en "Diagnostico histórico jurídico del poder legislativo en Chile 1960-1990" (Valparaíso, Editado por Centro de Estudios y Asistencia legislativa, Universidad Católica de Valparaíso). 
VICUÑA, Claudio (1893): "Política Chilena-Condenación al Ministro Vicuña", (Buenos Aires, editorial "El correo español", disponible en biblioteca del Congreso Nacional, colección raros y valiosos, monografías).

VOEGELIN, Eric (1968): "Nueva ciencia política" (trad. Emilio Sánchez Pintado, Madrid, Ediciones RIALP S.A.) p. 63.

\section{$\underline{\mathbf{w}}$}

WEBER, Max (1964): "Economía y Sociedad" (trad. José Medina, Juan Roura, Eduardo García, Eugenio Ímaz y José Ferrater, México, Editorial Fondo de Cultura Económico, segunda edición en español). Pp. 39 y 43.

WHEARE, K.C. (1971): "Las constituciones modernas" (trad. Fernando Morera y Ángel Alandí, Barcelona, Editorial labor S.A.).

WRIGHT MILLS, Charles (1963): "La elite del poder" (trad. Florentino M. Torner y Ernestina de Champourcin, México-Buenos Aires, editorial Fondo de Cultura Económico, cuarta edición en español) Pp. 229-234

\section{$\underline{\mathbf{X}}$}

XUCLÁ I COSTA, Jordi (2011) "El Control Parlamentario del Ejecutivo en España: Instrumentos y Propuestas de Mejora. Revista Económica y Derecho. Vol. 8, Núm. 9: Pp.35-45.

\section{$\underline{\mathbf{Y}}$}

YOUNG, G.M. (1882): "El gobierno y el parlamento de la Gran Bretaña" (Gran Bretaña, Editado por Adprint Limited London, Espasa Calpe Argentina S.A.).

\section{$\underline{\mathbf{z}}$}

ZÁRATE ROJAS, Sebastián (2009): "La responsabilidad política del gobierno y las comisiones parlamentarias de investigación en el derecho chileno". (Santiago, Tesis para optar al grado de Magíster en derecho público con mención en derecho constitucional. Pontificia Universidad Católica de Chile) pp. 62-69.

ZINK, Harold (1965): "Los sistemas contemporáneos de Gobierno" (trad. Andrés M. Mateo, México, Editorial Libreros Mexicanos Unidos, primera edición) p. 28. 
ZORRO SÁNCHEZ, Carlos (1965): "El Parlamento: sus orígenes y su posterior evolución" (Bogotá, tesis doctorado en ciencias jurídicas y económicas, Pontificia Universidad Javeriana) Pp. 222 y 224.

ZÚÑIGA URBINA, Francisco (1993): "Acusación en juicio político: notas sobre la justicia política", Revista Chilena de Derecho, Vol. 20 No 2/3, XXIV Jornadas Chilenas de Derecho Público (Mayo-Diciembre), pp. 705-724.

ZÚÑIGA URBINA, Francisco (1998): "El control parlamentario y las comisiones investigadoras", Revista chilena de Derecho, Número Especial. Pp. 316 y 322.

ZÚÑIGA URBINA, Francisco (2006): "Responsabilidad constitucional del Gobierno", Revista Ius et Praxis, Vol. 12 No 2, Pp. 43-74.

ZÚÑIGA URBINA, Francisco y Vega Méndez, Francisco (2005): "Control Político de la Cámara de Diputados en la reforma constitucional", en NOGUEIRA, Humberto (coordinador), "La Constitución Reformada de 2005" (Santiago, Editorial Librotecnia, Centro de Estudios Constitucionales de Chile, Universidad de Talca).

\section{Constitución Política de la República:}

* Constitución Política de la República de Chile 1833.

* Constitución Política de la República de Chile 1925.

* Constitución Política de la República de Chile 1980.

* Reforma Constitucional año 2005 Ley N²0.050.

* Ley Organica Consttiucional de Bases de la Administración del Estado Nº 18.575 .

\section{Normativa:}

* Ley Orgánica Constitucional del Congreso Nacional N 18.918.

* Reglamento de la Cámara de Diputados.

* Reglamento del Senado.

\section{Otros documentos:}

* Documentos Relativos a la Acusación de los ex -Ministros de Estado, 1892. (Santiago, Editorial Cervantes, Biblioteca del Congreso Nacional, Colección raro y valioso, Monografías) 
* Informe Nolan "Normas de conducta para la vida Pública" 1996. (Madrid, Ministerio de Administración Pública, Documentos Instituto Nacional de Administración Pública, No 9, Octubre).

* Historia de la Ley N²0.050 (Disponible en www.bcn.cl)

- Historia de los artículos de la Constitución. Actas Constitucionales Sesión No 341 de fecha 22 de marzo 1978. (Disponible en www.bcn.cl)

* Historia de los artículos de la Constitución. Actas constitucionales, Sesión No 353 de fecha 19 de abril del año 1978. (Disponible en www.bcn.cl)

* "Las Críticas del Gripo de los 24" 1981, publicado por APSI.

\section{Páginas Web:}

www.rae.es

www.camara.cl

www.senado.cl

www.ben.cl 